\author{
UNIVERSIDADE DE SÃO PAULO \\ FACULDADE DE FILOSOFIA, LETRAS E CIÊNCIAS HUMANAS \\ DEPARTAMENTO DE SOCIOLOGIA \\ PROGRAMA DE PÓS-GRADUAÇÃO EM SOCIOLOGIA
}

MARIA CARAMEZ CARLOTTO

Universitas semper reformanda?

\title{
A história da Universidade de São Paulo e o discurso da gestão à luz da estrutura social
}




\author{
UNIVERSIDADE DE SÃO PAULO \\ FACULDADE DE FILOSOFIA, LETRAS E CIÊNCIAS HUMANAS \\ DEPARTAMENTO DE SOCIOLOGIA \\ PROGRAMA DE PÓS-GRADUAÇÃO EM SOCIOLOGIA
}

MARIA CARAMEZ CARLOTTO

Universitas semper reformanda?

\title{
A história da Universidade de São Paulo e o discurso da gestão à luz da estrutura social
}

Tese apresentada ao Programa de Pósgraduação em Sociologia da Faculdade de Filosofia, Letras e Ciências Humanas da Universidade de São Paulo para a obtenção do título de doutor(a) em sociologia.

Área de concentração: Sociologia

Orientadora: Sylvia Gemignani Garcia

São Paulo

2014 
LICENÇA PARA FINS DE ESTUDO E PESQUISA

Autorizo a reprodução e divulgação total ou parcial deste trabalho, por qualquer meio convencional ou eletrônico, para fins de estudo e pesquisa, desde que citada a fonte. 


\section{AgRADECIMENTOS}

No atual contexto de pesquisa da universidade brasileira, talvez mais até do que em outros, não é retórico dizer que a realização de uma tese como esta dependeu, visceralmente, de uma extensa rede de apoios, individuais e institucionais, sendo, portanto, um resultado social. São alguns desses pilares de sustentação, sem os quais este trabalho não teria sido possível, que gostaria de reconhecer com estes agradecimentos.

Nesse sentido, gostaria de começar agradecendo aos dirigentes da Universidade de São Paulo, que encontraram um tempo, na sua agenda repleta, para responder às minhas inúmeras perguntas em entrevistas sempre extensas e demoradas.

Aos funcionários da USP que apoiaram ativamente a minha pesquisa, demonstrando por ela um interesse genuíno. Em especial, gostaria de agradecer aos funcionários das bibliotecas da Faculdade de Filosofia, Letras e Ciências Humanas, da Faculdade de Direito, da Faculdade de Economia e Administração, da Faculdade de Educação, da Faculdade de Arquitetura e Urbanismo, da Escola Politécnica, da Faculdade de Medicina, do Instituto de Estudos Brasileiros, do Instituto de Ciências Biomédicas e do Instituto de Física de São Carlos, que foram colaboradores ativos na busca por livros e documentos sobre a história da Universidade de São Paulo e a trajetória de seus professores. Aos funcionários do Jornal da USP, que me receberam em uma sede improvisada, se preocupando em me oferecer, na medida do possível, plenas condições de pesquisa. Aos servidores da Secretaria Geral que me ajudaram a acessar, de Paris, atas e outros documentos da USP.

Gostaria de agradecer, nominalmente, aos técnicos responsáveis pelo Anuário Estatístico da USP, Silvio Fernandes de Paula e Gisele Lopes Batista, e pelo Questionário Socioeconômico da FUVEST, Renan de Cerqueira Leite, pelo seu apoio absolutamente imprescindível ao longo desta pesquisa. Eles me mostraram, na prática, como a USP depende 
profundamente do trabalho cotidiano desses servidores que se dedicam integralmente a uma instituição na qual acreditam.

Por fim, a todos os funcionários da FFLCH, especialmente os do Programa de Pósgraduação em Sociologia, Ângela Ferraro e Gustavo Mascarenhas, por todo o apoio nesses quatro anos de doutorado.

A realização de uma tese em sociologia é o resultado de um longo processo de formação que devo, antes de tudo, aos meus professores do programa de pós-graduação em sociologia e do curso de ciências sociais. Gostaria de agradecer, em especial, a Francisco de Oliveira, Heloísa Martins, Maria Helena Augusto, Flávio Pierucci (in memoriam), Maria Arminda Nascimento Arruda, Vera Telles, Leopoldo Waizbort, Nadya Guimarães, Antônio Sérgio Guimarães, Marcos César Alvarez, Fernanda Peixoto, José Guilherme Magnani, Fernando Haddad, Bernardo Ricupero, Rafael Villa e Cícero Araújo.

A Ruy Braga eu agradeço, em especial, por todo o apoio, sempre pronto e generoso, desde o começo do meu mestrado.

A Ricardo Musse, pelos espaços de discussão e participação que me abriu e que foram fundamentais para a minha formação.

A Alvaro Comin, por ser um modelo, sempre.

A André Singer e Brasílio Sallum agradeço especialmente pela leitura atenta e crítica do meu texto de qualificação.

A Lincoln Secco, por sempre se lembrar de me enviar indicações fundamentais do que ia sendo produzido, sobre universidade, no campo da história.

A Paulo Arantes e Laymert Garcia dos Santos, por algumas das sugestões mais interessantes deste trabalho.

A Valéria de Marco, pela disposição de me explicar, sistematicamente, os meandros da transformação da USP, ajudando a iluminar a minha pesquisa de campo. 
A Lilia Schwarcz, pelo trabalho que constitui um dos pilares desta tese.

A Sergio Miceli, Fernando Limongi e Ana Paula Hey, devo o exemplo do que significa tentar não por limites ao olhar sociológico sobre a universidade.

E a Marilena Chauí, Franklin Leopoldo e Silva e Irene Cardoso, a inspiração crítica deste trabalho.

A Pablo Ortellado agradeço, além da amizade sempre paciente, a oportunidade de ter integrado o Grupo de Pesquisa em Política Pública para o Acesso a Informação, onde, além de realizar uma das pesquisas mais interessantes da minha trajetória, tive condições de conceber o projeto desta pesquisa. A todos os membros do Gpopai, em especial a Giseli Craveiro, Márcio Black, Jamila Venturi e Bráulio Santos Araújo, pelo convívio maravilhoso e pelo aprendizado.

Ao Grupo de Pesquisa em Sociologia da Educação, Cultura e Conhecimento, que por mais de uma vez discutiu o meu trabalho, agradeço por ter sido um espaço fundamental de formação e discussão, que se mostrou cada vez mais decisivo para a definição da abordagem teórica deste trabalho. Encontrei, ali, os colegas mais generosos, a quem eu devo inúmeras contribuições.

Ao Lemarx-USP, por ser sempre uma janela aberta para a transformação da sociedade capitalista brasileira e mundial.

Por fim, ao grupo de pesquisa em Filosofia, História e Sociologia da Ciência e da Tecnologia, por ser um espaço onde, com toda a liberdade, comecei a discutir o processo de mudança das instituições de produção e difusão do conhecimento, que esta tese tentou ajudar a entender. Agradeço especialmente a Pablo Mariconda, por não medir esforços para viabilizar esse espaço de crítica, investigação e discussão sobre os rumos da ciência contemporânea.

A Terry Shinn, por ter me ensinado a amar a pesquisa e a vida na mesma intensidade. E a Anne Marccovitch, pela amizade e carinho que me fizeram sentir em casa longe de casa. 
A todos da Revista Fevereiro, espaço vivo de debates e polêmicas, em especial ao Ruy Fausto, pelas longas conversas, em castelos e bibliotecas por aí afora.

A todos os amigos queridos que a USP, nesses 12 anos, me deu. Em especial, a Lígia Luchesi, Marcelo Souza, Renan Quinalha, Rafael Pereira, Cristina Beskow, Lucas Monteiro Oliveira, Nicolau Dela Bandeira, Natália Mello, Polly Rosa, Luiz Gustavo Soares, Bruno Carvalho, Helder Souza, Tomás Marques, Maria Morita, Thaís Pavez, Christian Schallenmueller, Mariana Rubiano e a todos os outros membros da APG, do CAF e do CEUPES pelo esforço em tentar construir uma universidade melhor, para além das suas estruturas.

A Patrícia Magalhães e Maria Fernanda Pinto agradeço, além disso, por serem mulheres tão maravilhosas!

A Camila Gui Rosatti, por todo o apoio, sempre empolgado e empolgante.

A Mariana Toledo por ser, além de uma companheira de militância, uma parceira de pesquisa e de vida.

A Elisa Klüger, pela amizade que me ajudou a viver Paris, sociológica e intensamente.

Ao Stefan Klein, por compartilhar comigo "a questão da universidade" e por me apoiar de modo tão presente a minha caminhada.

Aos amigos de Campinas, por deixarem a vida mais leve.

A Zé Luiz, Edu, Fernando, Gilberto, Douglas, Anderson, Bruno, Paulo, Felipe, Raquel, Lucas, Léo, Mariana, Silvinha, Rodrigo, Tati, Zé César e às Marinas-Marias, amigos da educação pela noite, pelas conversas regadas a cerveja e gargalhadas.

A Carlos, Caio, Fábio e Ilan, pela philia que, entre outros devaneios, me faz seguir acreditando na sociologia.

A Gabi e Dani, pelas afinidades infinitas, que só são possíveis entre grandes amigos.

A Zé Paulo, que além de companheiro de várias lutas e muitas pesquisas, é um "irmão" que a vida me deu. 
A Verena, Pedro Tito e Nico, que apesar da distância, estão sempre presentes.

A Ana Paula, pelas nossas correspondências que, nos momentos mais difíceis, me ajudaram a seguir avante siempre.

A Ana Elisa, amiga de uma vida toda.

E a Pati, companheira de todos os momentos.

A toda família Borghi, agradeço pelas semanas na Fazenda São Pedro, onde o clima de tranquilidade total permitiu a conclusão desta tese.

A Cecília, Jorge, Manuela e Pedro, pelo apoio sempre incondicional a esse longo e custoso processo.

A toda a minha família, por aceitar a minha obsessão. Em especial, aos meus primos, que são meus melhores amigos. A pequena Ella, agradeço particularmente pela ternura que me fez entender o amor incondicional. Aos meus tios, tias, e principalmente às minhas duas avós, por compreenderem a minha ausência nesses últimos anos. Aos meus irmãos, por contornarmos, juntos, todas as pedras. Ao meu pai, por simplesmente tudo o que fez para que eu pudesse concluir esse longo processo de formação. E, por fim, a minha mãe, por acreditar e apoiar, desde o começo, esta jornada. Que o fim deste ciclo nos permita estar mais próximos.

Ao Rica, meu companheiro no sentido mais profundo que consigo conceder à palavra, por caminhar sempre ao meu lado, compartilhando comigo a sua integridade.

E, por fim, a minha orientadora, Sylvia Gemignani Garcia, a quem eu devo muito mais do que sou capaz de agradecer, por ser o suporte pessoal, emocional e intelectual deste trabalho. 
Esta pesquisa foi financiada pela Fundação de Amparo à Pesquisa do Estado de São Paulo (FAPESP) e pela Coordenação de Aperfeiçoamento de Pessoal de Nível Superior (CAPES). 


\title{
RESUMO
}

Na literatura nacional e internacional sobre a transformação contemporânea das universidades, são muitos os estudos que enfatizam o impacto do conhecimento gerencial sobre a reorganização dos procedimentos de decisão, controle e coordenação do trabalho acadêmico. Partindo dessas análises, a presente pesquisa buscou interrogar o papel do discurso gerencial na redefinição do governo acadêmico das universidades brasileiras enfatizando a sua relação com a estrutura social, que se expressa, no interior da universidade, pela hierarquização política, social e acadêmica das suas diferentes unidades. Para tanto, esta tese baseia-se em um estudo de caso sobre a Universidade de São Paulo - uma das maiores, mais importantes e mais antigas universidades de pesquisa do país - que sofreu diretamente o impacto dos saberes gerenciais na redefinição das suas estruturas internas de governo a partir dos anos 1960. Em termos gerais, a tese essencial deste trabalho é de que o discurso gerencial conseguiu se impor na USP pela ação do seu polo dominante, formado pelas unidades profissionais tradicionais que conseguiram, justamente pela sua posição na estrutura social, impor sua visão de universidade e de governo acadêmico.

\section{Palavras-ChaVe}

Universidade de São Paulo, reforma universitária, gestão, governo acadêmico, sociologia histórica, história estrutural.

\begin{abstract}
Among the national and international literature upon the contemporary transformation of the universities, many studies underline the impact of the management knowledge on the reorganization of the procedures related to the decision, accountability and coordination of the academic work. Departing from these analysis, the present research intend to interrogate the role of the management discourse in the redefinition of the academic government of Brazilian university, emphasizing the relation with its social structure, expressed through the political, social and academic hierarchisation of university faculties. In that sense, this thesis is based on a case study about the São Paulo University - one of the biggest, oldest, and most important research university of Brazil - that suffered directly the impact of the management knowledge in the redefinition of its intern structure of government from the 1960 onwards. In general terms, the essential argument of this work is that the management discourse could impose itself in the São Paulo University through the action of the dominant pole, composed by the traditionalprofessional faculties that, due to its position in the social structure, achieved to impose its conception of university and academic government.
\end{abstract}

\section{KEYWORDS}

University of São Paulo, university reform, management, academic government, sociological history, structural history. 


\section{LISTA DE GRÁFICOS}

Gráfico 1. Evolução do número de cursos de "administração e gerenciamento" em funcionamento no país (1991-2005)

Gráfico 2. Evolução do número de unidades da USP (1934 - 2014)

Gráfico 3. Evolução do corpo docente da USP em números de professores contratados (1960 2012)

Gráfico 4. Evolução do corpo docente da USP pelo número de professores trabalhando o equivalente em RDIDP (1980 - 2012)

Gráfico 5. Evolução do percentual de docentes da USP em dedicação exclusiva (RDIDP) entre 1980 e 2010

Gráfico 6. Evolução do número de alunos de graduação, de pós-graduação e total de docentes da USP (1989 - 2012)

Gráfico 7. Percentual de dirigentes da USP vinculados aos polos profissional tradicional, técnico-profissional e acadêmico-científico (1934 - 2014)

Gráfico 8. Distribuição dos cursos de graduação realizados pelos dirigentes da USP (1934 1968)

Gráfico 9. Distribuição dos cursos de graduação realizados pelos dirigentes da USP (1968 2014)

Gráfico 10. Distribuição dos cursos de graduação realizados pelos dirigentes da USP (1934 2014)

Gráfico 11. Percentual de homens e mulheres entre os dirigentes da USP em três categorias $(1934-2014)$ 


\section{LISTA DE TABELAS}

Tabela 1. Evolução do corpo discente da USP (1989 - 2012)

Tabela 2. Evolução das vagas de graduação (1960 - 2012)

Tabela 3. Evolução dos cursos de graduação, mestrado e doutorado (1987 - 2012)

Tabela 4. Evolução do número de trabalhos científicos publicados por docente ativo da USP (1985 - 2012)

Tabela 5. Relação de unidades de ensino e pesquisa da USP segundo o ano de fundação, incorporação ou desmembramento e com informações sobre a localização e os principais cursos de graduação oferecidos em 2012

Tabela 6. Evolução dos cursos da USP por unidade de ensino e pesquisa, com indicação da progressão quinquenal do número de vagas e sua variação absoluta e percentual entre 1982 e $2010^{*}$

Tabela 7. Síntese dos cursos (ativos) criados a partir de 1982 com a respectiva unidade e ano de criação

Tabela 8. Cursos já existentes em 1982, hierarquizados segundo a variação percentual do número de vagas no período

Tabela 9. Carreiras da USP hierarquizadas pela relação candidato/vaga a partir dos inscritos no vestibular da Fuvest em 1999

Tabela 10. Carreiras da USP hierarquizadas pela relação candidato/vaga a partir dos inscritos no vestibular da Fuvest em 2009

Tabela 11. Reitores da USP entre 1934 e 2014, com a respectiva unidade de vinculação

Tabela 12. Unidades de ensino e pesquisa da USP hierarquizadas segundo o percentual de docentes em regime de dedicação exclusiva (2010)

Tabela 13. Unidades hierarquizadas pelo percentual de ingressantes em 2000 cuja mãe realizou o ensino superior completo

Tabela 14. Unidades hierarquizadas pelo percentual de ingressantes em 2005 cuja mãe realizou o ensino superior completo 
Tabela 15. Unidades hierarquizadas pelo percentual de ingressantes em 2010 cuja mãe realizou o ensino superior completo

Tabela 16. Unidades hierarquizadas pelo percentual de ingressantes em 2012 cuja mãe realizou o ensino superior completo

Tabela 17. Unidades hierarquizadas segundo o percentual decrescente de ingressantes que cursaram o ensino fundamental, integralmente ou na maior parte, em escola particular

Tabela 18. Unidades hierarquizadas segundo o percentual decrescente de ingressantes que cursaram o ensino médio, integralmente ou em parte, em escola particular

Tabela 19. Unidades hierarquizadas segundo o percentual decrescente de ingressantes que cursaram o ensino médio "comum"

Tabela 20. Unidade hierarquizadas segundo o percentual de ingressantes que cursaram o ensino médio no período noturno

Tabela 21. Unidades hierarquizadas segundo o percentual decrescente de ingressantes que não exercem nenhum tipo de atividade remunerada

Tabela 22. Unidades hierarquizadas segundo o percentual decrescente de ingressantes com pai que realizou a pós-graduação

Tabela 23. Unidades hierarquizadas segundo o percentual de ingressantes com pai proprietário de grande ou média empresa

Tabela 24. Unidades hierarquizadas segundo o percentual de ingressantes com pai profissional liberal

Tabela 25. Unidades hierarquizadas segundo o percentual de ingressantes proprietários de grande ou média empresa

Tabela 26. Unidades hierarquizadas segundo o percentual de ingressantes com mãe profissional liberal

Tabela 27. Unidades hierarquizadas segundo o percentual de ingressantes com renda familiar acima de 20 salários mínimos

Tabela 28. Unidades hierarquizadas segundo o percentual crescente de ingressantes que se declara de cor "parda" ou "preta"

Tabela 29. Unidades hierarquizadas segundo o percentual decrescente de ingressantes homens 
Tabela 30. Dirigentes da USP (reitores, pró-reitores e coordenadores gerais de administração) segundo período no cargo, faculdade de origem e formação

Tabela 31. Distribuição do orçamento da USP, na alíquota "outras despesas", que exclui o gasto em pessoal (1986 - 2012)

Tabela 32. Distribuição do orçamento total da USP, incluindo "gasto em pessoal" e "outras despesas" (1986 - 2012)

\section{LISTA DE FIGURAS}

Figura 1. Brasão d'armas da USP 


\section{Sumário}

Introdução

Capítulo 1. Posições sociais e visões do passado: por uma história estrutural da USP 33

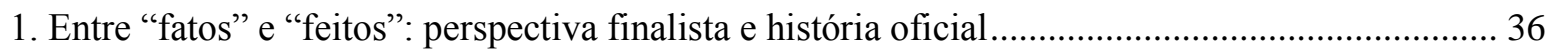

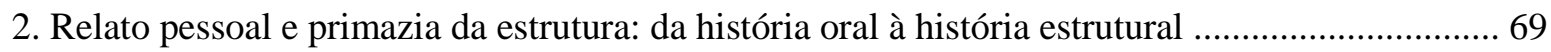

3. A "ideia" de universidade: perspectiva filosófico-pedagógica e história dos vencidos ................ 86

4. A universidade vista "a certa distância": a perspectiva estrutural sobre a história da USP ........ 112

Capítulo 2. Posições sociais e visões de futuro: a emergência da universidade como objeto de gestão

1. A gestão como um sistema de classificação e um dispositivo de saber-poder............................. 136

1.1. Conhecimento especializado e intervenção técnica como construção social da realidade... 137

1.2. A perspectiva estrutural da circulação internacional de saberes: a inflexão gerencial das universidades vista da perspectiva latino-americana.................................................................. 148

1.3. Importação e expansão do conhecimento gerencial no Brasil: a consolidação de um novo saber e seus efeitos culturais e políticos

2. A disputa pela reforma universitária nos anos 1960 vista a partir da estrutura universitária...... 176 2.1. Gestão colegiada e autogoverno: a proposta de reforma universitária do polo acadêmico-

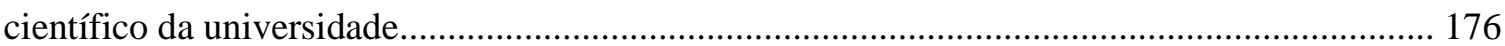

2.2. A universidade como objeto de gestão: a reação do polo politicamente dominante .............. 189

2.2.1. Profissionalização e gestão: o IPES e a visão econômica da educação........................ 189

2.2.2. Uma "nova geração de líderes": as consultorias norte-americanas e a conversão invisivel dos dirigentes acadêmicos brasileiros ................................................................. 197

2.2.3. A síntese governamental: o Grupo de Trabalho da Reforma Universitária, a Comissão

Especial Meira Mattos e a Lei 5.540/1968 para a reforma do ensino superior.

3. Impactos da gestão na USP: "conversão" de dirigentes, centralização administrativa e emergência das estatísticas universitárias 233

3.1. A “conversão invisível” dos dirigentes da USP a partir dos anos 1970: experts em gestão,

lideranças institucionais e professores na direção da universidade 235

3.1.1. A profissionalização de experts em gestão a partir dos anos 1970 .............................. 236

3.1.2. A reprofissionalização de "lideranças institucionais" nos anos 1970 e 1980 .............. 254

3.1.3. A influência do discurso da gestão sobre os especialistas em política acadêmica....... 264



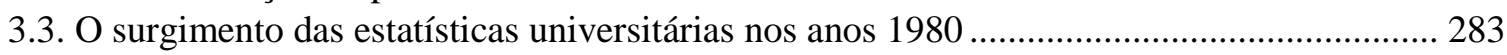


Capítulo 3. A transformação estrutural da USP: dominantes e dominados no contexto universitário.

1. Expansão e diversificação: mudanças na estrutura social e acadêmica da USP entre 1960 a 2010

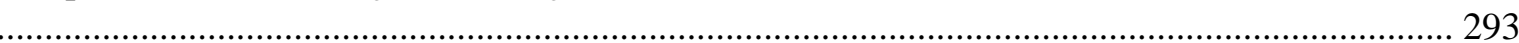

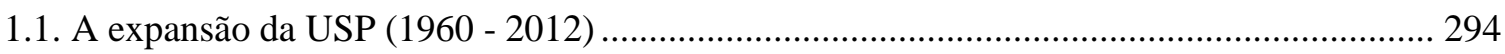

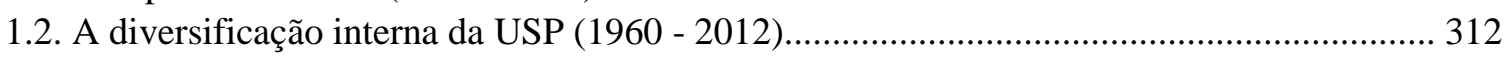

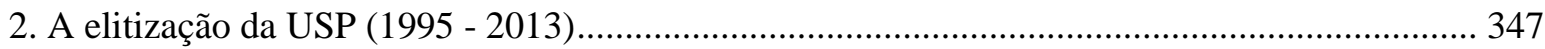

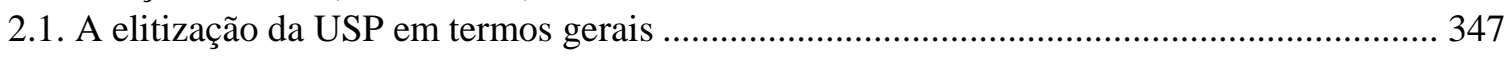

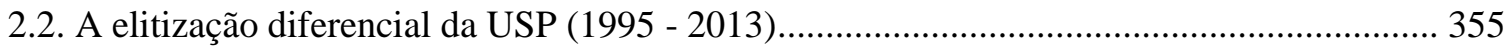

3. Dominantes e dominados no contexto universitário: a estrutura social da USP ........................ 383

Capítulo 4. Escolas de elite, escolas de poder: a socialização no polo dominante e o discurso da

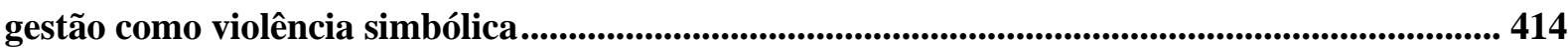

1. Escolas de poder, escolas de elite: a socialização para o controle e a produção social de uma elite



2. A produção social de elites dirigentes: socialização e homogeneidade do polo dominante da USP

2.1. A "imensa e poderosa família" das arcadas: socialização na Faculdade de Direito da USP 431

2.2. "Formando engenheiros e líderes": a socialização na Escola Politécnica.............................. 443

2.3. "Uma classe poderosa, preparada e coesa": a socialização na Faculdade de Medicina ....... 453

3. O discurso da gestão como violência simbólica: o novo vocabulário das disputas sobre as formas

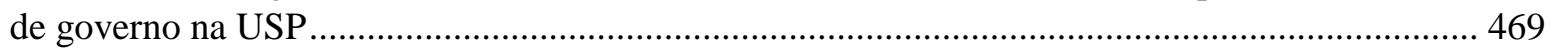

3.1. Os dirigentes centrais da USP: a hegemonia do polo profissional tradicional ...................... 471

3.2. O processo de imposição do discurso gerencial: reformas, programas e especialistas ......... 482

3.3. Categorias de avaliação do governo acadêmico: o discurso da gestão como violência

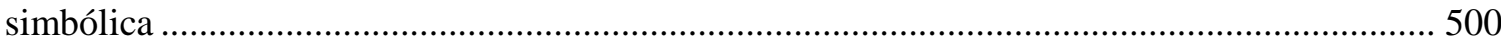

3.3.1. O olhar a partir "de cima": a capacidade de visão e o planejamento à luz da estrutura



3.3.2. A valorização da avaliação externa: a universidade de resultados.............................. 507

3.3.3. A valorização da liderança individual: a universidade centralizada .......................... 514

3.3.4. Crítica e resistência nos limites da gestão: a universidade gerenciada ........................ 520

Conclusão. 


\section{Introdução}

Conforme a ideia que ordinariamente se faz, a sociologia se coloca como finalidade revelar as estruturas mais profundamente enraizadas nos diferentes mundos que constituem o universo social, e também os "mecanismos" que tendem a assegurar a sua reprodução ou transformação. Mas [...] uma tal exploração das estruturas objetivas é, também e no mesmo movimento, uma exploração das estruturas cognitivas que os agentes engajam no seu conhecimento prático dos mundos sociais assim estruturados: existe uma correspondência entre as estruturas sociais e as estruturas mentais, entre as divisões objetivas do mundo social - notadamente em dominantes e dominados nos diferentes campos - e os princípios de visão e divisão que os agentes aplicam (Bourdieu, 1989, p. 7).

[...] em toda a sociedade, a produção do discurso é ao mesmo tempo controlada, selecionada, organizada e redistribuída por certo número de procedimentos que têm por função conjurar seus poderes e perigos, dominar seu acontecimento aleatório, esquivar sua pesada e temível materialidade (Foucault, 2011, p. 9).

Ao tratar sociologicamente "a questão da universidade" é preciso reconhecer, em primeiro lugar e como dimensão distintiva do problema, o fato de que ela constitui, há algumas décadas, o ponto de condensação de uma miríade de discursos conflitantes, não raro contraditórios, que disputam a melhor forma de descrever, para então ordenar, a instituição universitária. Ser objeto de disputas - particularmente de disputas discursivas que se desdobram no plano material, simbólico, cognitivo e político - é, portanto, um dos traços característicos da universidade contemporânea. A constatação dessa determinação incidiu profundamente sobre o desenho empírico da presente pesquisa. Metodologicamente, foi preciso operar um giro reflexivo no sentido de transformar as próprias noções que fundamentam os discursos sobre a universidade - em geral tidas como "evidentes" - em objeto de interrogação. Essa operação analítica pode ser explicitada, a título de ensaio, na tentativa de classificar o debate mais amplo que emerge das reformas universitárias da década de 1960 em dois grandes polos representados pelas posições sociais essenciais que estruturam, contemporaneamente, a instituição universitária.

Assim, em um primeiro extremo, estão os que consideram que a universidade vive, hoje, uma crise de dimensões abissais, cuja reversão depende de uma inflexão radical, sem a qual a única certeza é a do seu colapso. É partindo desse diagnóstico, por exemplo, que Bill Readings 
descreve a "universidade em ruínas" (1996) e Michel Freitag, o "naufrágio da universidade" (1995). A mesma sensação de declínio leva o historiador Peter Scott a evocar a "crise da universidade" (1984), atribuindo-lhe uma escala sem precedentes. Veredas semelhantes seguem os filósofos brasileiros José Arthur Giannotti e Franklin Leopoldo e Silva que, mobilizando diagnósticos opostos, descrevem "a universidade em ritmo de barbárie" (1986) e "a universidade em tempo de conciliação autoritária" (2004). Em uma dimensão mais mundana, porém igualmente significativa, podemos evocar as palavras de ordem que marcaram a greve de 2002 estudantil da Faculdade de Filosofia, Letras e Ciências Humanas da USP cuja pretensão era, justamente, resgatar a instituição do que parecia a sua ruína iminente: “acabou o amor. Isso aqui vai virar um inferno". Crise, declínio, agonia, destruição, regressão, perda são alguns dos elementos constitutivos do discurso da catástrofe universitária, percebida como tal no interior do polo acadêmico-científico. Constituído por campos disciplinares menos voltados à formação profissional, esse polo compõe o núcleo duro da clássica universidade de pesquisa ${ }^{1}$, tornandose o principal alvo das mudanças em curso.

No outro extremo, orbitam diagnósticos opostos que enxergam a universidade não como uma instituição que colapsa, mas como uma organização que se reinventa, mostrando-se, ao mesmo tempo, vigorosa e plástica, moderna e modernizável. A ideia norteadora, nesse caso, é a de que as transformações por que passa - ou deveria passar - a universidade são, além de positivas, "necessárias" e "desejáveis": trata-se de atualizar a universidade, aproximando-a de um funcionamento considerado "ideal" segundo os padrões da teoria organizacional moderna. As reformas são concebidas, nesse caso, como um processo que corrige "falhas" e "desvios"

\footnotetext{
${ }^{1}$ Estou denominando universidade de pesquisa as instituições inspiradas no chamado modelo alemão, que orientou grande parte das reformas universitárias do final do século XIX e início do XX e cujo cerne era a união entre as funções de ensino e pesquisa e a consolidação institucional da autonomia didática, científica e administrativa da universidade. Esse modelo tinha o seu núcleo, como no caso do projeto original da USP, nas áreas mais básicas de pesquisa, representadas, nesse caso, pela Faculdade de Filosofia, Letras e Ciências, em torno da qual se erguiam os institutos complementares, de matriz profissional. Nesse sentido, podemos dizer que todos os autores mencionados acima vêm desse "núcleo humboldtiano": Bill Readings foi professor de Letras. Michel Freitag, de filosofia e sociologia. Peter Scott é historiador. Arthur Giannotti e Franklin Leopoldo e Silva são, como dito, filósofos.
} 
atribuídos ao caráter excessivamente corporativo e acadêmico das universidades de pesquisa que, vistas dessa perspectiva “modernizante”, aparecem como “ultrapassadas”. É nesse registro, por exemplo, que Rudolph Atcon pretendia caminhar "rumo a uma reformulação estrutural da universidade brasileira" (1966), desenhando reformas de caráter administrativo para torná-la uma organização moderna. Foi compartilhando os mesmos pressupostos que James Ridgeway associou a crise das universidades norte-americanas ao seu caráter de "corporações fechadas" (1970), diagnóstico parecido ao que levou Burton Clark a prescrever, trinta anos depois, os caminhos para se criar uma "universidade empreendedora" (1998). A transição da corporação fechada para a organização empreendedora parece ter sido tão importante que se tornou objeto de diferentes análises, como a de Clark Kerr, que denomina esse processo de "a grande transformação", conferindo-lhe um aspecto marcadamente positivo (1991). A ideia de que essas transformações devem ser pensadas na chave de uma atualização é bastante disseminada determinando, por exemplo, as análises de Algo Henderson e Alfonso Borrero, ambos formuladores de política da Unesco, o primeiro, quando fala da "educação superior do mundo de amanhã" (1968) e o segundo, quando trata da universidade "como uma instituição hoje" (1993). Também no Brasil é possível encontrar exemplos significativos dessa visão otimista e engajada, como o título do documento publicado pelo Fórum de Pró-Reitores de Graduação das universidades brasileiras, "do pessimismo da razão ao otimismo da vontade" (1999). Modernização, atualização, adaptação, empreendedorismo, abertura, inovação, reforma são alguns dos tópicos dominantes no outro extremo do campo discursivo, formado não pelo corpo que sofre os impactos das reformas, mas pelos agentes diretamente envolvidos na sua produção, a partir de posições que lhe conferem poder para tanto ${ }^{2}$.

\footnotetext{
2 James Ridgeway foi jornalista investigativo de importantes semanários norte-americanos e documentarista. Escreveu e filmou temas diversos, dentre os quais um ensaio crítico sobre o funcionamento das universidades norte-americanas, que se tornou um best-seller nos anos 1970. Burton Clark é considerado um dos fundadores da chamada "moderna sociologia da educação", marcada pela importação da teoria das organizações para o campo de estudos educacionais. Como tal, ocupou um espaço privilegiado na formulação de políticas e orientações para a reforma do ensino superior no mundo todo, chegando a ser membro do Conselho Consultivo do Núcleo de
} 
Considerar a universidade, antes de mais nada, como objeto de formulações discursivas procurando associá-las às posições sociais de sua produção é, portanto, o desafio essencial do presente trabalho. Essa operação analítica implica, em primeiro lugar, conferir centralidade às disputas - em geral negligenciadas - pela imposição de uma linguagem, ou seja, de um sistema elementar de classificação, que estrutura o espaço dos possíveis e o campo do pensável no debate e no desenho de reformas universitárias, na medida em que determina, no plano cognitivo, a compreensão do que é, do que deve e do que pode ser uma universidade.

Dentre os diversos discursos que incidem sobre a instituição universitária, reivindicando a definição da sua função social e do seu ordenamento interno, esta pesquisa concentrou-se no discurso gerencial que, orientado pelas modernas teorias da gestão e inspirado em uma visão econômica da educação, tematiza o funcionamento do governo acadêmico segundo um vocabulário próprio, em que noções tais como eficiência, eficácia, metas, objetivos, resultados, diretrizes, planejamento, estratégia, liderança, missão, inovação e organização encerra todo um sistema de classificação e visão de mundo que está redefinindo completamente a universidade contemporânea. A decisão de priorizar o discurso da gestão inspirou-se em matrizes diversas.

Pesquisas sobre Educação Superior da USP (NUPES) no início dos anos 1990. Clark Kerr era economista de formação, inicialmente especializado em relações industriais, gestão do trabalho e negociações trabalhistas. Ganhou notoriedade internacional, no entanto, pela sua atuação e produção como "gestor" acadêmico. Ocupou altos cargos administrativos na Universidade de Washington e da Califórnia, tendo sido demitido desta última durante os protestos estudantis dos anos 1960, particularmente por conta dos desdobramentos do chamado Free Speech Movement, iniciado em 1964. Em 1967, tornou-se diretor da Carnegie Commission on Higher Education, posteriormente transformada na Carnegie Council on Policy Studies in Higher Education, ainda sob a direção de Kerr. Ambos foram, durante as décadas de 1960 e 1970, um dos centros mais importantes de estudo e orientação política do ensino superior, somando mais de 140 pesquisas entre 1967 e 1979 . Kerr trabalhou, ainda, para a Association of Governing Boards of Universities and Colleges Presidents e compôs inúmeras comissões políticas nacionais, dentre as quais: a Commission on National Goals (durante o governo de Dwight D. Eisenhower), o Advisory Committee on Labor Management Policy (durante o governo de John Kennedy), o National Committee for a Political Settlement in Vietnam. Também atuou na Rockefeller Foundation, na Carnegie Foundation for the Advancement of Teaching, no American Council on Education, and no Work in America Institute. Algo Henderson e Alfonso Borrero, como já mencionado, trabalharam como formuladores de política da Unesco. O primeiro é norte-americano, formado em direito e administração em Harvard, tendo atuado na Unesco nas décadas de 1960 e 1970. O segundo é colombiano, formado em arquitetura e teologia e trabalhou para a Unesco nos anos 1990. Ambos foram reitores de universidades e institutos de ensino superior em seus países. 
Em primeiro lugar, na literatura internacional sobre a mudança universitária, são muitos os trabalhos que enfatizam o impacto do conhecimento em gestão sobre a reorganização interna das instituições acadêmicas e dos seus procedimentos de decisão, controle e organização do trabalho. Alguns autores denominam esse processo de "colonização gerencial", associando-o a uma transformação estrutural das universidades públicas, europeias no caso (cf. Charle \& Soulié, 2007; Gall \& Soulié, 2007; Lorenz, 2007). Partindo de uma análise mais centrada nas universidades francesas, Christine Musselin fala em uma "onda de gestão" em que managers profissionais passam por cima das especificidades da instituição universitária para promover um conjunto de reformas inspiradas nos modelos abstratos da teoria organizacional (cf. 2005, 2006, 2007). No mesmo sentido, Georg Krücken, Albrecht Blümel e Katharina Kloke mencionam uma "virada gerencial" das instituições de ensino superior alemãs, mostrando que esse processo teve um impacto decisivo na sua transformação (cf. 2013). Na sua análise sobre a transformação da universidade inglesa, Marylin Strathern destaca a emergência de uma "cultura da auditoria" em que o discurso do management torna-se um idioma ubíquo pautado na regulação e na organização (cf. 2000, p. 2). Os noruegueses Ase Gornitzka, Svein Kyvik e Ingvild Larsen descrevem o que eles definem como uma "burocratização" das universidades nórdicas, justamente a partir da profissionalização da sua administração acadêmica (cf. Gornitzka, Svein \& Larsen, 1998; Gornitzka \& Larsen, 2004). De modo análogo, Gary Rhoades e Larry Leslie, tomando o exemplo dos Estados Unidos nos anos 1990, observavam um “crescimento dramático dos custos administrativos de universidades e colleges nas últimas duas décadas" (1995, p. 187), buscando enfatizar seus efeitos em termos de uma crise da profissão acadêmica. Olhando para as universidades europeias entre os anos 1980 e 1990, Rhoades, em parceria com Barbara Sporn, mencionam a emergência "de uma administração mais 'profissionalizada', com gestores permanentes, em dedicação integral e com poderes crescentes" (Rhoades \& Sporn, 2002, p. 3). Os autores identificam uma mudança semelhante 
nos métodos de gestão acadêmica das universidades norte-americanas, onde o processo assume uma feição ainda mais radical, a ponto das mudanças em curso serem descritas como a emergência de um “capitalismo acadêmico" (cf. Rhoades \& Sporn, 2002; Rhoades \& Slaughter, 2004; Slaugther \& Leslie, 1997).

Na literatura especificamente brasileira sobre a transformação da universidade, também não são poucas as referências à centralidade do conhecimento gerencial no desenho de reformas universitárias. Ao tratar do processo de modernização da universidade brasileira, Irene Cardoso, por exemplo, enfatiza a importância do "planejamento racional" das atividades acadêmicas, mostrando como esse processo implica "a burocratização crescente da esfera da cultura (e da ciência), com a transformação da universidade numa grande organização racional, na qual essa racionalidade de caráter funcional, instrumental, ou formal, está subordinada à ideia de cálculo" (2001, p. 67). A análise de Marilena Chauí sobre a obsolescência da universidade liberal no Brasil também enfatiza o papel crítico da administração, enquanto modelo organizacional baseado na grande empresa, na imposição de uma ideia de "progresso" como sinônimo de uma “organização administrativa e administrada da universidade” (Chauí, 2001, p. 66). Em um diagnóstico semelhante, Franklin Leopoldo e Silva afirma que as reformas universitárias dos anos 1960 e, sobretudo, 1980 construíram uma "universidade gerencial" baseada na desqualificação da política "em todos os níveis" como "parte de um projeto político de dimensões transnacionais, que a tecnoburocracia brasileira leva a efeito naquilo que lhe compete e de acordo com as diretrizes de órgãos internacionais" (Silva, 1999, p. 27). Essas diretrizes internacionais estabelecem o "economicismo como padrão de gestão eficiente e racional" o que, segundo o autor:

[...] é a razão pela qual, a partir do final dos anos 80 , instalou-se na USP a mentalidade do "gerenciamento", isto é, a definição clara e inequívoca da direção universitária como algo primordialmente ligado a organização e métodos administrativos, com a elevação dos critérios de eficácia empresarial ao primeiro plano na consideração dos requisitos de gestão universitária (Silva, 1999, p. 26). 
Mas para além dessa literatura nacional e internacional sobre a transformação da universidade, o fortalecimento do conhecimento gerencial ocupa um lugar central na teoria social que busca formular uma crítica do capitalismo contemporâneo, enquanto estrutura social de dominação que determina processos de subjetivação que definem esquemas de percepção, sentimento e ação. É nessa chave, por exemplo, que Luc Boltanski e Ève Chiapello vão afirmar que o discurso do management constitui, hoje, "a forma por excelência do espírito capitalista", enquanto ideologia voltada à justificação da atuação de gerentes e dirigentes, cuja adesão ao sistema econômico-social é indispensável ao seu funcionamento (1999, p. 51). No mesmo sentido caminha a análise de Pierre Dardot e Christian Laval sobre a "nova razão do mundo", o neoliberalismo, definido como "o conjunto de discursos, práticas e dispositivos que determinam um novo modo de governo dos homens baseado no princípio universal da concorrência” (2010, p. 6). Essa nova racionalidade, como os autores apontam, é inseparável da "prática dos experts e administradores" que definem a gestão como uma "nova tecnologia de controle" e um novo modo de subjetivação (cf. Dardot \& Laval, 2010, p. 371). É também em termos de "nova racionalidade" que Albert Ogien analisa a emergência do "espírito gestionário" que faz com que as questões propriamente políticas, sobre a organização dos processos de discussão e deliberação no interior das instituições sociais, sejam cada vez mais nomeadas e descritas a partir de um léxico gerencial, emprestado da economia e da contabilidade. Como resultado dessa imposição cognitiva, uma parte substancial das decisões políticas - sobre a forma mesma dessas decisões - encontra-se implicada nas técnicas de administração que se impõem progressivamente aos responsáveis pelo governo dos homens (cf. Ogien, 1995, p. 12).

Os exemplos podem parar por aqui porque a intenção é apenas mostrar como a preocupação com conhecimento gerencial e o seu significado social vêm ganhando espaço nas análises sobre a mudança da universidade contemporânea, no Brasil e no mundo, e sobre a 
transformação da sociedade capitalista ela mesma. É partindo dessas análises que a presente pesquisa buscou interrogar o lugar do discurso da gestão na redefinição da universidade brasileira através da sua reestruturação interna. Este desenho de pesquisa permaneceria, no entanto, incompleto, caso as noções que constituem o discurso gerencial fossem compreendidas como meras elaborações intelectuais, obras do pensamento puro, da imaginação livre ou, ainda, expressões imediatas da "verdade". A disciplina sociológica - seja ela inspirada no materialismo histórico, no historicismo weberiano ou no método durkheimiano - compartilha o pressuposto de que os discursos e suas categorias constitutivas são essencialmente produtos sociais que, tanto na sua origem quanto nos seus efeitos, encontram-se profundamente conectados às estruturas e aos conflitos que instituem a sociedade. Esta pesquisa incorpora à análise do discurso gerencial, portanto, a problemática essencial da sociologia do conhecimento que se põe como tarefa explicar a formação, a difusão e o impacto das categorias de percepção, classificação e ordenação do mundo, particularmente as que constituem discursos especializados, legitimados pelo seu caráter pretensamente “científico".

Assim, considerando a teoria da gestão como um discurso com pretensão de verdade, produzido e difundido para descrever e, a partir disso, normatizar o funcionamento da universidade, esta pesquisa visa analisar tanto o impacto da estrutura social da universidade sobre a formulação do conhecimento gerencial quanto deste sobre a ordenação interna da instituição universitária. Isso implica não só considerar a expansão da gestão como um processo de imposição cognitiva e cultural, como também analisar essa mesma imposição - e a possibilidade de resistir a ela - à luz da estrutura social, marcadamente a estrutura de classes, entendida como sistema de relações sociais, econômicas e políticas que hierarquizam os diferentes universos sociais, incluindo, no caso, a universidade.

Tentando traduzir esse problema sociológico geral procurei desenhar uma pesquisa empírica que, enquanto um estudo de caso, buscava analisar o processo de difusão do 
conhecimento gerencial em uma única instituição, a Universidade de São Paulo, enfatizando os seus efeitos para a desestruturação da profissão acadêmica, vista como uma forma históricosocial de organização do trabalho baseada na institucionalização da autonomia e do autogoverno que, juntas, preservam a diversidade de funções, tradições e estilos de trabalho que marca a história da universidade como instituição social. A opção por realizar um estudo de caso se justificava na medida em que o objetivo essencial da pesquisa era analisar, em profundidade, o processo social de produção e difusão do saber gerencial na universidade, enfatizando a relação entre esse discurso e a estrutura social. A escolha da USP como objeto de pesquisa baseou-se, essencialmente, no reconhecimento do lugar central que ela ocupa no campo do ensino superior brasileiro, ditando rumos e tendências.

De fato, a Universidade de São Paulo, com 80 anos de existência, é a maior e mais tradicional universidade pública do país, tendo sido recentemente considerada, pelos sistemas internacionais de ranqueamento, também a melhor e mais importante universidade de pesquisa da América Latina e uma das mais prestigiadas instituições universitárias do mundo. Do ponto de vista das suas dimensões internas, a USP também é uma instituição de peso, exercendo, por isso, efeitos sobre o conjunto do sistema. Para citar só os dados mais gerais, a USP tem quarenta e duas unidades de ensino e pesquisa, seis institutos especializados, quatro museus, quatro hospitais, quarenta e quatro bibliotecas que somam um acervo de mais de 8 milhões de livros, uma editora, uma rádio, pelo menos um jornal de média circulação e dezenas de revistas de distribuição nacional. Geograficamente, a USP se espalha por sete campi localizados em sete cidades diferentes. Todo esse aparato consumiu, em 2013, mais de R $\$ 4$ bilhões em repasses diretos do tesouro do estado de São Paulo, sem contar as outras formas de financiamento público e privado recebidos pela instituição no período. Muitos indicadores poderiam seguir demonstrando a centralidade da USP no campo brasileiro de ensino e pesquisa. Mas, talvez, o indício mais significativo, do ponto de vista sociológico, da proeminência da USP seja o seu 
caráter de quase-evidência, fruto da percepção socialmente compartilhada do seu predomínio: em suma, é possível afirmar a centralidade da USP sem precisar mobilizar dezenas de indicadores porque, afinal, "todo mundo sabe" o lugar que ela ocupa ${ }^{3}$.

É justamente como instituição dominante que a USP exerce enorme poder na definição de tendências em três dimensões centrais para a formação contemporânea da sociedade brasileira: o das práticas pedagógicas - com reflexos em todos os níveis de ensino -; o da pesquisa científica - desde as mais básicas até as voltadas para a aplicação econômica, política ou social -; e o das profissões especializadas - ligadas, portanto, à formação das elites profissionais que compõem, e de certo modo dirigem, o Estado brasileiro, a sociedade civil e o setor econômico, sobretudo a partir da profissionalização das funções de direção. Esse poder de influência sobre o sistema de ensino e pesquisa - instrumento essencial para a constituição e legitimação de estruturas sociais de dominação - torna a USP um objeto privilegiado de disputa entre diferentes classes, frações de classe e grupos sociais que travam, através de lutas na universidade e pela universidade, um dos frontes da batalha pelo sentido e orientação da sociedade brasileira.

Ao reconhecer essa função específica da universidade em geral e da USP em particular, o problema teórico geral desta pesquisa - a relação entre categorias de pensamento e estrutura social ou, se quisermos, entre sistemas de classificação e sistemas de dominação - pôde ganhar uma configuração empírica bastante concreta. Isso porque a USP, pela sua centralidade na constituição da sociedade local e nacional enquanto instrumento de produção e legitimação de estruturas sociais de dominação, torna-se ela mesma, objeto privilegiado de disputas que assumem, não raro, contornos violentos. Tais disputas se desenrolam, evidentemente, em múltiplos níveis, tais como: a escolha dos currículos acadêmicos e conteúdos disciplinares; a

\footnotetext{
${ }^{3}$ Reconhecer que a USP é, hoje, a mais importante universidade brasileira não significa ignorar o processo de construção dessa imagem da USP como exemplo máximo de "excelência" ou mesmo as inúmeras derrotas que a USP sofreu no plano das definições de padrões de funcionamento universitário e científico.
} 
criação de vagas, cursos e carreiras; o estabelecimento de prioridades, padrões e culturas de pesquisa; a legitimação de métodos científicos e pedagógicos; a determinação de áreas e formatos da chamada "extensão universitária"; e a mobilização de critérios de seleção e avaliação do alunado. No entanto, existe um nível de embate que é pressuposto para todos esses: a definição dos processos de ação, controle e decisão no interior da universidade, tal como expresso nas regras do seu governo ${ }^{4}$. E é precisamente sobre esse nível de disputa - como dito, essencial para todos os outros - que incide de modo paradigmático o discurso da gestão sendo, portanto, também sobre ele que se concentrou o meu esforço de pesquisa.

Assim, a hipótese geral deste trabalho, que estruturou toda uma primeira fase do processo de investigação, era de que o governo central da USP vinha se transformando nos últimos anos a partir da imposição dos princípios das modernas teorias da gestão, tal como descrito pela literatura sobre a mudança universitária em diversos países do mundo. Essa hipótese geral foi facilmente confirmada na primeira fase do meu trabalho de campo, voltada para a análise de atas, relatórios, manuais, portarias e outros documentos produzidos no âmbito central da universidade a partir dos anos 1980, momento em que parte importante da literatura localizava o início dessas mudanças, até 2010, quando se encerrava a presente pesquisa. Esse material me permitiu identificar claramente a influência dos princípios gerenciais, seja na implementação de dispositivos técnico-materiais de gestão, seja na legitimação de dirigentes que se apresentavam como portadores desse conhecimento específico.

No entanto, à medida que eu avançava na segunda fase da minha pesquisa de campo, que consistia em entrevistar reitores, pró-reitores e diretores administrativos da USP ${ }^{5}$ para

\footnotetext{
${ }^{4}$ Usamos o termo governo, e não outros mais comuns como gestão, administração, liderança ou governança acadêmica, justamente para escapar do vocabulário mobilizado nas disputas que vamos estudar. Embora ainda pouco usado no Brasil, o termo "governo acadêmico ou universitário" é bastante recorrente na literatura sobre história e funcionamento das universidades (cf. Friedberg \& Musselin, 1991; Henkel, 1991; Neave \& Van Vught, 1991; Rothblatt \& Wittrock, 1993; Rüegg, 2004).

${ }^{5}$ A amostra dos dirigentes da USP incluía todos os reitores, pró-reitores e diretores da Codage que ocuparam esses postos entre 1986 e 2010. Eu consegui entrevistar parte importante deles. Embora, metodologicamente, eu tenha optado por não nomear meus entrevistados optando por identificá-los por suas propriedades sociais relevantes,
} 
entender como eles participavam e avaliavam o processo de expansão do conhecimento gerencial na universidade, eu fui percebendo que, embora o domínio da gestão tivesse visivelmente se fortalecido na universidade a partir dos anos 1980, os dirigentes que atuaram nos órgãos centrais de direção, durante esse período, desprezavam taxativamente a "administração", tanto como um campo específico de conhecimento quanto como conjunto de práticas. Essa recusa assumiu, na grande maioria dos casos, um mesmo sentido: a administração era vista como simples atividade de execução a serviço de diretrizes, projetos e metas concebidos pela direção central da instituição. Não ser conduzido, conduzir era, portanto, o ideal que transparecia nessas avaliações que revelam, justamente, como os dirigentes da USP mobilizam um esquema categorial - expresso nas oposições entre alto/baixo, elevado/rasteiro, nobre/vulgar - que traduz hierarquias socialmente significativas entre direção/execução, comando/obediência ou, em casos extremos, pensamento/atividade e concepção/trabalho.

Em suma, o que o meu trabalho de campo revelava era que os principais responsáveis pela imposição da visão gerencial da USP, tanto como profissionalização de instrumentos e rotinas de coordenação, controle e avaliação quanto como construção de um modelo de gestão estratégica baseada em visões, diretrizes e metas claramente estabelecidas pelo poder central,

achei fundamental listar as entrevistas realizadas. Foram elas: José Goldemberg (entrevista realizada no Instituto de Eletrotécnica e Energia da USP em 21 de novembro de 2012); Roberto Leal Lobo (entrevista realizada no Instituto Lobo, em Mogi das Cruzes, em 07 de março de 2013); Ruy Laurenti (entrevista realizada no seu laboratório na Faculdade de Saúde Pública em 03 de dezembro de 2012); Flávio Fava de Moraes (entrevista realizada no gabinete da presidência da Fundação Faculdade de Medicina, na Faculdade de Medicina, em 25 de abril de 2013); Jacques Marcovitch (entrevista realizada na sala do Conselho de Departamento de Administração, na Faculdade de Economia, Administração e Contabilidade em 14 de maio de 2013); Joaquim José de Camargo Engler (entrevista realizada na Diretoria Administrativa da FAPESP em 21 de novembro de 2012); Hélio Nogueira da Cruz (entrevista realizada no Gabinete da Vice-reitoria da USP em três seções em 27 de maio, 07 de junho e 25 de junho de 2013); Erney de Camargo Plessmann (entrevista realizada na sua sala pessoal no Instituto de Ciências Biomédicas em 21 de maio de 2013); Hugo Armelin (entrevista realizada na sua sala pessoal no Instituto Butantã em 21 de maio de 2013); Carlos Alberto Barbosa Dantas (entrevista realizada nas suas salas pessoais no Instituto de Estudos Avançados e no Instituto de Matemática e Estatística em duas seções, em 11 de maio e 17 de junho de 2013); Geraldo Serra (entrevista realizada na presidência da Fundação Faculdade de Arquitetura em 16 de abril de 2013); Celso Beisiegel (entrevista realizada na sua sala pessoal na Faculdade de Educação em 25 de abril de 2013); Sônia Penin (entrevista realizada na sua sala pessoal na Faculdade de Educação em 03 de julho de 2013); Ada Pelegrini Grinover (entrevista realizada na sua residência em 06 de junho de 2013); Oswaldo Ubríaco (entrevista realizada na sua residência em 29 de novembro de 2012); Luiz Nunes de Oliveira (entrevista realizada na sua sala pessoal no Instituto de Física de São Carlos em 12 de junho de 2013); Sedi Hirano (entrevista realizada na Faculdade de Filosofia, Letras e Ciências Humanas em três sessões, em 28 de agosto, 04 de setembro e 12 de setembro de 2012). 
desprezavam a gestão e a administração seja como ciência específica seja como um repertório de procedimentos e práticas. Esse aparente paradoxo me obrigou a perguntar, afinal, como foi possível que a gestão reestruturasse completamente o governo da USP se os seus dirigentes, diretamente responsáveis por esse processo, se mostravam claramente contrários a ela? Para responder a essa questão e tentar dar conta desse aparente paradoxo, optei por conjugar dois caminhos de análise, pavimentados pelas referências teóricas que orientavam, desde o começo, esta pesquisa, porém não de modo tão determinante.

Por um lado, eu procurei entender a gestão como um sistema de classificação que pôde se impor no interior desse universo específico - a Universidade de São Paulo - justamente por se adequar à sua estrutura social interna incorporando, portanto, as oposições cognitivas que ela engendrava. Isso significava, em suma, assumir a perspectiva de Pierre Bourdieu de que, na análise sociológica, a “exploração das estruturas objetivas é, também e no mesmo movimento, uma exploração das estruturas cognitivas que os agentes engajam no seu conhecimento prático dos mundos sociais assim estruturados" (1989, p.7). Nessa chave, foi imprescindível pensar a história da USP no modelo de uma história estrutural que identificasse as estruturas essenciais de dominação social, política e acadêmica, procurando entender, ao mesmo tempo, como essas estruturas estão na raiz das categorias cognitivas que se impuseram para a totalidade da universidade em um claro movimento de violência simbólica (cf. Bourdieu, 1980, 1984, 1989).

Por outro, o andamento da pesquisa foi mostrando como era cada vez mais importante analisar a gestão enquanto uma formação discursiva que, pela mobilização de dispositivos técnico-materiais, transformava profundamente o funcionamento da universidade. Esse processo, de afirmação de instrumentos, rotinas, práticas e procedimentos gerenciais, contribuía para impor a gestão como linguagem específica reafirmando, assim, as suas categorias essenciais. Em outras palavras, foi preciso entender, à luz dos trabalhos de Michel Foucault, a o discurso da gestão como um dispositivo de saber-poder que se impôs em sua "pesada e temível 
materialidade" (Foucault, 2011, p. 9).

O presente trabalho parte de uma tentativa de estabelecer um diálogo entre essas duas tradições teóricas ${ }^{6}$ que, conjugadas, possibilitam realizar uma análise estrutural das formações discursivas sem que isso implique desconsiderar o papel dos discursos na construção de estruturas sociais. Esse esforço duplo foi mobilizado, nesta pesquisa, para entender tanto a história da Universidade de São Paulo e da sua transformação quanto o processo de difusão do discurso da gestão e a sua aplicação à universidade brasileira, à USP, em particular. Esse esforço de análise se distribui em quatro capítulos que se organizam da seguinte forma. O primeiro capítulo, Posições sociais e visões do passado: por uma história estrutural da USP, analisa as diferentes linhas de reconstrução da história da USP à luz das posições sociais e institucionais que fundamentam essas visões do passado, buscando justificar, na prática, a opção pela história estrutural. O segundo capítulo, chamado Posições sociais e visões de futuro: a emergência da universidade como objeto de gestão, é uma tentativa de analisar a gestão como um novo regime de verdade que, mobilizando dispositivos técnico-materiais e difundindo uma linguagem específica, conseguiu transformar a universidade em objeto de gestão, o que possibilitou a emergência de estatísticas universitárias que dão suporte ao terceiro capítulo, A transformação estrutural da USP: dominantes e dominados no contexto universitário, que se volta para as transformações do padrão de expansão da USP e seus efeitos sobre a estrutura social da universidade. $\mathrm{O}$ quarto e último capítulo, intitulado Escolas de elite, escolas de poder: a socialização no polo dominante e o discurso da gestão como violência simbólica, pretende analisar o processo de socialização no polo dominante da universidade, onde se formou a

\footnotetext{
${ }^{6}$ Eu já realizava a presente pesquisa quando foram publicados dois artigos de Gil Eyal, em colaboração com Larissa Buchholz e Grace Pok, que tematizavam justamente a possibilidade de unir a abordagem estrutural de Bourdieu à análise construtivista referenciada em Foucault (Eyal \& Buchholz, 2010; Eyal \& Pok, 2011). No mesmo sentido caminha o artigo de Bernard Lahire que defende, justamente, diálogo entre a perspectiva bourdieusiana que enfatiza a relação entre os discursos e as posições sociais, identificando o poder dos discursos ao lugar do campo social em que eles são produzidos, com a perspectiva foucaultiana que prioriza o poder dos discursos em si, tratando eles mesmos como uma estrutura (cf. Lahire, 2001). Ou mesmo o artigo de Remi Lenoir sobre a construção do objeto sociológico onde o diálogo entre essas duas tradições também aparece como um esforço importante (cf. 1998).
} 
maioria dos dirigentes que se engaja em atividades de coordenação e direção no âmbito da universidade, mostrando como o discurso da gestão, que se adequa à visão de universidade predominante nesse polo, passou a determinar os termos em que as disputas pelo governo acadêmico são travadas no interior da USP, em um caso típico de violência simbólica. A conclusão retoma as principais conclusões desta tese, apontando perguntas que ela permite formular, o que já indica que esta pesquisa não se encerra com o presente trabalho. 


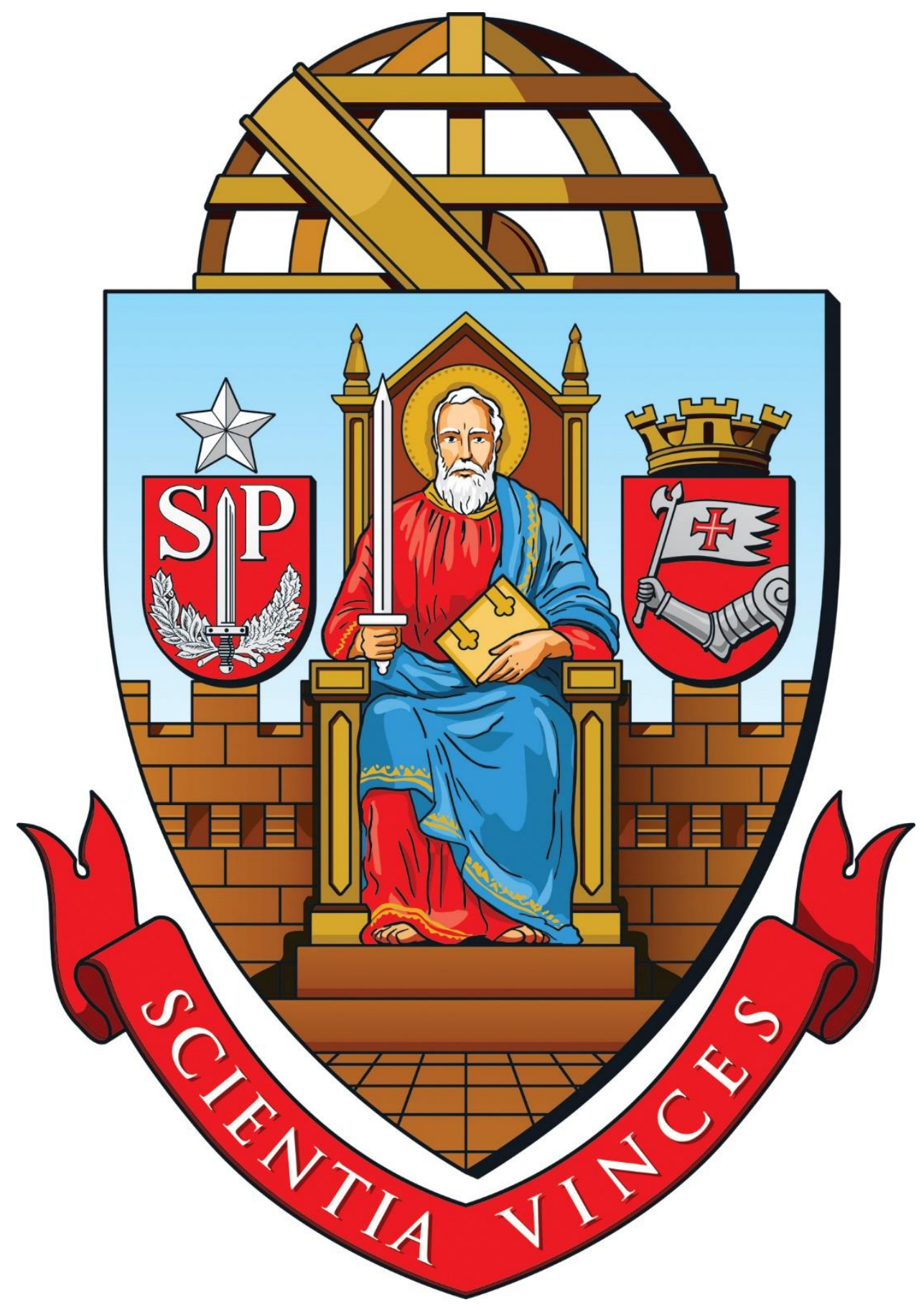

Figura 1. Brasão d'armas da USP 


\title{
Capítulo 1. Posições sociais e visões do passado: por uma história estrutural da USP
}

\begin{abstract}
Em escudo antigo o apóstolo São Paulo, sentado numa cátedra guarnecida de ouro encostada a um muro ameiado, acompanhado à destra pelo escudo do Estado de São Paulo e à sinistra pelo da Capital, ambos com seus timbres. O apóstolo de encarnação, vestido de vermelho e com manto azul, empunha com a destra uma espada em riste e mantém com a sinistra um livro. A cátedra é firmada sobre dois degraus e estes sobre o chão em ponta. Tudo de sua cor. O timbre, uma esfera armilar sainte de ouro. [Abaixo] um listão vermelho com a divisa "Scientiae Vinces" em letras de prata. São Paulo, dezembro de 1934. Explicação do brasão d'armas da Universidade de São Paulo por José Wasth Rodrigues (Ernesto de Souza Campos. A história da universidade de São Paulo, 1954, n.p.).
\end{abstract}

No romance machadiano praticamente não há frase que não tenha segunda intenção ou propósito espirituoso. A prosa é detalhista ao extremo, sempre à cata de efeitos imediatos, o que amarra a leitura ao pormenor e dificulta a imaginação do panorama. Em consequência, e por causa também da campanha do narrador para chamar atenção sobre si mesmo, a composição do conjunto pouco aparece. Entretanto, ela existe, e, se ficarmos a certa distância, deixa entrever as grandes linhas de uma estrutura social (Roberto Schwarz. Um mestre na periferia do capitalismo, 2000, p. 18).

A ideia de que a Universidade de São Paulo deva ter um brasão d'armas tem, em si, algo de excêntrico. Uma instituição fundada em pleno século $\mathrm{XX}$, expressão de um anseio essencialmente modernizador, recorrendo a um símbolo medieval como forma de forjar uma tradição milenar capaz de legitimá-la junto às suas congêneres mais antigas e, por isso, percebidas como mais autênticas, soa, no mínimo, deslocado. De início, a tentação é remeter tal iniciativa à extravagância das nossas “elites agrárias sedentas de títulos que as aproximassem das antigas aristocracias europeias" (Schwarcz, 1993, p. 110). No caso do brasão d'armas da USP, entretanto, no seu sentido e na sua função, constantemente atualizados, esconde-se algo de mais complexo.

De fato, ainda hoje, o brasão d'armas da USP constitui símbolo máximo da universidade ganhando, como tal, enorme visibilidade. Não por acaso, portanto, o brasão constitui o timbre oficial da USP, acompanhando grande parte dos seus documentos, particularmente os históricos escolares, os comprovantes de matrículas e outros registros acadêmicos de uso cotidiano dos alunos de graduação e pós-graduação. Além disso, mais recentemente, passou a ilustrar a página 
inicial do webmail institucional da USP e o site oficial da universidade. A partir de 2013, passou a constar, acompanhado da sua explicação oficial, na primeira página do anuário estatístico, publicação que divulga os números da USP para dentro e para fora da universidade. Mas o mais surpreendente e inusitado, a imagem do brasão d'armas também foi espalhada, nos últimos anos, por diversos locais de passagem como os restaurantes universitários reformados, as bibliotecas de diferentes institutos, em entradas e saídas de prédios da universidade. Sempre em posição de destaque, a imagem aparece para os uspianos que, no seu cotidiano repleto, atentam às paredes em volta, seja como uma ilustração qualquer e sem importância, seja como um reflexo natural da vida na mais tradicional universidade de pesquisa do país, seja ainda, para os mais críticos, como outra idiossincrasia da direção universitária que não vem ao caso. Em todas as alternativas, o brasão é visto como uma simples imagem, desprovida de qualquer significado mais profundo.

Ainda assim, o apóstolo Paulo armado segue encarando, indiferente, os uspianos que passam apressados e, à moda de uma esfinge, sugere que ali subsista alguma verdade mais essencial. E subsiste de fato. Como na prosa machadiana em que a profusão de detalhes e as peripécias do narrador amarram o leitor ao pormenor, impedindo-o de apreender o significado mais profundo do conjunto, o brasão d'armas da USP também esconde, nos seus traços mais insignificantes e insólitos, "as grandes linhas de uma estrutura social” que só se mostra, no entanto, "se ficarmos a certa distância" (Schwarz, 2000, p. 18).

A grande dificuldade de tentar realizar uma pesquisa que assume o pressuposto de que a análise das relações objetivas, expressão das estruturas sociais, só se completa com a análise dos esquemas de percepção, de pensamento e de ação, produto dessas estruturas sociais incorporadas enquanto estruturas cognitivas (Bourdieu, 1989, p. 7ss), é que o movimento de determinação entre uma estrutura e outra tem algo de circular. Dito de outro modo, embora a abordagem estrutural pressuponha a primazia da estrutura social, enquanto expressão de 
condições materiais de existência essencialmente distintas, inscritas em instituições e corpos (Bourdieu, 1980, p. 94-6), a possibilidade de apreensão dessa estrutura, assim como de sua reprodução ou transformação, depende essencialmente das categorias de pensamento e classificação que ela produz e reforça.

Essa dupla determinação impõe uma enorme dificuldade de exposição. Para seguir com a analogia machadiana, é fácil padecer da mesma dúvida que acomete o seu "defunto autor": começar pelo princípio ou pelo fim? Neste caso, pela estrutura social ela mesma ou pelas categorias de percepção, pensamento e ação que ela engendra? Nesta tese, como nas Memórias póstumas de Brás Cubas, a opção foi começar pelo fim, ou seja, pelas categorias cognitivas, tal como expressas nas diferentes representações da história da USP. Essa opção se justifica porque ela permite, a um só tempo, expor o objeto e justificar a abordagem adotada que, no caso, parte da análise das insuficiências da historiografia atual sobre a USP, para defender a opção por uma “história estrutural”. É importante frisar desde já que, na presente análise, essas historiografias ditas "parciais", porque incapazes de tomar a distância necessária para apreender o espaço estruturado da USP que lhes confere sentido, não são simplesmente descartadas como mero erro ou desvio, resultado de uma operação pré-científica e, portanto, inválida. Na verdade, essas historiografias foram restauradas como parte essencial do objeto. Em síntese, confere-se a essas "histórias" o estatuto de problema de investigação, o que implica projetar também sobre elas as categorias analíticas que estruturam o presente trabalho.

Este primeiro capítulo se divide em quatro seções. A primeira se dedica à historiografia "oficial" da USP, marcada por obras escritas a partir de posições de poder no interior da instituição. A segunda interrompe a descrição da historiografia para inserir as categorias essenciais da análise estrutural; a terceira retorna para a análise da historiografia tomando como objeto os trabalhos escritos a partir de uma posição institucional diametralmente oposta à que define a história oficial, ou seja, a partir dos estudos de história e filosofia da educação, social 
e academicamente dominados. Por fim, a conclusão resume a chave de leitura estrutural para retomar a análise do brasão d'armas da USP, a partir da distância capaz de revelar o seu sentido, o que abre caminho para localizar a tradição paulista de história estrutural à qual se filia o presente trabalho.

\section{Entre "fatos" e "feitos": perspectiva finalista e história oficial}

No dia 25 de janeiro de 2014, a maior e mais conceituada universidade pública brasileira, a Universidade de São Paulo, completou oitenta anos ${ }^{7}$. Nos eventos de comemoração, ainda era possível ouvir o eco dos bumbos e gritos de mais uma greve estudantil e dos debates e burburinhos de mais uma eleição para reitor. À primeira vista, essas duas expressões opostas da vida política universitária - a eleição reitoral e a greve estudantil - compõem apenas mais dois registros na sucessão de "fatos" e "feitos" que, ao longo das décadas, constituem a história da USP.

Por certo, na narrativa do movimento estudantil, a greve e a ocupação da reitoria serão descritas como mais um ato heroico de uma "comunidade sufocada" por uma "burocracia autoritária" e "indiferente à urgente democratização da universidade". Já na perspectiva dos dirigentes, a reintegração de posse da reitoria e a condução da eleição em meio aos protestos e pressões terá representado mais um momento de "coragem" em que se fez valer "a responsabilidade da direção" que, com "alma forte" e "têmpera de aço", conseguiu manter a

\footnotetext{
${ }^{7}$ A Universidade de São Paulo foi fundada em 25 de janeiro de 1934, com sede na cidade de São Paulo, pelo decreto estadual ${ }^{\circ} 6.283$, assinado pelo então interventor estadual Armando Salles de Oliveira. Na sua formação original, a USP era composta por faculdades profissionais pré-existentes - a Faculdade de Direito, a Escola Politécnica, a Faculdade de Medicina, a Faculdade de Odontologia e Farmácia, a Faculdade de Medicina Veterinária, a Escola Superior de Agricultura, o Instituto de Educação, e a Escola de Belas Artes, que não ficou muito tempo associada à nova universidade - às quais se somaram duas novas unidades: a Faculdade de Filosofia, Ciências e Letras, que entrou em funcionamento ainda em 1934, e o Instituto de Ciências Econômicas e Comerciais que só se efetivou em 1946, como Faculdade de Economia e Administração.
} 


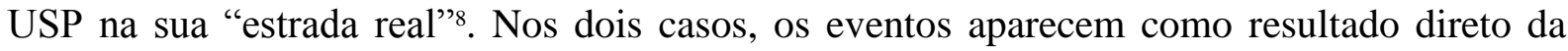
atuação consciente de homens imbuídos da certeza de que suas ações determinam a história. Entre essas duas forças historicamente contrapostas, a percepção secretamente compartilhada de que ambas, a despeito das suas profundas diferenças ideológicas e práticas, se sabem parte de uma mesma elite política9 .

Essa visão inerente aos "homens de ação", de que nada existe na história senão feitos, se traduz diretamente na historiografia predominante sobre a USP que, por partilhar uma "visão ingenuamente finalista da história" (Bourdieu, 1984, p. 12), marcada pela primazia da ação individual, confere à narrativa dos próprios uspianos, quase sempre de autoconsagração, um lugar absolutamente central. Essa perspectiva finalista concebe o desenvolvimento institucional como "um todo, um conjunto coerente e orientado que pode e deve ser apreendido como expressão unitária de uma 'intenção’ subjetiva e objetiva, de um projeto” (Bourdieu, 1986, p. 69; grifo meu). Essa perspectiva historiográfica reverte-se, no entanto, no seu aparente contrário: por conceber "uma história contínua, aberta ao trabalho de uma teleologia e aos processos indefinidos da causalidade" garantindo "os poderes de uma consciência constituinte" (Foucault, 2010, p. 275), essa mesma historiografia termina por conceber os acontecimentos históricos como uma mera sucessão de fatos desprovidos de significação, ignorando que os

\footnotetext{
${ }^{8}$ As expressões inseridas entre aspas neste parágrafo são falas dos próprios atores. Para caracterizar o discurso do movimento estudantil, utilizou-se termos e adjetivações de panfletos distribuídos durante a greve de 2013. Para caracterizar o discurso dos dirigentes, mobilizou-se as expressões utilizadas por Ernesto de Souza Campos para descrever a ação das diretorias da Faculdade de Medicina e da Escola Politécnica durante as primeiras mobilizações estudantis, ainda no começo do século XX (cf. Campos, 1954, p. 354).

${ }^{9}$ O movimento estudantil da USP é reconhecidamente um espaço importante para a formação de lideranças políticas. Só para exemplificar, na última eleição para a prefeitura de São Paulo, o segundo turno opôs dois antigos militantes do movimento estudantil da USP: José Serra (PSDB) e Fernando Haddad (PT). Ambos disputavam o lugar que cabia a outro uspiano, o então prefeito Gilberto Kassab (PSD), que também iniciou sua carreira política no movimento estudantil dessa instituição. No outro extremo, é importante frisar que existe um forte trânsito de dirigentes acadêmicos entre posições de controle da universidade e outras funções executivas no aparelho de Estado, em nível municipal, estatual e federal. Ainda que a porta de entrada na vida pública seja diferente - uns pela via propriamente política e os outros por um caminho pavimentado pela legitimidade burocrática -, tanto as lideranças do movimento estudantil quanto os dirigentes acadêmicos acabam formando uma mesma elite política que dirige, juntamente com outras forças sociais, o aparelho estatal brasileiro.
} 
acontecimentos devem ser vistos como "a irrupção de uma singularidade única e aguda, no lugar e no momento da sua produção" (Cardoso, 2001, p. 217).

A perspectiva finalista que concebe a história como o resultado da ação consciente de homens que dirigem a instituição assumindo um determinado sentido marca de modo significativo uma parte importante da historiografia sobre a USP, composta pelas obras que formam a sua história oficial. Podem ser incluídos nessa categoria todos os trabalhos escritos a partir de posições de poder repercutindo, nas suas reconstruções históricas, as visões inerentes a esse lugar institucional, ocupado pelo polo dominante da universidade formado, como se verá, pelas faculdades profissionais tradicionais.

Tem sido assim desde o primeiro livro que se pretende "uma história da USP", concluído pelo ex-reitor Jorge Americano em 1946 e intitulado A Universidade de São Paulo: dados, problemas e planos (Americano, 1947). Na mesma linha, as diferentes Memórias e Recordações do também ex-reitor Miguel Reale inserem-se como outro exemplo interessante (Reale, 1986a, 1986b, 1987 e 1994). Ambos, além de políticos importantes do estado de São Paulo, eram professores catedráticos da Faculdade de Direito da USP. Outros dirigentes acadêmicos também escreveram sobre a história da USP, seja sob a forma de artigos acadêmicos, seja sob a forma de memórias. No primeiro caso, pode-se incluir o recente artigo do também professor de direito e ex-reitor da USP, João Grandino Rodas, intitulado História da Universidade de São Paulo e escrito em parceria com Shozo Motoyama (Rodas \& Motoyama, 2011). No segundo caso, pode-se incluir as memórias do médico e ex-reitor Hélio Lourenço de Oliveira, publicadas em volume de homenagem a ele (Oliveira, 1995), ou ainda o diário do ex-reitor da USP e o professor de administração da FEA, Jacques Marcovitch, publicado com o título Universidade viva, diário de um reitor (2001). É nessa linha de trabalhos que se localiza, também, a obra intitulada Universidade de São Paulo: súmula de sua história, de Josué Camargo Mendes, que foi ex-diretor do Instituto de Geociências de 1970 a 1974 e 
vice-reitor da USP de 1973 a 1977 (Mendes, 1977). Pode além disso ser interpretado nessa direção o livro Universidade de São Paulo: subsídios para uma avaliação, organizado pela professora Eunice Lacava Kwaniscka da Faculdade de Economia e Administração da USP a pedido do engenheiro e então reitor da USP, Hélio Guerra Vieira, no momento em que se fortalecia, na universidade, um discurso da avaliação institucional. O livro reúne, assim, a colaboração de diversos professores da USP, tendo em vista subsidiar os processos de avaliação que estavam sendo projetados pelo poder central (Kwaniscka, 1985). No mesmo sentido, pode ser incluído nesse estilo de trabalho o livro preparado pela assessora da reitoria, Rosana Oba, Universidade de São Paulo: seus reitores e seus símbolos - um pouco da história (Oba, 2006). Publicado pela Edusp, o livro traz a história pessoal de todos os reitores da USP entre 1934 e 2006, seguida da análise da simbologia da administração universitária, expressa no cerimonial de posse do reitor, nas vestes utilizadas, no capelo e no colar doutoral, no brasão d'armas da universidade, na torre do relógio, no sino da reitoria, entre outros. Prefaciado pelo então governador Geraldo Alckmin, o livro testemunha que a história oficial da USP é escrita não só por aqueles que ocupam diretamente cargos de direção, mas por especialistas a quem se delega essa função.

Com efeito, as duas obras mais significativas dessa tradição foram escritas justamente por autores que, sem assumir diretamente as mais altas posições de poder na universidade, acabaram designados pela direção universitária e em função da sua trajetória institucional como docentes, para escrever a história da USP. São elas: o compêndio História da Universidade de São Paulo escrito por Ernesto de Souza Campos (1954) e o volume USP 70 anos, imagens de uma história vivida, organizado por Shozo Motoyama (2006). O primeiro foi redigido em 1954 a pedido do Conselho Universitário por ocasião da comemoração do IV Centenário da cidade de São Paulo e das duas décadas de fundação da USP. O segundo foi concluído em 2006 como mais um volume produzido pelo Centro Interunidades de História da Ciência, ligado à reitoria 
da USP e responsável por escrever a história de diversas instituições de ensino e pesquisa do estado de São Paulo.

Quando se passa da história da Universidade como um todo para a história das suas unidades constitutivas, a lista de trabalhos - muitas vezes de caráter memorialista - escritos a partir de posições estruturais de poder aumenta ainda mais. Sem pretensão de compor uma seleção exaustiva, é possível citar as Memórias para a história da Academia de São Paulo, escritas por Spencer Vampré que, além de catedrático, foi diretor da Faculdade de Direito em 1938 (Vampré, 1977). Ou ainda o livro Recordação das Arcadas, publicado pelo Departamento de Cultura e Ação Social da reitoria em 1953 (Lôbo, 1953). Outro livro que segue esse mesmo padrão é o Geologia USP: 50 anos, escrito por Celso de Barros Gomes, ex-diretor do Instituto de Geociências e ex-chefe de gabinete da reitoria no mandato de Adolpho Melfi (Gomes, 2007). O autor já havia organizado um livro - USP leste: a expansão da Universidade de oeste para o leste - sobre a história da fundação da Escola de Artes, Ciências e Humanidades, cuja implementação o geólogo coordenou no começo da década de 2000 (Gomes, 2005). Outro exemplo é o livro de Ruy Alberto Corrêa Altafim, 50 anos da Escola de Engenharia de São Carlos, unidade de que foi vice-diretor entre 2001 e 2005, pouco antes de se tornar Pró-reitor de Cultura e Extensão da USP (Altafim \& Silva, 2004). A Escola Politécnica também teve sua história registrada pelo Centro Interunidades de História da Ciência ligado à reitoria na publicação intitulada Escola Politécnica 110 anos, construindo o futuro (Motoyama \& Nagamini, 2004). De forma menos pretenciosa, a Faculdade de Filosofia, Letras e Ciências Humanas teve projetos de reconstrução de sua história tematizados no seu veículo oficial por professores ligados a postos de direção como, por exemplo, Sedi Hirano (2003) e Francis Aubert (2002) ${ }^{10}$.

\footnotetext{
${ }^{10}$ É interessante notar que, considerando o conjunto das unidades da USP, o volume das obras historiográficas dedicada a cada uma delas é bastante desigual. Enquanto a Faculdade de Direito, a Escola Politécnica e a Faculdade de Medicina concentram uma enorme quantidade de trabalhos historiográficos (cf. Adorno, 1988; Bontempi Júnior, 2013; Buzzoni, 2007; Castro, 1982; Cytrynowicz \& Cytrynowicz, 2011; Danila, 2009; Faria, 2007; Ficher,
} 
Em todos esses casos, o relato histórico é formulado a partir de posições de direção na estrutura universitária assumindo, assim, um conteúdo de celebração e legitimação institucional que ressalta o seu caráter de história oficial. Seus formuladores ou assumiram diretamente posições de poder na universidade (Americano, 1947; Reale, 1986a, 1994; Mendes, 1976; Oliveira, 1995; Marcovitch, 2001, Rodas \& Motoyama, 2011) ou, de modo mais mediado, escreveram a partir de espaços acadêmicos criados pela reitoria com a função específica de reconstruir a história oficial da instituição e marcando a profissionalização dessa historiografia oficial (Campos, 1954; Kwaniscka, 1985; Motoyama, 2006; Oba, 2006). Trata-se, portanto, de um padrão de reconstrução histórica que, pela sua importância, não se restringe às obras citadas acima. Ao contrário, marca parte importante da historiografia da USP e das suas respectivas unidades. Todo esse conjunto de trabalhos de história oficial, a despeito das suas diferenças internas, assume uma mesma perspectiva historiográfica que, elegendo o discurso dos dirigentes universitários como fonte privilegiada de pesquisa, concebe a história da USP como uma trajetória bem sucedida, operando, por esse mesmo movimento, uma legitimação dos grupos e indivíduos responsáveis pela sua concepção e direção, dos lugares sociais de onde provêm, bem como dos projetos de universidade de que são portadores ${ }^{11}$.

Essa tendência aparece de modo explícito na obra do ex-reitor Jorge Americano, um catedrático da Faculdade de Direito com extensa carreira política que, logo após deixar a reitoria

1995 e 2005; Lacaz \& Mazzieri, 1995; Marinho, 2001 e 2003; Marinho \& Mota, 2012; Martins \& Barbuy, 1998; Mota, 2005; Motoyama \& Nagamini, 2004; Nagamini, 1994; Nakata, 2003, 2007 e 2013; Padilha, 2010; Queiroz Filho, 2008; Reale, 1997; Ricci, 2006; Samara \& Facciotti, 2004; Santana, 1996; Santos, 1985, Venancio Filho, 2004), outras unidades de menor prestígio como a Faculdade de Odontologia, a Escola de Enfermagem, a Faculdade de Saúde Pública, para ficar apenas nas escolas profissionais da capital, possuem uma tradição historiográfica bem mais discreta (cf. Brener \& Cesar, 2010; Russo, 2006). Assim, a historiografia das diferentes unidades da USP confirma a afirmação de Pierre Bourdieu de que "quanto mais uma escola é célebre, mais ela é celebrada e mais atrai, para si, obras e artigos" (1989, p. 329). As obras específicas sobre as unidades profissionais tradicionais da USP serão trabalhadas no quarto capítulo desta tese.

${ }^{11}$ A mobilização da reconstrução histórica como instrumento de autolegitimação e de autoconsagração não é exclusivo da historiografia sobre a USP escrita a partir de posições de poder institucional da universidade. Nos livros de reconstrução da história de alguns centros acadêmicos de prestígio como o Centro Acadêmico Oswaldo Cruz, da Faculdade de Medicina da USP, e o Centro Acadêmico XI de Agosto, da Faculdade de Direito, são igualmente marcadas por um tom enaltecedor que, baseado em discursos dos próprios agentes, resulta em uma perspectiva finalista e autolegitimadora (cf. Mota, 2009; Centro Acadêmico XI de Agosto, 2003). 
da USP em 1946 e reconhecendo a falta de continuidade e informação na administração universitária, resolve elaborar um compêndio de "dados, problemas e planos" para orientar "o trabalho dos futuros administradores da instituição" (Americano, 1947, p. 5). Toda a reconstrução histórica proposta por Jorge Americano visa legitimar o ideal de autonomia universitária, nos termos concebidos pelo ex-reitor, que liderou politicamente um amplo movimento que culminou na transformação da USP em autarquia estadual ${ }^{12}$.

Nesse sentido, depois de apresentar os constantes embates entre a direção universitária e o movimento estudantil como o resultado de um simples "mal-entendido", ligado à excessiva e equivocada intervenção estatal na USP, o ex-reitor constrói a imagem irênica de uma comunidade unida na inquestionável luta pela autonomia universitária, obliterando todo e qualquer embate quanto ao sentido específico dessa autonomia. É da perspectiva dessa unidade idealizada que ele narra, em terceira pessoa, o movimento que protagonizou pela

\footnotetext{
12 O decreto de fundação da USP de janeiro de 1934, seguindo o Estatuto das Universidades Brasileiras de 1931, estabeleceu que a escolha dos dirigentes universitários seria feita pelo governador do estado, a partir de uma lista tríplice de professores catedráticos eleitos pelos respectivos conselhos, ou seja: pelo conselho universitário, no caso da escolha do reitor, e pela congregação, no caso da escolha dos diretores de unidade (cf. USP, 1934a). No entanto, no primeiro Estatuto da USP assinado por Getúlio Vargas e pelo então ministro da educação e saúde, Gustavo Capanema, em setembro do mesmo ano, a forma de provimento desses cargos se altera, em função de mudanças na legislação federal que visavam restringir a autonomia das instituições de ensino (cf. USP, 1934b). Com essa alteração, tanto o reitor da universidade quanto os diretores das suas respectivas unidades passaram a ser de escolha livre do governador do estado "entre brasileiros natos, professores catedráticos de qualquer dos institutos universitários", ou seja, independentemente de pertencerem ou não à unidade que iriam dirigir (USP, 1934b). Na prática, essa medida transformou os postos de direção da USP em cargos de confiança do governo, gerando uma total suspensão da autonomia universitária minimamente prevista do decreto original de fundação da USP. É contra essa situação que a direção da universidade se volta nas décadas de 1930 e 1940, no movimento que Jorge Americano ao mesmo tempo protagoniza e descreve. Como ele mesmo narra, contra a intervenção estatal, sucediam-se greves estudantis e acumulavam-se manifestações de professores e dirigentes universitários, que se demitiam em bloco como forma de protesto. Ainda assim, há outros indícios de que, entre a direção e o movimento estudantil, não reinava a harmonia que Americano postula (cf. Adorno, 1988; Campos, 1954; Danila, 2009; Fétizon, 1986; Nadai, 1981; Centro Acadêmico XI de Agosto, 2003). Em 1944, por efeito dos protestos, a USP se torna uma autarquia estadual, saindo do controle direto da Secretaria de Educação e Saúde Pública e conquistando o direito de restringir a escolha dos dirigentes por uma lista plurinominal. Em 1945, uma tentativa do governador de indicar diretamente o diretor da Faculdade de Filosofia, Ciências e Letras gerou nova demissão em massa do reitor e dos diretores, o que fez o governo instituir uma lista binominal para a eleição dos diretores de unidade, ainda submetida à decisão final do governador (cf. Americano, 1947, p. 176ss.; Antunha, 1971, p. 78ss.; Fétizon, 1986, p. 458ss.). Essa situação só se alterou com a reforma universitária de 1968, que suspendeu a autonomia universitária, sobretudo ao subordinar a escolha dos dirigentes acadêmico à decisão do executivo. Com a redemocratização do país e a reforma do estatuto da USP de 1988, os dirigentes máximos voltaram a ser escolhido, mediante lista tríplice preparada pelo Conselho Universitário, pelo governador do Estado, exatamente como previsto no decreto de fundação de 1934 (cf. USP 1934a).
} 
autonomização da USP, conferindo dignidade histórica aos feitos que realizou na sua passagem

pela reitoria:

Embora tivessem sido criados o órgão executivo [reitoria] e o órgão deliberante [Conselho Universitário], suas funções foram, inicialmente, reduzidas porquanto continuou o regime anterior à fundação da Universidade, de subordinarem-se os diretores de Faculdades à Secretaria da Educação. O reitor não tinha, na realidade, função dirigente, nem o Conselho Universitário, função deliberante, à falta de autonomia, quer didática, quer administrativa, quer financeiro-patrimonial [sic]. Por outro lado, instituiu o estatuto universitário a livre nomeação do Reitor e dos diretores pelo governo [...]. A ausência de autonomia administrativa [...] criava dificuldades. Sucediam-se greves de estudantes, de caráter político, e as medidas eram tomadas pelo governo, sem audiência da reitoria. Um tiroteio nas ruas, contra os estudantes, em novembro de 1943, ocasionou o pedido de exoneração do reitor e de todos os diretores, que foi negado pelo governo, sob compromisso deste de dar autonomia à Universidade. A autonomia, tal como foi então concedida, consistiu apenas no desligamento da Universidade da Secretaria da Educação, em fevereiro de 1944, conferindo-se ao Reitor a efetiva autoridade sobre os diretores das Faculdades, subordinado ele [reitor] diretamente ao chefe do Governo (Americano, 1947, p 2324).

O ex-reitor da USP parte dessa perspectiva finalista - em que a autonomização da universidade nos termos propostos pela sua direção, de centralização e fortalecimento do poder acadêmico no âmbito central, torna-se um fim legítimo e natural - para ressignificar uma série de fatos que assume, então, um sentido coerente. Assim, o afastamento sucessivo dos reitores da USP é apresentado como resultado direto da equivocada decisão do governo de não reconhecer a autonomia universitária, interferindo na escolha dos seus dirigentes. É interessante notar como Jorge Americano justifica o seu afastamento da reitoria em 1946 pelo caráter arbitrário da intervenção governamental na USP, que resulta na desmoralização e no enfraquecimento dos dirigentes universitários:

A quem considerar as várias substituições na direção suprema da Universidade, impressionarão desfavoravelmente os motivos de substituição dos reitores - ou uma causa política, ou um desconhecimento do que seja a autonomia universitária, por parte do Governo, considerando de sua confiança o cargo, ou uma desavença com o governo. Assim, o primeiro reitor, Reynaldo Porchat, exonerou-se por não querer servir após o golpe de estado de 10 de novembro [de 1937]. O segundo, Lúcio Rodrigues, exonerou-se por desentendimento com o governo. O terceiro, Rubião Meira, por mudança de governo. O quarto, Jorge Americano, por desavença com o governo. O quinto, Almeida Prado, declarou no discurso de posse que só serviria com o atual governo e, candidato ao Governo do Estado, afastou-se logo depois, exonerando-se afinal. [...] repelimos o critério absurdo, de considerar-se o mais alto cargo cultural da Universidade, de confiança do Governo, sem que seja da confiança da Universidade (Americano, 1947, p. 191; grifos do autor). 
Não obstante essa defesa intransigente da soberania da comunidade universitária na escolha da sua "direção suprema", uma vez que "são os próprios elementos da Universidade que melhor conhecem os professores e suas aptidões" (1947, p. 192), Jorge Americano termina por relativizar esse mesmo princípio ao defender a intervenção do reitor na escolha dos diretores de unidade alegando que a relação entre eles é muita "estreita", o que pressupõe uma certa “afinidade" (1947, p. 192) ${ }^{13}$. A autonomia que compõe princípio indiscutível da organização universitária deveria seguir, portanto, os termos e princípios propostos pelo ex-reitor e sistematizados em um anteprojeto de lei estadual para autonomização da USP que ele escreveu e encaminhou à Assembleia Legislativa, anexando ao seu volume dedicado à universidade (cf. 1947, p. 196-8).

É à luz dessa autonomia seletiva, que se desdobra em centralização, que Americano confere à sua narrativa um tom heroico, em que os dirigentes universitários e o movimento estudantil aparecem unidos em uma trajetória de sacrifícios cuja direção consciente e natural seria a autonomia universitária. Nessa perspectiva finalista, a história da instituição aparece, portanto, como uma sucessão coerente de eventos na qual um dos protagonistas é, ao mesmo tempo, ator e narrador. No interior dessa trajetória histórica coerente, pensada portanto como desenvolvimento, os eventos relativos à história da universidade podem ser apresentados, como o faz Americano, como meras “notícias sobre a formação e evolução da USP”, expostas em

\footnotetext{
${ }^{13}$ Vale frisar que esse argumento ganhou enorme força no contexto político da USP e é amplamente defendido até hoje, de modo que os diretores de unidade continuam sendo indicados pelo reitor, a partir de uma lista tríplice. $\mathrm{O}$ estatuto da USP de 1934 previa, no seu artigo 67 que os diretores de instituto seriam "nomeados pelo Governo do Estado, dentre os seus professores catedráticos, que sejam brasileiros natos" (USP, 1934b, n.p.). No estatuto de 1969, a atribuição de escolha dos diretores de unidade passou a ser do reitor da universidade, mediante lista tríplice preparada pelas congregações (cf. USP, 1969, n.p.), formato mantido no estatuto de 1988 e válido até hoje (cf. USP, 1989). No entanto, como se verá, mais do que testemunhar a autonomização da universidade em relação ao governo do estado, a escolha dos diretores de unidade pelo reitor expressa o fortalecimento da administração central da universidade, especialmente da sua reitoria.
} 
sucessão cronológica à parte da sua interpretação, como se fossem fatos desprovidos de significação $(1947, \text { p. } 23)^{14}$.

É também nessa chave de um constante e unidirecional "progresso institucional" que se pode ler as "memórias" e "recordações" de Miguel Reale sobre a Universidade de São Paulo (1986a e 1994). Ele também dedica particular atenção ao episódio narrado por Jorge Americano, de concessão de autonomia universitária à USP em 1944. O jurista que, por sua posição de liderança na Ação Integralista Brasileira, conseguiu, durante o Estado Novo, tornarse catedrático da Faculdade de Direito e membro do Conselho Administrativo do Estado ${ }^{15}$, reivindica para si o mérito da medida que concedeu autonomia administrativa à USP, elevandoa ao estatuto de "autarquia estadual". Segundo o ex-reitor, apesar de ter ingressado na Faculdade de Direito em 1930, lá permaneceu refém do isolamento dessa unidade, de modo que somente se aproximou da USP muitos anos depois, na sua condição de legislador do Estado Novo:

O primeiro contato significativo que tive com a Universidade de São Paulo deu-se, no entanto, apenas em 1944, quando, na qualidade de membro do Conselho Administrativo do Estado - entidade que, na época do Estado Novo, concentrava toda a tarefa legislativa dos estados e municípios - tive a oportunidade de estudar o projeto de lei que, uma vez aprovado por esse Conselho, foi promulgado [...] transformando a Universidade de São Paulo em autarquia. [...] Examinando a matéria, convenci-me que a autonomia seria ilusória se o Reitor continuasse a despachar com o Secretário de Educação para resolver os assuntos de ordem didática ou administrativa, razão pela qual resolvi apresentar emenda em virtude da qual todas as funções daquele Secretário, relativas ao ensino superior, passavam a ser exercidas pelo Reitor da USP, disposição esta que, em um primeiro momento, se estendeu aos atos normativos das novas universidades criadas. O certo é que graças a essa proposta aprovada unanimemente pelo Conselho, o Reitor adquiriu status de Secretário de Estado, passando a despachar semanalmente com o Chefe do Executivo Paulista (Reale, 1994, p. 25-6).

No enaltecimento das próprias realizações, Reale - que foi por duas vezes reitor da USP - oblitera as circunstâncias em que a autonomia da USP foi concedida: em plena ditadura do

\footnotetext{
${ }^{14}$ A proposta de apresentar os fatos relevantes sobre a história da USP como uma seção separada da interpretação é uma constante nos livros de história oficial. Ernesto de Souza Campos, por exemplo, nomeia essa seção de "efemérides".

${ }^{15}$ Miguel Reale precisou mobilizar toda a sua influência pessoal e política para validar, junto ao governo federal, através do seu Conselho Nacional de Educação, o concurso que prestou para a Faculdade de Direito do Largo São Francisco, em 1941, que foi questionado e invalidado no âmbito da Faculdade de Direito (cf. Reale, 1986b).
} 
Estado Novo, por um órgão executivo com funções legislativas, composto por membros nomeados e não eleitos. Mas a descrição de Reale das circunstâncias que levaram à autonomização administrativa da USP em 1944 interessa, sobretudo, por ser mais um exemplo da perspectiva finalista que orienta uma reconstrução da história marcada pelo predomínio da narrativa dos próprios uspianos e pela glorificação dos presumidos responsáveis pelo seu sucesso.

Nesse mesmo sentido e de modo ainda mais marcante, o compêndio intitulado História da Universidade de São Paulo e escrito por Ernesto de Souza Campos pode ser lido à luz desse conjunto de pressupostos que marca a concepção finalista de história. Ao conceber a fundação e o crescimento da USP como um percurso coerente e bem sucedido, a obra de Campos reflete, sem mediações, o discurso socialmente enraizado do seu narrador que, como Jorge Americano e Miguel Reale, fez toda a sua trajetória acadêmica no interior da instituição cuja história relata e cuja direção, por muito tempo, integrou (cf. Campos, 1954).

Formado originalmente pela Escola Politécnica, Ernesto de Souza Campos ingressou, em 1913, na primeira turma da Faculdade de Medicina de São Paulo. Como aluno mais velho e oriundo de uma família influente de São Paulo, ganhou posição de destaque na nova faculdade, sendo escolhido pelo então diretor, Arnaldo Vieira de Carvalho, para tornar-se presidente do Centro Acadêmico Oswaldo Cruz (CAOC), depois da suspensão do primeiro ocupante do cargo, por motivos políticos, logo no primeiro ano de funcionamento da nova escola ${ }^{16}$. Seguindo uma trajetória "natural", Campos tornou-se catedrático e diretor da

\footnotetext{
${ }^{16}$ A história da greve estudantil de 1913 na Faculdade de Medicina de São Paulo, que resultou na expulsão do primeiro presidente do CAOC e de dezenas de outros estudantes, é muito significativa para a compreensão do funcionamento das faculdades tradicionais da USP na sua primeira fase. Ao iniciar suas atividades didáticas em 1913, por imposição da Lei Rivadavia Corrêa (1911) que reinstituiu o ensino livre, a Faculdade de Medicina não selecionava seus estudantes nem impunha um limite de vagas. Consequentemente, iniciou o primeiro ano de Medicina uma quantidade de alunos elevada para os padrões da época, muitos dos quais com uma formação, considerada pela direção da faculdade, aquém do esperado para um aluno de medicina. Provavelmente, entre esses "maus alunos" estavam muitos filhos de imigrantes porque os relatos da época referem-se ao fato de que, nas provas, "o nosso idioma era horrivelmente maltratado" (Campos, 1954, p. 362). A solução para essa "má frequentação" (Bourdieu, 1989, p. 101ss) foi aumentar as exigências do curso a fim de reprovar grande parte da turma. Como relata Ernesto de Souza Campos: "O professor Xavier, recebendo as provas, estudou-as
} 
Faculdade de Medicina da USP. Por sua participação nos órgãos dirigentes da Faculdade, assumiu a interlocução com a Fundação Rockefeller ${ }^{17}$ que financiou a construção do Hospital das Clínicas e da atual sede da Faculdade de Medicina, tendo como contrapartida o estabelecimento de padrões profissionais de pesquisa nessa instituição (cf. Marinho, 2001). Com a fundação da USP em 1934, Campos passa a assumir posições de destaque na incipiente burocracia acadêmica, chegando a dirigir os trabalhos de planejamento e construção do campus da Cidade Universitária “Armando Salles de Oliveira” (cf. Xavier, 1999), depois de ter sido diretor da Faculdade de Filosofia, Ciências e Letras entre 1937 e 1938, quando os diretores eram nomeados pelo governado/interventor do Estado dentre todo o corpo docente da universidade (cf. Antunha, 1971).

Em 1954, por ocasião do IV centenário da Cidade de São Paulo, dos vinte anos da USP e em reconhecimento à trajetória de Ernesto de Souza Campos na instituição, o Conselho Universitário decide atribuir ao "filho espiritual da Escola Politécnica e da Faculdade de Medicina" a tarefa de escrever a história da universidade de São Paulo (cf. Leme, 1954, n.p.). Mas a relação de Campos com a USP, particularmente com a sua Faculdade de Medicina, era ainda mais profunda do que a sua trajetória institucional inicialmente sugere. Seguindo a sua narrativa, descobre-se que o "grande historiador da USP" era filho de um "homem bom de São

minuciosamente. Não lhe foi difícil separar o joio do trigo. E o joio era muito mais abundante do que o trigo; este, aliás, bem raro. Resultou dessa circunstância que a grande massa da turma ficou classificada abaixo da nota cinco" (Campos, 1954, p. 362). A consequência dessa reprovação em massa foi uma greve estudantil que levou ao fechamento da Faculdade e à suspensão - que, na prática, significou a expulsão - da grande maioria dos alunos da primeira turma de medicina, incluindo o então presidente do CAOC, Waldomiro Guilherme de Campos. Ele se mudou para o Rio de Janeiro onde concluiu o curso de medicina (cf. Mota, 2009, p. 71ss). Nesse contexto, Ernesto de Souza Campos foi escolhido para presidente do CAOC inicialmente pelo próprio diretor, Arnaldo Vieira de Carvalho, com quem tinha uma relação muito próxima. No final de 1913, foi reeleito presidente do CAOC. Logo depois, Arnaldo Vieira de Carvalho tornou-se "presidente de honra" do CAOC, cargo que manteve até a sua morte. Voltaremos a esse e a outros episódios históricos referentes às faculdades profissionais tradicionais da USP no quarto capítulo desta tese.

${ }^{17}$ No seu estudo sobre a atuação da Fundação Rockefeller na USP, Maria Gabriela Marinho afirma que Ernesto de Souza Campos, mais do que um interlocutor, era o verdadeiro "o ideólogo dessa parceria, sobretudo a partir de sua adesão aos valores da cultura norte-americana, no bojo da qual a Fundação Rockefeller exerceu o papel de uma poderosa agência de promoção daquela organização social” (2001, p. 6). A atuação da Fundação Rockefeller na USP será retrabalhada no próximo capítulo. 
Paulo", "republicano de primeira hora", o médico Antônio de Souza Campos que, senador da República durante o governo Floriano Peixoto, tornou-se "coronel médico de primeira classe no exército", "o mais elevado posto da medicina militar na época" (Campos, 1954, p. 345). Além de médico "de prestígio", o senador era, ainda, "amigo dileto" de Américo Brasiliense de Almeida Mello, bacharel em direito que fundou o Partido Republicano Paulista e se tornou, por ele, presidente da província de São Paulo. Inserido nessa rede de relações políticas e sociais privilegiadas, o pai de Ernesto de Souza Campos teria desempenhado um papel importante na promulgação da lei n 19 de 1891 que criou, no papel, a Academia de Medicina e Farmácia de São Paulo. Por adversidades políticas, essa instituição somente viria a ser implementada em 1912, já com o nome de Faculdade de Medicina e Cirurgia de São Paulo. Ao contar a história da relação de seu pai com Américo Brasiliense e a Faculdade de Medicina, Ernesto de Souza Campos conclui:

Esta digressão, irreprimível nota sentimental e simultaneamente homenagem a dois homens bons de São Paulo, tem o objetivo de trazer nosso testemunho pessoal sobre o interesse que o presidente Américo devotava à criação da sua projetada "Academia de Medicina e Farmácia" (Campos, 1954, p. 345; grifos meus).

O relato histórico presente no livro de 1954 é todo ele marcado por esse tom de “testemunho pessoal" de um membro da elite paulista, orgulhoso desse pertencimento. Não por acaso, ocupam um lugar central na obra de Campos as pequenas biografias, sempre de caráter consagrador, pelas quais o autor reconstrói as personagens heroicas que, segundo ele, protagonizaram a história da USP e das suas unidades constitutivas, revelando, por detrás de suas atitudes "nobres" e "altivas", uma vertiginosa cadeia de ascendência aristocrática. É como se Campos estivesse descrevendo verdadeiras "dinastias" - o que, de certo modo, fazia de fato.

É nessa chave, por exemplo, que Souza Campos descreve a nomeação de Arnaldo Vieira de Carvalho para a direção da Faculdade de Medicina pelo então governador de São Paulo, Rodrigues Alves:

O Conselheiro Rodrigues Alves, em toda a sua longa administração, tanto na órbita estadual, como na esfera federal, teve sempre fino tato na escolha dos seus auxiliares. 
Esta foi a razão essencial do êxito dos seus empreendimentos. Situou-se entre os três maiores estadistas da República, todos oriundos do altiplano de Piratininga. Arnaldo Vieira de Carvalho gozava de excepcional prestígio em São Paulo. Era portador de nome ilustre, granjeado pelo seu progenitor Dr. Joaquim José Vieira de Carvalho, deputado e lente da Faculdade de Direito. Nascido em Campinas, que tantos filhos eminentes tem dado ao nosso Estado, Arnaldo Vieira de Carvalho doutorou-se em medicina pela Faculdade do Rio de Janeiro em 1889. Tinha então 22 anos, pois nascera a 5 de janeiro de 1867. Recebeu a direção do corpo clínico da Santa Casa de Misericórdia de outro grande paulista, Luiz Pereira Barreto, em 25 de junho de 1897. [...] Em virtude das suas excepcionais qualidades, conservou-se neste posto, como na direção da nova Faculdade de Medicina, até a sua morte em 05 de junho de 1920. Mas o que caracterizava especialmente a figura social e profissional de Arnaldo era seu atrativo pessoal. Refletia-se na inconfundível atitude de comando, revelada nas deliberações rápidas e incisivas, na nobreza e na dignidade dos seus atos, nos gestos moderados e cortantes, no seu feitio de estimular os estudiosos e até na sua indumentária sempre correta (Campos, 1954, p. 346) ${ }^{18}$.

${ }^{18} \mathrm{O}$ culto em torno da figura de Arnaldo Vieira de Carvalho constitui um objeto de investigação à parte. Na década de 1960, por exemplo, a Faculdade de Medicina da USP encomendou uma "bibliografia crítica em dois volumes" a Antônio da Palma Guimarães, da qual imprimiu quinhentos exemplares que obtiveram distribuição "seleta". Na introdução desse duplo volume, seu autor explicita o sentido do culto em torno da figura do "Dr. Arnaldo": "A evidente intensidade e universalidade dos meios de difusão e comércio, cada vez mais poderosos entre os povos, há de restringir todos os fenômenos sociais a denominadores comuns e aniquilar o interesse à perpetuidade de qualquer deles. [...] Entretanto homens existem dignos de ser sempre lembrados e isto redime do que se diga ou disser de varões como este que lembramos" (Guimarães, 1967, p. XL). Vale a pena acompanhar a descrição que o autor apresenta, a partir de uma foto de época, de Arnaldo "príncipe e chefe": "Nesta fotografia de Arnaldo que vamos pormenorizando, é marcante a altaneira do príncipe e do chefe - termos que, de si, exprimem o mesmo conceito. Estatura pouco acima de mediana, corpo cheio [...] cabeça volumosa e masculina, bem conformada; cabelos de entradas definidas, penteados com simplicidade, risca à esquerda, pastinha e não topete à direita; sobrancelhas espessas, olhos escuros, miúdos e vivos - Arnaldo era uma bela estampa de dolicocéfalo. [...] Boca regularmente rasgada, apenas perceptível sobre os bastos bigodes, e exprimindo discreto e vago sorriso. Queixo rematado em barba cuidada, em ponta. Vestia na ocasião amplo sobretudo de lã clara que habitualmente envergava nas manhãs de inverno ao dirigir-se ao hospital. Casaco e colete pretos. A corrente do relógio, ao alto, trespassada a segunda casa do colete de gola. Colarinho engomado, alto e duplo. Gravata de seda preta de laço apertado e pérola corretamente espetada. Calças listradas de prega amplas. Botinas de pelica pretas, gáspeas de tom claro, com botões. Pois temos aqui um $d a n d y$ ? Ou antes: $d a n d y$ talvez não seja apelido conveniente. Arnaldo, homem de elegância correta e discreta, homem de hospital, não de salão, não era pessoa de paying excessive attention to smartness and fashion in dress. Melhor the assentaria o atributo de gentleman, de homem well bred and member of some profession, o que efetivamente era, e figura saliente em sua profissão. Apoia o pé esquerdo sobre o degrau e firma o direito no plano inferior. As mãos enfiadas nos bolsos das calças acentuam-lhes as pregas, não sem algum lastimável exagero, o que porém confirma, de outra parte, a despreocupação de pose e a graça do imprevisto. A atitude de apoio e repouso fixa a esbelteza da figura. Os artistas gregos, que mudaram o sentido da estatuaria com a introdução de movimento às figuras, gostavam de lhes dar um descansado sustentáculo, marcando desta forma a espontaneidade do movimento pela solicitação do repouso. E aí temos o instantâneo feliz de algum artista amador, tomado ao acaso em manhã de sol, pouco trabalho, e em momento cordial" (Guimarães, 1967, p. 16). O estilo marcadamente elegante do "Doutor Arnaldo", como era conhecido, assim como seus hábitos refinados aparecem constantemente nas descrições da sua figura. Assim, através de relatos de colegas, parentes e amigos do médico, que constam no livro encomendado pela Faculdade de Medicina, Antônio Guimarães procura reconstruir a rotina diária desse típico "homem da República e do Encilhamento", oferecendo um rico testemunho sobre os hábitos da elite paulista na Primeira República: "levantava-se entre 5h e $6 \mathrm{~h}$ e tomava em jejum uma garrafa de água de vichy quente. Ginástica sumária. Banho frio. Café preto e pão com manteiga" (cf. 1967, p. 17). Vestia "camisas de linho, muito alvas, a desabotoar à altura dos ombros, tinha-as confeccionado especialmente para si” (1967, p. 17). "Chegava ao hospital e ia direto à sua enfermaria, onde seus colaboradores o aguardavam" (1967, p. 18). Depois de operar durante as primeiras horas da manhã, "com elegância e firmeza nas mãos [...] retomava meticulosamente cada peça do vestuário e era de novo o gentleman que ia inspecionar os serviços e avistar-se com a administração" (1967, p. 19). Depois disso, voltava para casa, a pé, "por volta das 13h. Tomava um banho quente demorado e almoçava. Comia pouco e não dispensava o vinho tinto francês" (1967, p. 19). Por fim, "ia à Policlínica e ao seu consultório, na Rua S. Bento, de onde andava até a praça Antônio Penteado. De lá seguia ao jornal O Estado de S. Paulo onde se sentava, em geral ao lado de Nestor Pestana, para escrever suas crônicas e notas" (1967, p. 21). Sua casa, assinada pelo arquiteto Francisco Ramos de Azevedo, ficava na Rua Couto Magalhães. Todas as noites, aliás, 
O tom de enaltecimento prossegue quando o historiador vai apresentar, sem esquecer a importância dos laços nobiliárquicos que unem as "grandes famílias", o principal assessor de Arnaldo Vieira de Carvalho, o médico Ovídio Pires de Campos. O autor descreve Ovídio Pires como um "grande estudioso que norteara sua vida por alto espírito de ética e rigorosos conceitos de moral" e, mobilizando as palavras do seu biógrafo oficial, conclui:

No seu amor por São Paulo, no seu discreto orgulho de descendente de autêntica família bandeirante, revelava-se, sempre, o homem cioso da grandeza do seu berço. Essa grandeza não a queria assentada apenas no poderio econômico. Desejava-se projetada para o alto, no esplendor de uma civilização realçada por esplêndida cultura. Em todos seus trabalhos, essa preocupação da grandeza da pátria, o empenho em fazer do Brasil uma nação igual às maiores se revela em todo o instante. Pode-se dizer que é a dominante do seu espírito (Campos, 1954, p. 347).

O estilo não se altera quando o autor passa à análise da história da Escola Politécnica. Ao descrever problemas políticos vividos pela instituição, conclui: "mas ali também havia um homem de têmpera de aço, Antônio Francisco de Paula Souza. Inflexível, prestigioso, manteve a linha da disciplina" (Campos, 1954, p. 355).

Com as mesmas tonalidades, narra a criação da USP e da sua unidade central, atribuindo tal decisão a outro "grande paulista": "finalmente fundou-se, com a Universidade de São Paulo, a Faculdade de Filosofia, Ciências e Letras. A criação da universidade foi o ato de maior altitude e de maior repercussão do governo benemérito de Armando Salles de Oliveira" (Campos, 1954, p. 425).

Ao longo das mais de quinhentas páginas que compõem o luxuoso volume de 1954, reimpresso integralmente e em alto padrão em 2004, é possível mobilizar vários outros exemplos que, como os descritos até aqui, testemunham a constante referência à grandeza de

depois do jantar, ia a casa de Ramos de Azevedo. "Amigos reuniam-se ali, a jogar bilhares, a rir, a contar casos". Na volta para casa, passava na redação do jornal, na praça Antonio Prado: "era então um sodalício erudito que se reunia na sala de Júlio de Mesquita, e onde se encontravam cotidianamente, Victor da Silva Freire, J. M Bitencourt Rodrigues, Ricardo Severo e outros além de políticos. Da sala de Júlio de Mesquita se avistavam as redações de dois jornais: o Correio Paulistano e o Estado de S. Paulo - vale dizer, representantes de duas correntes políticas antagônicas, o Perrepismo e a Dissidência" (1967, p. 23). Por fim, por volta das dez da noite se recolhia para casa, e "por essas bilaquianas e extintas noites frias e brumosas da S. Paulo garoenta desse tempo, poderia ser visto, a gola do sobretudo levantada, um vulto solitário que cruzava a passo diferenciado o viaduto Santa Efigênia” (1967, p. 23). 
São Paulo e de sua elite dirigente, da qual a fundação da USP constitui o exemplo máximo. Assim, depois de discutir as "raízes d'além e d'aquém mar" da universidade, Campos passa a examinar as origens propriamente paulistas do projeto, remetendo-as à fundação, pelos jesuítas, do primeiro colégio de São Paulo até chegar "o dia, o grande dia” em que "o sol já começava a apontar a Universidade de São Paulo" (Campos, 1954, p. 97).

Ao reconstruir esse processo enraizando-o no período colonial, o autor sugere uma verdadeira odisseia dos paulistas na luta pela sua universidade. Odisseia que, ressalte-se, o próprio autor integrou, tanto como propagandista da ideia de universidade quanto como fundador e primeiro presidente da Sociedade de Philosophia e Lettras de São Paulo, precursora, segundo ele, da Faculdade de Filosofia, Ciências e Letras da USP (cf. Campos, 1954, p. 422). Todo esse longo trajeto teria sido orientado, sempre segundo o autor, por um mesmo "espírito comum" que, desde a fundação da cidade de São Paulo pelo padre Manoel da Nóbrega, passando pela ação das bandeiras de conquista, até chegar à criação da USP, inspira o "bravo povo paulista":

\begin{abstract}
Eis uma síntese da magnífica Ideia Fundamental que orientou a movimentação de Nóbrega entre os brasileiros. Sua Alma não estava apenas infiltrada pela doce e maravilhosa doutrina de Jesus, estruturada através das regras de Inigo Lopez de Recalde $\left[{ }^{19}\right]$. Estava ali também o português legítimo, o homem que continha em suas veias o mesmo sangue que preservara no seu cérebro, a mesma genialidade que empurrou para os mares a gente lusitana; o mesmo ideal, o mesmo fogo, a mesma tenacidade, a mesma rudeza que atirou, terras adentro, as bandeiras de conquista; o mesmo amor pela "alma mater" que, séculos em fora, se mantém inalterável, ou melhor, se revigora, entre os descendentes da gente portuguesa, de cepa magnífica, onde o coração adoça os imperativos da luta pela vida (Campos, 1954, p. 43).
\end{abstract}

Diferentemente do que pode parecer à primeira vista, o estilo historiográfico de Campos não representa a expressão despropositada de um elitismo pessoal ou de um arcaísmo descontextualizado. Tampouco o pressuposto finalista e o tom consagrador resultam do caráter amador da história escrita pelo engenheiro e médico. Ao contrário, durante a redação da sua História da Universidade de São Paulo, Ernesto de Souza Campos ocupava o cargo de

\footnotetext{
${ }^{19}$ Inigo Lopez de Recalde é outro nome atribuído a Ignacius López de Loyola, fundador da Companhia de Jesus.
} 
presidente do Instituto Histórico e Geográfico de São Paulo (IHGSP), instituição cuja sede, ainda hoje, preserva o seu nome. É, portanto, à luz dessa corrente e dos seus temas, estilos e pressupostos que se deve compreender, em um primeiro momento, o trabalho histórico de Ernesto de Souza Campos.

Ao analisar a influência de modelos raciais na construção de novas representações de país a partir da profissionalização da vida intelectual brasileira na década de 1870, Lilia Schwarcz confere lugar de destaque aos institutos históricos e geográficos, dentre os quais inclui, justamente, o IHGSP. Segundo a autora, essas instituições foram criadas ao longo do século XIX com a função de "construir uma história da nação, recriar um passado, solidificar mitos de fundação, ordenar fatos buscando homogeneidades em personagens e eventos até então dispersos" (Schwarcz, 1993, p. 99). Essas narrativas atendiam, portanto, à necessidade de mobilizar uma narrativa histórica que, tornada tradição, fosse capaz de unificar a nação através da imagem de um passado comum, marcado pelo perfil heroico da elite dos grupos sociais e econômicos que sustentavam objetiva e subjetivamente tais instituições ${ }^{20}$.

Esse perfil de classe dos institutos histórico e geográficos, nos quais o recrutamento se baseava mais em critérios de natureza socioeconômica do que propriamente intelectual, os diferenciava das demais instituições analisadas pela autora - particularmente os museus etnográficos e as faculdades de medicina e de direto -, marcadas por uma relativa autonomia a despeito do caráter igualmente elitista dos seus quadros. Os institutos, ao contrário, dependiam financeiramente dos seus membros e se voltavam para a produção de um saber oficial, fortemente atrelado à exaltação do país e de suas regiões e à consagração das elites locais e nacionais.

\footnotetext{
${ }^{20}$ Ao analisar a constituição do Estado Nacional brasileiro e a projeção de um imaginário comum para o conjunto da nação, José Murilo de Carvalho destaca não só o papel das elites em si mas, sobretudo, da sua experiência social compartilhada. Para ele, a coesão das elites nacionais, que impediu a fragmentação do Estado brasileiro, resultou em especial da experiência compartilhada de ensino superior, nas Escolas de Direito de Coimbra (cf. Carvalho, 1987, 2003, 2012). A socialização das elites formadas pelas faculdades profissionais tradicionais da USP é o tema do quarto capítulo desta tese.
} 
No caso específico do IHGSP, Schwarcz mostra que a intenção era produzir um discurso que reinterpretasse a história nacional à luz de São Paulo: "tratava-se, portanto, de ir buscar no passado fatos e vultos da história do estado que fossem representativos para construir uma historiografia marcadamente paulista, mas que desse conta do país como um todo" (1993, p. 127). Não por acaso o discurso historiográfico do Instituto conferia lugar central ao bandeirantismo que, tornado mito da grandeza de São Paulo, mostrava-se capaz de dotar essa província de "símbolos de 'civilização e cultura' até então concentrados na corte" (Schwarcz, 1993, p. 127).

Ao analisar mais detidamente a produção do IHGSP até 1930, a antropóloga mostra que ela se pautava, justamente, por "uma visão acentuadamente paulista e elitista" (1993, p.129). A perspectiva "paulista" se expressa na constante exaltação de São Paulo, ao passo que o "elitismo", no recurso reiterado a pequenas biografias como estratégia de consagração de personalidades locais. Esse elitismo ganha um caráter ainda mais eloquente no elogio genérico à ação civilizatória da elite branca, em especial os de origem europeia, que seria responsável por toda forma de desenvolvimento e progresso, desdobrando-se tanto em termos discursivos, na glorificação da figura dos colonizadores portugueses, quanto em termos práticos, na adoção de uma política migratória composta de leis restritivas à entrada de populações negras e asiáticas em benefício de brancos, de preferência europeus (cf. Schwarcz, 1993, p.130-31).

É justamente nessa chave de leitura que se deve inserir, portanto, o trabalho historiográfico de Ernesto de Souza Campos. Especialmente porque o declínio dos Institutos Históricos e Geográficos, a partir de 1930, foi acompanhado pelo ingresso dos seus membros no corpo docente das universidades criadas a partir de então, enraizando tal perspectiva nas novas instituições (cf. Schwarcz, 1993, p.138). Assim, longe de representar um erro ou um desvio, a História da Universidade de São Paulo escrita por Souza Campos reflete essa "forma bem específica de se fazer história", "pautada em nomes e personagens", como forma de 
consagração e legitimação das "elites agrárias" (Schwarcz, 1993, p. 109-110). Esse discurso historiográfico encerra, como a autora sugere, verdadeiros "sistemas de classificação" que orientam a construção de uma história épica e otimista, na qual o passado idealizado se presta à projeção de um futuro "insofismavelmente branco" e, portanto, moderno e civilizado (1993, p. 132-37). É também nesse sentido que Maria Gabriela Marinho interpreta a importância do livro de Campos sobre a USP que seria revelador, segundo ela, "da visão de mundo e de ciência, das concepções filosóficas e da personalidade de seu autor" (2001, p. 9).

Em síntese, pode-se dizer que todos os elementos distintivos do estilo historiográfico do IHGSP encontram-se presentes na obra de Ernesto de Souza Campos: o recurso a pequenas biografias como estratégia de consagração de grupos da elite local, o modelo bandeirante como exaltação da grandeza paulista e, particularmente, a idealização do passado colonial que tem, como contrapartida, a projeção de um futuro igualmente idealizado, necessariamente “civilizado", "branco" e "moderno". A intenção, no caso específico da obra de Campos, é construir uma narrativa histórica para a USP que fosse capaz de forjar uma tradição ${ }^{21}$ que não se limitasse apenas a ressignificar o passado, mas também de determinar, de antemão, todo o futuro, na forma de um devir inevitável.

É muito interessante percorrer, à luz dessas observações, o trajeto proposto por Campos no ensaio que compõe a primeira parte da sua história da USP: o autor inicia a análise dissecando as supostas raízes portuguesas da universidade e a encerra detalhando o projeto futurista da Cidade Universitária, com prédios em arquitetura moderna que nunca chegaram a

\footnotetext{
${ }^{21}$ É significativo, nesse sentido, que o livro de Ernesto de Souza Campos sobre a USP se abra com a reprodução de símbolos que buscam definir uma "tradição uspiana", tais como a imagem colorida do brasão d'armas da universidade seguido da sua explicação, uma versão da flâmula oficial da Universidade, a foto em preto e branco da medalha feita pela USP em comemoração ao quarto centenário da cidade de São Paulo, e um desenho da torre do relógio, "símbolo da cidade universitária da USP", seguido pelo poema em prosa intitulado "A Torre e o Sino", escrito pelo próprio autor e em que se lê: "A Torre é a síntese. O Sino é a alma. Exprimem pela imagem e pela vibração a estática e a dinâmica da Universidade - a forma e o espírito. [...] Eis a abertura do nosso ensaio histórico, situando, na Torre e no Sino, a mística sublime de um símbolo" (Campos, 1954, n.p.; grifo meu).
} 
ser construídos ${ }^{22}$. Entre o passado ressignificado e o futuro antevisto de maneira idealizada, o autor pretende traçar um elo explícito de continuidade, mostrando que as projeções de futuro não se separam das visões de passado.

Todo esse primeiro ensaio histórico, assim como as demais partes da obra que tratam das unidades específicas da USP, é ilustrado por imagens que explicitam ainda mais os pressupostos historiográficos do autor: retratos altivos de personagens importantes como Arnaldo Vieira de Carvalho, Armando Salles de Oliveira, o primeiro reitor da USP, Reynaldo Porchat e o então reitor, Ernesto Moraes Leme ${ }^{23}$; ilustrações de Bento Carlos de Arruda Botelho das atividades que expressariam a riqueza da vida universitária como o teatro, o esporte, a música, a arte e, sobretudo, o ensino e a pesquisa; desenhos e imagens de prédios e espaços simbólicos da universidade sempre representados em estilo imponente; e, por fim, fotos de alunos e professores da instituição nas suas funções cotidianas. Todos os retratados, sem exceção, são brancos. A maioria, homens. Em todos, a ciência aparece como atividade profissionalizada ${ }^{24}$ e elemento de distinção. A universidade, como espaço de atuação de homens abnegados e engajados no trabalho de produção e transmissão do conhecimento.

Mas além de incorporar os traços distintivos da historiografia paulista da primeira

\footnotetext{
${ }^{22}$ Ver, por exemplo, os desenhos da "Residência dos bolsistas", projetada por Oscar Gutierrez para o Escritório Técnico da Comissão da Cidade Universitária, ou ainda a "Casa do estudante", projetada pelos arquitetos Rino Levi e Cerqueira Cesar para receber os alunos na nova cidade universitária (cf. Campos, 1954, p. 152ss). Ambos voltados à moradia estudantil, os prédios não chegaram a sair do papel, dando lugar, mais tarde, a prédios prémoldados que constituem hoje os blocos residenciais CRUSP. A demanda por moradia constitui uma constante nos embates entre o movimento estudantil e a direção universitária, sendo tema, inclusive, da última greve estudantil, com ocupação da reitoria, iniciada em outubro de 2013. O movimento reivindicava que o prédio da antiga administração central fosse reconvertido em moradia estudantil, sua destinação original.

${ }^{23}$ Maria Gabriela Marinho enfatiza a importância das ausências nesse conjunto de representações, particularmente o silêncio em torno da importante figura do ex-reitor Miguel Reale, que revela as disputas no âmbito da universidade nas quais o próprio Campos se inseria (cf. Marinho, 2001, p. 10).

${ }^{24}$ Essa visão "profissional" é bem marcada na obra, em que se observa fotografias de estudantes e professores, quase sempre de jaleco branco, trabalhando no interior de grandes laboratórios. Essa observação é importante porque Ernesto de Souza Campos foi porta-voz do projeto de profissionalização da pesquisa na USP, tal como idealizado pela Fundação Rockefeller. Nesse projeto destaca-se o treinamento de pesquisadores, a melhoria da infraestrutura de pesquisa e a implantação do tempo integral (Marinho, 2001, p. 111ss).
} 
metade do século XX, a obra de Souza Campos não deve ser considerada um "desvio" também porque expressa de modo paradigmático o padrão que prevalece em parte importante dos trabalhos sobre a história da USP, em que a reconstrução factual ganha o caráter de uma narrativa no sentido forte do termo: a descrição de uma trajetória coerente e bem sucedida cujo sentido, pressuposto já no ato de fundação, desdobra-se a cada momento da vida institucional.

Para Souza Campos, esse projeto inerente à fundação da universidade era o ideal paulista de ensino superior, que já se expressara na Faculdade de Direito, criada ainda no período imperial, desdobrando-se nas sucessivas faculdades profissionais que vão integrando o ensino superior paulista para, "no momento certo", congregarem-se na Universidade de São Paulo. O autor reconstrói a história da USP, portanto, a partir da história das suas unidades profissionais isoladas, todas elas portadoras de um mesmo objetivo, de contribuir para o desenvolvimento do estado bandeirante e a felicidade, prosperidade e bem-estar do seu povo.

Esta análise mais detalhada da obra de Ernesto de Souza Campos não se justifica apenas pela riqueza com que o autor mobiliza, a partir dos pressupostos do IGHSP, os sistemas de classificação das elites ligadas ao ensino superior paulista ${ }^{25}$, tema que constitui um dos eixos centrais do presente trabalho. Tampouco por ser a expressão mais bem acabada da perspectiva finalista que marca de modo distintivo as histórias oficiais da USP. A sua importância se deve, sobretudo, ao fato dessa obra ter se constituído, ao longo do tempo, como uma das principais, senão a principal referência para a história da Universidade de São Paulo escrita em diferentes

\footnotetext{
${ }^{25}$ Na obra de Ernesto de Souza Campos, esse sistema de classificação aparece de modo marcante nas categorias fundamentais que ele mobiliza para pensar o problema do governo e da liderança acadêmica. Um exemplo interessante nesse sentido são as descrições de Campos das características pessoais de lideranças acadêmicas como Arnaldo Vieira de Carvalho, na passagem já citada: "Mas o que caracterizava especialmente a figura social e profissional de Arnaldo era seu atrativo pessoal. Refletia-se na inconfundível atitude de comando, revelada nas deliberações rápidas e incisivas, na nobreza e na dignidade dos seus atos, nos gestos moderados e cortantes, no seu feitio de estimular os estudiosos e até na sua indumentária sempre correta". Ou ainda: "Possuindo excepcional envergadura moral, dotado de grande inteligência, senhor de uma cultura vastíssima, adquirida pelo trato constante dos livros, tinha Dr. Arnaldo a seu serviço, extraordinárias qualidades de energia e decisão. Tinha, além do mais, o physique du role. Estas circunstâncias transpareciam no seu porte elegante, na caracterização marcante da fisionomia e refletia-se até no andar, e no fraseado cortante e rápido. Verdadeiro condutor de homens era também, na sua profissão, o primus interpares" (Campos, 1954, p. 346-9; grifos meus).
} 
perspectivas (cf. Antunha, 1971; Fernandes, 1984; Fétizon, 1986; Kwaniscka, 1985; Limongi, 1989; Lopes \& Santos, 2005; Motoyama, 2006). Cabe destacar que, apesar de analisar a história da instituição de uma perspectiva substancialmente distinta, Florestan Fernandes chega mesmo a recomendar explicitamente a leitura da obra histórica de Ernesto de Souza Campos sobre a USP (cf. Fernandes, 1984, p.113).

Esse diagnóstico sobre a importância da obra de Campos é reforçado em recente artigo de balanço bibliográfico, intitulado História da Universidade de São Paulo - apontamentos historiográficos, no qual Shozo Motoyama e seus colaboradores classificam-na como uma das poucas referências essenciais na área (cf. Motoyama et al., 2011). Apesar da pertinente ressalva de que se trata mais de um livro de memória do que propriamente de história, os autores não deixam de exaltá-lo, afirmando ser um dos dois únicos trabalhos que, com a pretensão de abarcar a história da USP como um todo, escaparia à regra predominante, de "obras de caráter comemorativo e de propaganda, aliás, de qualidade muito duvidosa" (Motoyama et al., 2011, p. 10).

A outra exceção, ao lado do compêndio de Ernesto de Souza Campos, seria, segundo os autores, o volume organizado pelo próprio Shozo Motoyama chamado USP 70 anos, imagens de uma história vivida (2006). Como o título sugere, a obra foi produzida por ocasião do septuagésimo aniversário da universidade e é composta de duas partes. Na primeira, intitulada USP e sua história, encontram-se quatro ensaios que buscam sistematizar a história da universidade desde a fundação da Faculdade de Direito até a redemocratização quando, em 1988, a instituição aprova um novo estatuto. Na segunda seção, que ocupa a maior parte da obra, o organizador insere dezenas de entrevistas de história de vida com dirigentes universitários que assumiram cargos de direção no âmbito do poder central da universidade a partir da década de 1980 e que relatam, ancorados na sua experiência na instituição, a história recente da USP. 
Do ponto de vista da forma, o livro de Shozo Motoyama sobre os setenta anos e o de Ernesto de Souza Campos sobre os vinte anos da USP se aproximam muito. Ambos são volumes extensos, publicados em edição luxuosa, de caráter comemorativo e repletos de imagens e ilustrações simbólicas de edificações e personagens considerados importantes para a história da instituição, marcadamente seus dirigentes, representados por pinturas oficiais a óleo dispostas ao longo do livro. O fato de tanto a obra de Campos quanto a de Motoyama terem sido apresentadas pelos reitores da época - Ernesto Moraes Leme e Suely Vilela - só reforça o caráter de história oficial e consagradora que as distingue ${ }^{26}$.

Essas semelhanças de forma correspondem, como é possível supor, a aproximações de conteúdo entre os dois trabalhos. Apesar da variação de tema e estilo, é possível dizer que a estrutura geral da narrativa histórica de Motoyama é a mesma daquela presente no compêndio de Souza Campos, especialmente pela tentativa de reconstruir normativamente o passado a partir de visões enraizadas em um campo de disputas materiais e simbólicas do presente. Nesse sentido, os dois trabalhos assumem um mesmo caráter teleológico ao postularem um sentido único que, incorporado de modo consciente por uma elite local engajada na construção do ensino superior paulista, determina o "passado, presente e futuro" da USP. É esse o espírito geral do ensaio que abre o volume sobre os setenta anos da USP, intitulado A Universidade São Paulo em três tempos e assinado por Shozo Motoyama.

O "tempo passado" refere-se às circunstâncias de fundação da instituição, pensada também na chave de um passado idealizado que se projeta, como espírito comum, em todo o

\footnotetext{
${ }^{26}$ A presença de prefácios escritos por dirigentes é uma marca constante na historiografia sobre a USP e suas unidades. Como já foi dito, o livro de Rosana Oba é prefaciado pelo então governador de São Paulo, Geraldo Alckmin e apresentado pelo então reitor, José Adolfo Melfi (cf. Oba, 2006). O livro escrito por Shozo Motoyama e Marilda Nagamini sobre os 110 anos da Escola Politécnica se abre com um prefácio do seu então diretor, Vahan Agopyan (cf. Motoyama \& Nagamini, 2004). O livro de Ana Luiza Martins e Heloísa Barbuy também é prefaciado, na sua primeira edição, pelo então diretor Álvaro Villaça Azevedo e, na sua segunda edição, pela então diretora Ivette Senise Ferreira. Além deles, o então reitor da USP Jacques Marcovitch também escreve uma apresentação à obra (cf. Martins \& Barbuy, 1998). Por fim, o livro de Carlos da Silva Lacaz e Berta Mazzieri sobre a história da Faculdade de Medicina da USP é prefaciado por Adib Jatene que, em 1995, era diretor da escola (cf. Lacaz \& Mazzieri, 1995).
} 
percurso da USP. Mas ao contrário de Campos, que remete tal fundação ao período colonial, Motoyama a localiza diretamente na Primeira República, que abriu espaço para o “empreendedorismo" da elite liberal paulista, treinada e socializada nas Arcadas da Faculdade de Direito. Esses “aprendizes do poder" (Adorno, 1988), atuando com outros "construtores da modernidade" (Motoyama, 2006, p. 93), iriam, a partir da concessão da autonomia estadual em 1889, fundar instituições de ensino e pesquisa que dariam suporte aos processos de industrialização e de urbanização que despontavam no estado de São Paulo. Nesse sentido, depois de constatar que o Brasil praticamente não criara instituições de ensino superior entre o Império e a República, o autor afirma:

\begin{abstract}
A exceção ficava por conta do estado paulista porque, após a proclamação da República, o governo bandeirante fundara a Escola Politécnica (1893), a Escola de Farmácia e Odontologia (1898), a Escola Superior de Agricultura "Luiz de Queiroz" (1901), a Faculdade de Medicina (1912), entre outros. Essas entidades contribuíram enormemente para a riqueza e a grandeza de São Paulo (Motoyama, 2006, p. 21).
\end{abstract}

É nessa chave, de uma instituição fundada pelo processo de desenvolvimento do estado de São Paulo e para ele voltada que Motoyama interpreta toda a história da USP, cuja fundação ele remonta, assim como postulado por Campos, à criação das suas escolas profissionais. A coerência dessa história é dada, portanto, pela realização de um mesmo "projeto original”, qual seja: o de um conhecimento a serviço da modernização que, não obstante conduzida por um grupo da elite paulista, beneficia a nação brasileira em seu conjunto. É como afirmava Júlio de Mesquita Filho, líder da "Comunhão Paulista" (cf. Cardoso, 1982), em frase especialmente selecionada pelo autor: "está na primeira plana [sic] o dever de substituir o conceito de saber por saber por outro: o de saber posto a serviço da coletividade" (Motoyama, 2006, p. 24).

Segundo esse esquema interpretativo, portanto, a concepção modernizadora e utilitária de conhecimento teria predominado na história da USP desde a fundação da sua primeira unidade, a Faculdade de Direito, quando "era necessário formar profissionais capazes de reger e administrar uma monarquia grande e dispersa" (Motoyama, 2006, p. 72; grifo meu). O mesmo 
ímpeto explicaria a urgência na instalação da Escola Politécnica, "instituição tão necessária para o desenvolvimento do país" porque capaz de "implantar uma infraestrutura moderna para que a burguesia ascendente pudesse se desenvolver" (Motoyama, 2006, p. 87-92; grifo meu). Na mesma chave, a Escola Superior de Agricultura Luiz de Queiróz, não obstante o ceticismo generalizado, conseguiu superar o desafio de "convencer os fazendeiros a adotar métodos mais modernos e mais científicos de praticar a agricultura", tornando-se um dos principais motores da modernização agrícola do país (Motoyama, 2006, p. 99). Também a fundação de uma Faculdade de Medicina "justificava-se perfeitamente" na "São Paulo da belle époque" que "vivia um fin de siècle nada confortável, com feias doenças e problemas, sem fim, de saúde" (Motoyama, 2006, p. 107). Em todos esses casos "a contribuição da Academia de Direito para a formação da classe política nacional não poderia ser contestada, assim como a da Escola Politécnica para a urbanização paulistana e a da Faculdade de Medicina para imprimir uma nova perspectiva à saúde" (Motoyama, 2006, p.23).

Mas o caráter pragmático do conhecimento não justificaria apenas a fundação das escolas profissionais no período Republicano, sob a sombra de uma ideologia do progresso e da modernização (cf. Nadai, 1981). Motoyama também interpreta nessa chave a própria criação de uma Faculdade de Filosofia, Ciências e Letras, idealizada como núcleo dinâmico da nova universidade. Segundo o autor, a necessidade desse espaço de pesquisa desinteressada e de formação básica se explicaria, paradoxalmente, pela sua contribuição específica para o desenvolvimento econômico e social, afinal "agora, os tempos eram outros [e] as escolas profissionais, por melhores que fossem, não bastavam" (Motoyama, 2006, p. 23). O impulso à pesquisa desinteressada e à formação científica se justificava, portanto, na exata medida em que o capitalismo, a partir da passagem do século XIX para o XX, passaria a demandar a aplicação sistemática da ciência à produção industrial e à organização geral da sociedade ${ }^{27}$ (cf. Motoyama,

\footnotetext{
${ }^{27}$ Enfatizar a importância da aplicação da ciência não só à produção industrial stricto sensu, mas também à organização geral da sociedade é importante para o presente trabalho porque ele pretende analisar, justamente, a
} 
2006, p.19ss). Desse modo, no plano das relações internacionais, a experiência da Primeira Guerra teria mostrado a centralidade do conhecimento científico para a garantia da soberania nacional. Ao mesmo tempo, no plano da organização das atividades humanas em diferentes níveis, o taylorismo e o fordismo exemplificariam a importância da racionalização científica do trabalho e reforçariam aqueles que defendem de maneira "entusiástica não só a tecnologia, mas a maneira de ser dos técnicos e engenheiros, que seria racional e sensata” (Motoyama, 2006, p. 22). Por fim, no plano estritamente produtivo, a ciência passaria a ser aplicada à indústria, gerando novos produtos e processos. Todas essas tendências teriam efeitos profundos sobre o contexto nacional, em que "a industrialização começava a se impor como uma necessidade para a economia brasileira" (Motoyama, 2006, p. 23). E isso sobretudo a partir da crise de 1929, quando se tornou imperativo abandonar o modelo agroexportador em prol de um processo de industrialização mais arrojado, à semelhança do que ocorria em outros países:

Entrementes, o mundo estava se alterando mais ainda. [...] A capacidade tecnológica das empresas e das nações progredira exponencialmente, graças à aplicação bem sucedida da ciência na resolução de questões técnicas. A ciência, finalmente, crescera e se aperfeiçoara o suficiente para encarar sem medo os grandes desafios da história industrial (Motoyama, 2006, p. 87).

Esse princípio modernizador e pragmático - que prioriza a aplicação da ciência à inovação industrial e social - seria, segundo Motoyama, norteador do projeto da USP, desdobrando-se com sucesso nos três momentos da vida da universidade. A projeção desse ideal de "ciência engajada" ao longo do tempo reforça a presença de uma perspectiva finalista de história, em que a reconstrução do passado opera como justificação do presente e do futuro, exatamente como pretendiam os Institutos Históricos e Geográficos que escreviam a história da pátria como "um exercício de exaltação" (Schwarcz, 1993, p. 103).

Mas o modelo de interpretação histórica proposto pela obra de Motoyama permite, ao

emergência de discursos e saberes com pretensão científica voltados à organização geral da universidade, reflexo da transposição de modelos gerais de organização social - como a teoria das organizações e da administração geral - para essa instituição específica. 
mesmo tempo, localizá-la entre um outro conjunto de trabalhos que, a partir da década de 1980, postula a primazia da tecnologia em relação à ciência, definindo a atividade científica em termos de objetivos exclusivamente práticos (cf. Forman, 2007). Desse modo, assim como a obra de Souza Campos não deve ser lida como erro ou desvio por se inserir em uma corrente histórica influente no seu tempo, o trabalho de Motoyama também precisa ser contextualizado no movimento intelectual mais amplo em que se insere, qual seja: o das pesquisas no âmbito da História da Ciência e da Tecnologia tal como institucionalizada a partir dos anos 1950.

É importante notar que a obra de Shozo Motoyama sobre os setenta anos da Universidade de São Paulo foi produzida no interior do Centro Interunidades de História da Ciência (CHC) que é, atualmente, o órgão da USP oficialmente encarregado por escrever a história da ciência e da tecnologia no Brasil e, principalmente, no estado de São Paulo ${ }^{28}$, testemunhando o processo de profissionalização e institucionalização da chamada história oficial das instituições de ciência e tecnologia. Fundado em 1988 como órgão ligado à reitoria, o CHC é desdobramento direto do Núcleo de História da Ciência e da Tecnologia da USP que passou a concentrar, em 1973, os trabalhos de pesquisa que, desde o fim da Segunda Guerra Mundial, vinham sendo desenvolvidos de modo autônomo, inspirados no grande desenvolvimento que a área alcançava nos Estados Unidos. Esse núcleo da USP recebeu, nas décadas de 1970 e 1980, financiamento da Unesco como parte do seu esforço para consolidar a subdisciplina de história da ciência e da tecnologia no país (cf. Motoyama, 2006, p. 45).

\footnotetext{
${ }^{28}$ Além da obra sobre os 70 anos da USP, o CHC foi responsável pela publicação dos seguintes trabalhos: Seade - uma história exemplar (Motoyama, Vargas \& Comengo, 2008); Fuvest: 30 anos da Fundação Universitária para o Vestibular (Motoyama \& Nagamini, 2007); Construindo o futuro - 35 anos de Pós-graduação da USP (Motoyama, 2004a); Escola Politécnica, 110 anos construindo o futuro (Motoyama \& Nagamini, 2004); Prelúdio para uma história: ciência e tecnologia no Brasil (Motoyama, 2004b); 50 anos do CNPq contados pelos seus presidentes (Motoyama, 2002); Fapesp - uma história de política científica e tecnológica (Motoyama, 1999a); Para uma história da Fapesp (Motoyama, 1999b); O Almirante e o Novo Prometeu (Motoyama, 1996); e Tecnologia e Industrialização no Brasil: uma perspectiva histórica (Motoyama, 1994). Além dessas obras produzidas no âmbito do CHC, Motoyama organizou ainda os seguintes volumes, depois da criação do centro: Memorial da América Latina, 21 anos (Motoyama \& Yamin, 2010); Uma associação para a tecnologia brasileira - ABIPTI 25 anos (Motoyama \& Marques, 2007); Educação técnica e tecnológica em questão - 25 Anos do Ceetep. História vivida (Motoyama, 1995).
} 
É justamente essa subdisciplina, que, no plano geral, vive seu processo de institucionalização a partir dos anos 1950, que constitui objeto da crítica formulada por Paul Forman ao analisar o silêncio dos trabalhos realizados nessa área, que ele identifica como a história da tecnologia ${ }^{29}$, quanto à mudança cultural que conduziu, desde o final da Segunda Guerra Mundial mas sobretudo a partir dos anos 1980, à desvalorização progressiva da ciência enquanto forma específica de conhecimento e à afirmação da primazia da tecnologia enquanto modo de aplicação desse saber científico. Segundo ele:

\begin{abstract}
Os historiadores da tecnologia deveriam estar entre os primeiros a reconhecer essa mudança epocal no significado e na valoração cultural da tecnologia. Eles deveriam assumir a perspectiva histórica que permitisse esse reconhecimento e, como é fácil de supor, seria do seu interesse apoiar esse reconhecimento; [...] os historiadores da tecnologia [no entanto] também ignoraram amplamente a avaliação contemporânea da tecnologia [...]. Essa relutância em reconhecer ou aceitar uma reorientação cultural de época que afeta tão favoravelmente a perspectiva geral do seu objeto, a tecnologia, e, assim, da sua disciplina, a história da tecnologia, é contrária à expectativa e exige uma explicação. A explicação repousa, me parece, no caráter ideológico dessa disciplina histórica e na ideologia específica adotada por ela, a partir do momento que esta assume a sua forma atual, entre os anos 1950 e 1980 (Forman, 2007, p. 53).
\end{abstract}

Essa ideologia é constituída, segundo Forman e em termos gerais, por um “fascínio" e um "entusiasmo" pela tecnologia que esses historiadores projetam, de modo anacrônico, para outros autores e momentos históricos chegando ao extremo de assumir uma posição antagônica em relação à própria noção de ciência, vista como um mito criado por teóricos ingênuos e ilusoriamente deslumbrados pelos ideais de objetividade, de neutralidade e de universalidade representados por essa forma de conhecimento (cf. Forman, 2007, p. 53ss). Em síntese, ao invés de reconhecer a ocorrência de uma mudança historicamente situada que alterou o lugar social

\footnotetext{
${ }^{29}$ A oposição entre uma História da Ciência e uma História da Tecnologia como subdisciplinas é muito forte nos Estados Unidos onde, como mostra Forman, existem duas tradições historiográficas distintas e, em certo sentido, opostas, com sociedades científicas diferentes, revistas especializadas separadas e seções científicas à parte. No Brasil, como a História da Ciência era uma subdisciplina ainda muito incipiente quando emergiu a assim chamada História da Tecnologia, a tendência foi que ambas permanecessem juntas, como demonstra o título do Núcleo da USP institucionalizado em 1973. Apesar de não experimentar o mesmo desenvolvimento obtido por essa área nos EUA, ela compartilha os mesmos pressupostos da sua congênere norte-americana, de modo que é possível notar aqui a mesma inflexão observada por Forman para os países centrais, sobretudo a partir dos anos 1980 quando, segundo indicação do autor, o processo de valorização cultural da tecnologia se intensifica (cf. Forman, 2007, p. 2).
} 
da tecnologia e reconfigurou a sua relação com a ciência e, logo, a ciência ela mesma, esses estudos buscam reinterpretar toda a história da ciência e da tecnologia à luz dessas novas relações, transformando em ontologia o que decorre, na verdade, somente de contingências históricas.

O campo das ciências sociais vive processo correlato com a defesa do abandono da noção de ciência em nome do conceito de tecnociência, supostamente mais preciso, abrangente e crítico (cf. Bensaude-Vincent, 2009; Hottois, 1984; Latour, 2011) 30. Já no plano do desenho e análise de políticas públicas, essa mesma tendência de releitura história pode ser observada na crítica generalizada ao chamado "modelo linear de inovação", que pressupõe uma diferença substancial entre o processo de produção da ciência e da tecnologia, sobretudo em termos de formulação de problemas e de objetos e objetivos de pesquisa (cf. Balconi, Brussoni \& Orsenigo, 2010; Godin, 2006). É no âmbito desse processo cultural de valorização de uma concepção pragmática de ciência e dos seus efeitos sobre o campo específico da História da Ciência e da Tecnologia que se deve inserir a interpretação histórica de Motoyama sobre a USP. No entanto, essa visão específica da ciência e da universidade não é apenas a concepção predominante de uma época. Ela é, também, no contexto nacional, a visão privilegiada de uma classe social. Segundo Elza Nadai, foi justamente essa visão pragmática do conhecimento científico que orientou a criação, pela burguesia paulista em ascensão no período republicano, das escolas profissionalizantes de ensino superior que, posteriormente reunidas, viriam a constituir a USP. Voltadas à formação de novos profissionais dispostos a romper com o bacharelismo em nome da ciência e da técnica, essas escolas superiores "deveriam ser instituições a serviço do progresso e da modernização, ideologia essa que legitimaria sobretudo

\footnotetext{
${ }^{30}$ Para uma crítica da noção de tecnociência ou do princípio de indiferenciação que a baseia ver: Gingras, 1995; Shinn, 2002; Shinn \& Ragouet, 2008. No Brasil, alguns trabalhos recentes têm perseguido essa mesma crítica através da realização de pesquisas empíricas circunstanciadas que procuram mostrar as limitações dos diagnósticos excessivamente gerais sobre a transformação recente da ciência, bem como a pertinência de distinções entre ciência e tecnologia (cf. Carlotto, 2012 e 2013; Ferreira, 2013).
} 
na República a burguesia cafeeira, em suas diversas frações, como classe dominante" (Nadai, 1981, p. 52).

Essa ideologia foi incorporada de modo marcante, conforme demonstra a autora, pelas unidades da USP criadas nesse período - particularmente a Escola Politécnica, a Faculdade de Medicina e a Escola Superior de Agricultura Luiz de Queiroz - todas elas voltadas, como foi dito, para os processos de modernização econômica e social de São Paulo. Nelas, essa perspectiva instrumental da ciência preservou-se como cultura institucional sendo constantemente reafirmada nos dispositivos voltados para a construção de um imaginário comum (cf. Nadai, 1981). É nesse sentido que tal visão que associa a ciência ao controle, à dominação e ao poder aparece, por exemplo, em um dos discursos de encerramento do ano letivo da Escola Politécnica de 1908-1909 citado por Nadai:

Instalara-se o domínio da "sciencia desde o dia em que se percebeu que pela sciencia pode-se dominar as forças brutas da natureza, tornando-as escravas da nossa vontade, que se pode por ella fazer prosperar a industria, augmentando a potência e riqueza das nações, o numero daqueles que a cultivavam por mera diversão cresceu extraordinariamente com o dos que procuram um fim utilitário e pratico" (Nadai, 1981, p. 59; grifo meu; ortografia original mantida).

Uma expressão marcante da íntima relação entre a reconstrução histórica realizada por Motoyama e a visão de mundo predominante nas escolas profissionais ditas tradicionais é a opção do historiador em dar voz, ao longo do seu ensaio histórico, a egressos dessas unidades que se tornaram, segundo ele, "executivos de sucesso" em diversos campos. Assim, da mesma maneira que Ernesto de Souza Campos ressalta a importância de membros da elite cafeeira na construção de uma universidade em São Paulo, Shozo Motoyama escolhe altos executivos paulistas, do setor agroindustrial e financeiro, para ilustrar o espírito “pioneiro" da USP. É assim que o autor, ao descrever a valorização da inovação pela instituição, remete ao exemplo de Olavo Egydio Setúbal, "um dos diplomados mais ilustres da Universidade de São Paulo, especificamente da Escola Politécnica, [que] captou esse espírito com acuidade e competência [e] tornou-se em um dos maiores empresários do país" (Motoyama, 2006, p. 19). No prefácio 
que escreve para o livro sobre os setenta anos da USP, Olavo Setúbal reitera o princípio que determina, na sua visão, o desenvolvimento da universidade:

\begin{abstract}
O novo não nasce do velho, mas emerge ao seu lado e o supera, dizia Schumpeter, ao analisar os ciclos de estagnação e expansão econômica. Pode-se chorar por aqueles que foram massacrados pelo avanço da tecnologia. Mas isto jamais detém o progresso nem, muito menos, altera seu resultado final, concluía. O conhecido processo de "destruição criadora" pode ser uma das chaves interpretativas, entre tantas possíveis, para analisar os sucessivos êxitos alcançados pela Universidade de São Paulo e os efeitos modernizadores que provocaram na sociedade brasileira (Motoyama, 2006, p. 13; grifo meu).
\end{abstract}

Mas não é apenas o exemplo do fundador do Banco Itaú que ilustra o ensaio histórico de Motoyama. Outros empresários "bem sucedidos", formados por unidades profissionais da USP, ganham destaque ao longo do texto. É o caso de José Carlos Moraes Abreu que, na Escola Politécnica, aprendeu "o amor pela liberdade", capacitando-se para se tornar "um dos pilares de um grande conglomerado financeiro" (Motoyama, 2006, p. 28). Destaque semelhante é dado ao esalquiano Einar Kok que, "como se sabe, tornou-se no decorrer da sua vida um bem sucedido industrial, tendo sido, também, secretário da Indústria, Comércio, Ciência e Tecnologia do Estado de São Paulo" (Motoyama, 2006, p. 35). Assim como Carlos Alves Seixas, também da Esalq, “que após uma passagem frutífera pelo campo da pesquisa, embrenhou-se, com êxito, no setor empresarial, sendo hoje um grande pecuarista" (Motoyama, 2006, p. 35). Em outra chave, o politécnico Antonio Jacinto Matias, que se tornou também "um bem sucedido executivo", exemplificaria a capacidade da USP de aliar o enfoque tecnológico com o humanístico para "lidar com o desconhecido", expressão tanto do êxito do empresário quanto da própria universidade que o formou (Motoyama, 2006, p. 37).

Sem a pretensão de serem exaustivos, os exemplos citados apontam outra semelhança estrutural entre a obra de Souza Campos e de Motoyama: o recurso sistemático a pequenas biografias consagradoras como forma de legitimar setores da elite paulista, cada vez mais formada e socializada pelo ensino superior do estado. Ao fazer isso, os autores acabam legitimando, também, a sua visão específica de ciência e o seu projeto correspondente de 
universidade. Isso porque tal operação - de valorização das elites que passam a ser formadas pelo ensino superior, portando, assim, um projeto específico para ele - pressupõe um discurso de consagração institucional, expresso na constante celebração de uma certa USP.

Esse conteúdo de celebração está ancorado, como aponta Franklin Leopoldo e Silva, na própria concepção de história que orienta essas análises que, pautadas pela noção de progresso, fazem "a experiência da modernidade como enaltecimento do presente" (2006, p. 193). Nessa chave compreensiva, o perfil atual da USP é considerado "inevitável, natural e necessário", porque "fruto do progresso", de modo que "qualquer coisa que viesse a pensar alternativamente seria o contrário do progresso, seria retrocesso" (Silva, 2006, p. 192-3). O resultado, como aponta o autor, é essencialmente apologético e conservador:

Isso redunda na consequência bem conhecida e cotidianamente sentida em nossos dias: a naturalização da história, a naturalização da vida. Tudo é como deveria ser e é insensato pensar de outra maneira. O progresso consiste em incorporar o presente, dado natural da realidade, e prosseguir, isto é, progredir, segundo as direções já assinaladas nessa incorporação (Silva, 2006, p. 193).

É nesse sentido que se deve compreender porque o ensaio de interpretação histórica escrito por Motoyama se abre com uma constatação essencialmente apologética que ressalta o caráter "mítico" da USP e, por conseguinte, o "brilho" de seus egressos e o "prestígio" e "consagração" da sua forma institucional contemporânea. Em algumas linhas, o autor sintetiza a sua compreensão do significado histórico da USP, explicitando a chave em que a história da instituição deve ser apreendida:

Bem poucas instituições universitárias exercem tamanha atração a tanta gente quanto a Universidade de São Paulo (USP). Não é sem razão que ela tornou-se quase um mito para uma parte da população. Mas, de onde vem toda essa consagração, todo esse prestígio? Com certeza, de fatores diversos, cujas origens se perdem nas brumas do passado. A história da USP, de fato, é riquíssima. Que outra entidade educacional poderia apresentar contribuição tão grande para a sociedade brasileira, seja no campo da cultura, seja no da economia ou mesmo no da política? Sim, qual seria o estabelecimento de docência e pesquisa capaz de ostentar um currículo com tantos educadores, cientistas, pesquisadores, engenheiros, empresários, intelectuais e outros, formados nos bancos de estudo, que fizeram a história do Brasil? [...] Esta amostra qualitativa, embora não representativa, não passa de uma pequena galáxia, brilhando nos confins de um universo povoado de miríades de outras, repletas de egressos da USP. A despeito de não existir ainda uma estatística completa, há indicações confiáveis para se acreditar que o sucesso de diversos acontecimentos nacionais contou com a participação efetiva dos uspianos. Certamente, muitos projetos 
nacionais não decolariam se não fosse a contribuição, muitas vezes anônima, dos formados pela primeira universidade do estado bandeirante (Motoyama, 2006, p. 17).

Esse discurso de autoconsagração tem, como efeito, não só o enaltecimento do processo de organização da universidade como, também, a valorização simbólica do pertencimento à instituição, em particular por parte daqueles que, por suas posições de direção e controle, contribuíram de modo mais significativo para o sucesso celebrado. Essa dimensão da história “como exercício de exaltação" não escapa à então reitora Suely Vilela que, na sua apresentação à obra de Shozo Motoyama sobre a USP, ressalta a responsabilidade que lhe cabe na linhagem de dirigentes à qual pertence:

Depoimentos de alguns dos seus reitores rememoram o papel que cada um deles desempenhou na construção da excelência, que coloca a instituição na posição de vanguarda, nacional e internacionalmente, como importante centro de geração e difusão do conhecimento. [...] Impressiona tomar conhecimento do sacrifício exigido dos pioneiros que tornaram realidade o sonho de construção de uma Universidade com as dimensões e o padrão de qualidade acadêmica que a USP hoje apresenta no país e na América Latina. [...] Tenho consciência da grande responsabilidade que me cabe, como reitora da Universidade, de honrar a memória de todos os que, antes de mim, ergueram tal patrimônio" (Motoyama, 2006, p. 9).

Outra formulação precisa sobre o sentido dessa historiografia oficial encontra-se no prefácio escrito pelo então governador de São Paulo, Geraldo Alckmin, ao livro de Rosana Oba sobre os reitores da USP. Intitulado História de quem fez história, o prefácio compartilha os pressupostos gerais dessa historiografia que busca consagrar a trajetória da USP consagrando, ao mesmo tempo, a atuação dos seus dirigentes ${ }^{31}$ :

Fundada em 1934, a Universidade de São Paulo nasceu em um momento no qual o Brasil passava por intensas transformações culturais, políticas e econômicas. Ela foi fruto desse processo de modernização. Porém, por suas qualidades, rapidamente passou à condição de efeito à causa permanente da modernização do país. [...] Quando a USP avança, é São Paulo que avança, é o Brasil que avança [...]. Este livro registra a história das pessoas que fizeram a história da USP. São histórias que se misturam, se completam e se identificam por estarem marcadas pelos mesmos princípios e ideais que têm orientado sua trajetória ao longo de mais de sete décadas. Ideais que podem ser sintetizados pela divisa - antiga e cada vez mais atual - incrustrada no próprio brasão da Universidade - "Vencerás pela ciência!" (Alckmin, 2006, p.13-4).

${ }^{31}$ É importante notar, nesse mesmo sentido, que o livro de Oba também inclui um "tributo a Miguel Reale", exreitor da USP que faleceu durante a finalização do livro (cf. Oba, 2006, p.19ss). 
É à luz dessa história oficial que concede aos dirigentes da USP o lugar de porta-vozes da história institucional que se deve compreender, criticamente, a escolha de Shozo Motoyama de reconstruir a história recente da USP a partir da fala dos seus dirigentes, tal como o faz na segunda parte do seu trabalho. Mas é importante notar que ele recorre a um discurso metodológico para justificar a opção "de deixar os próprios atores e atrizes, desse drama chamado universidade, falarem por si mesmos" (Motoyama, 2006, p. 68). Segundo o autor, essa opção remete a uma escolha metodológica consciente porque inscrita no movimento da chamada história oral ${ }^{32}$. E é justamente pelo contraste das proposições dessa corrente historiográfica, tomadas reflexivamente, que as contribuições de uma história estrutural tornam-se mais claras.

\section{Relato pessoal e primazia da estrutura: da história oral à história estrutural}

Acompanhando o argumento presente nas duas referências mobilizadas por Shozo Motoyama para inserir o seu trabalho na tradição da história oral (cf. Thompson, 1992; Prins, 1992), nota-se que o grande objetivo dessa corrente historiográfica forjada no pós-guerra era defender, por influência direta da sociologia ${ }^{33}$, a possibilidade de uso de registros orais como fonte para a reconstrução histórica, conferindo lugar de destaque às representações subjetivas da história.

Paul Thompson, considerado um dos grandes expoentes do movimento da história oral, sustenta que a recusa dos "historiadores tradicionais" em reconhecer os relatos individuais como fonte legítima para a historiografia deve-se essencialmente à opção teórica e política por

\footnotetext{
32 Outros autores que escreveram sobre a história da USP e das suas unidades isoladas também reivindicam a tradição da história oral como inspiração metodológica como, por exemplo, Ana Luiza Martins e Heloisa Barbuy (cf. 1998, p. 11).

${ }^{33}$ Paul Thompson, considerado por muitos como o grande teórico da história oral, começa a trabalhar com registros falados no Departamento de Sociologia da Universidade de Essex na década de 1960 (cf. Thompson, 1992).
} 
escrever uma história ligada à perspectiva dos dominantes. Nesse sentido, a estratégia de dar voz a quem tradicionalmente não tem voz tornava-se um instrumento de contestação desse comprometimento dos historiadores com o exercício da dominação:

\begin{abstract}
A História Oral não é necessariamente um instrumento de mudança; isso depende do espírito com que seja utilizada. Não obstante, a História Oral pode certamente ser um meio de transformar tanto o conteúdo quanto a finalidade da própria história. Pode ser utilizada para alterar o enfoque da própria história e revelar novos campos de investigação [...] (Thompson, 1992, p. 22).
\end{abstract}

Assumindo, portanto, esse sentido político original, o recurso a fontes orais representou, na prática, a ampliação dos horizontes da história com a inclusão de novos temas e problemas. Essa abertura de campos de investigação está particularmente ligada à emergência, por exemplo, de uma historiografia feminista e pós-colonial na primeira metade do século XX (cf. Patai, 2010; Vansina, 1985). Mas a principal contribuição da história oral, segundo Thompson, é de natureza metodológica. O recurso ao relato individual confere à narrativa histórica uma maior confiabilidade. Isso porque, se a maioria dos registros escritos mobilizados pelos historiadores "tradicionais" reflete o ponto de vista da autoridade, a história oral permite um julgamento mais imparcial ao evocar suas testemunhas também entre as classes subalternas (cf. Thompson, 1992, p. 26).

Por outro lado, o historiador Gwyn Prins promove uma defesa menos enfática e mais criteriosa do registro falado como fonte historiográfica (1992). Para ele, as fontes orais, do mesmo modo que as fontes escritas, apresentam limitações que é preciso considerar, sem prejuízo de reconhecer que os historiadores, particularmente os das sociedades modernas, industrializadas e alfabetizadas, são em geral excessivamente céticos quanto à validade das fontes orais para a reconstrução do passado pelo seu caráter supostamente "fluido" e "subjetivo" (cf. Prins, 1992, p. 163-5). Isso demonstra, segundo o autor, um certo preconceito com outras formas de registro e transmissão da experiência social que não somente a escrita, que representa o modo privilegiado com que os próprios historiadores se relacionam com o mundo: "se a nossa 
sociedade é, em geral, alfabetizada, os historiadores são alfabetizados por excelência: para eles a palavra escrita é soberana, estabelecendo seus padrões e seus métodos" (Prins, 1992, p. 169). Esse preconceito, ancorado na experiência intelectualizada, impediu os historiadores de tratarem as fontes orais como fontes de pesquisa válidas, limitando, assim, o alcance das suas reconstruções históricas.

Tanto na argumentação de Paul Thompson quanto na de Gwyn Prins, com maior ou menor critério, a questão essencial é, portanto, legitimar os registros orais enquanto fontes para o trabalho historiográfico. Mas por trás dessa defesa puramente metodológica reside um pressuposto teórico mais profundo: o de que a reconstrução dos discursos subjetivos - sob a forma do relato pessoal - permitiria restituir o lugar quase absoluto das representações individuais excluídas pelo historiador no seu trabalho de objetivação histórica. Para essa perspectiva fenomenológica, é como se a verdade dos acontecimentos históricos estivesse guardada na percepção íntima dos indivíduos que os vivenciaram - pressuposto que explica, por exemplo, o subtítulo da obra de Motoyama, "USP 70 anos: imagens de uma história vivida". É, portanto, a experiência individual, singular, única que transforma os indivíduos em portadores dos sentidos e dos significados dos acontecimentos históricos.

De uma perspectiva sociológica em geral e de uma sociologia histórica estrutural em particular, a defesa metodológica do registro falado operada pelo movimento da História Oral soa um tanto quanto deslocada, uma vez que as diferentes formas de relato pessoal - em especial, as narrativas de história de vida, os registros subjetivos dispersos e as entrevistas mais ou menos estruturadas - já são amplamente legitimadas como instrumentos de pesquisa nos marcos disciplinares da sociologia. Do mesmo modo, parece um tanto ingênua a aposta de que a subjetividade individual seja portadora da verdade histórica, ainda que as representações subjetivas constituam objeto privilegiado da sociologia.

Nesse sentido, ao criticar a perspectiva memorialista predominante na historiografia das 
grandes escolas francesas, Pierre Bourdieu ressalta que o grande problema desses testemunhos pessoais não é, como argumentam os historiadores "tradicionais", o seu caráter "fluido" ou "subjetivo", mas a incapacidade dos analistas, particularmente daqueles responsáveis pela reconstrução histórica, de objetivar as condições sociais em que tais narrativas são produzidas. Em outras palavras, o problema não estaria no relato pessoal em si, mas na falta de vigilância epistemológica ao utilizá-lo. Isso porque tanto os formuladores diretos desses discursos quanto os analistas que os mobilizam para reescrever a história institucional permanecem inconscientes dos interesses e sentidos específicos de que são portadores e que se explicam justamente pela relação social determinada que esses sujeitos estabelecem com a instituição cuja história relatam (cf. Bourdieu, 1989, p. 185-6).

Em registro semelhante, é preciso considerar que parte importante do trabalho de Irene Cardoso sobre a universidade, particularmente sobre a Universidade de São Paulo, desenvolvese a partir da interrogação do lugar da memória no processo de reconstrução histórica (cf. Cardoso, 1999 e 2001). Mas assim como Bourdieu enfatiza a necessidade de objetivar a posição de enunciação dos discursos individuais, particularmente pelas relações que tal posição encerra, Irene Cardoso condiciona a sua análise sociológica a uma reflexão profunda e sistemática sobre o lugar a partir do qual a memória e o esquecimento são construídos. Esse lugar, para a sociologia, deve ser pensado em termos gerais como uma posição no interior de um conjunto de posições possiveis, todas elas refletindo uma relação determinada do sujeito com a instituição. A objetivação dessas posições é justamente o que permite construir uma perspectiva "distanciada" da universidade, como descreve Cardoso:

Agora é possível voltar à questão do significado do memorial, após essa longa digressão sobre as transformações do sentido da universidade e do tipo de ligação entre a vida pessoal e o trabalho intelectual numa instituição universitária. Esta digressão fez-se necessária, no entanto, para que se pudesse chegar a algum esclarecimento acerca da posição daquele que escreve, posição esta que define a construção de um itinerário intelectual, cuja expressão escrita deverá tomar a forma de um memorial. Pode-se considerá-la como uma espécie de mapeamento das posições possíveis, que no entanto não se constitui como um traçado prévio exterior, no qual estas posições pudessem ser alocadas, mas já é a construção a partir de uma 
posição distanciada, que pode olhar a instituição, num momento do tempo que é o da atualidade (Cardoso, 1999, p.15; grifos meus).

Em outro registro mas com a mesma implicação, Michel Foucault, ao propor uma análise arqueológica dos discursos, também restitui a validade da enunciação subjetiva que, enquanto qualquer outro enunciado discursivo, deve compor, como documento, um arquivo voltado à reconstrução histórica (Foucault, 2010, p. 177). Mas para isso, é preciso reconhecer "que tantas coisas ditas por tantos homens desde há tantos milênios não surgiram apenas das leis do pensamento ou do jogo das circunstâncias" mas se devem essencialmente ao "conjunto de relações que caracteriza propriamente o nível discursivo" (Foucault, 2010, p. 177; grifo meu).

Para todos esses autores, portanto, a questão essencial não é negar a validade do registro falado, do relato pessoal ou da memória subjetiva como instrumentos de reconstrução histórica, mas interpretá-los a partir do lugar em que são enunciados, seja esse lugar pensado como uma posição social (Bourdieu, 1984, 1986 e 1989), uma posição discursiva (Foucault, 2001) ou uma posição temporal-psíquica (Cardoso, 1999 e 2001). É da primazia dessas posições, pensadas como expressão de relações sociais, que parte a história estrutural, como uma expressão específica da sociologia histórica.

A proposta de realizar uma história estrutural do ensino superior foi desenvolvida de modo sistemático por Pierre Bourdieu nas duas obras que dedicou ao tema nos anos 1980, quais sejam: Homo Academicus, publicada em 1984 e que trabalha a transformação do campo acadêmico partindo da análise da transformação das faculdades de letras e ciências humanas; e La noblesse d'état, publicada em 1989 e centrada mais especificamente no campo das grandes escolas francesas. Em ambas, o autor defende a história estrutural do ensino superior como uma forma privilegiada de elucidar o sentido das transformações no interior desse campo (cf. Bourdieu, 1984, p. 176ss; 1989, p. 279ss).

A opção de Bourdieu de nomear a sua história de "estrutural" não implica, no entanto, 
uma filiação direta ao estruturalismo, particularmente o de inspiração linguística que, nas ciências sociais, encontrou expressão acabada na antropologia de Claude Lévi-Strauss, mesmo considerando que essa corrente constitui a matriz teórica dos primeiros trabalhos bourdieusianos de etnografia da sociedade Kabyla (cf. Bourdieu, 1980, p. 9ss). Na verdade, os anos 1970 marcam um progressivo afastamento de Bourdieu em relação ao estruturalismo, o qual foi acompanhado por uma crítica sistemática que, originalmente metodológica, resultou em inflexões teóricas importantes, tal como explicitado em Le sens pratique, obra que antecede diretamente os estudos bourdieusianos sobre o ensino superior francês (cf. Bourdieu, 1980; 1984; 1989). É justamente esse movimento crítico ao estruturalismo e inerente à construção de uma teoria da ação pensada enquanto prática, explicitado nessa obra de síntese (cf. Bourdieu, 1980), que precisa ser recuperado para elucidar os pressupostos teóricos e metodológicos de uma história estrutural da universidade, nos termos propostos nesta tese.

Conforme Bourdieu argumenta em diversos momentos de Le sens pratique, por não analisar de modo reflexivo o seu trabalho de objetivação, o estruturalismo acaba projetando, sobre os agentes que investiga, a mesma relação teórica que mantém com o mundo, enquanto produto intelectual do trabalho de espectadores externos ou metodologicamente distanciados dos objetos que pretendem analisar (cf. 1980, p. 52ss). A projeção indevida da razão teórica do analista sobre a lógica prática dos agentes está na raiz dos dois principais equívocos do objetivismo estruturalista: primeiro, não reconhecer que o mundo social não é somente objeto de interpretações teóricas, mas também de engajamentos práticos, o que pressupõe considerar os interesses e as estratégias associadas a condições de existência materialmente distintas; segundo, introduzir na ação e na percepção dos agentes esquemas cognitivos fixos, conscientes e bem-acabados, que só aparecem como tal para o analista, a partir do seu trabalho de objetivação (cf. Bourdieu, 1980, p. 60). Nos dois casos, o estruturalismo ignora a lógica prática inerente à forma como os próprios agentes percebem, interpretam, significam e sentem o 
mundo, ao mobilizar de modo relativamente autônomo os sistemas de disposições incorporadas que funcionam com princípios geradores de práticas, os quais Bourdieu denominou habitus (cf. 1980, p. 89).

Não obstante a sua crítica à redução estruturalista, que define os sujeitos como simples autômatos e a história como mera variação, Bourdieu não deixa de reconhecer, e ressaltar, a contribuição essencial do estruturalismo: ter introduzido nas ciências sociais o método relacional de pensar que, rompendo com toda a forma de substancialização e funcionalismo, caracteriza cada elemento do sistema a partir da relação que ele estabelece com outros, dela extraindo o seu significado e a sua função (cf. 1980, p. 11). É esse pensamento relacional, assumido pela perspectiva estrutural, que confere primazia à estrutura social, pensada como um conjunto de posições às quais correspondem distintas condições materiais de existência, logo, distintas posições de classe, traduzidas, por relações de homologia, em hierarquias particulares a cada campo. Assumir esse pressuposto materialista e estrutural não implica, no entanto, recair no objetivismo cego que nega, como mero erro, as representações subjetivas e imediatas do mundo, expressas em crenças, doxa(s), illusio(s), em suma, em esquemas de classifícação, sentimento e ação, por vezes pré-conscientes, sem os quais a experiência social não seria possível.

O afastamento em relação à perspectiva fenomenológica, na qual se inclui o movimento da história oral, é acompanhado, assim, de um distanciamento simétrico em relação ao estruturalismo, representado pela antropologia lévi-straussiana. É, portanto, do esforço para superar tanto o subjetivismo fenomenológico, que pressupõe a pura liberdade dos agentes, quanto o objetivismo estruturalista, que se reverte em determinismo mecanicista (cf. Bourdieu, 1980, p. 43ss), que se alimenta a teoria da ação que está na base de uma história estrutural do ensino superior (cf. Bourdieu, 1984; 1989). Mas essas duas tendências opostas - a primazia absoluta do indivíduo e a primazia total da estrutura - não se impõem da mesma forma nos 
diferentes contextos de investigação. Na verdade, essas tendências retiram a sua força específica da relação particular que o pesquisador estabelece com os objetos que se propõe a analisar.

É preciso considerar, portanto, que o problema que se coloca para o sociólogo que pretende estudar o ensino superior em geral, e o campo universitário em particular, é em certo sentido oposto ao que se impõe para o etnógrafo que busca compreender formas de organização social que inicialmente desconhece. Se no esforço etnográfico o maior desafio é superar a distância que impede o analista de acessar as representações subjetivas que possibilitam e decorrem do engajamento prático, na análise do mundo acadêmico é o excesso de proximidade que induz o analista a aceitar tacitamente os sentidos imanentes a esse mundo, particularmente a valorização de uma história finalista voltada à exaltação das realizações individuais; atitude, vale dizer, típica de um universo social em que um dos objetivos é inscrever na história as contribuições particulares de natureza intelectual, tal como expresso na aspiração, da qual nem o analista escapa, de "construir um nome" (Bourdieu, 1984, p.11).

Nessa chave, os equívocos principais que a história estrutural pretende superar encontram-se inscritos na própria relação de pesquisa. No caso em que a relação do pesquisador com o objeto é de exterioridade, torna-se preciso reconhecer que o esforço de objetivação pressupõe uma relação teórica com o objeto, sob pena de ignorar o fato - essencial - de que os agentes se relacionam com esse mesmo objeto de modo prático, conectando-se a ele por interesses simbólicos e materiais e, mais do que isso, por categorias de percepção, sentimento e ação pré-conscientes, logo, pré-científicas. Já no caso em que a relação de pesquisa é de imersão, como no caso do(a) sociólogo(a) que pretende analisar a universidade, o movimento reflexivo tem que ser essencialmente outro: não se trata de problematizar a distância social que o impede de apreender as categorias inerentes ao engajamento prático, mas é o próprio engajamento prático que impede a construção de uma distância capaz de viabilizar a apreensão objetiva do objeto - a universidade, no caso. 
Nas duas situações, o ponto de partida analítico deve ser uma abordagem reflexiva das condições cognitivas e sobretudo materiais que possibilitam o trabalho de objetivação. É justamente essa abordagem que torna possível analisar criticamente as categorias subjetivas, socialmente estruturadas, que definem o senso comum enquanto expressão do "senso prático" - essa "visão quase corporal do mundo" que orienta os atores no espaço social através de operações classificatórias elementares e que constitui, tanto quanto a estrutura de que são produto, o objeto privilegiado das ciências sociais" (cf. Bourdieu, 1980, p. 111).

É esse movimento analítico duplo, que se volta tanto para as estruturas sociais quanto para a sua incorporação enquanto categorias cognitivas, que está na base de uma história estrutural da universidade enquanto operação sociológica. Seu ponto de apoio reside, portanto, em um pressuposto teórico mais amplo de que a ordem simbólica - que condensa as categorias percepção, pensamento e ação etc. - mantém uma relação de determinação recíproca com as estruturas sociais objetivas, marcadamente com a estrutura de classes. Assim, ao mesmo tempo em que traduz, em seus próprios termos, a estrutura social, a ordem simbólica contribui para a sua reprodução através de processos de legitimação, naturalização, denegação, consagração ou, se quisermos, reificação. É nessa chave que a violência simbólica - conceito central nos estudos de Bourdieu sobre o sistema escolar - procura descrever a construção e a manutenção de relações sociais de dominação enquanto um processo de imposição de esquemas de classificação que são internalizados por dominantes e dominados naturalizando as relações objetivas que os separam. Ou seja, por ser "a forma incorporada da estrutura, da relação de dominação, [esses esquemas] fazem essa relação aparecer como natural" (Bourdieu, 1997, p. 204; grifo meu). A naturalização da dominação, essencial à conservação da ordem estabelecida, só é possível porque encontra, assim, expressão em um plano essencialmente simbólico, ou, como afirma Bourdieu, “os sistemas simbólicos devem sua força própria ao fato de que as 
relações de força que exprimem só se manifestam sob a forma irreconhecível de relações de sentido [rapports de sens]" (Bourdieu, 2001, p. 210; grifo meu).

Nessa chave, um dos aspectos mais interessantes da análise sociológica de Bourdieu que consiste em mostrar a relação de duplo reforço entre estruturas sociais e estruturas cognitivas - revela-se justamente na forma como ele mobiliza a noção de sens. O seu Esboço de uma teoria da prática, escrito no começo dos anos 1970 como uma antecipação de $O$ senso prático (1980), se abre justamente com uma definição de sens: "Emprestado do latim sensus, 'ação, maneira de sentir; sentimento, pensamento, significação'. 'Faculdade de conhecer de uma maneira imediata e intuitiva"” (Bourdieu, 2000 [1972], p. 13). Ao se expressar sob a forma de categorias elementares de classificação, esses princípios fundamentais de visão e avaliação do mundo funcionam como um senso que orienta os agentes nos espaços sociais na medida em que hierarquiza - simbolicamente - as posições, as práticas, as instituições, os agentes e os produtos sociais:

O conhecimento prático do mundo social que supõe a conduta 'razoável' nesse mundo serve-se de esquemas classificatórios - ou, se preferirmos, 'formas de classificação', 'estruturas mentais', 'formas simbólicas', ou outras tantas expressões que, se forem ignoradas as respectivas conotações, são praticamente intermutáveis -, esquemas históricos de percepção e apreciação que são o produto da divisão objetiva de classes (faixas etárias, classes sexuais e classes sociais) que funcionam aquém da consciência e do discurso" (Bourdieu, 2008, p. 436).

Traduzida em esquemas de classificação, percepção e ação, "a dominação pode se exprimir independentemente das consciências e das vontades" porque resulta "inscrita nos corpos, fora do alcance da consciência” (Mauger, 2006, p. 96) ${ }^{34}$. A afirmação da centralidade

\footnotetext{
${ }^{34}$ No seu artigo intitulado Sur la violence symbolique, o sociólogo Gérard Mauger sugere que Bourdieu trabalha com dois conceitos de violência simbólica, um associado à sociologia do sistema escolar e outro à etnologia da sociedade Kabyle entre os quais existe, segundo ele, uma inflexão importante: "onde uma privilegia a "pedagogia explícita na sociogênese do habitus' a outra privilegia a 'pedagogia implícita' e a incorporação das disposições" (Mauger, 2006, p. 96). A proposta de Mauger é interessante na medida em que explicita a ruptura de Bourdieu em relação à filosofia da consciência que predominava no debate marxista francês durante os anos 1970. Porém, se essa dicotomia pode ser válida para pensar La reproduction, a primeira obra de Bourdieu sobre o sistema escolar publicada em 1970 (cf. Bourdieu \& Passeron, 1970), não me parece apropriada para descrever as análises sobre o sistema de ensino realizadas já nos anos 1980, em especial La noblesse d'état que está fortemente encorada, como procuramos mostrar ao longo desta tese, na centralidade das pedagogias implícitas como instrumento de inculcação de esquemas de percepção e ação quase corporais. A proposta analítica do presente item é, em certa medida, oposta
} 
da socialização dos corpos através da internalização de esquemas de classificação aproxima Bourdieu não só do esforço de Durkheim e Mauss, de explicar a origem social das categorias elementares do pensamento (cf. Durkheim, 1912; Durkheim \& Mauss, 1903), como também de parte importante da teoria crítica da segunda metade do século XX, em especial de Michel Foucault e da assim chamada Escola de Frankfurt (Foucault, 1975; Adorno \& Horkheimer, 1985; Horkheimer, 1980) ${ }^{35}$. Além disso, essa ênfase na socialização do corpo permite compreender porque o conceito de habitus é tão central na obra bourdieusiana. Disposições subjetivas que resultam da incorporação de estruturas objetivas, o habitus é composto, em suma, de "esquemas classificatórios, princípios de hierarquização, princípios de visão e divisão [...] que criam diferenças entre o bom e o mau, entre o bem e o mal, entre o distinto e o vulgar etc." (Bourdieu, 1994, p. 23). Em Le sens pratique, Bourdieu enfatiza que a origem social desses princípios de classificação e hierarquização é o que faz com que os indivíduos aprendam a reconhecer as posições dominantes e dominadas desde a muito cedo, como resultado da própria sociabilidade familiar:

[...] os efeitos estruturantes característicos de uma classe determinada de condições de existência que através da necessidade econômica e social que elas fazem pesar sobre o universo relativamente autônomo da economia doméstica e das relações familiares - ou melhor, através das manifestações propriamente familiares dessa necessidade (como a forma de divisão do trabalho entre os sexos, universo de objetos, modos de consumo, relação com os pais etc.) - produzem as estruturas do habitus que são os princípios de percepção, apreciação e ação de toda a experiência posterior (Bourdieu, 1980, p. 90-1).

à de Mauger justamente porque, como foi dito, procura ler as obras de Bourdieu sobre o sistema escolar publicadas ao longo dos anos 1980 à luz dos trabalhos de etnologia Kabyle sistematizados em Le sens pratique (cf. Bourdieu, 1980, 1984 e 1989).

${ }^{35}$ As análises de Foucault sobre a disciplina ou mesmo adestramento dos corpos (dressage des corps) constitui um momento importante da teoria social da segunda metade do século XX. Na mesma chave, a preocupação com os efeitos inconscientes ou pré-conscientes do processo de socialização também é um veio importante dos trabalhos da chamada Escola de Frankfurt, condensados em A dialética do esclarecimento (cf. Adorno \& Horkheimer, 1985). Nesse sentido, um dos eixos da crítica de Adorno e Horkheimer à assim chamada teoria tradicional é a sua inconsciência em relação aos processos de determinação social da percepção, como expressão dessa socialização quase corporal: “Os homens não são apenas um resultado da história em sua indumentária e apresentação, em sua figura e seu modo de sentir, mas também a maneira como veem e ouvem é inseparável do processo de vida social tal como este se desenvolveu através dos séculos. Os fatos que os sentidos nos fornecem são pré-formados de modo duplo: pelo caráter histórico do objeto percebido e pelo caráter histórico do órgão perceptivo. Nem um nem outro são meramente naturais, mas enformados pela atividade humana, sendo que o indivíduo se autopercebe, no momento da percepção, como perceptivo e passivo" (Horkheimer, 1980, p. 133). 
Em La noblesse d'etat, partindo dos mesmos pressupostos teóricos, Bourdieu vai enfatizar o papel da socialização escolar, que como continuação da socialização familiar também traduz em termos próprios diferenças entre classes e frações de classe, na formação de um "conformismo lógico" ligado à "homogeneidade das estruturas mentais" que definem esquemas de percepção, pensamento e ação sob a forma do ele chama de "esprit de corps" (cf. Bourdieu, 1989, p. 111ss).

Expressão de condições materiais de existência, o habitus expressa diferenças de classe e é nesse ponto que a análise bourdieusiana reencontra a abordagem marxista. Para Bourdieu, as disputas em torno da imposição das categorias socialmente dominantes mimetizam, no plano simbólico e, portanto, segundo regras próprias, diferenças e disputas de classe. Mas o essencial da relação de dominação não é apenas o domínio material mas, como já enfatizava Weber, a legitimação social dessa mesma dominação:

As diferentes classes e frações de classe são engajadas em uma luta propriamente simbólica para impor a definição do mundo social a mais adequada aos seus interesses; o campo de tomada de posições ideológicas reproduz sob uma forma transfigurada o campo de posições sociais. [E na nota que se segue] As tomadas de posição ideológica dos dominantes são estratégias de reprodução que tendem a reforçar na classe e fora da classe a crença na legitimidade da dominação da classe (Bourdieu, 2001, p. 207).

Reconhecendo a origem social do habitus, uma dimensão fundamental da análise sociológica passa a ser, portanto, reconstruir o processo de construção - que é, ao mesmo tempo, um processo de imposição - desses "esquemas classificatórios" que não só legitimam como reforçam e constroem estruturas sociais. Nesse caso, a força da análise reside no reconhecimento de que essas disputas ideológicas pela imposição de visões de mundo seguem regras próprias. Ou, como afirma Bourdieu, elas são duplamente determinadas: pelos interesses das classes e frações de classe que as posições exprimem, mas também pelos interesses específicos dos produtores simbólicos e pela lógica específica a cada campo de produção simbólica (Bourdieu, 2001, p. 208). O reconhecimento da especificidade dos campos de produção simbólica tem duas consequências: primeiro, contornar as armadilhas de uma análise 
determinista através do reconhecimento da autonomia relativa dos espaços de produção simbólica; segundo, revelar o princípio da eficácia simbólica e ideológica dessa produção. Para Bourdieu, portanto, a eficácia simbólica das visões de mundo impostas pelas classes dominantes reside justamente no seu poder de naturalizar a arbitrariedade do processo de produção social dessas classificações:

O efeito propriamente ideológico consiste precisamente na imposição de sistemas de classificação política sob a aparência legítima de taxonomias filosóficas, religiosas, jurídicas etc. (...) O poder simbólico de constituir o dado pela enunciação, de fazer ver e de fazer crer, de confirmar ou de transformar a visão do mundo e, logo, a ação no mundo e, portanto, o próprio mundo; poder quase mágico que permite obter o equivalente do que é obtido pela força (física ou econômica) graças ao seu efeito específico de mobilização, só se exerce quando é reconhecido, quer dizer, irreconhecível enquanto arbitrário (Bourdieu, 2001, p. 210).

Ao partir da reconstrução das relações sociais que estruturam o espaço universitário e do reconhecimento do efeito performativo e naturalizador que essa estrutura exerce sobre as categorias de percepção e os sistemas de classificação, a análise estrutural permite construir uma posição analítica capaz de romper com a illusio essencialmente subjetivista que marca a historiografia dominante sobre a universidade. É justamente essa ruptura que permite à análise estrutural ir além do "recito anedótico dos fatos e dos gestos dos agentes singulares, célebres ou desconhecidos, ao qual se sacrifica de boa vontade a história, nova ou velha" (Bourdieu, 1984, p. 12).

Essa tendência para a valorização de realizações individuais - visão encantada do mundo acadêmico que inspira grande parte das histórias da universidade - torna-se ainda mais explícita quando o objeto é a trajetória das instituições socialmente dominantes, como é inegavelmente o caso da USP, que, tomadas isoladamente e independentemente das relações objetivas que a definem, motivam “discursos de celebração declarados ou disfarçados [...] que são uma das manifestações mais evidentes dos efeitos de consagração conferidos pela agregação dos corpos de elite" (Bourdieu, 1989, p. 185).

É para contornar esses equívocos historiográficos que a análise sociológica precisa reconstruir as estruturas sociais que determinam as posições determinantes do espaço 
acadêmico. A história estrutural funciona, assim, como um instrumento teórico de ruptura que, objetivando a hierarquia de posições no interior da universidade, define as relações de dominação nesse contexto revelando, assim, o sentido mais profundo das lutas pela sua transformação:

Somente uma história estrutural comprometida em definir as relações objetivas que se estabelecem entre as diferentes instituições em virtude de suas posições relativas na hierarquia social e na hierarquia escolar permite, então, perceber a lógica dos processos invariantes e necessários lá onde frequentemente não se vê mais do que sucessões cronológicas de eventos arbitrários e contingentes (Bourdieu, 1989, p. 279).

Trata-se portanto e essencialmente de uma análise que busca explicar a mudança social, pensando-a como o resultado de um processo histórico de disputas socialmente estruturadas porém não mecanicamente determinadas. Compõe, nesse sentido, o esforço mais amplo pelo fortalecimento da sociologia histórica enquanto um campo de investigação que busca, através da restauração do caráter histórico da interrogação sociológica, superar a dicotomia entre ação e estrutura através de uma "dialética da estruturação" (Abrams, 1982, p. XVI). Em síntese, dizer que a mudança social é um processo histórico que decorre da dialética entre ação e estrutura implica reconhecer que a ação humana produz relações sociais que, enquanto estruturas sociais, assumem uma forma coisificada circunscrevendo os limites sociais da ação. Mas essa estrutura acabada não é imune à ação social, ao contrário, decorre de disputas estruturadas pela sua transformação.

A determinação da ação pela estrutura e a transformação da estrutura pela ação ocorrem como um processo no tempo. É partindo dessa ideia que a sociologia e a história se fundem e a sociologia torna-se capaz de responder à urgente questão sobre porque o mundo é como ele é (Abrams, 1982, p. 3).

Não é por acaso que Philip Abrams insere os trabalhos de Pierre Bourdieu sobre o sistema de ensino nesse movimento de redescoberta da história pela sociologia que implica conceber a mudança e a conservação social através de uma mediação entre estrutura e prática (cf. 1982, p. XVI). Pensando especificamente na universidade, é um consenso que essa instituição passou por mudanças importantes nas últimas décadas e são quase incontáveis os 
trabalhos que buscam descrever e explicar essa transformação. No entanto, são poucos os que o fazem a partir de um referencial teórico mais amplo, que tenha como eixo a interrogação da relação entre ação social e estrutura que constitui, segundo Abrams, a questão essencial da sociologia histórica e, segundo Bourdieu, a base da história estrutural do ensino superior.

É nessa chave, portanto, que o presente trabalho propõe analisar a história da USP para elucidar, para além de uma sucessão de fatos e feitos, o sentido geral da sua transformação e conservação ao longo das últimas décadas. Ao optar por uma abordagem estrutural, o presente trabalho insere-se não apenas em uma tradição sociológica mais ampla exposta em parte aqui como, também, em uma linha de estudos sobre a USP que, a despeito das suas diferenças internas, compartilham uma mesma visão sobre a importância da estrutura social na definição do destino do ensino superior e da universidade (cf. Fernandes, 1975 e 1984; Hey \& Catani, 2006; Hey, 2008; Limongi, 1989; Miceli, 1989; Nadai, 1981).

Esse esforço de construir "uma história sem nomes próprios" (Bourdieu, 1984, p. 12) pressupõe romper com as reconstruções históricas parciais que, de certo modo, hegemonizam a historiografia da instituição. Mas essa ruptura não significa mera negação. Ao contrário, o abandono de percepções "encantadas" do mundo acadêmico deve ser acompanhado pela restituição dessas mesmas percepções que, excluídas como referência, devem reaparecer na análise como objeto. As reconstruções históricas parciais, formuladas a partir de posições bem definidas do espaço social, devem ser consideradas, assim, como elemento constitutivo do problema de investigação, enquanto práticas produtoras de sentido que expressam visões e representações que ajudam a reproduzir as estruturas de que são produto, por meio de processos de legitimação e naturalização.

Nesse sentido, a "história oficial" da USP, escrita a partir de posições institucionais de poder, recai nos mesmos equívocos do subjetivismo anedótico e enaltecedor apontado por Bourdieu ao criticar a historiografia do ensino superior francês (1984, p. 11ss; 1989, p. 279ss). 
Ao partilhar uma perspectiva finalista, em que os sujeitos aparecem como portadores de um objetivo consciente que se desdobra ao longo da história da instituição, essa historiografia resulta necessariamente em discursos de celebração individual e institucional. Toda a transformação institucional é vista, nessa chave, como uma mudança conscientemente produzida que deve, portanto, ser reverenciada como expressão do progresso da USP. Mas é importante reconhecer que essa parcialidade encontra-se inscrita na própria posição a partir da qual essa história é contada. São, dessa perspectiva, equívocos socialmente necessários nos quais se engajam de corpo e alma os agentes e que devem, então, retornar à análise como visões e representações do mundo inerentes às posições de que provêm.

Ao analisar detidamente as obras que compõem a história oficial da USP, particularmente os trabalhos de Ernesto de Souza Campos e Shozo Motoyama, procurou-se mostrar em que medida elas se enraizavam em correntes historiográficas mais amplas, das quais retiravam seus temas, estilos e problemas. Foi nesse sentido que se procurou apontar a filiação de Souza Campos ao Instituto Histórico e Geográfico de São Paulo, e de Motoyama à subdisciplina de História da Ciência e da Tecnologia. No mesmo sentido, buscou-se indicar as semelhanças de forma e de conteúdo que uniam as demais histórias oficiais da USP em função do lugar institucional comum a partir da qual foram produzidas. Mas esse enraizamento teórico e institucional só explica em parte o conteúdo dessas obras. Os seus pressupostos mais essenciais - que definem a visão de universidade que compartilham - explicam-se pela posição que esses autores ocupam na hierarquia social e acadêmica que estrutura a Universidade de São Paulo. Perseguindo alguns traços distintivos dessa "história oficial" vê-se que, além de partilhar uma concepção finalista da história e um tom claramente enaltecedor, ela tende a remeter a fundação da USP a um projeto consciente de setores econômicos da elite paulista que, tendo em vista a necessidade de desenvolver o estado de São Paulo, fundam escolas de ensino superior as quais, ao alcançarem a maturidade, agregam-se para formar a USP. Desse modo, incorporam 
à sua interpretação histórica os pressupostos que atribuem à origem dessas escolas profissionais, em especial a valorização do caráter pragmático do conhecimento voltado ao desenvolvimento político, social e econômico de São Paulo e, a partir dele, do Brasil como um todo.

Em outras palavras, essas reconstruções históricas expressam de modo determinante as categorias essenciais do polo dominante da estrutura social e acadêmica da USP, formado pelas escolas profissionais tradicionais, voltadas para carreiras socialmente valorizadas que atraem, por isso, segmentos privilegiados que acumulam poder social, econômico e político o qual se traduz, no interior da instituição, em um poder institucional quase hegemônico.

Mas a análise estrutural pressupõe, como foi dito, um esforço essencialmente relacional, de modo que o conteúdo profundo das análises formuladas a partir do polo dominante da USP - ou seja, as categorias elementares que fundamentam essas análises - só se revela plenamente quando relacionado às visões inerentes ao polo dominado formado, nesse caso, pelas faculdades e institutos voltados para a formação científica, artística e intelectual que atraem segmentos sociais menos favorecidos e que, apesar de acumularem prestígio acadêmico e científico, esse não se traduz, internamente, em poder institucional. Para ilustrar a visão histórica inerente a esse polo dominado, privilegiou-se, em um primeiro momento, os trabalhos históricos formulados a partir de uma posição duplamente dominada, formada pela seção de Pedagogia da Faculdade de Filosofia, Ciências e Letras, hoje transformada em Faculdade de Educação. Em um segundo momento, a análise voltou-se para uma outra expressão historiográfica desse polo dominado, representado pelos trabalhos de história estrutural que se distinguem dos estudos educacionais pela sua pretensão explicativa que determina o seu relativo prestígio acadêmico. 


\section{A “ideia" de universidade: perspectiva filosófico-pedagógica e história dos vencidos}

Buscando construir uma análise relacional da historiografia sobre a Universidade de São Paulo, é preciso reconhecer que ela não se resume ao conjunto de trabalhos escritos a partir de posições institucionais de poder, assumindo a forma geral de uma história oficial. Uma linha distinta de reconstrução historiográfica merece destaque, justamente por ter sido produzida a partir de um lugar institucional diametralmente oposto: o dos estudos acadêmicos em filosofia e história da educação oriundos da Seção de Pedagogia da antiga Faculdade de Filosofia, Ciências e Letras da USP. Os dois trabalhos mais significativos dessa linha são a tese de livredocência de Heládio Gonçalves Antunha intitulada Universidade de São Paulo: fundação e reforma (1971), e a tese de doutorado em três volumes de Beatriz Alexandrina de Moura Fétizon chamada Subsídios para o estudo da Universidade de São Paulo (1986). Não por acaso, os trabalhos mais essenciais dessa área (Antunha, 1971; Fétizon, 1986) desenvolveram-se no âmbito da cadeira de Filosofia e História da Educação. Criada com o Instituto de Educação em 1933, essa cadeira foi incorporada à USP, juntamente com o seu Instituto, em 1934, e tornouse parte da Seção de Pedagogia da FFCL-USP, em 1938, desdobrando-se, finalmente, na atual Faculdade de Educação em 1969.

Ao contrário das obras de história oficial, redigidas quase que exclusivamente por ocasiões comemorativas e publicadas em edições esmeradas e luxuosas com amplo apoio institucional, os estudos ligados à área da educação foram escritos originalmente como teses acadêmicas e tiveram um publicação editorial posterior incerta e bem mais discreta: a livredocência de Heládio Antunha foi publicada apenas em 1974 como documento de trabalho na coleção "Documentos e estudos" do Centro Regional de Pesquisas Educacionais, ligado ao INEP/MEC, sem alcançar grande distribuição, ao passo que o doutorado de Beatriz Fétizon 
nunca chegou a ser publicado ${ }^{36}$. Essa fragilidade editorial testemunha o fato de que tal linha de interpretação histórica pode ser lida, em grande medida, como uma "história dos vencidos".

Em termos gerais, o traço distintivo dessa perspectiva subjugada é o seu caráter marcadamente idealista. O termo idealista, nesse caso, não assume um sentido filosófico forte sendo usado, portanto, mais como adjetivo do que como um conceito propriamente dito, buscando identificar uma historiografia cujo problema principal é analisar a realização de uma “ideia de universidade", conscientemente postulada pelos formuladores e reformadores da USP nos momentos essenciais de consolidação do seu projeto. Como explicita Heládio Antunha:

Iniciamos nosso trabalho com o exame do problema das concepções de universidade, com a finalidade de estabelecer alguns pontos de referência para ajudar-nos a compreender, criticar e avaliar as vicissitudes da Universidade de São Paulo em sua caminhada para adquirir uma autêntica estrutura universitária. $\mathrm{Na}$ realidade, as questões relacionadas com o problema da concepção ou da ideia de universidade adquirem uma especial relevância, particularmente nos dois momentos da vida da USP a que pretendemos dar maior atenção: o da Fundação e o da Reforma (1971, p. 3; grifo meu).

Para compreender o significado dessa historiografia marcadamente filosóficopedagógica ${ }^{37}$ é preciso analisar, na chave de uma história estrutural, como se produziu o lugar específico dos estudos educacionais no âmbito da USP e como esse lugar determina seus traços essenciais. Isso implica reconstruir a gênese histórica da área de pedagogia, em geral, e a cadeira de Filosofia e História da Educação, em particular, mostrando como elas passaram a ocupar uma posição duplamente dominada no contexto universitário.

De fato, como os próprios autores destacam (Antunha, 1971, p. 98-100; Fétizon, 1986, p. 450) e como uma linha subsequente de trabalhos desenvolve (Andrade, 1989; Bontempi

\footnotetext{
${ }^{36}$ É interessante notar, ainda, que enquanto os livros de Ernesto de Souza Campos (1954) e Shozo Motoyama (2006) encontram-se disponíveis em todas as bibliotecas da USP, as obras de Beatriz Fétizon (1986) e Heladio Antunha (1971) estão acessíveis apenas na biblioteca da Faculdade de Educação.

37 A indissociabilidade entre a filosofia e história, predominante nesses estudos educacionais, é o que permite denominar essa perspectiva historiográfica de "filosófica". Ao mesmo tempo, a ligação intrínseca com o campo dos estudos educacionais é o que obriga a caracterizá-la não somente de "filosófica", mas também de "fillosóficopedagógica".
} 
Junior, 2007 e 2011; Tomazetti, 1998), os estudos de educação realizados inicialmente na Seção de Pedagogia da FFCL-USP e, posteriormente, na Faculdade de Educação da mesma universidade ocupam um lugar inferior tanto na hierarquia de poder institucional, associada principalmente ao prestígio social das diferentes profissões universitárias, quanto na hierarquia essencialmente acadêmica, marcada pela escala de prestígio propriamente científico. Disso resulta que os estudos educacionais encontram-se ligados a posições que são, ao mesmo tempo, política e academicamente dominadas no interior da universidade ${ }^{38}$.

As explicações para isso, na literatura ligada aos estudos educacionais (cf. Antunha, 1971; Bontempi Junior, 2007 e 2011; Fétizon, 1986; Tomazetti, 1998), não variam muito. Todos seguem de modo mais ou menos direto as hipóteses formuladas originalmente por Heládio Antunha, para quem as razões do amplo desprestígio da pedagogia remontam à fundação do Instituto de Educação, por obra de Fernando de Azevedo, em $1933^{39}$. Esse Instituto, incorporado à Universidade de São Paulo como unidade autônoma em 1934 e anexado à FFCL-USP como Seção de Pedagogia em $1938^{40}$, foi a primeira instituição do estado de São Paulo a oferecer formação de nível superior para docentes do ensino fundamental e médio, na época chamados primeiro e segundo graus. Conforme Antunha argumenta, foi a súbita transformação do curso de aperfeiçoamento de professores, originalmente de nível secundário, em ensino pedagógico

\footnotetext{
${ }^{38}$ Mas a essa dupla dominação corresponde, ainda, uma ambiguidade essencial: apesar de institucionalmente dominada no contexto geral da USP, a área de pedagogia, particularmente a cadeira de História e Filosofia da Educação, afirmou-se como politicamente dominante no contexto institucional específico da FFCL-USP.

${ }^{39}$ A análise de Heládio Antunha sobre o processo de reforma que culmina com a fundação do Instituto de Educação foi desenvolvida em mais detalhe em um trabalho do autor sobre a reforma da educação pública de São Paulo a partir de 1920 (cf. Antunha, 1976). Mais conhecida como "Reforma Sampaio Dória", essas transformações também foram objeto de uma análise crítica no trabalho de Fernando Limongi sobre os Mentores e clientelas da Universidade de São Paulo (1989). Para Limongi, a Reforma de 1920 representa a primeira medida de reforma educacional promovida pelos representantes do "Grupo Estado" e da "Liga Nacionalista", organizados enquanto “educadores profissionais", que viriam a fundar a USP em 1934. Conforme se analisará adiante, as reformas que remontam à fundação do Instituto de Educação em 1933 são inseparáveis da criação da Universidade de São Paulo no ano seguinte.
}

${ }^{40}$ A FFCL tinha, então, três seções: Filosofia, Ciências, Letras. A partir de 1938 ela ganha uma quarta seção, a Pedagogia. 
de nível superior que resultou na formação de uma escola profissional híbrida, que não gozava do mesmo prestígio das suas congêneres ${ }^{41}$. Isso porque:

Embora fosse também uma escola superior profissional, o seu caráter misto (normal e superior), a sua situação de transitoriedade e o tipo de profissional que se propunha formar (e que indiscutivelmente não eram, na época, tão conceituados) não lhe permitiram ombrear-se com outras escolas superiores de São Paulo (Antunha, 1971, p. 98).

Essa diferença de estatuto era reconhecida pela própria legislação educacional do período que distinguia claramente a "educação pedagógica de grau superior ministrada na Escola de Professores do Instituto de Educação, de dois ou três anos" da "educação profissional de grau superior ministrada nas faculdades de ensino superior, em cursos de cinco a seis anos" (Antunha, 1971, p. 98). Embora os estudos educacionais de um modo geral destaquem a distância que separava as chamadas "faculdades tradicionais", voltadas à diplomação de profissionais liberais, do Instituto de Educação, orientado para a formação de professores de primeiro e de segundo grau, é somente no trabalho de Fernando Limongi, dedicado à relação entre o Instituto de Educação e a fundação da USP, que essa oposição torna-se mais clara.

Como destaca Fernando Limongi (cf. 1988 e 1989), a origem do Instituto de Educação remonta a um amplo movimento educacional cujo ideário político já se expressava na reforma do sistema de ensino estadual promovida por Sampaio Dória em 1920. Essa reforma tinha como eixo central a melhoria da qualidade do ensino público, processo que passava pela promoção de critérios de natureza técnico-pedagógica no interior do sistema e pela qualificação do seu corpo docente. A reforma Sampaio Dória está, portanto, na raiz do embate que opôs, no campo educacional de São Paulo, os "educadores profissionais", ligados ao movimento de renovação pedagógica, aos "educadores tradicionais", formados pela Escola Normal da Capital e resistentes às mudanças propostas. Mas Limongi traz, em seu trabalho, uma interpretação que

\footnotetext{
${ }^{41}$ É interessante como Fernando Limongi demonstra que, não obstante esse lugar mais baixo na hierarquia de prestígio profissional, o Instituto de Educação ocupou um lugar de destaque na criação e organização da USP (1989, p. 154-5).
} 
busca dar conta da complexidade dessas duas posições. Segundo ele, os "renovadores educacionais" que defendiam a profissionalização da educação eram portadores, no fundo, de uma concepção elitista de ensino que privilegiava a criação de cursos de formação pedagógica de nível superior em detrimento de uma política consistente de expansão do sistema de ensino como um todo ${ }^{42}$. Os "tradicionalistas", por sua vez, transigiam com uma prática clientelista que, minimizando o problema da qualidade do ensino, abria espaço para a sua expansão, ainda que submetendo-o aos interesses político-partidários hegemônicos no estado (cf. 1989, p. 134).

O educador Antônio Sampaio Dória era um dos principais líderes do "movimento de renovação pedagógica" e, assim como outros de seus membros, em especial Fernando de Azevedo e Lourenço Filho, mantinha relações estreitas com o chamado "grupo do Estado"43, assumindo seus pressupostos políticos essenciais, particularmente o reconhecimento da urgência da "questão educacional" e, consequentemente, da necessidade de criação de instituições voltadas à educação das elites dirigentes e à formação de professores para a rede pública de ensino (cf. Cardoso, 1982; Limongi, 1988 e 1989). O intuito original desses reformadores era criar instituições de nível superior, o que nem sempre foi possível. Nesse sentido, a reforma promovida por Sampaio Dória foi a primeira a projetar a criação de uma

\footnotetext{
${ }^{42}$ É interessante notar como Limongi rompe com a leitura hegemônica que atribui um caráter essencialmente progressista ao movimento de renovação pedagógica, sintetizado no Manifesto dos Pioneiros da Educação Nova. Segundo tal leitura, esse movimento se basearia em três pontos essenciais e naturalmente progressistas: i) a defesa do ensino laico; ii) da expansão quantitativa da escola pública; e iii) da igualdade de acesso à escola para ambos os sexos. No entanto, com base em dados estatísticos sobre os efeitos fundamentais das reformas promovidas por esse movimento, particularmente as baixas taxas de expansão do ensino e os resultados pouco significativos do propalado combate ao analfabetismo, o autor sugere uma análise mais cautelosa (cf. Limongi, 1989, p. 152). No fundo, como ele afirma, "independentemente da adoção de novos métodos, o grupo liderado por Dória não rompia com a característica principal da tradição do ensino paulista - a ênfase exagerada nas exigências para a formação do professorado" (1989, p. 140). Essa tendência assume, em si, uma propensão elitista que privilegia a qualidade do ensino em detrimento da ampliação do acesso.

${ }^{43}$ Segundo Irene Cardoso, "a expressão 'grupo do Estado' [...] é uma denominação que dá a si mesmo um grupo de políticos e intelectuais reunidos em torno do jornal $O$ Estado de S. Paulo, e simultaneamente a denominação, muito utilizada nesta época, por representantes de entidades partidárias, para referir-se àquele grupo" (1982, p. 27). Fernando Limongi, apesar de usar a expressão de modo pouco sistemático, afirma: "Para o mundo cultural paulista das primeiras décadas deste século, $O$ Estado de $S$. Paulo era um importante ponto de referência profissional e intelectual, local das rodas em que se discutiam os problemas e projetos culturais" (1989, p. 112).
} 
faculdade estadual de educação, originalmente denominada Faculdade de Filosofia, Letras e Educação que, prevista em lei, nunca chegou a sair do papel (cf. Limongi, 1989, p. 140) (4. $^{4}$ Pelo projeto original de 1920, essa Faculdade seria, ao mesmo tempo, um instituto de aperfeiçoamento pedagógico e de formação em cultura geral, o que a torna precursora tanto do Instituto de Educação, fundado por Fernando de Azevedo em 1933, quanto da Faculdade de Filosofia, Ciências e Letras, idealizada como núcleo central da universidade a ser fundada em São Paulo pelo "grupo do Estado" no mesmo período (cf. Cardoso, 1982; Limongi, 1989). Assim, para Limongi:

[...] é possível traçar uma linha de continuidade que parte da Faculdade de Educação projetada por Dória em 1920, passa pelo curso de aperfeiçoamento de professores primários de 1931 (Reforma Lourenço Filho) e pelo Instituto de Educação de 1933 (Reforma Fernando de Azevedo), para atingir seu ponto mais alto na criação da Faculdade de Filosofia, Ciências e Letras em 1934. [...] seja em suas origens - na campanha pela defesa da criação de uma universidade em São Paulo em meados dos anos vinte - seja no momento de construí-la em 1934, a Universidade de São Paulo é impensável sem o concurso destes educadores e da lógica subjacente à sua atuação (Limongi, 1989, p. 129).

É justamente na explicação da "lógica subjacente" à atuação desse grupo social que a análise de Fernando Limongi assume seus contornos mais ousados e mais esclarecedores. O autor demonstra que a "reforma educacional" promovida pelos chamados "educadores profissionais", apesar de buscar explicitamente a qualificação do ensino público de nível básico e médio, atendia, antes, aos interesses particulares desse setor específico das “camadas urbanas educadas", que se beneficiava diretamente da criação de postos de trabalho no topo do sistema de ensino. Inserindo esse processo em um quadro social mais amplo, Limongi ressignifica toda a atuação do grupo político ligado ao jornal $O$ Estado de $S$. Paulo que, nas primeiras décadas do século XX, formava um dos principais núcleos de oposição às forças políticas hegemônicas da Primeira República. Em síntese, o autor pretende romper com as leituras que postulam a existência de um projeto político mais ou menos explícito a orientar a atuação desse grupo (cf.

\footnotetext{
${ }^{44}$ No lugar da Faculdade, ficou um “curso de aperfeiçoamento pedagógico" ligado à Escola de Professores da Capital, que está na origem do Instituto de Educação.
} 
Limongi, 1988, p.1-21). Assim, mais do que se pautar por um ideário político explícito e bem definido, esse setor ilustrado da elite paulista reagia, a partir de uma posição social bem definida, às transformações sociais, econômicas e políticas que atingiam o estado de São Paulo, particularmente no interior do seu núcleo urbano, redefinindo a sua posição na estrutura social ${ }^{45}$. Dito de outro modo, diante do fechamento dos canais de participação política, a partir da profissionalização do Partido Republicano Paulista, e da ascensão econômica dos setores imigrantes, em especial de origem italiana, esse grupo passa a se autoproclamar membro de uma "elite cultural", distante tanto dos "políticos profissionais" quanto dos "imigrantes materialistas" (cf. Limongi, 1989). Essa estratégia de diferenciação correspondia ao esforço pela criação de novas posições sociais, fundadas na expansão da educação prolongada e do mercado de trabalho e de bens culturais que ela incentivava. A construção desse "novo lugar social" pressupunha a afirmação de "uma escala de valores [...] própria, em que o poder e o dinheiro [fossem] termos acessórios e subordinados" (Limongi, 1989, p. 123). É por isso que a criação de novas instituições de ensino superior, voltadas à valorização da cultura "pura" e do conhecimento "desinteressado", assume um lugar tão importante para esse grupo, afinal, é um movimento que "traz consigo a inegável tentativa de autovalorização de camadas intelectuais dedicadas ao ensino, projetando para si próprios um mundo em que possam estar protegidos das exigências e azares do mercado" (Limongi, 1989, p. 149). Desse modo, a reforma educacional defendida por essa elite culturalmente favorecida, mas ofuscada política e socialmente, da qual a USP é produto, abria caminho para uma concepção elitista da sociedade, da educação e da política que preservou quase intactas as desigualdades educacionais do país na mesma medida em que difundia uma defesa intransigente da meritocracia e da qualidade escolar.

\footnotetext{
${ }^{45}$ É interessante notar como o Movimento de Renovação Pedagógica tinha uma forte participação de bacharéis da Faculdade de Direito que, a partir da emergência do processo de urbanização e industrialização, viam a sua posição hegemônica na vida política ser disputada por novos profissionais como os engenheiros e os médicos e, futuramente, os economistas (cf. Almeida, 2008).
} 
Irene Cardoso (1982), na sua análise sobre os ideais políticos que orientaram a fundação da USP em 1934, confere ainda mais ênfase à dimensão elitista do projeto político-educacional dos setores ilustrados organizados em torno do jornal O Estado de S. Paulo. Segundo a autora, a própria concepção de sociedade que subsidia a sua política educacional pressupõe uma estratificação social que diferencia a elite, as classes médias e as massas segundo o seu grau de instrução (cf. Cardoso, 1982, p. 28-42). No âmbito dessa visão de mundo, o vértice da sociedade deveria ser ocupado por elites educadas e abertamente selecionadas por meio do sistema de ensino, o que impediria a formação de uma oligarquia contrária, em si, ao princípio democrático de organização social (cf. Cardoso, 1982, p. 37). Essa concepção piramidal de sociedade respondia, portanto, a uma "teoria das elites" que, ecoando um ideário político que ganhava projeção internacional $^{46}$, era explicitamente assumida por esse grupo quando se tratava de pensar a condução dos assuntos políticos em um contexto democrático.

É nessa chave que se deve compreender as considerações de Fernando de Azevedo fundador do Instituto de Educação e idealizador da USP - ao Inquérito sobre a Instrução Pública (cf. Azevedo, 1937). Nesse texto, o educador defende a importância de submeter a política educacional à condução de uma "elite orientadora", a única, segundo a leitura de Irene Cardoso, "que teria condições de propor um projeto para a nacionalidade que estivesse acima das paixões partidárias" (1982, p. 29). Nas palavras de Azevedo, "a preparação das elites intelectuais precedeu sempre, em toda parte, a instrução das massas", sendo que o grau atingido pelas diferentes civilizações dependeu, necessariamente, "do valor de suas classes dirigentes" (Azevedo, 1937, p. 451). Como, no mundo moderno, a formação dessas "elites condutoras" é obra do ensino superior, em especial das universidades, explica-se a ênfase dada por esse grupo à criação de instituições nesse nível de ensino. Nessa chave, portanto, o elitismo presente, como

\footnotetext{
${ }^{46}$ Existem algumas análises interessantes sobre a difusão internacional do elitismo como teoria política que opunha as categorias de massa e líder no começo do século XX, procurando revelar seu significado social mais profundo (cf. Albertoni, 1992; Codato \& Perissinotto, 2009; Cohen, 2013a, 2013b).
} 
demonstra Limongi (1988 e 1989), na lógica subjacente à política educacional formulada pelo "grupo do Estado", também se explicitaria em uma concepção de mundo conscientemente assumida por seus membros, como aponta Cardoso $(1982)^{47}$.

Dessa perspectiva, fica claro que a concepção educacional compartilhada pelo "grupo do Estado", ao qual Fernando de Azevedo pertencia como membro relativamente autônomo (Cardoso, 1982, p. 43), correspondia à posição que esses atores ocupavam na estrutura social de São Paulo, determinando a sua ênfase no caráter desinteressado do conhecimento e da cultura, colocando-os, por conseguinte, em rota de colisão com as concepções pragmáticas predominantes nas faculdades profissionais criadas antes de 1930.

De fato, quase todos os trabalhos dedicados à análise das condições sociais que determinaram a fundação da USP ressaltam a importância da contraposição que, desde a sua origem, opôs o ideal de ensino das faculdades profissionais tradicionais ao projeto de universidade apoiado pelo novo Instituto de Educação (cf. Cardoso, 1982; Fernandes, 1975 e 1984; Hey \& Catani, 2006; Limongi, 1988 e 1989; Miceli, 1989; Nadai, 1981). Segundo esses autores, a raiz dessa oposição é claramente social, apontando, portanto, para fora da universidade que surgia. Dessa perspectiva interpretativa, foi uma configuração socialmente específica que levou setores educados, porém política e economicamente subjugados da sociedade paulista, a projetar a criação de instituições de ensino superior voltadas à formação de uma elite propriamente intelectual. Essas instituições, por responderem aos interesses específicos desse grupo, de afirmação do valor intrínseco do conhecimento e da cultura,

\footnotetext{
${ }^{47}$ É importante notar que Fernando Limongi desenvolve a sua pesquisa sobre a origem da USP em oposição direta à interpretação de Heládio Antunha, Simon Schwartzman e, sobretudo, Irene Cardoso, a quem ele atribui um apego excessivo à ideia de que a USP resultaria de um projeto político consciente e explícito (cf. Limongi, 1988, p. 14ss). Nesse sentido, o autor abandona a descrição das concepções políticas explicitadas por esses atores nos seus discursos e intervenções públicas para dedicar-se à análise das posições políticas concretas que eles assumiram em diferentes contextos. Embora a abordagem proposta pelo autor tenha ganhos analíticos inegáveis, ela não invalida a abordagem de Irene Cardoso na medida em que as concepções políticas deliberadamente assumidas pelo chamado "grupo do Estado", em especial o seu apego ao elitismo em voga na época, também pode ser pensada enquanto prática e, como tal, analisada à luz da sua posição social, como o faz Limongi.
} 
terminavam por assumir um modelo ideal de funcionamento essencialmente distinto das escolas profissionais tradicionais, dedicadas à diplomação das elites política e economicamente consolidadas e, logo, pautadas por uma concepção utilitarista de saber especializado (cf. Nadai, 1981). Nesse sentido, tanto a criação do Instituto de Educação, em 1933, quanto a fundação da Universidade de São Paulo com a sua Faculdade de Filosofia, em 1934, devem ser entendidas como parte de um mesmo movimento de reforma educacional, protagonizado pelo grupo articulado em torno do jornal $O$ Estado de $S$. Paulo, que compartilhava um ideal de cultura "livre" e de conhecimento "desinteressado", em larga medida oposto à orientação pragmática que predominava nas faculdades tradicionais, voltadas à formação de profissionais que lideravam a ocupação do aparelho de Estado e o processo de industrialização em curso em São Paulo. É a partir dessa interpretação que se torna possível compreender porque a concepção da USP, tendo como centro uma Faculdade de Filosofia, Ciências e Letras voltada ao “desenvolvimento da cultura filosófica, científica, literária e artística”, ${ }^{48}$, contou com tanta resistência por parte das faculdades profissionais já consolidadas, sendo, por outro lado, ativamente apoiada pelo Instituto de Educação recém-criado ${ }^{49}$. Como afirma Fernando Limongi:

A incorporação das ditas "faculdades profissionais" ao projeto [de criação da USP] não parece ter sido objeto de negociações e contatos estreitos. Quaisquer que tenham

\footnotetext{
${ }^{48}$ Vale a pena acompanhar os termos do decreto de fundação da USP, assinado pelo interventor Armando Salles de Oliveira, ex-diretor do jornal O Estado de S. Paulo e membro do chamado "grupo do Estado" (cf. Cardoso, 1982 , p. 127ss), no que concerne à afirmação dessa escala de valores propriamente intelectuais: "O doutor Armando de Salles Oliveira, Interventor Federal no Estado de São Paulo, usando das atribuições que lhe confere o Decreto Federal n. 19.398, de 11 de novembro de 1930, e considerando que a organização e o desenvolvimento da cultura filosófica, científica, literária e artística constituem as bases em que se assentam a liberdade e a grandeza de um povo; considerando que, somente por seus institutos de investigação científica, de altos estudos, de cultura livre, desinteressada, pode uma nação moderna adquirir a consciência de si mesma, de seus recursos, de seus destinos; considerando que a formação das classes dirigentes, mormente em países de populações heterogêneas e costumes diversos, está condicionada à organização de um aparelho cultural e universitário, que ofereça oportunidade a todos e processe a seleção dos mais capazes; considerando que, em face do grau de cultura já atingido pelo Estado de São Paulo, com Escolas, Faculdades, Institutos, de formação profissional e de investigação científica, é necessário e oportuno elevar a um nível universitário a preparação do homem, do profissional e do cidadão, decreta: [...] Fica creada (sic), com sede nesta Capital, a Universidade de São Paulo [...]” (USP, 1934a, p. 1).

49 A elaboração dos Estatutos da USP em 1934 foi conduzida pelos educadores Fernando de Azevedo, Almeida Júnior e Sampaio Dória (cf. Limongi, 1989, p. 135).
} 
sido estes contatos, é certo que da parte destas não há quer um comprometimento anterior com a ideia, quer a iniciativa e o envolvimento profundo com esta causa que notamos entre os "educadores profissionais". [...] ao serem equiparadas em representação aos Institutos de Educação, Biológico e Agronômico, as "faculdades profissionais" perderam a possibilidade de liderar a redação do projeto. Os educadores se beneficiarão diretamente de sua participação decisiva na elaboração do projeto da nova faculdade; o Instituto de Educação não só será incorporado à universidade, superando a sua "transitoriedade", como também desempenhará um papel fundamental na estrutura criada (1989, p. 135-6).

No entanto, se no momento de fundação da USP, a presença do "grupo do Estado" no governo estadual favoreceu a atuação dos "educadores profissionais" ligados ao Instituto de Educação, essa posição politicamente privilegiada logo se inverteu, como o comprovam as análises sobre a concentração de poder e a resistência das faculdades tradicionais, no âmbito do Conselho Universitário, em aceitar o projeto original da USP, centrado na Faculdade de Filosofia, Ciências e Letras, e o posterior abandono desse projeto (cf. Antunha, 1971, p. 90ss; Celeste Filho, 2013, p. 15ss; Fétizon, 1986, p.399ss; Motoyama, 2006, p. 26ss; Witter, 1984, p.15ss). Os primeiros anos de funcionamento da USP foram marcados, portanto, por uma disputa entre esses dois polos opostos pela definição dos termos em que a nova universidade passaria a funcionar, sendo unânime a leitura de que as faculdades profissionais conseguiram impor o seu modelo de universidade pautado no isolamento institucional, descrito por Florestan Fernandes como o predomínio “do padrão brasileiro de escola superior isolada” (1975, p. 33ss).

No que concerne à análise das diferentes histórias da USP, importa notar que uma herança fundamental dessa configuração, que contrapôs os defensores da ideia original de universidade, centrada na unidade universitária e na valorização dos estudos desinteressados, aos partidários da preservação do isolamento institucional das unidades profissionalizantes pautadas por uma concepção pragmática de conhecimento, é uma disputa sempre reiterada pelo estabelecimento de uma interpretação hegemônica da história da USP. Portanto, essa longa exposição analítica sobre o lugar do Instituto de Educação na fundação da universidade permite elucidar a oposição fundamental entre vencedores e vencidos, ou antes, entre dominantes e dominados no interior da instituição, e que corresponde à contraposição entre uma visão 
pragmática de conhecimento associada ao polo dominante e um ideal desinteressado de ciência, educação e cultura inerente ao polo dominado.

O reconhecimento dessa oposição essencial, no entanto, não deve ocultar a existência de outras oposições no interior de cada um desses polos, como as que separam dominantes e dominados no interior do campo acadêmico e do campo profissional. Essas outras oposições revelam a pertinência de localizar a área de educação, nesse primeiro momento, em uma “terceira posição" marcada por uma dupla dominação, profissional e acadêmico-científica. É essa posição duplamente dominada - que, como veremos no terceiro capítulo desta tese, mimetiza, nos primeiros anos de fundação da USP, o lugar que corresponde, hoje, às formações técnico-profissionais das assim chamadas "novas profissões universitárias" - que explica a forma essencial da história escrita a partir dessa terceira posição.

É nesse sentido que os estudos educacionais, herdeiros do polo politicamente derrotado na disputa pelo desenho institucional da USP, constroem uma história que tem, como eixo, a análise da ideia original de universidade estabelecida no momento da sua fundação e seu desenvolvimento ao longo de sucessivas reformas. Assim, mais do que uma reconstrução analítica da história da USP capaz de explicar as posições e as tomadas de posição dos diferentes agentes da universidade agrupados em áreas, unidades, disciplinas e órgãos institucionais, esses estudos históricos ancorados na perspectiva filosófico-pedagógica representam uma defesa interessada da concepção de universidade de que são portadores. É como afirma Bontempi Júnior ao analisar a trajetória da cadeira de História e Filosofia da Educação da USP:

[...] a História da Educação implantou-se como apêndice da Filosofia da Educação e [e] passou a ter, em função dos objetivos previamente traçados no ideário escolanovista, sua eficácia medida pelo que poderia oferecer de justificativas para o presente e de guia para a construção do futuro, e não pelo que fosse capaz de explicar e interpretar dos processos históricos objetivos da educação (Bontempi Júnior, 2007, p. 85).

Parece evidente que essa relativa incapacidade explicativa dos estudos históricos associados à Seção de Pedagogia contribuiu para definir, por outro lado, a posição 
cientificamente dominada que eles assumem no âmbito da universidade, particularmente a partir do momento que se incorporam à FFCL-USP. No entanto, existem outras razões para o caráter academicamente dominado dos estudos educacionais e que, não por acaso, também remontam à trajetória do Instituto de Educação fundado por Fernando de Azevedo em 1933. Segundo Heládio Antuna, a incorporação do Instituto de Educação pela USP em 1934 elevou à categoria de docentes universitários, portadores dos direitos vitalícios da cátedra, antigos professores secundários, muitos dos quais sem nem mesmo possuir diploma de nível superior (1971, p. 101). A contradição entre a formação média dos professores da área de educação e o poder institucional por eles alcançado na nova universidade se intensifica a partir da incorporação do Instituto de Educação à FFCL-USP em 1938, quando se forma a Seção de Pedagogia dessa unidade. O encontro entre professores originalmente de nível secundário, portadores de todo poder institucional inerente à cátedra, com os docentes das missões estrangeiras que, a despeito da sua alta formação e do seu reconhecido prestígio acadêmico, não gozavam de qualquer poder institucional, gerou uma série de conflitos que estariam, segundo Antunha, na raiz do isolamento intelectual e do rebaixamento simbólico dos estudos educacionais no contexto da FFLC-USP (cf. Antunha, 1971, p. 101).

Somou-se a essa contraposição, contribuindo para o seu fortalecimento, o fato da Seção de Pedagogia cuidar exclusivamente da formação pedagógica dos futuros professores, requisito quase burocrático para a aquisição da chamada "licença", enquanto a formação cultural e científica desses professores permanecia atribuição exclusiva das demais seções da FFLC-USP (Antunha, 1971, p.99). Isso instituiu a importante separação entre o ensino "pedagógico", de caráter prático e profisssional (ligado à área de Educação), e o ensino de “conteúdo", de natureza teórica e científica (ligado às demais seções da FFCL-USP). Essa oposição está na raiz da dicotomia, ainda presente na universidade, entre a licenciatura e o bacharelado, a qual traduz uma hierarquia de prestígio ligada à oposição ensino-pesquisa que também remonta à 
configuração original da FFCL-USP (cf. Bontempi Júnior, 2011).

Esse esquema interpretativo, proposto originalmente por Heládio Antunha para explicar a falta de prestígio acadêmico dos estudos educacionais, influenciou diversos autores desse campo, sendo incorporado integralmente por Beatriz Fétizon que, depois de citar amplamente seu antigo professor, acrescenta:

\begin{abstract}
Um razoável número de cadeiras herdadas do Instituto [de Educação], cujos titulares tiveram grande expressão na Universidade e fora dela, evoluíram no sentido de perder o seu qualificativo "educacional", ampliando os seus objetivos e tornando-se “desinteressadas" e não mais propriamente pedagógicas [...]. Isso pode ter sido, a um só tempo, consequência e reforço do desprestígio dos estudos pedagógicos (Fétizon, 1986, p. 454).
\end{abstract}

Foi exatamente esse o caso, segundo Elza Tomazetti (1998), da cátedra de História e Filosofia da Educação, a partir da qual se desenvolveu, de modo mais sistemático, uma história específica da USP, orientada por uma perspectiva filosófico-pedagógica, representada aqui pelos trabalhos acadêmicos de Heládio Antunha (1971) e Beatriz Fétizon (1986). Essa historiografia tem como traço distintivo, conforme foi dito, a ênfase nas concepções filosóficopedagógicas que sustentam a ideia de universidade que está na raiz da fundação da USP. Pela sua posição específica - política e cientificamente dominada - essa perspectiva não se confunde nem com a histórica oficial, ligada às faculdades profissionais tradicionais que hegemonizam o poder institucional na USP, nem com a perspectiva histórico-estrutural que acabou predominando, academicamente, na FFCL-USP. É, nesse sentido, uma perspectiva propriamente educacional que se estabelece como continuidade direta do movimento de renovação pedagógica protagonizado pelos “educadores profissionais" ligados ao "grupo do Estado". Essa relação de continuidade se torna explícita no processo de desenvolvimento da cadeira de História e Filosofia da Educação, herdeira direta dessa tradição e no âmbito da qual foram produzidos os trabalhos que são objeto direto da presente análise.

Desde a incorporação do Instituto de Educação pela USP em 1934, a cadeira de História e Filosofia da Educação assumiu uma posição de destaque no âmbito dos estudos educacionais. 
O seu titular original fora o antigo professor do curso normal formado pela Faculdade de Direito do Largo São Francisco, Roldão Lopes de $\operatorname{Barros}^{50}$. Com a inclusão do Instituto de Educação na FFCL-USP, a cadeira de Filosofia e História da Educação passou a compor a IV Seção dessa unidade, a assim chamada "Seção de Pedagogia", passando a sofrer influência direta de outras áreas da FFCL, marcadas pelo impacto das missões estrangeiras que impunham um padrão mais "rigoroso" de pesquisa e de trabalho acadêmico. Foi por isso que, a partir do afastamento do seu titular por motivo de saúde em 1948, a cadeira de História e Filosofia da Educação sofreu um amplo processo de reestruturação nos moldes descritos por Fétizon (1986) e Tomazetti (1998), de imposição de um saber de natureza "desinteressada" - a filosofia - sobre um saber de caráter mais "prático" - a pedagogia. O primeiro passo nesse sentido foi a incorporação do filósofo Laerte Ramos de Carvalho ${ }^{51}$ como primeiro-assistente da cátedra em 1948, a qual assumiu definitivamente após a morte de Roldão Lopes de Barros em 1951, consolidando o domínio da perspectiva filosófica e do padrão de trabalho a ela associado no âmbito dos estudos histórico-educacionais ${ }^{52}$.

Pouco tempo depois de se tornar catedrático, Laerte de Carvalho designou como seus assistentes diretos outros dois filósofos formados pela FFCL-USP, Roque Spencer Maciel de Barros e João Eduardo Villalobos, fortalecendo ainda mais o predomínio da área de filosofia e

\footnotetext{
${ }^{50}$ Roldão Lopes de Barros foi titular da cadeira de Filosofia e História da Educação da FFCL-USP entre 1934 e 1952. Embora formado em Direito, lecionava originalmente no curso normal tornando-se professor catedrático em 1934 (cf. Tomazetti, 1998).

${ }^{51}$ Laerte Ramos de Carvalho era licenciado em filosofia pela FFCL-USP e trabalhava como assistente de João Cruz Costa na Cadeira de Filosofia, considerada a Cadeira I da FFLC-USP. Carvalho assume o cargo de primeiro assistente de Lopes de Barros depois da transferência de José Querino Ribeiro para a cátedra de Administração Escolar e Educação Comparada. Bontempi Júnior destaca que a transferência de Ramos de Carvalho da seção de Filosofia para a de Educação representou um rebaixamento simbólico da sua carreira, mas que este já estava dado desde a escolha do seu tema de tese, sobre a história do pensamento brasileiro, considerado um problema "menor" pela cadeira de filosofia da USP (cf. 2007, p. 94-96).
}

${ }^{52}$ Desdobrando o problema do desprestígio dos estudos educacionais, Elisete Tomazetti afirma que desde a institucionalização da disciplina História e Filosofia da Educação no país, "o saber filosófico tem se imposto ao saber educacional, ao invés de constituir-se em um saber próprio, construído a partir da relação entre filosofia e educação" (1998, p. 519). Nessa chave, a filosofia da educação torna-se uma simples aplicação de conceitos filosóficos ao campo educacional, de modo que "o importante passa a ser a construção de uma teoria que oriente a prática educacional como decorrência direta de uma doutrina filosófica privilegiada" (Guimarães, 1976, p. 100). 
do estilo de pesquisa a ela associado nos trabalhos desenvolvidos na cátedra de História e Filosofia da Educação. Ainda como parte do esforço de reestruturação, tendo em vista o padrão de trabalho predominante em outras seções da chamada "Faculdade de Filosofia", Laerte Ramos de Carvalho idealizou uma ampla pesquisa sobre história da educação no Brasil voltada à produção de conhecimento original na área. Em 1962, esse projeto de pesquisa histórica se institucionalizou, passando a receber um forte impulso pela sua incorporação ao Centro Regional de Pesquisas Educacionais de São Paulo, ligado ao INEP e dirigido por Laerte Ramos de Carvalho. Como o título da cátedra sugeria e como a formação dos professores a ela associados reforçava, as pesquisas em história da educação realizadas nesse contexto assumiam uma orientação também filosófica, buscando, com isso, legitimar-se junto às áreas academicamente dominantes da FFCL-USP, sobretudo porque ligadas à produção de conhecimento de natureza supostamente "desinteressada" (cf. Bontempi Júnior, 2007; Fétizon, 1986; Tomazetti, 1998).

Mas se o recrudescimento do caráter filosófico da historiografia desenvolvida no âmbito dos estudos educacionais pode ser atribuído à posição academicamente dominada que eles assumem no contexto da FFCL-USP, isso não deve ocultar o fato de que, enquanto herdeiras do movimento de reforma educacional protagonizado pelos educadores profissionais ligados ao “grupo do Estado", a Seção de Pedagogia, em geral, e a cadeira de Filosofia e História da Educação, em particular, acumulavam um relativo poder institucional, tanto no âmbito da FFCL-USP quanto no contexto de definição de uma política educacional em nível estadual e nacional.

Para entender esse relativo poder político da cadeira de Filosofia e História da Educação convém notar que, pouco antes de assumir a sua direção, Laerte Ramos de Carvalho tornou-se colaborador do jornal $O$ Estado de S. Paulo, para o qual redigia, a convite do próprio Júlio de Mesquita Filho, editoriais relacionados aos problemas educacionais na seção de Notas e 
Informações. Um pouco mais tarde, seus dois principais assistentes de cátedra também se tornaram colunistas do mesmo jornal (cf. Bontempi Júnior, 2007). Resulta dessa relação privilegiada com $O$ Estado de S. Paulo e da ligação intrínseca com os movimentos pedagógicos oriundos do antigo Instituto de Educação, o fato da história da educação proposta pela cadeira dirigida por Carvalho ter assumido tão claramente os pressupostos filosófico-pedagógicos que embasavam a concepção educacional partilhada pelo grupo que, orbitando em torno do jornal e do Instituto, foi responsável pela fundação da USP. Juntos e impulsionados pela projeção alcançada no Estado de S. Paulo, Laerte Ramos de Carvalho, Roque Spencer Maciel de Barros e João Eduardo Villalobos conquistaram para a cadeira de História e Filosofia da Educação, por pelo menos três décadas (1940-1970), “o direito à última palavra no discurso políticoeducacional da época" (Bontempi Júnior, 2007, p. 97), assumindo um protagonismo que coubera, anos antes, aos líderes do movimento de renovação pedagógica.

Esse domínio durou tanto tempo porque o golpe militar de 1964 fortaleceu ainda mais a influência da cadeira de História e Filosofia da Educação da FFCL-USP no cenário da política educacional. Foi nesse período, por exemplo, que Laerte Ramos de Carvalho tornou-se interventor da pioneira Universidade de Brasília, após a demissão de Zeferino Vaz. Vale notar que o próprio Zeferino Vaz também era uspiano e, assim como Laerte Ramos de Carvalho, foi nomeado interventor da UnB, em substituição a Anísio Teixeira, por sua proximidade com Luiz Antônio Gama e Silva que acumulava os cargos de Ministro de Estado e reitor da Universidade de São Paulo ${ }^{53}$. Dois anos mais tarde, em 1967, o catedrático de Filosofia e História passou a

\footnotetext{
${ }^{53}$ Luiz Antonio Gama e Silva tornou-se reitor da USP em 1963, depois de passar pela diretoria da Faculdade de Direito durante os quatro anos anteriores. Gama e Silva teve grande participação no Golpe Militar de 31 de março de 1964, assumindo, até por isso, a posição de Ministro da Educação já em abril deste mesmo ano. Em 1967, Gama e Silva foi reeleito reitor da USP, mais ou menos ao mesmo tempo em que passou a ocupar o cargo de Ministro da Justiça, posição que lhe permitiu participar ativamente da redação dos decretos que aposentaram, compulsoriamente, dezenas de professores da USP, bem como da redação do famigerado Ato Inconstitucional $\mathrm{n}^{\circ}$ 5, que suspendeu liberdades civis e políticas. Segundo Elio Gaspari, ainda, Gama e Silva, como membro do chamado "Comando de Caça aos Comunistas", teve participação direta na decisão dos estudantes da Universidade Presbiteriana Mackenzie de alvejar a sede da Faculdade de Filosofia, Ciências e Letras em 1968, resultando na chamada Batalha da Maria Antônia que levou à destruição e posterior abandono do referido prédio (cf. Gaspari, 2002, p. 299).
} 
integrar a Equipe de Assessoria ao Planejamento do Ensino Superior do MEC, resultado dos acordos MEC-USAID e voltada para a incorporação do modelo norte-americano ao ensino superior do país (cf. Cunha, 2007c, p. 41-2).

Paralelamente, Roque Spencer Maciel de Barros também exerceu um papel importante na política educacional do período ditatorial. Primeiro, por compor a Comissão Especial para a Reestruturação da Universidade de São Paulo, criada pelo Conselho Universitário em 1966 e responsável pelo famoso Memorial sobre a Reestruturação da USP, mais conhecido como Memorial Ferri, do qual Maciel de Barros foi o relator (cf. USP, 1968). Mas mais importante do que isso, o assistente de Laerte Ramos de Carvalho integrou o Grupo de Trabalho para a Reforma Universitária de 1968, responsável pelo anteprojeto de lei que reformou as universidades brasileiras nesse mesmo ano. Assim, nas palavras de Luiz Antônio Cunha, o governo militar resultava da "aliança [com] os liberais que não escondiam a sua antiga vocação autoritária", e no campo educacional, particularmente, com os professores de filosofia da educação "versados no idealismo alemão", como Newton Sucupira, idealizador da política de pós-graduação brasileira, e Roque Spencer Maciel de Barros, protagonista da Reforma Universitária de 1968 (cf. Cunha, 2007c, p. 20).

Assim, apesar de duplamente dominada, a Seção de Pedagogia, em geral, e a cadeira de Filosofia e História da Educação, em particular, conseguiram acumular, justamente em função do seu caráter híbrido, de uma escola profissional que foi incorporada à unidade propriamente científica da USP, poder suficiente para participar da política educacional e universitária, posição que foi praticamente vetada às demais seções da FFCL, sobretudo após a ditadura militar. Mas não para determinar o seu sentido geral, privilégio que coube - como se verá - às unidades profissionais de maior prestígio. No entanto, por pertencer à faculdade propriamente “científica" da USP, a pedagogia acabou assumindo, como forma de se legitimar internamente, os pressupostos e padrões acadêmicos que predominavam nas outras seções dessa instituição, 
afastando-se do âmbito puramente profissional e contribuindo para difundir, inclusive politicamente, os valores essenciais do polo acadêmico-científico, essencialmente dominado no âmbito da USP.

É à luz desse amplo contexto histórico-institucional que define o lugar ambíguo dos estudos de filosofia e história da educação que se deve ler, portanto, a história da USP escrita por Heládio Antunha. O autor, que realizou toda a sua formação intelectual no interior da Seção de Pedagogia da FFCL-USP, não esconde a sua filiação à cadeira de Filosofia e História da Educação agradecendo abertamente, na introdução da sua tese de livre-docência, aos professores Laerte Ramos de Carvalho, "pelo profundo estímulo intelectual e pessoal que vem nos dando desde o início de nossas atividades na Universidade de São Paulo”, e Roque Spencer Maciel de Barros, cujo "incentivo constante" teria sido responsável pela sua "disposição em progredir na carreira" (Antunha, 1971, p. 5-6).

Assim, apesar de ter sido escrita logo após a reforma universitária de 1968 e assumir parte da temática em voga na época, a exata compreensão do trabalho de Heládio Antunha sobre a USP remete, na verdade, ao contexto histórico mais amplo que marca o longo processo de profissionalização dos estudos educacionais. Iniciando-se com o movimento de renovação pedagógica protagonizado pelos “educadores profissionais" ligados ao "grupo do Estado", esse processo passa pela criação do Instituto de Educação em 1933, pela fundação da USP em 1934, pela incorporação do Instituto de Educação à FFCL em 1938, pelo efeito dessa medida sobre a área de História e Filosofia da Educação nos anos seguintes até culminar no lugar de destaque assumido pelos educadores da USP, ainda associados ao Estado de S. Paulo, na reforma universitária promovida pelo governo militar na década de 1960.

É somente inserindo o trabalho de Antunha no âmbito dessa longa tradição, que se define inicialmente pela posição socialmente ambígua das elites ilustradas paulistas que protagonizaram a criação de instituições de ensino superior na década de 1930 e, a partir de 
então, pelo lugar essencialmente híbrido que estudos educacionais passam a ocupar no interior dessas novas entidades, que se torna possível compreender seus traços mais essenciais. É partindo dessa filiação que se pode elucidar, por exemplo, porque a sua reconstrução histórica, escrita no final da década de 1960, assume tão claramente as concepções filosófico-pedagógicas que predominaram na fundação da USP, ocorrida três décadas antes. É considerando-se a posição institucional duplamente dominada dos estudos educacionais que se revela, ainda, o exato sentido da alegada inspiração "liberal" que levou Antunha a acreditar, na esteira do mito fundador cultivado pelo "grupo do Estado" ${ }^{54}$, que seria possível conceber uma universidade imune tanto aos "imperativos pragmáticos", que predominavam nas escolas profissionais, quanto aos "desvios ideológicos" inerentes ao "radicalismo político", que marcava setores importantes da Faculdade de Filosofia, Ciências e Letras. É à luz do lugar ambíguo dos estudos educacionais e do relativo poder por eles alcançado que se iluminam, ainda, as razões pelas quais essa linha filosófica "liberal" pôde conviver com uma forte inclinação autoritária que conduziu tanto à defesa de uma "cruzada anticomunista" durante o Estado Novo (cf. Cardoso, 1982), quanto ao engajamento direto na política educacional proposta pela ditadura militar, o que implicava aceitar inclusive suas diretrizes propriamente repressoras, expressas na perseguição política instaurada no interior das universidades (cf. Cunha, 2007c). Essa filiação político-ideológica ao liberalismo sui generis dos fundadores da USP é o pressuposto geral da tese de Antunha, como ele mesmo afirma:

O ponto de vista que presidiu à elaboração da presente tese é de que a existência da Universidade de São Paulo é um exemplo da tentativa para se implantar uma autêntica universidade liberal em nosso meio e das resistências que se levantaram a esse projeto. Acima das injunções utilitárias e pragmáticas ou ainda das pressões de natureza ideológica ou doutrinária, manifesta-se, predominante, nos grandes instantes da história da USP, a intenção de se impor e de pôr em prática uma concepção liberal

\footnotetext{
${ }^{54}$ Vale a pena notar que Irene Cardoso, no seu trabalho sobre o mito liberal-democrático de criação da USP, observa que o que causa surpresa não é a afirmação das raízes liberais da USP por Júlio de Mesquita Filho no pósguerra, mas a permanência desse mesmo mito na década de 1970, quando esses princípios liberais eram negados tanto pelo conteúdo autoritário do governo militar quanto pela orientação pragmática que passava a ser adotada (cf. Cardoso, 1982, p. 17ss). Mencionando explicitamente o trabalho de Heládio Antunha, a autora afirma: "Observe-se que no texto o autor preferentemente fala de vocação liberal, ao invés de liberdade de ensino, de pesquisa e de pensamento, subordinando estas àquela. Realçando o liberalismo no lugar das liberdades acadêmicas, liga a Escola ao Poder constituído, à 'realidade nacional ou internacional'” (Cardoso, 1982, p. 20).
} 
de universidade: isto é patente sobretudo na época da fundação e, mais do que nunca, no momento presente, em que as ameaças ao projeto são mais sérias e próximas (Antunha, 1971, p. 3-4; grifos meus).

Partindo dessa posição específica, a tese de Antunha se organiza em três partes. A primeira, intitulada "Considerações sobre o problema das concepções de universidade", dedicase a uma ampla reconstrução das ideias de universidade que, na era moderna, orientaram a construção e a reforma de instituições universitárias sobretudo a partir do século XIX. O marco essencial desse processo é, segundo o autor, a fundação da Universidade de Berlim que inaugura a preocupação essencial com a "concepção de universidade". Nesse sentido, o autor sobrevoa uma literatura alemã, de orientação filosófica, que marca de modo distintivo esse debate (cf. Jaspers, 1953; Newman, 1951 e 1960). Mas a reconstrução que Antunha promove do debate sobre as concepções de universidade vai além do chamado "modelo alemão", chegando a uma literatura hegemonicamente norte-americana, contemporânea ao autor (cf. Atcon, 1966; Brosan, 1971; Brown \& Mayew, 1967; Gelfand, 1968; Kerr, 1966; Livesey, 1967; Morison, 1966; Rogers, 1959; Whitehead, 1967), que se popularizou no Brasil sobretudo a partir dos anos 1960, quando se intensificam as consultorias norte-americanas como as que resultavam dos acordos MEC-USAID, amplamente citados pelo autor, e as que se ligavam ao assessor técnico Rudolph Atcon, também presente no trabalho de Antuha (cf. 1971, p. 7ss). Essa literatura é marcada pela defesa de uma orientação utilitária de ensino superior que, segundo Antunha, é só aparentemente inconciliável com os princípios filosófico-liberais de universidade, já que,

Na verdade, o caráter pragmático norte-americano, voltado para os problemas reais do mundo objetivo e para a ação, e preocupado com o rendimento, os resultados práticos, o "cash value", ajustou a concepção alemã às necessidades da vida quotidiana [...] Consegue-se, assim, realizar a aparentemente impossível conciliação entre as tendências ideais e as funcionais [da universidade] (Antunha, 1971, p. 34-8).

É interessante notar que, ao longo dessa ampla reconstrução das concepções de universidade, Antunha assume uma posição não somente em prol dos ideais liberais que orientaram o projeto original da USP - tema que define a segunda parte da sua tese, dedicada à 
“fundação da Universidade de São Paulo" - mas também a favor desses preceitos utilitários que pautaram a reforma universitária promovida pela ditadura militar - pano de fundo da última parte do seu trabalho, dedicada à "reforma da universidade de São Paulo". Essa tentativa aparentemente paradoxal de conciliar um modelo filosófico-liberal de inspiração europeia que, privilegiando o caráter desinteressado do conhecimento, predominou no projeto original da USP, com um modelo institucional de verve norte-americana que, valorizando a função social da universidade, determinou os termos gerais da sua reforma a partir de 1968, também resulta da posição essencialmente ambígua assumida pelos estudos educacionais, aos quais Antunha se filiava, nos dois momentos históricos em questão: de um lado, a fundação da USP, cujo desenho do modelo original de inspiração liberal os "educadores profissionais" lideraram e, de outro, a reforma universitária, da qual os pedagogos uspianos participaram ativamente.

Apesar de ser objeto de intenso silêncio, talvez pelo seu conteúdo abertamente conservador, que se projetava tanto no efusivo elogio da ditadura militar ${ }^{55}$ quanto na dura condenação do movimento estudantil e docente da época ${ }^{56}$, o trabalho de Heládio Antunha sobre a USP inaugurou toda uma linha de interpretação histórica que, até hoje, exerce uma influência significativa, inclusive para além da perspectiva original a que se filia (cf. Celeste Filho, 2013, p. $17 \mathrm{ss})$.

Em resumo, conforme foi dito, essa linha se expressa na especial atenção dada à ideia filosófica de universidade que teria embasado o projeto original da USP. A partir da identificação desse "modelo coerente e consciente" de universidade (Antunha, 1971, p. 5), a

\footnotetext{
${ }^{55}$ Sobre o Golpe de 1964, por exemplo, afirma o autor: "A Revolução de março de 1964, apesar de suas vacilações iniciais, terminou por dar um novo ritmo à evolução econômica, social e política da nação brasileira. [...] Não se pode negar, no entanto, que, pela primeira vez na história nacional se teve a audácia de tomar decisões capitais e a firmeza inabalável de levá-las adiante" (Antunha, 1971, p. 170-1).

${ }^{56}$ Sobre as paritárias, o autor conclui: "O período das paritárias foi, na realidade, em muitos casos, um momento de delírio coletivo, em que estudantes e alguns professores chegaram a 'posar para a história' e pronunciar frases de efeito, que a crônica da USP merece registrar: 'são as minorias que fazem a história', 'todo poder para as paritárias' e outras de teor semelhante" (Antunha, 1971, p. 176). Ele assume como verdade, ainda, as denúncias feitas pelo então general Meira Mattos no seu relatório sobre o movimento estudantil, tido como uma "minoria terrorista" (p. 43-4).
} 
pesquisa histórica se concentra nos momentos em que ele é implementado ou transformado, ou seja, na fundação e na reforma da USP. Outra consequência dessa ênfase nas concepções filosófico-pedagógicas de universidade sobre o modelo de reconstrução histórica é que, partindo desse ponto de vista normativo, segundo o qual a concepção de universidade define "as ideias e os princípios superiores que devem orientar a vida da instituição" (Antunha, 1971, p. 10; grifo meu), o escopo da pesquisa tende a se restringir à fase "propriamente universitária" da USP, que começa a partir da fundação da sua unidade "verdadeiramente universitária", a Faculdade de Filosofia, Ciências e Letras (cf. Antunha, 1971, p. 4). Assim, ao contrário da história oficial que busca as raízes remotas da USP, enfatizando particularmente o papel precursor das escolas profissionais tradicionais, os princípios normativos assumidos pelos estudos em filosofia e história da educação enfatizam a fundação da universidade propriamente dita, o que leva à condenação, implícita ou explícita, da dinâmica isolada das escolas profissionais, bem como do sentido utilitário do conhecimento por elas produzido. Passa para o primeiro plano, portanto, a valorização do caráter "desinteressado" dos estudos universitários e o papel "integrador" da FFCL, célula mater da instituição e na qual os estudos educacionais buscavam consolidar-se.

Esse conjunto de proposições também orienta diretamente a tese de doutorado de Beatriz Alexandrina de Moura Fétizon defendida na Faculdade de Educação da USP em 1986. Excetuando-se o estilo mais informal, as tintas menos conservadoras e a riqueza de detalhes, a história da USP escrita por Fétizon nos anos 1980 segue a mesma linha interpretativa proposta por Heládio Antunha no começo da década de 1970.

Não por acaso, portanto, a autora dedica as mais de trezentas páginas do primeiro volume da sua tese à reconstrução das concepções filosóficas de universidade a partir do surgimento da instituição no século XII. A partir disso, a autora desenvolve, ao longo do seu segundo volume, as ideias liberais que orientaram o "modelo originário" da USP, tal como 
formulado pelo "grupo do Estado", com Júlio de Mesquita Filho à frente (cf. Fétizon, 1986, p. 383-98). Dessa ênfase no modelo original da USP resulta uma restrição à sua "história propriamente universitária", que atrela o percurso da instituição ao percurso da sua Faculdade de Filosofia, Ciências e Letras, como explicita a própria autora:

\begin{abstract}
Decorreram, desse esquema [de universidade centrado na FFCL], duas consequências importantes a serem consideradas no esboço histórico da Universidade de São Paulo: em primeiro lugar, daí decorreu que é impossível separar, ao longo de todo o período de vigência do modelo originário da USP (1934-1969), a história da Universidade de São Paulo da de sua Faculdade de Filosofia, Ciências e Letras; e em segundo lugar, que o maior ou menor sucesso na implantação do modelo originário da USP dependia irremediavelmente do maior ou menor sucesso na implantação da Faculdade de Filosofia, Ciências e Letras (1986, p. 415-6).
\end{abstract}

A periodização histórica proposta pela autora também segue de perto a ênfase de Heládio Antunha no que ele considera os dois momentos centrais da história da USP, quais sejam: a fundação da universidade a partir de um modelo conceitual idealizado e a sua reforma nos anos 1960 (Antunha, 1971, p. 3; Fétizon, 1986, p. 399). É interessante notar que os dois autores compartilham, inclusive, a mesma perspectiva sobre o significado das décadas de 1940 e 1950 para a história da USP. Nesse sentido, Fétizon (1986, p. 472) assume deliberadamente a leitura de seu professor, que nomeia esse período de "anos de transição" entre o modelo original e o reformado, considerando-o "pobre em fatos universitários" mas importante "porque representa um longo, porém contínuo ciclo histórico, no qual se geram os problemas e inquietações que iriam gerar o chamado Movimento da Reforma Universitária” (Antunha, 1971, p. 121).

Assim como no trabalho de Antunha, os princípios normativos dessa leitura histórica, que parte de uma definição conceitual de universidade que deveria realizar-se no desenvolvimento institucional da USP como valorização do saber desinteressado e da integração universitária, levam, na tese de Fétizon, à condenação explícita do isolamento e do pragmatismo das escolas profissionais, responsáveis, segundo a autora, por "alguns dos mais duradouros problemas da universidade que se criava" (1986, p. 414). 
O impacto negativo da resistência das escolas profissionais ao modelo original da USP é o tema que orienta, também, a recente e muito bem documentada reconstrução histórica proposta por Macioniro Celeste Filho. Formado no curso de história da Faculdade de Filosofia, Letras e Ciências Humanas da USP, o autor defendeu uma tese na área de educação da PUCSP, publicada posteriormente em livro e intitulada A Constituição da Universidade de São Paulo e a Reforma Universitária da década de 1960 (2013). Assim, além da coincidência temática, marcadamente a escolha da fundação e da reforma da USP como momentos essenciais da instituição, Celeste Filho se aproxima também da perspectiva normativa presente nos estudos de filosofia e história da educação aqui analisados.

Segundo Celeste Filho, os "conflitos fundadores" da USP, que resultaram na organização universitária que precisou ser reformada nos anos 1960, se explicam pela resistência das escolas profissionais, particularmente da Escola Politécnica, em aceitar a primazia da Faculdade de Filosofia, Ciências e Letras no modelo de universidade originalmente projetado para a USP. O trabalho de Celeste Filho, apesar de abandonar os pressupostos filosóficos liberais que fundamentam os trabalhos de Antunha (1971) e de Fétizon (1986), testemunha não só a persistência dos temas e problemas levantados pelo campo de estudos educacionais, particularmente ligados à cadeira de História e Filosofia da Educação da FFCLUSP, como também a sua influência sobre todo o polo dominado da USP, revelando o quanto se trata, na verdade, de uma visão necessária a essa posição. Em especial, a importância da integração acadêmica para a consolidação de uma instituição verdadeiramente universitária se mostra uma questão constante. É interessante observar, nesse sentido, como o próprio autor atribui a persistência desses temas e problemas a uma percepção socialmente difundida entre determinadas unidades da USP, que sofreram diretamente o impacto da reforma universitária de 1968:

Entrar na Universidade de São Paulo nos primeiros anos da década de 1980 significava participar de um daqueles raros momentos de plenitude existencial que a vida nos oferece. Porém, algo interferia na integração discente nessa universidade. 
Em meados da década de 1980, ouvia-se ainda pelos corredores do Departamento de História, onde estudava, um zumbido de descontentamento cotidiano com a universidade que me formava. A dissonância era fruto da inconformidade do corpo docente ao tratar o que tínhamos e o que poderíamos ter sido se a ditadura não tivesse feito o que fez (Celeste Filho, 2013, p. 9).

A observação de Celeste Filho explicita o fato de que essa história, escrita a partir de concepções pedagógico-filosóficas que operam como diretrizes normativas, pode ser lida, em grande medida, como uma história dos "vencidos". É a constatação da falência dos ideais filosóficos que orientaram a fundação da USP, no curso do seu desenvolvimento institucional, antes e depois da reforma universitária, que confere a essa perspectiva historiográfica uma inclinação claramente crítica e que não deixa espaço para o elogio constante da direção universitária, traço distintivo da história oficial.

Apesar de assumir uma perspectiva que permite problematizar o desenvolvimento institucional da USP, a história escrita a partir da posição dos estudos em filosofia e história da educação também incorpora uma concepção finalista, semelhante àquela que marca os trabalhos ligados a posições de poder, analisados anteriormente. No entanto, ao invés de postular o sentido do desenvolvimento universitário no projeto consciente de grupos da elite econômica paulista, esses outros autores o atribuem a um ideal filosófico estático, de tintas liberais, que deve se realizar para que a USP possa assumir uma "autêntica estrutura universitária" (Antunha, 1971, p. 3). Esse ideal se expressa, no caso da USP e segundo Heládio Antunha, nos princípios que orientam a sua fundação, quais sejam: a universalidade, que valoriza o conhecimento geral de vocação universal; a integração, que se expressa na necessidade de promover o reconhecimento da unidade do saber e da formação; e a autonomia, pensada como liberdade em relação a todas as formas externas de determinação, sejam elas de natureza política, social ou econômica (Antunha, 1971, p. 39ss). Oblitera-se, com essa construção, que os princípios filosófico-pedagógicos que orientaram a fundação da USP correspondem, na verdade, a uma visão de mundo inerente à posição social do grupo responsável pela concepção original da USP, 
conforme sugerem as análises históricas de orientação estrutural que, a despeito das suas diferenças internas, compartilham um mesmo pressuposto analítico, de que existe uma correspondência mais ou menos direta entre posições sociais e as visões e representações inerentes a essas posições.

\section{A universidade vista "a certa distância": a perspectiva estrutural sobre a história da USP}

A visão histórica que predomina nos trabalhos de história oficial escritos a partir do polo social e institucionalmente dominante da universidade é, portanto, diametralmente oposta àquela que marca o polo antagônico, formado pelos estudos de filosofia e história da educação oriundos da antiga Seção de Pedagogia da FFCL-USP. Se um polo remonta a origem da USP à criação das escolas profissionais da primeira República, o outro enfatiza o papel determinante da Faculdade de Filosofia, Ciências e Letras, fundada já na Era Vargas. Se um extremo destaca o caráter útil dos saberes produzidos pela USP para o desenvolvimento do estado de São Paulo, o outro enfatiza a natureza desinteressada do conhecimento universitário, ligada à sua condição de saber com pretensão universal. Enquanto um vértice valoriza a associação entre a universidade e os interesses econômicos, o outro considera a autonomia como valor máximo da instituição. Se um extremo destaca a expertise, a técnica e a tecnologia, o outro elogia a ciência, a arte e a filosofia. Enquanto um polo naturaliza a desagregação pela sanção da máxima de que "no universo da cultura, o centro está em toda a parte" 57 , o outro repisa o problema da integração como fundamento da experiência universitária.

Do ponto de vista da análise sociológica, interessa notar que, por trás desses modelos de interpretação histórica opostos, esconde-se todo um conjunto de esquemas categoriais que,

\footnotetext{
${ }^{57}$ A frase é do ex-reitor Miguel Reale que, durante o seu segundo mandato na reitoria da USP, mandou escrevê-la no chão da praça central da cidade universitária, em torno da Torre do Relógio, onde permanece até hoje. Para mais detalhes: < http://www.reitoria.usp.br/>. Acesso em: 15 mar. 2013.
} 
na sua contraposição, mimetizam a polarização essencial do espaço universitário uspiano: cursos profissionais - cursos cientificos; utilidade - desinteresse; local - universal; comprometimento - autonomia; expertise - conhecimento; prática - teoria; tecnologia ciência; técnica - filosofia; isolamento - integração. São algumas das oposições cognitivas, ao mesmo tempo lógicas e axiológicas, que revelam a força dos dois extremos principais que estruturam a Universidade de São Paulo.

De um lado, está o polo formado pelas profissões socialmente dominantes, em geral ligadas ao exercício do poder econômico, político e social, que são ensinadas nas faculdades tradicionais pré-universitárias e nas unidades delas derivadas. Representando um lugar estruturalmente dominante, essas unidades acumulam, no âmbito da USP, um poder institucional quase hegemônico. De outro, encontra-se o polo formado originalmente pelo Instituto de Educação e, hoje, pelas unidades oriundas da antiga Faculdade de Filosofia, Ciências e Letras ou a ela fortemente conectadas que, representando os valores intelectuais por excelência, carecem de poder interno para viabilizá-los plenamente. Essa estrutura geral da USP é, como se verá no terceiro capítulo, inseparavelmente social e acadêmica, não excluindo polarizações internas. A sua força define, como esta tese pretende demonstrar, toda a disputa pelo funcionamento da universidade, particularmente a organização do seu poder central, sob a forma cada vez mais centralizada do "governo acadêmico".

É nessa contraposição essencial entre esses dois vértices opostos - que correspondem também a formas opostas de relação com o conhecimento e com a cultura - que reside o significado mais profundo do brasão d'armas da Universidade de São Paulo que vemos hoje espalhado pela USP e cuja interrogação introduziu o presente capítulo. Para analisá-lo é preciso lembrar que, ao tentar entender o funcionamento social da crença, Pierre Bourdieu não hesita em afirmar que todas as ordens sociais tiram partido do uso social dos corpos (1980, p. 116). Essa tendência geral de mobilização de disposições corporais emerge com força sobretudo nos 
momentos em que os grupos buscam "dar uma representação solene" de si mesmos, na “intenção sem dúvida mais obscura de ordenar os pensamentos e de sugerir os sentimentos através de uma ordenação rigorosa das práticas e da disposição regrada dos corpos" (Bourdieu, 1980, p.116). É o caso, por exemplo, das festas oficiais, das celebrações, dos cerimoniais e dos ritos que mobilizam diretamente os corpos individuais, assim como das imagens simbólicas que inscrevem significados sociais na forma de figuração do corpo. Através dessas representações solenes, os valores sociais são incorporados "pela transubstanciação operada na persuasão clandestina de uma pedagogia implícita, capaz de inculcar toda uma cosmologia, uma ética, uma metafísica e uma política" em oposições aparentemente insignificantes, como entre alto e baixo, superior e inferior, direita e esquerda (Bourdieu, 1980, p. 117). É justamente essa incorporação de sistemas de classificação que constitui o senso prático como uma capacidade de percepção e localização do espaço social.

É nesse sentido que o brasão d'armas da USP, representação solene por excelência, coloca o apóstolo Paulo em sua imagem clássica, mas dotado, então, de novo significado. Sentado em uma cátedra de ouro, São Paulo empunha na mão direita uma espada em riste, símbolo explícito do poder temporal, ligado, no caso da USP, às faculdades profissionais, enquanto segura com a mão esquerda um livro, representando a aspiração intelectual, cuja expressão máxima são as unidades marcadas pelo predomínio da atividade científica, pedagógica e artística. A hierarquia entre um polo e outro é explícita, e reforçada pelo paralelismo com os escudos do governo estadual, postado à direita, e da cidade de São Paulo, unidade administrativa indubitavelmente inferior, situado à esquerda. Além disso, a espada levantada, indicando uma ação iminente, revela um tom ameaçador que sugere uma relação de subjugação entre esses dois polos opostos. E mesmo que a presença do livro possa representar a intenção de guiar a ação da espada pelo conhecimento - sentido reforçado pelo lema Scientiae Vinces, subscrito ao brasão -, é inegável que a imagem prioriza a representação do apóstolo 
como um homem de ação, que se vale do conhecimento como instrumento, a serviço do exercício do poder, simbolicamente identificado à espada. Essa representação, vale notar, é de todo afinada à historiografia oficial da USP, não por acaso, uma das principais responsáveis pela consagração do brasão como símbolo institucional ${ }^{58}$. É a estrutura da Universidade de São Paulo com a sua ordem cristalizada de valores corporificada na imagem do "apóstolo de encarnação" (Campos, 1954, n.p.). Uma estrutura ao mesmo tempo social e acadêmica que hierarquiza o espaço de tomadas de posição na universidade, definindo as possibilidades de ação no seu interior.

A oposição encarnada pelo brasão d'armas da USP repõe uma polaridade que não é nova, tampouco subsiste só na USP. Immanuel Kant, ao descrever $O$ conflito das faculdades, no final do século XVIII, localiza a "classe das faculdades superiores", comprometidas com os interesses do governo, logo, com o exercício do poder, à direita do parlamento da ciência, ao passo que a "faculdade inferior", "aquela que unicamente tem de velar pelo interesse da ciência", permanece à esquerda desse parlamento (Kant, 1993, p.40). Nesse caso, as faculdades localizadas à direita eram representadas pelo Direito, a Medicina e a Teologia, as três principais formações profissionais da época, ao passo que a faculdade à esquerda era essencialmente a Faculdade de Filosofia, expressão do polo científico em um momento em que as ciências não se encontravam, ainda, institucionalizadas em diferentes disciplinas. Mas por trás dessas variações históricas, o exemplo de Kant, não por acaso mobilizado também por Bourdieu (cf. 1984, p. 54), permite pensar nos invariantes estruturais da história universitária.

Como indicado na introdução do presente capítulo, a análise do brasão d'armas da USP seguiu de perto a indicação de Roberto Schwartz, de que a estrutura social que se esconde por traz do conjunto de uma obra - mesmo que essa seja a mera imagem de um brasão - só se revela

\footnotetext{
${ }^{58}$ Como foi dito, o livro de Ernesto de Souza Campos traz o brasão d'armas da USP e a sua descrição logo na abertura (cf. 1954). Rosana Oba, funcionária da reitoria e autora do livro Universidade de São Paulo seus reitores e seus símbolos - um pouco da história, também se dedica à análise do brasão d'armas da USP (cf. 2006).
} 
ao analista caso ele permaneça "a certa distância" (Schwarz, 2000, p. 18). A noção de distância, nesse caso, opera quase como uma metáfora do processo de objetivação da estrutura social que busca revelar o sentido mais profundo dessas representações simbólicas do mundo social. É esse movimento de objetivação que caracteriza, em linhas gerais, a terceira e última linha de reconstrução histórica da USP: a história de tipo estrutural.

Formulada no âmbito das ciências humanas, originalmente agrupadas na Faculdade de Filosofia, Ciências e Letras e hoje concentradas na Faculdade de Filosofia, Letras e Ciências Humanas da USP, essa linha de trabalhos se caracteriza, em termos gerais, pela ênfase explicativa, pelo rigor metodológico e, sobretudo, pelo pressuposto de que as concepções de universidade que marcam as disputas internas à USP se explicam, em grande medida, pela posição social dos diferentes setores engajados nesses conflitos.

Dentre as ciências humanas, foram as ciências sociais, em particular a sociologia, que procurou escrever com mais sistematicidade essa história da USP pautada por esse ideal de "distância"59. Não é coincidência, portanto, que seja também em termos de "distância" que Pierre Bourdieu define "o privilégio epistemológico do observador” (1980, p. 29). Privilégio, esse, que permite romper com a apreensão imediata do mundo, inscrita no senso comum hegemônico em diferentes espaços, para construir um conhecimento objetivo do universo social capaz de identificar as diferentes posições que estruturam a realidade social e a sua percepção, inclusive, para não dizer sobretudo, a própria posição de observador "distanciado". É nesse sentido que a objetividade depende não somente do afastamento metodológico em relação ao objeto mas, principalmente, do movimento reflexivo de análise das condições sociais que

\footnotetext{
${ }^{59}$ Essa "distância" deve ser pensada em termos metodológicos, e não políticos. Ela representa, portanto, um esforço de distanciamento do objeto pela mobilização de métodos e instrumentos de análise que possibilitem romper com as percepções e visões determinadas diretamente pela experiência nesse mundo, não um distanciamento prático, como possível sinônimo de "neutralidade", das disputas materiais e simbólicas que se travam no interior da política universitária.
} 
permitem tal "distanciamento", fonte da possibilidade mesma de objetivação do mundo ${ }^{60}$.

Essas diferentes formas de relação com o objeto correspondem, na verdade, a modos distintos de relação com o mundo material, e que se organizam, grosso modo, segundo dois padrões extremos que, não por acaso, correspondem aos dois polos opostos da USP e às suas respectivas leituras historiográficas: de um lado, uma relação eminentemente teórica que, por tomar uma certa distância do objeto, torna-se relativamente capaz de suspender as suas demandas e necessidades mais imediatas e, de outro, uma relação essencialmente engajada que, por se dar em um contexto de imersão social, acaba condicionada pelos imperativos da prática. Essas duas formas opostas de percepção da realidade não decorrem, como Bourdieu ressalta, de diferenças culturais ou de visões de mundo, mas de condições materiais diferenciadas, que resultam em posições sociais igualmente distintas:

É porque a teoria, a palavra já diz, é um espetáculo que só se pode contemplar a partir de um ponto de vista situado fora da cena onde se desenvolve a ação, que a distância está, sem dúvida, menos lá onde em geral se procura, quer dizer, na diferença entre tradições culturais, do que na diferença entre duas relações com o mundo, teórica e prática; essa distância está, por isso mesmo, associada a uma distância social, que é preciso reconhecer como tal e cujo verdadeiro princípio é preciso conhecer, ou seja, trata-se da distância diferenciada em relação à necessidade, e isso sob pena de se imputar à diferença de "culturas" e "mentalidades" àquilo que é o efeito da diferença de condições (e que se encontra na experiência nativa do etnólogo sob a forma de diferenças de classe) (Bourdieu, 1980, p. 30).

Essa contraposição entre uma percepção condicionada pela distância objetivante e outra definida pela proximidade engajada está no centro da análise de Antonio Candido sobre as condições histórico-sociais que possibilitaram a Sergio Miceli desenvolver uma análise capaz de "desmistificar" os intelectuais brasileiros atuantes nas décadas de 1920 e 1940, na sua

\footnotetext{
${ }^{60}$ Dirá Bourdieu: "Se contra o intuicionismo que nega ficticiamente a distância entre o observador e o observado, eu me mantinha ao lado do objetivismo que buscava compreender a lógica das práticas, ao preço de uma ruptura metódica com a experiência originária, eu não deixei de pensar que era preciso também compreender a lógica específica dessa forma de 'compreensão sem experiência' que possibilita o conhecimento dos princípios da experiência; [assim como não deixei de considerar] que era preciso, ao invés de abolir magicamente a distância por uma falsa participação primitivista, objetivar essa distância objetivante e as condições sociais que a tornam possível, como a exterioridade do observador, as técnicas de objetivação de que dispõe etc.” (Bourdieu, 1980, p. 29-30).
} 
relação com a classe dirigente nacional (cf. 2001, p. 76ss); possibilidade, essa, vedada ao crítico literário justamente pelo modo prático e próximo com que ele se relacionava com eles. Analisando as contribuições da obra de Miceli, Antonio Candido conclui:

\begin{abstract}
A sua maneira de trabalhar depende do que se poderia chamar a formação da perspectiva histórica, no suceder de uma geração pela outra. Ele fala de homens catalogados, quase sempre remotos para ele, autores de livros que leu sem associá-los à figura e ao gesto de quem escreveu; que se tornaram objeto de informação contra ou a favor, e que ele avalia por comparação, por redução aos conceitos, conforme as necessidades de argumentar. Numa palavra, Miceli já dispõe de uma perspectiva temporal, que permite certo afastamento e, portanto, o olhar sem paixão e quem sabe "sem piedade". Mas eu não os vejo assim, porque me formei olhando-os na rua, nas fotografias de jornal, nas salas, no noticiário e na referência viva de terceiros. Tomei partido, julguei seus atos em função dos meus, orientei os meus pelos deles. [...] Miceli já pode fruir do distanciamento e dar forma inteligível ao varejo, enquadrando-o nas categorias explicativas do atacado (Candido, 2001, p. 72-3; grifo meu).
\end{abstract}

É interessante notar como o crítico associa a sua relação próxima com os intelectuais da primeira metade do século XX - ele se formou olhando-os na rua, lendo-os nos jornais, assistindo-os nas salas, tomando partido, julgando-os, orientando as suas ações pelas deles com a sua incapacidade de os "olhar sem paixão". A essa visão apaixonada contrapõe-se, justamente, a perspectiva eventualmente "impiedosa" de Miceli, possibilitada pelo afastamento temporal que o deixou reconstruir as relações objetivas em um movimento inerente à análise de tipo estrutural.

O comentário de Antonio Candido não é mobilizado, nesta tese, apenas pela forma elegante com que traduz a questão bourdieusiana da distância objetivante, mas também pelo fato de voltar-se para a obra de Sergio Miceli que, em um esforço claramente reflexivo, analisou as condições materiais que condicionaram o desenvolvimento de uma perspectiva de tipo estrutural pelas ciências sociais da USP na primeira metade do século XX. Nesse sentido, Miceli permite identificar com maior precisão o lugar social da terceira linha principal de reconstrução da história da USP, formada pelos estudos histórico-estruturais que se ligam, em grande medida, a essa tradição (cf. Fernandes, 1975 e 1984; Limongi, 1989; Miceli, 1989; Nadai, 1981).

$\mathrm{Na}$ sua análise sobre Os condicionantes do desenvolvimento das ciências sociais no 
Brasil entre 1930 e 1964, Sergio Miceli apresenta uma ampla explicação de porquê, na tradição sociológica uspiana, predominou justamente uma abordagem voltada às "condições estruturais" (cf. 1989, p. 93). Segundo o autor, a consolidação das ciências sociais brasileiras dependeu de dois padrões diferenciados de institucionalização associados a demandas sociais igualmente distintas: um, marcado "pelo impulso da organização universitária", atendeu às demandas de grupos sociais emergentes; outro, ligado à "concessão de recursos governamentais para a montagem de centros de debate e investigação", respondeu aos interesses de setores políticos dirigentes $(1989$, p. 72$)$.

Como o autor demonstra, esses dois perfis de consolidação institucional, que atravessaram quase todo o século XX, diferenciavam o tipo de ciência social desenvolvida nos dois principais centros urbanos da época, São Paulo e Rio de Janeiro, segundo diversos aspectos mas, especialmente, a partir do espaço social de recrutamento dos seus realizadores, da distância em relação às faculdades profissionais tradicionais e do seu grau de autonomia relativa (cf. 1989). O contraste entre um polo e outro é tão grande, que o autor chega a afirmar, de modo extremo, que "o Rio de Janeiro está para a política assim como São Paulo está para a ciência" (Miceli, 1989, p 89). Mas ao invés de atribuir essa diferença à cultura ou à mentalidade distintas das duas cidades, Miceli incorpora o pressuposto materialista de Bourdieu e a procura na desigualdade "de condições" (cf. Bourdieu, 1980, p. 30), mais especificamente, de condições de realização da atividade intelectual.

Nesse sentido, a partir do seu desenvolvimento universitário, as ciências sociais em São Paulo foram marcadas por um padrão de recrutamento distinto do que caracterizava, até então, outros setores do ensino superior, como as faculdades profissionais, consequência da abertura da carreira de cientista social a mulheres e a filhos de imigrantes, incluindo os de origem japonesa, árabe e judia (cf. Miceli, 1989, p. 74-80). Essa distância social em relação às faculdades tradicionais, marcadas por um recrutamento mais seletivo, foi reforçada pelo 
estabelecimento de "procedimentos, exigências e critérios acadêmicos de avaliação, titulação e promoção" (1989, p. 81) até então inexistentes nesses outros espaços, sobretudo a partir da influência de professores estrangeiros que contribuíram para a profissionalização do trabalho intelectual. Tudo isso concorreu para consolidar um padrão de pesquisa e trabalho marcado por uma considerável margem de autonomia, em que a escolha de temas e problemas de investigação respondia antes a uma hierarquia científica do que a uma escala de relevância político-social. Esse padrão de desenvolvimento diferenciado incidiu sobre a própria definição "do que seja a ciência social",

[...] prevalecendo no Rio de Janeiro uma concepção "intervencionista", "militante" e "aplicada", cuja expressão intelectualmente acabada são as teorias desenvolvimentistas, enquanto em São Paulo parece se impor uma preocupação marcante com o treinamento metodológico, as leituras dos clássicos, o trabalho de campo individual e/ ou em equipe e toda uma socialização acadêmico-disciplinar então sob hegemonia do paradigma sociológico-funcionalista. Nesse sentido, a ciência social carioca, em especial aquela praticada nos anos 50, sempre se mostrou decididamente politicista, a braços com a formulação de diagnósticos e respectivas palavras de ordem, ao passo que a mentalidade cientificista paulista voltou sua atenção para as condições estruturais de formação e expansão da sociedade brasileira em seu rosto paulista [...] (Miceli, 1989, p. 92-3; grifo meu).

O interesse da análise de Miceli, nesse caso, reside na forma sistemática como o autor analisa as condições materiais, intelectuais e institucionais que possibilitaram à ciência social uspiana desenvolver uma abordagem estrutural marcada essencialmente por um "esforço de objetivação", inerente à sua "mentalidade cientificista". É claro que essa perspectiva estrutural não assume uma feição única. Entre as tintas funcionalistas que caracterizavam as pesquisas dos anos 1950 à sociologia bourdieusiana que passa a influenciar parte importante dos trabalhos dessa escola a partir dos anos 1980 existe uma sucessão de críticas internas, rupturas e distanciamentos. Ainda assim, é possível reconhecer - sobretudo em relação às outras tradições de reconstrução histórica analisadas anteriormente - uma linha de continuidade na ênfase dada à identificação e à análise das estruturas sociais, também nomeadas "condicionantes", "determinantes" ou "constrangimentos", que definem os limites e possibilidades da ação social e, com ela, do desenvolvimento institucional. Essa ênfase se manifesta de modo marcante nas 
análises histórico-estruturais sobre o ensino superior e, em especial, sobre a própria Universidade de São Paulo. Essa sociologia histórica de tipo estrutural, que este trabalho atribuiu inicialmente a Pierre Bourdieu (1984 e 1989), encontra, portanto, um desenvolvimento particular no contexto brasileiro, que define uma ordem própria de objetos e problemas. São exemplos dessa linha de reconstrução histórica os trabalhos de Florestan Fernandes (1975 e 1984), Sergio Miceli (1989), Fernando Limongi (1988 e 1989), Elza Nadai (1981) e, em certo sentido, Irene Cardoso (1982).

A despeito das suas diferenças internas, esses estudos compartilham um mesmo pressuposto de que a história da USP é marcada por uma longa disputa pela definição de modelos institucionais e de padrões de trabalho intelectual aos quais correspondem concepções de mundo inerentes às posições sociais ocupadas pelos agentes e grupos que protagonizam essas disputas. Essa tese geral tende a ser sustentada por uma pesquisa empírica extensa e sistemática, seja de perfil mais estatístico (cf. Fernandes, 1975 e 1984; Limongi, 1989; Miceli, 1989) ou propriamente documental (cf. Cardoso, 1982; Nadai, 1981). Em ambos os casos, a investigação segue um enquadramento teórico bem definido e uma preocupação metodológica correlata, o que testemunha a permanência do padrão de trabalho intelectual que Miceli associa às ciências sociais paulistas entre 1930 e 1964 (cf. 1989, p. 84ss).

O rigor teórico-metodológico que marca esses trabalhos explica o fato deles ocuparem uma posição cientificamente dominante em relação a outros estudos dedicados à história da USP. São consideradas, no âmbito das ciências humanas, as interpretações mais potentes do ponto de vista explicativo, o que se expressa de modo significativo no padrão de publicação desses trabalhos. Todas as principais obras de tipo estrutural foram lançadas em livro por editoras acadêmicas de ampla circulação e considerável prestígio, algumas delas alcançando mais de uma edição, o que testemunha o fato de serem vistas como "literatura de referência" na área. Nesse sentido, Florestan Fernandes lançou sua primeira coletânea de artigos sobre a 
universidade - Universidade brasileira: reforma ou revolução? - pela editora Alfa-ômega (1975), dedicada à publicação de trabalhos acadêmicos, em especial os ligados ao campo de esquerda. Anos depois, lançou outro volume dedicado exclusivamente à USP e publicado pela editora Brasiliense em1984. Sergio Miceli coordenou a coleção História das Ciências Sociais no Brasil em dois volumes, onde foram publicados tanto o seu trabalho sobre o padrão de desenvolvimento das ciências sociais (1989) quanto o artigo de Fernando Limongi sobre os Mentores e clientelas da Universidade de São Paulo (1989). Esse último texto sintetiza a dissertação de mestrado de Limongi, defendida na Unicamp em 1988. Essa coleção, que reúne cientistas sociais de reconhecido mérito acadêmico, gerou enorme repercussão na área alcançando, por isso, duas edições. A primeira saiu em 1989 pela Editora Vértice com apoio do Idesp e da Finep. A segunda edição, revisada, foi lançada em 2001, pela Editora Sumaré. Irene Cardoso publicou o seu livro Universidade da Comunhão Paulista pela Editora Cortez em parceria com a Autores Associados, tornando-se uma referência praticamente obrigatória sobre a história da USP. Elza Nadai publicou sua tese de doutorado defendida no departamento de história da USP e intitulada Ideologia do progresso e ensino superior (São Paulo 1891-1934) pela Edições Loyola em 1987. Todas as editoras citadas são originalmente de São Paulo, dedicando-se à publicação de trabalhos especializados no âmbito das ciências humanas ${ }^{61}$.

Do ponto de vista que orienta este trabalho, é importante notar que às três linhas de reconstrução histórica da USP analisadas neste capítulo correspondem padrões de publicação radicalmente distintos, o que reforça a ideia de que tanto a forma quanto o conteúdo desses trabalhos ligam-se às posições sociais e acadêmicas a partir das quais foram produzidos. Conforme foi dito, as obras ligadas à história oficial da USP apareceram, quase sempre, por ocasião de datas comemorativas, tendo sido publicadas com amplo apoio institucional,

\footnotetext{
${ }^{61}$ Segundo Sergio Miceli, a existência de um mercado editorial de ciências sociais relativamente mais consolidado em São Paulo, com a presença de editoras acadêmicas, contribui para explicar a forma específica da produção intelectual nesse contexto (cf. 1989, p. 94ss).
} 
particularmente por parte da reitoria. A esse apoio institucional soma-se o patrocínio privado de bancos, empresas e associações de classe ${ }^{62}$. Esse suporte institucional e financeiro resulta em edições extensas e luxuosas, repletas de imagens e fotografias coloridas que funcionam como recursos meramente ilustrativos. A impressão é sempre de alto padrão e a circulação no mercado editorial, por isso mesmo, relativamente restrita. Tudo isso sugere que o papel essencial desses volumes não é funcionar como instrumento de pesquisa ou obra de referência - o que pressuporia edições mais acessíveis e de fácil manuseio -, mas como objetos de valor simbólico ou decorativo, particularmente no contexto da administração universitária ${ }^{63}$. Já os trabalhos realizados no âmbito da cadeira de Filosofia e História da Educação, como visto, foram produzidos como teses acadêmicas em educação, não chegando a alcançar publicação comercial, alcançando, portanto, um impacto relativamente restrito ao campo dos estudos educacionais. O padrão de publicação dos trabalhos de história estrutural da USP, por sua vez, distingue-se radicalmente das duas linhas anteriores. Todos foram lançados comercialmente por editoras de relativo prestígio acadêmico tornando-se, na maior parte das vezes, literatura de referência para o estudo da instituição universitária no país. O perfil da sua publicação é típico dos livros universitários: são edições em formato pequeno, de fácil transporte e manuseio, impressas exclusivamente em preto e branco e em papel padrão ${ }^{64}$. No lugar das fotos e imagens,

\footnotetext{
${ }^{62}$ Para citar alguns exemplos: o livro de Shozo Motoyama sobre a história da USP teve patrocínio do Banco Itaú e da Companhia Brasileira de Alumínio (cf. Motoyama, 2006). O livro de Ana Luiza Martins e Heloisa Barbuy contou com o apoio da Bolsa de Mercadorias e Futuros (cf. Martins \& Barbuy, 1998). O livro de Shozo Motoyma e Marilda Nagamini sobre a Escola Politécnica contou com o financiamento da Associação Brasileira de Cimento Portland (cf. Motoyama \& Nagamini, 2004).
}

${ }^{63}$ Durante as entrevistas com dirigentes universitários realizados ao longo desta pesquisa, observei que, em praticamente todas as salas de trabalho situadas em órgãos de gestão acadêmica, era possível encontrar esses livros ilustrativos, no geral em posição de relativo destaque.

${ }^{64}$ No seu trabalho sobre os intelectuais na Idade Média, Jacques Le Goff chama a atenção para esses diferentes usos sociais do livro e o quanto eles indicam um grau de autonomização e um sentido social específico para a atividade intelectual. Assim, o livro da alta Idade Média era composto de manuscritos magníficos redigidos em uma caligrafia esmerada com iluminuras trabalhosas que se assemelhavam a obras de arte. Essa forma específica indica que o livro era usado, então, como ornamento possuindo uma velocidade de circulação ainda reduzida. Não sendo feito para ser lido, o livro era um objeto para ser exposto. Era um bem econômico mais do que intelectual, servindo para aumentar os tesouros das igrejas e dos palácios. Nesse contexto, como indica o autor, os monges que laboriosamente escreviam esses livros nos scriptoria dos monastérios se interessam de forma muito secundária 
tabelas e quadros. Ao invés de apresentação de dirigentes e empresários, prefácios e agradecimentos tipicamente acadêmicos.

Essa observação sobre o padrão de publicação das diferentes linhas de reconstrução da história da USP reforça a ideia de que a perspectiva histórica estrutural, embora compartilhe com os estudos educacionais uma posição politicamente dominada no âmbito da USP, distingue-se daqueles por seu caráter relativamente dominante em termos acadêmicocientíficos. É, nesse sentido, uma posição distinta a partir da qual se escreve a história da USP, marcada por uma perspectiva teórica que busca identificar uma correspondência entre a estrutura mais ampla da sociedade brasileira e as posições significativamente distintas no interior da universidade, a partir das quais se definem os seus conflitos essenciais.

Todos esses traços podem ser encontrados na obra de Florestan Fernandes sobre a USP. O sociólogo dedicou dois trabalhos sistemáticos ao tema. O primeiro - intitulado Universidade Brasileira: reforma ou revolução? - reúne um conjunto de conferências e palestras dadas pelo autor ao longo da década de 1960, “com vistas à participação militante e responsável” (1975, p. 34), em especial no debate sobre a necessidade da reforma do superior no país (cf. Fernandes, 1975). O segundo, chamado A questão da USP, foi publicado quase uma década depois, quando a abertura democrática gerava pressões por mudanças na USP e, nesse sentido, também assume um caráter de intervenção política. Lançado pela coleção de divulgação Qual é? o livro, que retoma parte dos pressupostos analíticos desenvolvidos no trabalho de 1975, assume uma

pelo seu conteúdo, uma vez que a cópia em si era vista apenas como uma forma de penitência (cf. Le Goff, 1985, p. 13-4). Segundo o autor, o livro universitário é completamente diferente do livro da alta Idade Média, o que se expressa em mudanças nas suas técnicas de confecção. A transformação do livro em um instrumento intelectual que precisa ser consultado e transportado - faz com que ele tenha que se tornar mais leve e mais maleável. A nova minúscula gótica, mais rápida de ser copiada, tornou-se então a letra mais usada, justamente porque conferia rapidez na produção editorial, aumentando a velocidade de circulação das obras. A ornamentação do livro também diminuiu, iluminuras e miniaturas passaram a feitas em série, perdendo valor artístico. Muitas vezes, os livros eram vendidos com espaços vazios, para que pudessem ser comprados a um preço mais baixo, pelos que não faziam questão dos ornamentos, ou posteriormente complementados, para os que a faziam. A tudo isso soma-se o uso crescente de abreviações. É nesse contexto que surgem os "manuais" - os livros para consulta, manuseáveis que testemunham a aceleração do processo de circulação do conhecimento e do fortalecimento da cultura da escrita e da sua difusão. Segundo o autor, isso marcou "uma primeira revolução [...] o livro não é mais objeto de luxo, tornando-se instrumento" (Le Goff, 1985, p. 97). Essa mudança testemunha a consolidação da vida intelectual da época. 
linguagem simples e direta, por vezes coloquial, o que confere a algumas passagens um tom de manifesto político (cf. Fernandes, 1984).

O contexto de produção desses textos - voltados à intervenção política com Florestan Fernandes já aposentado pela ditadura - determina a sua forma geral. Reunidos, compõem uma justaposição de análises críticas relativamente autônomas que, por isso mesmo, resultam às vezes redundantes e pouco detalhadas. Não obstante, é possível identificar nesse todo - formado pelos textos das décadas de 1960 e de 1980 - um conjunto coerente de teses que perfazem a interpretação estrutural de Florestan Fernandes sobre o desenvolvimento do ensino superior brasileiro em geral e da USP em particular.

Toda a interpretação histórica de Fernandes parte do pressuposto analítico de que a forma institucional do ensino superior resulta da sua relação com a estrutura social mais ampla da sociedade brasileira. Isso porque, "se são as instituições que formam a sociedade, como queria Durkheim, não é menos certo que as sociedades regulam os dinamismos estruturais e históricos das instituições" (Fernandes, 1975, p. 51). Nesse sentido, o núcleo da análise de Florestan Fernandes consiste em identificar uma correspondência entre o padrão de desenvolvimento da sociedade capitalista brasileira e os modelos institucionais predominantes no ensino superior nacional. Assim, ao caráter subdesenvolvido na estrutura social local determinada por uma economia dependente e voltada para o exterior - corresponde um padrão homólogo de ensino superior, igualmente subdesenvolvido e pautado de fora. Segundo Fernandes, portanto, "a universidade não é um mundo à parte no cenário brasileiro: ela é, claramente falando, uma universidade subdesenvolvida e extrai o caráter do seu subdesenvolvimento da própria estrutura e dinâmica da sociedade de classes sob o capitalismo dependente" (1975, p. 192).

Dessa configuração social específica resultam, portanto, as “limitações estruturais" que determinam um "padrão brasileiro de escola superior", que o sociólogo define como 
“especializada, isolada e autárquica”, cuja expressão máxima são as escolas profissionais formadas no império e na república, também chamadas "faculdades tradicionais" (Fernandes, 1975, p. 70). Esse padrão específico, como mostra Florestan, acaba por se impor sobre todo o sistema de ensino superior, tanto no setor público quanto no privado, determinando a própria organização universitária no país que assumiu "o caráter de uma conglomeração de escolas superiores" (Fernandes, 1975, p. 70).

A “inflexibilidade" desse padrão advém do fato dele ser determinado pela própria estrutura da sociedade brasileira, que define as suas funções sociais, sendo a mais importante delas, o efeito conservador que essas escolas exerciam sobre a "monopolização do poder pelos setores dominantes das classes possuidoras", na medida em que compactuavam com o caráter elitista da educação, voltada para a formação dos quadros dirigentes do país (cf. 1975, p. 53). Tratava-se portanto, de uma "escola de elite e para a elite" que contribuía para a manutenção de uma estrutura social extremamente desigual em termos econômicos, políticos, culturais e educacionais (cf. 1975, p. 37).

Se a estrutura social brasileira determinava a força da "escola superior isolada" e do seu desdobramento histórico mais importante, a "universidade conglomerada", foi justamente a sua transformação que conduziu, a partir do final dos anos 1950, à crise desse modelo (cf. 1975, p. $65 \mathrm{ss})$. Ou seja, foi o processo de urbanização que impulsionou as classes médias urbanas e, com elas, a pressão pela expansão do ensino superior, assim como foi o avanço da industrialização, dentro e fora do país, que impôs novas demandas para a universidade e para o tipo de pesquisa por ela produzida. Tudo isso contribuiu, segundo Fernandes, para fortalecer o movimento pela reforma universitária visando construir uma universidade "integrada e multifuncional", que rompesse com a dependência, ineficiência e improdutividade da escola superior isolada. Esse quadro analítico, como foi dito, é sustentado por um conjunto de dados estatísticos sobre o ensino superior e a sua expansão, através do qual busca demonstrar a pertinência e a validade 
das teses apresentadas (cf. 1975, p. 33-43; 46-50; 133-134) ${ }^{65}$.

É a partir desse modelo estrutural geral que Florestan Fernandes constrói um esquema interpretativo para a história da USP. A essência desse esquema reside no conflito entre o núcleo dinâmico da universidade, inscrito na Faculdade de Filosofia, Ciências e Letras com o seu ideal de integração universitária (cf. Fernandes, 1984, p. 27), e as "forças conservadoras" representadas pelas "escolas superiores tradicionais", detentoras do controle do poder político na USP ${ }^{66}$. Esse embate, que surge com a própria fundação da universidade, atinge seu auge no processo de reforma universitária, quando o movimento pela reestruturação da USP pôs em questão alguns dos aspectos essenciais do modelo tradicional, em especial, a concentração de poder inerente ao regime de cátedras, o isolamento das unidades de ensino e pesquisa que comprometia o ideal de integração universitária e os limites à profissionalização da docência e da pesquisa dados na fragilidade da carreira universitária e na ampla persistência do regime de tempo parcial. Segundo Florestan Fernandes, na oposição entre as faculdades profissionais tradicionais e a faculdade de filosofia reside o âmago da questão da USP. Isso porque:

\begin{abstract}
A Universidade de São Paulo representou um enorme avanço cultural - um avanço tão grande, que não foi absorvido até hoje pelas unidades autônomas que entraram artificialmente em sua composição, e que exigiram a mutilação expiativa do seu verdadeiro núcleo dinâmico, a Faculdade de Filosofia, Ciências e Letras. [...] O aparecimento tardio da universidade como instituição oficial [...] iria promover a composição de um Frankenstein. As escolas superiores deixaram, aparentemente, de ser "isoladas", no entanto elas se viam como verdadeiros núcleos dinâmicos do sistema de ensino e se erigiram nas cidadelas da resistência à formação de uma universidade integrada e multifuncional. A USP viveu esse drama em uma intensidade limite. As escolas superiores, que deviam compor e compor-se no todo, possuíam prestígio e poder. A tradição estava com elas e o poder também (Fernandes, 1984, p. 27-33).
\end{abstract}

\footnotetext{
${ }^{65}$ Nesse sentido, é importante notar que Heládio Antunha também apresenta dados relativos à USP, alguns de caráter muito interessante. Mas esses dados cumprem, no seu trabalho, um papel lateral, meramente descritivo, não sendo portanto essencial para a tese apresentada.

${ }^{66}$ A avaliação de Florestan Fernandes sobre os órgãos de poder da USP é bastante dura: “O Conselho Universitário caiu na mão dessas escolas todo-poderosas e operou como um centro predominantemente conspirativo, antiuniversitário por excelência, e castrador de todo desenvolvimento institucional universitário, sem qualquer rebuço ou constrangimento. Ele dominava a ordem da instituição e em comum acordo com os reitores títeres, fortaleceu as escolas superiores antigas e impediu o advento de uma reforma universitária de origem interna" (1984, p. 33-4). O historiador Celeste Filho, na sua análise sobre a reforma universitária de 1968 na USP, confere certa razão à crítica de Fernandes ao mostrar como as escolas profissionais, depois de perderem a condução da reforma universitária da USP em 1968, mobilizaram sua influência fora da universidade para reverter parte das decisões. Como consequência desse processo, o reitor em exercício, Lourenço Filho, terminou cassado, conforme demonstra Celeste Filho (cf. 2013, p. 157ss).
} 
Nesse sentido, se na análise que Fernandes realiza do desenvolvimento geral da universidade brasileira prevalece uma leitura funcionalista que aponta a homologia quase automática entre forma social e forma institucional, no tratamento específico da história da USP, o sociólogo complexifica a sua interpretação enfatizando, antes, o conflito que opõe dois setores específicos da universidade na disputa pela implementação de modelos institucionais distintos. Nessa chave, perde espaço a ideia de um padrão de ensino superior socialmente determinado e ganha relevo o conflito entre posições distintas, essas sim, correspondentes à estrutura social mais ampla. Nas palavras de Florestan Fernandes, “é como se existissem várias universidades dentro da USP” (1984, p. 24), e elas disputavam entre si espaço para a implementação de um modelo de universidade e de sociedade. A estrutura interna da USP opunha, desse modo, os partidários da escola superior isolada, voltada à formação de elites comprometidas com a manutenção de uma estrutura societária desigual, e os defensores do modelo da universidade integrada e multifuncional, capaz de operar como fator de desenvolvimento e de democratização social. Essa oposição assume, sempre segundo o autor, um significado político mais amplo na medida em que representa um polo socialmente conservador e um polo crítico essencialmente radical e revolucionário:

\begin{abstract}
A USP não é o que parece ser. Enganam-se os estratos mais conservadores e reacionários da burguesia interna e estrangeira. Ela jamais poderá ser apenas um centro cultural do poder conservador preso às servidões da ordem. É também um centro cultural do pensamento crítico radical e revolucionário, polarizado pelas lutas de classe e pelos interesses populares na transformação da sociedade (Fernandes, 1984, p. 10).
\end{abstract}

Nesse embate propriamente político, não existe espaço para determinação absoluta, como o comprovam, segundo Fernandes, as disputas pela reforma universitária dos anos 1960, “em que a margem do poder de decisão tanto poderia ter ficado presa à inspiração conservadora [...] quanto poderia ter se vincado à inspiração inovadora e autonomizadora de estabelecer elos fortes entre a transformação da universidade e da sociedade" (1984, p. 18). Se historicamente o polo conservador venceu, foi porque ele extraiu a sua força relativa da estrutura social mais 
ampla, recrudescida pelo autoritarismo militar (cf. 1975 e 1984).

A análise de Florestan Fernandes sobre a história da USP sintetiza a tese essencial da abordagem histórico-estrutural, segundo a qual o desenvolvimento institucional da universidade é marcado por um conflito essencial entre um polo formado pelas escolas profissionais tradicionais, às quais corresponde um padrão de recrutamento social elevado, e um polo formado pelos cursos de vocação intelectual e científica, acessado por setores relativamente menos privilegiados, particularmente das classes médias urbanas que buscam, na universidade, um caminho para a sua profissionalização (cf. Limongi, 1989; Miceli, 1989; Nadai, 1981). O pressuposto, como foi dito, é de que o fundamento de concepções de ensino superior e de trabalho intelectual que se opuseram ao longo da história uspiana reside, na verdade, na estrutura social mais ampla. Nessa linha de interpretação histórica, merecem destaque os trabalhos de Elza Nadai sobre as escolas profissionais fundadas na Primeira República (1981), de Fernando Limongi sobre a origem do Instituto de Educação, da Universidade de São Paulo e da Faculdade de Filosofia, Ciências e Letras (1989), além dos já mencionados trabalhos de Sergio Miceli sobre o desenvolvimento das ciências sociais na USP (1989) e de Irene Cardoso (1982) sobre a ideologia dos fundadores da universidade.

Na sua tese de doutorado defendida em 1981 no departamento de História da FFCLHUSP, Elza Nadai analisou o projeto de ensino superior que orientou a fundação de três das faculdades profissionais de São Paulo - a Escola Politécnica, a Faculdade de Medicina e a Escola de Agronomia Luiz de Queiróz - no período que vai de 1889 a 1930. O objetivo da autora é mostrar como o perfil e o discurso dessas escolas correspondem à posição social dos grupos que lideraram a sua fundação, em especial a burguesia agroexportadora, defensora de uma concepção que opunha ensino de massa e ensino de elite, associando este último ao acesso e à conservação de posições de poder. Segundo a autora:

No caso paulista, a burguesia agroexportadora elaborou um projeto educacional como um dos componentes do seu projeto político mais amplo, visando estruturar e manter sua dominação. E, nesse projeto, a instrução superior ocupou uma posição destacada, 
fato que não passou desapercebido por seus próprios idealizadores. Afinal, 'as escolas superiores de São Paulo são um instrumento de hegemonia de São Paulo' [...] (Nadai, 1981, p. 10).

Para sustentar sua tese, a autora realizou uma extensa pesquisa histórica voltada para a reconstrução do debate republicano sobre o ensino superior. Para tanto, consultou todos os jornais de grande circulação da época, os registros das reuniões das Câmaras de Deputados e de Senadores de São Paulo entre 1889 e 1930, além de quase toda a documentação disponível sobre a fundação e os primeiros anos de funcionamento das escolas analisadas. A partir desse rico corpus documental, Nadai vai mostrando como as faculdades profissionais foram sendo criadas como "instituições a serviço do progresso e da modernização" (Nadai, 1981, p. 52), o que abria espaço a um novo tipo de instrução que extrapolava o ensino jurídico. Aliás, era principalmente em relação ao bacharelismo que essas escolas procuravam se afirmar, até porque “se o Império criou uma burocracia centrada no bacharelismo, a República a considerava pouco eficiente para compor seu aparelho de Estado" (Nadai, 1981, p. 62). No seu lugar, deveria emergir uma burocracia firmada na competência técnica, nos ideais de modernidade e no domínio de novos saberes. É para formar esses novos quadros dirigentes, associados à expansão do Estado e ao processo de modernização urbana, agrícola e industrial, que se formaram a Escola Politécnica, considerada instituição modelo pelas classes dirigentes do país na primeira república (cf. Nadai, 1981, p. 62ss), a Escola Superior de Agricultura Luiz de Queiróz, voltada à modernização agrícola do estado (cf. 1981, p. 138ss), e a Faculdade de Medicina e Cirurgia, impulsionada pela necessidade de se criar um aparelho de saneamento ligado diretamente ao exercício do poder na Primeira República (cf. 1981, p. 247ss). Nos três casos, como demonstra a autora, a relação estreita entre essas faculdades profissionais e as elites paulistas, responsáveis tanto pela concepção do projeto educacional dessas escolas quanto pelo fornecimento dos seus alunos e professores, determinava tanto a sua forma institucional quanto a sua ideologia específica. 
Se Elza Nadai procura explicar as raízes sociais por trás da criação de instituições de ensino superior em São Paulo na Primeira República, Fernando Limongi se dedica à origem das instituições criadas a partir da Era Vargas, em especial, o Instituto de Educação e a Faculdade de Filosofia, Ciências e Letras que estão na raiz da Universidade de São Paulo. A sua tese de doutorado intitulada Educadores e empresários culturais na criação da USP, defendida na Unicamp em 1988, serviu de base para o artigo Mentores e clientelas da Universidade de São Paulo, publicado no primeiro volume da já mencionada coleção História das Ciências Sociais no Brasil. Conforme já analisado, o autor demonstra como os ideias educacionais do grupo responsável pela fundação do Instituto de Educação e da Universidade de São Paulo correspondiam a uma posição social específica, inerente às elites educadas porém econômica e politicamente dominadas na nova configuração social que marcava o estado e a cidade de São Paulo. A análise se completa pelo esforço de mostrar, através de uma pesquisa empírica sistemática das primeiras turmas de formados da FFCL, como esse objetivo não pôde ser atingido, dado o perfil específico das clientelas dessas escolas, formadas por segmentos socialmente dominados como imigrantes, normalistas e mulheres. Com isso, a nova universidade, com a sua Faculdade de Filosofia, Ciências e Letras à frente, voltou-se para a formação de professores de ensino primário e médio e docentes de ensino superior, enquanto a função de formação de quadros dirigentes manteve-se com as escolas profissionais tradicionais (cf. Limongi, 1989).

Na sua análise sobre a fundação da USP Fernando Limongi encontra, portanto, a mesma oposição que Florestan Fernandes reconhece como o núcleo da instituição, a saber, a contraposição entre as escolas profissionais, marcadas pelo recrutamento elevado e, portanto, destinadas à formação das elites dirigentes, e a Faculdade de Filosofia, Ciências e Letras com um alunado bem menos privilegiado e, portanto, sensível ao problema da profissionalização da atividade de ensino e pesquisa. É um argumento que, em síntese, também se encontra na obra 
de Sergio Miceli (1989) que não hesita em confrontar o perfil dos formandos em ciências sociais - marcado pelo predomínio de mulheres e imigrantes - e em direito - marcado pela exclusão desses grupos sociais menos privilegiados. Seguindo o argumento de Elza Nadai, esse perfil de elite das escolas profissionais remete ao momento da sua formação e marca um contraponto às unidades que surgem na Era Vargas.

É justamente essa contraposição entre unidades voltadas para a formação de profissionais socialmente prestigiados e unidades marcadas pelo predomínio de atividades acadêmico-científicas rotinizadas, isso é, entre as faculdades profissionais tradicionais e as unidades acadêmico-científicas, que define, até hoje, a estrutura social da USP. Mas para demonstrar essa proposição sociológica é preciso reconstruir, estatisticamente, as relações objetivas que aproximam e separam as diferentes unidades da USP, constituindo os seus polos essenciais. Nesse sentido, a possibilidade de elaborar uma análise estrutural da USP e das suas unidades constitutivas depende diretamente da existência de dados estatísticos globais sobre a instituição, o que é resultado direto de processos históricos de afirmação de uma certa visão de universidade e da consequente construção de instâncias centralizadas de produção de dados. É justamente esse o tema do próximo capítulo que se volta para as visões de futuro que orientaram as reformas universitárias, transformando a instituição a partir dos anos 1960. 


\title{
Capítulo 2. Posições sociais e visões de futuro: a emergência da universidade como objeto de gestão
}

\begin{abstract}
Conhecimento é poder; sem ele não se pode planejar. O poder do planejador, em última instância, descansa no seu conhecimento dos fatos institucionais. Se é capaz [sic], seus conhecimentos automaticamente o fazem poderoso, o que, por sua vez, lhe permite ser eficaz, sem a necessidade de adquirir poderes administrativos de um interventor institucional. [...] Como se necessitam de dados de toda a índole para o planejamento, e como estes, na maioria dos casos, faltam por completo, a primeiríssima ocupação de qualquer planejador deve ser organizar um serviço contínuo e fidedigno de estatística sobre dados universitários e de cooperar com outras universidades para que se estabeleça, o quanto antes, um sistema estatístico uniforme (Rudolph P. Atcon. Administração integral universitária: uma teoria unificada da estruturação e administração universitárias, 1974, p. 15, 20).
\end{abstract}

\begin{abstract}
As genealogias são precisamente anticiências. Não que elas reivindiquem o direito lírico à ignorância e ao não saber [...] Não é disso que se trata. Trata-se da insurreição dos saberes. Não tanto contra os conteúdos, os métodos ou os conceitos de uma ciência, mas de uma insurreição sobretudo e acima de tudo contra os efeitos centralizadores de poder que são vinculados à instituição e ao funcionamento de um discurso científico organizado no interior de uma sociedade como a nossa. [...] É exatamente contra os efeitos de poder próprios de um discurso considerado científico que a genealogia deve travar combate (Michel Foucault. Em defesa da sociedade, 1999, p.14)
\end{abstract}

Ao buscar recuperar as três principais linhas de reconstrução histórica da USP, identificando como a cada uma delas corresponde um lugar específico no âmbito da universidade, o capítulo anterior procurou mostrar, na prática, como uma abordagem de tipo estrutural é analiticamente capaz de revelar o significado mais profundo das diferentes interpretações sobre a gênese e o desenvolvimento da Universidade de São Paulo, através da reconstrução da hierarquia de posições sociais que define a universidade como um espaço socialmente estruturado. Se a análise estrutural permite iluminar os embates pela interpretação do passado da USP, ela certamente é capaz de revelar o sentido mais profundo das disputas pela definição do seu futuro. De fato, assumindo o pressuposto teórico de que existe "uma correspondência entre as estruturas sociais e as estruturas mentais, entre as divisões objetivas do mundo social - notadamente em dominantes e dominados nos diferentes campos - e os princípios de visão e divisão que os agentes aplicam” (Bourdieu, 1989, p. 7), a análise estrutural 
permite reconhecer o fundamento social dos projetos de reforma universitária que, desde os anos 1960, vêm buscando definir o que a universidade é para determinar o que ela deve ser.

A proposta de realizar uma análise estrutural do embate entre projetos antagônicos de reforma universitária pressupõe reconstruir as relações sociais que estruturam a universidade, definindo suas polaridades essenciais, especialmente entre dominantes e dominados em diferentes planos. Empiricamente, o retrato das estruturas que limitam o espaço social da USP depende do conjunto de dados estatísticos disponível sobre a Universidade de São Paulo e suas respectivas unidades. Depois de uma pesquisa inicial, constatou-se que as duas principais fontes empíricas seriam as informações demográficas e acadêmicas publicadas anualmente no Anuário Estatístico da USP, organizado pelo Departamento de Informática da antiga Coordenadoria de Administração Geral, hoje Vice-reitoria Executiva de Administração, e os dados sobre o perfil social e econômico dos ingressantes da USP produzidos, também anualmente, pelo Questionário Socioeconômico da Fuvest. No entanto, como o desenvolvimento da pesquisa mostrou, em uma das suas descobertas mais importantes, essas duas instâncias de produção de dados sobre a USP - a Coordenação Geral de Administração nas suas sucessivas denominações e a Fundação Universitária para o Vestibular - são resultado direto do processo de transformação das estruturas de governo da USP que este trabalho pretende analisar. Tornou-se impossível, portanto, mobilizar esse conjunto de dados sem, antes, reconstruir a história das suas instâncias produtoras e de como elas se relacionam com as concepções de gestão ${ }^{67}$ que inspiraram a reforma das universidades brasileiras a partir dos anos 1960.

\footnotetext{
67 A palavra "gestão" assim como o termo "gerencial” serão usados neste capítulo como sinônimos preferenciais do termo em inglês management. Em português, a palavra management foi inicialmente traduzida por “administração" que, nesse sentido específico, já era de uso corrente na língua portuguesa desde o século XVI (cf. Machado, 1952). Por outro lado, a palavra "gestão", assim como as suas variações "gerencial", "gestor", "gestionário", "gerenciamento" e os verbos "gerir" e "gerenciar", surgiram em português no final do século XIX, popularizando-se a partir dos anos 1950, em um processo repleto de disputas materiais e simbólicas. Assim, embora os principais dicionários de língua portuguesa apontem o substantivo "gestão" e os verbos "gerir" e "gerenciar" como sinônimos de "administração" e "administrar" respectivamente, todos são unânimes em reconhecer que as duas palavras surgem em momentos e contextos bastante distintos. Segundo José Pedro
} 
É justamente este o objetivo do presente capítulo que se concentra na análise da redefinição do governo acadêmico, a partir da emergência e do fortalecimento de instâncias centralizadas de ação e decisão no âmbito da universidade, incluindo aquelas responsáveis pela produção de dados estatísticos. Partindo de uma literatura que enfatiza os efeitos sociais e políticos dos saberes com pretensão de verdade materializados em dispositivos técnicos e sociais de natureza diversa e associando-a a uma abordagem estrutural da circulação nacional e internacional do conhecimento, este capítulo analisa o processo de importação e expansão do conhecimento gerencial ${ }^{68}$ no Brasil e da sua aplicação à universidade em um contexto marcado pelo acirramento da disputa entre diferentes projetos de reforma universitária.

\begin{abstract}
Machado, no seu Dicionário etimológico da língua portuguesa (cf. 1952), o verbo "administrar" deriva do latim administrare que vem de ministrere e significa "servir, ajudar, fornecer, dirigir" (1952, p. 86). No português, o seu uso mais corrente foi originalmente religioso, ligado à expressão "ministrar os sacramentos", que depois se tornou "administrar os sacramentos". Foi por esse uso específico que o termo "administração", do latim administratione, passou a significar, em português, "os deveres do diácono", assumindo portanto, desde o século XVI, o sentido mais geral e moderno de "encarregado e incumbido de algo" (1952, p. 86). Ainda segundo José Pedro Machado, o verbo "gerir" também vem do latim gerere que significava "levar uma coisa, encarregar-se dela, fazer, realizar, cumprir, executar" (Machado, 1952, p. 1096). Já o termo gestão, do latim gestione, é um derivado de gestio. Pelo radical, a palavra se aproxima do termo latino gesto ou gestum, que significa "atitude do corpo, gesto do orador ou ator, mímica, gesto, gestão, administração". Ao mesmo tempo, relaciona-se com o verbo gestare, no sentido de "levar consigo, transportar" (Machado, 1952, p. 1096). Nessa acepção de "dirigir", "conduzir", "encarregar-se de algo", o uso da palavra "gestão", em português, data do século XIX, sendo o seu primeiro registro em português de 1890 segundo o Dicionário da Língua Portuguesa de Antonio de Morais Silva (1952, p. 1096). Na leitura de Deonísio da Silva, o uso consideravelmente recente do termo "gestão" na língua portuguesa fez com que alguns filólogos "puristas" o considerassem, na verdade, um galicismo, enquanto tradução da palavra francesa gestion (cf. Silva, 2005, p. 295). No entanto, segundo o Dicionário Houaiss, apesar do seu uso em português datar do século XIX, a palavra "gestão" e o verbo "gerir" têm origem latina e sua raiz etimológica vem de gero, gestum e gerere significando "andar com, ter consigo, trazer sobre o corpo, nutrir, manter, proceder, adquirir, produzir, criar, praticar, executar, fazer, encarregar-se voluntariamente de, cuidar de um negócio, administrar" (Houaiss, 2003, p. 1877). Outros dicionários consultados não apresentaram variação significativa no significado da palavra. Por essa acepção mais completa e por seu uso mais recente, o termo "gestão" e seus derivados "gerencial", "gerenciar", "gerir", "gestionário" são opções melhores para traduzir o termo em inglês management. Ver nota seguinte.
\end{abstract}

${ }^{68}$ Mesmo reconhecendo que o termo management knowledge foi traduzido em português primeiramente por "conhecimento administrativo" ou "conhecimento em administração", estou optando por traduzir essa expressão por "conhecimento gerencial" ou "conhecimento em gestão" porque elas fazem referência mais direta ao termo inglês management. Sobretudo porque a língua inglesa também tem um termo específico para a palavra administração, que é justamente administration. Além disso, embora em português esse corpo de conhecimentos tenha recebido denominações distintas, nos Estados Unidos, de onde foi diretamente importado desde o final do século XIX e com maior intensidade a partir dos anos 1950, sua designação foi sempre a mesma: management knowledge. Essa opção envolve, no entanto, dois riscos: o primeiro é recair em um certo anacronismo ao usar os termos "gestão" e "gerencial" para descrever os primeiros anos de ingresso do management knowledge no país quando, na verdade, as palavras usadas na época eram "administração" e "administrativo". O segundo, a meu ver mais grave, é obliterar o fato de que a difusão da palavra gestão é um processo de imposição linguística correlato ao que resultou na própria expansão do conhecimento gerencial no país a partir dos anos 1950. Mesmo 


\section{A gestão como um sistema de classificação e um dispositivo de saber-poder}

Como visto no capítulo anterior, ao definir o processo de imposição simbólica como o poder de "constituir o dado pela enunciação, de fazer ver e de fazer crer", Pierre Bourdieu procurava enfatizar o potencial produtivo dos sistemas de classificação, enquanto mecanismos de construção e de legitimação social da realidade (cf. Bourdieu, 2001, p. 210). Partindo dessa definição geral, foi justamente enquanto sistemas de classificação que esta tese procurou compreender as visões de passado e de futuro que orientam as reconstruções históricas e os projetos de reforma universitária que, no âmbito da USP, expressam as disputas pela definição do que a instituição foi, do que ela é e, sobretudo, do que ela deve $\operatorname{ser}^{69}$. No processo de análise da dimensão performativa desses sistemas de classificação, percebemos que era importante estabelecer um diálogo mais intenso entre a teoria bourdieusiana, que parte de uma perspectiva estrutural para analisar os efeitos performativos dos esquemas de percepção, pensamento e ação, e a abordagem foucaultiana, que enfatiza de modo ainda mais determinante os efeitos produtivos dos sistemas de classificação, sistematizados em regimes de verdade (cf. Foucault, 1999, 2004, 2010 e 2011) ${ }^{70}$. Partindo, portanto, dos trabalhos de Michel Foucault sobre os efeitos de poder dos sistemas de saber, chegamos a uma literatura mais contemporânea sobre

reconhecendo esses perigos, mantive a opção porque o principal objetivo é reconhecer a unidade desse corpo de conhecimentos que foi sistematicamente importado para o país desde o final do século XIX.

\footnotetext{
${ }^{69}$ No seu trabalho sobre a construção de um campo acadêmico sobre o ensino superior no Brasil, a socióloga Ana Paula Hey enfatiza justamente a dimensão performativa das visões que se reivindicam "científicas" sobre o ensino superior, afirmando-se, então, como um saber legítimo e legitimado de intervenção política. Segundo a autora: "a luta que opõe os pesquisadores desse espaço acadêmico adota a forma de uma luta pelo poder propriamente simbólico de fazer ver e fazer crer, de predizer e de prescrever, de dar a conhecer e de fazer reconhecer, que é ao mesmo tempo uma luta de distribuição do poder sobre os poderes públicos e da administração do Estado" (Hey, 2008, p. 27).

${ }^{70}$ É interessante notar que a tentativa de estabelecer um diálogo mais intenso entre os trabalhos de Pierre Bourdieu e de Michel Foucault tem se mostrado uma tendência importante na sociologia contemporânea, como indicam os trabalhos de Bernard Lahire (2001), Gil Eyal \& Buchholz (2010) Eyal \& Pok (2011) e Remi Lenoir (1996). Lahire chega a ser enfático ao afirmar que o estudo dos regimes de verdade desenvolvido por Foucault permite resolver uma deficiência do arcabouço teórico de Bourdieu ao oferecer ferramentas especificas para a "análise frontal" dos discursos e do seu poder específico. Segundo o autor, o trabalho de Bourdieu oferece poucas ferramentas para uma análise interna às obras, privilegiando a correspondência estatística entre posições e tomadas de posição, o que o leva a negligenciar os discursos e seus efeitos de poder (cf. 2001, p. 45ss).
} 
os efeitos produtivos dos conhecimentos especializados na reorganização de concepções, rotinas e práticas de governo (cf. Burchell, 1991; Callon, 1998b, 1998c, 2006, 2007; Çaliskan \& Callon, 2009; Donzelot, 1979; Eyal \& Buchholz, 2010; Eyal \& Pok, 2011; Eyal, 2013; Mackenzie, Muniesa \& Siu, 2007; Muniesa \& Callon, 2008; Rose, 1989; Rose, O’Malley \& Valverde, 2006). Foi esse conjunto de trabalhos que me permitiu descrever a emergência da gestão como um dispositivo de saber-poder, enfatizando os seus efeitos sobre a reconfiguração do exercício do governo da universidade, que também se organiza enquanto um contexto de trabalho. O presente item busca reconstruir essa literatura construtivista, que enfatiza o papel dos sistemas de classificação sistematizados em discursos com pretensão de verdade, dialogando com uma perspectiva estrutural sobre a circulação internacional de conhecimentos especializados para, então, descrever a importação do saber gerencial no Brasil, a partir dos primeiros anos do século $\mathrm{XX}$.

\subsection{Conhecimento especializado e intervenção técnica como construção social da realidade}

Na sua análise das "formações discursivas", posteriormente denominadas "regimes de verdade" ${ }^{71}$, Michel Foucault interpreta os saberes especializados com pretensão de verdade como dispositivos de poder capazes de produzir objetos e práticas que definem processos de

\footnotetext{
${ }^{71}$ Conforme Foucault argumenta, o fundamento social das "formações discursivas" reside essencialmente no controle que a sociedade exerce sobre os lugares de produção dos discursos com pretensão de verdade (cf. Foucault, 2011). Esse controle social sobre a produção discursiva opera sobretudo por meio de três mecanismos de exclusão: os mecanismos de interdição - que determinam a construção de tabus -; de oposição entre razão $e$ loucura - que deslegitimam os discursos considerados irracionais -; e de contraposição entre verdadeiro e falso - que constituem os "regimes de verdade" (Foucault, 2011). Embora o filósofo tenha procurado analisar esses três mecanismos, foi sobretudo em direção a uma "analítica da verdade" que a sua obra caminhou. Isso porque, segundo ele, é o princípio de verdade que orienta e modifica as censuras discursivas e a divisão racional/irracional, ou seja, os mecanismos de interdição e de oposição razão/loucura (2011, p. 19). Não obstante a importância crescente da "vontade de verdade", o autor mostra que opera sobre ela uma espécie de silêncio tácito. A "verdade", ou seja, as visões com pretensão de verdade são vistas, nas sociedades modernas que lhe conferem um estatuto privilegiado, como algo necessário, natural, evidente. É justamente essa naturalização da verdade e das suas instituições produtoras, como as universidades e demais instituições científicas, que esconde e fortalece a relação imanente entre verdade e poder que Foucault pretende explicitar. Como ele mesmo afirmava: "o discurso não é simplesmente aquilo que traduz as lutas ou os sistemas de dominação, mas aquilo por que e pelo que se luta, o poder do qual queremos nos apoderar" (Foucault, 2011, p. 10).
} 
subjetivação. O poder dos discursos que reivindicam o estatuto de "ciência" reside, portanto, no seu "efeito produtivo" (Foucault, 2010, p. 61), consequência da sua materialização em práticas, procedimentos, técnicas e instituições socialmente legitimados pelo seu caráter de conhecimento "verdadeiro". Essa dimensão material e produtiva dos discursos obriga a tratálos não somente como um conjunto de signos e significados, que opera em um plano abstrato, mas como uma prática discursiva que, em um plano propriamente material, forma, deforma, constrói e destrói os objetos de que fala (cf. Foucault, 2010). Essa prática, através das categorias que mobiliza, está na base dos processos de construção social da realidade, pelos quais a ação individual ou coletiva interfere diretamente nas estruturas que a determinam.

O projeto genealógico ${ }^{72}$ de analisar os efeitos de poder que os regimes de verdade exercem nas sociedades modernas se expressa claramente no curso dado por Foucault no Collège de France, entre 1978 e 1979, intitulado O nascimento da biopolítica. O objetivo do curso é mostrar como, a partir do século XVIII, o liberalismo econômico, expressão da nascente Economia Política, se constituiu como um novo dispositivo de saber-poder que transpôs a reflexão sobre as práticas de governo do plano da legitimidade e da justiça para o plano da $\operatorname{verdade}^{73}$. A consequência mais imediata da emergência desse novo regime de verdade foi uma certa naturalização do exercício do governo. Assim, obliterada a sua dimensão política, as decisões governamentais reduzem-se cada vez mais a um conjunto de decisões consideradas

\footnotetext{
$72 \mathrm{O}$ descolamento em direção à análise das formações discursivas enquanto regimes de verdade capazes de produzir dispositivos de saber-poder justifica a transição, que marca a obra do filósofo francês, de uma arqueologia do saber para uma genealogia da verdade (cf. Foucault, 1999).
}

73 Segundo Foucault: “A economia política reflete sobre as próprias práticas de governo, e não interroga essas práticas governamentais para saber se elas são legítimas ou não. Ela não as encara da perspectiva da sua origem, mas dos seus efeitos. Por isso ela deixa de perguntar 'quem autoriza o soberano a aumentar os impostos?', para interrogar 'quando se eleva este imposto nesse momento determinado, sobre tais categorias de pessoas ou mercadorias, o que acontecerá?'. Pouco importa que esse direito seja legítimo ou não, o problema é saber quais serão os efeitos e se eles serão negativos. (...) Dito de outro modo, o que a economia política descobre não são os direitos naturais anteriores ao exercício da governamentalidade, mas uma naturalidade própria à prática governamental" (Foucault, 2004, p. 17-18) 
puramente técnicas. Essa nova forma de exercício do governo, baseada em um novo regime de veridição, Foucault denomina "governamentalidade".

A análise de Michel Foucault sobre a emergência de uma nova "arte de governar" instruída por um novo tipo de saber, de inspiração econômica, teve enorme impacto no estudo das práticas de governo, cada vez mais concebidas enquanto práticas de controle que, inspiradas por um regime de verdade que pretende estabelecer o que são e como funcionam as diferentes instituições sociais, redefinem o exercício do governo em contextos sociais diversos. É possível identificar pelo menos três linhas de investigação que, partindo das indicações de Foucault, buscam analisar contemporaneamente os efeitos da mobilização de saberes especializados, materializados em dispositivos concretos de intervenção, sobre a organização e o exercício do poder em diferentes instituições.

A primeira dessas linhas, a chamada analítica da governamentalidade (cf. Burchell, 1991; Rose, 1989; Rose, O’Malley \& Valverde, 2006), desenvolve uma série de pesquisas empíricas sobre a emergência de novas formas de governo buscando "tornar o poder visível, na vida cotidiana e no interior das instituições, de um modo mais tangível e material [...]" (Rose, O’Malley \& Valverde, 2006, p. 86). Para apreender essa dimensão material e cotidiana do $\operatorname{poder}^{74}$, esses trabalhos propõem algumas inflexões na maneira com que se pensa as formas de governo.

Em primeiro lugar e seguindo diretamente as indicações de Michel Foucault, esses autores buscam analisar as práticas de governo como um exercício de poder diretamente associado à mobilização do conhecimento: "para governar, portanto, seja uma casa, um navio

\footnotetext{
${ }^{74}$ Por reivindicar um olhar mais cotidiano e concreto sobre o poder, esses autores afirmam promover uma ruptura explícita com a forma como a tradição marxista concebia o controle e a dominação (cf. Rose, 1989; Rose, O'Malley \& Valverde, 2006, p. 86ss). Em resposta a essa interpretação, que insiste na separação estrita entre os pressupostos foucaultianos de análise e a teoria marxista, alguns autores têm procurado mostrar como "a ideologização tendencial dos conceitos foucaultianos" impediu que se visse as profundas relações entre a análise de Foucault e de Marx, particularmente no estudo da governamentalidade (cf. Dardot \& Laval, 2010; Legrand, 2004; Lemke, 2004; Santos, 2013).
} 
ou uma população, é necessário saber sobre o que será governado e governar à luz desse conhecimento" (Rose, O’Malley \& Valverde, 2006, p. 87). Para esses autores, ainda, o saber constitui-se como instrumento de poder não apenas quando assume a forma abstrata de conceitos, noções e teorias mas, sobretudo, quando se materializa em estratégias, práticas e instrumentos de governo que mobilizam suportes materiais diversos, tais como ferramentas estatísticas, programas de computador, tecnologias de avaliação e controle, manuais de gestão, desenhos e modelos de reforma institucional, planos de intervenção e procedimentos de normatização (cf. Donzelot, 1979). Por fim, esses estudos mostram como tais suportes materiais, embora construídos de modo difuso, assumem muitas vezes um sentido político coerente. Isso porque, mesmo quando se dá por meio de instâncias descentralizadas, o exercício do poder acaba produzindo efeitos políticos centralizadores, de modo relativamente independente dos interesses e intenções implicados na produção dos dispositivos, ferramentas e práticas que lhe dão suporte.

Essa mudança na concepção do exercício do poder tem impactos metodológicos importantes. Em primeiro lugar, ela obriga a considerar novos materiais de pesquisa. Assim, ao invés de analisar os grandes tratados de filosofia e política, o foco recai sobre textos até então tidos como "menores", escritos, em suma, por experts diversos, por exemplo polemistas, jornalistas, consultores, formuladores de programas e administradores que analisam contextos locais diversos para torná-los passíveis de serem conhecidos e, portanto, administráveis (Rose, O’Malley \& Valverde, 2006, p. 86). Do mesmo modo, como esse processo de conhecimento e intervenção depende da mobilização de suportes materiais diversos, a pesquisa deve buscar, ao máximo, catalogar, descrever e analisar esses instrumentos por meio dos quais o poder se exerce. Essa abertura da perspectiva da governamentalidade para o exercício do poder em um registro mais geral pressupõe e possibilita, por fim, que a análise extrapole as instâncias tradicionalmente vistas enquanto fundamento do poder, como o Estado e o mercado, mostrando 
a dispersão das formas de controle social por toda as instituições sociais, como, por exemplo, a universidade e a escola. Uma vez que a governamentalidade é entendida no sentido amplo de técnicas e procedimentos que organizam "o governo dos homens" em diferentes universos sociais, a análise pode se voltar para todo e qualquer domínio que emerge como um espaço calculável e gerenciável a partir da intervenção de dispositivos de saber-poder. Dentre esses dispositivos, conforme analisam Rose, O’Malley e Valverde, destaca-se justamente o chamado "conhecimento em gestão", com suas técnicas de contabilidade, mensuração estatística, desenho organizacional, avaliação institucional e controle de recursos humanos que buscam cada vez mais produzir conhecimento sobre diferentes espaços de trabalho para, então, desenvolver novos modos de governá-los (cf. 2006, p. 94).

Uma segunda linha de pesquisa inspirada nas análises foucaultianas sobre os efeitos produtivos dos conhecimentos é o chamado programa performativo, que também enfatiza a necessidade de analisar os efeitos que os saberes especializados exercem, através de agenciamentos materiais, sobre os objetos e relações que descrevem pretensamente de modo neutro e distanciado (cf. Callon, 1998b, 1998c, 2006, 2007; Çaliskan \& Callon, 2009; Mackenzie, Muniesa \& Siu, 2007; Muniesa \& Callon, 2008). Se os estudos da governamentabilidade estão sediados sobretudo em instituições inglesas, o programa performativo tem um perfil predominantemente francês. Não obstante essa diferença de origem, é possível encontrar, entre eles, uma forte confluência de temas e problemas.

O foco principal dos estudos performativos é analisar de que modo a mobilização da ciência, em especial da ciência econômica e dos saberes especializados a ela associados como a contabilidade, a estatística, o marketing e a gestão ${ }^{75}$, incide sobre os universos sociais que

\footnotetext{
${ }^{75}$ A noção de performatividade, originalmente mobilizada pela pragmática da linguagem, foi retrabalhada por Michel Callon para operar uma inflexão no campo específico da sociologia econômica (cf. Callon, 1998a). O programa performativo concebe a ciência econômica em sentido amplo. Em primeiro lugar, porque considera tanto os saberes propriamente acadêmicos, representados pelas teorias formuladas no âmbito universitário, quanto o conhecimento mais operacional, mobilizado no interior de empresas, agências, comissões governamentais etc. Além disso, o programa não se limita à análise da ciência econômica na sua corrente hegemônica, neoclássica,
} 
descreve produzindo, neles, um conjunto de reorientações e mudanças institucionais. Esse efeito produtivo do conhecimento econômico pressupõe, também para essa literatura, a sua materialização em práticas, técnicas e instituições que esses autores denominam “agenciamentos materiais" (cf. Callon, 2006, p. 13). Tratam-se dos diversos suportes materiais, humanos e não humanos que constituem uma rede, por meio da qual o conhecimento circula, consolidando o seu poder produtivo. Os exemplos de agenciamentos materiais dos saberes são diversos: dos cursos e programas de treinamento à circulação de consultores, profissionais e especialistas; da padronização de técnicas e procedimentos à difusão de conceitos e representações sociais; das reformas institucionais às certificações técnicas; dos mecanismos de divulgação do saber como seminários, workshops e manuais aos programas de computador; dos programas de formação universitária aos padrões de mensuração estatística. Em todos esses casos, os agenciamentos materiais funcionam como suportes para que os portadores de determinados conhecimentos construam a realidade segundo uma descrição contida na teoria que adotam. Em suma, enquanto descrevem como o mundo supostamente funciona, os saberes especializados e certificados constroem agenciamentos materiais que operam para que o mundo passe a funcionar segundo a sua descrição teórica original (cf. Callon, 2006, p. 14) ${ }^{76}$.

Assim, além de deliberadamente inspirado no projeto genealógico foucaultiano, o programa performativo se associa aos chamados estudos sociais da ciência e da tecnologia, que também se ocupam dos efeitos políticos, sociais e cognitivos das práticas científicas (cf. Callon,

mas olha também para as outras tradições teóricas como a economia política, o keynesianismo e o neoinstitucionalismo. Também merecem atenção, como foi dito, os saberes derivados da economia como o marketing, a contabilidade, a engenharia financeira e, o que é particularmente importante para esta pesquisa, a gestão.

\footnotetext{
${ }^{76}$ Um exemplo interessante desse efeito performativo são as teorias econômicas sobre a ciência, que estão na raiz da recente redefinição das políticas nacionais de ciência e tecnologia a partir da ênfase no incentivo à chamada "inovação". No mesmo momento em que defendiam o postulado teórico de que a ciência é uma atividade econômica como outra qualquer, podendo portanto ser medida em termos de investimento e retorno, os economistas da inovação buscavam desenvolver, no âmbito de instituições políticas diversas, todo um ferramental estatístico capaz de proceder essa mensuração e, assim, viabilizar um tratamento econômico da ciência. Eu apresento uma análise desse processo em um trabalho publicado recentemente sobre a transformação da ciência brasileira (cf. Carlotto, 2013).
} 
1986; Callon \& Latour, 1991; Desrosières, 1993; Galison, 1997; Latour, 1984; Pickering, 1995). Essa relação com uma sociologia da ciência de tipo construtivista torna os estudos sobre a performatividade particularmente sensíveis aos efeitos da legitimação dos conhecimentos reconhecidos como "científicos"77, o que permite evidenciar a importância dos conflitos internos à esfera científica, também concebida como um espaço estruturado, envolvendo disputas pela legitimação de conhecimentos especializados, cujos exemplos paradigmáticos são as controvérsias científicas e as lutas pela institucionalização de novos saberes no interior das universidades $^{78}$.

Por fim, uma última linha de estudos inspirada pelos trabalhos de Michel Foucault é o programa de pesquisa autodenominado sociologia da expertise, proposto recentemente por Gil Eyal e seus colaboradores, sediados sobretudo na Universidade de Columbia (cf. Eyal \& Buchholz, 2010; Eyal \& Pok, 2011; Eyal, 2013). Partindo explicitamente das contribuições da

\footnotetext{
${ }^{77}$ No âmbito específico da sociologia da ciência, existe um conjunto de trabalhos que se voltam para a análise da legitimação dos saberes certificados como "científicos" e dos efeitos que isso gera em termos de impacto político. Sem assumir explicitamente a influência de Michel Foucault, esses trabalhos também oferecem contribuições fundamentais para o estudo dos efeitos práticos do conhecimento, a partir da mobilização dos seus suportes materiais. Um primeiro exemplo interessante desse campo de estudos é o trabalho de Benoît Godin (2004a) sobre o papel da Organização para a Cooperação e o Desenvolvimento Econômico (OCDE) na difusão de concepções e discursos que, legitimados junto à academia e à comunidade científica, reivindicam no plano político internacional a centralidade da ciência e da tecnologia nos processos de desenvolvimento econômico, cujo auge foi a construção de um consenso em torno da ideia de "nova economia" (cf. 2004a). Benoît Godin dedicou, ainda, uma série de estudos ao processo de construção de estruturas técnicas - em particular de um ferramental estatístico sofisticado - que permitiram a difusão das noções e concepções inerentes à tese da nova economia, explicitando o papel dos saberes especializados no subsídio e legitimação de políticas de Estado (2002, 2003, 2004a, 2004b). No mesmo sentido, o trabalho de Naubahar Sharif (2006) sobre o desenvolvimento do conceito de Sistemas Nacionais de Inovação (SNI) demonstra o poder político dos discursos reputados como "científicos". O objeto de Sharif é particularmente interessante para abordar a questão da legitimação dos discursos pretensamente científicos porque, como ele mostra, o conceito de SNI surgiu simultaneamente nos campos acadêmico e político, valendo-se do papel dual dos seus formuladores e da legitimidade cruzada de que se beneficiavam por atuarem ao mesmo tempo como acadêmicos de prestígio e consultores políticos de Estados e agências internacionais (Sharif, 2006, p. 752ss). Para uma síntese dessa discussão sobre as teorias performativas sobre a ciência ver também (Carlotto, 2013, p. 49ss).

${ }^{78}$ Partindo de um outro referencial teórico, mais próximo do neoinstitucionalismo, David Frank e John Meyer observam que um dos aspectos centrais da transformação da universidade contemporânea é a sua expansão ligada à criação de novos cursos e áreas de pesquisa a partir da sistematização de "materiais culturais diversos" classificados, a partir da sua institucionalização na universidade, como "científicos". Essa expansão, ligada à certificação de novos saberes, está no cerne, segundo os autores, das disputas pela redefinição da universidade desde o início da era moderna (cf. Frank \& Meyer, 2007). Trata-se, essencialmente, de uma luta classificatória que implica efeitos sociais profundos, sobretudo em função do poder acumulado pela ciência na sociedade contemporânea, conforme reconhece parte importante da teoria social da segunda metade do século XX nas suas diferentes vertentes (cf. Adorno \& Horkheimer, 1985; Bourdieu, 2004a, 2004b; Foucault, 1999; Habermas 2001).
} 
analítica da governamentalidade e do programa performativo, essa linha de pesquisa dá um passo a mais ao buscar diferenciar duas formas específicas de saber especializado, quais sejam: o conhecimento profissional e a assim chamada expertise. Segundo os autores, nos dois casos, a intenção é delimitar um domínio sobre o qual o conhecimento pode exercer influência direta, definindo um repertório de práticas, técnicas e procedimentos legitimados socialmente. No entanto, no caso do conhecimento profissional, esses limites assumem, em geral, uma forma estanque dada pelo estabelecimento de mecanismos claros de monopolização, certificação e credenciamento como, por exemplo, a obrigatoriedade de uma formação universitária longa e controlada, a proliferação de provas de certificação e títulos e a afirmação de uma linguagem tecnicamente hermética com procedimentos de intervenção complexos. A expertise, por outro lado, funciona de modo bem mais fluido. Assim, pelo fato de não impor controles profissionais e, sobretudo, pelo conteúdo mais acessível do seu esquema categorial elementar, a expertise torna-se acessível, inclusive, para portadores de diferentes formações profissionais. Em síntese, a expertise como forma específica de conhecimento especializado, não assenta o seu poder no caráter restritivo das suas fórmulas e formulações, como no caso dos monopólios técnico e cognitivo estabelecidos pelo conhecimento profissional mas, ao contrário, na sua expansão acelerada para diferentes contextos sociais, onde passa a funcionar como uma espécie de língua franca $^{79}$, cujo domínio passa a ser um pressuposto para a legitimação de ocupantes de posições de comando.

O reconhecimento dessa diferença entre conhecimento profissional e expertise implica uma mudança de ênfase. Se a sociologia das profissões pôde se desenvolver como uma análise marcadamente institucional, a sociologia da expertise pressupõe, por outro lado, uma

\footnotetext{
${ }^{79}$ Essa expressão aparece originalmente na tese de Roberto Grün sobre a expansão do conhecimento gerencial no país. Segundo ele, na esteira dos processos "de reconversão da cultura técnica dos engenheiros em cultura gerencial”, são incluídas nos currículos de engenharia diversas disciplinas de gestão, o que "acaba produzindo uma continuidade ainda maior no universo, com a linguagem do management fazendo as vezes de língua franca" (Grün, 1990, p. 23).
} 
abordagem mais ligada às práticas sociais, já que a única forma de acessar o conteúdo preciso da expertise é atentar "para o que os experts realmente fazem, para como eles dão visibilidade a problemas tornando-os objeto de ação" (Eyal \& Pok, 2011, p. 7). Essa operação implica considerar as formas de circulação e institucionalização do conhecimento que permitem aos seus portadores intervir diretamente sobre a construção da realidade social. Mais uma vez, a questão que emerge diz respeito aos efeitos produtivos dos saberes especializados nos objetos sobre os quais incidem e que dependem estritamente da sua materialização em "uma rede de arranjos concretos e práticos" (Eyal \& Pok, 2011, p. 9).

Em síntese, essas diferentes leituras inspiradas nos trabalhos de Michel Foucault - a analítica da governamentalidade, o programa performativo e a sociologia da expertise pressupõem a existência de uma estreita relação entre conhecimento e poder que deriva, justamente, dos efeitos produtivos que os saberes especializados exercem sobre os objetos que descrevem e produzem ao materializarem-se em dispositivos de saber-poder de natureza diversa. Assim, considerando essas três linhas de análise em conjunto, é possível constituir um referencial bastante completo para analisar a emergência do conhecimento em gestão e seu impacto sobre a universidade.

Isso porque a analítica da governamentalidade, ao enfatizar a transformação do exercício do poder em diferentes contextos sociais por meio do impacto de saberes especializados, ajuda a compreender o impacto do conhecimento em gestão na reconfiguração do governo acadêmico, sobretudo a partir do surgimento de novos dispositivos de intervenção como os indicadores de produtividade acadêmica, as práticas de avaliação institucional, as estatísticas educacionais, a uniformização de normas e procedimentos e, por fim, as reformas universitárias que resultam na criação de novos órgãos de intervenção - exatamente como ocorreu nas universidades brasileiras, incluindo a USP, a partir dos anos 1960. O programa performativo, por sua vez, ilumina o aspecto decisivo do apelo ao caráter "científico" do 
conhecimento gerencial, particularmente importante quando o que está em jogo é a sua aplicação ao contexto universitário, marcado pela valorização intrínseca da ciência e do seu papel na orientação de práticas de intervenção social - conforme inscrito no brasão d'armas da USP, Scientia Vinces, ou "vencerás pela ciência". Por fim, os trabalhos em sociologia da expertise elucidam a especificidade do conhecimento em gestão, que funcionando de modo mais aberto e fluido do que o conhecimento profissional, tende a difundir-se rapidamente por diferentes contextos, estimulando processos internos de reprofissionalização (cf. Hafferty \& Light, 1995) que permitiram, por exemplo, com que professores universitários encarregados da direção acadêmica pudessem operar como gestores - ou, segundo uma descrição que os uspianos encarregados do governo universitário certamente preferem, como dirigentes acadêmicos cuja margem de ação foi reconfigurada pelo predomínio das ferramentas modernas de gestão ${ }^{80}$. Em todos esses casos, o essencial é perceber que os efeitos produtivos do conhecimento gerencial não pressupõem a aceitação explícita dos seus pressupostos. Inerentes a dispositivos de intervenção técnica aparentemente neutros, discursos científicos de caráter performativo ou a uma linguagem de expertise altamente difundida e, portanto, igualmente naturalizada, as categorias e os efeitos do conhecimento gerencial se estabelecem quase como uma estrutura social, de natureza cognitiva, que se impõe independentemente da intenção explícita dos agentes envolvidos na sua imposição.

Assumindo, portanto, essa perspectiva abertamente construtivista sobre os efeitos produtivos do saber, com os seus diferentes desdobramentos, torna-se possível descrever e analisar o papel que a gestão, enquanto conhecimento especializado, exerceu sobre a

\footnotetext{
${ }^{80}$ Ao longo das entrevistas que realizei com os reitores, vice-reitores e pró-reitores da USP entre 1986 e 2010, notei que eles não aceitavam bem a denominação de "gestores" porque se entendiam, antes, como "dirigentes acadêmicos". Ao invés de negar a influência das concepções gerenciais sobre a universidade, essa disputa classificatória reforça o impacto dos modelos gerenciais importados a partir dos anos 1960, onde é possível notar a ênfase na separação explícita entre um nível central de concepção política, onde atuam justamente os "dirigentes" da instituição, e o nível de execução das diretrizes estabelecidas pelo nível central. No plano da execução, operam os chamados "gestores", classificados, por isso, como de nível mais baixo do que os dirigentes propriamente ditos, responsáveis pela formulação (cf. Atcon, 1966, p. 83ss).
} 
organização do governo acadêmico e, consequentemente, sobre a estrutura da própria universidade que se torna objeto de gestão, que opera ao mesmo tempo enquanto uma forma de conhecimento e um mecanismo de intervenção social. No entanto, da perspectiva sociológica que orienta esta tese, essas análises de inspiração construtivista só fazem sentido se associadas a uma abordagem de tipo estrutural, que busca inserir o processo de construção social da realidade no interior das estruturas sócio-históricas nas quais ele se desenvolve. Em outras palavras, se os conhecimentos constroem a mundo, é somente através de atores sociais cujas possibilidades de ação são (de)limitadas pela posição que eles ocupam no interior de uma estrutura social dada.

No entanto, se até recentemente era possível associar essas estruturas às posições de classe em âmbito nacional, o aprofundamento do processo de globalização obriga a considerar, contemporaneamente, a constituição de estruturas internacionais de dominação, ainda que elas sejam nacionalmente enraizadas e determinadas (cf. Boltanski, 1981; Bourdieu, 2002; Bourdieu \& Wacquant, 1998; Dezalay, 1993; Dezalay \& Garth 1998, 2002, 2006; Lebaron, 1998). Isso posto, é certo que a universidade, em contextos nacionais diversos, constitui um lugar privilegiado para acompanhar tanto a intensificação do processo de internacionalização das classes dominantes, as assim chamadas elites ${ }^{81}$ (cf. Charle, 2006; Garcia, 1993, 1998; Loureiro, 1998; Vasconcellos, 1998), quanto o efeito dessa internacionalização sobre a transformação das instituições centrais do Estado, pela difusão de saberes especializados e de concepções de mundo por eles legitimadas (cf. Charle, 1994; Drahos \& Braithwaite, 2004; Gingras, 2002, 2003; Milot, 2003). Reconhecendo isso, é possível afirmar que a universidade latino-americana constitui um objeto ainda mais estratégico para descrever e analisar o impacto da circulação internacional de conhecimentos e grupos sociais sobre a constituição de redes

\footnotetext{
${ }^{81}$ Para uma discussão sobre a recente expansão da sociologia das elites ver o artigo de Shamus Rahman Khan The sociology of elites (cf. Kahn, 2012) e o número especial da Revista Tomo dedicado à Sociologia do poder e das elites (Seidl, 2008).
} 
internacionalizadas de controle e de dominação que passam, justamente, pelos processos de exportação e importação de saberes e técnicas especializados. Isso porque, como se sabe, a história da América Latina é marcada, desde muito cedo, por "sucessivas importações de técnicas econômicas 'modernas' direta e explicitamente introduzidas a partir do modelo estadunidense" (Lebaron, 1998, p. 105). Para justificar a pertinência dessa pretensão, é preciso analisar a literatura internacional recente sobre a transformação do ensino superior a partir da expansão do discurso e da prática da gestão sob um novo foco, qual seja, o dos estudos brasileiros e latino-americanos sobre a reforma educacional iniciada na década de 1950, essencialmente marcada por um processo de importação e legitimação do conhecimento gerencial no Brasil.

\subsection{A perspectiva estrutural da circulação internacional de saberes: a inflexão gerencial das universidades vista da perspectiva latino-americana}

Na literatura contemporânea sobre a mudança universitária, são muitos os trabalhos que enfatizam o impacto do conhecimento em gestão sobre a reorganização interna das instituições acadêmicas e dos seus procedimentos de decisão, controle e organização do trabalho (cf. Charle \& Soulié, 2007; Gall \& Soulié, 2007; Gornitzka, Svein \& Larsen, 1998; Gornitzka \& Larsen, 2004; Krücken, Blümel \& Kloke, 2013; Lorenz, 2007; Musselin, 2005, 2006, 2007; Rhoades \& Leslie, 1995; Rhoades \& Slaughter, 2004; Rhoades \& Sporn, 2002; Slaugther \& Leslie, 1997). Em todas essas análises, predominantemente europeias e norte-americanas, existem pelo menos dois consensos claros sobre a recente transformação do ensino superior: primeiro, a emergência do conhecimento em gestão impactou de modo decisivo o funcionamento institucional das universidades e, segundo, esse processo se inicia sobretudo a partir dos anos 1980, com a crise do Estado de bem-estar social e a emergência das políticas neoliberais da nova gestão pública que reconfiguraram o funcionamento dos serviços estatais, incluindo, 
portanto, a educação. A aceitação desse marco temporal parece ser unânime, inclusive, para quem analisa, a partir desses países "centrais", a expansão do conhecimento gerencial em termos mais amplos. Nesse sentido, Kerstin Sahlin-Anderson e Lars Engwall, ao descreverem a difusão da gestão para países e setores sociais diversos, localizam o início desse processo nos anos 1980, enfatizando o papel da proliferação de diferentes suportes na transmissão desse conhecimento. Segundo eles:

\begin{abstract}
Os anos 1980 e 1990 assistiram à dramática expansão e o rápido fluxo do conhecimento gerencial entre continentes e setores sociais. Como parte desse desenvolvimento, uma ampla gama de provedores e promotores do conhecimento em gestão emergiu e cresceu. Os programas de educação gerencial estão prosperando em todo o mundo [...]. As consultorias em gestão e as firmas de aconselhamento empresarial formaram-se, expandiram-se e os seus modelos foram aplicados para muitas novas áreas [...]. Publicações em gestão de vários tipos - incluindo a imprensa científica, popular e de negócios - proliferaram, assim como as pesquisas e os textos sobre gestão [...]. De modo mais geral, os "gurus" e os pesquisadores em gestão desempenharam um papel importante na divulgação e circulação dos conceitos e receitas da gestão (Sahlin-Anderson \& Engwall, 2002, p. 3).
\end{abstract}

Embora seja evidente que a expansão do conhecimento gerencial, na sociedade em geral e na universidade em particular, ganhou impulso com a difusão das políticas de reforma do Estado durante as décadas de 1980 e 1990, é importante notar que, da perspectiva de quem analisa essas mudanças a partir da América Latina, o processo parece ser um pouco distinto. Como demonstram as análises recentes de Yves Dezalay e Bryant Garth (cf. 1998, 2002 e 2006), os países latino-americanos passaram a funcionar, a partir dos anos 1950, como um "terreno de experimentação" de diferentes saberes ligados ao Estado, em especial daqueles associados a uma visão neoclássica do desenvolvimento econômico, dentre os quais se destaca o conhecimento em gestão ${ }^{82}$. A constituição desse "mercado de exportação de expertises" foi

\footnotetext{
${ }^{82}$ A ênfase no fortalecimento da gestão como conhecimento e como instrumento está diretamente associada à transição de uma perspectiva estrutural do desenvolvimento econômico, que pressupõe a ação do Estado, para uma perspectiva neoclássica ou neoliberal, que prescreve a limitação da interferência estatal. Dito de outro modo, na passagem de uma visão econômica que priorizava a ação política como forma de superação dos limites estruturais ao desenvolvimento econômico para outra que enfatiza a redução da ação política para criar situações de livreconcorrência, a gestão emerge como o principal mecanismo de desenho institucional e redefinição de práticas tendo em vista a aquisição de ganhos locais de eficiência e produtividade. Para uma análise muito interessante da disputa entre o polo estruturalista e o polo neoclássico na definição de estratégias de desenvolvimento no Brasil ver o artigo de Afrânio Garcia intitulado La construction interrompue: Celso Furtado, la guerre froide et le développement du Nordeste (1998). Para uma análise do fortalecimento das estratégias de gestão associado à
} 
resultado direto, segundo esses autores, das estratégias de hegemonia norte-americana durante a Guerra Fria, associadas às disputas acadêmicas que se tratavam no interior dos Estados Unidos e aos embates que opunham, no cenário político dos países latino-americanos, frações das suas elites nacionais, cada vez mais internacionalizadas (cf. Dezalay \& Garth, 2002, p. 24ss; 2006, p. 309ss). Dessa perspectiva, se nas estratégias de internacionalização dos importadores e exportadores de conhecimento especializado reside a chave para a compreensão da reconfiguração dos saberes de Estado, é apenas na medida em que elas se submetem à estrutura social dos contextos nacionais em que são geradas, o que pressupõe associar, como foi dito, a abordagem construtivista sobre o papel do conhecimento especializado na produção social da realidade à leitura estrutural que enfatiza o peso das posições sociais sobre as possibilidades dessa ação "produtiva":

Se nós insistimos sobre as estratégias de internacionalização é porque elas revelam os campos nacionais de poder nos quais se enraízam. Não podemos nos interessar pelos importadores e pelos exportadores sem examinar como suas estratégias são moldadas e determinadas pelas suas posições no interior dos seus campos nacionais respectivos (Dezalay \& Garth, 2002, p. 34).

Partindo desse referencial geral, é possível afirmar, em síntese, que tanto a expansão do conhecimento gerencial no Brasil quanto as transformações geradas pela sua aplicação às universidades públicas nacionais não são meros transplantes de mudanças que aconteceram antes na Europa e nos Estados Unidos, tampouco o resultado de uma conversão súbita às receitas neoliberais difundidas nos anos 1980 e menos ainda o efeito automático de transformações ocorridas na esfera estritamente econômica no mesmo período. Na verdade, a afirmação da gestão enquanto conhecimento e enquanto mecanismo de intervenção social seria produto de um longo e trabalhoso processo de imposição cultural baseado na importação, legitimação e experimentação de conhecimentos especializados, especialmente materializados

afirmação da perspectiva neoliberal de desenvolvimento ver a tese de Tatiana Maranhão chamada Governança mundial e pobreza: do Consenso de Washington ao consenso das oportunidades (2009) e de Márcia Cunha, Do planejamento à ação focalizada: IPEA e a construção de uma abordagem de tipo econômico da pobreza (2012), ambas defendidas no Departamento de Sociologia da USP nos anos 2000. 
em dispositivos técnicos de natureza diversa. Essas novas expertises, ao mesmo tempo que contribuiriam para a afirmação de uma hegemonia norte-americana na América Latina, fortaleceriam setores específicos da elite nacional que, através da sua posição privilegiada na estrutura social local e das estratégicas de internacionalização mobilizadas a partir dela, puderam afirmar seus projetos políticos, incluindo aqueles destinados à reforma do ensino superior (cf. Almeida, 2008; Dezalay \& Garth, 2002, 2006; Garcia, 1998; Loureiro, 1998; Vasconcellos, 1998).

Essas hipóteses gerais encontram respaldo na literatura nacional sobre a emergência de concepções e práticas de gestão nas instituições educacionais latino-americanas, em geral, e brasileiras, em particular. Assim, embora uma parte desses trabalhos assuma a perspectiva europeia predominante e atribua tais mudanças à importação de políticas neoliberais e às inflexões de natureza econômica ocorridas a partir dos anos 1980 (cf. Martins, 2008; Michels, 2006; Oliveira, 2008; Oliveira e Adrião, 2002), a grande maioria dos autores reconhece que, na América Latina, tal processo - mesmo reforçado pela crise do Estado de bem-estar social e pela expansão do neoliberalismo dela decorrente - começa, na verdade, algumas décadas antes, com a importação de uma concepção econômica da educação e a consequente mobilização de modelos de organização e administração acadêmica por ela inspirados.

Nesse sentido, ao estudar a reforma e a diversificação institucional do ensino superior brasileiro, Maria das Graças Ribeiro reconhece a profunda semelhança entre as recomendações dos organismos internacionais nos anos 1990 e aquelas presentes nos relatórios de Rudolph Atcon e de outros consultores norte-americanos ligados à United States Agency for International Development (Usaid) e outras agências internacionais que começam a atuar no país a partir dos anos 1950 (cf. Ribeiro, 2002). Na mesma direção, Maria de Fátima de Paula, na análise da "modernização universitária" da USP e da UFRJ, localiza a gênese das políticas de "racionalização" e "burocratização" das universidades no trabalho das "equipes 
especializadas em administração" que impuseram a essas instituições uma racionalidade burocrático-planificadora a partir do final dos anos 1960 (Paula, 2000, p. 190). De modo semelhante, o analista da Unesco, Juan Casassus, tratando da reforma educacional da América Latina dos anos 1990, com sua ênfase em "gestão e qualidade", reconhece que essas mudanças formam, na verdade, um "segundo ciclo de reformas educativas na região", sendo o primeiro constituído pelas medidas implementadas a partir dos anos 1960 em diversos países latinoamericanos (cf. Casassus, 2001). Conclusão parecida subsidia o trabalho de Jorge Fernando Hermida sobre o Plano Nacional de Educação aprovado pelo Congresso Nacional em 2001. Mesmo afirmando que o projeto educacional posto em prática no Brasil durante os anos 1990 buscava "adequar o Estado às significativas mudanças que ocorriam no mundo capitalista" (Hermida, 2006, p. 241), o autor não deixa de enfatizar que suas origens encontram-se na importação de políticas educacionais de verve norte-americana durante os anos 1960:

\begin{abstract}
Na época da elaboração do Plano Decenal de Educação Para Todos (durante o governo Itamar Franco), já era possível identificar iniciativas no sentido de redefinir prioridades educacionais a partir dos objetivos e diretrizes estabelecidas e apontadas pelos principais organismos internacionais: a Organização das Nações Unidas para a Educação, a Ciência e a Cultura (Unesco), o Fundo das Nações Unidas para a Infância (Unicef), o Banco Mundial e o Fundo Monetário Internacional (FMI). As iniciativas educacionais apresentavam uma natureza neoliberal - que se localiza nas fontes e nas finalidades que inspiraram a proposta - constituídas de teorias externas que procuravam contribuir para a construção de um projeto histórico defensor de interesses das agências financiadoras articuladas ao capital internacional. A problemática das fontes externas e de intelectuais estrangeiros orientando processos de elaboração de documentos para a educação não era nova, pois ela se manifestava também em outros países da América Latina. Basicamente eram inspirados em expressões encontradas, nas últimas décadas, na "Aliança para o Progresso", nas incursões da United States Development Agency (Usaid), nos projetos da UNESCO/CEPAL/PNUD e nas diretrizes do Banco Mundial, cujas palavras de ordem eram qualidade, produtividade e equidade (Hermida, 2006, p. 243-4).
\end{abstract}

De modo ainda mais enfático, uma série de trabalhos brasileiros produzidos recentemente tem procurado mostrar, na esteira das contribuições de Dezalay e Garth (cf. 1998, 2002 e 2006) e de outras análises críticas da globalização (cf. Boltanski, 1981; Bourdieu, 2002; Bourdieu \& Wacquant, 1998; Dezalay, 1993; Dezalay \& Garth 1998, 2002, 2006; Lebaron, 1998), o papel desempenhado pelos organismos e agências internacionais, sempre em parceria 
com atores nacionais, na redefinição da educação brasileira a partir do fim da Segunda Guerra Mundial.

Nesse sentido, na sua tese de doutorado defendida na Faculdade de Educação da Unicamp em 1998, Francis Mary Nogueira enfatiza que a influência de matrizes estrangeiras na definição de políticas educacionais constitui um padrão no Brasil desde os anos 1950, quando se consolidam estratégias de financiamento externo a projetos educacionais. Isso porque, segundo a autora, "dos anos 50 aos anos 90, as transações econômico-financeiras se articulam com as definições de políticas educativas emanadas e negociadas pelos acordos e empréstimos concedidos ao governo brasileiro pela Usaid e pelo BIRD” (Nogueira, 1998, p. 22). Na mesma direção, a socióloga Ana Maria Almeida, também da Faculdade de Educação da Unicamp, mostra como o processo de imposição de uma visão econômica da educação, que legitimou os economistas enquanto produtores de políticas públicas na área, tem suas origens na associação entre grupos profissionais locais e organismos internacionais, especialmente norte-americanos, no contexto da Guerra Fria (cf. 2008, p. 165ss). Pelo mesmo caminho segue Maria Sylvia Bueno que, na sua análise sobre o papel do Banco Mundial na imposição de modelos de gestão educativa na América Latina nos anos 1990, reconhece que "a falta de resistência e a permeabilidade às recomendações internacionais" na região se explica por uma “complexa trama de elementos sócio-históricos e culturais", na qual "as políticas de importação de modelos de planejamento, avaliação, administração e supervisão", sobretudo a partir de 1970, desempenharam um papel central (Bueno, 2004, p. 448). Esse argumento reaparece na tese de doutorado de Hivy Damasio Araújo Mello (2012), defendida também na Unicamp, sobre as políticas educacionais do Banco Mundial. Apesar de afirmar que a ação do Banco no campo educacional se fortalece a partir dos anos 1990, a autora parte dos trabalhos de Dezalay e Garth para reconhecer a importância dos arranjos internacionais do pós-guerra no fortalecimento de organismos como o BIRD e a Usaid - hoje conhecidos como Banco Mundial - na promoção 
de "políticas, ideias e práticas transnacionais" (2012, p. 27) que permitiram "a consagração e a legitimação de um determinado olhar econômico sobre a educação" (2012, p. 29). O historiador Rodrigo de Sá Motta, em trabalho lançado este ano sobre a transformação das universidades durante o regime militar, também enfatiza o papel das agências norte-americanas no fortalecimento de grupos locais engajados na "modernização" do ensino superior (cf. 2014). Em consonância com essa produção mais recente, quase todos os trabalhos que se voltaram para a reconstrução do processo de reforma do ensino superior brasileiro nos anos 1960, que fortaleceram métodos e técnicas de gestão, reconhecem a influência dos organismos internacionais, particularmente norte-americanos, na difusão de saberes e práticas que orientaram a transformação das universidades brasileiras (cf. Cardoso, 2001; Chauí, 2001; Cunha, 2007c; Fávero, 1991 e 2006; Fernandes, 1975 e 1984; Souza, 1981).

Passando por cima das suas diferenças internas ${ }^{83}$ e considerando esses trabalhos em conjunto, é possível concluir que tanto a difusão de uma concepção econômica da educação quanto, em termos mais específicos, a imposição de ferramentas, métodos e práticas de gestão nas instituições educacionais constituem um processo histórico longo, cujas raízes remontam às estratégias de importação de conhecimentos especializados a partir do final da Segunda Guerra Mundial, se aprofundam com a disputa pela reforma universitária dos anos 1960,

\footnotetext{
${ }^{83}$ Entre esses diversos trabalhos, é possível apontar uma série de diferenças. Da perspectiva que interessa à presente pesquisa, importa notar duas. A primeira e mais importante refere-se à ênfase dada ao papel da ditadura militar no processo de transformação da educação brasileira. Nos trabalhos produzidos no período ditatorial ou logo após a redemocratização, existe um forte consenso de que as reformas educacionais dos anos 1960, especialmente as do ensino superior, foram obra direta dos militares. No entanto, à medida que se consolida um certo afastamento temporal, essa ênfase vai se diluindo e no lugar da ação militar vai ganhando relevo o papel das elites civis que transitam de um regime político para o outro. Essa inflexão foi evidenciada recentemente por Luiz Antônio Cunha que, ao relançar o seu estudo histórico A universidade reformanda: o golpe de 1964 e a modernização do ensino superior (cf. 2007c), incluiu um novo prefácio para explicitar o quão errônea é a ideia de que a Lei da Reforma Universitária de 1968 expressou um projeto dos militares (2007c, p. 9). Segundo ele, fica cada vez mais evidente que praticamente todas as medidas implementadas em 1968 já "vinham sendo gestadas no interior das instituições de ensino, particularmente nas universidades públicas" desde o final dos anos 1950 (2007c, p. 10). Outra diferença que merece ser ressaltada é de ordem disciplinar: enquanto nos trabalhos da área de educação, a ênfase recai sobre os efeitos pedagógicos e institucionais das mudanças produzidas pela emergência de concepções gerenciais de educação (cf. Casassus, 2001; Hermida, 2006; Paula, 2000; Ribeiro, 2002), as análises realizados no âmbito da sociologia ressaltam os efeitos dessas mudanças também em termos da reprodução e do fortalecimento das estruturas sociais mais amplas de dominação (cf. Almeida, 2008; Mello, 2012; Nogueira, 1998).
} 
culminando nas reformas educacionais promovidas ao longo dos anos 1980 e 1990. No entanto, é possível reconhecer, no âmbito dessa literatura, uma espécie de paradoxo: enquanto os trabalhos que oferecem uma análise mais detalhada dos arranjos nacionais e internacionais que viabilizaram a importação de políticas educacionais tomam como objeto preferencial o processo de imposição de uma visão econômica da educação (cf. Almeida, 2008; Mello, 2012; Nogueira, 1998), aqueles estudos que se dedicam à expansão de um conhecimento gerencial propriamente dito no campo educacional não apresentam, em geral, uma análise mais detida do processo social de imposição desses saberes e práticas (cf. Bueno, 2004; Casassus, 2001; Ribeiro, 2002; Paula, 2000).

Para que essa observação se torne mais clara, é preciso notar que a expansão do conhecimento gerencial está diretamente associada à difusão de uma concepção econômica da educação - entendida no seu duplo sentido, de uma perspectiva que atribui à educação, enquanto investimento em capital humano, um lugar central na promoção da produtividade e do crescimento econômico e, por outro lado, de uma visão que pensa a própria educação em termos econômicos, sujeitando-a a cálculos econométricos de investimento e retorno (ou inputs/output $)^{84}$ que orientam a ação de indivíduos e instituições à luz das pretensas taxas de produtividade e rentabilidade da educação. Embora irmanado a essa visão econômica da educação, o conhecimento gerencial não se confunde diretamente com ela. Primeiramente, porque se trata de um saber voltado especificamente à organização do exercício do poder no interior das instituições educacionais. Além disso, porque funciona como uma expertise que, pelo seu conteúdo fluido e pouco sistematizado, difunde-se rapidamente para diferentes espaços sociais diferenciando-se, assim, dos conhecimentos propriamente econômicos, inspirados no privilégio profissional. Por fim, porque sua difusão se baseia antes em dispositivos técnico-

\footnotetext{
${ }^{84}$ Em trabalho anterior, desenvolvi uma análise sobre a transformação da ciência em problema econômico e da consequente emergência de dispositivos de gestão da ciência baseado nas categorias de input/ouput ou investimento/retorno (cf. Carlotto, 2013, p.74ss).
} 
materiais tais como ferramentas estatísticas, software de gestão e modelos organizacionais do que em conceitos estruturados sobre o que é a educação.

Nesse sentido, a proposta de Ana Maria Almeida (cf. 2008) de analisar a difusão de uma visão econômica da educação enquanto expressão de "uma luta mais abrangente que envolve dois grupos profissionais, o dos bacharéis-educadores e o dos economistas, em disputa pelo reconhecimento de suas competências técnicas como as mais apropriadas às questões de governo, incluídas aí as relacionadas com a educação" (2008, p. 164; grifo meu), embora descreva de modo preciso a afirmação dos economistas no plano das políticas educacionais, não constitui um modelo exato para explicar o processo de expansão do conhecimento gerencial, especialmente no âmbito das instituições de ensino e pesquisa. Como a própria autora demonstra, no caso da economia, a lógica de afirmação desse tipo de conhecimento pressupôs a construção de monopólios cognitivos e profissionais, em que "a competência estatística e econométrica" funcionou como uma barreira à participação de "bacharéis-educadores" no desenho de políticas educacionais, pautadas cada vez mais por formas complexas de planificação educacional (cf. Almeida, 2008, p. 168). O conhecimento gerencial, por outro lado, opera de modo inverso. O que possibilitou a sua expansão no interior das instituições brasileiras de ensino e pesquisa não foi a afirmação de um novo grupo profissional portador de saberes herméticos e técnicas complexas de intervenção mas, ao contrário, o processo de incorporação desse novo conhecimento, marcado justamente pela "plasticidade de suas formas e polissemia dos seus conteúdos" (Robert, 2007, p.8), em ferramentas, procedimentos e técnicas mobilizados pelo mesmo grupo de profissionais que, historicamente, governa a universidade: os professores que, por sua posição privilegiada na carreira docente e na estrutura interna da universidade, conseguiram acumular poder institucional.

Para entender como se desenrolou esse processo de difusão do saber gerencial no interior da universidade brasileira em geral e da USP em particular é preciso reconstruir, antes, 
a história da importação e legitimação de um conhecimento gerencial no Brasil elucidando qual foi o seu papel no desenho das propostas de reforma universitária ao longo dos anos 1960. Essa história revela, portanto, como a gestão enquanto um conhecimento e um mecanismo de intervenção social - ou, se quisermos, como um sistema de classificação e um dispositivo de saber-poder - expandiu-se no país através de uma rede de suportes materiais construídos sob os limites impostos pela estrutura social local, contribuindo em grande medida para fortalecêla.

\subsection{Importação e expansão do conhecimento gerencial no Brasil: a consolidação de um novo saber e seus efeitos culturais e políticos}

Historicamente, a questão da organização racional do trabalho surgiu no Brasil ainda na primeira metade do século XIX, quando se implementavam as unidades fabris inaugurais do país (cf. Pena, 1985). No entanto, o cerne da preocupação para os primeiros industriais nacionais era mais de natureza político-social do que propriamente gerencial, associando-se, antes de tudo, ao temor de "explosões e revoltas", tendo em vista a "reunião de um grande número de pessoas pobres e compelidas ao trabalho" (Pena, 1985, p. 23). Consequentemente, a "gestão", no contexto dessa economia escravocrata em que as relações trabalhistas eram baseadas na violência e na superexploração, passava mais pela imposição de mecanismos de controle e organização da vida privada do trabalhador do que por intervenções diretas no seu contexto de trabalho. A prioridade dada ao bom comportamento e à docilidade dos operários em detrimento da sua produtividade, bem como a mobilização de técnicas de dominação pessoal que visavam prolongar relações de dependência como o sistema de parcerias, que reinstalava o regime de servidão, e a disseminação de vilas operárias, que possibilitava o controle de todos os aspectos da vida do trabalhador, são expressões dessa primeira configuração das técnicas de controle e organização do trabalho no país (cf. Pena, 1985, p. 23). 
A descrição desse padrão inicial permite perceber com clareza o significado da mudança gerada, a partir do fim da escravidão e da expansão do trabalho urbano-industrial, pela importação dos princípios da gestão científica, voltados diretamente para a organização do trabalho no seu contexto de realização, tendo em vista o aumento de produtividade e não somente os esforços de contenção político-social ${ }^{85}$. Esse movimento é, portanto, inerente à mudança das práticas de controle do trabalho que passam a se tornar cada vez mais sistematizadas, dando origem a um conhecimento específico, o management ou, em português, a gestão. No entanto, a própria ideia de que esse conhecimento foi importado e exportado entre diversos países descarta a ideia de que ele é uma consequência natural do processo de desenvolvimento capitalista. $\mathrm{Na}$ verdade, uma parte importante da literatura, nacional e internacional, tem procurado analisar o chamado "movimento doutrinário do management" (cf. Ferreira, 2008, p. 60) que busca descrever, em suma, os diversos processos sociais ligados à imposição das categorias da gestão, pensada como um sistema de classificação.

Em um primeiro momento, os princípios da gestão entraram no país sob a forma de uma ideologia difusa, cujo primeiro espaço de divulgação foi o Centro Industrial do Brasil, fundado em 1904 (cf. Pena, 1985). Depois disso, a criação da Organização Internacional do Trabalho (OIT), logo depois do fim da Primeira Guerra Mundial, fez com que os processos de racionalização e organização do trabalho ganhassem um novo impulso para além da expansão do taylorismo e fordismo (cf. Oliveira, 1990). Segundo sua descrição oficial, a OIT "foi fundada em 1919 sob a égide do Tratado de Versalhes [...] e se inscreve no âmbito de uma reflexão segundo a qual uma paz universal e durável só pode ser fundada sob a base da justiça social” (OIT, 2013, n.p.). Ainda em 1919, acontece em Washington a primeira Conferência Internacional do Trabalho que instala o Bureau Internacional du Travail, responsável pelo secretariado permanente da Organização. Com ele, difundem-se as regulamentações

\footnotetext{
85 "E não somente" porque as tentativas de contenção política e social dos trabalhadores não está fora do horizonte das modernas teorias da gestão.
} 
internacionais do trabalho e as comissões de experts responsáveis pela "implementação do sistema de controle e aplicação de normas da OIT" e "pelos programas de cooperação técnica com os países em desenvolvimento" (cf. OIT, 2013, n.p.).

A emergência de uma instância internacional voltada à regulamentação das relações de trabalho teve impactos diretos no Brasil, fortalecendo iniciativas promovidas por agentes locais para a promoção do incipiente conhecimento gerencial e de formas mais gerais de racionalização do trabalho. Assim, sob influência direta da OIT e tomando como modelo a Taylor Society norte-americana ${ }^{86}$, foi fundado no Brasil, em 1931, o Instituto de Organização Racional do Trabalho (Idort) ${ }^{87}$, com apoio da Associação Comercial de São Paulo e tendo como seus principais articuladores o engenheiro e futuro fundador da USP, Armando Salles de Oliveira, e o também engenheiro e professor da Escola Politécnica, Roberto Mange (cf. Oliveira, 1990; Curado, 2001; Ferreira, 2008). O Idort, sob hegemonia dos engenheiros ${ }^{88}$, foi um dos principais centros de divulgação dos princípios da organização racional do trabalho no Brasil a partir da década de 1930. Para tanto, mantinha "uma programação regular de cursos voltados para a racionalização do trabalho, notadamente na área empresarial” (Oliveira, 1990, p. 42), cujo referencial teórico era praticamente todo importado, sendo constante a presença dos

\footnotetext{
${ }^{86}$ Com sede em Nova York, a Taylor Society constituía "uma sociedade internacional para a promoção da ciência e da arte da administração e da gestão" (cf. Taylor Society, 1920, p. 91). Os objetivos da sociedade eram "através da pesquisa, discussão, publicação e outros meios apropriados: 1. Assegurar a compreensão e o direcionamento inteligente dos princípios de governo do esforço organizado para a realização de objetivos industriais ou demais propósitos sociais para o benefício mútuo da comunidade, do trabalho, do gerente e do empregador; 2 . Garantir a eliminação gradual do esforço desnecessário e dos procedimentos demasiadamente morosos no trabalho no mundo; 3. Promover o estudo científico e o ensino dos princípios que governam o esforço organizado e dos mecanismos de sua aplicação e adaptação sob variadas e diferentes condições; 4. Promover o reconhecimento geral do fato de que a avaliação e aplicação desses princípios e mecanismos concernem mutuamente à comunidade, ao trabalho, à gestão e ao empregador; 5. Inspirar nos trabalhadores, gestores e empregadores uma adesão constante à alta concepção ética das suas responsabilidades sociais coletivas” (Taylor Society, 1920, p. 92).

${ }^{87} \mathrm{O}$ fundo de documentação do Idort, assim como o arquivo pessoal do engenheiro Roberto Mange, está disponível no Arquivo Edgard Leuenroth da Unicamp. Para maiores informações consultar: <http://www.unicamp.br/unicamp/acervos>.

${ }^{88}$ Como observam Maria Rita Loureiro (1997) e Afrânio Garcia (1998), antes da Fundação das primeiras faculdades de economia do Brasil, quem ocupava o lugar dos economistas de Estado eram diplomados em engenharia ou em direito. O mesmo acontecia com os primeiros "administradores", que eram, em geral, engenheiros formados que passaram a disputar espaço seja com os bacharéis de formação mais geral, seja com os engenheiros com formação mais técnica (cf. Grün, 1990).
} 
clássicos da gestão, como o norte-americano Frederick W. Taylor, responsável pela publicação do histórico volume The Principles of Scientific Management e, do francês Henri Fayol, autor do igualmente importante Administration Industrielle et Genéralle, publicado pela primeira vez em 1916 (cf. Oliveira, 1990; Curado, 2001).

No entanto, se a ideologia gerencial entrou no país ligada aos esforços de racionalização do trabalho industrial, foi por meio das tentativas de modernização do Estado que essa forma de conhecimento se difundiu de modo mais sistemático no país. Assim, a tentativa do governo Getúlio Vargas de construir um aparelho estatal moderno e apto a intervir nos domínios econômico e social pressupunha a emergência "de uma administração pública competente, capaz de implementar e conduzir as diretrizes de modernização econômica e desenvolvimento almejados" (Abrucio, Pedroti \& Pó, 2010, p. 35). Foi visando esse objetivo que "as metodologias administrativas enquanto técnicas para aplicação imediata foram sistematicamente importadas e utilizadas a partir da década de 1930" (Oliveira, 1990, p. 39), quando a organização e racionalização do trabalho "transformou-se num domínio prático e discursivo" submetido à intervenção direta do Estado (Pena, 1985, p. 29).

O marco essencial desse processo foi a criação do Departamento Administrativo do Serviço Público, o DASP, por meio de um decreto-lei assinado por Getúlio Vargas em 1938, em pleno Estado Novo. O idealizador e futuro diretor do DASP foi o também engenheiro Luiz Simões Lopes que, com o aval de Vargas, viajou aos Estados Unidos e à Europa para estudar modelos de administração, de onde retornou "imbuído da importância de uma administração pública moderna e eficaz" (cf. Vasconcellos, 1998, p.63). Como dentre os objetivos formais do DASP estava o fortalecimento da eficiência do Estado, a sua atuação caminhou no sentido de promover um conjunto de reformas, denominadas então "administrativas", em praticamente toda a estrutura estatal, com efeitos inclusive sobre as universidades públicas ${ }^{89}$. Mas a atuação

89 É importante notar que a reforma administrativa promovida pelo DASP levou à criação de unidades administrativas relativamente autônomas, como as fundações e autarquias (cf. Abrucio, Pedroti \& Pó, 2010, p. 39). 
do DASP não se limitou à promoção de reformas, incluindo também a difusão do conhecimento gerencial através da implantação dos primeiros cursos de treinamento "em administração", voltados para a qualificação de funcionários públicos, segundo um conjunto de princípios e práticas oriundos de outros países, especialmente dos Estados Unidos (cf. Fischer, 1984).

O passo decisivo da consolidação do ensino em gestão no Brasil, no entanto, foi a criação da Fundação Getúlio Vargas (FGV) em 1944. Idealizada por Luiz Simões Lopes, enquanto ocupava a direção do DASP, a FGV deveria dedicar-se à formação de um "novo profissional” voltado aos "problemas concretos da administração" (Vasconcellos, 1998, p. 63). Seu objetivo geral era estudar e difundir os princípios e métodos de organização racional do trabalho, conforme definido no seu decreto de fundação:

\begin{abstract}
O Presidente do Departamento Administrativo do Serviço Público fica autorizado a promover a criação de uma entidade que se proponha ao estudo e à divulgação dos princípios e métodos da organização racional do trabalho e ao preparo de pessoal qualificado para a administração pública e privada, mantendo núcleos de pesquisas, estabelecimentos de ensino e os serviços que forem necessários, com a participação dos órgãos autárquicos e paraestatais, dos Estados, Territórios, do Distrito Federal e dos Municípios, dos estabelecimentos de economia mista e das organizações privadas (Brasil, 1944, n.p.; grifo meu).
\end{abstract}

Enquanto uma instituição de ensino e pesquisa, a FGV foi essencial para a consolidação do saber administrativo-gerencial no país sobretudo porque constituiu uma porta de entrada dos convênios firmados, a partir do final da Segunda Guerra Mundial, tanto com a Organização das Nações Unidas (ONU) quanto com o governo dos Estados Unidos, “para a disseminação de saberes e modelos administrativos no país" (Barros \& Carrieri, 2013, p. 257). Assim, na esteira de um processo mais amplo de racionalização burocrática do Estado brasileiro, que caminhava no sentido de instituir a meritocracia e a universalidade como princípios do serviço público nacional, o conhecimento gerencial expandiu-se no Brasil como um corpo de saberes especializados importado diretamente de centros formuladores, concentrados na Europa e nos

Foi no bojo desse processo que a USP conseguiu a sua autonomia administrativa em 1944, por decisão de um órgão ligado ao Estado Novo, conforme relatado no capítulo anterior. 
Estados Unidos. De fato, como mostra Maurício Roque Oliveira (cf. 1990), a introdução do conhecimento administrativo no país foi, acima de tudo, um processo de importação de procedimentos e conceitos. Na mesma chave, para Isabela Curado, “o processo de evolução do saber administrativo brasileiro está intimamente relacionado à importação de modelos do Hemisfério Norte, principalmente de modelos norte-americanos" (Curado, 2001, p. 66). Amon Barros e Alexandre Carrieri vão além e falam em uma "americanização" do Brasil a partir da importação e difusão do conhecimento em gestão (cf. 2013). Para esses e outros autores (cf. Grün, 1990; Vasconcellos, 1998), a influência norte-americana no Brasil, através da importação de um saber especializado como o management, se intensificou a partir da Segunda Guerra Mundial, quando os Estados Unidos passaram a assumir uma política deliberada de aumento da sua influência na região, através de programas de cooperação técnica e educacional que atingiram especialmente as instituições de ensino superior.

É importante notar que os processos de importação de concepções e modelos educacionais para o ensino superior no Brasil não se iniciam com os programas de cooperação técnica com os Estados Unidos durante a Guerra Fria. Na verdade, desde a formação das primeiras faculdades profissionais do país, ainda no século XIX, é possível observar uma incorporação sistemática de estruturas e procedimentos institucionais predominantes na Europa e provenientes especialmente de Portugal, França e Alemanha ${ }^{90}$. A própria fundação da USP, em 1934, constitui, em grande medida, um processo de importação dos modelos universitários francês e alemão e de procedimentos acadêmicos predominantes nos países europeus, a partir da constituição de "missões estrangeiras" de professores de diferentes países da Europa (cf. Antunha, 1971; Cardoso, 1982; Paula, 2002). Até a primeira metade do século XX, era sobretudo na Europa que o Brasil espelhava o seu sistema de ensino superior. O papel dos

\footnotetext{
90 Assim, a Academia de Direito de São Paulo, fundada em 1827, foi integralmente inspirada no modelo de Coimbra (cf. Adorno, 1988). A Escola Politécnica, por sua vez, baseou-se no modelo francês da École Polytechnique e no alemão, da Technische Hochschule (cf. Nadai, 1981).
} 
Estados Unidos e das instituições norte-americanas era ainda pouco importante, limitando-se a acordos de cooperação bastante pontuais.

As primeiras formas de incentivo norte-americano ao ensino e à pesquisa no Brasil ocorreram por meio de agências internacionais de filantropia que atuavam no país desde a década de 1910 (cf. Marinho, 2001; Miceli, 1990). Enquanto ações de entidades não governamentais, esses incentivos prescindiam de acordos formais entre os governos dos dois países assumindo, antes, o caráter de negociações diretas entre membros das elites acadêmicas de São Paulo - ligados à Faculdade de Medicina e posteriormente à USP - e dos Estados Unidos - associados à Fundação Rockfeller. Nesse sentido, a atuação da Fundação Rockfeller na América Latina se inicia em 1915, com entendimentos informais entre representantes da recémcriada Faculdade de Medicina de São Paulo e da primeira comissão de especialistas da Rockfeller enviados à região com o objetivo de estabelecer acordos de cooperação em saúde pública e ensino médico (Marinho, 2001, p. 53ss). Com os primeiros contratos assinados em 1916, a cooperação se estendeu até pelo menos 1952 e resultou, no caso da USP, na criação do Instituto de Higiene de São Paulo, que deu origem à Faculdade de Saúde Pública; na construção da atual sede da Faculdade de Medicina e do Hospital das Clínicas; na fundação da Faculdade de Medicina de Ribeirão Preto; no desenvolvimento de pesquisas em genética e genética humana e; mais importante, na difusão de um padrão norte-americano de ensino e pesquisa expresso na valorização do trabalho experimental, na limitação do número total de alunos ingressantes no curso de formação médica e, principalmente, na universalização da dedicação exclusiva em tempo integral (cf. Marinho, 2001; Motta, 2014; Ferreira, 2013).

A partir da Segunda Guerra Mundial, no bojo de uma reconfiguração da cooperação internacional em termos globais, o padrão de colaboração entre Brasil e Estados Unidos se altera e, para além da atuação de agências filantrópicas no incentivo a áreas e padrões específicos de trabalho, os governos dos dois países se engajam diretamente em processos de 
importação e exportação de saberes e técnicas especializadas. É nesse contexto que surgem os primeiros acordos governamentais de cooperação técnica dos dois países, datados oficialmente de 1945 (cf. Fischer, 1984; Usaid, 1968; Barros \& Carrieri, 2013). Uma das principais consequências da mudança no processo de cooperação entre os dois Estados foi a criação, em 1948, da Comissão Mista Brasil-Estados Unidos, cujo objetivo essencial era traçar conjuntamente um plano de desenvolvimento econômico para o Brasil. Esse processo não se deu, porém, sem tensões, uma vez que a pressão dos Estados Unidos para que a economia brasileira se abrisse ao capital internacional, particularmente norte-americano, chocou-se com os esforços do Estado brasileiro na promoção da industrialização nacional (cf. Barros \& Carrieri, 2013, p. 259ss; Garcia, 1998).

Os anos que se seguiram à Segunda Guerra Mundial foram marcados por uma intensificação da ajuda norte-americana tanto aos países "subdesenvolvidos" quanto às nações “em reconstrução", ajuda cada vez mais pautada em programas de cooperação técnica (cf. Bourdieu \& Wacquant, 1998; Boltanski, 1981; Dezalay \& Garth, 2002; Garcia, 1998). Um marco explícito dessa ênfase crescente no papel dos conhecimentos especializados nas políticas de auxílio internacional é o chamado "Ponto IV", termo que designa uma mensagem enviada pelo presidente dos Estados Unidos, Harry Truman, ao Congresso norte-americano em 1949, explicitando as bases da nova política governamental de assistência aos chamados países subdesenvolvidos. Tratava-se, conforme documento do Departamento de Estado dos Estados Unidos, "de um empreendimento de longo prazo e relativo baixo custo [...] para levar experiência e know-how americanos diretamente para os outros povos de países subdesenvolvidos" (apud Nogueira, 1998, p.39) Foi no âmbito do Ponto IV que os Estados Unidos estabeleceram uma série de programas de cooperação técnica com países da América Latina que visavam, basicamente, aumentar a influência norte-americana na região via 
exportação de conhecimentos, procedimentos e técnicas especializados (cf. Barros \& Carrieri, 2013).

A partir dessa inflexão política, são firmados os principais acordos bilaterais entre o governo brasileiro e o norte-americano que possibilitaram justamente a expansão de acordos de cooperação técnica no ensino superior. Primeiro, em 1950, surge o Acordo Técnico de Cooperação Básica entre os Governos do Brasil e dos Estados Unidos, voltado ao “intercâmbio de conhecimentos técnicos e a cooperação em atividades correlatas" (Brasil, 1950, n.p.). Depois, em 1953, esse convênio é complementado pelo Acordo sobre Serviços Técnicos Especiais, pelos quais o governo norte-americano fica responsável por fornecer "serviços técnicos e especializados em qualquer setor de atividades que se relacione com o desenvolvimento econômico do Brasil” (Brasil, 1953, n.p.).

Uma das primeiras áreas contempladas por esses acordos bilaterais de cooperação técnica foi, justamente, o “ensino de gestão" (management education), chamado inicialmente no Brasil de "ensino de administração". E isso não só porque a internacionalização do conhecimento em gestão era uma medida explícita da política externa norte-americana, como apontam as análises que associam a expansão desse saber especializado às estratégias de construção de hegemonia dos Estados Unidos na Europa (cf. Boltanski, 1981) ${ }^{91}$ e, particularmente, na América Latina (cf. Alcadipani \& Bertero, 2012; Barros \& Carrieri, 2013; Cooke, 2004, 2010; Cooke; Kelley \& Mills, 2006; Vasconcellos, 1998). Mas sobretudo porque havia setores da elite política brasileira que consideravam a consolidação do conhecimento gerencial uma prioridade, como demonstram a experiência do IDORT, do DASP e especialmente da FGV.

\footnotetext{
${ }^{91}$ No seu artigo intitulado America, America, le plan Marschall et l'importation du management, Luc Boltanski mostra como a expansão do conhecimento gerencial na Europa também esteve ligada às estratégias da política externa norte-americana (cf. 1981). Essa questão reaparece no seu livro mais recente, escrito com Ève Chiapello intitulado O novo espirito do Capitalismo (cf. Boltanski \& Chiapèllo, 1999).
} 
Não é coincidência, portanto, que a FGV tenha sido a grande mediadora da importação do conhecimento gerencial no país, especialmente a partir de 1952, quando dá origem às duas primeiras escolas de administração do Brasil: a Escola Brasileira de Administração Pública (EBAP-FGV), com sede no Rio de Janeiro e fundada ainda em 1952, e a Escola de Administração de Empresas de São Paulo (EAESP-FGV), criada dois anos depois. Ambas foram resultado de "convênios com entidades norte-americanas que transferiram o know-how existente, incluindo currículos, ementas de disciplinas e respectivas bibliografias" (Oliveira, 1990, p. 40), o que permitiu que se constituíssem como modelo e como centro de treinamento para as demais escolas de administração pública e privada no país e na América Latina.

Analisando com um pouco mais de detalhe essa história, os registros indicam que as primeiras reuniões visando a criação de uma escola de administração pública no Brasil ocorreram em 1949 nos Estados Unidos reunindo representantes da FGV e professores norteamericanos sob coordenação da ONU (cf. Vasconcellos, 1998). Na verdade, por proposição da delegação norte-americana, a Assembleia Geral da ONU de 1948 estabeleceu como uma das prioridades da organização a promoção do ensino de administração, especialmente para países subdesenvolvidos, o que resultou na criação do United Nations Programme on Public Administration, Finance and Development (cf. Barros \& Carrieri, 2013, p. 264). As avaliações desse programa indicam que ele foi responsável pela fundação de dezenas de centros de pesquisa e treinamento em administração pública em diversos países do mundo entre o final da década de 1940 e começo da década de 1960, dentre os quais se inclui a EBAP-FGV. Embora a escola tenha se originado desse programa da ONU, contando com o apoio da Organização durante os seus primeiros anos de funcionamento ${ }^{92}$, ela também se beneficiou do apoio oficial do governo norte-americano, como consta no Report on Examination of Getulio Vargas

\footnotetext{
${ }^{92}$ Esse apoio se deu, sobretudo, sob a forma de travel grants, ou seja, financiamentos de viagem, seja para alunos brasileiros que quisessem estudar administração na Europa ou nos Estados Unidos seja para professores norteamericanos que se responsabilizassem por cursos no país.
} 
Foundation Construction da Usaid: "Até 1958, a FGV recebeu assistência técnica das Nações Unidas e, em 1959, o governo norte-americano começou a prover assistência técnica em

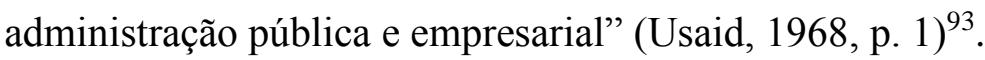

A Escola de Administração de Empresas de São Paulo (EAESP-FGV), por sua vez, foi criada já sob a vigência do Acordo sobre Serviços Técnicos Especiais (Brasil, 1953) e, portanto, beneficiou-se ainda mais diretamente das possibilidades de cooperação técnica governamental entre o Brasil e os Estados Unidos. O interesse do governo norte-americano era "criar uma escola de administração capaz de caminhar com as suas próprias pernas, porém adotando o modelo norte-americano", o que significava formar "profissionais que pensassem o desenvolvimento e a modernização com base em uma visão norte-americana" (Alcadipani \& Bertero, 2012, p. 296). Nesse sentido, a EAESP-FGV beneficiou-se de um convênio intermediado pelo governo norte-americano com a Universidade Estadual de Michigan pelo qual esta última ficaria responsável por fornecer à escola "toda a assistência técnica necessária até 1964" (Oliveira, 1990, p. 52). Isso significou tanto o envio de professores norte-americanos ao Brasil e de estudantes brasileiros aos Estados Unidos (cf. Oliveira, 1990, p. 51-52) quanto a colaboração direta da Universidade de Michigan na elaboração de programas, currículos, bibliografias e métodos pedagógicos utilizados pela FGV (cf. Vasconcellos, 1998, p. 64). O objetivo central era que a EAESP-FGV se tornasse um modelo para outras escolas de administração de empresas no Brasil e na América Latina (cf. Barros \& Carrieri, 2013; Alcadipani \& Bertero, 2012), o que implicou um alto volume de investimento, por parte dos

\footnotetext{
93 A USAID propriamente dita só foi criada em 1961, no âmbito da Aliança para o Progresso promovida pelo governo John Kennedy como forma de aumentar a influência norte-americana na América Latina, tornada área prioritária de intervenção a partir da Revolução Cubana de 1959. Antes da USAID, a agência responsável pela cooperação internacional na região era chamada ICA (Internacional Cooperation Administation) que se encarregava basicamente das políticas previstas no ponto IV (cf. Motta, 2014, p. 115).
} 
Estados Unidos, para que a FGV se tornasse o polo dominante dos estudos de administração do Brasil (cf. Usaid, 1968) ${ }^{94}$.

Mas a influência norte-americana na introdução sistemática do conhecimento gerencial no Brasil não se limitou à FGV. Na verdade, existem registros de ajuda técnica e financeira, por parte do governo norte-americano, a todos os cursos de administração fundados ou previstos até 1960, incluindo os das Universidades Federais de Pernambuco, Bahia, Minas Gerais e Rio Grande do Sul (cf. Barros \& Carrieri, 2013, p. 257). Além disso, sob a égide dos acordos de cooperação técnica firmados no começo da década de 1950, os governos do Brasil e dos Estados Unidos assinam, em 1959, “o programa de cooperação mais decisivo para o desenvolvimento das escolas brasileiras de administração", pelos quais o governo norte-americano se responsabilizaria por "fornecer os serviços dos professores norte-americanos para prestar assistência no que se refere à elaboração de currículos, métodos e técnicas de ensino, instalações de serviços de biblioteca e de consulta, bem como em pesquisas e outros aspectos da criação de cursos de treinamento em administração pública e de empresas” (Fischer, 1984, p. 112). Na prática, esse acordo resultou no estabelecimento de programas de formação de professores brasileiros de administração não só com a Universidade Estadual de Michigan, mas também com a Universidade Estadual da Califórnia. Os dois convênios foram intermediados pelo governo norte-americano, e elegiam a FGV como centro articulador da seleção de professores e difusão de programas e modelos (cf. Fischer, 1984; Oliveira, 1990; Usaid, 1968). A ajuda norte-americana ao ensino de administração em geral e à FGV em particular continuou ao longo

\footnotetext{
${ }^{94}$ No relatório da Usaid sobre a construção da FGV, consta que durante os primeiros cinco anos de funcionamento das duas escolas de administração da Fundação, a EBAP e a EAESP, foram concedidas 300 bolsas para que estudantes latino-americanos de outros países estudassem na escola (cf. Usaid, 1968, p. 4). O fato da FGV ter funcionado como um centro difusor do conhecimento gerencial no Brasil e na América Latina ajuda a explicar porque os Estados Unidos financiaram diretamente a construção dessas escolas, seja assumindo os custos das suas instalações físicas, seja garantindo o funcionamento dos cursos através da importação de professores, metodologias de ensino e materiais didáticos (cf. Usaid, 1968).
} 
dos anos 1960, via Usaid, por meio de um programa mais amplo da agência intitulado Improvement of Higher Education in Brazil (Usaid, 1968, p. 3).

Mas o apoio norte-americano ao desenvolvimento do conhecimento gerencial no Brasil não se limitou ao plano governamental. Como mostra o estudo de Sérgio Miceli, a partir da Revolução Cubana e no âmbito da Aliança para o Progresso, as relações acadêmicas entre instituições brasileiras e norte-americanas se intensificaram, sendo o marco decisivo desse processo, segundo o autor, "a decisão político-institucional tomada pelos dirigentes da Fundação Ford de se envolverem com o estudiosos, cientistas e centros de estudo e pesquisa da região" (1990, p. 17). Assim, a partir dos anos 1960, a Fundação passou a apoiar diretamente a criação de centros de excelência, encontros e associações acadêmicas, particularmente no âmbito das ciências sociais, sendo absolutamente decisiva no processo de expansão e institucionalização da área no país. E sobretudo porque a estabilidade do financiamento e a relativa autonomia em relação ao governo norte-americano, que eliminava as suspeitas de subordinação a mecanismos de cooptação, tornaram o financiamento da Fundação Ford uma espécie de "selo de qualidade", ou seja, uma:

[...] credencial indispensável para o ingresso no clube fechado das instituições legítimas, estendendo-se a vigência dessa chancela às demais iniciativas das lideranças, aos próprios projetos e aos resultados científicos das instituições brindadas com tal apoio externo" (Miceli, 1990, p. 19).

No começo dos anos 1960, quando a Fundação inaugura uma linha de ação na América Latina, a prioridade foi dada justamente à formação de economistas e administradores "que adiante serviram como as novas lideranças técnicas em condições de gerenciar os negócios públicos e as frentes abertas pelas doutrinas do planejamento" (Miceli, 1990, p. 23). Assim, quase todo o financiamento da Fundação, nesse primeiro momento, se dirigiu aos programas de graduação em economia e administração existentes, já que a prioridade dessa fase era dada “à formação de economistas nativos no exterior, de preferência em universidades norteamericanas, bem como à importação de professores visitantes também norte-americanos" 
(Miceli, 1990, p. 24). Ou seja, a política da Fundação Ford em sua frente de operações latinoamericana assumiu o desafio de equacionar a questão do desenvolvimento "em termos de crescimento econômico, avanço tecnológico e competência gerencial aperfeiçoada", incorporando as ciências sociais apenas na medida de sua "dimensão instrumental" (Miceli, 1990, p. 24)

Assim, mesmo que a prioridade de apoio da Fundação Ford tenha passado posteriormente ao apoio das ciências sociais "clássicas", sobretudo na sociologia, antropologia e ciência política, no começo dos anos 1960, a atuação da Fundação ia na mesma direção da atuação institucional do governo norte-americano, de financiamento da expansão do conhecimento gerencial no país, através do incentivo à fundação de centros de formação no país e ao treinamento de brasileiros no exterior.

Um dos principais efeitos da expansão do conhecimento gerencial no Brasil foi o fortalecimento da administração escolar como uma área específica de conhecimento, com cursos, associações e uma produção editorial própria. Ao reconstruir a produção nacional em administração escolar, Leonor Maria Tanuri destaca que, até o começo da década de 1960:

\begin{abstract}
Embora já se desenvolvesse farta literatura de origem norte-americana desde a década de cinquenta, no Brasil destacavam-se, além de ensaios, relatórios e trabalhos descritos de natureza normativa e legal, apenas o livro introdutório de Carneiro Leão (Faculdade Nacional de Filosofia) - Introdução à Administração Escolar (1939); as tentativas de análise do processo administrativo escolar a partir de Fayol, realizadas pioneiramente por José Querino Ribeiro (USP) em Fayolismo na administração das escolas públicas (1938) e em Ensaio de uma teoria de Administração Escolar (1952); o manual didático de Ruy de Ayres Bello, Princípios e normas de Administração Escolar (1956); além de trabalhos diversos de Anísio Teixeira sobre a organização, administração e política da educação, principalmente o livro que contempla sua experiência administrativa (1931-1935) como diretor-geral de Instrução Pública do Distrito Federal - Educação para a democracia (1936) (Tanuri, 2007, p. 9).
\end{abstract}

Diante da necessidade de desenvolver essa área ainda incipiente, alguns professores de Administração Escolar, liderados por José Querino Ribeiro ${ }^{95}$, da USP, convocaram uma reunião

\footnotetext{
${ }^{95}$ José Querino Ribeiro era, como visto no capítulo anterior, o primeiro assistente da cátedra de Filosofia e História da Educação da Seção de Pedagogia da FFCL-USP, tendo abandonado essa cadeira em 1948 para assumir, justamente, a cátedra de Administração Escolar e Educação Comparada da FFCL-USP. No seu lugar assumiu a cátedra de História e Filosofia da Educação, como visto, o filósofo Laerte Ramos de Carvalho.
} 
da área em São Paulo, em 1961, onde estiveram presentes nomes importantes da incipiente subdisciplina de administração escolar, a maioria deles ligada ao tema por razões práticas, como o próprio Anísio Teixeira, que ocupava posições de direção no sistema educacional. Dessa reunião surge a Associação Nacional de Professores de Administração Escolar, hoje denominada Associação Nacional de Política e Administração da Educação, ANPAE (cf. Tanuri, 2007, p. 9-10).

Em 1963, dois anos depois da fundação da ANPAE, surge a primeira edição de Organização e Administração Escolar, de Lourenço Filho - que foi um dos membros mais ativos do chamado Movimento de Renovação Pedagógica, que está na raiz da criação do Instituto de Educação e, posteriormente da USP, conforme analisado no capítulo anterior. O livro é um exemplo da forte influência da teoria gerencial norte-americana sobre professores e pedagogos que se aproximaram do campo da administração escolar em função de suas trajetórias institucionais e, através da importação de categorias específicas, ajudaram a constituir essa área como um campo de conhecimento novo, que passou a contar não só com um corpo teórico-conceitual próprio mas, também, e consequentemente, com programas de treinamento especializados que passam a ser pré-condição para o exercício de cargos administrativos ${ }^{96}$. Segundo Tanuri, no trabalho de Lourenço Filho:

[A] vasta, longa e variada experiência no âmbito da administração da educação foi certamente capitalizada a serviço de seus trabalhos acadêmicos, em especial de seu livro Organização e Administração Escolar, onde alia a experiência ao conhecimento atualizado da teoria administrativa já desenvolvida, sobretudo, nos Estados Unidos. Aliás, uma leitura atenta do livro e de suas referências bibliográficas deixa claro o domínio desses conhecimentos e a abrangência da revisão da literatura especializada, com a menção de grande número de autores relevantes da época (Lipham, Getzels, Campbell, Griffiths, Hanlon, Halpin, Sears, Simon, entre outros), alguns dos quais seriam traduzidos para o português bem mais tarde, como, por ex., J. B. Sears, $A$ natureza do processo administrativo, em 1971; H. Simon, O comportamento administrativo, em 1970; B. Bloom, Taxonomia dos objetivos educacionais, em 1972 (Tanuri, 2007, p. 10)

\footnotetext{
${ }^{96}$ É importante notar, dessa perspectiva, que em maio de 1969, o Conselho Federal de Educação fixou o currículo mínimo dos cursos de pedagogia, regulamentando a habilitação específica em "princípios e métodos de administração escolar" e "administração da escola de primeiro grau".
} 
O livro de Lourenço Filho é um divisor de águas na história da administração escolar não só pela riqueza do conteúdo mas também pela projeção que alcançou: o livro obteve sete edições entre 1963 e 1976, que alcançaram tiragens de 8.000 a 3.000 exemplares, consideradas bastante expressivas para a época (cf. Tanuri, 2007, p. 11). O impacto do livro de Lourenço Filho nos anos 1960 testemunha não só a influência da administração, hoje amplamente denominada gestão, sobre o campo da educação, como o início de um processo de "conversão" de educadores e dirigentes às categorias gerenciais o que expressa, sem dúvida, o impacto das políticas de expansão da gestão no país.

De fato, já em 1968, a Usaid avaliava o programa de incentivo ao ensino da gestão no país como "bem sucedido" (cf. Usaid, 1968, p. 1). O êxito da política norte-americana para a expansão do conhecimento gerencial dependeu diretamente da existência de setores das classes dominantes brasileiras dispostos a liderar essa política no contexto nacional, como estratégia de fortalecimento dos seus próprios projetos de reforma administrativa do Estado e de incentivo à formação de um novo tipo de "dirigente" através da cooperação com universidades norteamericanas. Como consequência mais direta dessa "afinidade eletiva" entre os interesses da política externa norte-americana, das instituições acadêmicas dos Estados Unidos e de setores da elite dirigente brasileira, a gestão alcançou um enorme desenvolvimento no país, sobretudo a partir dos anos 1960.

Segundo dados do MEC, o número de matrículas nos cursos de graduação em “administração e economia"97 passou de 8.838 em 1960 para 52.218 em 1971, um aumento de 40,83\% ao ano, acumulando um crescimento de quase $500 \%$ em uma década, uma taxa de expansão muito maior do que as verificadas em outras profissões tradicionais como medicina, engenharia e direito cujas matrículas aumentam, entre 1960 e 1971, em 200\%, 264\% e 230\%

\footnotetext{
97 Os dados referentes aos cursos de graduação em administração, exclusivamente, não estão disponíveis nos relatórios publicados pelo MEC (cf. 1972 e 1974). Para o período que vai de 1960 a 1974, os dados disponíveis referem a cursos de "economia e administração". Não encontrei dados sistematizados entre 1975 e 1990.
} 
respectivamente (cf. MEC, 1972). O crescimento do número de matrículas reflete um aumento igualmente significativo do número de cursos de administração em funcionamento no país. Segundo dados apresentados por Roberto Grün, se em 1954 havia apenas 2 escolas de administração no Brasil, em 1967 já se contavam 31 escolas e em 1979, 245 escolas, a grande maioria delas, já no setor privado (Cf. Grün, 1990, p. 7). Ainda segundo o autor, com base nos Censos Demográficos de 1950 e 1980, é possível afirmar que as ocupações administrativas cresceram, no período, a uma taxa anual de 5,4\%, quintuplicando em 30 anos ao ponto desse setor representar, em 1980, 21,1\% da População Economicamente Ativa do país (cf, Grün, 1990, p. 2).

Desde que Grün publicou sua tese sobre A revolução dos gerentes brasileiros, em 1990, o ensino de administração só cresceu até se tornar, em 2002, o curso de graduação com o maior número de matrículas no país, superando o de direito que, pela sua antiguidade e influência, pode ser considerada a formação profissional mais tradicional do país (cf. Adorno, 1988, Schwarcz, 1993, Venancio Filho, 2004). O crescimento do número de matrículas de graduação em "administração e gerenciamento" 98 nos últimos anos resulta de um crescimento igualmente significativo do número de cursos, conforme o gráfico abaixo.

\footnotetext{
98 Segundo dados do INEP, as matrículas em cursos de graduação em "administração e gerenciamento" - a categoria é do próprio instituto - teriam passado de 338.789 em 2000 para 874.076 em 2009. Ver: Censo da educação superior do INEP. Disponível em: < http://portal.inep.gov.br/web/censo-da-educacao-superior>. Acesso em 21 de abr. 2014.
} 


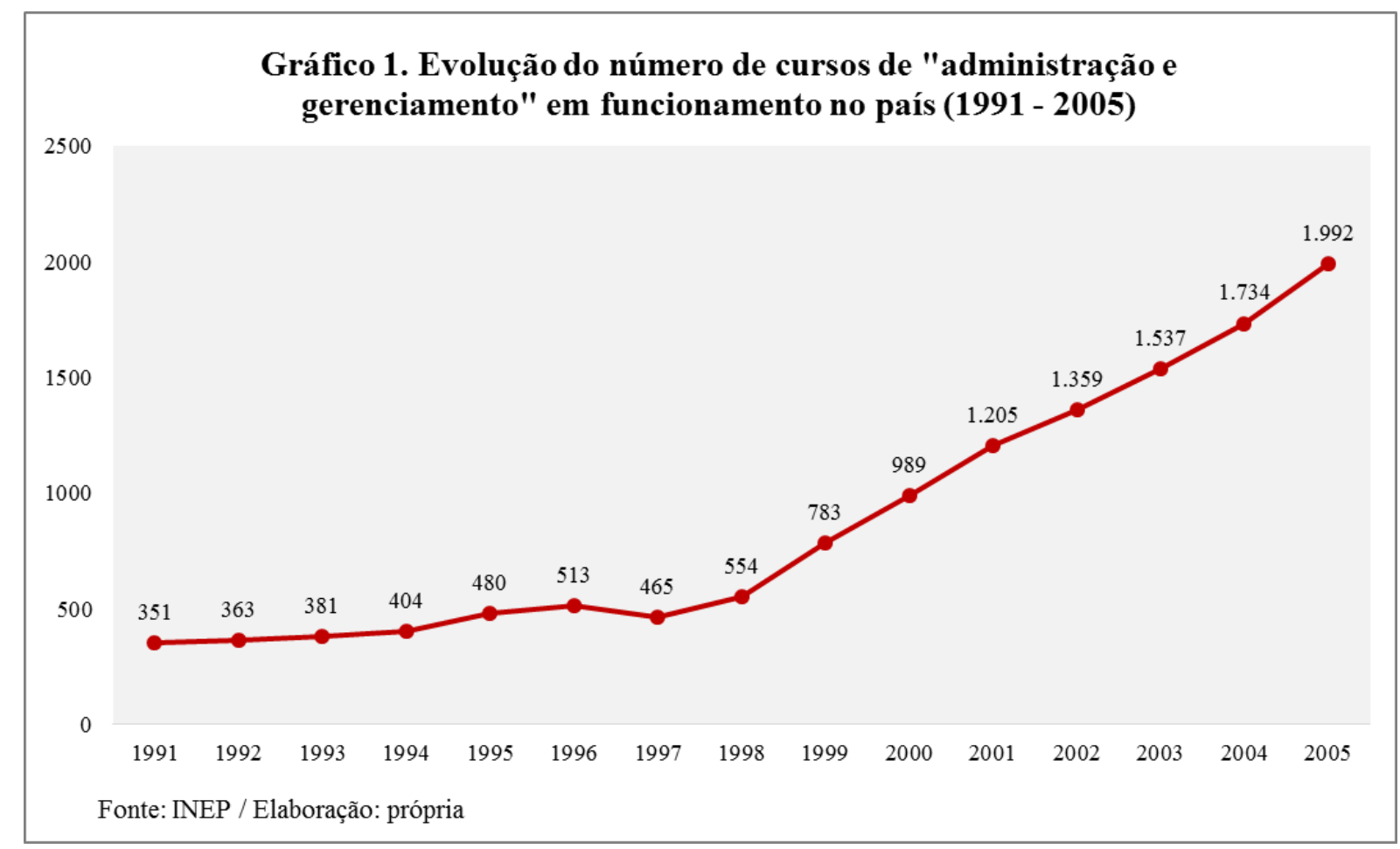

Atualmente, os cursos de "administração e gerenciamento" constituem a maior formação profissional de nível superior do país, com mais de um milhão de estudantes matriculados em 2012 $2^{99}$. Além disso, como apontam Márcio Pochmann et al., segundo o Censo do IBGE de 2000, a formação em "administração" era a principal graduação realizada pelos "empregadores brasileiros", categoria que reúne os donos de empresa do país constituindo, portanto, parte importante da sua elite dirigente, ao menos no plano econômico (cf. 2009, p. 87).

Nesse sentido, é importante notar que a expansão do conhecimento gerencial, assim como da visão econômica que lhe é inerente, faz parte de um processo social mais amplo de formação de uma nova elite burocrática, constituída por economistas e administradores, que construíram e legitimaram um novo saber de Estado que, no Brasil, foi se tornando aos poucos predominante. Esse predomínio conduziu esses profissionais a ocupar um lugar privilegiado

\footnotetext{
${ }^{99}$ Ver Censo da educação superior do INEP. Disponível em: < http://portal.inep.gov.br/web/censo-da-educacaosuperior>. Acesso em 21 de abr. 2014.
} 
nos espaços de poder antes hegemonizados pelo direito, pela engenharia e pela medicina social (cf. Motta, 1994, p. 82ss).

Esse processo não é exclusivo do Brasil. Pierre Bourdieu também identificou a expansão das formações em administração e gestão, simbolizadas pela criação da École Nationale de Administration (ENA), em 1945, como um dos principais movimentos que, sem chegar a alterar a estrutura essencial do campo de ensino superior francês, marcado pela oposição entre autonomia e heteronomia, ou entre um polo intelectual e um polo temporal, contribuiu para um reposicionamento das suas principais escolas (cf. Bourdieu, 1989, p. 225ss). Esse movimento, que levou os egressos da ENA a "assegurar um verdadeiro monopólio sobre as posições mais elevadas da alta função pública" (Bourdieu, 1989, p. 284), resultou, na França, da pressão dos detentores de poder econômico pela criação "de um ensino subordinado às suas exigências técnicas e sobretudo sociais, quer dizer, ético-políticas" (Bourdieu, 1989, p. 231). Consequentemente, o principal efeito desse reposicionamento forçado pela expansão de um novo saber de Estado sobre o ensino superior francês foi o "enfraquecimento da autonomia do campo universitário" que veio "acompanhado de um declínio dos valores que podemos denominar intelectuais", como o "desinteresse e a gratuidade", "em favor de um sucesso secular" (Bourdieu, 1989, p. 302). O enfraquecimento dos valores da autonomia, do desinteresse econômico e da gratuidade, inerentes às escolas ligadas ao polo intelectual - ou acadêmico-científico - da universidade, e o consequente fortalecimento dos valores da utilidade, do pragmatismo e do interesse econômico, inerente ao polo secular - ou profissional -, econômico e politicamente dominante, são processos de enormes consequências na medida em que fortalecem as relações de dominação, sobretudo de natureza econômica, que se afirmam e se ocultam através de relações propriamente acadêmicas:

Se os conflitos a propósito da educação assumem a forma de antinomias insuperáveis a respeito dos valores últimos é porque eles têm, como objeto de disputa, através do controle dos instrumentos de reprodução cultural e social, a reprodução dos fundamentos mesmos da dominação, a existência e os valores dos dominantes e a hierarquia dos princípios de dominação (Bourdieu, 1989, p. 233). 
Partindo das reflexões sobre o caso francês, é possível dizer que a expansão do ensino de gestão no Brasil nas últimas décadas é, portanto, a faceta mais visível de um processo mais amplo de importação e consolidação de um conhecimento gerencial em diferentes contextos institucionais, que vão desde as empresas multinacionais até os órgãos mais tradicionais do aparelho de Estado, como as universidades, alterando as bases profundas da sua organização interna, da sua ligação com o mundo externo e, principalmente, das relações de dominação no seu interior. A transformação do governo acadêmico das universidades de pesquisa do país a partir da influência desse novo dispositivo de saber-poder com seus instrumentos, métodos e técnicas de organização e controle, bem como do novo padrão de expansão do ensino superior, que resulta da visão econômica da educação que lhes é inerente, são as expressões mais marcantes desse processo. No entanto, o significado social mais profundo da imposição desse novo sistema de classificação que, instituindo novas maneiras de "fazer ver e de fazer crer" se volta sobre a própria educação para reorganizá-la internamente, só fica claro quando essa disputa é inserida no interior da estrutura social da universidade brasileira, uma das arenas privilegiadas desse embate.

\section{A disputa pela reforma universitária nos anos 1960 vista a partir da estrutura universitária}

\subsection{Gestão colegiada e autogoverno: a proposta de reforma universitária do polo acadêmico-científico da universidade}

A historiografia contemporânea sobre a instituição universitária reconhece que, desde a sua origem medieval, a universidade é uma instituição caracterizada essencialmente pela existência de formas colegiadas de ação e decisão, o que as transforma em uma experiência exemplar de autogoverno institucional (cf. Charle \& Verger, 1996; Gerbord, 2004; Le Goff, 1985; Rashdall, 1936; Rothblatt \& Wittrock, 1993; Rüegg, 2004). Mesmo a partir do século 
XIX, quando surgem os primeiros ministérios e órgãos governamentais voltados especificamente à organização da educação, subordinando as instituições educacionais à burocracia estatal (cf. Rüegg, 2004, p. 15ss), as universidades conseguiram manter, em geral com bastante sucesso, a sua autonomia institucional e os seus mecanismos de autogoverno. Nesse sentido, ao analisar as mudanças no financiamento e na gestão da universidade entre o século XIX e XX, Paul Gerbod conclui:

Fortes nas suas tradições medievais, definidas quando a universidade era uma comunidade de mestres e pupilos autogovernada sob a tutela, em geral teórica, do bispo local ou do papado, as universidades europeias foram bem sucedidas em preservar suas formas essenciais de gestão para além do século XVIII [...]. Na base desse sistema, estão os conselhos em que os membros da corporação elegem representantes e decidem todas as questões universitárias (2004, p. 118-119).

É justamente esse sistema quase milenar de autogoverno, baseado na autonomia e na decisão colegiada, que a expansão do saber gerencial, com seus processos de centralização e tecnicização, atinge. Para analisar a história da mobilização do conhecimento em gestão no campo do ensino superior brasileiro e dimensionar o seu impacto, é preciso considerar que, no final da década de 1950, enquanto o governo brasileiro assinava mais um acordo bilateral com os Estados Unidos para garantir a extensão da assistência técnica à expansão dos cursos de administração no Brasil (cf. Fischer, 1984; Oliveira, 1990), iniciava-se no país uma intensa disputa pela definição de um projeto de reforma do ensino superior que acabou por opor os dois polos estruturais da universidade brasileira: o polo acadêmico-científico, relativamente mais autônomo, e o polo profissional tradicional, marcadamente mais heterônomo.

A reivindicação por uma reforma profunda das universidades brasileiras foi inicialmente protagonizada pelas áreas científicas das universidades, em geral concentradas nas Faculdades de Filosofia, Ciências e Letras que, existentes em todas as universidades do país, queriam mudanças na estrutura acadêmica e política da universidade. De fato, como apontam as análises de Florestan Fernandes (1975 e 1984), Luiz Antônio Cunha (2007b e 2007c), Heládio Antunha (1971), Beatriz Fétizon (1986), Macioniro Celeste Filho (2013) e Rodrigo Patto Sá Motta 
(2014), a ideia de que a universidade brasileira precisava passar por uma reforma profunda vinha sendo gestada, no interior das próprias universidades ${ }^{100}$, ao longo da década de 1950.

As raízes da insatisfação com a organização da universidade residiam em grande medida na fragilidade da carreira de docência e pesquisa, tal como desenhada pelo Estatuto das Universidades Brasileiras, que regulamentou a organização universitária no país em 1931. Em síntese, esse marco legal incorporou às universidades criadas a partir da década de 1930, o regime de cátedras vigente nas faculdades profissionais pré-universitárias, pelo qual a cada disciplina curricular deveria corresponder um, e somente um, professor catedrático, integralmente responsável pela organização do trabalho e pela contratação docente naquela área do conhecimento. O estatuto de 1931 - assim como a Constituição de 1946 e a Lei de Diretrizes e Bases da Educação Nacional de 1961 que ratificaram os seus aspectos centrais - apesar de afirmar o caráter vitalício da cátedra, instituiu a obrigatoriedade de concurso de prova e títulos para o provimento desse cargo ${ }^{101}$. No entanto, pela lógica de funcionamento do regime, o

\footnotetext{
${ }^{100}$ Se é verdade, como foi dito, que existe um consenso cada vez mais consolidado na literatura de que aspectos centrais da reforma universitária realizada pelos militares em 1968 vinham sendo formulados e testados, na verdade, no interior das próprias universidades de pesquisa, desde a segunda metade da década de 1950, é preciso abandonar, como pretendo mostrar nesta tese, a ideia geral de que a universidade constitui um bloco monolítico, o que implica trazer para o primeiro plano as disputas que se desdobram em seu interior, pela definição geral do seu funcionamento, relacionando as diferentes propostas de reforma universitária às posições decisivas da estrutura universitária. Essa perspectiva fornece uma chave para entender algumas das disputas mais essenciais dos anos 1960, envolvendo diferentes propostas de reforma universitária.
}

101 Antes de 1931, a nomeação de professores catedráticos pelo governo não era incomum, ao contrário. Embora houvesse uma pressão da opinião pública e de parte da frágil comunidade acadêmica para o estabelecimento da obrigatoriedade dos concursos para o provimento dos cargos de professor universitário na Primeira República, o fato é que a resistência ao concurso ainda era grande e a nomeação direta, em geral, prevaleceu. Um exemplo muito interessante dessas disputas em torno do estabelecimento de critérios universalistas e meritocráticos para a escolha dos professores catedráticos é a batalha de Euclides da Cunha para conseguir tornar-se professor da Escola Politécnica de São Paulo (cf. Santana, 1996). Ao criar a Escola Politécnica, o governo de São Paulo determinou que os primeiros cargos seriam preenchidos por nomeação mas que os seguintes seriam obrigatoriamente preenchidos por concurso público, o que constituía a única chance de Euclides da Cunha tornar-se professor da Politécnica, dado seu desentendimento público com o fundador e primeiro diretor da escola, Antônio Francisco de Paula Souza, inclusive em relação a sua atuação na organização da Escola Politécnica de São Paulo. Apesar de alguns cargos terem sido preenchidos por concurso, há indícios de que o critério político prevaleceu, sobretudo porque no interior da Congregação da escola, predominava a opinião de que os concursos deveriam ser suprimidos. Segundo José Carlos Santana, "boa parte da 7a sessão ordinária da Congregação, em 2 de setembro de 1896, foi destinada à discussão para se encontrar uma solução que permitisse a apresentação ao Congresso Estadual de um projeto de supressão dos concursos sem que o ônus da medida fosse atribuído pela opinião pública à Escola" (1996, p. 317). 
concurso público só se tornou regra ${ }^{102}$ para o grau mais alto da carreira docente, representado justamente pela cátedra. Nos outros níveis da carreira, vigorava a livre vontade do catedrático o que tornava a carreira docente praticamente uma ficção, conforme explica Celeste Filho:

O Estatuto das Universidades Brasileiras, ao manter a cátedra, acarreta um adiamento da criação de uma carreia docente para o magistério superior. Os diversos auxiliares do catedrático, quer sejam chefes de clínica, chefes de laboratórios, assistentes ou auxiliares de ensino, deveriam ser de confiança do respectivo catedrático. Eram por ele escolhidos, e sua permanência no cargo, dele quase sempre dependia. A ascensão na carreira dos assistentes e auxiliares estava calcada na vontade do catedrático, em decisões tendenciosas e às vezes eivadas de autoritarismo (2013, p. 16).

Além disso, o regime de cátedras representava um empecilho ao desenvolvimento das atividades de pesquisa, que pressupunham não só o aumento do corpo de docentespesquisadores e a diversificação mais ágil das disciplinas oferecidas, como uma alteração da dinâmica de decisão interna às faculdades, tendo em vista o compartilhamento das decisões sobre a distribuição de recursos e prioridades didáticas e de pesquisa. Como é possível supor, essa fragilidade da docência e da pesquisa sob o regime de cátedras era percebida com mais intensidade nas unidades em que a atividade científica e a cultura acadêmica haviam conseguido se consolidar minimamente, o que significa, em suma, professores que tinham na universidade a sua primeira opção de carreira, pretendendo atingir, portanto, o chamado "tempo integral", hoje denominado Regime de Dedicação Exclusiva à Docência e à Pesquisa (RDIDP).

Nesse sentido, ao comparar o percentual de docentes em tempo integral nas diferentes unidades da USP em 1969, Heladio Antunha vai observar que as unidades profissionais como as Faculdades de Direito e de Arquitetura e Urbanismo eram as que tinham um percentual mais baixo de professores em dedicação exclusiva, justamente em função "da situação privilegiada de certas classes de profissionais para os quais - mercê da alta remuneração que podem receber extramuros - não há interesse em se dedicar inteiramente à Universidade” (1971, p. 167). No

102 Segundo Maria de Lourdes Albuquerque Fávero, o Estatuto de 1931 previa uma exceção à realização do concurso público: um professor poderia ser nomeado catedrático caso provasse ter "realizado invento ou descoberta de alta relevância, ou tenha publicado obra doutrinária de excepcional valor" (2001, p. 225). 
outro extremo, o alto percentual de professores em tempo integral era típico, segundo ele, “daquelas escolas e daqueles domínios do saber cujos professores têm em geral menores possibilidades de exercício profissional altamente remunerado fora da universidade, ou então daquelas áreas do conhecimento em que há uma especial motivação para as atividades de pesquisa" (1971, p. 168). No caso da USP, justamente, esses dois perfis de alto percentual de professores em dedicação exclusiva correspondiam a dois espaços acadêmicos distintos. De um lado, estava a Faculdade de Filosofia, Ciências e Letras que, além de concentrar os cursos científicos e pedagógicos da universidade, sofrera diretamente o impacto das missões europeias na consolidação de um padrão relativamente autônomo de pesquisa, que incluía a dedicação exclusiva à docência e à pesquisa. De outro, estavam as áreas básicas da Faculdade de Medicina e das Faculdades de Saúde Pública de São Paulo e de Medicina de Ribeirão Preto, que foram espaços institucionalmente moldados pela Fundação Rockfeller, que procurou instituir uma cultura de pesquisa na área médica da USP, com a expansão do tempo integral, o incentivo à formação de pesquisadores e a promoção da dedicação exclusiva à pesquisa (cf. Marinho, 2001). Não por acaso, portanto, serão essas duas unidades que vão protagonizar, na USP ${ }^{103}$, as tentativas de eliminação do regime de cátedras e de criação dos departamentos universitários na década de 1960 (cf. Antunha, 1971; Celeste Filho, 2013; Fernandes, 1975 e 1984).

No cenário universitário brasileiro de modo geral, onde a atuação de fundações como a Rockfeller foi menos sistemática, o polo reformador, responsável pela formulação da proposta de substituição das cátedras por departamentos, será formado quase que exclusivamente pelas

\footnotetext{
${ }^{103}$ Essa história será retomada em detalhe no próximo capítulo. Por hora, cabe notar que a Faculdade de Medicina de São Paulo contou com o apoio da Fundação Rockefeller sobretudo nas áreas básicas, o que gerou uma unidade cindida entre as áreas predominantemente clínicas e as áreas predominantemente científicas. Consequentemente, essa unidade viveu, ao longo dos anos 1960 e particularmente depois de 1964, um violento conflito interno ligado, justamente, às disputas pela modernização da universidade entre um polo "científico" (voltado à formação para a pesquisa) e um polo "profissional" (voltado à formação do médico exclusivamente). Esse conflito resultou na demissão e na aposentadoria de uma significativa parcela dos docentes, especialmente nas áreas básicas (cf. ADUSP, 2004), e está na raiz da criação do Instituto de Ciências Biomédicas (ICB), a partir da reforma universitária aprovada na USP em 1969.
} 
Faculdades de Filosofia, Ciências e Letras, e a oposição entre o polo acadêmico-científico e o polo profissional tradicional, ou se quisermos, entre uma visão de universidade pautada na autonomia e outra marcada pela heteronomia, será mais evidente.

A tensão estrutural da universidade brasileira se torna mais intensa a partir dos anos 1950, quando a instituição passa a sofrer mudanças, também estruturais, ligadas à expansão do corpo docente e discente das Faculdades de Filosofia, Ciências e Letras (cf. Antunha, 1971; Fernandes, 1975; Fétizon, 1986). Segundo dados do MEC, a forte expansão dessas unidades alterou um quadro em que as Faculdades de Direito eram as principais responsáveis pelas matrículas de ensino superior no país, chegando a concentrar $25 \%$ do alunado nacional em 1960. Como as FFCLs seguiram um ritmo acelerado de crescimento desde a segunda metade dos anos 1950, essas unidades se tornariam, já em 1964, as principais responsáveis pelas matrículas de ensino superior no país, atingindo o patamar de 100 mil alunos matriculados no primeiro semestre de 1969. Em termos proporcionais, isso representava quase um terço do alunado de ensino superior em 1969, um percentual muito superior ao de outras unidades profissionais como as Faculdades de Direito, de Medicina, de Engenharia e de Economia e Administração que, em 1969, respondiam, respectivamente, por 17,7\%, 8,0\%, 7,6\% e 8,9\% das matrículas de ensino superior (cf. MEC, 1972, p. 98). Além disso, os dados mostram que a expansão das Faculdades de Filosofia contemplava especialmente o público feminino. Assim, se em 1960 as mulheres já representavam 63\% dos alunos de Filosofia, Ciências e Letras do país, em 1971, o percentual de mulheres matriculadas nessas instituições chegou a representar $71 \%$ do alunado, sendo considerável a diferença em relação aos demais cursos profissionais como direito, com $25 \%$ de mulheres em 1971, medicina com 24\%, administração e economia com $15 \%$ e engenharia com apenas $3 \%{ }^{104}$.

${ }^{104}$ A ausência de mulheres nas unidades do polo profissional tradicional foi um tema recorrente nas minhas entrevistas com dirigentes da USP. Um deles, formado na ESALQ nos anos 1960, chega a descrever o fato de que, na época, a unidade não tinha sequer banheiro feminino. Outra dirigente, formada na Faculdade de Direito nos anos 1950, afirma que mulheres não podiam entrar no centro acadêmico, pois os colegas ameaçavam ficar nus. 
Um dos principais resultados do crescimento das Faculdades de Filosofia, Ciências e Letras ao longo dos anos 1960 foi a necessidade de expansão do seu corpo docente que, restrito pelas regras do regime de cátedra ${ }^{105}$, assumiu um caráter cada vez mais precário, com um percentual crescente de professores limitados aos níveis mais baixos da carreira ${ }^{106}$. Portanto, esse espaço acadêmico que já valorizava a regulamentação da carreira docente em função da sua cultura acadêmica historicamente enraizada, tornou-se em decorrência da conjuntura dos anos 1960, ainda mais crítico às cátedras e mais defensor da ideia dos departamentos, cuja extinção parecia representar tanto a regulamentação da carreira acadêmica quanto a sua democratização. A criação de uma estrutura departamental envolvia, ainda, uma concentração das disciplinas universitárias afins, o que não só era visto como uma medida de racionalização dos custos - abrindo caminho para a expansão das vagas e das atividades de pesquisa - mas também como uma estratégia de integração universitária que romperia com o isolamento das unidades profissionais tradicionais ${ }^{107}$.

Enquanto os homens controlavam esse espaço, as mulheres ficavam restritas a um "departamento feminino", do qual ela não tem boas lembranças: "[Pergunta] Professora, as mulheres da sua turma romperam muitas barreiras. Vocês chegaram a compor a gestão do XI de agosto? [Resposta] Não, no meu tempo não. De jeito nenhum. Nós não íamos nem no centro acadêmico, nós tínhamos um departamento feminino, que era um horror. Quem ia lá? As meninas que não iam assistir às aulas, que cabulavam a aula e ficavam pintando unha, fazendo coisas desse tipo".

$105 \mathrm{O}$ regime de cátedras impedia tanto a criação de uma carreira docente minimamente estruturada quanto a expansão do percentual de professores catedráticos por disciplina.

106 Segundo Heládio Antunha, em 1969, o corpo docente da Faculdade de Direito da USP era formado majoritariamente por professores catedráticos ou livre-docentes: de um total de 91 docentes, apenas $14 \%$ eram instrutores. No outro extremo, na Faculdade de Filosofia, Ciências e Letras da USP, de um total de 634 professores, $53 \%$ eram instrutores (cf. 1971, p. 167).

${ }^{107} \mathrm{O}$ isolamento das faculdades profissionais tradicionais é outro tema constantemente mencionado nas minhas entrevistas. Um dos dirigentes, médico, formado na Faculdade de Medicina no começo dos anos 1960, comenta sua residência no Hospital das Clínicas e o começo da sua carreira docente: "Então eu fiz residência, fui residente três anos, e aí aproveitei e fiz a minha tese de doutoramento, que naquele tempo era diferente do que você faz hoje com créditos. Eu fiz uma tese experimental, que também não era comum na Faculdade de Medicina. Agora, é preciso reconhecer que a Faculdade de Medicina é totalmente isolada. E não só no Brasil. Lendo alguns estatutos de universidades americanas, você vai ler no finalzinho... this do not aplly to medical school. Então, para ser franco, eu não tinha ideia do que era licenciatura. Nós não tínhamos nada disso. Até depois, se tentou, que os alunos queriam aprender um pouco mais sobre didática. Então a medicina era a medicina nesse sentido". A dirigente que se formou na Faculdade de Direito nos anos 1950, além de perceber o mesmo isolamento, entende que ele permanece até hoje: "[Pergunta] É interessante professora, porque se comenta muito do isolamento da Faculdade de Direito em relação à USP. A senhora viveu esse isolamento durante a graduação? [Resposta]Completamente, eu nem conhecia a USP. A gente não tinha nenhum contato com a USP. Eu tinha 
Nesse sentido, portanto, o cerne da proposta original de reforma visava, de um lado, a consolidação da carreira docente com a transição do regime de cátedras para o sistema departamental baseado na decisão colegiada e, de outro, o fortalecimento da universidade enquanto espaço integrado de produção de conhecimento, o que pressupunha uma reforma do seu modelo institucional, baseado em faculdades isoladas. O empenho crescente em prol dessas mudanças refletiu-se na redação final da Lei de Diretrizes e Bases da Educação Nacional (LDB), aprovada em 1961, que excluiu a obrigatoriedade tanto das Faculdades de Filosofia, Ciências e Letras - possibilitando a criação de universidades baseadas em institutos especializados como no caso da UNB e, posteriormente, da reforma da UFMG - quanto das cátedras - o que abriu caminho para a sua substituição por departamentos, como previsto igualmente no projeto original da $\mathrm{UNB}^{108}$ e em algumas unidades da USP (cf. Cunha, 2007c, p. 109ss).

Ao longo dos anos 1960, o Conselho Federal de Educação (CFE) - responsável pela regulamentação das ambiguidades e omissões da $\mathrm{LDB}$ - vai se se tornar palco privilegiado de uma intensa disputa entre, de um lado, o polo que defendia a obrigatoriedade do regime de cátedras e a manutenção do status quo universitário e, de outro, o polo que pleiteava mudanças mais intensas na estrutura das universidades, em especial a substituição das cátedras por departamentos e a criação dos institutos voltados à pesquisa (cf. Celeste Filho, 2013, p. 39ss).

contato com a Faculdade de Arquitetura, a FAU, porque o meu namorado estudava Arquitetura, que era na Rua Maranhão, não era nem na Cidade Universitária. Não tinha contato nenhum. [Pergunta]E como a senhora avalia essa questão hoje? A Faculdade de Direito ainda é isolada? [Resposta] - Ah, é isolada. É isolada. Participa pelos órgãos colegiados com representantes. Mas a Faculdade de Direito é uma coisa, a USP é outra. É como Medicina. Não tem nada a ver".

\footnotetext{
108 A proposta original da Lei de Diretrizes e Bases da Educação Nacional aprovada pelo Congresso Nacional em 1961 afirmava, no seu artigo 74: “o ensino das disciplinas obrigatórias dos cursos de graduação será ministrado por professor catedrático"; e no seu artigo 79: "as universidades constituem-se pela reunião, sob administração comum, de cinco ou mais estabelecimentos de ensino superior, um dos quais devendo ser uma Faculdade de Filosofia, Ciências e Letras". No entanto, segundo aponta Celeste Filho, "a redação final da LDB é alterada substancialmente por vetos do Executivo" que atingem especialmente o regime de cátedras e a obrigatoriedade das FFLCs. Consequentemente, o artigo 74 é suprimido e a redação final do artigo 79 exclui a referência à FFCL (cf. Celeste Filho, 2013, p, 42).
} 
Ainda segundo Celeste Filho, as duas figuras icônicas desse embate no âmbito do CFE foram Antônio Ferreira de Almeida Júnior - catedrático de Medicina Legal da Faculdade de Direito da USP - e Maurício Rocha e Silva - catedrático de Farmacologia da Faculdade de Medicina de Ribeirão Preto da USP e presidente da Sociedade Brasileira para o Progresso da Ciência. O primeiro tornou-se o principal defensor da obrigatoriedade das cátedras e da resistência às mudanças inseridas na LDB, ao passo que o segundo atuou como grande porta-voz do projeto de reforma universitária cujas bases estavam dadas na lei de $1961^{109}$.

Embora Macioniro Celeste Filho não o tenha apresentado nesses termos, para quem interpreta essa oposição no CFE à luz da estrutura geral da USP, instituição em que lecionavam os dois conselheiros em questão, é possível identificar claramente o embate entre um polo profissional tradicional - representado, no caso, pela Faculdade de Direito da USP - e um polo acadêmico-científico - representado pela FMRP e pelas demais áreas de pesquisa da mesma universidade ${ }^{110}$. Essa contraposição aparece de forma ainda mais clara em diversos discursos e

\footnotetext{
109 Apoiado nos seus "mestres de Direito" como Miguel Reale e Washington de Barros Monteiro, o conselheiro Almeida Júnior vai alegar que a obrigatoriedade das cátedras constitui matéria constitucional - mais do que pedagógica - o que impediria a sua substituição por departamentos. Para ele, portanto, a implementação do sistema departamental, facultado pela LDB, não deveria se dar em substituição ao regime de cátedras, mas articulado a ele. Já Maurício Rocha e Silva vai insistir na incompatibilidade entre o departamento e a cátedra. Segundo Silva, "a cátedra mata o departamento, como talvez o contrário também seja verdadeiro: a ideia de departamento exclui a cátedra" (Celeste Filho, 2013, p. 56). Por isso, para ele, "o sistema correto foi proposto pela Universidade de Brasília, em que a unidade básica é o departamento e o chefe é eleito pelos seus membros [...] mas todos em pé de igualdade, correspondendo a iguais deveres, iguais direitos num sistema de integração que é o único aceitável num departamento" (Celeste Filho, 2013, p. 56). O parecer de Maurício Rocha e Silva acabou sendo aprovado pelo CFE em 1963.
}

${ }^{110}$ Maurício Rocha e Silva era professor da Faculdade de Medicina de Ribeirão Preto (FMRP) que, como dito, foi criada com financiamento da Fundação Rockfeller quando ela procurava instituir uma cultura de pesquisa na área médica da USP. Assim, como contrapartida do apoio financeiro, a Fundação Rockfeller exigiu a expansão do tempo integral, a formação de pesquisadores experimentais e criação de condições para a dedicação exclusiva à pesquisa (cf. Marinho, 2001). Tudo isso tornou a FMRP uma das mais importantes unidades científicas da USP nos anos 1960 e, consequentemente, o principal núcleo reformador dessa universidade no período. Por integrar o polo profissional da USP, enquanto uma escola de medicina, e adotar práticas acadêmicas e de pesquisa inerentes ao polo científico, a FMRP conseguiu, por essa posição ambivalente, acumular poder junto ao Conselho Universitário, o que a levou à reitoria da universidade justamente durante a votação da reforma universitária, no segundo semestre de 1968. Nesse sentido, Hélio Lourenço de Oliveira (FMRP) foi eleito vice-reitor da USP em 1968, depois do afastamento de Mário Guimarães Ferri (FFCL) que, também na posição de vice-reitor, substituía o catedrático da Faculdade de Direito, Luiz Antônio Gama e Silva, afastado da USP desde 1967 para ocupar o cargo de Ministro da Justiça no Governo Costa e Silva. Hélio Lourenço de Oliveira foi orientando de Antônio Barros de Ulhôa Cintra, que também foi reitor da USP de 1960 a 1964 quando promoveu reformas importantes. Oliveira permaneceu como reitor em exercício da USP até 1969, quando foi aposentado compulsoriamente por decreto federal, assinado tanto pelo então presidente Costa e Silva quanto por seu Ministro da Justiça. Quem 
pareceres de Maurício Rocha e Silva que, como presidente eleito da SBPC, atuava como representante oficial da incipiente "comunidade" científica brasileira ${ }^{111}$, sediada nas áreas básicas das universidades públicas do país. Em um parecer de 1962, por exemplo, o cientista defende a importância "de uma imediata e radical reforma da universidade brasileira" que visasse colocar "o desenvolvimento das ciências, das letras e das artes como a base do ensino", o que pressupunha enxergar "a pesquisa como a base em que se deve assentar o ensino" (apud Celeste Filho, 2013, p. 60). Em um outro parecer, apresentado em 1965, Rocha e Silva é ainda mais enfático ao afirmar que "é contra essa mentalidade retrógrada de formar apenas médicos, engenheiros e advogados que devemos nos insurgir, porque o Brasil precisa muito mais do indivíduo que descobre as causas do que do que corrige sintomas", sendo que "descobrir causas e investigar razões é o objetivo da pesquisa científica" (apud Celeste Filho, 2013, p. 68) ${ }^{112}$.

Com a oposição entre a formação profissional e a pesquisa científica posta na mesa, o chamado "movimento pela reforma universitária" (cf. Fernandes, 1975, p. 201ss) passa a mirar seus dois alvos principais: por um lado, a fragilidade da carreira docente cuja regulamentação e democratização encontravam-se limitadas pelo regime de cátedras e, por outro, a falência do projeto de universidade integrada e voltada para a pesquisa, resultado do predomínio das faculdades profissionais isoladas (cf. Celeste Filho, 2013; Cunha, 2007c; Florestan, 1975 e 1984). Nesse sentido, o cerne da reforma delineada pelo polo acadêmico-científico das assumiu o lugar de Hélio Lourenço de Oliveira foi o então diretor da Faculdade de Direito, Alfredo Buzaid. Vale
observar que Buzaid não foi o vice-reitor mais votado pelo Conselho Universitário da USP, assumindo o cargo de
apenas por ter sido escolhido pelo então governador no expediente da lista tríplice. Alfredo Buzaid permaneceu
no cargo de reitor até a eleição de Miguel Reale, também da Faculdade de Direito, no final de 1969, tendo logo
depois se tornado Ministro da Justiça, no lugar de Gama e Silva. Essa longa descrição dos ocupantes do cargo de
reitor da USP ao longo dos anos 1960 sugere que houve, no período, praticamente uma alternância de poder entre
um polo acadêmico-científico, de ímpeto reformador e representado pela FMRP e FFCL, e um polo profissional
tradicional que visava preservar o status quo da USP, representado pela Faculdade de Direito (cf. Celeste Filho,
2013).
${ }^{111}$ É importante notar que o uso do termo comunidade científica, nesse caso, não implica a aceitação da ideia,
inerente à noção de "comunidade", de que se trata de um corpo social unido e desprovido de conflitos internos.
${ }^{112}$ Não consegui ter acesso direto aos pareceres do Conselho Federal de Educação citados por Macioniro Celeste
Filho e, por isso, tomei a liberdade de citar a partir do trabalho desse autor (cf. 2013). 
universidades brasileiras consistia em substituir o regime de cátedras por departamentos que funcionariam como órgãos colegiados e enfraquecer as faculdades profissionais isoladas transformando todas as unidades universitárias, sem exceção ${ }^{113}$, em institutos voltados à pesquisa que compartilhariam a responsabilidade pela formação científica e profissional dos estudantes de graduação favorecendo a expansão da pós-graduação. O objetivo geral dessa reforma seria promover a atividade científica ${ }^{114}$, o que explica a presença de outras propostas correlatas, como a criação de mecanismos sistemáticos de financiamento universitário (cf. Fernandes, 1975, p. 252), o incentivo à pós-graduação (cf. Cunha, 2007c, p. 110), a defesa da autonomia acadêmica e científica (cf. Fernandes, 1975, p. 229) e o fortalecimento de outros órgãos colegiados ou mesmo paritários como as assembleias universitárias (cf. Celeste Filho, 2013, p. 161).

Mas o essencial é que, durante os anos 1960, a proposta de fortalecimento da universidade de pesquisa com os seus órgãos colegiados de decisão assumia, também, um sentido político mais profundo, de fortalecimento de mecanismos autônomos de decisão capazes de preservar a universidade enquanto um espaço de formulação crítica, o que implicava afastá-la de qualquer ideal de subsunção às necessidades sociais mais imediatas. Essa posição gerava um paradoxo para os setores de esquerda do polo acadêmico-científico que se viam obrigados a defender dois princípios aparentemente opostos: por um lado, a preservação da

\footnotetext{
${ }^{113} \mathrm{~A}$ proposta de transformar todas as unidades, e não apenas a $\mathrm{FFCL}$, em institutos voltados à pesquisa aparece claramente no caso da USP. Foi em grande medida contra essa proposta que se voltaram as faculdades profissionais como se verá no próximo capítulo.

114 Macioniro Celeste Filho sintetiza bem a proposta desse "polo científico" embora não a nomeie como tal, atribuindo-a de modo mais geral aos "intelectuais brasileiros": "Pretende-se uma mudança de paradigma, na acepção que Thomas Kuhn dá a esse termo, na concepção do que deveria ser a universidade brasileira; há incisivo esforço em transformá-la em produtora de ciência. Até então, sua maior preocupação destinava-se à formação profissional, inclusive nas Faculdades de Filosofia, Ciências e Letras, que, segundo seus críticos, deveriam ter mudado isso desde a década de 1930. Nesta visão, a universidade como conglomerado de escolas e faculdades de formação não era coesa e nem tinha a produção de ciência como meta prioritária. A transformação das Faculdades de Filosofia, Ciências e Letras em institutos proporcionaria coerência científica às diversas áreas do saber. Com a substituição do sistema de cátedras pelos departamentos, o caminho para a produção científica seria mais bem adaptado. Essa nova configuração universitária deveria contaminar as demais escolas superiores de formação profissional, transformando-as também em algo integrado e coeso à nova universidade" (2013, p. 39-40).
} 
universidade como espaço autônomo e crítico e, por outro, o atendimento às crescentes demandas sociais por educação através da abertura do ensino superior a setores menos favorecidos. Esse paradoxo não é exclusivamente brasileiro. O teórico crítico Peter Hohendahl, ao analisar as diferentes propostas de reforma universitária formuladas pelos setores de esquerda na Alemanha dos anos 1960, aponta claramente essa tensão entre as propostas de democratização do ensino superior enquanto expansão de vagas e de democratização enquanto fortalecimento da autonomia universitária com seus mecanismos de autogestão:

\begin{abstract}
No começo, o movimento estudantil, em parte influenciado pelo seu congênere dos Estados Unidos, estava seriamente envolvido com a ideia de uma reforma da universidade como parte de reformas sociais mais amplas. Os líderes do movimento sentiam que a universidade alemã permitia liberdade individual mas não encorajava a participação em sua governança. Os representantes estudantis, em uma conferência de 1967 - Jens Litten, Ulrich Preuss, e Kurt Nevermann -, contestaram não apenas a ideia de práxis de Dahrendorf, mas também o seu conceito de democratização. Para eles, responder simplesmente aos anseios da sociedade existente não era suficiente, $\mathrm{e}$ a reforma que deixava a hierarquia da presente universidade intacta não podia encorajar a democratização ou responder aos problemas do futuro. [...] o movimento estudantil enfatizava o aspecto comunal, ou seja, a democratização necessária da universidade como parte de uma sociedade democrática moderna. A universidade tinha de ser salva das reformas que a tornariam parte de um projeto mais amplo de criar uma formierte Gesellschaft (uma sociedade regulada tecnologicamente), com ênfase em eficiência e orientação por resultados; uma sociedade caracterizada por sua efetiva carência de abertura e igualdade (Hohendahl, 2013, n.p.).
\end{abstract}

Esse paradoxo revela a importância, no contex to específico da universidade, do ideal de conhecimento desinteressado, com seus mecanismos correlatos de autonomia e autogoverno. No Brasil, igualmente, um dos aspectos essenciais da reforma proposta pelos movimentos estudantil e docente concentrados, ainda que não exclusivamente, nas áreas menos profissionalizantes, logo mais autônomas da universidade, era a ênfase na democratização dos mecanismos internos de decisão e ação, o que implicava defender o fortalecimentos dos órgãos de gestão colegiada, de preferência com ampla participação estudantil (cf. Cardoso, 2001; Celeste Filho, 2013; Chauí, 2001; Fernandes, 1975 e 1984) ${ }^{115}$. O apelo democrático dessa

\footnotetext{
${ }^{115}$ Rodrigo Patto Sá Motta chama a atenção, com razão, para o fato de que nem todos os professores que apoiavam a reforma universitária aceitavam as propostas mais radicais do movimento estudantil, de compartilhamento do poder universitário entre estudantes e professores (cf. Motta, 2014, p. 68). Ainda assim, é importante notar que havia uma forte aceitação, entre os professores ligados ao movimento da reforma universitária, das propostas de
} 
proposta de reforma universitária contribuiu para ampliar, no contexto autoritário da ditadura militar, a sua legitimidade junto a setores acadêmicos e sociais cada vez mais amplos. Além disso, a rápida expansão do corpo docente e discente das Faculdades de Filosofia, Ciências e Letras nos anos 1960 e a crescente radicalização do movimento estudantil no Brasil e no mundo ajudavam a fortalecer as demandas formuladas no interior do polo acadêmico-científico das universidades.

Em resposta ao crescimento do movimento pela reforma universitária, começam a surgir, sobretudo a partir de 1964, outros espaços de discussão e formulação de propostas para as mudanças que pareciam cada vez mais incontornáveis ${ }^{116}$. São exemplos dessa reação os seminários sobre reforma educacional promovidos pelo Instituto de Pesquisas e Estudos Sociais (IPES), os acordos de cooperação técnica entre o Brasil e os Estados Unidos para o planejamento do ensino superior, conhecidos como acordos MEC-Usaid, as demais consultorias norte-americanas para a reestruturação do ensino superior, como a de Rudolph Atcon, que levam à criação de órgãos não governamentais para o planejamento universitário, em especial o Conselho de Reitores das Universidades Brasileiras (CRUB) e, por fim, os comitês governamentais para a reforma universitária, como o Grupo de Trabalho da Reforma

\footnotetext{
transformação dos conselhos departamentais em instâncias prioritárias de decisão acadêmica por incluírem, sem distinções internas, a totalidade do corpo docente da universidade. Além disso, também havia um consenso, expresso em deliberações inclusive da reforma universitária, de aumento da representação estudantil nos órgãos de representação, para além do limite de 1/5 estabelecido pela lei da reforma universitária ou mesmo 1/10 estabelecido na USP. Por fim, também é possível notar a aceitação, pelo polo acadêmico-científico que reivindicava uma reforma mais profunda da universidade, de propostas de criação de órgãos paritários, não necessariamente deliberativos, para a discussão de temas gerais da universidade, como chegou a ser aprovado, com o voto vencido das faculdades profissionais tradicionais, pelo conselho universitário da USP em 1969, embora a revisão da reforma promovida por Alfredo Buzaid tenha revogado essa decisão (cf. Celeste Filho, 2013). Tudo isso explicita que a reforma defendida pelo polo acadêmico-científico buscava fortalecer mecanismos internos de autogoverno que não se confundem necessariamente com a aplicação do conceito de soberania popular e sufrágio universal à universidade. Voltaremos a isso.

${ }^{116}$ A ideia de que a reforma universitária resultou da reação de forças sociais originalmente conservadoras que foram obrigadas, a partir do golpe militar, a migrar de uma posição de simples recusa a qualquer mudança no status quo para uma posição reativa de promoção efetiva de reformas, mas com novo conteúdo, é constantemente mobilizada pelos analistas da reforma universitária, desde os primeiros trabalhos acadêmicos escritos sobre o tema (cf. Fernandes, 1975, p. 84-5) até os últimos (cf. Motta, 2014, p. 65).
} 
Universitária e a Comissão Especial sobre os problemas estudantis, presidida pelo então coronel Carlos de Meira Mattos, que resultaram na lei 5.540 de 1968 que viabilizou a reforma universitária.

Não é intenção desta tese reconstruir em detalhe a história e os materiais produzidos por esses espaços institucionais, sobretudo porque já existem bons trabalhos dedicados à análise detalhada de cada um deles ${ }^{117}$. O objetivo é, antes, mostrar como, juntos, esses espaços sociais foram responsáveis pela importação e legitimação de um conhecimento gerencial sobre a universidade que, embasado em uma visão econômica da educação, resultou na imposição de ferramentas, técnicas e procedimentos de gestão, o que subverteu parte das propostas de reforma elaboradas, originalmente, no interior das universidades nacionais, especialmente pelo seu polo acadêmico-científico, cuja base era o modelo colegiado, integrado e autônomo de universidade. Esses lugares sociais constituíram, a partir da segunda metade da década de 1960, um verdadeiro campo de influência marcado por uma forte circulação de ideias e pessoas, conforme analisado nos itens que se seguem.

\subsection{A universidade como objeto de gestão: a reação do polo politicamente dominante}

\subsubsection{Profissionalização e gestão: o IPES e a visão econômica da educação}

O Instituto de Pesquisas e Estudos Sociais (IPES), fundado em 1961 com sede em São Paulo e no Rio de Janeiro, foi uma instituição sui generis na história brasileira. Reunindo

\footnotetext{
${ }^{117}$ Sobre o Instituto de Pesquisas e Estudos Sociais ver Souza (1981) e Dreifuss (1981). Sobre os acordos MECUsai ver Cunha (2007c), Fernandes (1975), Fávero (1991 e 2006) e Motta (2014). Sobre a consultoria de Rudolph Atcon e a fundação do CRUB ver Cunha (2007c) e Fávero (1991 e 2006). Sobre o Grupo de Trabalho para a Reforma Universitária ver Cardoso (2001), Cunha (2007c), Fernandes (1975), Fávero (1991 e 2006) e Rothen (2008). E, por fim, sobre o relatório da Comissão Especial presidida por Meira Mattos ver Cardoso (2001), Cunha (2007c), Fávero (1991) e Rothen (2008).
} 
empresários, políticos e militares das duas maiores cidades do país, o IPES constituiu-se como uma organização não-governamental voltada a estudos de problemas brasileiros e à proposta de soluções tecnicamente qualificadas. Maria Inêz de Souza o descreve como "um grupo de pressão e propaganda ideológica" que contava com a colaboração de "professores universitários, técnicos e especialistas" para a formulação de propostas de reforma inspiradas nas experiências dos "países avançados” (Souza, 1981, p. 20-1). Para René Dreifuss, o IPES, juntamente com o IBAD ${ }^{118}$, foi mais do que um grupo de pressão e propaganda, constituindose, na verdade, como o núcleo ativo do Golpe Militar, descrito pelo autor como um "golpe de classe", que visava fortalecer a fundação de um regime tecnocrático-empresarial, marcado pela abertura ao capital externo, restrição da organização da classe trabalhadora e fortalecimento do capitalismo dependente (cf. Dreifuss, 1981). Partindo dessa definição, é possível concluir que se tratava, portanto, de um dos primeiros e mais controversos ${ }^{119}$ think tanks brasileiros que, com influência no Estado e financiamento empresarial local, conseguiu reunir atores decisivos para a construção política da ditadura civil-militar brasileira agregando professores, deputados, generais e futuros ministros de Estado $^{120}$.

\footnotetext{
118 O Instituto Brasileiro de Ação Democrática (IBAD) foi fundado em 1959, com financiamento de empresários nacionais e estrangeiros, para "combater o comunismo no Brasil e influir nos rumos do debate econômico, político e social do país” (CPDOC, 2004, n.p.).

${ }^{119}$ Em 1963, o Congresso Nacional montou uma Comissão Parlamentar de Inquérito para apurar a atuação do Instituto Brasileiro de Ação Democrática (IBAD) durante a eleição de 1962. O IPES acabou incluído nas investigações acusado, com o IBAD, de intermediar o financiamento norte-americano a candidatos de oposição na eleição de 1962, o que era proibido pela legislação. Ao final das investigações, o IPES acabou absolvido. A tese de René Dreifuss, no entanto, conseguiu reunir um amplo material que comprova atuação conjunta do IPES com o IBAD. Assim, segundo Maria Vitória Benevides, "um dos grandes méritos da pesquisa de Dreifuss consiste, justamente, em revelar a estreita ligação entre o IPES e o IBAD" (2003, p. 256). Sobretudo porque "à época em que foi fundado (novembro de 1961, após a renúncia de Jânio e a ascensão de Goulart à presidência), o IPES vinha marcado por inegável respeitabilidade. Suas propostas espelhavam o prestígio dos projetos da 'Aliança para o Progresso', a qual só seria desmascarada por Che Guevara em 1962, na Conferência de Punta del Este. Ao IBAD, estigmatizado desde o início, competia o 'jogo sujo', da manipulação de recursos de fontes equívocas para financiar campanhas dos candidatos conservadores e 'corrupções' de vários calibres. As evidências apresentadas por Dreifuss conseguem aproximar as duas entidades, o que a CPI do IBAD tentou em 1963, mas não logrou fazer" (Benevides, 2003, p. 256).
}

${ }^{120} \mathrm{Na}$ sua pesquisa sobre o IPES, Maria Inês de Souza mapeia um conjunto de especialistas que teriam atuado tanto no interior do IPES quanto em diferentes órgãos do governo militar. Na sua lista constam nomes importantes como o do General Golbery do Couto e Silva (membro da Escola Superior de Guerra, chefe do SNI no governo Castello Branco e ministro-chefe da casa civil no governo Geisel), Luiz Gonzaga do Nascimento e Silva 
Desde a sua fundação, e particularmente depois do golpe militar que potencializou o seu impacto político, o IPES dedicou-se ao estudo de temas diversos como a reforma agrária, a organização sindical, as políticas de produtividade e desenvolvimento, o problema educacional e, por fim, os modelos administrativos ${ }^{121}$. Como aponta Maria Inêz de Souza, o interesse do IPES pelo tema da educação surge, no entanto, tardiamente: fundado em 1961, foi somente a partir de 1964, quando já estava em curso uma ampla discussão sobre reforma educacional no país promovida pelas próprias instituições de ensino, que o instituto passou a se dedicar à elaboração de um projeto específico para a reforma da educação (cf. 1981, p. 31ss).

As bases essenciais desse projeto foram delineadas em dois eventos públicos. O primeiro foi o Simpósio sobre a reforma da educação organizado em 1964 pelo General Jaul Pires de Castro, com a colaboração de Peri Pôrto - que na sequência do seminário se tornou diretor da Equipe de Planejamento do Ensino Médio criada por um dos acordos MEC-Usaid e colaborador de Roberto Campos para a elaboração do Plano de Ação Econômica do Governo para o triênio 1964-1966 - e de João Roberto Moreira - que depois de publicar trabalhos importantes sobre a educação brasileira nos Estados Unidos no começo dos anos 1960, inclusive em parceria com pesquisadores norte-americanos do campo da economia da educação, tornouse funcionário da Unesco, atuando em diversos países latino-americanos na promoção de políticas de modernização da educação e promoção do desenvolvimento (cf. Souza, 1981). O segundo evento do IPES sobre reforma educacional, que alcançou maior repercussão, foi um fórum intitulado A educação que nos convém, organizado em outubro de 1968, em parceria

(presidente do BNH, ministro do trabalho no governo Castello Branco e ministro da Previdência Social no governo Geisel), Mario Henrique Simonsen (ministro da fazenda do governo Geisel e presidente do Mobral), Roberto Campos (ministro do planejamento do governo Castello Branco); Raymundo Padilha (deputado da Arena e Governador do Rio de Janeiro entre 1971 e 1975), entre outros (cf. Souza, 1981, p. 203-4).

121 A partir de 1967, o IPES passa a se dedicar menos ao estudo dos problemas brasileiros e mais à formação de executivos para os quais oferecia cursos de economia e, principalmente, de administração (cf. Souza, 1981). 
com a PUC-Rio e com financiamento do Jockey Club brasileiro, das indústrias Klabin e da editora APEC (cf. IPES, 1969, p.iii).

As discussões do simpósio de 1964 estão sintetizadas em um texto de Roberto Moreira intitulado Delineamento geral de um plano de educação para a democracia no Brasil (cf. Moreira, 1964) e em um documento básico sem autoria definida que subsidiaria o Simpósio. Os debates do fórum A educação que nos convém estão transcritos em detalhe em um relatório homônimo publicado em 1969 (cf. IPES, 1969). Considerados em conjunto, esses documentos apresentam uma enorme coerência. Partindo de uma visão essencialmente econômica da educação, eles defendem a importância de promover políticas capazes de "levar a educação a uma maior produtividade [...] com um ensino mais prático e que esteja de acordo com a realidade brasileira [o que pressupõe que] a universidade também terá de modernizar-se e adotar práticas de racionalização da sua administração" (Souza, 1981, p. 90).

Nesse sentido, já nos documentos que sintetizam o Simpósio de 1964, é possível encontrar referências a trabalhos de teoria econômica da educação, especialmente norteamericanos, que embasavam uma visão mais pragmática das funções do ensino e à necessidade da superação do equívoco histórico da cultura brasileira de valorizar "a educação por si mesma”, sem atentar para o seu valor real, de natureza instrumental (cf. Souza, 1981, p. 55). A mobilização de teorias econômicas sobre a educação aparece ainda com mais força nas intervenções do fórum de $1968^{122}$. Segundo Souza, das onze conferências apresentadas ao longo de todo o fórum, oito defendiam "a ideia de uma educação voltada para o desenvolvimento, através do treinamento dos recursos humanos necessários a uma sociedade tecnologicamente avançada" recomendando, por isso, "um ensino de caráter prático e utilitário, criticando-se o ensino humanista que é sem objetividade e distanciado das necessidades imediatas da

\footnotetext{
122 Todas as intervenções realizadas no fórum bem como as discussões que se seguiram a cada uma delas estão transcritas na íntegra no documento A educação que nos convém (IPES, 1969). Para uma análise comparativa do seu conteúdo ver Souza (1981, p. 77ss).
} 
sociedade" (1981, p. 88). De modo paradigmático, a apresentação do economista e então ministro do planejamento, Roberto de Oliveira Campos, sobre a relação entre educação e desenvolvimento econômico, defende essa posição. Assim, ao iniciar a sua intervenção, ele enfatiza os avanços alcançados pela recente aplicação dos pressupostos econômicos ao problema da educação promovida pela teoria do capital humano:

Até hoje, um dos grandes instrumentos de cálculo econômico para propósitos, digamos, desenvolvimentistas, ainda é a relação capital/produto. Mas só ultimamente o uso desse instrumento se tem orientado no sentido de considerar, na função capital, os recursos humanos e a qualidade do fator humano (IPES, 1969, p. 73).

A expansão dessa visão econômica da educação resultava na valorização de uma visão mais pragmática da questão educacional que significava, em termos políticos, segundo Campos, a substituição de um "planejamento que se poderia chamar demográfico, pelo planejamento de mercado" (IPES, 1969, p. 75). Se o primeiro havia levado, ao longo da década de 1960, à expansão "desmesurada" das Faculdades de Filosofia, Ciências e Letras, o segundo consistia, em síntese, em ajustar a oferta de vagas do sistema de ensino superior às demandas diretas do mercado, o que pressupunha aumentar o grau de profissionalização da educação universitária. Assim, na transcrição dos debates do fórum $A$ educação que nos convém, consta que, ao responder a Mario Henrique Simonsen, engenheiro de formação, sobre a existência de uma possível "correlação entre o grau de agitação estudantil e a falta de ajustamento das escolas ao mercado de trabalho" (IPES, 1969, p.79), Roberto Campos reitera:

Esse ajustamento das verbas e das facilidades financeiras à efetiva demanda de educação setorial é um elemento importante para o progresso educacional. Diria que a inquietação estudantil, certamente, se alicerça bastante nesta constatação, pelo aluno, da futilidade do seu treinamento face ao mercado de trabalho. Isso lhe dá um sentido de revolta e explica o porquê da explosividade das faculdades de filosofia, cuja vocação prática é menos definida (IPES, 1969, p. 79).

Nesse sentido, se para o polo acadêmico-científico que iniciou o movimento pela reforma universitária ainda na década de 1950, o essencial era romper com a excessiva profissionalização das universidades, tornando "o desenvolvimento das ciências, das letras e 
das artes [...] a base do ensino" (cf. Celeste Filho, 2013, p. 60), para esse outro polo, beneficiado pela sua posição estratégica tanto no interior das universidades quanto no aparelho de Estado, a solução para a crise do ensino superior era, em suma, mais, e não menos, profissionalização. Essa guinada pragmática implicava, porém, não somente a subsunção da universidade às necessidades do mercado, como também aos seus métodos. Para o ministro do planejamento, tratava-se de um processo inexorável dado pelo ingresso das sociedades na "era organizacional" em que "a preocupação não é tanto surgimento de talentos como a sua boa administração" (IPES, 1969, p. 74).

De modo ainda mais enfático, Lucas Lopes, engenheiro que também ocupava a posição de economista de Estado, de onde presidiu o $\operatorname{BNDE}(\mathrm{S})$ e coordenou o Plano de Metas do governo Juscelino Kubitschek ${ }^{123}$, expressa a centralidade da gestão científica no projeto de reforma do ensino superior formulado nesse campo de influência formado pelo IPES, pelas consultorias norte-americanas, pelos órgãos de governo dedicados à síntese das propostas de reforma universitária e, no interior das universidades, pelo seu polo profissional tradicional. O trecho é longo mas sintetiza de modo explícito o consenso que se formava, entre os responsáveis pela política educacional brasileira dos anos 1960, quanto à necessidade de se adotar uma concepção norte-americana de gestão que funcionaria, então, como porta de entrada para outras mudanças sociais, econômicas e políticas:

Para Robert McNamara ${ }^{124}$, em seu célebre discurso The Three Gaps - Economic, Technological and Educational, o grande avanço da economia americana sobre a

\footnotetext{
${ }^{123}$ No seu artigo sobre a emergência dos economistas e, em menor medida, dos administradores como uma nova elite burocrática cada vez mais hegemônica, Marly Silva da Motta confere destaque à atuação de Lucas Lopes na afirmação desse novo campo de atuação em planejamento, social e econômico, locus privilegiado de atuação dessa nova "elite tecnicoburocrática" (cf. Motta, 1994, p. 82ss).

${ }^{124}$ Robert MacNamara nasceu em São Francisco, Califórnia, em 1916. Graduou-se em Economia e Filosofia na Universidade da Califórnia, Berkeley, em 1937, destacando-se pela sua excelência acadêmica. No mesmo ano, tornou-se aluno de pós-graduação e logo professor da Harvard Graduate School of Business Administration "onde aprendeu as técnicas de gestão que se tornaram características do seu estilo de liderança” (World Bank, 2013, n.p.). MacNamara aplicou seu conhecimento em gestão na área militar durante a Segunda Guerra Mundial e na indústria automobilística depois da Guerra. Em 1960, MacNamara tornou-se presidente da Ford Motor Company, sendo nomeado, um mês depois, Secretário de Defesa do Governo John Kennedy, que lhe atribui um "mandato para manter a área militar sob controle através da aplicação de formas eficientes de gestão" (World Bank, 2013, n.p.). Em 1968, MacNamara tornou-se o quinto presidente do Banco Mundial, onde permaneceu até 1981, ampliando,
} 
europeia está no educational gap e no managerial gap. A educação adequada e extensiva em todos os níveis e a formação de pessoal de nível superior em número e qualidade são condições necessárias ao processo de desenvolvimento, mas não serão suficientes sem a introdução de uma concepção moderna de management, de administração científica, de racionalização, no governo, na escola, em todas as atividades econômicas. Creio com MacNamara que [o] management é a porta através da qual as alterações sociais, políticas, econômicas e tecnológicas serão racional e eficientemente difundidas. [...] A universidade que se pretende reformar deve ter como objetivo inicial ser um eficiente instrumento de educação. Isto significa possuir um grau elevado de produtividade, quer em termos quantitativos quer qualitativos. Não apenas pela concepção de sua estrutura de departamentos, escolas, cursos, currículos mas principalmente pela introdução de métodos de racionalização e scientific management, de administração armada de instrumentos próprios para formular planos e decidir opções, pode a universidade perseguir o ideal da alta eficiência. [...] A introdução de métodos modernos de planejamento, tais como os estudos de viabilidade, a pesquisa operacional, os systems analysis, o P.P.B Planing, Programing, Budgeting etc. encontrou naturais reações no âmbito da universidade que, no dizer do professor Gass (The educational revolution in OECD countries), tem sido basicamente consequência da justificada prioridade que a educação deve dar ao indivíduo em relação ao sistema. Mas a managerial revolution, que é um sinal do nosso tempo, na esfera das indústrias, da defesa nacional e de outras áreas da administração, precisa ganhar uma nova posição de destaque no campo da universidade. Não se deseja transformar a universidade numa usina, numa linha de montagem de robôs. É, entretanto, essencial que a universidade, como centro de produção de cultura e de indivíduos educados, aprenda a buscar eficiência em sua expansão e operação, num processo contínuo de programação e planejamento que permita adequar relações de meios e fins. O problema da adequação da universidade ao mercado de técnicos de nível superior é tipicamente um problema de scientific management. Não é apenas uma análise de mercado em que se investiga a demanda de certos tipos de técnicos de nível superior em face da tendência de sua absorção pela empresa ou por outras instituições. É também um problema de planejamento da universidade, em termos de investimento, de expansão de cursos, de renovação de currículos, de ajustamento dinâmico da sua oferta para cobrir as mutações da demanda. [...] A universidade tem que dar o exemplo de racionalização e eficiência (IPES, 1969, p. 125).

O discurso de Lucas Lopes é revelador da constituição de um campo de influência dado primeiramente no plano da linguagem, marcada por construções de língua inglesa e termos especializados - de uma concepção moderna de gestão, já diferenciada, pela mobilização de uma palavra específica, da simples administração. Essa perspectiva gerencial, que deve ser aplicada, sem distinção, às atividades econômicas, ao governo e à escola, entende a universidade não só em termos de eficiência e produtividade, o que expressa a influência de

segundo a versão oficial do próprio Banco, a ajuda aos países subdesenvolvidos e a atuação do Banco Mundial no campo de pesquisa acadêmica sobre desenvolvimento. No resumo da sua trajetória apresentado pelo Banco, há grande destaque ao papel que o conhecimento gerencial desempenhou nos diversos cargos que MacNamara exerceu: "O conceito de gestão baseado na acumulação e análise de dados quantitativos associado à sua mente disciplinada proveram-no com uma ferramenta para exercer controle sob condições incertas” (World Bank, 2013, n.p.). 
uma visão econômica da educação, mas sobretudo como dependente de um "processo contínuo de programação e planejamento" que seja capaz de "adequar relações de meios e fins" (IPES, 1969, p. 125, grifo meu). Lopes deixa explícito, portanto, que o objetivo específico da gestão moderna não é a mera racionalização dos procedimentos decisórios da universidade visando aprimorar a produtividade e a eficiência interna mas, antes, a construção de todo um novo modo de organização interna, por uma "administração armada de instrumentos próprios" capazes de implantar uma rotina intensiva de "programação" e "planejamento" que passam a definir tanto as deliberações sobre os meios quanto, e talvez sobretudo, as decisões sobre os fins da universidade. Não por acaso, Lopes acredita, com McNamara, que mais do que a simples expressão de formas racionalizadas de governo, o management é uma porta de entrada para que outras mudanças "sociais, políticas, econômicas e tecnológicas" sejam "racional e eficientemente difundidas" (IPES, 1969, p. 125).

O consenso em torno da necessidade de aplicar às universidades brasileiras os métodos e técnicas de gestão moderna não foi construído apenas no âmbito do IPES. O trabalho das consultorias norte-americanas foi, nesse ponto, essencial. Voltados inicialmente para órgãos federais, como o então Ministério da Educação e Cultura e a sua Diretoria de Ensino Superior (DES), as consultorias e os acordos de cooperação técnica norte-americanos foram, aos poucos, deslocando-se para o incentivo à formação e ao treinamento de dirigentes acadêmicos, formando, com isso, um campo de atuação mais estável que se prolongou por toda a década de 1970, criando condições para que as propostas de reforma institucional que emergiram nos anos 1980, durante a redemocratização do país, pudessem ser implementadas com relativa facilidade. 


\subsubsection{Uma "nova geração de líderes": as consultorias norte-americanas e a conversão invisível dos dirigentes acadêmicos brasileiros}

Os acordos firmados nos anos 1960 entre o governo brasileiro, via Ministério da Educação e Cultura, e o governo norte-americano, via United States Agency for Internacional Development, mais conhecidos como acordos MEC-Usaid, visavam "o assessoramento americano aos técnicos brasileiros encarregados de estudar uma reforma do ensino" (Brasil, 1968a, p.11) ${ }^{125}$. Conforme consta em um dos seus relatórios finais (cf. Brasil, 1968a), os acordos MEC-Usaid estavam inseridos no âmbito dos tratados bilaterais de cooperação técnica assinados pelos governos brasileiro e norte-americano no começo dos anos 1950, como o Acordo Geral de Cooperação Técnica (Brasil, 1950) e o Acordo sobre Serviços Técnicos Especiais (Brasil, 1953) que fortaleceram, como visto, o apoio oferecido pelos Estados Unidos à expansão do ensino de administração no país pelo menos desde 1949 (cf. Alcadipani \& Bertero, 2012; Barros \& Carrieri, 2013; Usaid, 1968).

Embora o governo dos Estados Unidos tenha financiado projetos específicos para o ensino superior desde a década de 1940, a atuação da Usaid priorizou, originalmente, o chamado ensino básico que, reunindo os níveis primário e secundário, era visto como tendo um impacto político e social mais amplo ${ }^{126}$. Nesse quadro, os primeiros auxílios da Usaid ao ensino superior brasileiro, no começo dos anos 1960, ocorreram por solicitação direta das próprias instituições nacionais que contavam com os subsídios norte-americanos para implementar projetos específicos de programas e disciplinas (cf. Mattos, 2014, p. 116ss). Nesse primeiro momento, portanto, a atuação da Usaid no ensino superior brasileiro foi esporádica, ligada ao

\footnotetext{
${ }^{125}$ Os acordos MEC-Usaid documentados foram, ao todo, sete: três envolvendo o planejamento do ensino básico, secundário e superior. Três mais específicos voltados à formação industrial, à publicação de obras especializadas e, finalmente, o que é até hoje considerado o mais bem sucedido de todos, voltado à modernização administrativa das universidades brasileiras (cf. Cunha, 2007c; Mattos, 2014). Nesse item, vamos examinar apenas os dois acordos voltados ao ensino superior.

${ }^{126}$ De fato, mesmo inserindo o ensino superior no seu âmbito de atuação, a Usaid seguiu privilegiando os ensinos primário e secundário que receberam cerca de $70 \%$ do total de investimentos da agência em educação no país durante os anos 1960 (cf. Mattos, 2014, p. 139).
} 
financiamento de instituições e programas circunscritos, como a expansão do ensino de economia e administração e a modernização das escolas agrícolas (cf. Cunha, 2007c). No entanto, a partir de 1963, a Usaid dá indicações de que pretendia alterar a sua política educacional no país. Expressando essa mudança, os primeiros consultores norte-americanos para o ensino superior chegaram ao Brasil, por solicitação da agência, entre o final de 1963 e o começo de 1964, tendo como objetivo estudar o cenário educacional nacional e propor caminhos para otimizar a ajuda externa norte-americana na área. A partir da visita desses especialistas em educação superior, a Usaid passou a traçar planos para interferir não apenas em instituições isoladas mas no sistema como um todo, sobretudo porque, na avaliação da agência, “a chave para que o Brasil permanecesse uma 'sociedade livre' e um 'amigo próximo' dos Estados Unidos estava no ensino superior, pois o que os brasileiros pensariam nas gerações vindouras dependeria dos professores universitários que formam os dirigentes do país [...]" (Cunha, 2007c, p. 158).

Nesse sentido, uma segunda equipe de consultores denominada Higher Education Team, visitou o país com financiamento da Usaid entre março e abril de 1964, concluindo seu relatório com a recomendação de que a agência norte-americana não firmasse apenas acordos com instituições específicas, como o que mantinha com a FGV, buscando incidir de modo mais direto sobre o desenho institucional do ensino superior como um todo. Para tanto, os consultores recomendam duas frentes principais de ação: incentivar o desenho de uma reforma universitária através de um programa de assistência técnica ao MEC e ao CFE e construir um campo de influência que se centrasse nos próprios dirigentes acadêmicos através da realização de uma Conferência de Reitores Universitários e Dirigentes de Instituto com apoio financeiro da Usaid (cf. Cunha, 2007c, p. 158). Do ponto de vista da formulação de uma proposta alternativa de reforma do ensino superior, essas duas frentes de ação - a assessoria governamental e a 
influência de dirigentes acadêmicos - tiveram um enorme impacto, embora se saiba que não foram eles que, sozinhos, ditaram os rumos da reforma universitária brasileira.

A assessoria técnica da Usaid ao MEC, tendo em vista a elaboração de um projeto de reforma do ensino superior, iniciou-se oficialmente com a assinatura de um acordo entre a Diretoria de Ensino Superior do MEC, o representante do Brasil para a Cooperação Técnica ou "Ponto IV" e a Usaid, em junho de 1965. Evocando os compromissos assumidos pela Carta de Punta del Este e a adesão brasileira à Aliança para o Progresso, o convênio estabelece, entre seus objetivos principais, "a elaboração de uma série de planos exequíveis para a ampliação e reestruturação do sistema nacional de ensino superior" com a "criação de um quadro de técnicos em planejamento educacional brasileiro" (Brasil, 1968a, p. 12). Para tanto, estava prevista a criação de uma Equipe de Planejamento do Ensino Superior gozando de amplos poderes, composta de educadores brasileiros de "alto nível" e especialistas norte-americanos de "reconhecida competência", com um prazo de trabalho fixado em 24 meses. No entanto, como mostra Luiz Antônio Cunha, as reações contrárias ao acordo, na opinião pública nacional, nas universidades e por parte do próprio Conselho Federal de Educação, que viu sua autoridade contestada, inviabilizaram a implementação e levaram à sua completa reelaboração (cf. Cunha, 2007c, p. 163ss). Nesse sentido, depois de manter o acordo MEC-Usaid por um longo tempo em segredo, o governo brasileiro, sob pressão direta do Congresso Nacional (cf. Alves, 1968), anunciou publicamente a reestruturação do acordo, em maio de $1967^{127}$, através da assinatura de um novo Convênio de Assessoria ao Planejamento do Ensino Superior que, em síntese, restringia o papel dos especialistas norte-americanos, rebaixando-os da categoria de "planejadores" para a de "assessores de planejamento" e sugerindo que o protagonismo da

\footnotetext{
${ }^{127}$ Antes disso, o acordo já vinha enfrentando dificuldades técnicas para a sua implementação. Primeiro, em função da demora do governo brasileiro, na figura do CFE, em indicar os representantes brasileiros, embora a USAID já tivesse apresentado um Consórcio de Universidades do Meio-Oeste (Midwest University Consortium) para o fornecimento de especialistas norte-americanos. Segundo, por conta da desistência sucessiva dos representantes brasileiros que alegavam "a exigência em tempo integral e os salários reduzidos" (Brasil, 1968a, p. 13).
} 
reforma cabia, ainda, aos brasileiros (cf. Cunha, 2007c, p. 181). Segundo consta no seu relatório final, o novo convênio "alterava, ampliava e substituía o convênio original" tendo em vista, dentre outros objetivos, "dirimir algumas interpretações errôneas provocadas pelo texto anterior" ao deixar claro que "somente às autoridades brasileiras caberá determinar, como sempre, a política e as normas da educação, aprovar ou não todos os planos elaborados e executá-los quando aprovados" (Brasil, 1968a, p. 16). Porém, como as resistências no âmbito do CFE e do MEC se mantinham, ao lado de interrogações e críticas por parte da opinião pública, do movimento estudantil e do Congresso Nacional ${ }^{128}$, a Usaid terminou por cancelar o convênio, unilateralmente, em junho de 1968 (cf. Brasil, 1968a).

Mesmo com a participação dos Estados Unidos suspensa, o resultado desse acordo foi a produção de um relatório, assinado pela Equipe de Assessoria ao Planejamento do Ensino Superior (EAPES) que, como foi dito, reunia professores norte-americanos e educadores brasileiros, estes últimos indicados pelo Conselho Federal de Educação ${ }^{129}$ (cf. Brasil, 1968a). O relatório traz uma síntese inicial escrita pelos assessores brasileiros e um conjunto de textos isolados escritos pelos consultores norte-americanos, alguns dos quais ainda na versão original, em inglês ${ }^{130}$. Em resumo, o relatório parte da mesma visão econômica da educação que orientava a perspectiva do IPES, de modo que o seu primeiro item intitulado "Educação e

\footnotetext{
128 O Congresso Nacional, através do então deputado Márcio Moreira Alves, passou a requerer ao MEC formalmente informações sobre o convênio, chegando a convocar o então Ministro da Educação, Tarso Dutra, para prestar esclarecimentos sobre uma possível interferência norte-americana na política educacional brasileira (cf. Alves, 1968). Ao mesmo tempo, os acordos MEC-USAID eram objeto de críticas públicas nos jornais de grande circulação do país, como $O$ Estado de S. Paulo, que publica um manifesto de professores da USP contra a intervenção norte-americana ainda em 1965 e o Jornal do Brasil que publica um editorial contrário ao convênio em 1967, sem contar toda a pressão do crescente movimento estudantil, no qual "o lema Fora MEC-USAID só rivalizava em força e generalidade com Abaixo a ditadura" (Cunha, 2007c, p. 218).
}

${ }^{129}$ Do lado norte-americano, os consultores eram: Martin Klotsche (chanceler da Universidade de Wisconsin), John Ryder (Diretor da Escola de Engenharia da Universidade Estadual de Michigan), Henry Hoge (professor de espanhol e português da Universidade de Wisconsin) e John Hunter (professor de economia da Universidade Estadual de Michigan). Do lado brasileiro foram José Fernando Carneiro (Catedrático de Medicina da Universidade Federal de Porto Alegre), Laerte Ramos de Carvalho (Catedrático de Filosofia e História da Educação da USP e interventor na UNB), Rubens d'Almada Horta Porto (membro do Conselho Diretor da FGV) e Osmar Ferreira (sem informação).

${ }^{130} \mathrm{O}$ conteúdo do relatório foi analisado em detalhe por Luiz Antônio Cunha (cf. 2007c, p. 155ss). 
desenvolvimento" começa afirmando: “a educação não é apenas uma responsabilidade social mas também fator de desenvolvimento" (Brasil, 1968a, p. 23).

Em consonância com essa visão, o texto propõe diversas medidas voltadas ao aumento da produtividade e da rentabilidade do ensino superior, tais como: i) a cobrança de mensalidade nas instituições públicas; ii) a adoção do modelo de fundações como solução administrativa de curto prazo; iii) a adequação dos cursos oferecidos ao mercado de trabalho; iv) a flexibilização dos currículos; v) a criação de departamentos nas universidades que viessem a ser fundadas; vi) a racionalização do vestibular por meio da sua unificação; e vii) a criação de mecanismos centralizados de planejamento universitário (cf. Brasil, 1968a).

Uma parte dessas medidas coincidem com as recomendações finais do Grupo de Trabalho da Reforma Universitária, que redigiu a primeira versão da Lei 5.540 de 1968, responsável pela reforma do ensino superior brasileiro alguns meses depois da publicação do relatório da EAPES. No entanto, é difícil afirmar que o relatório tenha influenciado diretamente a política brasileira para o ensino superior. É mais plausível supor, com Luiz Antônio Cunha, que o principal papel do acordo MEC-Usaid ligado à Equipe de Planejamento do Ensino Superior foi indireto e, de certo modo, acidental: "ao atrair sobre si os ataques, [a EAPES] livrou deles o caminho dos convênios voltados para o ensino de $1^{\circ}$ e $2^{\circ}$ grau e, no $3^{\circ}$ grau, do Conselho de Reitores, que, este sim, provocou modificações significativas no ensino superior brasileiro" (2007c, p. 218).

De fato, enquanto o famigerado acordo MEC-Usaid para o planejamento do ensino superior esbarrava em resistências políticas diversas - inclusive uma jornada de lutas convocada pela UNE, já clandestina - um outro convênio firmado entre o MEC e a agência norteamericana, bem menos pretensioso porém mais impactante, avançava com tranquilidade. Tratava-se da Assessoria para a modernização da administração universitária que partia do diagnóstico de que a proliferação das instituições de ensino superior no país ao longo das 
últimas décadas havia gerado uma série de problemas de natureza administrativa que precisava, então, ser equacionada por um conhecimento novo, o conhecimento gerencial. Diante disso, o texto original do convênio assume o pressuposto de que:

\begin{abstract}
O número de universidades oficializadas no Brasil aumentou de 3 para 37 desde 1944. Este aumento, consequência do desenvolvimento social e econômico brasileiro, realizou-se de maneira tão rápida que não houve tempo suficiente para cuidar-se dos problemas de administração universitária. Caso este setor não seja, em futuro próximo, alvo de atenção, e caso a proliferação de instituições de ensino superior continue no ritmo atual, problemas de administração, tais como sistemas de vestibulares, planejamento acadêmico, administração financeira e planejamento físico de cidades universitárias, tornar-se-ão tão complexos que limitarão severamente a eficiência destas instituições e terão fatalmente efeito prejudicial no desenvolvimento do ensino superior no Brasil (Alves, 1968, p.34).
\end{abstract}

Para atacar esses problemas administrativos o convênio previa uma série de medidas,

dentre as quais se destacavam:

1) Consultoria Técnica a ser proporcionada a instituições determinadas de âmbito mais amplo e que estejam preparadas para iniciar programas específicos de reforma administrativa.

2) Uma série de seminários, a fim de estimular outras instituições interessadas a considerar a execução de programas semelhantes.

3) Cursos de curta duração, nos Estados Unidos, para treinamento e especialização de pessoal brasileiro necessário à avaliação, adaptação e instituição de novos processos e técnicas administrativas essenciais (Alves, 1968, p. 34-5).

Segundo o relatório sobre os acordos MEC-Usaid preparado pelo então deputado Márcio Moreira Alves, embora a relação de Rudolph Atcon com a Usaid não seja totalmente clara, foi no âmbito desse convênio para a modernização administrativa das universidades brasileiras que ele atuou de modo mais sistemático (cf. Alves, 1968). No entanto, pelas poucas informações disponíveis sobre a trajetória de Rudolph Atcon no Brasil ${ }^{131}$, é possível afirmar que a sua colaboração no desenho de políticas educacionais no país começou antes e terminou depois da vigência desse acordo MEC-Usaid.

\footnotetext{
${ }^{131}$ Ao longo da pesquisa, procurei informações mais detalhadas sobre a trajetória de Rudolph Atcon mas encontrei poucos detalhes disponíveis. Na introdução do seu livro publicado em 1974, há uma pequena biografia com algumas informações. Pela descrição de Luiz Antônio Cunha, fica claro que ele não teve acesso a informações muito mais detalhadas do que as presentes nesse documento do MEC. Mas acrescenta, aos dados gerais, que Atcon era grego de nascimento, estudou na Alemanha e naturalizou-se norte-americano (cf. Cunha, 2007c; Atcon, 1974).
} 
A primeira visita de Atcon ao Brasil ocorreu no começo da década de 1950, quando o consultor foi contratado pelo educador Anísio Teixeira para auxiliar na fundação e na organização da Coordenação de Aperfeiçoamento de Pessoal de Nível Superior (Capes) entre 1953 e 1956. Depois dessa passagem pelo Brasil, Atcon atuou em diversos países latinoamericanos como o Chile, a Colômbia, a Venezuela, Honduras e Caribe, onde colaborou com projetos de reestruturação universitária (cf. Atcon, 1974). Em função da sua atuação em reformas educacionais da América Latina, Atcon redigiu um relatório, em 1958, intitulado Outline of a proposal for US policy concentration in Latin America on university reorganization and economic integration, apresentado publicamente na Universidade de Princeton. Esse relatório de trabalho foi publicado em 1961 com o título The Latin American University, sendo traduzido para o alemão em 1962 e para o espanhol em 1963, ano em que foi incorporado pela Usaid como diretriz para a sua atuação no continente (cf. Fávero, 1991, p. 19ss), data que coincide, como visto, com a inflexão na política da agência no país.

Em 1965, pouco depois da assinatura do primeiro acordo MEC-Usaid, Rudolph Atcon volta a colaborar com órgãos de formulação de política científica e educacional dessa vez como contratado pela Diretoria de Ensino Superior do MEC para estudar e propor "alterações estruturais que julgasse necessárias para as universidades brasileiras" (Cunha, 2007c, p.188). No âmbito desse projeto, cuja relação com a Usaid não é explícita, visitou pelo menos doze universidades brasileiras entre junho e setembro de 1965, o que resultou no seu famoso relatório intitulado Rumo à reformulação estrutural da universidade brasileira (Atcon, 1966), também conhecido como "plano Atcon”. Na definição de Maria de Lourdes Albuquerque Fávero, o plano Atcon pretendia acelerar "o processo de transformação do ensino superior no país, rumo à modernização, segundo os paradigmas norte-americanos de então, da racionalidade institucional"' (1991, p. 19). 
Dentre todas as recomendações produzidas ao longo da década de 1960, as de Rudolph Atcon foram as que mais enfatizaram a importância da modernização administrativa das universidades. Em linhas gerais, o projeto de modernização proposto pelo consultor previa a autonomização administrativa e financeira das universidades em relação ao Estado e o consequente desenvolvimento de controles internos efetivos através da construção de uma estrutura administrativa centralizada e inspirada no modelo empresarial, que era então praticamente inexistente nas universidades. Desse modo, ao descrever as linhas gerais da sua proposta de "reforma administrativa", Atcon dizia:

\begin{abstract}
Autonomia administrativa implica uma desvinculação da universidade dos controles administrativos e financeiros do Estado. Como corolário, tem que implicar a existência de controles internos à instituição, porque em algum lugar devem existir controles objetivos e funcionais que garantirão a produção educativa e impedirão a arbitrariedade individual ou coletiva. É necessário, então, estabelecer estes controles internos e fazê-los funcionar bem, antes que se conceda um maior grau de autonomia à instituição. [...] Por essas razões, um planejamento dirigido à reforma administrativa da universidade brasileira, no meu entender, tem que se dirigir ao propósito de implantar um sistema administrativo tipo empresa privada e não do serviço público [...] porque é um fato implacável que uma universidade autônoma é uma empresa grande e não uma repartição pública (Atcon, 1966, p. 81-2; grifo meu).
\end{abstract}

Partindo dessa proposta geral, Atcon vai detalhar o seu modelo de funcionamento administrativo da universidade, baseado na "separação completa entre a formulação e a execução da política da universidade" (Atcon, 1966, p. 83; grifo meu). Configurando esse divórcio, a administração universitária seria composta, por um lado, de altos dirigentes acadêmicos responsáveis pelo planejamento estratégico da instituição e, por outro, de uma equipe de gestores técnicos, voltados à execução das políticas concebidas pelo nível central. Se o primeiro nível envolveria, preferencialmente, professores universitários que atuam como reitores, vice-reitores, assessores estratégicos ou membros dos Conselhos Centrais ${ }^{132}$, o segundo seria formado por funcionários técnico-administrativos de carreira, com treinamento em instrumentos, métodos e técnicas de gestão acadêmica. Entre um nível e outro, atuaria,

\footnotetext{
${ }^{132}$ É importante notar que Atcon foi o primeiro a propor a criação das chamadas "pró-reitorias" que seriam órgãos executivos responsáveis pela formulação de programas e políticas nas diferentes áreas da universidade. No caso da USP, essa medida foi implementada nos anos 1980.
} 
segundo Atcon, a figura do "administrador" que não se confundiria com outros postos de direção, como a vice-reitoria e a chefia de gabinete, estando mais próximo de um "técnico em administração, de preferência contratado da indústria" (cf. Atcon, 1966, p. 84-7). Para que esse nível central - composto por um polo de concepção e um polo de execução de políticas acadêmicas - pudesse se viabilizar, era preciso construí-lo efetivamente e, para isso, o consultor previa uma série de medidas concretas e detalhadas tais como:

- A mecanização dos procedimentos administrativos: a implantação geral de um sistema mecanizado de administração central em cada universidade federal, estadual ou privada [...];

- Contratação de administradores centrais: a criação da nova posição de administrador central em cada universidade, proveniente da indústria e contratado com bases realistas [...];

- Preparação de técnicos em estatística educacional: cada universidade deveria dispor de pelo menos um técnico em estatística educacional. De preferência, todos eles deveriam ser preparados de forma idêntica para poderem manipular as mesmas categorias estatísticas, com procedimentos estandardizados $[\ldots]$;

- Preparação de diretores de Bibliotecas Centrais: a mesma argumentação anterior [...];

- Preparação de administradores hospitalares: Umas quinze pessoas, altamente qualificadas e devidamente prestigiadas nas suas respectivas especialidades, deveriam ser escolhidas e preparadas, seja em São Paulo seja no estrangeiro, como administradores hospitalares [...]; (Atcon, 1966, p. 1114)

É importante notar que o modelo gerencial proposto por Atcon está ancorado, na prática, nessas medidas concretas, aparentemente de pouco alcance pelo seu caráter técnico, que visavam assentar as bases para o que seria, no seu entender, uma gestão moderna e centralizada. No entanto, essas medidas de ordem técnica emanavam de um modelo conceitual geral que invertia, quase que completamente, a concepção de universidade que vinha subsidiando o projeto de reforma elaborado pelo polo acadêmico-científico das instituições de ensino e pesquisa brasileiras, a partir do final dos anos 1950. Isso porque, em primeiro lugar, na universidade gerenciada sugerida pelo consultor norte-americano, a integração acadêmica não emana de um projeto pedagógico e científico elaborado e compartilhado pelas diferentes unidades de ensino e pesquisa - tal como implícito nas discussões em torno da transformação das unidades universitárias isoladas, incluindo as então Faculdades de Filosofia, Ciências e 
Letras, em institutos voltados à pesquisa que compartilhariam, sem privilégio ou precedência, a responsabilidade pela formação científica e profissional dos estudantes. Na versão de Atcon, ao contrário, independentemente das relações acadêmicas que se estabeleçam entre as diferentes unidades universitárias, é para o âmbito da administração central que se transfere a responsabilidade de integrar, científica e academicamente, as diferentes áreas da universidade, através da formulação centralizada e uniforme de projetos, programas e diretrizes acadêmicocientíficas. Isso se expressa sobretudo na medida em que o modelo de universidade de Atcon subverte o lugar concedido ao departamento enquanto unidade decisória básica da universidade. Ao monopolizar as decisões fundamentais sobre a universidade, denominadas na nova linguagem gerencial de "planejamento institucional" ou "planejamento estratégico", a administração centralizada esvazia a função política original dos departamentos - que, como defendia Maurício Rocha e Silva em 1963, contribuíam para a distribuição do poder universitário igualmente entre o conjunto do corpo docente - transformando-os em instâncias de execução de políticas de ensino, pesquisa e extensão determinadas pelas esferas superiores. A subversão das principais propostas originais do projeto de reforma universitária não implica, porém, a sua completa negação. Há, com efeito, mais convergência do que divergência entre o plano Atcon e o projeto de reforma universitária de 1968: tanto a criação dos institutos de pesquisa, a partir da fragmentação das FFCLs, quanto a substituição das cátedras por departamentos, transformados formalmente em núcleo da política universitária, foram medidas sugeridas e aprovadas. No entanto, como se verá, o seu sentido geral foi subvertido, o que permite explicar, por um lado, por que a reforma universitária, mesmo realizando parte dos seus objetivos, não foi entendida como uma vitória pelo movimento universitário em geral (cf. Fernandes, 1975) e, por outro, por que a nova estrutura pôde conviver com aspectos centrais do antigo modelo, como a manutenção do isolamento das unidades universitárias e a transferência 
de certos privilégios dos professores catedráticos aos assim chamados "titulares" (cf. Cunha, 2007c).

É importante notar que, no final desse relatório publicado em 1966, Rudolph Atcon aponta os atores que, na sua visão, tenderiam a ser os protagonistas da reforma administrativa por ele proposta: a nova geração de reitores "líderes", apoiados por "jovens assessores". Segundo o consultor:

Em quase todas as universidades visitadas, me encontrei com uma nova geração de reitores, conscientes da sua responsabilidade frente à comunidade e imbuídos de uma genuína angústia para atender às instituições que dirigem. É uma nova geração de líderes que a Universidade Brasileira está adquirindo, cujo desejo de não só ocupar, formalmente, um cargo honorífico, se manifesta de maneira impressionante. [...] Assim, o novo binômio de Reitores líderes e assessores jovens promete ação; só resta saber que tipo de ação se desenvolverá. Mas cabe dizer que, sem o aparecimento deste tipo de liderança dinâmica, não se poderia fazer nada, da mesma forma que, sem angústia coletiva, não poderia modificar-se nenhum mecanismo institucional (Atcon, 1966, p. 77-8).

Para essa "nova geração de líderes", o consultor reservou um plano específico: a construção de um Conselho de Reitores, completamente independente do Estado, que "através da sua Secretaria Executiva [...] teria plena liberdade de organizar qualquer tipo de planejamento, estudo ou pesquisa que servisse à aclaração de qualquer dificuldade ou ao aperfeiçoamento de qualquer procedimento do sistema universitário" (Atcon, 1966, p. 117). Em consonância com essa proposta, o CRUB, Conselho de Reitores das Universidades Brasileiras, foi fundado em abril de 1966 tendo Rudolph Atcon como seu primeiro secretário executivo. Foi no âmbito desse cargo que Atcon pôde participar ativamente da implementação do acordo MEC-Usaid para a modernização administrativa das universidades brasileiras. Contando com financiamento direto da Usaid e do Ministério do Planejamento - ocupado ainda pelo economista ligado ao IPES, Roberto de Oliveira Campos - o CRUB assumiu a responsabilidade de implementar o acordo que previa uma série de projetos de pesquisa, treinamento e coordenação, visando o aumento da produtividade do sistema nacional de ensino superior, dentre os quais, destacam-se: 
- Projeto de pesquisa sobre a situação socioeconômica do estudante universitário brasileiro;

- Projeto de pesquisa sobre a unificação e operação mais racional e funcional de exames de admissão para universidades;

- Projeto de estudo destinado à apresentação de proposta sobre soluções alternativas quanto ao financiamento de estudo universitário para estudantes de pouco ou nenhum recurso;

- Projeto de treinamento, abrangendo todas as universidades brasileiras, sobre operações e funcionamento na administração centralizada [...];

- Projeto de treinamento, sob acordo bilateral, de limitada assistência técnica, visando a estimular métodos administrativos avançados em planejamento universitário, registros centrais, contabilidade centralizada, auditoria, financiamento etc.;

- Projeto de coordenação de todas as comissões de planejamento universitário e de incentivo para a criação de tais comissões, onde quer que estas ainda não existam [...];

- Projeto de coordenação visando à assistência a todas as universidades, no que diz respeito ao melhor preparo e controle de seus orçamentos anuais;

- Projeto de pesquisa e treinamento, em escala nacional, sobre técnica de planejamento universitário;

- Projeto de treinamento para preparação simultânea de grupos de dirigentes de bibliotecas centrais para todas as universidades;

- Projeto de treinamento para preparação simultânea de estatísticas educacionais para todas as universidades;

- Projeto de treinamento, no país e no exterior, para preparação simultânea de administradores de hospitais para os hospitais universitários da nação;

- Projeto de estudo sobre política nacional de salários, visando à formulação de meios e métodos para assegurar a justa remuneração para os professores no ensino de tempo integral, bem como para pessoal de pesquisa (Alves, 1968, p. 39-40).

Em 1968, tendo como pano de fundo as críticas à intervenção norte-americana no ensino superior brasileiro, Rudolph Atcon deixou a secretaria executiva do CRUB, o que não significou, no entanto, o seu afastamento dos projetos de modernização do ensino superior brasileiro. Ao contrário, Atcon continuou assessorando individualmente as universidades brasileiras nos seus projetos de modernização administrativa (cf. Cunha, 2007c) e colaborando com a Diretoria de Ensino Superior do MEC que, nos anos 1970 e em parceria com o Banco Interamericano de Desenvolvimento (BID), publicou a obra mais completa de Rudolph Atcon, intitulada Administração Integral Universitária: uma teoria da estruturação e administração universitárias (cf. Atcon, 1974). Nesse volume de pretensões teóricas mais ousadas, o autor busca sistematizar os seus planos de reforma sob a forma de "uma teoria internamente consistente e coerente sobre os fundamentos filosóficos, os objetivos intrínsecos, a estrutura organizacional e a coincidente administração central da universidade" (Atcon, 1974, p. 3). 
Em suma, se é verdade que a criação do CRUB foi a recomendação de Atcon que teve "maior alcance" e visibilidade (Cunha, 2007c, p. 195), foi justamente porque ele possibilitou uma ação de reestruturação das universidades brasileiras no longo prazo, através do convencimento, ou, mais do que isso, da conversão praticamente invisível dos dirigentes universitários brasileiros. É isso que vão enfatizar alguns analistas como, por exemplo, Luiz Antonio Cunha:

A partir de 1969, estando fora Atcon e MEC-Usaid, fechados os canais de participação política ostensiva, os consultores tiveram o seu caminho aplainado e vieram em numerosas levas [...] e conseguiram orientar os dirigentes universitários brasileiros para a reestruturação administrativa e pedagógica das instituições de ensino superior de acordo com o modelo vigente nos Estados Unidos [...] (Cunha, 2007c, p. 218).

O consenso em torno da modernização administrativa das universidades disseminou-se em tal grau que hegemonizou completamente o sentido subjacente à ideia de "racionalização administrativa" das universidades que, antes da expansão e consolidação dessa visão gerencial, comportava ambiguidades que expressavam disputas importantes. É nessa chave das disputas em torno do significado da racionalização acadêmica que se torna possível compreender porque Florestan Fernandes, um dos críticos mais radicais da reforma universitária proposta pelos consultores norte-americanos em parceria com o governo militar e os setores mais tradicionais da universidade, também defende medidas de "racionalização do uso de recursos" e "controle de produtividade", como é possível notar no trecho abaixo:

Em suma, a racionalização do uso de recursos financeiros, materiais e humanos aparece como um dos requisitos da passagem da universidade conglomerada para a universidade integrada. A multiplicação de fontes de gastos dispersivos, em serviços didáticos, técnicos ou de pesquisas, a tendência ao exagerado incremento dos custos operacionais e ausência de controle do rendimento (ou produtividade) dos serviços são inerentes a uma organização escolar que confere ao catedrático, como indivíduo e como grupo, um poder ilimitado e autoritário de decisão. [...] Os meios racionais de decisão e de controle pressupõem, do ponto de vista da organização escolar existente, uma perda de poder de mando dos catedráticos e uma espécie de democratização das decisões essenciais em diferentes linhas (Fernandes, 1975, p. 83-4).

Embora Florestan Fernandes defenda aparentemente o mesmo processo de Atcon, de racionalização e eficiência universitária, tanto o seu sentido social quanto o seu significado 
político são essencialmente distintos. Como o sociólogo brasileiro faz questão de enfatizar, o pressuposto da racionalização da universidade não é o avanço de um conhecimento gerencial que profissionalize e, portanto, centralize, os meios de ação e decisão entre os altos dirigentes portadores desse novo saber. Ao contrário, a racionalização da universidade passa necessariamente pela "perda de mando" dos escalões mais altos da instituição e a consequente “democratização das decisões essenciais em diferentes linhas" (Fernandes, 1975, p. 84). O princípio da racionalização universitária reside, portanto, no reconhecimento da dimensão política das decisões universitárias e no pressuposto de que a democracia é a forma mais racional de governo acadêmico, entendendo democracia, nesse caso, mais como processo de tomada de decisão, baseado no amplo, público e livre exercício da crítica, do que como forma de governo propriamente dita.

Para Rudolph Atcon, ao contrário, a racionalização da universidade passa justamente pela negação da dimensão política das decisões acadêmicas que, reinterpretadas como escolhas técnicas, devem estar concentradas em pequenos grupos de altos dirigentes cuja competência não deriva mais da experiência universitária compartilhada - ou seja, do pertencimento a uma comunidade acadêmica em seus diferentes níveis - mas, antes, do controle de conhecimentos gerenciais especializados sobre o funcionamento da universidade e de dispositivos materiais a eles associados. As decisões acadêmicas tornam-se racionais não porque foram submetidas ao amplo debate, à crítica aberta e à livre escolha da comunidade universitária, mas porque se adequaram a uma visão "correta" sobre o funcionamento da universidade. Como afirma o próprio Atcon, "a estrutura organizacional e a coincidente administração central da universidade" resultam diretamente de uma "teoria internamente coerente e consistente" sobre o que é a universidade, “com seus fundamentos filosóficos e seus objetivos intrínsecos” (1974, p. 3). Portanto é a emergência de uma "teoria integral sobre a totalidade universitária" (1974, p. 3), capaz de definir o que a universidade é e como ela deve se organizar, que passa a orientar 
as escolhas acadêmicas, que se tornam racionais na medida em que adequadas a um novo regime de verdade. Nas palavras de Atcon:

\begin{abstract}
$\mathrm{Na}$ universidade, o planejamento apareceu na década de cinquenta, concomitantemente com as primeiras tentativas, mais ou menos conscientes, de reestruturar a instituição. Até então, ela havia sofrido reformas, mas pouca estruturação deveras planejada, porque faltava, como falta ainda por toda a parte, um planejamento em conformidade consistente com uma teoria (Atcon, 1974, p. 13; grifo meu).
\end{abstract}

A racionalização administrativa das universidades, nessa nova perspectiva inspirada pelo conhecimento gerencial, assume um sentido exclusivamente instrumental, passando a expressar apenas o modo mais "correto" de organização institucional, que Atcon define como:

[...] uma administração central de serviços, em função da estrutura institucional estabelecida e não de estruturas antigas ou alheias. Suas facetas devem obedecer ao princípio de um serviço normativo centralizado com descentralização executiva, para que o todo passe a ser uma só preocupação a favor do desenvolvimento acadêmicocientífico ininterrupto. Abarca a totalidade de controle e serviços, desde atividades genéricas - como orçamento, manutenção, construção et al. - até serviços especializados - como teatro, biblioteca, lojas, refeitório et al. - ou qualquer outra atividade extracurricular, de extensão artística ou social e, por certo, acadêmicocientífica (Atcon, 1974, p. 13).

Assim, a racionalização administrativa passa a ser sinônimo de uma adequação das estruturas de governo aos princípios das teorias modernas da gestão, sejam elas as teorias administrativas da universidade, como a formulada por Atcon a partir do final dos anos 1960, as teorias organizacionais, que passaram a se difundir no país a partir dos anos 1970, ou, ainda, as teorias da nova gestão pública que inspiram as reformas administrativas dos anos 1980 e 1990. Em todos esses casos, trata-se da aplicação de um sistema de classificação particular que, sob a forma de um conhecimento gerencial, valoriza a eficiência, a utilidade, o controle, afirmando, através dessas diretrizes e valores, uma concepção pragmática e heterônoma de universidade e de conhecimento.

Nesse sentido, talvez a consequência mais profunda da expansão do conhecimento gerencial - enquanto um novo regime de verdade com seus dispositivos de saber-poder correspondentes e como um sistema de classificação a ele associado - foi a imposição de um 
sentido único para o ideal de racionalização universitária que, antes da sua afirmação como resultado exclusivamente ligado à aplicação do conhecimento gerencial, estava sob franca disputa teórica, simbólica e política. A expansão desse novo saber, que corresponde a um esquema de percepção, pensamento e ação, pode ser considerada, portanto, um caso típico de imposição simbólica. Ao se afirmar como a visão legítima, porque baseada em pressupostos "verdadeiros", logo "científicos", sobre o funcionamento da universidade, esse novo conhecimento afirmou, ao mesmo tempo, a visão de universidade inerente ao polo dominante desse espaço social, formado pelas faculdades profissionais tradicionais que valorizam o caráter pragmático, utilitário e eficiente do conhecimento, que está na base não só dos novos dispositivos de governo e controle, como do novo padrão de expansão universitária que emerge dessas reformas.

Em síntese, a legitimação de uma visão gerencial delimitou o campo do pensável em termos de ensino superior, impondo-se como uma espécie de "bom senso", uma visão "sensata" 133 do que é e de como deve funcionar a universidade. A afirmação de um ideal técnico de racionalização universitária, em que racionalização significa eficiência de gestão, é uma das expressões mais significativas desse processo de afirmação de uma visão de mundo e constitui um exemplo, dos mais interessantes, de violência simbólica (cf. Bourdieu, 1989, p. 48ss). Essa visão, ao obliterar a sua gênese social, acaba naturalizando-se como a única visão sensata sobre o funcionamento da universidade. A intenção da investigação de como esse processo se desenvolveu no Brasil e na USP é resgatar, em parte, a gênese social dessa visão de universidade, a partir da derrota do polo mais autônomo, na reforma universitária implementada pelo governo militar no final dos anos 1960.

\footnotetext{
${ }^{133}$ Ao analisar os discursos dos dirigentes da USP ficará mais claro como as categorias de "bom senso" e "sensatez", oposta à loucura, irresponsabilidade e ingenuidade é fundamental para organizar a retórica sobre o funcionamento do ensino superior.
} 


\subsubsection{A síntese governamental: o Grupo de Trabalho da Reforma Universitária, a Comissão Especial Meira Mattos e a Lei 5.540/1968 para a reforma do ensino superior}

O primeiro semestre de 1968 foi marcado pelo fortalecimento do movimento estudantil e docente no país e das suas propostas de reforma universitária. Tendo como pano de fundo a crescente radicalização da luta contra a ditadura, a crise dos excedentes e a explosão de protestos estudantis em diversos países, setores cada vez maiores das universidades passaram a reivindicar a abertura de processos internos de reforma universitária. A situação da USP - que, naquele momento, já podia ser considerada a maior e mais importante universidade pública brasileira -, com as comissões paritárias, era paradigmática. Incluindo professores e estudantes em proporções iguais e baseadas no padrão colegiado de decisão, as comissões paritárias pretendiam constituir-se como um modelo democrático para a reforma do ensino superior e testemunhavam a força do movimento social em prol de uma reforma autônoma das universidades brasileiras (cf. Fernandes, 1975).

A primeira instância paritária da USP surgiu no começo de 1968, durante um processo de reforma curricular do curso de ciências sociais da FFCL-USP, provocando uma enorme discussão, no âmbito da congregação dessa faculdade, sobre a sua legitimidade institucional (cf. Celeste Filho, 2013). Em meio ao acirramento das disputas no interior do corpo docente da FFCL-USP, o movimento estudantil também intensificou a pressão interna pela democratização da USP. A notícia, veiculada pelos jornais de São Paulo, de uma visita do consultor norteamericano Rudolph Atcon à USP, supostamente em 12 de junho de 1968, foi o mote para que o movimento ocupasse a reitoria por algumas horas para exigir, em audiência com o reitor, a participação estudantil no processo de reforma da $\mathrm{USP}^{134}$. Aos poucos, o movimento começa a

\footnotetext{
${ }^{134}$ A ocupação da reitoria em 12 de junho de 1968, por ocasião de uma suposta visita de Rudolph Atcon à USP, durou algumas horas e envolveu por volta de 2 mil estudantes. No seu livro sobre a reforma da USP, Macioniro Celeste Filho insere um longo trecho do depoimento dado pelo então reitor, Mario Guimarães Ferri, em agosto de 1968, à CPI criada pelo Congresso Nacional para investigar "a extensão da violência contra o movimento estudantil em todo o país" (cf. Celeste Filho, 2013, p. 170-3).
} 
ganhar força inclusive nas faculdades profissionais mais tradicionais da universidade: em 23 de junho de 1968, os estudantes da tradicional Faculdade de Direito da USP, liderados pelo seu importante centro acadêmico, o XI de Agosto, iniciam uma ocupação da faculdade que denominaram "a tomada", que duraria 26 dias tendo como objetivos principais a reforma acadêmica do curso e a instalação de uma comissão paritária para a reforma universitária (cf. Centro Acadêmico XI de Agosto, 2003, p. 78-9) ${ }^{135}$.

Foi nesse contexto político que a Comissão Especial pela Reestruturação da USP, criada pelo Conselho Universitário em 1966, encerrou seus trabalhos encaminhando ao órgão o seu Memorial sobre a reestruturação da Universidade de São Paulo (USP, 1968). Em $1^{\circ} \mathrm{de}$ julho de 1968, o reitor remeteu a proposta da Comissão Especial a todas as unidades da USP para que fosse discutida no âmbito das congregações, com as apreciações sendo remetidas para a decisão final do Conselho Universitário. Foi justamente a partir da afirmação desse caminho institucional para a reforma da USP que a experiência original da comissão paritária das ciências sociais foi reapropriada pelo movimento estudantil e docente da universidade na tentativa de afirmar uma alternativa ao movimento "oficial" de reforma. Com esse sentido político específico, as comissões paritárias se espalharam rapidamente pela universidade. Primeiro, a FFCL-USP aprovou, em uma reunião aberta e controversa da sua congregação, a criação de uma comissão paritária no âmbito da faculdade. Em seguida, outras unidades, incluindo faculdades profissionais como a Faculdade de Economia e Administração, a Faculdade de Arquitetura e Urbanismo, a Faculdade de Saúde Pública, a Faculdade de Odontologia e a Faculdade de Medicina de Ribeirão Preto criaram comissões ou fóruns, se não

\footnotetext{
135 No manifesto publicado pelo Centro Acadêmico XI de Agosto em 24 de junho de 1968, um dia depois da ocupação, os ocupantes explicitam seus objetivos: "O primeiro objetivo de novo movimento é a total reforma da nossa escola". E depois de explicitar os aspectos pedagógicos da mudança reivindicada, concluem exigindo a formação de uma comissão paritária e remetendo o movimento para a disputa geral pela reforma universitária. O documento conclui afirmando que "enquanto não for encaminhado satisfatoriamente o problema da reestruturação das universidades" os alunos continuariam ocupando a faculdade (cf. Centro Acadêmico XI de Agosto, 2003, p. 78). A faculdade terminou invadida pela Polícia Militar, a pedido do então diretor Alfredo Buzaid, sem que as reivindicações dos estudantes fossem atendidas.
} 
paritários, ao menos formados por representantes de professores e alunos para a discussão da proposta oficial da reitoria e a elaboração de sugestões alternativas ou complementares. Presentes nas diferentes unidades e tendo como pano de fundo uma crise institucional ligada à falta de autonomia dos órgãos centrais no contexto ditatorial, as comissões paritárias foram, aos poucos, se afirmando como uma instância legítima e viável para a reforma universitária ${ }^{136}$, aprofundando ainda mais o conflito interno à Universidade de São Paulo (cf. Celeste Filho, 2013; Cunha, 2007c).

Em resposta à crise da USP e de outras universidades que também vivenciavam um aumento das suas tensões internas ${ }^{137}$, o presidente Costa e Silva instituiu, por decreto, um “Grupo de Trabalho para promover a reforma universitária” (Brasil, 1968b, p. 11). Composto de onze membros nomeados diretamente pelo Presidente da República, incluindo dois estudantes que declinaram da indicação, o GT da Reforma Universitária, como ficou conhecido, iniciou seus trabalhos em 10 de julho de 1968, funcionando em tempo integral durante 30 dias sob a presidência do então Ministro da Educação, Tarso Dutra. O resultado final do GT foi um relatório publicado em agosto do mesmo ano sob o título Reforma Universitária: relatório do grupo de trabalho criado pelo decreto $n^{\circ} 62.937 / 68^{138}$. Depois de algumas considerações de ordem geral, o relatório apresentava, em anexo, um anteprojeto de lei para a organização do

\footnotetext{
${ }^{136}$ Chegou a ser apresentada no Conselho Universitário da USP a proposta de que a reforma fosse realizada por uma outra instância formada pelas diferentes comissões paritárias, o que está na raiz da proposta de um "congresso estatuinte da USP", reapropriada nos anos 1980 pelos movimentos estudantil, funcional e docente da universidade. Essa proposta não chegou a ser votada no Conselho Universitário, mas os relatórios das diferentes comissões paritárias da USP foram anexados, como subsídio, ao processo de reforma universitária da USP votado pelo órgão, o que indica o seu reconhecimento institucional. Celeste Filho vai além e afirma que a proposta de encaminhamento da reforma, proposta por Hélio Lourenço de Oliveira ao Conselho Universitário e finalmente aprovada, resulta dos trabalhos da Comissão Paritária da FMRP e que a ideia de uma instância paritária na estrutura decisória da universidade, denominada então "Assembleia Universitária", foi proposta e aprovada pela reforma universitária da USP de 1969 (cf. Celeste Filho, 2013).

${ }^{137}$ Existem registros de crises semelhantes, em 1968, em diversas universidades importantes do país como a UnB, a UFMG, a UFRGS, a UFPA e a PUC (cf. Celeste Filho, 2013; Cunha, 2007c; Mattos, 2014).

${ }^{138}$ Há duas versões, uma de agosto e outra de setembro de 1968. Entre elas há diferenças mínimas, mas a de setembro é mais completa. Em todo caso, é importante notar que em agosto de 1968 os resultados dos trabalhos da comissão já eram conhecidos (cf. Brasil, 1968a; 1968b).
} 
ensino superior, seguido de outros anteprojetos de leis e decretos complementares (cf. Brasil, 1968b, p. 69ss). Juntos, essas leis e decretos constituíram, com pequenas alterações, o marco legal da reforma universitária. Seu sentido geral está expresso no primeiro artigo do decreto $\mathrm{n}^{\circ}$ 62.937 de 2 de julho de 1968 que instituiu o GT da Reforma Universitária testemunhando de modo paradigmático a força do consenso em torno da centralidade da dimensão administrativa no equacionamento da crise universitária brasileira:

Art. $1^{\circ}$ - Fica instituído, no Ministério da Educação e Cultura, um grupo de trabalho, com onze membros, designado pelo Presidente da República, para estudar a Reforma da Universidade brasileira, visando à sua eficiência, modernização, flexibilidade administrativa e formação de recursos humanos de alto nível para o desenvolvimento do país (Brasil, 1968b, p. 5; grifo meu).

Partindo do princípio de que o cerne das mudanças viabilizadas pela reforma universitária deveria ser, acima de tudo, de ordem administrativa, visando a eficiência, a eficácia, e a produtividade das universidades, o Grupo de Trabalho resumia os objetivos essenciais da reforma universitária nos seguintes termos:

Do primeiro ponto de vista, a reforma tem objetivos práticos e tende a conferir ao sistema universitário uma espécie de racionalidade instrumental em termos de eficiência técnico-profissional, que tem por consequência o aumento da produtividade dos sistemas econômicos (Brasil, 1968b, p. 24; grifos meus).

A ideia de que a prioridade da reforma universitária deveria ser o aumento da racionalidade instrumental das instituições isoladas e a eficiência administrativa do sistema como um todo estava, portanto, disseminada e passava a orientar os trabalhos do grupo instituído pelo governo militar para redesenhar o funcionamento e a organização das universidades nacionais. Ao analisar o resultado desse trabalho do grupo, Luiz Antônio Cunha também reconhece a força desse consenso difuso. Segundo o historiador, "o Relatório estava de tal modo impregnado da ideia de racionalização que isso não pode ser atribuído apenas à influência dos dois economistas que compunham o GT" (2007c, p. 237) $)^{139}$. Mais do que uma

\footnotetext{
${ }^{139}$ No seu trabalho sobre a reforma universitária, Rodrigo Patto Sá Motta afirma que o processo de constituição do GT da reforma universitária foi iniciativa de técnicos de planejamento ligados ao IPEA, à Seplan (Secretaria de Planejamento) e à Finep, especialmente João Paulo dos Reis Velloso (cf. Mattos, 2014, p. 104). Mas Rothen
} 
influência lateral, “a ideia da racionalização é o princípio básico da reforma universitária proposta, dela derivando as demais diretrizes, balizadas em categorias próprias da linguagem tecnicista: eficiência, eficácia, produtividade e outras" (Cunha, 2007c, p. 237). O que o historiador denomina genericamente de "linguagem tecnicista" constitui, na verdade, uma concepção mais propriamente gerencial - como regime de verdade, prática de intervenção social dele derivado e sistema classificatório elementar - que é ao mesmo tempo causa e consequência da transformação da universidade em objeto de gestão.

O anteprojeto de lei formulado pelo Grupo de Trabalho da Reforma Universitária foi enviado ao Congresso Nacional em outubro de 1968. Pelo prazo estipulado pelo governo, a Câmara e o Senado teriam quarenta dias para analisar, discutir e votar a proposta. Depois de algumas semanas de debate parlamentar, o projeto de lei da reforma universitária foi aprovado no Congresso com o acréscimo de algumas emendas que procuravam, no geral, aumentar a participação estudantil nos órgãos colegiados da Universidade e assegurar a autonomia universitária protegendo as instituições de intervenções diretas do Estado, sobretudo na escolha dos seus dirigentes (cf. Celeste Filho, 2013, p. 73ss; Cunha, 2007c, p. 219ss).

Poucos dias depois da tramitação da reforma universitária pelo Congresso, em 28 de novembro de 1968, o Presidente Costa e Silva sancionou a lei 5.540/68 que "fixa normas de organização e funcionamento do ensino superior e sua articulação com a escola média e dá outras providências” (Brasil, 1969, p. 54). A versão final da Lei da Reforma Universitária, sancionada pelo executivo, não respeitou as emendas congressuais propostas na Câmara e no Senado, tampouco acatou integralmente a proposta do GT pela reforma universitária ${ }^{140}$. A intervenção do executivo nos dois casos caminhou em um mesmo sentido: limitar a autonomia

enfatiza também o papel do Conselho Federal de Educação que buscava ampliar sua influência na política educacional (cf. 2008).

${ }^{140}$ Os debates e as emendas parlamentares, bem como os vetos presidenciais de que foi objeto a lei, são analisados em detalhe por Luiz Antônio Cunha (2007c) e Macioniro Celeste Filho (2013). 
e as tentativas incipientes de democratização universitária. Nessa direção, foram vetados todos os artigos e parágrafos que definiam os termos específicos da autonomia didático-científica, disciplinar, administrativa e financeira das universidades, funcionando como garantias à intervenção estatal. Também foram vetados os dispositivos que asseguravam a participação estudantil nos órgãos colegiados em um percentual superior a $20 \%$ do corpo docente, bem como os que estabeleciam as regras de eleição dos dirigentes acadêmicos independentemente da intervenção estatal. Em suma, o governo militar interviu no sentido de restringir a participação estudantil nos órgãos colegiados e aumentar a influência governamental sobre as universidades, limitando a sua autonomia.

Em termos mais concretos, a interferência do governo militar na lei da reforma universitária sugerida pelo Grupo de Trabalho e aprovada pelo Congresso teve um único princípio: incorporar as principais recomendações do Relatório Meira Mattos, como ficou conhecido o documento final da Comissão Especial "para propor medidas relacionadas com os problemas estudantis" (Brasil, 1967, p. 69), criada pelo decreto federal $n^{\circ} 62.024$ de 29 de dezembro de 1967. Presidida pelo então coronel Carlos de Meira Mattos, a Comissão Especial buscava indicar meios práticos para "controlar o movimento estudantil e enfrentar o problema dos excedentes do exame vestibular" (Rothen, 2008, p. 460). Enquanto o Grupo de Trabalho pela Reforma Universitária foi marcado pela hegemonia dos técnicos de planejamento e do Conselho Federal de Educação representando, sobretudo, a proposta dos educadores profissionais, bacharéis ou economistas (cf. Almeida, 2008), ligados ao regime, a Comissão Especial presidida pelo coronel Meira Mattos representou, por outro lado, a proposta de reforma dos próprios militares. Isso explica por que, não obstante os pontos de contato entre uma proposta e outra, existem divergências sobretudo na forma como os dois documentos concebem a autonomia universitária (cf. Rothen, 2008). 
Ao se acompanhar a argumentação do Relatório Meira Mattos, como é conhecido o relatório final da Comissão Especial, é possível notar que, assim como os outros documentos produzidos pelo campo governamental no período, ele compartilha tanto uma visão econômica da educação, expressa na necessidade de articular pragmaticamente educação e desenvolvimento social, quanto a perspectiva gerencial dela derivada, que resultava na ênfase em aprimorar a eficiência das universidades através da aplicação de ferramentas administrativas, o que indica que essa perspectiva era, de fato, o substrato comum às diferentes propostas formuladas, na época, pelo plano governamental. No entanto, mais do que qualquer outro documento, o relatório destaca a importância de fortalecer a "estrutura de comando" das instituições de ensino isoladas e do sistema educacional como um todo, como meio de enfrentar tanto os crescentes protestos estudantis quanto a chamada crise dos excedentes, ou seja, para governar e expandir as universidades. Assim, inspirada na estrutura militar de comando, e legitimada pelas modernas teorias de gestão que enfatizavam o papel dos líderes institucionais, uma das principais recomendações do relatório era simplificar e centralizar a estrutura decisória do sistema educacional:

É condição fundamental para o bom funcionamento de qualquer empresa a existência de uma estrutura adequada a sua finalidade. A estrutura empresarial deve oferecer uma organicidade lógica, criando escalões sucessivos de direção técnica e de administração, tudo no sentido de assegurar a fluição [sic] natural das ordens e diretrizes, a sua apreciação por setores especializados, a intercomunicação entre esses setores, a coordenação administrativa e técnica e o fácil trânsito vertical de cima para baixo e de baixo para cima. Somente uma estrutura racional e equilibrada, sem estrangulamentos nem evasões, pode assegurar a dinâmica do fluxo administrativo nos sentidos horizontal e vertical, justificando as mais modernas teorias de técnica organizacional defendidas pelos professores de Administração, Richard Johnson, Fremont Kast e James Rosenweig, da Universidade de Washington. Por outro lado, um dos princípios básicos da boa administração, que deve estar esquematizado nas organizações das empresas, sejam do serviço público sejam privadas, é o requisito de que "a estrutura do sistema deve conter o menor número possível de níveis de chefia, e forme a cadeia de comando mais curta possível" (The practice of management, de Peter Drucker) (Brasil, 1968c, p. 81-2).

Partindo dessas teorias gerenciais de origem norte-americana, o relatório atribui à ausência de uma cadeia de comando bem definida tanto a inoperância do MEC e de seus órgãos complementares, “emperrados por uma estrutura que não resiste à menor lógica” (Brasil, 1968c, 
p. 82), quanto a crise de autoridade do sistema educacional, seja em função do excesso de poder do Conselho Federal de Educação, seja por conta da "ampla autonomia administrativa e disciplinar conferida às universidades pela Lei de Diretrizes e Bases” (Brasil, 1968c, p. 85). No caso do CFE, a proposta geral do Relatório Meira Mattos foi transferir suas prerrogativas, sobretudo legislativas, para o ministro da educação, de modo que o governo tivesse o poder de impor políticas educacionais sem "esbarrar em várias atribuições que são de competência exclusiva do Conselho Federal de Educação" (Brasil, 1968c, p. 84). Já no caso específico das universidades, o cerne da proposta do relatório era fortalecer os cargos executivos como os de reitor e de diretor de unidade que, uma vez indicados direta ou indiretamente pelo governo, federal, estadual ou municipal, deveriam concentrar as decisões acadêmicas, disciplinando o poder disperso entre o conselho universitário, as congregações de unidades e demais órgãos colegiados da universidade:

\begin{abstract}
Com efeito, pelo sistema da atual legislação, reitores e diretores de escola dividem os seus deveres e responsabilidades, respectivamente, com os Conselhos Universitários e as Congregações, órgãos que, inegavelmente, podem exercer pressão sobre os ditos reitores e diretores, os quais só podem ser nomeados após incluídos na lista tríplice elaborada pelos mesmos colegiados. Parece evidente que, dependendo do voto de diretores de escola ou dos professores colegas de congregação, o reitor e o diretor, respectivamente, hão de assumir compromissos que os impedem de exercer com inteira isenção as suas altas funções. Por outro lado, várias de suas decisões administrativas e disciplinares dependem das aprovações dos respectivos Conselhos ou Congregações (Brasil, 1968c, p. 85-6).
\end{abstract}

Nesse sentido, para contornar os males do governo colegiado e superar tanto o problema dos estudantes excedentes quanto o dos excessos estudantis, o relatório Meira Mattos propõe, por um lado, a restrição da autonomia da comunidade universitária na escolha do seus dirigentes máximos e, por outro, o esvaziamento dos órgãos colegiados de gestão com a consequente concentração de poder administrativo e disciplinar no executivo da universidade, representados pela figura do reitor e dos diretores de unidade. Foi justamente nesse sentido que caminhou a intervenção do governo federal na Lei da Reforma Universitária de novembro de 1968 que, no entanto, preservou os traços modernizantes presentes do texto original proposto pelo Grupo de 
Trabalho da Reforma Universitária e aprovado, em linhas gerais, pelo Congresso Nacional. A coexistência entre o princípio da disciplina e o princípio da modernização administrativa é um aspecto central da reforma universitária promovida nos anos 1960 segundo a historiadora Maria de Lourdes de Albuquerque Fávero, que identifica em Rudolph Atcon e Carlos de Meira Mattos os dois ideólogos principais da nossa reforma universitária de 1968 (cf. Fávero, 1991).

Partindo da reconstrução do percurso e das concepções gerais da reforma universitária de 1968 para uma análise mais detida da lei 5.540 de 1968, apresentamos abaixo seus aspectos centrais com a íntegra dos artigos correspondentes a cada um desses pontos:

a) O primeiro artigo da lei traz, em termos bastante sintéticos, os objetivos do ensino superior brasileiro conferindo à pesquisa e ao desenvolvimento das ciências, das letras e das artes o mesmo peso da formação profissional. Estão explicitados, mais uma vez, os dois polos essenciais que estruturam o ensino superior brasileiro.

Art. $1^{\circ} \mathrm{O}$ ensino superior tem por objetivo a pesquisa, o desenvolvimento das ciências, letras e artes e a formação de profissionais de nível universitário.

b) A lei mantém a "universidade" como forma institucional privilegiada do ensino superior mas, ao contrário da LBD que estabelecia a obrigatoriedade da Faculdade de Filosofia, Ciências e Letras para que um conjunto de escolas pudesse ser denominado "universidade", a nova lei suspendeu a obrigatoriedade das FFCLs, abrindo caminho não só para a sua eliminação como para a consequente diversificação do ensino superior que, hoje, assume cada vez mais, um perfil "não universitário" (Inep, 2006, p. 15). Nesse sentido, o segundo artigo da lei afirma sem maiores distinções:

Art. $2^{\circ} \mathrm{O}$ ensino superior, indissociável da pesquisa, será ministrado em universidades e, excepcionalmente, em estabelecimentos isolados, organizados como instituições de direito público ou privado.

c) Como já foi dito, a versão final da lei 5.540/68 eliminou todos os incisos e parágrafos 
que qualificavam a autonomia universitária, substituindo-os por uma formulação genérica que estabelecia o exercício da autonomia "nos termos da lei". Essa imprecisão abriu espaço, na prática, para diversas formas de submissão das universidades aos executivos federal, estadual e municipal, dependendo do seu atrelamento institucional. Essa suspensão de garantias jurídicas foi acrescida de outros artigos que feriam, igualmente, a autonomia universitária. No artigo $5^{\circ}$, a lei estabelecia que os estatutos e regimentos universitários deveriam ser submetidos ao conselho de educação competente - federal, no caso das universidades federais, e estadual, no caso das estaduais. $\mathrm{O}$ artigo $16^{\circ}$, por sua vez, definia as regras de nomeação dos reitores a partir de uma lista sêxtupla que conferia enorme poder ao Estado na escolha dos dirigentes acadêmicos. Paralelamente, o artigo conferia, no seu inciso $4^{\circ}$, poder disciplinar aos cargos executivos, representados pelo reitor e pelos diretores de unidade, testemunhando o seu fortalecimento em detrimento dos órgãos colegiados correspondentes.

Art. $3^{\circ}$ As universidades gozarão de autonomia didático-científica, disciplinar, administrativa e financeira, que será exercida na forma da lei e dos seus estatutos. Art. $5^{\circ} \mathrm{A}$ organização e o funcionamento das universidades serão disciplinados em estatutos e em regimentos das unidades que as constituem, os quais serão submetidos à aprovação do Conselho de Educação competente.

Art. 16. A nomeação de Reitores e Vice-Reitores de universidades e Diretores e ViceDiretores de unidades universitárias ou estabelecimentos isolados far-se-á com observância dos seguintes princípios:

I - o Reitor e o Vice-Reitor de universidade oficial serão nomeados pelo respectivo Govêrno e escolhidos de listas de nomes indicados pelo Conselho Universitário ou colegiado equivalente;

$\S 1^{\circ}$ Os Reitores, Vice-Reitores, Diretores e Vice-Diretores das instituições de ensino superior, mantidas pela União, salvo o disposto no $\S 3^{\circ}$ dêste artigo, serão indicados em lista de seis nomes pelos respectivos colegiados e nomeados pelo Presidente da República.

$\S 2^{\circ}$ Será de quatro anos o mandato dos Reitores, Vice-Reitores, Diretores e ViceDiretores, vedado o exercício de dois mandatos consecutivos.

$\S 3^{\circ}$ (Vetado).

$\S 4^{\circ}$ Ao Reitor e ao Diretor caberá zelar pela manutenção da ordem e disciplina no âmbito de suas atribuições, respondendo por abuso ou omissão.

d) No mesmo sentido, ao definir os princípios da organização universitária, a lei enfatizava a importância das instâncias centrais de poder que deveriam 
"supervisionar o ensino e a pesquisa com atribuições deliberativas", o que significava, na prática, o enfraquecimento dos órgãos colegiados e a concentração de poder nos órgãos executivos acadêmicos. Em total consonância com a centralização do poder e com o fortalecimento dos órgãos executivos centrais, a lei reafirmava princípios gerenciais elementares como a racionalidade, a flexibilidade e a eficiência no uso dos recursos:

Art. 11. As universidades organizar-se-ão com as seguintes características: a) unidade de patrimônio e administração; b) estrutura orgânica com base em departamentos reunidos ou não em unidades mais amplas; c) unidade de funções de ensino e pesquisa, vedada a duplicação de meios para fins idênticos ou equivalentes; d) racionalidade de organização, com plena utilização dos recursos materiais e humanos; e) universalidade de campo, pelo cultivo das áreas fundamentais dos conhecimentos humanos, estudados em si mesmos ou em razão de ulteriores aplicações e de uma ou mais áreas técnico-profissionais; f) flexibilidade de métodos e critérios, com vistas às diferenças individuais dos alunos, às peculiaridades regionais e às possibilidades de combinação dos conhecimentos para novos cursos e programas de pesquisa;

Art. 13. Na administração superior da universidade, haverá órgãos centrais de supervisão do ensino e da pesquisa, com atribuições deliberativas, dos quais devem participar docentes dos vários setores básicos e de formação profissional.

$\S 1^{\circ}$ A universidade poderá também criar órgãos setoriais, com funções deliberativas e executivas, destinados a coordenar unidades afins para integração de suas atividades. $\S 2^{\circ}$ A coordenação didática de cada curso ficará a cargo de um colegiado, constituído de representantes das unidades que participem do respectivo ensino.

e) Um outro exemplo da perda de autonomia das universidades é a transferência da responsabilidade de organização da pós-graduação para o Conselho Federal de Educação. A pós-graduação, que concentrará a expansão das atividades de pesquisa das universidades, passará a ser um caminho decisivo para a intervenção federal no funcionamento interno das instituições universitárias:

Art. 24. O Conselho Federal de Educação conceituará os cursos de pós-graduação e baixará normas gerais para sua organização, dependendo sua validade, no território nacional, de os estudos neles realizados terem os cursos respectivos credenciados por aquele órgão.

f) Com o esvaziamento da autonomia universitária, o fortalecimento dos órgãos executivos e a centralização do poder acadêmico, a proposta de extinguir as cátedras e tornar o departamento a unidade básica da universidade foi aprovada, mas perdeu o seu sentido original, de órgão colegiado responsável por incluir todos os 
professores nas decisões essenciais da universidade. Como correlato da departamentalização, a regulamentação da carreira docente também foi aprovada e a despeito do enorme impacto que gerou na organização e profissionalização da atividade acadêmica, não pôde cumprir um dos seus objetivos principais, de distribuição igualitária dos direitos e deveres concentrados pela cátedra para o conjunto do corpo docente. Esse objetivo geral foi frustrado por um decreto complementar de $1969^{141}$ que equiparou o cargo dos antigos "catedráticos" ao dos novos "titulares", contribuindo para subverter ainda mais o ideal de democratização pressuposto na defesa original da departamentalização e da consolidação da carreira docente pelas FFCLs e demais áreas de pesquisa da universidade, organizadas principalmente na SBPC.

Art. 12. O departamento será a menor fração da estrutura universitária para todos os efeitos de organização administrativa, didático-científica e de distribuição de pessoal, e compreenderá disciplinas afins.

Art. 32. Entendem-se como atividades de magistério superior, para efeitos desta lei: a) as que, pertinentes ao sistema indissociável de ensino e pesquisa, se exerçam nas universidades e nos estabelecimentos isolados, em nível de graduação, ou mais elevado, para fins de transmissão e ampliação do saber; b) as inerentes à administração escolar e universitária exercida por professores.

$\S 1^{\circ}$ Haverá apenas uma carreira docente, obedecendo ao princípio da integração de ensino e pesquisa.

$\S 2^{\circ}$ Serão considerados, em caráter preferencial, para o ingresso e a promoção na carreira docente do magistério superior, os títulos universitários e o teor científico dos trabalhos dos candidatos.

Art. 33. Os cargos e funções de magistério, mesmo os já criados ou providos, serão desvinculados de campos específicos de conhecimentos.

$\S 1^{\circ}$ (Vetado).

$\S 2^{\circ}$ Nos departamentos, poderá haver mais de um professor em cada nível de carreira. $\S 3^{\circ}$ Fica extinta a cátedra ou cadeira na organização do ensino superior do País.

g) Outra demanda que é em parte aprovada, em parte subvertida é a presença da representação estudantil nos órgãos colegiados. Subvertida porque além dos

${ }^{141}$ O Decreto-Lei n ${ }^{\circ} 465$ de 11 de fevereiro de 1969 que "estabelece normas complementares à Lei 5.539 de 27 de novembro de 1968 e dá outras providências" define que os cargos e funções do magistério superior seriam compostos de três níveis hierárquicos: professor titular, professor adjunto e professor assistente, esses dois últimos supridos por concurso de provas e títulos. Quanto aos professores titulares, o decreto afirma no seu artigo 11: "Os atuais ocupantes de cargos de professor catedrático passam automaticamente a professores titulares" (Brasil, 1969, p. 103). 
colegiados terem sido relativamente esvaziados pela reforma, o movimento continuou a ser controlado e disciplinado por instâncias superiores tal como previsto pela chamada Lei Suplicy Lacerda (cf. Cunha 2007c). Cabe destacar, por sinal, que a tutela das entidades estudantis conferiu ainda mais força à cisão que se estabeleceu entre o movimento estudantil organizado em órgãos representativos muitas vezes clandestinos, os chamados diretórios livres, e o movimento oficial organizado em torno dos novos representantes discentes, submetidos a critérios de rendimento escolar e pautados pelo princípio de "cooperação com a administração".

\footnotetext{
Art. 38. O corpo discente terá representação, com direito a voz e voto, nos órgãos colegiados das universidades e dos estabelecimentos isolados de ensino superior, bem como em comissões instituídas na forma dos estatutos e regimentos.

$\S 1^{\circ}$ A representação estudantil terá por objetivo a cooperação entre administradores, professores e alunos, no trabalho universitário.

$\S 2^{\circ}$ A escolha dos representantes estudantis será feita por meio de eleições do corpo discente e segundo critérios que incluam o aproveitamento escolar dos candidatos, de acordo com os estatutos e regimentos.

$\S 3^{\circ}$ A representação estudantil não poderá exceder de um quinto do total dos membros dos colegiados e comissões.

Art. 39. Em cada universidade ou estabelecimento isolado do ensino superior poderá ser organizado diretório para congregar os membros do respectivo corpo discente.

$\S 1^{\circ}$ Além do diretório de âmbito universitário, poderão formar-se diretórios setoriais, de acordo com a estrutura interna de cada universidade.

$\S 2^{\circ}$ Os regimentos elaborados pelos diretórios serão submetidos à aprovação da instância universitária ou escolar competente.

$\S 3^{\circ} \mathrm{O}$ diretório cuja ação não estiver em consonância com os objetivos para os quais foi instituído será passível das sanções previstas nos estatutos ou regimentos.

$\S 4^{\circ}$ Os diretórios são obrigados a prestar contas de sua gestão financeira aos órgãos da administração universitária ou escolar, na forma dos estatutos e regimentos.
}

h) Outra medida que teve impacto decisivo na reorganização do ensino superior foi a possibilidade da criação de cursos profissionais ainda não regulamentados pelo CFE bem como de graduações de curta duração. Inspirados na concepção econômica da educação que defendia, como foi dito, aproximar a universidade do mercado de trabalho para aumentar a eficiência, a eficácia e a rentabilidade do ensino superior, a abertura de novas profissões e de formações universitárias curtas redefiniu o padrão de expansão do ensino superior brasileiro. A partir de 1968, esse novo padrão de expansão fortaleceu o polo profissional que, conforme se verá no próximo 
capítulo, se expandiu sem democratizar o acesso às profissões mais tradicionais da universidade como medicina, engenharia, direito e, cada vez mais, economia e administração:

\begin{abstract}
Art. 18. Além dos cursos correspondentes a profissões reguladas em lei, as universidades e os estabelecimentos isolados poderão organizar outros para atender às exigências de sua programação específica e fazer face a peculiaridades do mercado de trabalho regional.

Art. 23. Os cursos profissionais poderão, segundo a área abrangida, apresentar modalidades diferentes quanto ao número e à duração, a fim de corresponder às condições do mercado de trabalho.

$\S 1^{\circ}$ Serão organizados cursos profissionais de curta duração, destinados a proporcionar habilitações intermediárias de grau superior.

$\S 2^{\circ}$ Os estatutos e regimentos disciplinarão o aproveitamento dos estudos dos ciclos básicos e profissionais, inclusive os de curta duração, entre si e em outros cursos.
\end{abstract}

i) Por fim, face à necessidade de equacionar o problema dos excedentes e aumentar a eficiência do processo seletivo das universidades, em consonância com o ideal de centralização presente ao longo de todo o texto, a lei da reforma universitária define a obrigatoriedade da construção de um vestibular racionalizado e unificado no âmbito das instituições de ensino superior:

Art. 21. O concurso vestibular [...] abrangerá os conhecimentos comuns às diversas formas de educação do segundo grau sem ultrapassar este nível de complexidade para avaliar a formação recebida pelos candidatos e sua aptidão intelectual para estudos superiores.

Parágrafo único. Dentro do prazo de três anos a contar da vigência desta Lei o concurso vestibular será idêntico em seu conteúdo para todos os cursos ou áreas de conhecimentos afins e unificado em sua execução, na mesma universidade ou federação de escolas ou no mesmo estabelecimento isolado de organização pluricurricular de acordo com os estatutos e regimentos.

Em síntese, a universidade que emerge da reforma da década de 1960 não tem um projeto científico-acadêmico pré-estabelecido, o que abriu espaço para a emergência das mais variadas formas institucionais, produzindo um sistema de ensino superior extremamente diversificado. Como corolário da diversificação institucional, o ideal de integração universitária que deveria se expressar nos projetos científico-acadêmicos das diferentes instituições moldando, inclusive, o desenho arquitetônico das cidades universitárias - foi sendo, aos poucos, transferido para a administração central, que se tornava responsável por: i) supervisionar e 
deliberar sobre os assuntos acadêmicos, incluindo a organização do ensino e da pesquisa; ii) apurar e julgar os desvios disciplinares concebidos em registro amplo; iii) desenhar e implementar o planejamento estratégico da universidade; iv) organizar e coordenar o processo de seleção dos alunos de graduação, a partir da unificação do vestibular, entre outras medidas. Implícito a esse movimento de centralização das decisões e de fortalecimento dos órgãos executivos acadêmicos, o ideal de formação de uma cadeia de comando clara e direta no ensino superior ganhava espaço, reforçado por uma definição abstrata da autonomia universitária que permitia ao presidente ou governador indicar, a partir de uma lista sêxtupla, os reitores das universidades. Como resultado geral de todo esse processo, o enfraquecimento relativo dos órgãos colegiados das universidades esvaziou o potencial de democratização das propostas de departamentalização, regulamentação da carreira docente e ampliação da representação discente nos órgãos colegiados. Por fim, a ausência de um projeto acadêmico-científico claro e de uma autonomia universitária bem definida, somada à centralização das decisões, ao fortalecimento do executivo acadêmico e ao esvaziamento dos órgãos colegiados onde se expressavam as tensões entre os polos essenciais da universidade abriram caminho para a implementação de um projeto de profissionalização das universidades, seja através da expansão das novas profissões, seja por meio da própria profissionalização da ciência, expressa na crescente regulamentação central da pós-graduação.

É essa nova universidade - mais centralizada, mais gerenciada, mais disciplinada e mais profissional - que emergiu da reforma universitária dos anos 1960. Gestada no interior de um campo de influência formado por institutos empresariais de desenho de políticas como o IPES, por consultorias técnicas norte-americanas, por conselhos de dirigentes acadêmicos como o CRUB e, por fim, por órgãos governamentais voltados à reorganização do ensino superior, a reforma universitária implementada surgiu, em grande medida, como resposta ao movimento protagonizado pelo polo científico-acadêmico das universidades desde os anos 1950 
representando, em última instância, uma vitória do polo oposto, formado pelas unidades profissionais tradicionais, como é possível notar pela influência de engenheiros, economistas e juristas na elaboração do consenso básico em torno da reforma. Como sugere Florestan Fernandes, esse polo - que ele denomina "conservador" - partiu de uma posição defensiva, quando o movimento pela reforma universitária assumia a liderança do processo de reivindicação das reformas, para uma posição de "liderança política" do processo de reforma, inspirado, então, pelas “tendências modernizadoras" oriundas seja do próprio país, seja de organismos internacionais hegemonizados pelos Estados Unidos:

\begin{abstract}
A última batalha pelo padrão brasileiro de escola superior não foi travada em defesa dessa escola [profissional isolada], que não contava muito em si e por si mesma. A batalha se deu por interesses dissimulados e pela preservação da onipotência dos profissionais liberais, que teimavam em não se transformar em autênticos universitários. Do outro lado, a reação conservadora mudou rapidamente de tática. Em uma primeira fase, ela absorveu os interesses, a ansiedade e as frustrações dos professores catedráticos, lançando a repressão policial e a violência na defesa das suas posições. Em seguida, porém, ela percebeu que se precipitara e que a extinção do antigo padrão de escola superior isolada não ameaçava o status quo. Sob pressão constante de tendências modernizadoras, que partiam do interior do país, dos Estados Unidos e de organismos econômicos, educacionais ou culturais internacionais, e sob o desafio crescente da rebelião estudantil, a reação conservadora preferiu tomar a liderança política da "reforma universitária". Ao proceder desse modo, rompia, naturalmente, com o padrão de escola superior, herdado do passado. Mas conquistava uma posição que lhe permitia dirigir a "reforma universitária" de acordo com os interesses, as conveniências, os valores da atual situação conservadora. No ápice da crise, portanto, as antigas tradições da escola superior não iriam morrer: sob o controle conservador da "reforma universitária", elas renasceriam das cinzas e empolgariam, na era da universidade, o domínio dos espíritos (Fernandes, 1975, p. 58-9).
\end{abstract}

Do ponto de vista da transição de uma posição defensiva em relação à reforma para uma posição ativa de promoção das mudanças, é bastante significativo o movimento que atingiu o âmago do polo profissional tradicional, representado pelas faculdades de direito durante a década de 1960. Tendo resistido às sucessivas tentativas de reforma universitária, desde a aprovação da Lei de Diretrizes e Bases da Educação Nacional, de 1961, até à reforma universitária propriamente dita, em 1968, as faculdades de direito também passaram a sofrer a influência de tendências reformadoras, principalmente a partir do momento em que os bacharéis passaram a ser preteridos por economista e administradores nos postos de controle no aparelho 
de Estado. Os cursos de direito, por influência imediata das agências internacionais associadas a grupos reformadores locais, viram-se constrangidos, então, a se abrir para novas áreas disciplinares, como o direito administrativo e econômico. É interessante acompanhar a descrição do jurista Alberto Venancio Filho que protagonizou uma dessas tentativas de reforma do ensino jurídico. Ao narrar, no final dos anos $1970^{142}$, a história da criação de um novo programa de pós-graduação em direito, o autor sintetiza:

\begin{abstract}
As faculdades de Direito, via de regra, têm se revelado pouco receptivas à ideia da reforma universitária. Pretendendo manter uma posição de isolamento, em alguns casos, recusando-se transferir-se para o campus universitário, em alguns casos com a impetração de mandados de segurança por suas congregações, têm resistido elas às ideias renovadoras da reforma universitária. [...] A experiência mais importante no campo da renovação do ensino jurídico nos últimos anos foi o Centro de Estudos e Pesquisas no Ensino do Direito (Ceped) [...]. Embora vinculado à Faculdade de Direito dessa Universidade [Universidade do Estado da Guanabara], a resolução deu grande autonomia à direção do centro, o que permitiu a sua instalação na Fundação Getúlio Vargas e, com isto, uma colaboração extremamente frutuosa com a Escola de Pós-graduação em Economia sob direção de Mário Henrique Simonsen. Dirigido desde a sua fundação pelo professor Caio Tácito Sá Viana Pereira de Vasconcelos, professor de Direito Administrativo da Faculdade de Direito da Guanabara, o Ceped na verdade reuniu um grupo de professores insatisfeitos com o status quo, movimento de que foi a figura catalisadora o então Consultor Jurídico da Agência do Desenvolvimento Internacional do Governo dos Estados Unidos (Usaid), o professor David Trubek, hoje na universidade de Wisconsin. [...] Refletindo a respeito, verificou, em consequência, que esta posição subalterna ocupada pelo advogado, no Brasil, decorria, em grande parte, da má formação haurida nas faculdades de Direito, que não habilitava o advogado para estas novas tarefas da vida econômica e para os esquemas de formulação dos negócios (Venancio Filho, 2004, p. 324-5).
\end{abstract}

Segundo informações do autor, que foi colaborador do novo programa, a principal atividade do Ceped foi a organização de um curso de "advogados de empresa" que contou com o auxílio financeiro da Usaid, da Fundação Ford e da Aliança Para o Progresso. Essas instâncias financiaram, também, um seminário sobre o ensino jurídico no Brasil, em 1967, com a presença de professores visitantes, sobretudo das Universidades de Harvard e Illinois, bem como estágios de pesquisa de brasileiros no exterior, em especial para os Estados Unidos, nos anos seguintes. Até 1972, os cursos de direito empresarial e administrativo do centro haviam formado cerca de 220 advogados, um décimo deles, segundo Venancio Filho, tornou-se docentes universitários,

\footnotetext{
${ }^{142}$ A primeira edição de Das arcadas ao bacharelismo: 150 anos de ensino jurídico no Brasil é de 1977. Utilizei, no entanto, a edição de 2004 que não chegou a ser atualizada pelo autor (cf. Venancio Filho, 2004).
} 
"fazendo-se divulgadores e aperfeiçoadores da ideia que inspirou o Ceped" (Venancio Filho, 2004, p. 328).

No caso específico da USP, a Faculdade de Direito também oscilou de uma posição de recusa à qualquer tentativa de reforma universitária para um lugar de protagonismo na reforma promovida. Para entender como isso aconteceu, é preciso acompanhar a excelente reconstrução histórica feita por Macioniro Celeste Filho dos debates em torno da reforma universitária que ocorreram no Conselho Universitário da USP, entre o segundo semestre de 1968 e o primeiro semestre de 1969, por ocasião da aprovação da reforma universitária da instituição (cf. Celeste Filho, 2013, p. 201ss). Sintetizando as informações apresentadas pelo autor, é possível notar que o Conselho Universitário da USP, que iniciou um processo interno de reforma antes da aprovação da Lei da Reforma Universitária em âmbito federal, sendo por ela limitado, se dividiu em torno de alguns pontos principais durante a votação da reforma universitária: i) a extinção das cátedras; ii) a criação dos departamentos; iii) a forma de organização dos departamentos; iv) a transformação de todas as unidades, inclusive as faculdades profissionais, em institutos centrados em pesquisa; iv) e a criação de uma assembleia paritária composta de estudantes e professores, paralela aos departamentos e ao Conselho Universitário, com a função de discutir os temas considerados centrais pela comunidade acadêmica.

Em todos esses pontos, o Conselho Universitário - formado, na época, por diretores de unidade, representantes das congregações e dois representantes discentes - se dividiu entre, de um lado, as unidades profissionais tradicionais, lideradas pela Faculdade de Direito, Faculdade de Medicina e Escola Politécnica, e, de outro, pelas unidades que na época representavam o polo acadêmico-científico com destaque para a Faculdade de Filosofia, Ciências e Letras e para a Faculdade de Medicina de Ribeirão Preto. Com o decorrer das votações da reforma universitária na USP, o representante da Congregação da Faculdade de Medicina de Ribeirão Preto, Hélio Lourenço de Oliveira, foi ganhando destaque no Conselho, sobretudo depois de 
apresentar e aprovar uma proposta para o encaminhamento das votações, a qual tomou emprestado, sem dizer a origem, da comissão paritária da sua faculdade (cf. Celeste Filho, 2013, p. 204). Com uma atuação coerente e determinada em prol de uma reforma mais profunda da USP, Hélio Lourenço foi construindo, aos poucos, uma legitimidade com parte importante do Conselho Universitário, dividido na época entre unidades com mais e menos tradição de pesquisa. Assim, por ocasião da renúncia do vice-reitor em exercício, o diretor da FFCL, Mário Guimarães Ferri, em outubro de 1968, o Conselho Universitário, em uma votação extremamente dividida, elegeu Hélio Lourenço de Oliveira como novo vice-reitor da USP, lembrando que o reitor de fato, Luiz Antônio Gama e Silva, encontrava-se afastado da universidade pela sua participação, como Ministro da Justiça, no governo Costa e Silva.

Como reitor em exercício, Hélio Lourenço de Oliveira passou a presidir as sessões do Conselho Universitário, que durante a reforma ocorriam duas vezes por semana, o que favoreceu a aprovação de uma reforma surpreendentemente radical, dado os limites impostos pela lei federal recém aprovada. Na reforma, além da extinção das cátedras e da criação dos departamentos, estava previsto, talvez o seu ponto mais polêmico, a criação de uma Assembleia Universitária Paritária, com representação igualitária de estudantes e professores que, de caráter não deliberativo, complementaria as funções do Conselho Universitário (cf. Celeste Filho, 2013).

Horas depois que as votações da reforma universitária da USP se encerraram, no final de abril de 1969, foi publicado um decreto federal aposentando compulsoriamente dezenas de professores da USP, dentre os quais o então reitor em exercício, Hélio Lourenço de Oliveira. Para Macioniro Celeste Filho, a atuação do vice-reitor na reforma da USP pode ter sido decisiva para a sua aposentadoria quase imediata:

É improvável que seja apenas coincidência a determinação de Hélio Lourenço de Oliveira em preservar a ideia de representação paritária [na Assembleia Universitária]; sua aprovação pelo Conselho Universitário da USP em 29.04.1969; e a aposentadoria compulsória do reitor pelo AI-5 horas após isso ter ocorrido (Celeste Filho, 2013, p. 225). 
Com a aposentadoria de Hélio Lourenço de Oliveira e de outros professores que se engajaram no movimento de reforma universitária, a correlação de forças no Conselho Universitário de alterou substancialmente (cf. Fétizon, 1986, p. 658ss) e o lado mais conservador do polo profissional tradicional teve condições de reverter alguns aspectos da reforma originalmente aprovada. Isso foi possível porque, por determinação da Lei da Reforma Universitária, a universidade foi obrigada a submeter os seus novos estatutos à apreciação do Conselho Estadual de Educação. Enquanto se esperava os pareceres do Conselho Estadual, o governador de São Paulo escolheu como vice-reitor da USP o segundo mais votado pelo Conselho Universitário, o então diretor da Faculdade de Direito, Alfredo Buzaid. Quando a avaliação do CEE chegou à USP, Buzaid usou os novos poderes conferidos ao reitor para, sem consultar o Conselho Universitário, nomear unilateralmente uma comissão para rever os estatutos aprovados, o que possibilitou reverter algumas das decisões tomadas, inclusive a criação da Assembleia Universitária. Avaliando esse processo, Celeste Filho conclui que uma das principais mudanças na reforma dirigida por Buzaid em relação à promovida por Hélio Lourenço foi que o Conselho Universitário tornou-se "coadjuvante dos processos de que era protagonista" (2013, p. 232). Foram os primeiros efeitos do processo de centralização do poder e de enfraquecimento dos órgãos colegiados que marcaria a USP nos anos seguintes.

De fato, a "vitória" de um projeto de reforma universitária afinado com as posições e objetivos do polo profissional nos anos de recrudescimento do regime civil-militar criou condições para um conjunto de mudanças que impactaram a estrutura e a organização das universidades brasileiras a partir dos anos 1970 e que, na USP, se expressaram tanto na alteração do padrão de expansão universitária - tema do terceiro capítulo desta tese - quanto na redefinição geral do governo acadêmico em prol de uma crescente centralização - que constitui o tema central do último item deste capítulo. 
Como já foi dito, para analisar o processo de transformação estrutural da USP - o que pretendemos fazer por meio de uma descrição do seu padrão de expansão que impactará profundamente em termos de diversificação e composição social do corpo discente - é preciso acessar os dados estatísticos produzidos por instâncias centralizadas que, em grande medida, resultaram da reforma universitária de 1968, contribuindo para impor o discurso e a prática gerencial na universidade. Assim, como passagem para o próximo capítulo, este se encerra precisamente com a reconstituição da emergência das estatísticas universitárias na USP. No entanto, buscando enfatizar a gênese social da imposição das categorias gerenciais e de seus dispositivos técnico-materiais de um modo geral, bem como descrever as consequências específicas da reforma universitária de 1968 na USP, a reconstituição dessa emergência das estatísticas universitárias é precedida por uma descrição, em linhas gerais, dos processos de conversão invisível dos dirigentes universitários da USP nos anos subsequentes à reforma e de centralização do poder na instituição a partir da criação e do fortalecimento dos seus órgãos executivos centrais.

\section{Impactos da gestão na USP: "conversão" de dirigentes, centralização administrativa e emergência das estatísticas universitárias}

Até o presente momento, a intenção deste capítulo foi descrever o processo social de importação do conhecimento gerencial no Brasil, sobretudo a partir da década de 1950 e o seu impacto no fortalecimento de um projeto específico de reforma universitária aprovado no final dos anos 1960. No entanto, esses dois movimentos, de ordem nacional, não se impuseram de modo imediato na USP. Ao olhar para essa instituição social específica é possível perceber, na verdade, que o conhecimento gerencial seguiu aí caminhos particulares, ainda que fortemente determinados pelos processos nacionais de transformação do ensino superior. Assim, como bem 
observa Franklin Leopoldo e Silva, a USP implementou as diretrizes nacionais da reforma universitária, sobretudo nos ideais de racionalidade gerencial, mesmo sem ser obrigada a tanto:

Há de se constatar, então que, mesmo sem estar subordinada às mesmas injunções legais por meio das quais o MEC podia interferir nas universidades federais, a USP optou por acompanhar de perto o modelo federal, inclusive nos pontos em que uma pretensa racionalidade de gestão e supostos critérios de aprimoramento organizacional encobrem escolhas doutrinais e ideológicas que incidem sobre o perfil histórico da instituição (Silva, 1999, p. 19)

A imposição do conhecimento gerencial enquanto um corpo de saberes e práticas voltado à estruturação do governo universitário foi moldada, na USP, pelas tensões e contradições subjacentes à sua própria estrutura social e à sua história institucional específica. Foi nesse sentido que eu apresentei, na introdução desta tese, um processo que apareceu, inicialmente, como um paradoxo do meu trabalho de campo: ou seja, embora o domínio da gestão tenha visivelmente se fortalecido na USP a partir dos anos 1970 - na esteira de processos cujas raízes remontam, como visto, aos anos 1950 -, uma parte importante dos dirigentes uspianos entrevistados por mim ao longo da pesquisa desprezava veementemente a "administração" e a "gestão", tanto como campo de conhecimento quanto como um conjunto de práticas sociais voltado à organização do governo acadêmico.

Parte da resposta para essa aparente paradoxo reside justamente no fato de que, como foi proposto ao longo deste capítulo, enquanto um dispositivo de saber-poder, a gestão não se impôs somente sob a forma de esquema conceitual internamente coerente - ou seja, como uma teoria da gestão -, mas também enquanto um vocabulário específico, um conjunto de medidas organizacionais e um corpo de dispositivos técnico-materiais que, juntos, definiram as categorias de linguagem que passaram a determinar os termos em que se pensa, se discute e se projeta o governo da USP. Esse processo em que a gestão passou a funcionar como uma espécie de estrutura - determinando padrões de pensamento e ação - tem três faces: a primeira é a difusão do conhecimento gerencial através da conversão, mais ou menos profunda, de agentes sociais; a segunda é a produção de reformas organizacionais que criaram posições para a 
atuação desses agentes portadores das novas categorias gerenciais; e a terceira é a implementação de dispositivos técnicos que incorporaram e fortaleceram o discurso da gestão na $\mathrm{USP}^{143}$. São esses três processos que analisamos no item final deste capítulo.

\subsection{A “conversão invisível" dos dirigentes da USP a partir dos anos 1970: experts em gestão, lideranças institucionais e professores na direção da universidade}

Partindo de uma análise de trajetória dos dirigentes da USP, particularmente os que passaram a atuar em postos de direção na universidade a partir da reforma de $1968-1969^{144}$, foi possível identificar três padrões de "conversão" ao discurso gerencial que correspondem, por sua vez, de modo mais ou menos direto, a três posições institucionais na estrutura de poder da universidade: a "profissionalização" de experts em gestão; a "reprofissionalização" de lideranças institucionais; e a influência do discurso gerencial sobre outros professores envolvidos, de modo mais ou menos transitório, em atividades político-administrativas no âmbito da universidade. A opção por nomear esse processo como uma "conversão invisível" busca enfatizar duas dimensões importantes. A primeira, implícita no termo "conversão", refere-se ao longo e sistemático trabalho de "sensibilização", "doutrinamento" e "treinamento" - todos termos do próprio vocabulário gerencial mobilizado pelos dirigentes da USP - que resultou na imposição das categorias da gestão no interior da universidade. A segunda

\footnotetext{
${ }^{143}$ É interessante que ao desenhar um modelo de modernização da administração acadêmica, Rudolph Atcon elencou essas três medidas pragmáticas para a viabilização desse projeto: i) a formação de gestores e dirigentes acadêmicos; ii) a mecanização dos procedimentos administrativos; iii) e a preparação de técnicos em estatísticas educacionais (cf. Atcon, 1966, 1974). Paralelamente, a lei da reforma universitária estabeleceu novas medidas concretas de centralização como, por exemplo, a obrigatoriedade da criação de órgãos de supervisão do ensino e da pesquisa no âmbito da reitoria, a responsabilização do executivo acadêmico pela questão disciplinar e a unificação dos vestibulares dentro do prazo de três anos (cf. Brasil, 1969). Todas essas mudanças tiveram impacto na USP ao longo da década de 1970, redefinindo o modo de funcionamento do seu governo acadêmico. Essas mudanças se fizeram sentir, sobretudo, a partir dos anos 1980 quando o processo de redemocratização abriu espaço para o fortalecimento da autonomia universitária e, com ela, para a livre atuação, em órgãos executivos fortalecidos, de dirigentes acadêmicos que se apropriaram de saberes gerenciais ao longo dos anos 1970.

${ }^{144}$ Como dito na introdução desta tese, montei um banco de dados formados por reitores, desde 1934; pró-reitores, desde 1988; e coordenadores da Codage, desde 1973. Eu procurei reconstruir, a partir de informações disponíveis, a trajetória acadêmico-política de todos eles. Para a realização das entrevistas, priorizei as gestões pósdemocratização.
} 
dimensão, relacionada ao adjetivo "invisível”, enfatiza a naturalização dessas categorias pelo esquecimento de todo o intenso trabalho social que está na base do seu processo de afirmação.

\subsubsection{A profissionalização de experts em gestão a partir dos anos 1970}

O primeiro padrão de "conversão" de dirigentes universitários observado durante a presente pesquisa resulta da formação de experts em gestão através de processos formais de treinamento e educação. A "conversão", nesse caso, pode ser descrita como um processo de profissionalização stricto sensu, baseado na formação de longo prazo e na aquisição de conhecimentos certificados por títulos formais. Concretamente, tratam-se principalmente de professores da USP que fizeram graduação ou pós-graduação em economia ou administração a partir dos anos 1960 e que, portanto, se formaram no âmbito de acordos de cooperação entre instituições brasileiras e norte-americanas para o fortalecimento do conhecimento econômico e gerencial no país. São, em suma, professores universitários que têm na teoria gerencial - no campo da economia ou da administração - o seu principal objeto de pesquisa e que, pelo domínio desse conhecimento específico, se legitimaram para atuar na administração central da universidade. Para ilustrar esse padrão de "conversão" apresento a seguir três trajetórias representativas.

A primeira é a do dirigente $26^{145}$, que foi diretor de unidade nos anos 1980 e reitor da USP nos anos 1990. Formado em administração pela FEA, em 1968, o dirigente realizou, entre 1970 e 1972, um mestrado na Graduate School of Management da Vanderbilt University, nos

\footnotetext{
145 Assumindo a proposta de realizar uma história estrutural sem nomes próprios, optei por não nomear os dirigentes da USP, identificando apenas os atributos sociais significativos para esta análise, em especial os que distinguem as suas trajetórias no interior da instituição. Essa opção, de natureza metodológica, não visa ocultar identidades, como pode ser percebido pela quantidade de atributos apresentados, o que torna possível reconhecelos individualmente. Os números que acompanham esses dirigentes correspondem ao lugar que eles ocupam em uma lista cronológica de dirigentes formada por: i) todos os reitores da USP que ocuparam o cargo de 1934 a 2014; ii) todos os diretores administrativos, que ocuparam a direção da Codage, hoje VREA, de 1973 a 2014; e iii) todos os pró-reitores que assumiram esse cargo de 1988 a 2014. Dessa lista, que reúne ao todo 75 dirigentes, procurei entrevistar todos os reitores, pró-reitores e diretores administrativos que assumiram cargos a partir de 1968 o que, na prática, acabou se viabilizando apenas para os que assumiram cargos no âmbito central a partir de 1986.
} 
Estados Unidos, sob orientação de Igor Ansoff, um matemático de origem russa que fez carreira universitária em instituições norte-americanas e é considerado, até hoje, um dos teóricos do management mais importantes do século XX pela sua contribuição à chamada "teoria da gestão estratégica" (cf. Ansoff, 2007). Não por acaso, o tema de mestrado do dirigente 26 foi a gestão estratégica de organizações inovadoras e o de doutorado, um estudo sobre a eficácia organizacional.

A sua pós-graduação nos Estados Unidos, no começo dos anos 1970, foi viabilizada por uma bolsa do IPE (Instituto de Pesquisas Econômicas), ligado à FEA-USP, que, na época, mantinha um acordo com a Usaid para a formação de economistas justamente na Vanderbilt University. O historiador Rodrigo Patto Sá Motta, ao analisar a influência norte-americana no ensino superior brasileiro durante os anos 1960, dedica algumas linhas ao programa FEAVanderbilt:

\begin{abstract}
A Usaid apoiou projetos de pesquisa e pós-graduação em outros setores além do agrícola. A área de economia foi uma delas, por ser considerada estratégica para a formação de técnicos para os projetos de modernização. A Usaid colaborou com a instalação do mestrado de economia da USP por meio de financiamento de bolsistas (45 mestrandos e doutorandos) nos Estados Unidos, compra de livros e pagamento de professores da Universidade de Vanderbilt para lecionar em São Paulo. As atividades conjuntas começaram em 1969, quando quinze professores do setor passaram a atuar em tempo integral. O projeto com a USP previa a disseminação dos resultados por outras doze universidades, que seriam beneficiadas pelo mestrado e cursos de extensão baseados em São Paulo. Uma planilha com os gastos da (US)AID no IPE/USP até 1972 mostrava o dispêndio de US \$ 2,5 milhões (a Fundação Ford entrou com recursos suplementares), e eles estavam custeando quatorze doutorandos nos Estados Unidos naquele momento, com a previsão de criar outro curso de mestrado e enviar mais dois professores americanos para um ano de permanência (Mattos, 2014, p. 144).
\end{abstract}

Apesar de contemplar originalmente apenas a área de economia, que na época era praticamente hegemônica na $\mathrm{FEA}^{146}$, o convênio com a Vanderbilt acabou se estendendo também à administração, por pressões internas à faculdade, como comenta em entrevista concedida a mim, em 2013, o próprio dirigente:

\footnotetext{
${ }^{146}$ O curso de economia da FEA-USP foi criado em 1946 e o de administração, somente em 1960, no bojo dos programas de expansão dos cursos de gestão no país.
} 
[Pergunta] Professor, falando um pouco da sua trajetória acadêmica, em 1970, o senhor conseguiu, por intermédio do IPE, uma bolsa para fazer sua pós-graduação nos Estados Unidos. É interessante porque é o momento em que a administração está se consolidando como área no Brasil. E eu queria saber por que o IPE está incentivando a formação de administradores nesse momento e qual foi a importância dessa experiência para a sua formação?

[Resposta] A importância foi extraordinária. Agora, o financiamento do IPE foi uma daquelas coisas tipicamente de "relações institucionais". O IPE já era uma instituição consolidada que tinha colocado a economia em um patamar bem elevado, bem reconhecido quando aparece a área de administração, sempre vista como a "prima pobre”, a área que estava nascendo, o que hoje já não é mais o caso. Mas na época, com a emergência da administração surgiu uma demanda do tipo: "Olha, no mundo de bolsas que vocês têm na economia, por que é que vocês não dão duas ou três bolsas para administração?”. Que era uma forma, também, de evoluir o convênio FEAVanderbilt para uma nova frente. Porque o [convênio] na área de economia já existia há algum tempo. Então os gestores do convênio FEA-Vanderbilt se perguntaram se não era o caso de começar a abrir uma frente na área de administração também. Foi a partir de então que escolheram alguns alunos para fazer o mestrado nos Estados Unidos. A experiência americana foi extraordinária, eu acho que até hoje eu tenho que reconhecer que o que nós aprendemos lá em termos de gestão da inovação e de estratégias de gestão foi fundamental. E especialmente por ser uma escola de Management e não uma escola de Business. Quer dizer, era uma escola, uma das primeiras escolas de administração, criada por um russo-americano, Igor Ansoff, que desenvolveu esse conceito da gestão de organizações heterodoxas que basicamente dizia: "a empresa sim, é importante, mas existem muitas organizações que precisam de boa gestão". E foi assim que ele criou a Graduate School of Management de Vanderbilt e, a partir daí, passa a oferecer uma formação que envolve essas técnicas, que envolve estratégia, gestão de projetos, gestão da inovação, resolução de problemas, uma série de instrumentos de gestão e um conhecimento na área de gestão que pode ser utilizado em várias instituições.

Partindo do projeto de ampliar o escopo da teoria da gestão, ao voltar para o Brasil, o dirigente 26, juntamente com outros professores da FEA que também passaram pelo convênio Vanderbilt, fundou o Programa de Administração em Ciência e Tecnologia - ou, simplesmente, PACTo. O objetivo do programa era desenvolver instrumentos de gestão para instituições científicas e tecnológicas, especialmente universidades e institutos estatais de pesquisa. É interessante notar que a história do PACTo se encontra, novamente, com a atuação da Usaid no Brasil. Em 1973, o estado de São Paulo criou, com financiamento da agência norte-americana, um programa de incentivo à ciência e à tecnologia chamado Programa Ciência e Tecnologia, ou Procet, que visava "dinamizar o potencial de pesquisa [...] do estado" através de convênios entre instituições paulistas de pesquisa e institutos internacionais, particularmente norteamericanos (Vasconcellos et al., 1989, p.90). Inicialmente, o programa financiou seis convênios 
envolvendo instituições públicas de pesquisas de São Paulo como o ITAL (Instituto de Tecnologia de Alimentos), o IPT (Instituto de Pesquisas Tecnológicas) e o Instituto Butantã. A esses seis programas iniciais de cooperação, somou-se um sétimo que foi justamente o PACTo, cujo objetivo essencial era "capacitar gerencial e administrativamente as seis organizações brasileiras" envolvidas no Procet (cf. Vasconcellos et al., 1989, p. 60). Ainda segundo os autores, o PACTo evoluiu rapidamente de simples iniciativas de "doutrinamento" e "sensibilização" para um processo mais ativo de produção e divulgação de conhecimento gerencial que extrapolou, inclusive, as instituições visadas originalmente:

\begin{abstract}
Inicialmente, o PACTo dedicou-se a uma tarefa doutrinária procurando disseminar a importância da ideia da administração, promovendo seminários de sensibilização e programas de treinamento no exterior, compreendendo visitas a organizações similares àquelas que, no Brasil, estavam envolvidas no Procet, e cujos técnicos eram os participantes dos eventos mencionados. Desse modo, procurava-se ter contato com soluções administrativas já existentes, que pudessem ser aqui adaptadas. Com o tempo o PACTo evoluiu para uma abordagem instrumental em suas atividades, passando a empregar, como docentes em seus programas de treinamento, aqueles técnicos que haviam sido "alunos participantes" em suas atividades iniciais. Isso permitiu construir uma rede de colaboradores que, a partir dos materiais didáticos produzidos, dedicaram-se a escrever trabalhos sobre administração. Daí surgiram livros, artigos e simpósios que eram e continuam sendo formas de registrar e possibilitar a disseminação do conhecimento administrativo. Em curto espaço de tempo a missão original do PACTo ampliou-se, de modo que de suas atividades passaram a participar outras organizações públicas de pesquisa, além das seis que estavam inicialmente no âmbito do Procet (Vasconcellos et al., 1989, p. 91-92).
\end{abstract}

Em 1978, quando termina o convênio do PACTo com a Secretaria de Ciência e Tecnologia do Estado de São Paulo, encerrando-se também o apoio da Usaid ao Procet, o PACTo passou a atuar por projetos contratados, sendo o principal deles, o Protap, Programa de Treinamento e Administração de Pesquisas Científicas e Tecnológicas, instituído em âmbito federal pela Finep em 1974, com o objetivo de "promover a formação e a atualização de quadros técnicos capacitados a gerenciar as atividades de pesquisa básica, aplicada e de desenvolvimento nos setores governamental e privado" (Stal \& Neto, 1987, p. 84). Contratando inicialmente uma consultoria estrangeira, a Arthur D. Little, o Protap tornou-se um programa nacionalmente importante, sendo financiado simultaneamente pelo II Plano Básico de Desenvolvimento Científico e Tecnológico (II PBDCT), pela Organização dos Estados 
Americanos (OEA) e pelo Programa das Nações Unidas para o Desenvolvimento (PNUD). Em 1978, os dirigentes do Protap encerraram o convênio com a Arthur D. Little, substituindo-o por um acordo com o PACTo, o que testemunha o processo de capacitação nacional na área de gestão de instituições e ciência e tecnologia (cf. Stal \& Neto, 1987).

Em termos de resultados, entre 1975 e 1985, o programa federal de formação de gestores de C\&T havia oferecido 11 cursos modulares, 6 cursos voltados para toda a América Latina, 158 seminários e workshops, 45 bolsas de estudo no exterior e 10 simpósios sobre pesquisa em administração de P\&D atingindo, ao todo, mais de 6 mil pessoas (cf. Stal \& Neto, 1987, p. 84). O Protap existiu na Finep, com esse nome, até pelo menos 1999, quando foi publicado um balanço qualitativo das suas ações ao longo dos seus 25 anos de funcionamento (cf. Cadernos de Gestão Tecnológica, 1999). Assim como no caso do Protap, as atividades do PACTo como um todo também se concentraram, entre 1973 e 1987, em atividades de treinamento. Os 198 “cursos", "seminários" e "encontros" desenvolvidos pelo programa responderam por 70\% das atividades realizadas no período, atingindo, ao todo, cerca de 5.700 pessoas. Além de treinamento, o programa desenvolveu, ao longo dos seus primeiros 15 anos de funcionamento, consultorias (25\% das atividades) e, em menor escala, pesquisas (5\% das atividades) (cf. Vasconcellos et al., 1989, p.92ss). Em 1981, o PACTo transformou-se no Núcleo de Política e Gestão Tecnológica, um Núcleo de Apoio à Pesquisa (NAP) ligado à FEA-USP que, até hoje, desempenha um papel importante no campo da gestão de ciência, tecnologia e inovação ${ }^{147}$. O núcleo, apesar de formalmente ligado à FEA, conta atualmente com a colaboração de mais de 50 pesquisadores de diferentes unidades da USP, o que testemunha não só a consolidação dessa área de pesquisa no país como o sucesso do projeto original do PACTo de "sensibilizar" as instituições de ensino e pesquisa, incluindo as universidades, para a importância da gestão.

\footnotetext{
${ }^{147}$ Para mais informações, ver: < http://www.fea.usp.br/npgtusp/>. Acesso em 21 de abr. 2014.
} 
$\mathrm{Na}$ esteira desse processo, o projeto teórico-político que o dirigente 26 atribui a Igor

Asnoff e à sua escola, qual seja, de afirmar o management como um conhecimento voltado não só ao funcionamento de empresas, mas à estruturação de outras organizações sociais, que eles denominam "heterodoxas", foi, aos poucos, se viabilizando. Nesse sentido, é interessante notar que ao responder sobre o que significa aplicar conhecimento gerencial, originalmente formulado para descrever e normatizar o funcionamento de empresas, em instituições de ciência e tecnologia, o dirigente 26 esclarece que, na verdade, não se trata de transpor conhecimentos de um espaço social para outros mas, simplesmente, de reconhecer que as diferentes organizações, incluindo empresas e universidades, têm princípios comuns de funcionamento que definem, por sua vez, diretrizes igualmente comuns de gestão:

[Pergunta] Eu queria entender como é que o senhor avalia a transposição desse conhecimento que foi formalmente criado para descrever o funcionamento de empresas para outras organizações. Evidentemente, que eu não estou pensando em uma transposição imediata ou direta, você teve toda uma adaptação desse conhecimento para pensar outras organizações, como as de ciência e tecnologia, mas como se dá essa aplicação?

[Resposta] É um pouco diferente do que você está dizendo. O que existe é que alguns conhecimentos em administração que são muito semelhantes, independentemente de onde eles estão sendo aplicados. Por exemplo, "gestão de projetos". O que é que é gestão de projetos? Gestão da inovação? Você tem duas formas de ver as organizações. Você pode ver a organização como um ente que nasce, se estrutura e só vai desaparecer quando ele se degrada, que tipicamente são as grandes burocracias, cujo êxito é a sua contínua expansão ou a sua afirmação crescente. Esse é o modelo das organizações burocráticas e das grandes empresas familiares. O que há de específico na inovação? É que se aceita que o êxito de uma estrutura organizacional está no seu desparecimento. Isso é característica da inovação, porque se a inovação permanecer por muito tempo, ela deixa de ser inovação para se tornar rotina. Então, na gestão da inovação, seja na empresa, seja em um instituto de pesquisa ou em uma universidade, o reconhecimento da efemeridade da estrutura organizacional é uma característica inerente. Isso significa que o ciclo de vida de uma organização - da concepção da inovação, da sua estruturação, da sua execução e da sua avaliação para o seu desaparecimento - se aplica à universidade, a um instituto de pesquisa e a uma empresa de modo quase idêntico. Não é por acaso que durante todo o nosso projeto no Pacto e hoje no Núcleo [de Política e Gestão Tecnológica], o centro de pesquisa de empresas e os núcleos de universidade que lidam com a inovação conviviam na mesma sala. Primeiro, porque há interesse das pesquisas de empresas e de universidade de estarem juntas. Mas além disso, porque nós estamos tratando do mesmo assunto. Então, voltando um pouco a sua pergunta inicial, sobre como transpor esse conhecimento. Não, não há transposição. Há um conhecimento que se aplica de forma quase idêntica. Digo quase, porque a lógica é distinta, o tempo da empresa, o tempo da ciência não são tempos iguais, mas o padrão de gestão é muito semelhante. 
Descrita, portanto, como um novo regime de verdade que simplesmente reconhece o funcionamento efetivo de diferentes organizações, a gestão aparece não como um esquema conceitual parcial que se universaliza de modo indevido a diversas instituições sociais (cf. Bleiklie \& Kogan, 2007; Brunsson \& Sahlin-Andersson, 2000; Drori et al., 2006, Musselin, 2006), mas como uma teoria universal que, respeitando o funcionamento efetivo do próprio objeto, se aplica sobre ele de modo quase natural. No entanto, no caso específico do PACTo/Procet, o treinamento em gestão dos membros de instituições públicas de pesquisa de São Paulo não se desenvolveu com tanta naturalidade. Ao contrário, as disputas em torno da imposição desses saberes e rotinas gerenciais foram, na verdade, extremamente "violentas". O próprio dirigente 26 relata esses confrontos entre os pesquisadores e os gestores, ao descrever os objetivos e as dificuldades enfrentados na implementação do programa:

A ideia, naquela época, era que seria preciso quebrar um pouco as corporações, que entendiam que os institutos de pesquisa deviam ser, no fundo, quase universidades, portanto dirigidos para a criação do conhecimento. [...] Só que no estado de São Paulo, isso se confrontou com as chamadas "associações", especialmente a dos Pesquisadores em Tempo Integral, que viam, nesse grupo, identificado com a "administração da inovação" ou a "gestão da inovação", uns burocratas que queriam tomar conta da pesquisa em São Paulo. E então nós tivemos embates extremamente duros [ênfase]. Eu me lembro de debates moderados pelo Pavan lá no Instituto de Física, entre os pesquisadores do Instituto Butantã e esse nosso grupo de gestão da inovação, que foram extremamente violentos. Porque, no fundo, eles diziam o seguinte: "gestão é um problema de burocrata e nada temos a ver com vocês". E nós procurando transmitir que, sem algum nível de gestão, de definição de objetivos, de estruturação, de execução e de avaliação, as coisas não iam avançar. Mas eram culturas totalmente opostas. Hoje, todo mundo fala em gestão, todo mundo fala em inovação, mas naquela época, década de 1970, foi um período de confrontos.

A trajetória do dirigente 26 é, portanto, exemplar da atuação desses experts em gestão que se engajaram, individual ou coletivamente, na difusão do conhecimento gerencial, a partir da década de 1970, travando em nome dele lutas intensas. Depois de quase duas décadas de participação na consolidação do conhecimento gerencial, o dirigente foi eleito diretor da FEA nos anos 1980 e, na segunda metade dos anos 1990, reitor da USP, marcando a sua legitimação enquanto especialista em gestão de instituições de ensino e pesquisa, particularmente universidades. Entre todos os casos de especialistas em gestão analisado foi, sem dúvida, o que 
alcançou o cargo mais alto da hierarquia universitária. Mas ele não está sozinho. Outro exemplo do processo de profissionalização de experts em gestão que, pelo seu domínio de conhecimentos específicos, legitimaram-se para assumir e permanecer em postos importantes da gestão de instituições de ciência e tecnologia é a trajetória do dirigente 36.

O objetivo original do dirigente 36 era cursar engenharia na Escola Politécnica de São Paulo durante os anos 1960. No entanto, contingências pessoais e limitações de ordem financeira acabaram levando-o ao curso de engenharia agronômica na Escola Superior de Agricultura Luiz de Queiroz. Apesar do desempenho acadêmico brilhante e da vida acadêmica intensa em torno das repúblicas estudantis e do centro acadêmico, o dirigente fez seu curso com pouco entusiasmo até se deparar, no último ano, com as disciplinas de economia que, já na época, segundo ele, envolviam também conhecimentos de administração, campo de conhecimento que lhe motivou particularmente. $\mathrm{O}$ excelente desempenho acadêmico obtido nessa disciplina e em outras disciplinas ao longo do curso lhe rendeu, além de prêmios escolares, um convite para tornar-se, após a conclusão do curso em 1964, assistente da Cátedra de Economia Rural da Esalq. Na época, a economia e a administração agrícolas eram áreas ainda muito incipientes mas, com o tempo, conforme o próprio professor descreve, elas cresceram até constituírem, hoje, o maior departamento da Esalq:

Então quando eu entrei para o departamento ele era bem restrito: tinha um professor catedrático, um professor adjunto e um assistente. Então entramos mais dois, esse colega meu, que foi fazer o mestrado nos Estados Unidos, e eu. Depois, o departamento começou a crescer até se tornar, hoje, o que tem o maior número de docentes na Esalq.

O crescimento inicial da área de economia e administração agrícola no país de um modo geral, e na Esalq em particular, também resultou de acordos entre instituições brasileiras e norteamericanas com apoio direto da Usaid. De novo, é possível encontrar no trabalho de Rodrigo Patto Sá Motta algumas linhas sobre o acordo que envolvia, além da Esalq e da Usaid, a Universidade Estadual de Ohio: 
No caso do convênio com a Esalq, em 1971, a Usaid estava custeando cinco especialistas da Universidade de Ohio em Piracicaba, assim como lhe fornecera livros e equipamentos. Ela havia ajudado a criar mestrados em entomologia e economia agrícola e, até aquele ano, os investimentos da [US]AID no projeto montavam US\$ 3 milhões (Motta, 2014, p. 143).

Foi justamente no âmbito desse convênio entre a Esalq e a Universidade Estadual de Ohio que, entre 1968 e 1971, o dirigente 36 realizou sua pós-graduação sobre "a produtividade agrícola do estado de São Paulo" nos Estados Unidos, muito embora, como ele mesmo relata, sua viagem não tenha contado com financiamento direto da Usaid:

[Pergunta] Professor, voltando um pouco, em 1968, o senhor vai para a Universidade de Ohio fazer a sua pós-graduação. Como surgiu essa oportunidade, como era essa relação?

[Resposta] A Esalq tinha, na época, um convênio com a Universidade Estadual de Ohio para intercâmbio de professores e alunos. Então, alguns professores americanos vinham para Piracicaba, participavam da atividade didática, de certa forma compensando a ausência do professor que ia para lá. Portanto, os professores mais novos iam fazer a pós-graduação no exterior enquanto isso esses professores norteamericanos vinham para o Brasil.

[Pergunta] Essas pós-graduações eram sempre em Ohio?

[Resposta] A maioria era em Ohio, por causa do convênio. Quer dizer, se fosse uma área do conhecimento que a Universidade de Ohio não contemplasse, então poderia ser outra instituição, mas o convênio era com a Universidade Estadual de Ohio.

[Pergunta] E o senhor foi um dos primeiros a fazer o doutorado nessa área de Economia na Esalq?

[Resposta] No departamento, fora do Brasil, foi sim. [...] A minha bolsa era da Fapesp. Depois surgiu um problema orçamentário na Fapesp, e ela suspendeu as bolsas e então eu tive uma bolsa da Fundação Ford. A Fundação Ford, na época, tinha um convênio com a Universidade Federal de Viçosa para formação de corpo docente e esse convênio foi expandido para a Esalq, mas eu já estava nos Estados Unidos. Então, os que foram depois da minha ida para lá já foram com a bolsa da Fundação Ford. Quando eu fui, ainda não existia o convênio. No entanto, quando surgiu esse problema orçamentário na Fapesp, eu solicitei uma bolsa à Fundação Ford, ela consultou a USP, se eu poderia ser incluído nas bolsas, embora sem estar originalmente contemplado. Enfim, foi aceito. Então eu fiquei mais ou menos um ano com a bolsa da Fapesp, depois o restante foi com a bolsa da Fundação Ford.

Ao retornar dos Estados Unidos, já depois da reforma de 1968, o dirigente 36 passou a se dedicar a atividades político-administrativas diversas, dentro e fora da universidade, sobretudo em função do número restrito de docentes da Esalq. Assim, entre 1972 e 1980, o dirigente 36 foi chefe do Departamento de Economia, Administração e Sociologia da unidade. Entre 1971 e 1980, coordenador do convênio USP-Fundação Ford para o desenvolvimento de programas de pós-graduação. Ainda em 1971, tornou-se assessor científico da FAPESP e em 1975, assessor 
técnico da Secretaria de Ciência, Tecnologia e Desenvolvimento Econômico do Estado de São Paulo. O dirigente desempenhou, ainda, um papel central na construção da pós-graduação em economia agrícola na Esalq, cuja coordenação assumiu em 1974. O curso, nessa época, contava com apoio direto de professores da FEA-USP, tais como José Pastore, também ligado ao PACTo. A relação estreita com a FEA inspirou o dirigente 36 a criar, com outros professores da Esalq e nos moldes da FIA e da FIPE, a FEALQ, Fundação de Estudos Agrários da Esalq, voltada ao apoio à pesquisa na instituição.

A sua participação ativa na construção da pós-graduação depois da reforma universitária fez com que o dirigente 36 fosse indicado pela Esalq, em 1973, para compor uma comissão de especialistas do MEC responsável por elaborar, junto à Capes, a estrutura do sistema nacional de avaliação da pós-graduação, cujas linhas gerais ainda estão em vigor. A atuação na consolidação da pós-graduação em âmbito nacional resultou em um convite para que ele assumisse a presidência da Capes durante os anos 1970, o que acabou não acontecendo porque a Esalq, de novo em função da falta de docentes, não autorizou o seu afastamento da unidade. Por outro lado, foi essa mesma atuação junto à Capes e ao MEC que possibilitou ao professor de economia e administração da Esalq participar, entre 1976 e 1977, de um programa para a formação de dirigentes universitários, fruto de um convênio entre o MEC e a Universidade de Michigan. Na entrevista realizada por mim em 2012, na sede da FAPESP, o dirigente falou brevemente sobre o convênio:

\footnotetext{
Era um programa de orientação em que o MEC contratou a Universidade de Michigan para a formação de dirigentes universitários. Eu fui em um grupo que tinha diretores e reitores das universidades federais. Eu era o único que não era de universidade federal, eu era da USP, e que também não era diretor, eu era professor. [...] Nós ficamos uns três meses na Universidade de Michigan, acompanhando todo o desenvolvimento da universidade. Nós tínhamos algumas palestras e uma parte vivencial. Então, vinha alguém de uma determinada universidade, fazia a apresentação, dava uma palestra e depois nós passávamos alguns dias dentro daquele setor da universidade, acompanhando o seu funcionamento como convidado, como se você fizesse um estágio naquele setor. Nós participávamos das atividades de diversos setores da administração universitária, desde a graduação até a pós-graduação, funcionamento dos departamentos, a parte administrativa, a parte orçamentária. Foi daí que eu mexi muito com a parte orçamentária, a confecção de orçamentos lá que acabou sendo útil no retorno para cá.
} 
De fato, alguns anos depois de retornar desses cursos nos Estados Unidos, a percepção de que o dirigente possuía uma habilidade especial para a administração, somada aos seus conhecimentos específicos na área, resultou em um movimento, no âmbito da Esalq, para que ele se tornasse diretor da unidade. Assim, no começo da década de 1980, com praticamente a unanimidade dos votos da congregação, o dirigente 36 tornou-se diretor da Esalq e, consequentemente, membro do Conselho Universitário da USP. Pela sua atuação no Conselho Universitário, o dirigente 36 foi eleito, em 1983, para compor a sua Comissão de Orçamento e Patrimônio (COP), à qual pertencia pelo menos até o começo de 2014. Dez anos depois de ingressar na COP, tornou-se responsável, também, pela diretoria administrativa da Fapesp, posição que também mantinha nos primeiros meses de 2014. Por fim, o dirigente também assumiu a coordenação do Anuário Estatístico da USP, responsável, como foi dito, pela centralização de informações estatísticas sobre a universidade que possibilitou, por sua vez, uma série de políticas específicas na área de avaliação, organização e racionalização administrativa. A sua longa permanência nesses diferentes órgãos, tanto na USP quanto na FAPESP, está associada à percepção, bastante difundida entre os dirigentes entrevistados ao longo da pesquisa, do seu domínio de técnicas especializadas de administração, especialmente no plano orçamentário ${ }^{148}$ que, como ele mesmo aponta, foram adquiridas, ao menos em parte,

\footnotetext{
${ }^{148}$ É importante notar que a COP elabora uma proposta orçamentária anual que é posteriormente aprovada pelo Conselho Universitário da USP. Portanto, do ponto de vista formal, o controle do orçamento da USP pela COP é sobretudo de natureza técnica, embora exista uma forte tendência, por parte do Conselho Universitário, de aprovar o orçamento tal como elaborado no âmbito dessa comissão. Atualmente, o processo de aprovação do orçamento da USP segue duas etapas. Primeiro, a COP elabora uma proposta de "diretrizes orçamentárias" que, em síntese, apresenta diversos critérios para a distribuição do orçamento da USP entre as suas diferentes unidades. Uma vez aprovadas as "diretrizes orçamentárias" pelo Conselho Universitário, a COP aplica esses critérios sobre o repasse anual previsto, excluindo os gastos fixos em salário e aposentadoria, chegando a uma distribuição do orçamento relativo a "outras despesas" entre as diferentes unidades. A aprovação de diretrizes orçamentárias representou, em grande medida, uma racionalização do processo de distribuição de parte do orçamento da USP, que passou a seguir critérios públicos, discutidos e aprovados no âmbito do Conselho Universitário. No entanto, uma parte significativa desse mesmo orçamento, relativo às "outras despesas", que exclui portanto o gasto com pessoal, permanece centralizada, sendo executada por "órgãos centrais de direção e serviços", "atividades integradas" e "fundos e projetos especiais" que se organizam no âmbito central. Só para se ter uma ideia, em 2012, excluindo-se os gastos com pessoal (ativos e inativos), as unidades de ensino e pesquisa, os centros e institutos especializados, os hospitais, serviços anexos e museus concentravam apenas $26,08 \%$ do orçamento da USP distribuído na alíquota "outras despesas". O restante foi executado no âmbito central, sendo 33,78\% por órgãos centrais de direção e
} 
no curso de formação de dirigentes realizado nos Estados Unidos entre 1976 e 1977.

Mas o mais interessante, no caso do dirigente 36, é que, apesar de todo o seu envolvimento com atividades de administração universitária, bem como o seu enraizamento no polo profissional tradicional, é possível notar que ele defende um modelo de governo acadêmico que predomina justamente no polo oposto, formado por unidades de perfil mais científico, onde se observa uma defesa mais incisiva de um governo acadêmico baseado nos órgãos colegiados, com a reitoria e as diretorias de unidade funcionando como instâncias meramente executivas.

\begin{abstract}
[Pergunta] Professor, e na gestão da universidade, qual seria o papel dos órgãos colegiados? Por que, de certa forma, eles implicam uma imprevisibilidade ao planejamento. Ou não?

[Resposta] Os colegiados têm função normativa, eles são órgãos normativos e a execução é reitoral.

[Pergunta] Mas o senhor acha que os colegiados atrapalham ou ajudam a administração?

[Resposta] Eu acho que ajudam! Porque seria muito perigoso ficar apenas com o executivo. Mas você poderia dizer: "Não, mas se você não tivesse os colegiados as coisas poderiam ser mais rápidas", mas nem sempre teriam sido tomadas as melhores decisões. Então eu acho que essa pluralidade dos colegiados é muito importante. Eu sempre digo, todo o colegiado com representação discente, docente e funcional é importante porque ele gera uma responsabilidade maior nos membros, porque você está preocupado com uma outra categoria que vai avaliar aquilo. Em suma, a política da universidade tem que ser definida pelos colegiados, e a sua execução por parte dos dirigentes executivos, os reitores e diretores.
\end{abstract}

A defesa da gestão colegiada, em si, contraria a ideia difundida a partir da reforma universitária de 1968, de que é preciso fortalecer os órgãos executivos da universidade, responsáveis por oferecer diretrizes para o funcionamento da instituição, através da definição de projetos, diretrizes e metas. A posição do dirigente 36 explicita uma visão dos que reconhecem que a gestão, seja como conhecimento específico seja como conjunto de dispositivos e práticas, não deve intervir sobre a organização do governo acadêmico, limitandose, nas suas palavras, "a apoiar as atividades-fim, porque se a administração assumisse funções

serviço, $29,61 \%$ por atividades integradas, $9,54 \%$ por fundos e projetos especiais e $0,20 \%$ por programas de expansão. A atual crise da USP incide justamente sobre essas "outras despesas", sugerindo que pode haver uma inflexão dos processos de centralização descritos nesta tese, em função da perda do potencial de investimento desses órgãos centrais. Para dados sobre o orçamento da USP, ver Anuário Estatístico (USP, 1987). Disponível em: <https://uspdigital.usp.br/anuario/> Acesso em: 21 de abr. 2014. Para mais detalhes, ver também tabelas 31 e 32 do quarto capítulo desta tese. 
que não seja apoiar as atividades-fim será muito ruim para a universidade”. É interessante que, ao contrário da visão predominante dos dirigentes da USP que, como se verá no último capítulo, desprezam a administração pela sua função instrumental, o dirigente 36 enxerga justamente no seu caráter de mero instrumento o valor da administração. Talvez por isso, justamente, ele recuse com veemência a diferença entre gestão e administração e, consequentemente, o predomínio da linguagem gerencial:

\begin{abstract}
[Pergunta] Professor, indo para as questões mais gerais. Existe uma discussão, hoje, sobre a diferença entre administrar e gerir. Na sua opinião, qual a diferença entre a gestão e a administração da universidade? Existe essa diferença? [Resposta] Olha, eu acho que não.

[Pergunta] Porque tem toda uma discussão sobre isso, não é? A transição da administração para a gestão.

[Resposta] É. Mas eu já acho que a "gestão" é mais um modernismo. Por exemplo, fala-se muito de "gestores". Eu não uso essa expressão nunca! Nunca! Hoje, voltando da Secretaria da Fazenda, no caminho para casa, eu estava pensando em um texto que eu tinha escrito de manhã aqui. Então, em um momento eu pensei em escrever uma frase que começava "o bom gestor..." E eu falei para mim mesmo: "Não vou usar! Eu não gosto dessa expressão!!”. Eu sei que está na moda e que muitos esperam que eu escreva isso em determinado parágrafo, ou seja, o que cabe ao "bom gestor", mas talvez eu não me acostume mais a isso. O problema é que eu não sei o que realmente se quer dizer quando se fala "os gestores". Mas quem são os gestores? O gerente, abaixo do gerente? Então por que você não fala "os administradores dessa área"? Quer dizer, eu acho que hoje pegou, é moda, essa expressão ficou muito usual e talvez eu não tenha escolha (risos).
\end{abstract}

Essa observação, aparentemente despretensiosa, é paradigmática do processo social pelo qual o discurso da gestão vai se impondo, independentemente da vontade e da intenção consciente dos agentes sociais. Assim, mesmo recusando as categorias gerenciais, mantendose ligado a uma visão mais tradicional de administração, o dirigente 36 percebe um conjunto de constrangimentos, que ele traduz em termos de expectativas sociais, para a adoção do novo vocabulário.

A explicação mais completa e interessante do processo de imposição da linguagem gerencial na universidade através da afirmação da gestão como um dispositivo de saber-poder é oferecida pelo dirigente 37 , que constitui a terceira trajetória de experts em conhecimentos gerenciais que analisamos nesse item. Depois de cursar o ensino secundário em um dos colégios 
públicos mais importantes do interior do estado de São Paulo, o Ginásio Culto à Ciência de Campinas, o dirigente 37 ingressou no curso de economia da FEA em 1968, onde encontrou um ambiente fortemente marcado pelo momento político. Sua experiência política de secundarista, quando atuava junto à Juventude Estudantil Católica (JEC), tornava-o relativamente propenso a participar de movimentos de esquerda. No entanto, o recrudescimento da repressão militar no ano do seu ingresso na universidade e a consequente desestruturação do movimento estudantil impediram que ele se envolvesse mais diretamente com organizações de esquerda naquele momento, como ele mesmo descreve em entrevista concedida a mim, na reitoria da USP, em 2013:

\begin{abstract}
[Pergunta] Professor, nesse contexto político todo, de 1968, o senhor chegou a participar do movimento estudantil mais ativamente? $O$ senhor foi do centro acadêmico, por exemplo?

[Resposta] Pois é, nesse momento, as portas já estavam se fechando, os grupos não estavam buscando mais militantes. Então, tinha coisas assim: você ia ao teatro e recebia ali no para-brisas uma mensagem pedindo apoio, pedindo dinheiro, pedindo coisas desse tipo, mas você nem sabia como doar, porque eles deixavam a mensagem e iam embora, fugiam. Era, portanto, um movimento todo desestruturado e você acabava não conseguindo entrar.
\end{abstract}

Sem encontrar espaços mais efetivos de atuação política, um dos eventos mais importantes da sua graduação, como ele mesmo aponta, foi a participação em um programa da Associação Universitária Interamericana (AUI) ${ }^{149}$ que recrutava lideranças político-estudantis, de diferentes tendências ideológicas mas, sobretudo, de esquerda ${ }^{150}$, para uma visita de cerca

\footnotetext{
${ }^{149}$ A Associação Universitária Interamericana era uma entidade civil brasileira, sem fins lucrativos, organizada por uma norte-americana que morava no Brasil. Segundo informações da própria AUI, ela reuniu praticamente todo o financiamento para as viagens dos jovens brasileiros com empresários locais, especialmente norteamericanos, contando com uma pequena contribuição financeira do Departamento de Estado e da embaixada norteamericana no Brasil.

${ }^{150}$ Nos registros históricos da AUI, existe uma transcrição de um diálogo, gravado pela Casa Branca, entre o então presidente John Kennedy e o embaixador norte-americano no Brasil, Lincoln Gordon, em que o embaixador explica as linhas gerais do programa, uma vez que o então presidente norte-americano receberia os estudantes brasileiros do programa no dia seguinte, 31 de julho de 1962. Segundo o embaixador, se tratavam de " 70 estudantes de quatro diferentes estados brasileiros [...] que estiveram em Harvard durante duas semanas. Formam um grupo de tendências variadas, desde uma formação fortemente democrática, pró-americana até outra quase comunista, altamente nacionalista, claramente antiamericana". Ver <http://www.aui.org.br/livro/historia.asp >. Acesso em 21 de abr. 2014.
} 
de um mês aos Estados Unidos. O programa, cujo objetivo era "identificar futuros líderes políticos, sociais e empresariais no Brasil e complementar a sua formação dando uma visão abrangente da sociedade americana" ${ }^{" 151}$, existiu de 1962 a 1971 e, nesse período, financiou a viagem de quase 900 jovens brasileiros, dentre os quais futuras lideranças políticas de diferentes partidos políticos, como, por exemplo, Pedro Malan, Paulo Renato Souza, Dalmo Dallari, Marco Maciel, Luiz Aluysio Nunes, Flávio Arns e Luciano Coutinho ${ }^{152}$. A primeira etapa do programa da AUI era um curso de três meses no Brasil, no caso de São Paulo, realizado na Escola de Sociologia e Política. A segunda etapa era um curso em Harvard, de dois módulos, chamados Problems of Economic Development e Life and Institutions in the United States. Ao falar sobre o programa em outra entrevista, o dirigente comenta:

\begin{abstract}
Essa associação tinha como base a ideia de que o intercâmbio de pessoas, entre países, contribuía para a paz e o progresso. No caso, procurava levar para os EUA estudantes brasileiros, em boa parte líderes estudantis de esquerda, com finalidade de conhecerem aquela realidade, entrarem em contato com o sistema universitário e a democracia norte-americana. Passava-se mais ou menos uma semana com uma família norte-americana e o resto do período, nas universidades. Era um grupo de cerca de 90 estudantes, que foram selecionados em todo o Brasil. [...] Passamos uma semana na Universidade de Harvard, outra semana na Universidade de Columbia e o resto do mês em Washington, com visitas ao Departamento de Estado, FMI etc. Foi um impacto cultural muito forte. [...] Certamente um dos objetivos [era propaganda norte-americana]. Nada é gratuito. Eles selecionavam um grupo de jovens que, na sua maioria, mais de $80 \%$, era de esquerda [...]. Durante a viagem, aconteciam aulas e palestras, mas o efeito imediato provavelmente foi apenas o de umas férias excelentes. Mas o resultado a longo prazo foi diferente. [...] Enfim, a vivência naquele país mostrava a enorme distância em que nos encontrávamos e explicitava a nossa pobreza política, econômica e cultural (Motoyama, 2006, p. 369).
\end{abstract}

De volta ao Brasil, o dirigente 37 concluiu a graduação na FEA em 1971 e realizou o mestrado e o doutorado na mesma instituição entre 1972 e 1977. Ao concluir o doutorado sobre “inovação e difusão tecnológica”, realizou um pós-doutorado em Yale sobre mesmo tema, onde

\footnotetext{
${ }^{151}$ A AUI foi refundada em 2002 pelo ex-vice-presidente Marco Maciel e outros ex-bolsistas da Associação com o nome de Associação Internacional de Universidades. Desde então, mantém um programa chamado "Jovens líderes do Brasil" voltado à promoção de "atividades acadêmicas, de integração comunitária e social, de lazer e cultura". No site da Associação existem várias informações sobre o programa original, que funcionou a partir de 1962 < http://www.aui.org.br/ >. Acesso em 21 de abr. 2014.

${ }^{152}$ A lista completa dos bolsistas da AIU está disponível em: <http://www.aui.org.br/livro/bolsistas.asp>. Acesso em 21 de abr. 2014.
} 
colaborou com pesquisadores importantes da área como Jorge Katz, atualmente na CEPAL. Em 1981, em função do seu domínio do tema da economia da inovação, passou a integrar o Núcleo de Política e Gestão de Ciência e Tecnologia cuja origem, como visto, remonta ao PACTo, criado em 1973.

No começo dos anos 1990, o reitor da USP à época decidiu colocar na direção da Coordenadoria Geral de Administração, a Codage, um especialista da Faculdade de Economia e Administração. Para tanto, recorreu formalmente à FEA, solicitando que a unidade apresentasse uma indicação formal, como o próprio reitor descreve, em entrevista realizada por mim em 2013:

Chegou um dado momento em que eu resolvi convocar o pessoal da FEA para que eles indicassem um especialista. Eu me lembro que eu disse: 'Eu acho um absurdo uma reitoria que tem uma Faculdade de Economia e Administração não ter o seu coordenador de administração vindo de lá. Me indiquem um nome'.

Foi em função desse convite formal a FEA que o dirigente 37 assumiu a Codage, onde permaneceu de 1991 a 2001, com um breve período de afastamento em 1992. Em 2001, logo depois de deixar a Codage, tornou-se vice-reitor da USP, dando continuidade aos programas centrais que desenvolvia na Coordenadoria, como a Comissão Permanente de Avaliação, criada em 1992, e o Programa Permanente de Qualidade e Produtividade, criado em 1996. Ao avaliar os quase 15 anos contínuos em que permaneceu na reitoria à frente da área administrativa, o dirigente apresenta uma descrição muito rica da dinâmica política e social que possibilitou "que essa linguagem, de planos e metas, fosse aceita por toda a comunidade":

[Pergunta] O senhor entrou na Codage, me corrija se eu estiver enganada, em 1991. Eu queria saber como a Codage atuou e como ela evoluiu. Eu sei o que o senhor não ficou o tempo inteiro na Codage, mas sempre acompanhou muito de perto esse âmbito da administração geral.

[Resposta] Olha, inicialmente eu cheguei à reitoria para lidar com alguns problemas financeiros que a universidade enfrentava, mas rapidamente eu passei para a Codage. No período em que eu fiquei na Codage, eu tive um enorme espaço de atuação. Quer dizer, todos os reitores, em grande parte do período, me deram enorme espaço de levar adiante minhas ideias, sempre mediadas pelo jogo político que é o reitor quem faz. Então, eu era "o técnico", portador desse tipo de ideia tentando, dentro do grupo, levar adiante o que eu pensava. Mas todo jogo político era feito pelos reitores, eu era protegido disso [...]. Por exemplo, a parte de informatização, para mim era muito fácil, 
claro que nós devemos informatizar. Quem pensa em mudança tecnológica fala que a informática tem que avançar, a parte administrativa tem que avançar. Tive e dei apoio para que isso ocorresse. A própria carreira dos funcionários, a primeira versão foi inspirada em administração japonesa do just in time, aprendizagem contínua, treinamento, tudo isso nós colocamos como ideias, e essas ideias modernas, então, vingaram. Depois tinha planos, projetos especiais de racionalização de uso de água, de energia etc. [...]. Então eu acolhia essas ideias, que eram óbvias para mim e, em certo sentido, eu acho que também eram óbvias para muita gente. Os reitores, por exemplo, aceitavam e gostavam [...] e, por isso, eu fazia parte de todos os fóruns de decisão, de contratação e tudo isso. Você vai entender bem porque: essa linguagem é sedutora. Parecia que eu estava falando coisas sensatas. E talvez outros não estivessem tão preparados em termos de assumir uma concepção mais organizada do funcionamento da universidade. Então as minhas ideias acabavam sendo bem recebidas, elas tinham uma certa articulação, [...] consequentemente, eu não era uma pessoa que chegava para falar da parte financeira exclusivamente. A minha trajetória acadêmica me possibilitava falar de administração de ciência e de tecnologia e era tudo o que eu gostava de fazer. Aliás, eu vim por isso e fiquei tanto tempo por isso: porque eu encontrava um ambiente favorável para testar as minhas ideias e até implementá-las, em certa medida [...]. Claro que a tempestade ficava com o reitor. Quer dizer, o jogo político ficava com ele [...]. Do que eu realizei nesse período, o que eu considero mais importante é a forma de contratação de docentes, junto com a avaliação institucional, ou seja, essa cultura de ter planos e metas! Fazer com que essa linguagem fosse aceita por toda a comunidade. A primeira vez que eu falei disso aqui, houve um certo desprezo. "Claro, um cara da FEA só pode falar essas bobagens". Era esse tipo de tom. Mas aos poucos, foram adotando essa linguagem. A linguagem, inclusive, é bastante disseminada hoje... Você não pede recurso para a FAPESP sem ter um projeto. Então, a cultura de projetos, de planos, de metas, alimentando as decisões estratégicas de contratação de docentes, de criação de cursos, enfim... disso eu participei com força.

Esse longo e rico relato da experiência do dirigente 37, que se define como um "técnico" portador de uma "concepção organizada" de administração de instituições de ensino e de ciência e de tecnologia, é revelador do processo pelo qual a "cultura de projetos, de planos e de metas", com a sua linguagem correspondente, foi aos poucos se impondo na universidade, através da atuação desses especialistas que, graças ao domínio de discursos considerados legítimos e sensatos, adquiriram uma considerável margem de atuação e influência. Mas o papel desses experts em conhecimento gerencial, nos seus diferentes matizes, não foi o único fator para a disseminação dessa linguagem. De novo, a análise do dirigente 37 é reveladora. Segundo ele, não se tratou de "um herói, com uma ideia, enfrentando grande oposição e que travou batalhas homéricas". Embora tenha havido muito trabalho para conseguir "adesões" à visão gerencial, o seu curso teve algo de "natural" porque seguiu "a tendência das coisas": 
[Pergunta] Ao longo da minha pesquisa no jornal da USP, por exemplo, eu fui um pouco atrás de quando é que surgiram, na USP, as discussões sobre a importância da gestão. É possível notar que, no começo, era algo muito incipiente e que, hoje, tornouse praticamente consensual.

[Resposta] É sim, é um consenso. É bastante consensual.

[Pergunta] E como foi essa evolução? Como o senhor entende que essa linguagem se impôs?

[Resposta] Veja, eu acho, primeiro, que nós caminhamos junto com as tendências das coisas. Era o caminho que as coisas estavam adotando. Eu tinha uma certa orientação teórica que me permitia ajudar a identificar essas tendências. Agora, a gente nunca pode exagerar muito aqui. Muitos colegas foram parceiros, pessoas de muitas áreas de conhecimento interagindo nacional e internacionalmente, que também traziam a grande tendência para a USP. Quer dizer, não foi um herói com uma ideia, enfrentando grande oposição, que travou batalhas homéricas. Não, pelo contrário, foi mais natural, uma ideia que vai conseguido adesões, com treinamento, com muitos eventos, e isso vai perpassando todas as áreas. A carreira dos funcionários foi uma carreira inspirada nesse tipo de literatura. Não só a carreira de funcionários, como a de docentes. Então veja, tem uma unidade, se você quiser buscar essa unidade de visão, você pode encontrar nessa evolução da universidade.

A observação do dirigente 37 sugere, justamente, que o processo social de imposição das categorias gerenciais assume duas dimensões. Por um lado, se é verdade que houve um intenso e sistemático trabalho social para viabilizar a sua difusão, por outro, é preciso reconhecer que essas mesmas categorias se difundiram com certa facilidade porque traduziram, em seus próprios termos, elementos da visão de universidade já predominante no polo dominante da universidade. De novo, como foi dito, o objetivo essencial desta tese é dar conta dessa dupla dimensão da imposição das categorias gerenciais, a sua imposição como um dispositivo de saber-poder e enquanto um sistema de classificação afinado ao polo dominante da universidade.

Em síntese, as três trajetórias analisadas até aqui revelam que, embora no interior do grupo dos experts em gestão possam existir diferenças e tensões importantes ${ }^{153}$, é possível dizer que eles contribuíram, de modo mais ou menos intencional, para a difusão do discurso da gestão na universidade, seja através de programas efetivos de "sensibilização", "doutrinamento" e

\footnotetext{
${ }^{153}$ É possível notar que existe uma forte disputa em torno dos termos "gerencial", "econômico" e "administrativo", o que expressa a existência de batalhas classificatórias importantes no interior desse grupo. O princípio dessas disputas é a oposição entre concepção e execução, à primeira vista como uma dimensão "nobre" e "elevada" e a segunda, como uma prática "baixa" e "rasteira". No entanto, pelos outros dirigentes que compõem a amostra desta pesquisa, eles são visivelmente reconhecidos como "técnicos em gestão" e, apesar de toda a batalha classificatória, eles mesmos reconhecem-se nessa posição.
} 
"treinamento", como no caso do dirigente 26 , seja por meio da implementação de dispositivos e rotinas administrativas, como no caso do dirigente 36 , seja pela imposição de uma cultura gerencial com sua linguagem própria, como no caso do dirigente 37 . Do ponto de vista da dinâmica de difusão das categorias gerencias, não parece exagero considerar os experts em gestão o núcleo difusor a partir do qual essas ideias se propagam, tal como ondas sonoras, pelo espaço da universidade. O primeiro grupo a ouvir a melodia gerencial são, como já pôde ser observado nas falas dos experts, os reitores que atuam ao seu lado e que também passaram, a seu modo, por processos específicos de “conversão invisível”.

\subsubsection{A reprofissionalização de "lideranças institucionais" nos anos 1970 e 1980}

Se o primeiro padrão de "conversão" de dirigentes universitários ao discurso da gestão foi descrito como um processo de profissionalização, concentrado nos anos 1970 e associado a dinâmicas nacionais e internacionais de circulação de conhecimentos especializados, o segundo padrão de "conversão" é melhor compreendido enquanto uma reprofissionalização individual, associada à transição, muitas vezes definitiva das atividades de ensino e pesquisa para as atividades de direção em instituições públicas ou privadas. A noção de reprofissionalização se inspira, nesse caso, no trabalho de Frederic Hafferty e Donald Light (1995) sobre a transformação estrutural da profissão médica nos Estados Unidos, sobretudo a partir da emergência de "uma nova elite médica", voltada ao controle, avaliação e coordenação de atividades internas à profissão, em especial no interior de instituições hospitalares. Segundo os autores, os médicos que, nas últimas décadas, migraram da clínica e da pesquisa para as atividades de gestão foram obrigados a enfrentar, justamente por conta dos dispositivos e rotinas de gestão cada vez mais complexos, um processo de reprofissionalização individual que envolve não só uma transformação da identidade profissional mas, sobretudo, a aquisição de 
novas habilidades e competências que estão na base desse deslocamento identitário (cf. Hafferty

\& Light, 1995, p. 138ss).

A análise dos autores sobre a transformação da profissão médica nos Estados Unidos pode servir perfeitamente de inspiração para pensar as transformações da profissão acadêmica, expressas nas inflexões da administração central da USP, especialmente quando tomamos como objeto as trajetórias individuais dos mais altos dirigentes a partir do final da década de 1970 . Se até a redemocratização, a escolha dos reitores da USP se dava exclusivamente em função da sua trajetória política externa à universidade, a partir de 1985 e progressivamente, tornam-se igualmente importantes tanto a trajetória interna à instituição quanto as habilidades e competências ligadas à gestão acadêmica, usualmente auferidas pela experiência pregressa em cargos de gestão. Essa transformação no perfil dos dirigentes máximos da USP expressa não só uma mudança do sistema político nacional e dos seus efeitos sobre o formato da eleição para os cargos executivos da universidade ${ }^{154}$ como, também, os efeitos da atuação prolongada de

\footnotetext{
154 A principal mudança na eleição para os cargos executivos das universidades estaduais paulistas durante a redemocratização foi a extinção da lista sêxtupla que, na prática, representava a ampla possibilidade de intervenção do governo estadual na escolha dos dirigentes máximos da instituição. Desde então, a tendência quase unânime, por parte dos governadores, é o respeito à eleição interna, expressa na hierarquia da lista tríplice. A única exceção, desde 1982, foi a escolha de João Grandino Rodas pelo então governador José Serra. Quanto à forma de eleição, no momento da mudança do estatuto da USP, em 1988, havia uma pressão interna, especialmente por parte das entidades representativas, ADUSP, SINTUSP e DCE, por uma mudança mais radical na forma de eleição dos dirigentes internos, ou seja, reitores e diretores, através da instituição de mecanismos de eleição direta, paritária ou não paritária. Essa posição, no entanto, foi derrotada no processo de mudança do estatuto por uma outra, que defendia que a escolha dos dirigentes deveria ser feita por um colégio eleitoral formado pelos órgãos colegiados da universidade. No interior dessa segunda posição, no entanto, existiam e existem tensões importantes. Sobretudo no que concerne à forma de escolha do reitor. A maior parte do Conselho Universitário, em 1988, defendeu um sistema de eleição em dois turnos, que predominou na USP até 2013. Segundo esse sistema, um primeiro turno, para a escolha de oito candidatos, era composto por um colégio eleitoral formado por todas as congregações de unidade e órgãos análogos, pelo Conselho Universitário e pelos Conselhos Centrais (de Graduação, PósGraduação, Pesquisa e Cultura e Extensão) e um segundo turno, voltado exclusivamente à elaboração da lista tríplice, era formado somente pelos Conselhos Universitário e Centrais. A vitória dessa posição, vale dizer, já indica a força das propostas centralizadoras na reforma de 1988. Uma outra posição, minoritária à época mas predominante nos últimos anos, defendia a extinção do segundo turno e a formação de um colégio eleitoral único, que envolvesse todas as congregações e colegiados centrais da USP. Entre os defensores do turno único para a escolha do reitor existe, ainda, uma terceira posição, que defende a ampliação do colégio eleitoral para os Conselhos de Departamento. Os defensores dessa última proposta são, em geral embora não exclusivamente, membros do polo acadêmico-científico que tentam viabilizar um governo universitário que minimize os processos de centralização, conferindo poder aos órgãos colegiados de diferentes instâncias. Depois da reforma estatutária, de outubro de 2013, passaram a compor o colégio eleitoral da USP: o Conselho Universitário, os Conselhos Centrais (Graduação, Pós-Graduação, Pesquisa e Cultura e Extensão Universitária), as Congregações das Unidades e os Conselhos Deliberativos de Museus e Institutos Especializados. Em 2013, esse colégio somava 2.134 eleitores,
} 
experts em gestão sobre a complexificação do governo acadêmico a partir da emergência de novos dispositivos e rotinas, com a consequente imposição de uma nova linguagem gerencial. Portanto, assim como ocorreu em outras profissões, como a medicina (cf. Hafferty \& Ligth, 1995), esse processo de autonomização, complexificação e fortalecimento da gestão trouxe uma mudança profunda na estrutura interna da profissão acadêmica, a partir da emergência de uma "nova elite", responsável pela gestão universitária, que se torna portadora de habilidades e competências específicas que definem uma transição, em alguns casos definitiva, para o campo da administração de instituições de ensino e pesquisa.

Tomando emprestado as categorias mobilizadas pelos entrevistados ${ }^{155}$, optamos por nomear o grupo de dirigentes formado pelos reitores da USP de lideranças institucionais. No que concerne ao processo de "conversão" dessas lideranças, é importante notar que, ao contrário dos experts que passaram por processos longos e formalizados de formação, na graduação ou pós-graduação, a "educação gerencial” dos reitores é menos linear e estruturada assumindo, portanto, formatos e padrões diversos. Para exemplificar essa diversidade, tomemos algumas trajetórias paradigmáticas.

A primeira é a do dirigente 20 , que assumiu a reitoria da USP na segunda metade dos anos 1970. Formado na Escola Politécnica da USP no começo dos anos 1950, tornou-se docente dessa instituição, na área de matemática, no final dessa mesma década. Com a reforma universitária da USP de 1968-1969, foi transferido para o novo Instituto de Matemática e Estatística, tornando-se quase que imediatamente diretor da unidade, o que testemunha a força política dos professores originários do polo profissional tradicional na estrutura universitária da

que representavam 1,86\% da universidade que, em 2013, tinha 58.303 alunos de graduação, 28.498 alunos de pósgraduação, 5.860 docentes e 16.837 funcionários técnico-administrativos.

155 Ao longo das entrevistas, como veremos no último capítulo, era muito comum os entrevistados se referirem aos reitores da USP como "líderes" ou "lideranças". 
USP pós-reforma, especialmente no interior dos institutos recém-criados ${ }^{156}$. Foi justamente no período em que esteve na direção do IME que o dirigente 20 resolveu fazer um curso, na Escola Superior de Guerra, voltado “à administração de instituições” que, segundo ele, o ajudou a enfrentar a crise financeira e política da USP no período em que esteve à frente da reitoria (cf. Motoyama, 2006, p. 215). Essa primeira trajetória de "conversão" ao discurso gerencial, ligada a treinamentos de curta duração, indica que os processos de reprofissionalização de lideranças institucionais para o exercício de cargos executivos não coincide, imediatamente, com a redemocratização e as alterações na forma de eleição de dirigentes uma vez que, como viemos enfatizando, trata-se de um processo anterior aos anos 1980.

A ideia de institucionalizar o treinamento de dirigentes acadêmicos chegou a ser aventada algumas vezes na USP, como indica o dirigente 22, que foi reitor da universidade nos anos 1980. Assim como o dirigente 20, o dirigente 22 era professor catedrático da Escola Politécnica e transferiu-se para o Instituto de Física da USP depois da reforma de 1969, tornando-se rapidamente, como no caso anterior, diretor da unidade. Depois de permanecer no cargo por quase uma década, assumiu posições de direção fora da universidade, voltando à USP na metade dos anos 1980 para assumir a reitoria. Ao falar sobre a proposta de tornar obrigatórios

\footnotetext{
${ }^{156}$ O Instituto de Matemática e Estatística (IME), por exemplo, foi formado a partir da reunião de cadeiras da Faculdade de Filosofia, Ciências e Letras e da Escola Politécnica, tendendo a ser dirigido, nos seus primeiros anos de funcionamento, por catedráticos oriundos da segunda unidade, pertencente ao polo profissional tradicional, dominante. O Instituto de Física também foi formado por professores oriundos da FFCL e de outras unidades profissionais tradicionais, especialmente a Escola Politécnica, também sendo dirigido, com mais frequência nesse primeiro momento, por catedráticos oriundos da Poli. Por fim, podemos citar o caso do ICB, que também foi formado a partir da reunião de cadeiras de pesquisa básica na área médico-biológica, provenientes de diferentes unidades, sobretudo da Faculdade de Medicina, da Faculdade de Odontologia, da Faculdade de Medicina Veterinária e Zootecnia e da Faculdade de Filosofia, Ciências e Letras repondo, no seu interior, as hierarquias que marcavam na época a própria universidade. É nesse sentido, por exemplo, que um professor oriundo da Faculdade de Medicina, ao comentar sobre as consequências da formação do ICB nos seus primeiros anos de funcionamento, avalia, aplicando as hierarquias comuns na época como hoje: "A curto prazo, a formação do ICB foi ruim para todo mundo. A Faculdade de Medicina perdeu os departamentos básicos, que era onde estava a força da pesquisa. E o ICB resultou da reunião da Odontologia, Veterinária, enfim, gente que não tinha a tradição da Medicina, em termos de pesquisa. [...] Para piorar, as cassações da ditadura nos atingiram demais. Então você tinha a medicina enfraquecida na unidade, e ainda com esses apêndices, que era gente que não tinha nem ideia do que era pesquisa".
} 
os cursos de gestão para dirigentes, à qual se diz contrário, o ex-reitor sugere que os líderes institucionais, no caso reitores e diretores, se cerquem de "bons administradores":

\begin{abstract}
Eu não acho que deveria ter um cursinho para ser reitor ou para ser diretor. Claro que tem uns diretores muito ruins administrativamente, sobretudo na Faculdade de Filosofia. Tanto que se falou, nos anos 1980, que para ser diretor de escola seria preciso fazer um curso. Eu fui contrário, quer dizer, os diretores que não são bons administradores que encontrem bons administradores. Porque ele tem que tomar as decisões e, às vezes, você até toma as decisões corretas, mas não é um bom administrador para implementar.
\end{abstract}

A ideia de que o dirigente precisa se cercar de bons administradores aponta a existência de um outro modelo de conversão de lideranças, justamente através da convivência contínua com experts em gestão. Esse modelo apareceu com relativa frequência nas entrevistas. Assim, além do dirigente 22 , é o caso, por exemplo, do dirigente 24 , que foi reitor da USP nos anos 1990 e é médico de formação e professor da Faculdade de Saúde Pública, onde foi realizada a entrevista na qual o dirigente comentou, de passagem, que "fez uma verdadeira escola de administração" no período em que foi vice-diretor da sua unidade. Tentando entender melhor o significado dessa expressão, perguntei:

[Pergunta] O senhor comentou que quando foi vice-diretor, fez uma "escola", entre aspas, de administração. Por que o senhor diz isso?

[Resposta] Ah... é que quando eu fui vice-diretor, a minha diretora tinha uma experiência muito grande na parte administrativa. Ela era professora titular da área de administração hospitalar, na verdade. Quanto ela assumiu, ela me convidou formalmente para acompanhar de perto o cotidiano da diretoria. Então, todo dia ela despachava os relatórios, e eu sentava do lado e ficava ouvindo os trâmites e isso foi, para mim, uma escola.

Um outro padrão de reprofissionalização de líderes institucionais, ainda mais paradigmático, é a do dirigente 21 que, depois de passar pela direção de diferentes instituições nacionais de pesquisa, incluindo o CNPq, tornou-se, como dito, vice-reitor da USP no final dos anos 1980 e reitor da instituição no começo dos anos 1990. Foi durante o seu mandato na vicereitoria que o dirigente 21 passou a compor, como representante formal da universidade, redes internacionais de discussão e atuação no ensino superior, o que o colocou em contato com toda uma "nova" literatura sobre gestão universitária, transformando-o em um dos maiores 
especialistas no tema do país. O trecho abaixo é longo mas muito importante por descrever em

detalhes o fortalecimento, a partir dos anos 1980, de uma rede internacional de circulação de

dirigentes universitários, que contribuiu para difundir padrões comuns de avaliação e

organização acadêmica baseados em teorias de gestão:

[Pergunta] Professor, o senhor disse que uma gestão científica é uma gestão baseada nas modernas teorias da gestão. Como essa discussão chegou à USP, foi por meio do convênio com o BID, que previa uma parte de modernização administrativa ${ }^{157}$ ?

[Resposta] Pelo que eu me lembre, foi através do Laurent Schwartz, aquele matemático francês que organizou uma avaliação das universidades francesas ${ }^{158}$. Aquela avaliação teve um impacto tremendo na USP. Em mim, em particular, teve um impacto enorme. Então nós dissemos: "é esse o caminho! A avaliação existe, faz-se e é importante; os franceses vão fazer e nós vamos ficar para trás!" A percepção disso foi muito traumática! E foi então que começaram a haver vários simpósios sobre avaliação, seminários...

[Pergunta] No Brasil ou internacionalmente?

[Resposta] Internacionalmente. E no Brasil também. Eu fui ao Rio de Janeiro várias vezes para falar sobre isso. Em 1985, 1986 já se começava a falar mais intensamente nisso. Então, em 1987, foi criado o Projeto Columbus, não sei se você conhece? O Projeto Columbus é um projeto que foi concebido por alguns reitores latinoamericanos que foram aos encontros e conferências de reitores europeus e acharam que os europeus estavam fazendo um processo de avaliação baseado nessas ideias de gestão moderna e que a América Latina estava muito para trás, precisávamos modernizar, aumentar o contato com a Europa. Por isso, foi criado um projeto junto à Unesco, chamado Projeto Columbus, com financiamento da Comunidade Europeia, para intercâmbio de experiência de gestão acadêmica entre a América Latina e a Europa. Várias universidades entraram nesse projeto, a USP entrou e eu era representante da USP.

[Pergunta] E então era um projeto da Unesco?

[Resposta] Era na sede da Unesco, com apoio da Unesco e financiamento da Comunidade Europeia. Havia também algum financiamento das universidades latinoamericanas. As universidades latino-americanas entravam com uma anuidade, mas o grosso do financiamento vinha da Comunidade Europeia. Então, nesse primeiro

${ }^{157}$ O Convênio da USP com o Banco Interamericano de Desenvolvimento (BID) foi firmado em 1987 e previa um grande empréstimo, a ser pago pelo governo do Estado, para a realização de diversas obras de infraestrutura, sobretudo na Cidade Universitária. O convênio previa, ainda, um programa de modernização administrativa que, a princípio, julguei ser importante para a entrada do discurso da gestão na USP porém, ao longo do trabalho de campo, percebi que ele foi pouco significativo. Mais importante foi a formação de experts em gestão, ao longo dos anos 1970, e o processo de circulação internacional de lideranças institucionais nos anos 1980 e 1990, conforme demonstro neste item.

158 No começo dos anos 1980, o matemático francês Laurent Schwartz, famoso por ter sido premiado com a medalha Fields nos 1950 e por militar em organizações de esquerda, especialmente anticolonialistas, escreveu um livro sobre a crise das universidades francesas intitulado Pour sauver l'université (cf. Schwartz, 1983). Nesse primeiro trabalho, ele já atacava o que ele mesmo descreve como "o conservadorismo e o corporativismo" das universidades francesas, sobretudo ao recusar formas rígidas de seleção e avaliação. No ano seguinte, em função da repercussão do seu livro, foi nomeado pelo então presidente socialista François Mitterrand para presidir o recém-criado Comité National d'Évaluation des établissements publics à caractère scientifique, culturel et professionnel, que começou a elaborar uma série de estudos e avaliações sobre as instituições francesas que, pelo seu impacto, resultou, inclusive, em leis específicas para a reestruturação do governo e do funcionamento dessas instituições (cf. Schwartz, 1986 e 1987). O livro de Schwartz foi publicado no Brasil em 1984 com prefácio de Roque Spencer Maciel de Barros que aproveita para criticar "os sindicalistas e participacionistas" que, segundo ele, estavam implantando uma cultura da mediocridade nas universidades brasileiras (cf. Schwartz, 1984, p. 2). Para uma visão crítica desse processo ver Cardoso, 2001; Charles \& Soulié, 2007; Musselin \& Friedberg, 1992. 
momento, eu fui como representante da USP. Depois, quando eu assumi a reitoria, eu fui para o Conselho do Columbus. Por fim, quando deixei a reitoria, tornei-me consultor do Projeto Columbus. Então fiquei mais quatro anos indo a Paris umas cinco vezes por ano para discutir com eles o Projeto e foi onde eu ganhei muita experiência em gestão internacional de universidades. A partir disso, nós preparamos um modelo de curso para a gestão na América Latina, o tema era gestão de Universidade na América Latina. Demos três cursos desses, baseados na experiência da Comunidade Europeia. Eu fiz o curso da Comunidade Europeia para reitores sobre gestão. Foi em Florença, bem legal. Depois disso, trouxe o modelo para o Brasil. Fizemos dois ou três cursos desses. Foi muito interessante.

[Pergunta] Muito interessante mesmo. E o conteúdo do curso era associado às modernas teorias da gestão, teoria das organizações?

[Resposta] Modernas teorias da gestão: planejamento estratégico, avaliação, gestão financeira. Tinha trabalho em grupo também para aplicar conceitos. É a questão da organização acadêmica, como construir uma organização, como avaliar corpo docente, esse tipo de questão.

O surgimento desse circuito de circulação internacional, tendo como eixo não apenas os Estados Unidos, mas também a Europa, representou a principal mudança no padrão de difusão da gestão universitária, a partir dos anos 1980, contribuindo para ampliar significativamente o impacto desse discurso e suas práticas na USP. Não por acaso, diversos autores têm procurado analisar a construção social e os impactos dessa "agenda globalizante" para as universidades, baseada nas modernas teorias gerenciais, especialmente a teoria organizacional (cf. Bleiklie e Kogan, 2007; Brunsson \& Sahlin-Andersson, 2000; Drori et al., 2006; Hedmo et al. 2006; Krücken \& Meier, 2006; Meyer et al., 2006; Musselin, 2006; Powell \& DiMaggio, 1991). Essa mudança foi tão importante no caso da USP, que passou a marcar a trajetória individual de praticamente todos os seus dirigentes, particularmente reitores, a partir do final dos anos 1980. Nesse sentido, a trajetória do dirigente 24 também é paradigmática. Formado em odontologia pela USP, em 1960, fez mestrado e doutorado na Faculdade de Odontologia ao longo dessa década, tornando-se professor dessa faculdade antes de ser transferido, pela reforma universitária de 1968-1969, para o recém-criado Instituto de Ciências Biomédicas da USP, o ICB, tornando-se também seu diretor no começo dos anos 1980. Ao deixar a diretoria do ICB, tornou-se diretor científico da Fapesp. Depois de um longo período à frente da Fundação, tornou-se reitor da USP, na metade dos anos 1990, acumulando, depois disso, uma série de cargos administrativos, seja no interior da USP ou instituições vinculadas a ela, como a 
Fundação Faculdade de Medicina, seja no âmbito estadual, junto à Secretaria de Ciência e Tecnologia e à Fundação Seade. A trajetória do dirigente 24 é muito interessante porque congrega diversas modalidades de relação com o conhecimento gerencial: o contato prolongado com experts em gestão, treinamentos de curta duração até, finalmente, a circulação em redes internacionais de formulação de agendas e políticas para o ensino superior, particularmente no plano da gestão, a partir do momento em que se torna reitor:

[Pergunta] Professor, eu tenho uma questão especifica sobre como o senhor escolheu o seu coordenador administrativo, para a Codage. Digo, que critérios o senhor mobilizou?

[Resposta] Quando eu fui para a reitoria, na área de gestão, eu fiz uma coisa que um reitor antes de mim fez. Ele foi à Faculdade de Economia e de Administração, pegou um professor e disse: "Olha, você não ensina Administração?”. Ele respondeu: "Ensino". "Então agora você vai parar de ensinar e vai fazer. Vá à reitoria e faça!’. E foi o que eu fiz também.

[Pergunta] Então o senhor procurou um técnico. Mas o senhor nunca foi atrás dessa literatura sobre teoria da administração, de teoria da gestão...?

[Resposta] Não, nunca fui atrás nesse sentido de pesquisar. Mas fiz algumas disciplinas, como se fossem disciplinas optativas, Por exemplo, agora, todo dia tem esses simpósios em que trazem alguns americanos e brasileiros para debater gestão, mas antes não, eram os chamados seminários: seminários sobre previdência do funcionário público e eu frequentava esporadicamente.

[Pergunta] Isso já quando o senhor era diretor do ICB?

[Resposta] Como diretor do ICB, principalmente. E na própria Fapesp. Mas na Fapesp eu atuava mais na área cientifica, porque ela tem um diretor que cuida especificamente da administração. Agora, quando eu estava na Reitoria, já tive uma visão um pouco mais internacionalizada.

[Pergunta] Isso que eu ia perguntar. A relação com esses conhecimentos mudou a partir da sua chegada na reitoria?

[Resposta] Mudou, mudou totalmente. Ali você tem que se envolver mais diretamente em como é o financiamento, a gestão, a capacitação, a educação continuada do corpo docente e funcional, como são as outras linhas de pesquisa, como você realmente faz gestão compartilhada [...]

[Pergunta] E onde o senhor passou a buscar conhecimentos específicos nessa área? Foi na Associação Internacional de Universidades, da qual o senhor foi vicepresidente?

[Resposta] Principalmente. A prova de que eu me empenhei tanto a ver as experiências internacionais, as pedagogias, a seleção, a procura de talentos, a retenção de pessoas competentes, a política salarial, é que um dos meus pró-reitores, que depois foi reitor, fez um trabalho, que eu tinha interesse em fazer lá na Unesco, e ele acabou realizando depois que eu saí da reitoria, que foi uma pesquisa nas universidades do mundo inteiro para saber como elas escolhem o seu reitor.

[Pergunta] E além desse, quais eram os temas centrais que a AIU discutia?

[Resposta] Sempre gestão, pedagogia, financiamento, diversidade. 
A Associação Internacional de Universidades, com sede na Unesco, em Paris, é distinta do Projeto Columbus ${ }^{159}$. Trata-se de uma associação de universidades fundada em uma conferência internacional de reitores e dirigentes acadêmicos realizada em Nice, na França, em dezembro de 1950. No seu estatuto original, o objetivo da AIU era, sinteticamente:

[...] assegurar, no plano internacional, a cooperação entre as universidades e instituições de ensino superior similares de todos os países, assim como entre organizações cuja atividade se relacione de modo geral ao ensino superior, apoiando a sua causa (AIU, 1950, p. 1).

Atualmente, em linguagem mais "moderna”, a Associação é apresentada, em relatórios e documentos oficias nos seguintes termos:

Hoje, mais de cinco décadas depois da fundação da Associação Internacional de Universidades, o fundamental da sua missão permanece intacto. AAUI funciona como um fórum global onde os líderes da educação superior podem se reunir para discutir, examinar e promover ações em temas de interesse comum e compartilhar objetivos comuns no sentido de uma maior cooperação (AIU, 2012, n.p.).

Até o ano 2000, a AIU promovia a sua conferência internacional, da qual participavam representantes de todas as universidades-membros, a cada cinco anos. Desde então, as conferências acontecem a cada quatro anos. $\mathrm{O}$ dirigente 24 foi vice-presidente da associação por dois mandatos seguidos. Em 2004, talvez em função da sua participação mais intensa na Associação, a Conferência Geral da AIU ocorreu em São Paulo, tendo como tema “o papel das universidades na promoção do diálogo e do desenvolvimento"160.

A expansão desse campo global para a normatização do ensino superior contribuiu para consolidar uma agenda internacional para as universidades, ancorada na função social da

\footnotetext{
$159 \mathrm{Na}$ verdade, além de serem diferentes, eles eram instâncias em certa medida concorrentes. O reitor que participava mais ativamente da AIU apresenta críticas ao Projeto Columbus: "[Pergunta] Professor, o senhor conhece o Projeto Columbus? [Resposta] Conheço, é um projeto interessante, mas tinha uma limitação. Você tinha que fazer um triângulo de instituições: uma brasileira, uma europeia e uma outra latino-americana. Parece que era um triângulo e não era um binômio de instituições. E, mais ou menos, eles faziam esse triângulo só com as entidades que aderiam ao projeto. E havia uma reclamação de que a USP era obrigada, às vezes, a se colocar dentro de um triângulo cujas instituições eram muito mais fracas do que ela mesma. Além disso, havia uma anuidade, precisava pagar para participar".

${ }^{160}$ Para mais informações: <http://www.iau-aiu.net/> e < http://www.unesco.org/iau/> Acesso em 21 de abr. 2014.
} 
universidade e no aprimoramento da gestão interna, agenda, essa, que já vinha sendo formulada desde os anos $1950^{161}$. Ao mesmo tempo, esse campo global possibilitou, sobretudo a partir dos anos 1980, a afirmação de um princípio de concorrência entre as instituições, cuja expressão atual são os rankings internacionais, que foi fundamental para a centralização do governo acadêmico, aplacando as resistências de parte das suas unidades, em especial as mais tradicionais. O dirigente 37 que, como dito, foi coordenador da Codage e vice-reitor da USP durante os anos 1990 e 2000, procurou explicar essa relação entre internacionalização e centralização em termos da dependência crescente das unidades em relação à consolidação internacional da "marca USP":

\begin{abstract}
Apesar da USP se organizar como uma federação de unidades, cada vez mais você tem dimensões que são muito centrais. Por exemplo, a contratação de professores, que é o que há de mais importante na universidade, hoje ela é central. Ou seja, a Comissão de Claros Docentes reúne os pedidos das unidades, compara e decide o que se justifica ou não em termos de contratação docente. Então, as unidades perdem um pouco de autonomia nesse aspecto. Na contratação de funcionários também. Nesse sentido, algumas unidades acham, algumas das mais antigas, que elas têm ainda a autonomia anterior e podem se afastar desse processo central. E em alguns casos, elas de fato não seguem muito bem a orientação geral, e eu diria que a administração tem sido tolerante com isso: "está bem, quer ser diferente...". Agora, não chegou a um ponto de ruptura, quer dizer, das unidades abandonarem a USP. Até porque, hoje, a USP é importante demais e nenhuma unidade gostaria de viver sem ela. Então, em certo sentido, as unidades perdem um pouco da liberdade que tinham quando elas eram pequenininhas, sozinhas, no seu canto. Agora elas têm que negociar, se posicionar entre os pares, tudo isso. Mas o "jogo USP” tornou-se muito importante, até porque nós temos um círculo virtuoso em curso aqui há muito tempo [...]. A USP tem os melhores alunos do estado de São Paulo que tem os melhores alunos do Brasil. Ela tem, de uma maneira geral, os melhores professores do país, porque é o lugar que tem melhores condições de pesquisa, que dá mais prestígio etc. Em alguns pontos a Unicamp pode ser melhor, o ITA é uma ilha de excelência mas, de modo geral, há pouca concorrência dentro do
\end{abstract}

\footnotetext{
${ }^{161}$ Os temas das conferências gerais da AIU expressam claramente isso. Em 1950, o tema da conferência de Nice, na França, foi $O$ papel das universidades face às transformações materiais e morais das sociedades contemporâneas e ligadas aos progressos científico e tecnológico. Em 1955, a conferência realizada em Istambul, O papel das universidades em uma sociedade em rápida evolução. Cinco anos depois, na Cidade do México, a conferência discutiu A universidade e a formação de quadros para a vida pública, o diálogo entre ciências $e$ humanidades e a expansão do ensino superior. Em 1965, a conferência foi a Tóquio discutir A autonomia universitária, o acesso ao ensino superior e a contribuição do ensino superior para o desenvolvimento econômico e cultural. Em 1970, a conferência de Montreal discutiu A universidade e as necessidades da sociedade contemporânea e a cooperação internacional entre as universidades. A conferência de 1975 em Moscou discutiu $O$ ensino superior às vésperas do século XXI: a universidade e os problemas do desenvolvimento econômico e social e a inovação. Em 1980, nas Filipinas, o tema essencial era, de novo, O papel específico das universidades no desenvolvimento e na cooperação internacional, através de políticas de desenvolvimento e acesso ao ensino superior. Em 1985, a conferência de Los Angeles tematizou As responsabilidades internacionais das universidades. Em 1990, o tema discutido em Helsinque era Universidade, diversidade e interdependência: a missão da universidade. Cinco anos depois, Nova Déli discutiu, de novo, A cooperação universitária internacional. Em 2000, a conferência de Durban falava da Universidade, porta aberta para o devir. Em 2004 e 2008 os temas voltaram a ser desenvolvimento local e o papel das universidades (cf. AIU, 2010, n.p.)
} 
Brasil para a USP. Só que o jogo, agora, é crescentemente internacional [...]. Hoje, as universidades menores, dentro e fora do país, estão se agrupando porque o jogo é grande. E você ter uma marca internacional como a USP é muito importante. A autonomia que, no passado, significava muito, aos poucos foi perdendo importância para a "marca USP", que passou a contar muito com suas regras, com a sua estabilidade, inclusive. [...]. Então, a USP foi ganhando, com essa centralização, uma necessidade de planejamento. Planejamento significa ter regras comuns. Então, todo mundo tem regras mais ou menos comuns. Por exemplo, a informática é a mesma em todos os lugares. As regras das bibliotecas são as mesmas. As regras de promoção de

funcionários e carreira docente são as mesmas.

Foi justamente a partir da necessidade de ter um planejamento comum, com regras centralizadas e compartilhadas que, no estatuto da USP sancionado em 1988, foram criadas as pró-reitorias, ou seja, instâncias executivas para orientar e implementar uma política comum para a universidade no âmbito da graduação, da pós-graduação, da pesquisa e da cultura e extensão. Foi nesse espaço que passou a atuar o terceiro grupo de dirigentes que compõem a minha amostra, ou seja, os "especialistas acadêmicos" que, pela sua trajetória no interior da universidade, tornam-se responsáveis pelo desenho de políticas acadêmicas comuns que devem ser aplicadas, através das pró-reitorias, para toda a universidade.

\subsubsection{A influência do discurso da gestão sobre os especialistas em política acadêmica}

Comparados aos experts em gestão, que atuam sobretudo nos órgãos especializados de administração universitária, e às lideranças institucionais, que ocupam os postos mais altos do governo acadêmico, os especialistas acadêmicos, responsáveis pelas pró-reitorias da universidade, mantêm, com o discurso da gestão, uma relação muito mais ambígua que reflete, por sua vez, um processo mais conflituoso de "conversão" ao discurso da gestão. De fato, diferentemente dos experts e das lideranças institucionais que apreenderam o conhecimento gerencial segundo padrões relativamente claros, entre os especialistas acadêmicos não foi possível identificar a mesma sistematicidade.

Nesse sentido, enquanto o processo de profissionalização de experts e de reprofissionalização de lideranças que envolveram, de algum modo, um aprendizado contínuo 
ou a permanência prolongada em postos de direção, os especialistas acadêmicos tendem a se relacionar com a gestão de modo bem mais esporádico. Consequentemente, ao longo da pesquisa, não foi possível identificar, entre os pró-reitores ${ }^{162}$, dirigentes que tenham realizado qualquer curso de gestão de longa, média ou curta duração. Do mesmo modo, a convivência prolongada com experts em gestão também não apareceu como um fator relevante, seja nas entrevistas, seja na análise de trajetória com base em outras fontes. Além disso, a circulação internacional desses dirigentes não acontece em redes internacionais de dirigentes do ensino superior, onde a gestão aparece como um tema constante. Na verdade, a circulação desses reitores associa-se, de modo geral, à própria atividade acadêmica, sob a forma de estágios de pós-graduação, ensino ou pesquisa. No entanto, apesar da inexistência de padrões explícitos de conversão à gestão entre os especialistas acadêmicos, é possível identificar uma certa influência das categorias gerenciais, uma vez que a busca por livros e artigos relacionados à gestão apareceu em algumas entrevistas, especialmente no caso dos pró-reitores mais jovens, formados depois dos anos 1960.

Essa diversidade das formas de relação com o conhecimento gerencial e os seus pressupostos - que torna os "especialistas acadêmicos" um grupo particularmente interessante para explorar as tensões e contradições que marcam, atualmente, o debate sobre a organização do governo acadêmico - está diretamente relacionada à própria diversidade de trajetória desses dirigentes.

Em primeiro lugar, embora a transição para o campo da gestão acadêmica possa ser, em certos casos, definitiva, não são raros os exemplos, entre os pró-reitores da USP, em que a permanência em cargos de administração, mesmo no âmbito central ${ }^{163}$, resulta apenas

\footnotetext{
${ }^{162}$ Nesse caso, não estou considerando no grupo de "especialistas acadêmicos" os pró-reitores que se tornaram reitores ou vice-reitores e que, portanto, passaram a atuar como "lideranças institucionais".

${ }^{163}$ Digo "mesmo no âmbito da reitoria" porque nos cargos de direção mais descentralizados, envolvendo a direção e a coordenação de atividades no âmbito das unidades e departamentos, essa transitoriedade é muito mais evidente.
} 
transitória. A probabilidade do engajamento em atividades de gestão tornar-se definitivo ou provisório está relacionada, de modo geral, ao âmbito do campo universitário de onde provêm esses especialistas acadêmicos. Em síntese, quanto mais próxima ao polo acadêmico-científico da universidade for a trajetória desses dirigentes, maior a probabilidade da passagem por postos de direção ser apenas transitória. Por outro lado, quanto mais enraizado no polo profissional ${ }^{164}$ for o seu percurso universitário, maior a chance do engajamento com a gestão ser uma via de mão única. Para explicitar essa tendência pode-se recorrer ao fato de que, dos trinta e dois próreitores que passaram pela USP entre 1988, quando surgem as pró-reitorias, e janeiro de 2014, quando se encerra a presente pesquisa, ao todo sete se tornaram reitores ou vice-reitores da instituição, sugerindo a sua permanência nas funções do governo acadêmico, todos oriundos do polo profissional tradicional da universidade ${ }^{165}$.

Além disso, a diversidade da interação com as atividades de direção e, consequentemente, com a gestão ela mesma, aparece com mais força entre os pró-reitores da USP justamente por se tratar de um cargo que, pela sua natureza, implica a indicação de "especialistas" em política universitária no âmbito da graduação, da pós-graduação, da pesquisa e da cultura e extensão. É esse perfil "especializado" que explica, por exemplo, o predomínio de professores da Faculdade de Educação entre os pró-reitores de graduação, a relativa recorrência de professores da Faculdade de Filosofia, Letras e Ciências Humanas entre os pró-reitores de cultura e extensão,

\footnotetext{
${ }^{164}$ As definições de polo acadêmico-científico e polo profissional ficarão mais claras no próximo capítulo. Por ora, é importante notar que, da perspectiva estrutural, essas definições não têm sentido em si mesmas, apenas na relação que estabelecem entre si: em outras palavras, o polo profissional envolve, evidentemente, um conjunto de atividades científicas e acadêmicas enquanto o polo científico-acadêmico também incorpora a formação profissional. No entanto, quando contrapostos, revela-se o predomínio desses diferentes aspectos, o que justifica a referida denominação.

${ }^{165}$ São eles: Ruy Laurenti (Faculdade de Saúde Pública) foi pró-reitor de cultura e extensão e vice-reitor da USP, chegando a torna-se reitor em exercício. Jacques Marcovitch (Faculdade de Economia e Administração) também foi pró-reitor de cultura e extensão e reitor da USP. Adolpho José Melfi (Escola Superior de Agricultura Luiz de Queiroz) foi pró-reitor de pós-graduação e reitor da USP. Franco Maria Lajolo (Faculdade de Ciências Farmacêuticas) foi pró-reitor de pós-graduação e vice-reitor da USP. Suely Sampaio Vilela (Faculdade de Ciências Farmacêuticas de Ribeirão Preto) foi pró-reitora de pós-graduação e reitora da USP. Vahan Agopyan (Escola Politécnica) também foi pró-reitor de pós-graduação e hoje é vice-reitor da USP. E Marco Antonio Zago (Faculdade de Medicina de Ribeirão Preto) que foi pró-reitor de pesquisa e é o atual reitor da instituição.
} 
e a força de áreas consideradas como cientificamente produtivas e dominantes, como a física, a bioquímica e a biologia molecular, entre os pró-reitores de pós-graduação e de pesquisa. Essa diversidade de áreas e, portanto, de faculdades, implica o engajamento de professores oriundos não só do polo profissional tradicional, mas também do polo acadêmico-científico, sendo esse o segundo fator que contribui para explicar a diversidade de padrões de relação com o conhecimento gerencial no interior desse grupo específico de dirigentes.

Por fim, um outro fator que contribui para explicar a interação diferenciada com a gestão é de, como foi dito, ordem geracional, cuja variação também é maior no interior desse grupo. Assim, entre os pró-reitores que se formaram antes da década de 1960, o vocabulário gerencial é visto, em geral, com bastante desconfiança, embora os seus pressupostos - a importância da centralização institucional, da liderança individual, da definição de metas, da avaliação externa e de outras medidas anticorporativas - possam ser aceitos com facilidade. Por outro lado, entre os professores formados depois dos anos 1960, o discurso gerencial pode até ser incorporado com mais naturalidade, embora a sua visão em relação aos pressupostos mencionados possa variar, sobretudo em função da posição ocupada no interior do campo acadêmico. Essa variação sugere que a relação com o conhecimento gerencial tende a ser mais intensa entre os pró-reitores que ingressaram na universidade quando essas categorias já circulavam com certa intensidade nesses espaços, indicando o resultado do trabalho social de construção e afirmação da linguagem da gestão.

Dessa perspectiva, é particularmente interessante acompanhar a posição de especialistas acadêmicos que concluíram a sua graduação antes da década de 1960. É o caso, por exemplo, do dirigente 52. Formado em física pela FFCL-USP em 1959, passou a compor o corpo docente do IME depois da reforma universitária de 1968-1969, tornando-se pró-reitor de graduação na década de 1990. Na sua percepção, a teoria da gestão é uma fantasia com cunho ideológico: 
[Pergunta] E, por exemplo, hoje tem uma discussão muito grande, sobre noções de administração, teoria da gestão, o que o senhor acha?

[Resposta] Eu acho que tudo isso é bobagem. Isso é fantasia, e tem um cunho ideológico.

[Pergunta] Em que sentido, professor?

[Resposta] No sentido de que você transfere para a administração a responsabilidade pela universidade, e a administração é só um meio.

Um outro exemplo, nesse mesmo sentido, é o da dirigente 54, que se formou em direito pela USP em 1958, tornando-se pró-reitora de graduação também nos anos 1990. Depois de elogiar a gestão do reitor da época pelo seu caráter estritamente político, a dirigente contrapõe essa experiência com a de outro dirigente, formado em administração, que se guiava por cartilhas de gestão, tornando-se muito "fossilizado":

[Pergunta] Professora, a senhora mencionou um caso mal sucedido, na sua época, de administração em um órgão da reitoria. Como foi isso?

[Resposta] Má administração mesmo. Quem era o responsável pelo órgão era também um administrador... Muito bem intencionado, mas muito burocrático, guiando-se muito por cartilhas de gestão. Excelente pessoa, mas não sei se era a personalidade ou era a formação, também não posso dizer isso porque não tenho muito contato com administradores e gestores, mas foi ruim. Havia muitas interferências, construção de modelos, limites para que as pessoas agissem mais de acordo com o seu perfil, em suma, muito fossilizado.

Por fim, um outro caso de especialista acadêmico formado durante a década de 1950 que mantém uma relação de estranhamento com o vocabulário gerencial. Depois de fazer a graduação na Faculdade de Medicina da USP durante os anos 1950 e a pós-graduação na mesma instituição durante os anos 1960, o dirigente 64 foi transferido para o ICB após a reforma de 1968-1969, onde se tornou diretor do Instituto e no final dos anos 1980, pró-reitor de pósgraduação. Em tom de brincadeira, ele expressa a sua recusa ao vocabulário gerencial:

[Pergunta] E esse discurso da gestão que tem entrado na universidade, propondo uma administração mais humanizada?

[Resposta] É o pessoal que transforma a seção de pessoal em recursos humanos? A mesma porcaria. [...] Como era aquela história? Ah, o planejamento estratégico!! Eu me lembro sempre do termo. Quando me falam em planejamento estratégico eu tenho vontade de puxar a pistola. Não tinha essa história? Quando falam de ata eu puxo o revólver? Então, eu sou assim com esse termo. 
Esses exemplos de recusa da gestão e do seu vocabulário tornam-se particularmente relevantes quando contrastados com a postura de especialistas formados depois dos anos 1960, que tendem a ser mais abertos às expressões formalizadas dessa linguagem específica. É o caso, por exemplo, da dirigente 55, que foi pró-reitora de graduação nos anos 2000. Formada em pedagogia na FFCL-USP em 1967, a educadora participou, desde o começo da década de 1980, de órgãos e comissões governamentais ligadas à área educacional em nível municipal, estadual e federal, tornando-se sensível à importância desse conhecimento específico:

\begin{abstract}
[Pergunta] Professora, quando eu estava apresentando a minha pesquisa, eu comentei que meu objetivo era entender as mudanças do governo, da administração ou da gestão acadêmica, enfatizando que a escolha da palavra, nesse caso, importa. E a senhora respondeu: "Concordo, e a palavra é gestão". Eu queria que a senhora explicasse porque prefere a palavra "gestão" nesse caso.

[Resposta] A palavra administração toma um aspecto administrativo puramente. E a noção de gestão já tem a questão política incluída. Quer dizer, eu estou querendo fazer algumas mudanças de meio para atender a algumas metas e objetivos mais amplos, seja no nível político, seja no nível cultural mais amplo[...] Então a questão é essa, não dá para pensar a gestão, ou seja, como resolver um problema específico de funcionários, ou de organizar um organograma de uma instituição, sem ter mais claramente objetivos e finalidades bem estabelecidos. E para isso você tem as questões básicas, que é a própria sociedade que define. Qualquer instituição responde a uma realidade social, e a universidade tem uma missão específica, assim como a escola básica também tem uma missão, enquanto finalidade social. É a partir daí que eu vejo a gestão. Ela ajuda a organizar uma instituição com objetivos e finalidades bem estabelecidas e que responda à sua missão social para a qual ela foi criada.
\end{abstract}

Um outro exemplo é o do dirigente 62. Formado em física no Instituto de Física de São Carlos na década de 1970, tornou-se professor desse instituto ainda nos anos 1970, quando fez estágios de pesquisa nos Estados Unidos e na Europa. Ao tornar-se pró-reitor de pesquisa, na década de 2000, não tinha exercido cargos de direção nem tido qualquer contato mais intenso com o discurso da gestão e com suas práticas essenciais. Em função disso, optou por procurar uma literatura especializada, o que sugere a percepção difusa da importância desse conhecimento:

[Pergunta] É interessante porque o senhor, nos dois casos, funcionou como mediador, como uma pessoa capaz de resolver conflitos. E o senhor foi atrás dessa literatura especializada em resolução de conflitos? Em algum outro momento da sua experiência politica e administrativa o senhor precisou recorrer a literaturas especializadas para lidar com situações de conflito?

[Resposta] Para lidar com situações de conflito, não, mas para administrar, sim. 
Quando eu assumi a pró-reitoria de pesquisa, que era uma coisa que eu não estava esperando de jeito nenhum [...] eu peguei livros de administração para ver alguns princípios.

[Pergunta] E ajudou?

[Resposta] Ah, ajudou muito porque esses livros falam que você não pode só ir tocando a administração, tem que planejar. E tem um método de como é que se planeja. Então isso ajudou muito. E tem livros muito bons que falam de situações práticas.

[Pergunta] E como o senhor encontrou essas referências? Desculpe fazer essas perguntas, mas é que uma das minhas preocupações de pesquisa é mapear a entrada desses conhecimentos especializados. Então essas referências, o nome desses livros, como o senhor buscou...?

[Resposta] Na Internet, procurando, pesquisando. Depois, mais adiante, quando eu já estava na pró-reitoria, eu perguntei para professores da administração da FEA, eles me ajudaram também.

O caso do dirigente 36 é paradigmático do processo de afirmação do conhecimento gerencial e das suas categorias, a ponto dele passar a ser visto quase como um pré-requisito para os cargos de direção, inclusive por parte daqueles que não concordam com os seus pressupostos hegemônicos e passarão a travar uma batalha no interior do próprio campo da gestão, tema do último capítulo desta tese. Essa imposição do discurso gerencial dependeu não só dos processos de conversão de dirigentes, mas também das reformas organizacionais que a partir de 1968-69 passaram a centralizar o poder na USP e da imposição de dispositivos técnicomateriais ligados a esse conhecimento, tema dos itens que encerram o presente capítulo.

\subsection{A centralização do poder na USP}

Analisando, nas suas linhas gerais, a reforma universitária implementada nos anos 1960, é possível dizer que uma das suas principais consequências foi o fortalecimento dos órgãos executivos das instituições educacionais, representados, no caso das universidades, pelas reitorias e diretorias de unidade. Esse fortalecimento não foi, no entanto, apenas resultado de dispositivos legais implementados pela lei da reforma universitária de 1968. Igualmente importante foi a difusão de saberes gerenciais que orientaram essa e outras reformas organizacionais no interior das universidades, no sentido de uma progressiva centralização, expressa, de modo imediato, na criação de órgãos de administração e serviços, ligados seja ao 
Conselho Universitário, seja à reitoria, encarregados de desenhar políticas universais e uniformizantes para todas as unidades que compõem essas instituições. No caso da USP, essa evolução é explícita.

Em 1934, quando o então presidente Getúlio Vargas e o seu Ministro da Educação e Cultura, Gustavo Capanema, aprovaram e publicaram os estatutos da USP, o nível central da universidade era formado basicamente por três órgãos: a Reitoria, o Conselho Universitário e a Assembleia Universitária. A Reitoria, nesse primeiro momento, contava com apenas duas seções: a contabilidade e a secretaria, essa última coordenada por um secretário particular da confiança do reitor (cf. USP, 1934b, p. 14-15). O Conselho Universitário era formado, por sua vez, por três comissões: i) ensino e regimentos; ii) legislação e recursos; e iii) orçamento e regência patrimonial (cf. USP, 1934b, p. 17). Por fim, a Assembleia Universitária, composta por todos os professores catedráticos da universidade, se reunia pelo menos uma vez por ano para "tomar conhecimento, por exposição do reitor, das principais ocorrências da vida universitária e dos progressos e aperfeiçoamentos realizados nos institutos universitários”, bem como "assistir à entrega dos títulos honoríficos" (USP, 1934b, p. 18). Além dessa reunião anual de caráter solene, a Assembleia poderia ser convocada a qualquer momento, por proposta do Conselho Universitário, para opinar "sobre alienação de bens imóveis da Universidade e sobre greves universitárias gerais" (USP, 1934b, p. 18).

A primeira reforma nessa estrutura geral da USP ocorreu em fevereiro de 1944, quando o decreto-lei $\mathrm{n}^{\circ} 13.855$ transformou a universidade em autarquia estadual, o que fez com que a reitoria passasse a concentrar "todos os atos administrativos da Universidade, Institutos Universitários e respectivas dependências que antes eram processados pela Secretaria de Estado da Educação e Saúde Pública” (São Paulo, 1944, p. 1). Com essa mudança, tornou-se responsabilidade do reitor "a prática de todos os atos administrativos da Universidade" (São Paulo, 1944, p. 1), marcando uma primeira forma, ainda rudimentar, de centralização. 
Assim, como resultado dessa mudança, foi aprovada pelo Conselho Universitário, em julho de 1944, a criação de um órgão voltado especificamente para a administração no âmbito central da universidade (USP, 1945, p. 8). Ligado originalmente ao Conselho Universitário, o Departamento Administrativo foi transferido para a reitoria durante a primeira gestão de Miguel Reale (1949-1950), na reforma do Regimento Interno de 1949, realizado sob influência direta das diretrizes do DASP (cf. USP, 1950, p. 5). Em um estudo sobre a administração da USP realizado em 1951 pelo Instituto de Administração do Estado de São Paulo ${ }^{166}$, consta que o Departamento de Administração tinha "por finalidade, como órgão centralizador de administração, a coordenação, a execução e a fiscalização de todas as atividades administrativas da reitoria" (Instituto de Administração, 1951, p. 7; grifo meu). Ao lado do Departamento de Administração, passaram a constituir órgãos da reitoria da USP, na época:

I) a Comissão de Pesquisa Científica;

II) o Gabinete do Reitor;

III) a Secretaria Geral;

IV) a Consultoria Jurídica;

V) o Departamento de Ação Cultural;

VI) a Comissão de Compras;

VII) a Tesouraria Central.

A reforma promovida pelo reitor Miguel Reale em 1949-1950, sob influência direta dos modelos do DASP, foi, portanto, a primeira a ampliar o número de órgãos e comissões centrais. Ainda assim, pelo menos do ponto de vista da política acadêmica, o alcance dessas instâncias ainda era pequeno, de modo que praticamente não havia coordenação no nível central da universidade.

A reforma do estatuto aprovada entre 1968 e 1969 e implementada em 1970 começou a alterar esse quadro. Em primeiro lugar, além de eliminar a Assembleia Universitária - tornada

\footnotetext{
${ }^{166}$ Criado para funcionar, na esfera estadual, de modo análogo ao DASP, o Instituto responsabilizou-se, ao longo dos anos 1950, por estudos e planos para uma reorganização do Estado. O documento intitulado Indicador da organização administrativa da reitoria da Universidade de São Paulo, publicado pelo Instituto em 1951, visava produzir um "guia da organização" da USP, "a exemplo do que já há algum tempo vem sendo publicado pelo DASP, com referência à esfera federal, e de outros publicados no estrangeiro" (Instituto de Administração, 1951, p. 1).
} 
órgão consultivo paritário por proposta do reitor em exercício Hélio Lourenço de Oliveira, cassado no começo de 1969 - a reforma implementada ampliou os órgãos centrais da universidade. Além da Reitoria e do Conselho Universitário, foram criados o Conselho Técnico-administrativo e o Conselho de Ensino, Pesquisa e Extensão de Serviços à Comunidade, este último formado por quatro câmaras: Câmara de graduação, Câmara de pósgraduação, Câmara de pesquisa e Câmara de extensão de serviços à comunidade. Com a criação dessas novas instâncias de discussão e deliberação, o âmbito central da universidade passou a dispor, pela primeira vez, de poder de agenda sobre as diferentes unidades, formulando uma política de ensino, pesquisa e extensão para a universidade como um todo. Isso se expressa claramente nas atribuições do Conselho Técnico-administrativo que, segundo o Estatuto de 1969, eram:

I) deliberar sobre acordo entre Unidades Universitárias e entidades oficiais ou particulares, para realização de atividades didáticas, de pesquisa, bem como as concernentes à extensão de serviços à comunidade;

II) promover o entrosamento entre a Universidade e o mercado de trabalho;

III) determinar a expedição de segunda via de diplomas, em caso de extravio;

IV) deliberar sobre instituição, modificação e extinção de funções autárquicas, bem como fixar o respectivo sistema remuneratório;

V) aceitar legados e doações feitos à Universidade, às Unidades Universitárias e aos Órgãos Anexos;

VI) propor ao Conselho Universitário a fixação do quadro de docentes, ouvidas as Congregações;

VII) deliberar sobre propostas de criação, modificação e extinção de órgãos nas Unidades e nos Museus;

VIII) deliberar sobre relotação de cargos e funções, proposta pelo Reitor;

IX) deliberar sobre normas para concessão de bolsas de estudo e para afastamento remunerado;

X) deliberar sobre a alienação de bens móveis da Universidade;

$\mathrm{XI}$ ) exercer quaisquer outras atribuições decorrentes de lei, deste Estatuto, bem como do Regimento Geral, excluídas as da competência do Conselho Universitário (USP, 1969, p.9)

Já ao Conselho de Ensino, Pesquisa e Extensão de Serviços à Comunidade competia:

I) propor ao Conselho Universitário a criação e a organização de novos cursos, ouvidas as Congregações interessadas;

II) organizar os currículos globais de formação profissional, fixando o elenco das disciplinas obrigatórias e optativas, ouvidas as Congregações interessadas;

III) definir e regulamentar os cursos de especialização, aperfeiçoamento e extensão universitária;

IV) estudar a conveniência de agrupamento, parcial ou global, de currículos que 
envolvam disciplinas de aplicação;

V) indicar às Congregações normas de avaliação de ensino e promoção de alunos;

VI) decidir, por proposta dos Departamentos, entre programas de estudo concernentes a uma só matéria, se constituem ou não disciplinas distintas;

VII) estabelecer, anualmente, o número de vagas para cada currículo, considerada a demanda social e ouvida a Congregação interessada;

VIII) propor as áreas de formação universitária, elidindo duplicidade de programas;

IX) deliberar quanto à forma de ingresso de candidatos aos currículos de graduação;

$\mathrm{X})$ conceituar e uniformizar os critérios referentes às "Unidades de Crédito";

$\mathrm{XI}$ ) aprovar e catalogar, anualmente, ouvidas as Unidades, as disciplinas de graduação e pós-graduação;

XII) julgar os pedidos de transferência de estudantes de um curso para outro, bem como de outras Instituições de Ensino Superior para a Universidade;

XIII) julgar os pedidos de trancamento de matrícula;

XIV) coordenar o ensino de pós-graduação;

$\mathrm{XV}$ ) deliberar sobre a concessão de bolsas;

XVI) coordenar os trabalhos pertinentes à extensão de serviços à comunidade, ouvidas as Unidades quando for o caso;

XVII) fixar o calendário escolar, anualmente;

XVIII) reconhecer os títulos universitários obtidos no exterior, ouvida a

Congregação interessada;

XIX) estabelecer normas para a fixação do quadro docente da Universidade;

$\mathrm{XX)}$ exercer quaisquer outras atribuições decorrentes de lei, deste Estatuto e do Regimento Geral, em matéria de sua competência (USP, 1969, p. 10-1).

As consequências dessa primeira reforma que criou o CEPE se fizeram sentir sobretudo na pós-graduação que estava sendo criada nesse momento. Pelo menos é essa a avaliação do primeiro pró-reitor de pós-graduação da USP que compara a situação da graduação e da pósgraduação naquele momento em entrevista realizada por mim em 2013:

Você imagina que a USP é a reunião de Faculdade de Filosofia, da Escola Politécnica, da Faculdade de Medicina, da Veterinária, da Faculdade de Direito [...] Todas escolas centenárias. Então, a graduação da Faculdade de Medicina não tinha nada que ver com a USP, você não conseguiria jamais dar uma mesma forma. Enquanto que a pósgraduação, por outro lado, já nasceu centralizada, com a reforma de $1972^{167}$, quer dizer ela já surgiu com $a$ USP forte.

A "USP forte”, nesse caso, é sinônimo de órgãos executivos centrais fortes. Tanto que com a reforma de 1968-1969, a reitoria da USP, ao contrário do Conselho Universitário, viu seus órgãos aumentarem, passando a ser composta pelas seguintes seções, todos sob controle do reitor:

${ }^{167}$ Em 1972, foi aprovado o Regimento Geral da USP que regulamentou a reforma de 1968-1969 (cf. USP, 1972). 
I) Gabinete do Reitor,

II) Secretaria Geral

III) Consultoria Jurídica

IV) Coordenadoria Geral de Administração (Codage)

V) Coordenadoria de Atividades Culturais (Codac),

VI) Coordenadoria de Saúde e Assistência Social (Coseas),

VII) Grupo de Planejamento Setorial e

VIII) Prefeitura da Cidade Universitária (cf. USP, 1969, p. 11).

O Regimento Geral da USP, de 1972, que regulamentou a reforma de 1968-1969, aumentou ainda mais o número de órgãos da reitoria, que passou a incluir:

IX) a Editora da Universidade;

$\mathrm{X}$ ) o Coral da Universidade (CORALUSP);

XI) a TV- Educativa;

XII) o Centro de Computação Eletrônica (CCE);

XIII) a Comissão de Extensão de Serviços à Comunidade (COESCO);

XIV) o Centro de Tecnologia na Educação (CETEUSP) (USP, 1972, p. 11).

Do ponto de vista da organização administrativa da universidade, a partir do estatuto de 1969 - consequência direta da reforma universitária aprovada pelo governo federal no ano anterior -, o antigo Departamento de Administração foi promovido à Coordenadoria de Administração Geral (Codage), cujas funções foram regulamentadas pelo Regimento Geral da USP, aprovado em 1972, sob a segunda reitoria de Miguel Reale, passando a funcionar a partir do ano seguinte ${ }^{168}$. Permanecendo ligado à reitoria, a Codage alcançou um âmbito de atuação mais amplo do que o antigo Departamento de Administração que se voltava exclusivamente às atividades da reitoria. Segundo o Regimento Geral, constituíam finalidades da Codage "o estudo, a orientação e o controle da administração geral da USP, a coordenação e articulação de suas atividades com as [atividades] de outros órgãos da USP; e a execução de serviços de

\footnotetext{
${ }^{168}$ Desde 1973, foram coordenadores da Codage: Fausto Haroldo Ribeiro da Faculdade de Direito (de 1973 a 1982), Sérgio Baptista Zacarelli da Escola Politécnica (de 1982 a 1986), André Ricciardi Cruz da Faculdade de Filosofia, Ciências e Letras de Ribeirão Preto (em 1986), Fábio Prado, formado na Faculdade de Direito (em 1986), Elisa Wolynec do Instituto de Física (de 1986 a 1988), Joaquim José de Camargo Engler da Esalq (de 1988 a 1991), Hélio Nogueira da Cruz da Faculdade de Economia e Administração (de 1991 a 2001, com um intervalo entre 1992 e 1993), José Roberto Drugowitch do Instituto de Física (de 1992 a 1993), Adilson Carvalho da FFLCH (de 2002 a 2006), Douglas Wagner Franco (de 2006 a 2007), Dante Pinheiro Martinelli da FEA (de 2007 a 2009) Antonio Roque Dechen (de 2010 a 2014). Atualmente quem responde pela Vice-reitoria executiva de administração, como passou a se chamar a Codage, é o vice-reitor da USP, Vahan Agopyan, da Escola Politécnica.
} 
administração geral” (USP, 1972, p. 14; grifo meu). Já ao Grupo de Planejamento Setorial caberia "assessorar o Reitor, competindo-lhe orientar, rever e acompanhar as atividades de planejamento, programação e orçamento" (USP, 1972, p. 14). Eram os primeiros órgãos voltados à administração e ao planejamento universitário em que passaram a atuar os experts em gestão na USP.

A reforma de 1987, que resultou no Estatuto de $1988^{169}$, foi um passo decisivo no fortalecimento do poder central na USP, especialmente a partir da criação das pró-reitorias de graduação, pós-graduação, pesquisa e cultura e extensão e da transformação das Câmaras do CEPE em quatro novos conselhos centrais. Além de ter sido a medida que mais chamou a atenção da mídia durante a reforma ${ }^{170}$, a criação das pró-reitorias foi a principal modificação apontada pelos dirigentes da USP durante as entrevistas realizadas para a presente pesquisa. $\mathrm{O}$ dirigente 24, por exemplo, que era diretor de unidade em 1987-1988 e, portanto, membro do Conselho Universitário durante a reforma, explicita porque, na sua opinião, as pró-reitorias foram tão importantes:

[Pergunta] Professor, eu queria voltar rapidamente ao tema da Reforma do Estatuto. O senhor participou da Reforma ativamente porque era diretor de unidade, na época. Do que o senhor viveu, o que o senhor se lembra que eram os objetivos gerais, ou seja, o que se procurava com a reforma?

[Resposta] Olha, foi uma reforma muito importante e de uma maneira geral o que se queria era que algumas coisas mudassem. E, de fato, foi uma reforma que alterou questões críticas. Nós não tínhamos as pró-reitorias. E isso foi crucial. Atualmente, as coisas cresceram muito. Como o reitor, sozinho, poderia cuidar da USP? Então hoje, só a pró-reitoria de pós-graduação é um mundo. E a universidade está crescendo demais em todas as áreas, a graduação, a pesquisa, todas as quatro pró-reitorias são muito grandes. Enfim, para mim a principal mudança da reforma foi realmente a criação das pró-reitorias.

\footnotetext{
${ }^{169}$ A aprovação do novo estatuto da USP pelo Conselho Universitário ocorreu em dezembro de 1987. Uma vez aprovado no âmbito da universidade, o estatuto seguiu para avaliação do Conselho Estadual de Educação que, em 31 de agosto de 1988, aprovou o novo estatuto por unanimidade. O estatuto foi publicado no Diário Oficial do Estado em 08 de outubro de 1988 pelo então reitor José Goldemberg, sem a prévia autorização do então Governador Orestes Quércia.

${ }^{170}$ O jornal O Estado de S. Paulo trouxe, na sua primeira página de 11 de dezembro de 1987, a manchete "Novo estatuto. Para renovar a USP". Em destaque, a matéria sobre as pró-reitorias intitulada "Criação de pró-reitorias, o remédio para o gigantismo" (OESP, 1987, p.1).
} 
O dirigente 23 , que era vice-reitor na época da reforma tornando-se depois reitor da universidade, também confere especial importância à criação das pró-reitorias durante a reforma do estatuto de 1987-1988:

\begin{abstract}
[Pergunta] Professor, quanto à reforma de 1987-1988, como o senhor avalia o resultado final?

[Resposta] Eu acho que muitas coisas avançaram e outras nem tanto. Eu acho que o estatuto abriu a possibilidade de se criarem as pró-reitorias, que foi uma coisa muito importante porque antes, era uma loucura. Não sei se você sabe como era? Havia um conselho único [o CEPE] e tinha um presidente de Conselho. Mas esse não era um órgão executivo. Como resultado, ninguém cuidava da graduação, por exemplo, que era totalmente solta. [...] Então, nesse sentido, as pró-reitorias foram uma profissionalização da USP e essa foi uma batalha que eu tive na defesa do Estatuto. [...] O nosso conceito eram as vice-presidencies norte-americanas que se mostravam fundamentais. Então as pró-reitorias foram uma coisa determinante.
\end{abstract}

Nesse mesmo sentido aponta o dirigente 64, quando descreve a criação das pró-reitorias como uma medida que "deu estrutura" para as antigas câmaras favorecendo a expansão, por exemplo, da pós-graduação:

\begin{abstract}
[Pergunta] Professor, rapidamente, pensando no estatuto de 1987-1988, quais foram as mudanças mais importantes?

[Resposta] A carreira universitária, a constituição dos órgãos colegiados, a criação das pró-reitorias.

[Pergunta] O que vocês estavam buscando com essas mudanças? Que universidade vocês estavam querendo construir naquele momento? Ou o que vocês estavam querendo destruir? Em suma, quais eram os objetivos?

[Resposta] É difícil dizer. Era modernizar, em certo sentido. [...] Foi por isso que resolvemos transformar as câmaras em pró-reitorias, quer dizer: dar a elas uma estrutura. Se você olhar o desenvolvimento da pós-graduação, por exemplo, ela cresce, não me lembro bem os valores, mas é uma explosão depois da criação das próreitorias. Inclusive houve uma queixa generalizada no Conselho Universitário porque ele estava se esvaziando.
\end{abstract}

A criação das pró-reitorias representou, na percepção dos dirigentes da USP portanto, a principal mudança da estrutura de poder da USP a partir de 1988. A função desses órgãos, segundo o estatuto de 1988, é "promover atividades" de graduação, pós-graduação, pesquisa e cultura e extensão, "estabelecendo as normas que julgar necessárias para esse efeito" (USP, 1988, p. 9). Em suma, o poder de normatizar as atividades-fim da universidade é o que define as pró-reitorias e orienta a ação dos conselhos centrais cujo presidente, escolhido entre o conjunto de professores titulares da USP, deve ser indicado pelo reitor e sancionado pelo 
Conselho Universitário, de modo que suas ações estejam "sempre subordinadas aos interesses maiores da Universidade, representada pelo Reitor" (USP, 1988, p. 9). De fato, considerandose a estrutura geral do âmbito central de poder, a criação dos Conselhos Centrais e das próreitorias foi a principal mudança no âmbito central da USP, cujos órgãos, depois das mudanças, passaram a ser:
I) a Reitoria;
II) o Conselho Universitário;
III) o Conselho de Graduação;
IV) o Conselho de Pós-graduação;
V) o Conselho de Pesquisa;
VI) o Conselho de Cultura e Extensão;
VII) a Pró-reitoria de Graduação;
VIII) a Pró-reitoria de Pós-graduação;
IX) a Pró-reitoria de Pesquisa;
X) a Pró-reitoria de Cultura e Extensão
XI) o Conselho Consultivo (USP, 1988, p. 4).

O Conselho Universitário, que continuou sendo “o órgão máximo [...] com funções normativas e de planejamento, cabendo-lhe estabelecer a política geral da universidade para a consecução de seus objetivos" (USP, 1988, p. 5), manteve a sua estrutura interna praticamente inalterada preservando, com pequenas mudanças de nomenclatura, as mesmas comissões que tinha em 1934, quando foi fundado junto com a universidade. Até hoje, portanto, compõem o Conselho Universitário: i) a Comissão de Legislação e Recursos; ii) a Comissão de Orçamento e Patrimônio; e iii) a Comissão de Atividades Acadêmicas. Já o Conselho Consultivo, presidido pelo reitor e formado pelo vice-reitor, pelos pró-reitores e por "seis pessoas eminentes, escolhidas pelo Reitor, que não estejam em exercício na USP” (USP, 1990, p. 6), deveria representar a sociedade mas não alcançou posição de destaque no âmbito da universidade. Por outro lado, a reitoria da USP, enquanto órgão executivo por excelência, viu suas seções internas aumentarem mais uma vez, passando a englobar, segundo o Estatuto de 1988:

\footnotetext{
I) o Gabinete do Reitor;

II) as Pró-Reitorias;

III) a Secretaria Geral;

IV) a Consultoria Jurídica;

V) a Coordenadoria de Administração Geral;

VI) a Coordenadoria de Saúde e Assistência Social;
} 
VII) o Grupo de Planejamento Setorial;

VIII) as Prefeituras dos Campi;

IX) a Assessoria Jurídica do Reitor;

X) a Comissão de Planejamento;

XI) a Comissão Especial de Regimes de Trabalho;

XII) a Comissão de Cooperação Internacional (USP, 1988, p. 9)

Desde a Reforma de 1988, os órgãos internos da reitoria só vêm aumentando. Seguindo as informações publicadas anualmente pelo Anuário Estatístico, em 1990 a reitoria da USP era formada pelos seguintes órgãos:

1) Gabinete do reitor (GR);

2) Gabinete do vice-reitor (GVR);

3) Secretaria geral (SG);

4) Consultoria Jurídica (CJ);

5) Assessoria Jurídica do reitor (AJR);

6) Coordenadoria de Administração Geral (Codage);

7) Coordenadoria de Comunicação Social (CCS);

8) Coordenadoria de Assistência Social (COSEAS);

9) Sistema Integrado de Saúde da USP (SISUSP);

10) Fundo de Construção da USP (FUNDUSP);

11) Centro de Computação Eletrônica (CCE);

12) Sistema Integrado de Bibliotecas (SIBI);

13) Centro de Práticas Esportivas da USP (CEPEUSP);

14) Editora da Universidade de São Paulo (EDUSP);

15) Comissão Especial de Regimes de Trabalho (CERT);

16) Comissão de Cooperação Internacional (CCint);

17) Comissão Central de Informática (CCI);

18) Conselho Comunitário;

19) Comissão de Planejamento (CP);

20) Grupo de Planejamento Setorial (GPS);

21) Pró-reitoria de Graduação;

22) Pró-reitoria de Pós-graduação;

23) Pró-reitoria de Pesquisa;

24) Pró-reitoria de Cultura e Extensão;

25) Prefeitura do Campus de São Paulo;

26) Prefeitura do Campus de São Carlos;

27) Prefeitura do Campus de Bauru;

28) Prefeitura do Campus de Ribeirão Preto;

29) Prefeitura do Campus de Piracicaba.

Em 1995, o número de órgãos havia aumentado para 32, incluindo o Centro de Informática de São Carlos (CISC), a Coordenadoria Executiva de Cooperação Universitária e de Atividades Especiais (CEACE), e a prefeitura do novo campus de Pirassununga: 
30) Prefeitura do Campus de Pirassununga;

31) Centro de Informática de São Carlos (CISC);

32) Coordenadoria Executiva de Cooperação Universitária e de Atividades Especiais (CEACE).

Em 2000, mantendo mais ou menos a mesma estrutura, os órgãos gerais também haviam aumentado, em função da incorporação de órgãos do interior e da criação de novas comissões centrais, tal como é possível observar na listagem abaixo que traz em destaque os novos órgãos criados:

33) Centro de Informática do Campus Luiz de Queiroz (CIAGRI)

34) Centro de Informática de Ribeirão Preto (CIRP)

35) Comissão Central de Recursos Humanos (CCRH)

36) Comissão Especial de Saúde Ocupacional (CESO)

No final da década de 2000, a estrutura geral da reitoria da USP já havia sofrido uma série de reformas organizacionais, com a criação de órgãos centrais que passam a integrar e coordenar as atividades de órgãos antes descentralizados e autônomos. São exemplos, nesse sentido, a transformação do Fundo de Construção da USP em Coordenadoria do Espaço Físico, em 2002, com a instalação de escritórios regionais; a criação de uma Coordenadoria de Tecnologia da Informação (CTI), em 2004, para integrar os centros de informática dos diferentes campi; a fundação de uma Agência de Inovação, em 2005, para articular iniciativas nessa área; e, principalmente, a transformação das prefeituras de campus em Coordenadorias, em 2008, que tornaram-se órgãos integrados por meio de uma Diretoria Administrativa ligada ao Gabinete da Reitoria (DAGR). Como resultado dessas mudanças, a estrutura geral da reitoria da USP em 2009 passou a ser:

1) Gabinete do reitor;

2) Gabinete do vice-reitor;

3) Pró-reitoria de graduação;

4) Pró-reitoria de pós-graduação;

5) Pró-reitoria de pesquisa;

6) Pró-reitora de cultura e extensão;

7) Secretaria geral;

8) Consultoria Jurídica (CJ);

9) Assistência Jurídica do reitor;

10) Coordenadoria de Administração Geral (CODAGE);

11) Coordenadoria de Assistência Social (COSEAS);

12) Coordenadoria do Espaço Físico (COESF); 
13) Grupo de Planejamento Setorial (GPS);

14) Comissão de Planejamento (CP);

15) Comissão Especial de Regimes de Trabalho (CERT);

16) Comissão de Cooperação Internacional (CCInt);

17) Comissão Permanente para Apuração de Acidentes com Veículos Oficiais (COPAVO)

18) Centro de Práticas Esportivas da USP (CEPEUSP);

19) Sistema Integrado de Bibliotecas (SIBI);

20) Editora da USP (EDUSP);

21) Coordenadoria de Comunicação social (CCS);

22) Agência USP de Inovação (USP inovação);

23) Coordenadoria de Tecnologia da Informação (CTI);

24) Diretoria Administrativa das Coordenadorias de campus

25) Coordenadoria do Campus da Capital;

26) Coordenadoria do Campus de Bauru;

27) Coordenadoria do Campus de Ribeirão Preto;

28) Coordenadoria do Campus de Piracicaba;

29) Coordenadoria do Campus de São Carlos;

30) Coordenadoria do Campus de Lorena;

31) Coordenadoria do Campus de Pirassununga;

32) Coordenadoria do Quadrilátero da Saúde e do Direito.

Mas foi sobretudo a partir de 2010 que a estrutura da USP, sobretudo dos seus órgãos executivos, se transformou de modo mais determinante. Em primeiro lugar, pela substituição da Consultoria Jurídica por uma Procuradoria Geral com uma ampla estrutura ${ }^{171}$ em 2010. Depois, por uma ampla reforma organizacional, realizada pela Resolução n ${ }^{\circ} 6061$ de 27 de fevereiro de 2012, que alterou o Estatuto da USP de 1988, justamente no artigo referente à composição da reitoria, dando-lhe nova formulação o que, na prática, representou uma profunda reforma organizacional que conferiu mais poder de atuação aos órgãos centrais da universidade, transformados agora em vice-reitorias e superintendências:

1) Gabinete do Reitor (GR);

2) Gabinete do Vice-reitor (GVR)

3) Pró-reitoria de graduação

4) Pró-reitoria de pós-graduação;

5) Pró-reitoria de pesquisa;

6) Pró-reitoria de cultura e extensão;

7) Secretaria Geral (SG);

8) Procuradoria Geral (PG);

9) Vice-Reitoria Executiva de Administração (VREA);

10) Superintendência de Assistência Social (SAS);

${ }^{171}$ A Procuradoria Geral conta, hoje, com 59 procuradores distribuídos em cinco escritórios regionais (em Bauru, São Carlos, Ribeirão Preto, Piracicaba e Pirassununga), oito consultorias específicas (de pessoal docente e técnicoadministrativo, acadêmica e convênios, patrimonial, contratos administrativos e licitações, judicial e cível, recuperação de ativos, disciplinar e judicial trabalhista) e um gabinete geral. 
11) Superintendência do Espaço Físico (SEF);

12) Superintendência de Tecnologia da Informação (STI);

13) Grupo de Planejamento Setorial (GPS);

14) Prefeitura do campus da capital;

15) Prefeitura do campus de Bauru;

16) Prefeitura do campus de São Carlos;

17) Prefeitura do campus de Ribeirão Preto;

18) Prefeitura do campus de Pirassununga;

19) Prefeitura do campus de Piracicaba;

20) Prefeitura do campus de Lorena

21) Prefeitura do Quadrilátero da Saúde e do Direito;

22) Superintendência Jurídica (SJU);

23) Comissão de Planejamento (CP);

24) Comissão Especial de Regimes de Trabalho (CERT);

25) Vice-Reitoria Executiva de Relações Internacionais (VRERI);

26) Superintendência de Comunicação Social (SCS);

27) Superintendência de Saúde (SAU);

28) Superintendência de Gestão Ambiental (SGA);

29) Superintendência de Relações Institucionais (SRI);

30) Superintendência de Segurança (SEG);

31) Editora da USP (EDUSP);

32) Sistema Integrado de Biblioteca (SIBI);

33) Centro de Práticas Esportivas (CEPEUSP).

Como resultado dessa reforma geral, que deu mais estrutura para os órgãos executivos centrais, o percentual gasto pela reitoria e suas seções internas de direção e serviços aumentou significativamente quando considerado o percentual do orçamento da USP gasto em "outras despesas", que exclui o gasto com pessoal. Em 1990, 68,03\% das despesas da USP, excluindo gasto com pessoal, eram centralizadas, sendo executadas pelos "órgãos centrais", "atividades integradas" ou "projetos especiais". Dessas, 15,41\% eram de responsabilidade exclusiva dos órgãos centrais (cf. USP, 1991). Em 2012, mesmo com o aumento do número de unidades de ensino e pesquisa, $73,13 \%$ do total de despesas da USP, excluindo gastos com pessoal, eram executadas no âmbito central, 33,78\% pelos órgãos centrais de direção e serviços. Para se ter uma ideia comparativa, no mesmo ano de 2012, a FFCLH, maior unidade da USP, gastou 1,01\% do orçamento da USP relativo a "outras despesas" que, como dito, exclui o gasto com pessoal. As 42 unidades de ensino e pesquisa da USP executaram, juntas, no mesmo ano, apenas 19,72\% do orçamento relativo a outras despesas ${ }^{172}$.

\footnotetext{
172 Todos esses dados são, como dito, publicados anualmente no Anuário Estatístico da USP. Os dados são de acesso público e estão disponíveis em <https://uspdigital.usp.br/anuario> Acesso em: 21 abr. 2014.
} 
Foi no âmbito desse processo contínuo de centralização, que também pode ser descrito como um empoderamento dos órgãos executivos da universidade, em detrimento dos seus órgãos colegiados, que propomos interpretar o surgimento das estatísticas universitárias cuja análise encerra o presente capítulo.

\subsection{O surgimento das estatísticas universitárias nos anos 1980}

Ao analisar a construção de uma gestão acadêmica efetiva, Rudolph Atcon afirmava que, do ponto de vista da "moderna gestão acadêmica", "conhecimento é poder [porque] sem ele não se pode planejar" (1974, p. 15). Nesse sentido, o desenvolvimento de órgãos capazes de produzir e sistematizar dados estatísticos confiáveis sobre a USP foi ao mesmo tempo consequência do processo de fortalecimento do poder central da USP e pressuposto para o seu recrudescimento a partir dos anos 1990.

Nos estudos que se voltam para a história da Universidade de São Paulo produzidos antes da década de 1980, não é raro encontrar observações sobre a carência de estatísticas sistematizadas e confiáveis sobre a USP. Heládio Antunha, por exemplo, ressalta, na introdução do seu estudo histórico realizado no final dos anos 1960, a inexistência de dados confiáveis sobre a evolução da instituição, razão que o leva a criticar a organização interna da USP:

\footnotetext{
Tivemos muita dificuldade para obter dados estatísticos sobre o desenvolvimento da Universidade de São Paulo em geral; mesmo os que obtivemos - graças à extrema gentileza da Divisão de Difusão Cultural da Reitoria - não se mostraram inteiramente satisfatórios. Na realidade, uma das nossas críticas à situação atual da USP refere-se exatamente à inexistência, até o presente, de um serviço de estatísticas e informações sobre as ocorrências gerais da Universidade (Antunha, 1971, p. 5).
}

A observação procede. De fato, até a década de 1980, quando surge o Questionário Socioeconômico da Fuvest e passa a ser publicado o seu Anuário Estatístico, a Universidade de São Paulo não dispunha de estatísticas confiáveis sobre a instituição como um todo, resultado da dispersão dessas informações entre as diferentes unidades de ensino e pesquisa, que ainda 
representavam, apesar das mudanças implementadas a partir da reforma de 1968, um núcleo ativo da vida administrativa da USP. Assim, a história da emergência dessas duas instâncias produtoras de dados - que dão suporte à análise sobre a expansão, diversificação e hierarquização da USP - é inseparável do processo de transformação da universidade em objeto de gestão, através da criação e fortalecimento de órgãos, mecanismos e dispositivos voltados à administração e à construção de instâncias de centralização da política universitária. Dessas, vamos destacar especificamente duas: a criação da FUVEST em 1976 e a criação do Anuário Estatístico em 1987.

A ênfase na necessidade de centralizar os exames vestibulares como forma de aumentar o planejamento e a eficiência da expansão universitária era um lugar comum nos diferentes estudos e relatórios que embasaram a Reforma Universitária de 1968. Não por acaso, como visto, a lei 5.540/1968 trazia um artigo específico sobre os exames vestibulares, estabelecendo um prazo para a unificação da sua execução. Foi no âmbito do novo Conselho de Ensino, Pesquisa e Extensão (CEPE) e atendendo às mudanças exigidas pela lei de 1968, que a USP criou, em 1973, sua primeira Comissão de Vestibulares. Depois de algum tempo de trabalho, a comissão reiterou a importância de realizar um vestibular unificado de todas as áreas criando, para tanto, uma Comissão Permanente do Vestibular, composta de sete membros indicados pelo reitor $^{173}$. Além da criação da Comissão Permanente, foram propostas outras medidas como:

[...] a unificação dos programas [de seleção], já em 1975, nas três áreas de ensino, o direito da Universidade determinar, dentro da legislação vigente, os critérios para a escolha de seus discentes em consonância com a sua política educacional; servir de norte para o ensino médio, uma vez que não existem programas oficiais nesse nível escolar (Motoyama \& Nagamini, 2007, p. 77).

\footnotetext{
${ }^{173}$ Data dessa época, pós-reforma universitária de 1968, a prática que se tornou hegemônica de atribuir ao reitor, e não ao Conselho Universitário, a responsabilidade pela nomeação de comissões, órgãos e conselhos no interior da universidade o que, somado ao poder de escolha dos diretores de unidade pela lista tríplice, atribui ao executivo universitário ainda mais poder.
} 
A Comissão Permanente estabeleceu como objetivo principal criar uma estrutura que permitisse à USP realizar o seu próprio vestibular unificado, partindo do modelo de organizações responsáveis, na época, pelo processo seletivo unificado de profissões liberais altamente concorridas como a Mapofei (que reunia os cursos de engenharia da Mackenzie, Poli e FEI), o Cescem (Centro de Seleção de Candidatos às Escolas Médicas) e o Cesea (Centro de Seleção de Candidatos às Escolas de Administração). A solução encontrada pela Comissão para a organização de um vestibular unificado para toda a USP foi a criação de uma fundação forma jurídica proposta como modelo para as instituições educacionais pelos relatórios finais do primeiro acordo MEC-Usaid, da consultoria de Rudolph Atcon e do Grupo de Trabalho da Reforma Universitária. Assim, em fevereiro de 1976, o Conselho Universitário da USP aprovou a criação da Fundação Universitária para o Vestibular, mais conhecida como Fuvest, que alterou completamente as bases de seleção dos ingressantes da USP. A ideia inicial - proposta pela Fundação Seade no âmbito de uma política de racionalização dos gastos do Estado de São Paulo - era que a Fuvest se tornasse responsável pelos vestibulares da USP, da Unesp e da Unicamp, o que foi possível apenas por um curto período de tempo. Em 1980, a Unesp abandona o vestibular conjunto para criar a Vunesp e, em 1987, a Unicamp também se retira da Fuvest, alegando pouca participação na organização das provas, e passa a organizar o seu próprio processo seletivo (cf. Motoyama \& Nagamini, 2007, p. 80ss). Ainda assim, entre 1977, no ano seguinte à sua fundação, e 1979, a Fuvest chegou a realizar o vestibular unificado das universidades estaduais paulistas, com 92.261 inscritos para 8.218 vagas distribuídas em 50 carreiras (cf. Motoyama \& Nagamini, 2007, p. 530).

Desde 1980, a Fuvest tornou obrigatório, no ato de inscrição, o preenchimento de um Questionário Socioeconômico que acabou se tornando a primeira fonte confiável de dados sobre a USP, produzida por uma instância central, embora referente apenas ao perfil socioeconômico dos inscritos e dos ingressantes no vestibular. A capacidade da Fuvest de gerar e administrar um 
grande Banco de Dados se explica pelo apoio que a Fundação recebeu, desde os seus primeiros anos de funcionamento, do Centro de Computação Eletrônica da USP (CCE-USP). O CCE foi criado pela Escola Politécnica em 1962, sob a denominação de Centro de Cálculo Numérico. Em 1971, logo depois da reforma universitária, foi incorporado pela reitoria como parte da sua assessoria (cf. Motoyama \& Nagamini, 2007, p. 95), no bojo do processo, já analisado, de centralização e empoderamento dos órgãos centrais da universidade.

Foi justamente o apoio do CCE que viabilizou, igualmente, o projeto do reitor José Goldemberg (1986-1989) de criar um Anuário Estatístico para reunir todas as informações demográficas, acadêmicas e patrimoniais da USP como um mecanismo ao mesmo tempo de gestão de prestação de contas. Originalmente, o Anuário estava ligado a uma comissão central de planejamento, criada por Goldemberg no começo da sua gestão, sob coordenação de Joaquim José de Camargo Engler, que assumiu a função de organizar um Anuário Estatístico.

Nesse sentido, compreende-se porque o Anuário foi publicado, originalmente, como um volume da coleção Cadernos de Planejamento, que sistematizava informações estratégicas sobre a universidade. No entanto, em 1988, o Anuário ganhou autonomia. Por meio da portaria 2.344/88, o reitor criou a Comissão Coordenadora do Banco de Dados da Universidade de São Paulo, "em vista da necessidade de se consolidar as informações básicas sobre a Universidade, para servir de instrumento para o planejamento de suas atividades e fornecer subsídios para o processo decisório a nível central e nas unidades universitárias” (USP, 1988, n.p.). A Comissão Coordenadora do Banco de Dados é presidida, desde 1988 até hoje, pelo dirigente 36, que integrava a gestão à época enquanto diretor da Comissão de Planejamento, criada pelo Novo Estatuto para fortalecer a capacidade da administração central de traçar planos, estratégias e diretrizes para a universidade, bem como enquanto diretor da Coordenadoria de Administração Geral, responsável pela administração da universidade com um todo. A função da Comissão Coordenadora do Banco de Dados era, basicamente, reunir as informações estatísticas antes 
concentradas no CCE (Centro de Computação Eletrônica), órgão incorporado pela reitoria em 1971, na Codage (Coordenadoria de Administração Geral), implementada em 1973, e no SIBI (Sistema Integrado de Bibliotecas), criado em 1964. Em um primeiro momento, a execução do Anuário ficou a cargo da Coordenadoria Adjunta de Processamento Administrativo do CCE. A partir de 1995, passou para o Departamento de Informática da Codage que, em 2012, como resultado de um novo processo de reforma administrativa, tornou-se Vice-reitoria Executiva de Administração.

Ao relatar a história da criação do Anuário Estatístico, cuja elaboração coordena desde a sua primeira edição, o dirigente 36 enfatiza as dificuldades administrativas associadas à ausência de informações estatísticas sobre a USP, indicando que a decisão de centralizar a produção de dados pela reitoria ligou-se diretamente à tentativa de se criar um órgão de planejamento universitário no âmbito do poder central durante a gestão 1986-1989. É interessante notar que o dirigente começa o seu relato pelas circunstâncias que o levaram a se aproximar da administração central da USP nos anos 1970, quando ela se caracterizava, ainda, por um relativo amadorismo, ligado à rigidez das estruturas hierárquicas da administração, que não abria espaço para os saberes administrativos mais novos, que o expert então possuía não só pela sua área de especialização - em economia aplicada - mas também, como visto, pela sua participação em um programa de formação de dirigentes universitários, resultado de um convênio entre o MEC e a Universidade de Michigan nos anos 1970.

Eu tive um grande aprendizado quando assessorava o Diretor da ESALQ. Ele tinha sido meu professor [...] e achava que na área administrativa eu estava bem preparado. Então, quando ele assumiu a diretoria da ESALQ, ele me indicou como assessor. Eu era, nessa época [1972-1980], chefe de departamento e o assessorava na direção da unidade. Com isso, eu vinha muito à reitoria para tratar de assuntos administrativos, principalmente na área financeira, que era considerada um grande tabu em que ninguém mexia: "Seu Marinho é seu Marinho", ninguém queria falar com seu Marinho, que era funcionário e diretor financeiro da universidade, o todo poderoso (risos). Eu me lembro da primeira vez que eu fui conversar com ele, discutir o problema de uma licitação que estava parada na Esalq, e perguntei se não era possível agilizar, e ele falou: "Bom, o senhor o que é lá na Esalq?". "Sou professor". E ele respondeu: "Ah, então eu não vou perder tempo com o senhor. Professor não entende de administração, professor não entende de finanças, professor isso, professor aquilo". Eu engoli seco e falei: "Tá bom seu Marinho". Mas eu continuava indo lá a pedido do então diretor da ESALQ, de quem ele gostava muito. Eu me lembro que o seu Marinho 
me atendia, mas antes dizia: "Olha, eu vou te atender só porque o diretor não veio, porque eu só atendo diretor". E eu respondia (em tom humilde): “Tá bom seu Marinho". E aos poucos ele foi vendo que a minha intenção era ajudar e eu fui começando a conhecer como funcionava a administração da universidade. [Mais tarde], quando foi eleito o novo reitor e eu terminava meu mandato de diretor na ESALQ, ele me chamou e disse: "Bom, você já trabalhou muito na sua unidade, agora eu quero que você me ajude aqui na reitoria. Eu estou querendo criar uma Assessoria de Planejamento e quero que você assuma esse órgão". E eu vim trabalhar na reitoria. Logo de imediato, o reitor tinha um problema com as estatísticas da USP. Ou seja, as diferentes fontes de dados. Se você conversasse com três pessoas diferentes, você tinha três informações diferentes. Se conversasse com dez, você tinha dez, porque cada pessoa tinha um dado. Então, precisava ter uma certa uniformização, uma certa confiança, e disso surgiu o Anuário Estatístico da USP, que eu comecei a fazer em 1987. [...] O objetivo do anuário era obter informações que fossem fidedignas para a USP. Tanto como uma prestação de contas à comunidade paulista, financiadora da universidade, como também um elemento para planejamento das atividades. Porque toda vez que precisava de alguma informação, ficava aquela correria. Então, por exemplo, quantos docentes a USP tem? Era incrível, a universidade não sabia. E não sabia mesmo! Tinham falhas gritantes na forma de computar esses dados. [...] Como não tinha orçamento na época, não tinha tanto problema. Mas naquele momento, Goldemberg estava negociando melhorias orçamentárias, estava surgindo a nossa autonomia, então essas falhas ficavam mais gritantes. Nós precisávamos saber com que números nós estávamos trabalhando. Mas as informações eram das unidades e cada unidade informava do seu jeito, e o órgão central, quando reunia, reunia mal. Não havia um entrosamento entre os diversos órgãos e a informatização era muito reduzida, então complicava ainda mais.

O relato do dirigente indica claramente o impacto da emergência de um conhecimento especializado sobre a gestão acadêmica, que ele adquiriu em programas de treinamento oferecidos pelo MEC em parceria com universidades norte-americanas nos anos 1970, sobre a organização do governo acadêmico, com a criação de comissões especiais de planejamento, de procedimentos sistematizados de decisão e, principalmente, de instâncias centralizadas de produção de dados sobre a universidade como um todo que permitissem, ao nível central, conhecer, controlar e planejar a vida universitária. Mas ele não é o único que tem essa percepção. O dirigente 23, que era vice-reitor da USP durante a criação do Anuário Estatístico, considera que a produção de estatísticas confiáveis sobre a universidade foi pré-condição para o surgimento de uma "gestão científica":

[Pergunta] Professor, voltando à questão da gestão política e da gestão científica. Qual é a diferença para o senhor?

[Resposta] Uma gestão científica é aquela que trabalha em cima de dado, exatamente como a gente faz pesquisa [risos]. Então, eu, por exemplo, sempre trabalhei em cima de uma gestão científica. Quando eu assumi administração, eu disse: "Eu vou fazer administração do jeito que eu fazia Física. Então eu tenho que ter indicador, eu tenho que ter dados, estudos, para poder tomar uma decisão". [...] foi por isso que participei da criação do Anuário. [...] Porque antes, não tinha um dado confiável!! Então a unidade pedia uma vaga, a reitoria nem sabia quantos alunos por professor ela tinha, 
qual era o indicador, se tinha mais ali do que na outra, se não tinha, se o pessoal produzia muito ou pouco. Você não tinha um dado confiável. Cada um fazia a coleta do jeito que queria e informava a reitoria do jeito que queria. Como é que se pode fazer uma gestão em cima disso? [...] Então o Anuário serviu para começar a dar uma certa estrutura de dados para a Universidade. E foi importantíssimo.

Essa percepção sobre a importância do Anuário Estatístico reapareceu em várias entrevistas, sobretudo entre experts em gestão e lideranças acadêmicas, ou seja, entre dirigentes da área administrativa e reitores e vice-reitores. Mas o importante é perceber que as duas principais instâncias produtoras de dados sobre a USP, a Fuvest, por meio do seu Questionário Socioeconômico, e a Coordenadoria de Administração, hoje Vice-reitoria executiva, responsável pela publicação do Anuário Estatístico, surgem como desdobramentos das mudanças promovidas a partir da reforma universitária da década de 1960, inspirada por uma concepção econômica da educação e uma visão gerencial de universidade.

Mas as transformações da USP a partir dos anos 1960 não resultam apenas da expansão do conhecimento administrativo. O processo de expansão e diversificação das unidades e cursos, bem como a preservação das linhas gerais da sua estrutura social, são igualmente importantes para compreender a transformação da Universidade de São Paulo ao longo das últimas décadas. As afinidades existentes entre a expansão do paradigma gerencial, que busca redefinir o governo das universidades, e os novos modelos pedagógicos, que inspiram a recente expansão da universidade, já foi apontada pela literatura e existem análises interessantes sobre isso (cf. Garcia, 2000; Readings, 1996; Strathern, 2000). Nesse sentido, ao reconhecer a relação intrínseca entre a expansão do procedimento de avaliação institucional, que "atinge o âmago da concepção tradicional da universidade como instituição que abriga tensões e perspectivas conflitantes segundo a própria lógica do princípio primeiro de liberdade de investigação" (Garcia, 2000, p. 135) e os princípios pedagógicos estão na base da “crítica à especialização dos saberes associada à notável valorização da chamada formação interdisciplinar” (Garcia, 2000, p. 136), Sylvia Garcia vai concluir que: 
Em suma, as diretrizes da atual reforma universitária parecem encontrar sua expressão mais acabada no ensino técnico-profissionalizante, no qual o objetivo de aprendizagem de habilidades para a realização de tarefas específicas não tem que disputar espaço com o propósito tradicional de transmissão de um patrimônio cultural. Nesse sentido, elas apontam, em geral, para uma redefinição da histórica tensão entre as tarefas da formação cultural e da qualificação profissional que tende, no limite, a destruí-la enquanto tensão, por meio do esvaziamento de um de seus polos, isto é, pela ausência de reprodução das condições de possibilidade da autonomia intelectual e da formação cultural no nível básico dos cursos de graduação. Um dos tópicos mais reiterados nos diagnósticos do esgotamento histórico da concepção tradicional da universidade é a crítica à especialização dos saberes associada à notável valorização da chamada formação interdisciplinar. Nesse sentido, a concepção até então predominante da educação, em todos os seus níveis, como esfera de ensino de conhecimentos e saberes organizados em disciplinas tende a ser substituída pela noção de educação como esfera de aprendizagem de habilidades específicas, centralizada na figura do estudante como sujeito individual de sua própria formação. A difusão das noções de desempenho, eficiência e, especialmente, competências é uma das expressões mais visíveis dessa tendência geral (Garcia, 2000, p. 138).

É exatamente a análise desta tensão entre os dois polos essenciais da universidade, de formação cultural e qualificação profissional, que só assumem esse sentido específico em relação um ao outro, que compõe o foco do próximo capítulo, cujo objeto central são os padrões de expansão, diversificação e elitização da USP descritos a partir das estatísticas universitárias produzidas pelo Questionário Socioeconômico da Fuvest e pelo Anuário Estatístico. O capítulo analisa, ainda, o processo de atualização da estrutura interna da USP, a partir do fortalecimento do ensino técnico-profissionalizante, que representa uma terceira polaridade no interior da universidade, que não chega a desmontar a sua oposição essencial. 


\title{
Capítulo 3. A transformação estrutural da USP: dominantes e dominados no contexto universitário
}

\begin{abstract}
Não se passa mecanicamente do crescimento de tamanho das universidades ao crescimento da complexidade da burocracia universitária (por outro lado, é certo esse crescimento?) ou, segundo o estereótipo erudito, à transformação da 'comunidade' em 'massa' ou, menos ainda, do 'scholar' em 'trabalhador educacional'. Do mesmo modo, o surgimento de um corpo de administradores científicos e o crescimento do seu peso na estrutura dos poderes universitários só pode ser compreendia por uma análise da estrutura do campo em seu conjunto, das lutas e do partido que os diferentes campos podem tirar do crescimento do número de estudantes e das diferentes categorias de professores [...]. É por isso que a análise do efeito que as transformações morfológicas exerceram sobre o corpo de professores, sua visão do mundo universitário e suas divisões, passa por uma história estrutural do campo universitário que é preciso ao menos esboçar, na medida em que os dados estejam disponíveis (Bourdieu, 1984, p. 173-6).
\end{abstract}

A proposta de realizar uma análise estrutural da USP capaz de identificar as relações de homologia entre, de um lado, as posições sociais determinantes no interior da universidade e, de outro, as interpretações simbólicas sobre o seu passado (expressas nas principais tradições historiográficas que recontam a trajetória da USP) e as visões pragmáticas sobre o seu futuro (incorporadas nos projetos opostos de reforma universitária que disputaram a reestruturação do ensino superior nos anos 1960) depende estritamente do esforço de reconstruir uma história estrutural da USP que identifique os padrões de transformação e reprodução da sua estrutura social ao longo das últimas décadas. Em síntese, é esse o intuito do presente capítulo que, para reconstruir essa história estrutural da USP, se organiza em três partes.

A primeira utiliza os dados gerais sobre a USP, especialmente os de natureza demográfica produzidos pelo Anuário Estatístico, para descrever o processo de expansão e diversificação ocorrido a partir dos anos 1960 e, sobretudo, 1980, quando informações cada vez mais detalhadas sobre o perfil dos seus cursos, programas e unidades se tornaram disponíveis por meio da centralização da produção de dados estatísticos. Essa seção busca, ainda, traçar a evolução da concorrência de alguns cursos da USP e do seu efeito sobre o perfil 
socioeconômico dos seus ingressantes a partir de uma análise dos dados publicizados anualmente pela Fuvest.

A segunda parte do capítulo, por sua vez, dedica-se ao processo de elitização diferencial da USP entre 1995, quando a informatização total do processo da Fuvest possibilita a utilização dos dados do Questionário Socioeconômico, e 2013, ano mais recente para o qual existiam dados disponibilizados no momento de conclusão da presente pesquisa.

A última parte, dedicada à reconstrução das hierarquias internas à USP, retrabalha os dados sobre o perfil social dos seus ingressantes para mostrar como a expansão das últimas décadas não alterou, em essência, a estrutura geral da universidade, marcada, segundo as análises histórico-estruturais tratadas anteriormente, pela oposição entre unidades profissionais tradicionais, de recrutamento social elevado, e unidades acadêmico-científicas, caracterizadas por uma relativa abertura a setores sociais menos favorecidos (cf. Fernandes, 1975 e 1984; Limongi, 1988 e 1989; Miceli, 1989).

Essa polarização essencial encontra-se, hoje, complexificada por mudanças que ocorreram, sobretudo, no interior do polo profissional, que se desdobrou criando novas carreiras que são responsáveis pela forte expansão recente da universidade ao mesmo tempo que concentram o ingresso de novos setores, contribuindo para a preservação do caráter homogêneo e altamente seletivo do polo profissional tradicional. O perfil socioeconômico dos ingressantes desses cursos sugere que, ao lado do polo profissional tradicional e do polo acadêmicocientífico consolidou-se, hoje, um terceiro polo, que pode ser descrito como técnicoprofissional. Justamente pela sua relação intrínseca com o polo profissional tradicional, do qual representa um desdobramento histórico, o polo técnico-profissional também pode ser analisado da perspectiva da hierarquização das formações profissionais que, como visto no primeiro capítulo, sempre existiu, como mostra a posição ambígua da área de educação. Essa constatação não invalida a proposição essencial da análise estrutural do ensino superior, segundo a qual é 
possível encontrar as oposições essenciais do campo universitário no interior de cada um dos subcampos que o compõem (cf. Bourdieu, 1989, p. 205). Desse modo, ao constatar que a mudança mais essencial na hierarquização interna da USP, ou seja, o surgimento e a expansão das formações profissionais de caráter técnico, repõe, como se verá, a oposição essencial entre dominantes e dominados no interior da instituição, é possível concluir que a trajetória da USP nos últimos cinquenta anos foi marcada pela atualização das suas estruturas fundamentais.

\section{Expansão e diversificação: mudanças na estrutura social e acadêmica da USP entre 1960 a 2010}

Se fosse preciso descrever a trajetória da Universidade de São Paulo entre 1960 e 2010 em apenas duas palavras, essas certamente seriam expansão e diversificação. Isso porque, ao longo de todo esse período, a USP não só aumentou significativamente os seus cursos, unidades e programas, ao que correspondeu um crescimento homólogo do número de alunos de diferentes níveis e, em menor escala, de docentes e de funcionários, como essa expansão, associada um aumento da produtividade do seu corpo docente, esteve atrelada a um intenso processo de diversificação interna que fez com que, às unidades e aos cursos que tradicionalmente compunham a USP, se somasse, a partir da década de 1970, uma série de novas faculdades e carreiras que alterou a configuração original da universidade mais tradicional do país. Através de uma análise dos dados e indicadores sistematizados pelo Anuário Estatístico da USP, esta seção pretende analisar esses dois processos - de expansão e de diversificação - que, juntos, e assim como ocorreu em outros contextos, contribuíram para atualizar a estrutura social, acadêmica e política da USP, fortalecendo o papel das suas hierarquias internas (cf. Arum, Gamoran \& Shavit, 2007; Bourdieu, 1984, 1989; Bourdieu \& Saint Martin, 1987; Dubet, DuruBellat \& Vérétout, 2012; Euriat \& Thélot, 1995; Gall \& Soulié, 2007; Garcia \& Poupeau, 2003; Merle, 1996). 


\subsection{A expansão da USP (1960 - 2012)}

Pelos dados estatísticos disponíveis ${ }^{174}$, a USP contava, em 1960, com aproximadamente 9.786 alunos de graduação. Em 1968, esse número já havia praticamente dobrado, chegando a 15.249 estudantes (cf. MEC, 1972, p. 107). Em 1971, considerando não só os alunos regularmente matriculados, como também os que participavam de cursos de extensão universitária, a USP contava com 26.540 estudantes. A pós-graduação, que dava seus primeiros passos nesse momento, contava, em 1965, com 2.781 alunos inscritos (cf. Antunha, 1971, p. 161). Embora não existam dados disponíveis sobre a evolução do número de alunos da USP ao longo da década de 1970 e $1980^{175}$, é plausível supor que a universidade seguiu crescendo porque, no final da década de 1980, quando o Anuário Estatístico apresenta as primeiras sistematizações desses dados, o número de alunos de graduação regularmente matriculados no primeiro semestre de 1989 chegava a 31.987, e os de pós-graduação chegavam a quase 15.000 estudantes no mesmo ano. Mas foi sobretudo a partir do final dos anos 1990 que a expansão se consolida com mais força. A tabela 1 apresenta de modo sistematizado a evolução do corpo discente da USP nas suas diferentes modalidades - graduação, pós-graduação e alunos especiais -, o que permite visualizar o rápido crescimento da universidade a partir de 1989

\footnotetext{
${ }^{174}$ Como já foi dito, não existiam dados estatísticos sistematizados sobre a USP no período anterior a 1987, quando se organiza o Anuário Estatístico. Para o número de alunos, os dados realmente confiáveis são os consolidados a partir de 1989, quando o processo de coleta e processamento dessas informações pelo anuário tornou-se mais sistematizado. Para a década de 1960, os únicos dados estatísticos disponíveis são, primeiro, os fornecidos por Heládio Antunha que, depois de criticar a universidade por não possuir um serviço de estatística centralizado, afirma ter conseguido, junto à Divisão de Difusão Cultural da Reitoria, alguns dados "não inteiramente satisfatórios" (cf. 1971, p. 5) e, segundo, as Estatísticas Educacionais do MEC publicadas em 1972 e 1974 pelo Serviço de Estatística da Educação e Cultura e que sintetizam algumas informações gerais sobre a USP entre 1960 e 1971 (cf. MEC, 1972, p. 107). É importante frisar que, ao longo da pesquisa, eu procurei ter acesso a esses dados de diversas maneiras, como a consulta a bibliotecas de unidades, ao arquivo da USP e ao Anuário Estatístico da universidade. Esse último órgão, vale notar, também se engajou, sem sucesso, na busca por essas informações estatísticas referentes aos anos 1960, 1970 e, em certa medida, 1980. A pesquisa mostrou, por fim, que os únicos dados estatísticos anteriores a 1980 e produzidos oficialmente pela USP são uma primeira série de anuários estatísticos produzida de 1934 a 1941 disponível na Biblioteca Digital de Obras Raras do SIBI-USP (cf. <http://www.obrasraras.usp.br> Acesso 21 de abr. 2014). Mas essa série não traz, evidentemente, dados sobre as décadas de 1960 e 1970.
}

175 O Anuário Estatístico fornece dados sobre o corpo docente e de funcionários desde 1980. Mas sobre o corpo discente, as informações são a partir de 1989. Embora existam dados para o número de alunos em 1986 e 1987, esses são claramente inconsistentes e foram abandonados pelo próprio Anuário nas séries posteriores a 1989. 


\begin{tabular}{|c|c|c|c|c|c|}
\hline \multicolumn{6}{|c|}{ Tabela 1. Evolução do corpo discente da USP (1989 - 2012) } \\
\hline Ano & $\begin{array}{c}\text { Total de } \\
\text { alunos de } \\
\text { graduação }\end{array}$ & $\begin{array}{c}\text { Alunos de } \\
\text { pós- } \\
\text { graduação } \\
\text { regularmente } \\
\text { matriculados }\end{array}$ & $\begin{array}{l}\text { Alunos } \\
\text { especiais }\end{array}$ & $\begin{array}{c}\text { Total de } \\
\text { alunos de } \\
\text { pós- } \\
\text { graduação }\end{array}$ & $\begin{array}{c}\text { Total de } \\
\text { alunos }\end{array}$ \\
\hline 1989 & 31.897 & 12.914 & 2.026 & 14.940 & 46.837 \\
\hline 1990 & 31.607 & 13.625 & 2.356 & 15.981 & 47.588 \\
\hline 1991 & 33.244 & 12.745 & 3.326 & 16.071 & 49.315 \\
\hline 1992 & 33.266 & 15.217 & 5.493 & 20.710 & $\mathbf{5 3 . 9 7 6}$ \\
\hline 1993 & 33.900 & 14.080 & 5.352 & 19.432 & 53.332 \\
\hline 1994 & 33.808 & 15.844 & 5.387 & 21.231 & 55.039 \\
\hline 1995 & 32.834 & 14.084 & 5.599 & 19.683 & 52.517 \\
\hline 1996 & 32.963 & 20.524 & 2.927 & 23.451 & 56.414 \\
\hline 1997 & 33.020 & 19.713 & 4.207 & 23.920 & 56.940 \\
\hline 1998 & 33.934 & 21.009 & 5.118 & 26.127 & 60.061 \\
\hline 1999 & 39.155 & 22.570 & 5.514 & 28.084 & 67.239 \\
\hline 2000 & 39.326 & 22.774 & 5.521 & 28.295 & 67.621 \\
\hline 2001 & 40.162 & 23.765 & 5.196 & 28.961 & 69.123 \\
\hline 2002 & 42.554 & 23.709 & 6.604 & 30.313 & 72.867 \\
\hline 2003 & 44.696 & 24.312 & 6.954 & 31.266 & 75.962 \\
\hline 2004 & 45.946 & 24.408 & 6.851 & 31.259 & 77.205 \\
\hline 2005 & 48.530 & 25.007 & 7.052 & 32.059 & 80.589 \\
\hline 2006 & 51.980 & 24.836 & 6.573 & 31.409 & 83.389 \\
\hline 2007 & 54.361 & 25.443 & 6.383 & 31.826 & 86.187 \\
\hline 2008 & 55.863 & 25.495 & 5.824 & 31.319 & 87.182 \\
\hline 2009 & 56.998 & 25.591 & 5.672 & 31.263 & 88.261 \\
\hline 2010 & 57.300 & 25.568 & 5.094 & 30.662 & 87.962 \\
\hline 2011 & 57.902 & 27.795 & 5.322 & 33.117 & 91.019 \\
\hline 2012 & 58.303 & 28.498 & 5.263 & 33.761 & 92.064 \\
\hline
\end{tabular}

Considerando apenas os alunos de graduação, que passaram de 31.897 em 1989 para 58.303 em 2012, o crescimento foi da ordem de 82,78\%. Considerando os alunos de pósgraduação regularmente matriculados, a expansão foi ainda maior, passando de 12.914 matrículas em 1989 para 28.498, em 2012, um crescimento de 120,67\%. Somando o total de 
alunos de graduação e de pós-graduação, o crescimento foi da ordem de 96,56\% no período. O crescimento da pós-graduação, observado na tabela, resulta diretamente da constituição de um sistema nacional de formação de pesquisadores, a partir dos anos 1970, com a consolidação da política de bolsas, implementadas por agências de fomento à pesquisa como a CAPES, o CNPq e a FAPESP, e a consequente profissionalização da formação em pesquisa. A expansão do número de alunos de graduação, por sua vez, reflete sobretudo o processo de expansão da USP, através do crescimento do número de unidades, cursos, programas e vagas a partir de 1960 e, sobretudo, 1990.

Levando-se em consideração, em primeiro lugar, o número de vagas de graduação, a tabela 2 apresenta os dados atualmente disponíveis. É possível notar, em suma, que entre 1960 e $2012^{176}$ as vagas de primeiro ano da USP cresceram mais de $350 \%$ em cinquenta anos, passando de 2.334 em 1960 para 10.602 em 2012. Esse crescimento ocorreu em dois momentos principais: de 1960 a 1968, ligado à expansão da FFCL, e de 1999 a 2012, ligado a novos cursos profissionais. O crescimento da quantidade de vagas de primeiro ano na USP e do número de alunos matriculados em diferentes níveis foi acompanhado, ainda, por um aumento significativo do número de cursos de graduação, conforme é possível notar pela tabela 3 . O mesmo ocorreu com os programas de mestrado e doutorado que, em função da política nacional de pósgraduação, também se expandiram significativamente nos últimos anos. A expansão da USP por meio da abertura de novos cursos e programas sugere, desde já, que o crescimento da universidade veio acompanhado de uma forte diversificação interna. Considerando, portanto, o número de cursos oferecidos pela USP, o crescimento foi de 97,62\% na graduação, entre 1989 e 2012, e de 94,83\% na pós-graduação, entre 1987 e 2012.

\footnotetext{
${ }^{176}$ Para os dados demográficos, optou-se por produzir, sempre, a maior série histórica possível, para explicitar os movimentos tendenciais de longo prazo, que se manifestam nos intervalos temporais mais extensos.
} 


\begin{tabular}{cc}
\hline \multicolumn{2}{c}{ Tabela 2. Evolução das vagas de graduação (1960 - } \\
2012)
\end{tabular}

Fonte: Anuário Estatístico

Elaboração: própria

* Para 1960 e 1969 ver Heládio Antunha. Universidade de São Paulo: Fundação e Reforma (1971, p. 153). 
Tabela 3. Evolução dos cursos de graduação, mestrado e doutorado (1987 - 2012)

\begin{tabular}{|c|c|c|c|c|}
\hline Ano & $\begin{array}{l}\text { Cursos de } \\
\text { graduação }\end{array}$ & $\begin{array}{l}\text { Cursos de } \\
\text { mestrado }\end{array}$ & $\begin{array}{l}\text { Cursos de } \\
\text { doutorado }\end{array}$ & $\begin{array}{c}\text { Total de } \\
\text { cursos de } \\
\text { mestrado e } \\
\text { doutorado }\end{array}$ \\
\hline 1987 & $\mathrm{~s} / \mathrm{d}$ & 205 & 164 & 369 \\
\hline 1988 & $\mathrm{~s} / \mathrm{d}$ & 202 & 162 & 364 \\
\hline 1989 & 126 & 230 & 189 & 419 \\
\hline 1990 & 126 & 232 & 190 & 422 \\
\hline 1991 & 126 & 236 & 192 & 428 \\
\hline 1992 & 126 & 257 & 219 & 476 \\
\hline 1993 & 126 & 260 & 219 & 479 \\
\hline 1994 & 130 & 257 & 219 & 476 \\
\hline 1995 & 132 & 257 & 219 & 476 \\
\hline 1996 & 129 & 253 & 219 & 472 \\
\hline 1997 & 130 & 257 & 224 & 481 \\
\hline 1998 & 130 & 257 & 230 & 487 \\
\hline 1999 & 162 & 257 & 230 & 487 \\
\hline 2000 & 158 & 259 & 237 & 496 \\
\hline 2001 & 179 & 261 & 240 & 501 \\
\hline 2002 & 189 & 267 & 252 & 519 \\
\hline 2003 & 200 & 271 & 255 & 526 \\
\hline 2004 & 202 & 280 & 264 & 544 \\
\hline 2005 & 214 & 289 & 274 & 563 \\
\hline 2006 & 222 & 311 & 291 & 602 \\
\hline 2007 & 236 & 319 & 296 & 615 \\
\hline 2008 & 238 & 316 & 295 & 611 \\
\hline 2009 & 239 & 309 & 299 & 608 \\
\hline 2010 & 240 & 308 & 299 & 607 \\
\hline 2011 & 247 & 319 & 308 & 627 \\
\hline 2012 & 249 & 332 & 309 & 641 \\
\hline
\end{tabular}

Fonte: Anuário Estatístico

Elaboração: própria 
Parte importante desses novos cursos de graduação e de pós-graduação são oferecidos por novas unidades da USP. Na verdade, desde a reforma universitária de 1968, introduzida na USP pelo Estatuto de 1969 (cf. USP, 1969), o número de unidades de ensino e pesquisa da USP - que, como tais, possuem assento no Conselho Universitário ${ }^{177}$ - cresce de modo contínuo. Assim, se em 1934, ano de fundação da USP, a universidade contava com dez unidades de ensino e pesquisa, oito delas realmente efetivas ${ }^{178}$, em 1974 já eram trinta e duas unidades, oito delas resultado da fragmentação da antiga Faculdade de Filosofia, Ciências e Letras. A partir de 1980, a USP criou, em média, três novas unidades por década, o que fez com que, nos seus 80 anos, completados em 2014, a USP tivesse quarenta e duas unidades de ensino e pesquisa, conforme é possível observar no gráfico abaixo, que apresenta a evolução do número de unidades da USP entre 1934 e 2014.



\footnotetext{
${ }^{177}$ Em todos os Estatutos da USP (cf. USP, 1934b, 1969 e 1988), apenas as unidades de ensino e pesquisa, originalmente chamadas institutos universitários (cf. USP, 1934b), têm assento individual no Conselho Universitário através do seu Diretor e de um representante eleito pela Congregação. Os Museus, Órgãos Complementares e Órgãos de integração estão presentes no Conselho Universitário por meio de um representante.

${ }^{178}$ Em 1934, a USP foi criada com 10 unidades de ensino e pesquisa, mas tornaram-se efetivamente unidades da USP: a Faculdade de Direito, a Escola Politécnica, a Faculdade de Medicina, a Faculdade de Medicina Veterinária, a Escola Superior de Agricultura, a Faculdade de Odontologia, a Faculdade de Farmácia e a Faculdade de Filosofia, Ciências e Letras. A Escola de Belas Artes, criada juntamente com a USP, não se manteve ligada à universidade e a Faculdade de Ciências Econômicas e Comerciais só foi efetivada em 1946 como Faculdade de Economia e Administração.
} 
Apesar do forte crescimento do número de unidades, cursos, vagas e alunos, a expansão do corpo docente da USP não seguiu o mesmo ritmo, sobretudo a partir de 1980. A sequência de gráficos apresentada a seguir busca descrever a evolução do corpo docente da USP entre 1960 e 2012 a partir de diferentes informações. Primeiro, a evolução do número de docentes contratados pela universidade entre 1960 e $2012^{179}$. A seguir, o número de docentes trabalhando o equivalente ao Regime de Dedicação Integral à Docência e à Pesquisa (RDIDP) ${ }^{180}$. Por fim, a evolução do percentual de docentes contratados em tempo integral ou seja, em dedicação exclusiva em relação ao total de docentes da universidade. Juntos, esses gráficos mostram que, não obstante o crescimento do percentual de docentes da USP trabalhando em tempo integral (RDIDP), o número de docentes da USP, depois de um forte crescimento nos anos 1960 e 1970, manteve-se, em larga medida, estável entre 1980 e 2012, período em que a universidade, como visto, aumentava a sua oferta de vagas e cursos e, consequentemente, ampliava o seu alunado.

\footnotetext{
${ }^{179}$ É importante notar que, no Anuário Estatístico da USP, só estão disponíveis os dados a partir de 1980. Para 1960 e 1970, utilizo as informações disponibilizadas por Heládio Antunha (cf. 1971, p. 165).

180 Essa medida "disponibilidade de docentes equivalentes em RDIDP" é produzida pelo Anuário Estatístico da USP desde a sua primeira edição (cf. USP, 1987) na tentativa de descrever a capacidade "real" de trabalho do corpo docente da USP medidas em tempo de trabalho. Partindo do pressuposto de que os docentes que trabalham em Regime de Dedicação Integral à Docência e à Pesquisa (RDIDP) equivalem a 1,0 docente, ao passo que os que trabalham em Regime de Turno Completo (RTC) equivalem a 0,6 docentes em RDIDP, e os que trabalham em Regime de Turno Parcial (RTP) a 0,3 docentes em RDIDP, a medida busca descrever de modo mais preciso a evolução do corpo docente da USP ao longo dos últimos anos. Em resumo, a variável busca indicar que, apesar do número de docentes ter permanecido praticamente estagnado entre 1980 e 2012, depois de um declínio relativamente acentuado nos anos 1990, essa estagnação foi compensada pelo aumento progressivo do número de docentes trabalhando em tempo integral, o que se expressa em um aumento da "disponibilidade de docentes equivalentes em RDIDP”, ou seja, um aumento do número de horas de trabalho disponíveis.
} 


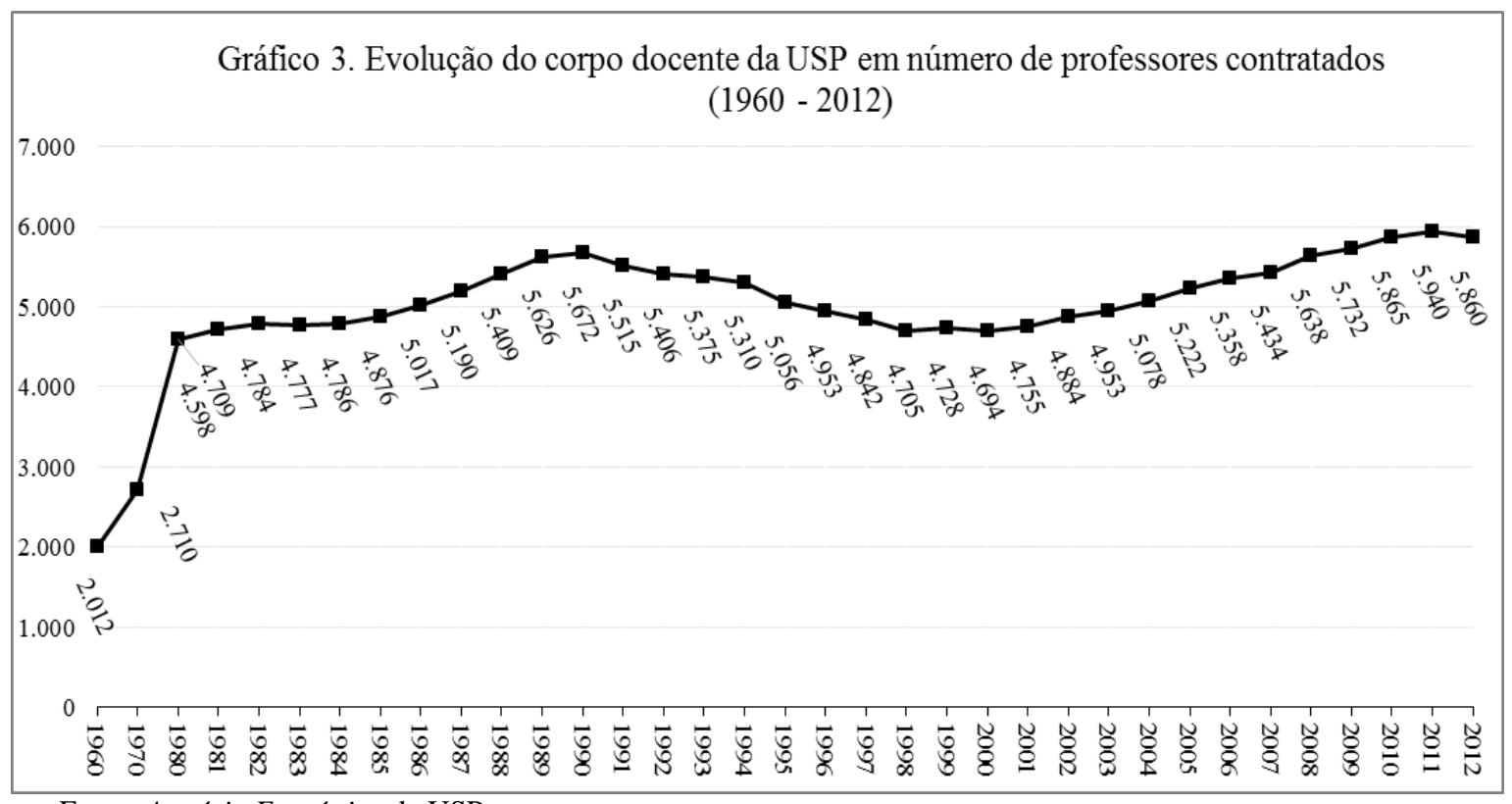

Fonte: Anuário Estatístico da USP

Elaboração: Própria

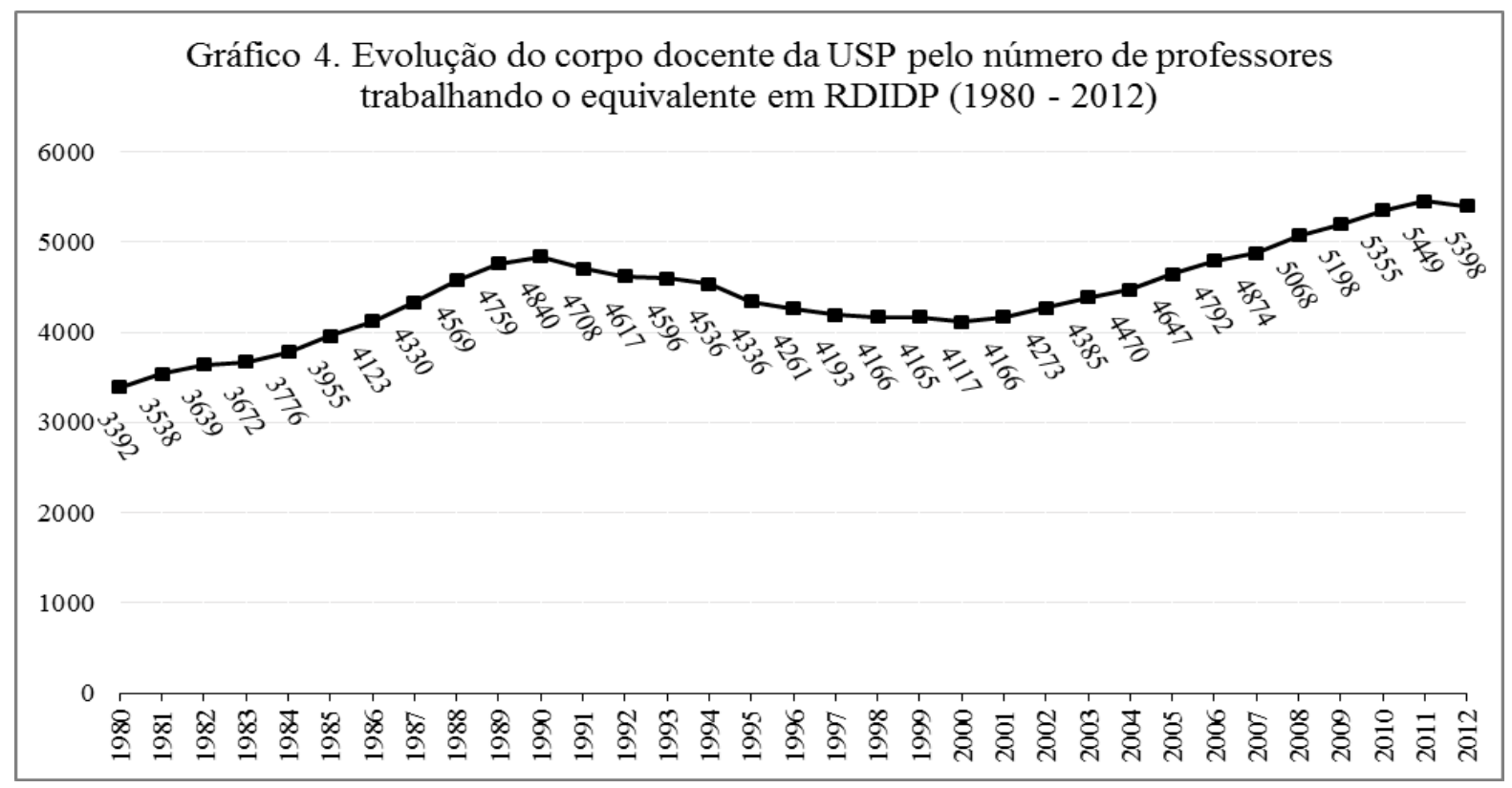

Fonte: Anuário Estatístico da USP

Elaboração: Própria 


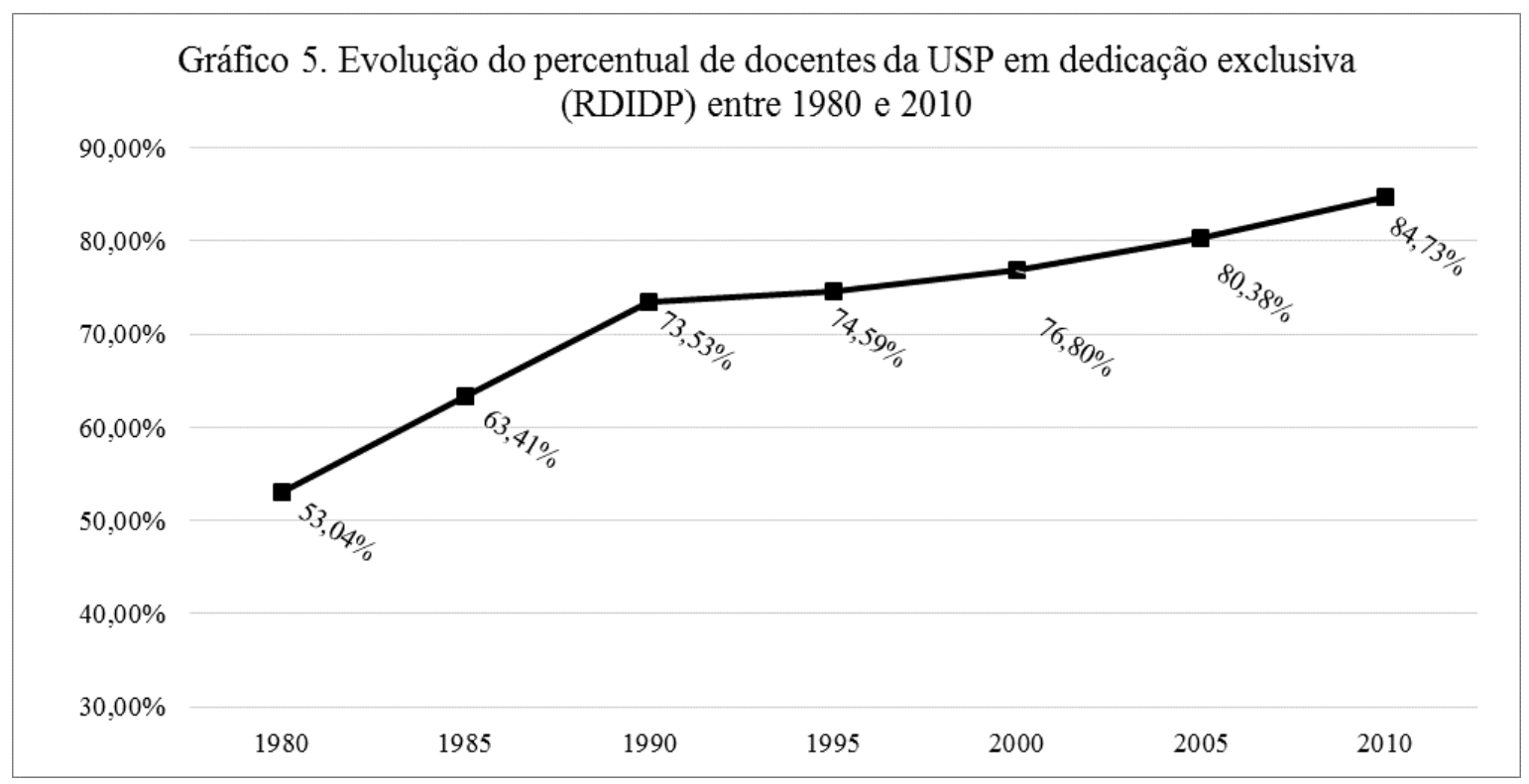

Fonte: Anuário Estatístico da USP

Elaboração: Própria

Assim, embora o crescimento da dedicação exclusiva entre os professores da USP tenha sido intenso, passando de 53,04\% para 84,75\% entre 1980 e 2010, é possível dizer que a expansão dos estudantes de graduação e pós-graduação não foi acompanhado por um crescimento análogo do número de docentes. Essa disparidade do ritmo de expansão dos corpos docente e discente da USP resultou em aumento do número de estudantes por docente, tanto na graduação quanto na pós-graduação, conforme o gráfico 5, abaixo. Por ele, é possível notar que, desde 1989, quando esse indicador passou a ser produzido pelo Anuário Estatístico, o número de alunos por docente cresceu progressivamente na graduação até 2007, quando passa a apresentar uma oscilação, sugerindo uma discreta tendência de queda até 2011, quando o número de alunos de graduação por docente volta a aumentar. Já na pós-graduação, o processo não é tão linear. Depois de um crescimento contínuo do número de alunos de pós-graduação por docente até 2003, resultado da diminuição do corpo docente da USP ao longo dos anos 1990, essa relação caiu progressivamente até 2010, quando a relação aluno/docente voltou a subir também na pós-graduação em função de uma pequena redução do corpo docente da USP. 


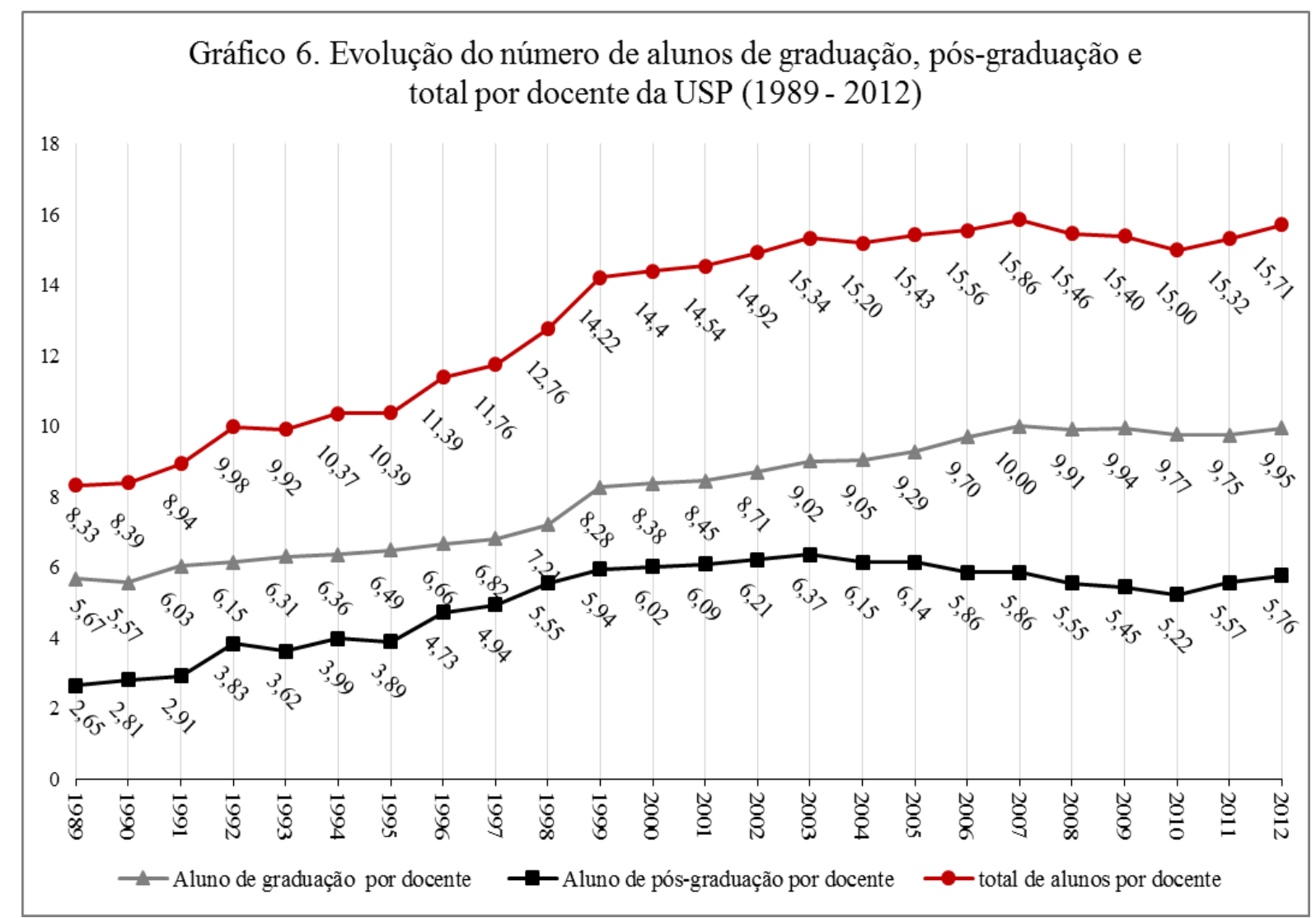

Fonte: Anuário Estatístico

Elaboração: Própria

O crescimento do número de alunos por docente na USP, embora não seja um indicador direto de massificação ou de perda da qualidade é, certamente, um indicador do aumento do volume de trabalho dos docentes da USP. Assim, partindo dos dados acima expostos, é possível dizer que, ao longo dos últimos anos, a USP não só se expandiu, como se tornou uma instituição mais "eficiente" e "produtiva", realizando, portanto, os objetivos estabelecidos pela reforma universitária de 1968 (cf. Brasil, 1968b e 1969). Essa constatação é reforçada não só pela relação aluno/docente mas, igualmente, pelos dados disponíveis sobre a produção científica dos docentes da USP nesse mesmo período.

Considerando, em primeiro lugar, o número de trabalhos científicos publicados por docente, é possível observar que essa relação também cresceu progressivamente a partir de 
1985, como é possível observar na tabela 4. A princípio, a relativa diminuição do número de publicações científicas da USP e, consequentemente, a queda do número de artigos publicados por docente da instituição, a partir de 2009, se deve a razões metodológicas. Os dados relativos à publicação científica dos docentes da USP são produzidos pelo cadastramento da produção docente feito manualmente pelas diferentes bibliotecas de unidade que, anualmente, repassam a informação para o SIBI (Sistema Integrado de Bibliotecas) responsável, por sua vez, por consolidar os dados repassando-os para o Anuário Estatístico da USP. Como é produzido, em larga medida, manualmente, esse dado demora até quatro anos para ser consolidado, gerando uma diminuição relativa do número de publicações anuais para os anos mais recentes fruto do não cadastramento. Essa informação não foi apenas transmitida a mim pelos responsáveis pelo Anuário Estatístico, como pude verificá-la, ao acompanhar a série histórica do anuário e observar o padrão das correções anuais que são feitas nesse tipo de dado ao longo do tempo. Apesar disso, não se deve descartar de todo a possibilidade de que a tendência histórica de evolução dos indicadores da USP esteja se alterando desde 2009 e, sobretudo, 2011, como pode ser observado em relação a outros indicadores tais como o número de docentes da USP, que diminuiu em termos absolutos entre 2011 e 2012, o número absoluto de vagas, que caiu no mesmo período, e o número de alunos de pós-graduação por docente, que aumentou a partir de 2010. Ou seja, é possível supor que a década de 2010 constitua um novo período na USP, com professores mais produtivos, com uma carga horária de aulas maior e, consequentemente, menos tempo para a pesquisa. A recente suspensão de futuras contratações docentes em função da crise orçamentária da universidade reforça essa hipótese. 


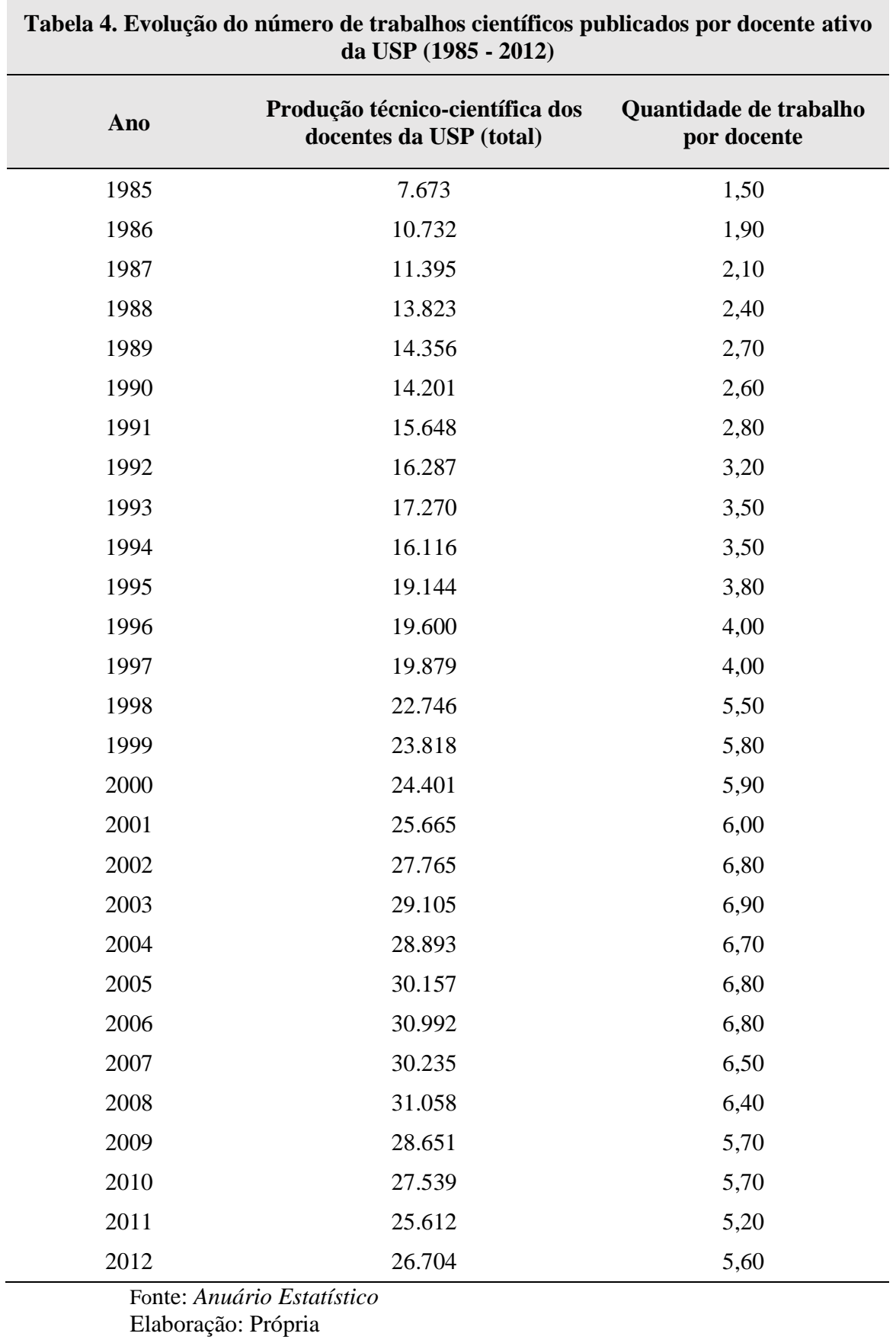

A análise de outros indicadores de produção científica reforça a ideia de que houve um aumento progressivo do volume de atividades desenvolvidas pelos docentes da USP, pelo menos desde o final da década de 1980. Por exemplo, a participação dos docentes da USP em comissões julgadoras - leia-se, bancas de qualificação, defesa de mestrado, doutorado, livredocência e titularidade e concursos em geral -, realizadas dentro da USP, cresceu de modo 
contínuo desde o final dos anos 1980, passando de 7.116 participações em 1989 para 71.451 em 2012. O número de participações em comissões julgadoras homólogas realizadas fora da USP também cresceu, embora em ritmo menor, passando de 2.617 participações em 1989 para 6.662 em 2006, quando o dado parou de ser publicado no Anuário. A participação dos docentes da USP em eventos científicos realizados no Brasil também aumentou, passando de 14.473 em 1989 para 25.631 participações em 2004, enquanto a participação em eventos internacionais aumentou de 2.484 para 4.255 no mesmo período. Consequentemente, o número de trabalhos científicos publicados em anais de congressos e eventos científicos também subiu, passando de 6.161 em 1989 para 14.529 trabalhos em 2008. É possível supor que o aumento da atividade de ensino e pesquisa dos docentes da USP é o que explica a redução das atividades de cultura e extensão desenvolvidas pelos professores da USP nos últimos anos. Considerando todo o período, o Anuário registra 1.883 cursos de cultura e extensão em 1989, atingindo um pico de 5.713 cursos em 1993, caindo desde então até chegar a 993 cursos oferecidos em $2012^{181}$.

Em síntese, mesmo com a redução das atividades de cultura e extensão, provável resultado do volume de trabalho ligado à docência e à pesquisa, é inegável que a USP expandiu significativamente suas atividades ao longo dos últimos anos em diversos âmbitos, tais como o número total de alunos, o número de cursos de graduação e pós-graduação oferecidos, o número de unidades, o número de publicações e de participações em eventos científicos e bancas julgadoras por docente, entre outros indicadores. Mesmo que isso tenha representado uma diminuição das atividades de cultura e extensão, é bastante plausível supor que esse processo, porque não foi acompanhado por um crescimento homólogo do número de docentes da USP, representou um aumento de produtividade da universidade e, consequentemente, um crescimento do volume de trabalho dos seus docentes. Isso sugere que a evolução da USP nos últimos anos pode se aproximar daquela verificada em outros contextos nacionais e

\footnotetext{
181 Todos esses dados estão disponíveis na série histórica do Anuário Estatístico (1987 - 2013).
} 
institucionais, em que o avanço de uma cultura gerencial - com seus requisitos de avaliação, eficiência e produtividade - teve impactos importantes sobre o trabalho acadêmico, no sentido de uma corrosão das condições de desenvolvimento das diferentes atividades universitárias, antes controladas de modo mais direto pelos próprios professores (cf. Dill \& Sporn, 1995; Gornitzka, Svein \& Larsen, 1998; Hackett, 1990; Ingersoll, 2003; Krucken, Kosmützky \& Totka, 2007; Musselin, 2007; Neave, 1988; Rhoades, 1996, 1998).

Por outro lado, esse mesmo processo pode ser visto do ponto de vista da democratização quantitativa do ensino superior, amplamente observada e descrita em nível nacional e internacional, em termos da expansão absoluta do número de vagas e da relativa inclusão de novos setores sociais no ensino superior de praticamente todas as regiões e países do mundo (cf. Arum, Gamoran \& Shavit, 2007; Bourdieu, 1984, 1989; Dubet, Duru-Bellat \& Vérétout, 2012; Euriat \& Thélot, 1995; Gall \& Soulié, 2007; Garcia \& Poupeau, 2003; Merle, 1996).

No entanto, para além de descrever o processo de expansão do ensino superior em termos gerais, é igualmente importante analisar a forma específica como essa expansão se manifesta nas diferentes unidades e carreiras profissionais. Em suma: o processo diferencial de crescimento universitário, que define o grau de procura e de permeabilidade social dos diferentes cursos, é causa e consequência do valor diferencial dos diplomas superiores, que constitui um dos fatores essenciais das desigualdades do ensino superior. Considerando que a democratização qualitativa, "que designa unicamente o prolongamento da duração dos estudos", não implica uma democratização quantitativa, "que descreve o enfraquecimento da relação entre diploma e origem social” (Garcia \& Poupeau, 2003, p. 75), um conjunto de estudos de sociologia da educação tem mostrado que a recente expansão do ensino superior, não vem reduzindo as desigualdades no interior desse nível de ensino mas, ao contrário, em certos casos, tem promovido o seu aumento (cf. Arum, Gamoran \& Shavit, 2007; Bourdieu, 
1984, 1989; Dubet, Duru-Bellat \& Vérétout, 2012; Euriat \& Thélot, 1995; Gall \& Soulié, 2007;

Garcia \& Poupeau, 2003; Merle, 1996).

Assim, se antes eram os ensinos primário e médio que funcionavam como os principais espaços de diferenciação escolar e social, essa função foi internalizada pelo ensino superior, a partir da sua intensa expansão, sobretudo porque a chegada de novas camadas sociais ao ensino superior foi acompanhada pelo relativo fechamento dos setores mais elitizados desse sistema a jovens de origem social mais baixa reforçando as desigualdades internas (cf. Garcia \& Poupeau, 2003, p. 76). Em suma, a democratização quantitativa do ensino superior, pela ampliação do número absoluto e percentual de vagas e alunos, não implicou a sua democratização qualitativa. Ao contrário, o que se observou, em muitos casos, foi o aumento das desigualdades internas a esse nível de ensino, o que se expressa de modo paradigmático nas chamadas "escolas de elite", que se tornaram, em geral, ainda mais fechadas a setores sociais menos privilegiados, mantendo com isso a sua função histórica de preparação de uma elite dirigente, em geral selecionada entre setores sociais privilegiados, em um processo social em que a escola contribui para reproduzir as estruturas sociais de dominação, constituindo-se como uma força social essencialmente conservadora.

Empiricamente, um dos primeiros trabalhos a descrever esse efeito paradoxal da abertura do ensino superior a novas camadas sociais e que constitui a grande referência do presente trabalho foi o estudo de Pierre Bourdieu sobre as grandes escolas francesas (cf. Bourdieu, 1989). Ao observar a expansão do sistema de ensino superior francês a partir de 1960, sua conclusão essencial foi que:

As [suas] oposições principais foram mantidas entre os anos 1960 e 1980, a despeito do sobressalto de 1968 que, longe de revolucionar as estruturas do campo das instituições de ensino superior, parecem ter favorecido reações individuais e coletivas que tenderam a reforçá-las. É possível observar, no entanto, um conjunto de deformações do campo que é preciso interpretar com prudência. As escolas que se encontravam, e se encontram ainda, localizadas no topo da hierarquia propriamente social, viram crescer ainda mais a parcela dos seus alunos que saem das regióes dominantes do espaço social, o que implicou, como efeito, o aumento da distância que separa as pequenas escolas das universidades. [...] tudo tende a sugerir que a distância cresceu fortemente, do ponto de vista da relação entre capital herdado e valor 
social dos títulos, entre as escolas de grande e pequeno porte ou, mais precisamente, entre as escolas de poder como a ENA, a Science-po, a HEC e a Essec, e as faculdades de letras, ciências e também de direito, cujo recrutamento não para de se rebaixar ao mesmo tempo em que elas se feminizam (Bourdieu, 1989, p. 272, grifo meu).

Essa constatação empírica foi confirmada por Michel Euriat e Claude Thélot no seu estudo sobre o topo do sistema escolar francês, no qual mostraram que, ao contrário do que ocorreu com o conjunto do sistema de ensino superior, as "escolas prestigiosas" pouco se abriram para novos alunos e camadas sociais (cf. 1995, p. 412). No mesmo sentido, Pierre Merle (1996) demonstrou que a expansão do ensino superior implicou um aumento das suas segregações internas, o que só pode ser apreendido por uma análise do seu desenvolvimento diferencial que, em síntese, procura descrever como a expansão desse nível de ensino se deu de modo essencialmente diferente segundo as carreiras e instituições, o que levou o autor a concluir, de novo, que a abertura do ensino superior a novas camadas sociais correspondeu a um fechamento relativo do topo do sistema escolar e, consequentemente, a um aumento das suas desigualdades internas (cf. Merle, 1996).

Essas análises, que nada mais são do que desdobramentos da teoria da reprodução (cf. Bourdieu \& Passeron, 1970), foram desenvolvidas sobretudo com base no caso francês. Como bem apontam François Dubet, Marie Duru-Bellat e Antoine Vérétout (2012), a tese de que "a escola reproduz as desigualdades sociais por ser mais favorável aos alunos social e culturalmente privilegiados [...] é demasiado geral para explicar as grandes variações na amplitude dessa reprodução" (2012, p. 22).

Partindo, portanto, de uma ampla pesquisa comparativa internacional, os autores conseguiram mostrar que a reprodução social produzida pela escola, que traduz desigualdades sociais em desigualdades escolares legitimadas como "meritocráticas", varia, basicamente, i) segundo a organização interna dos sistemas escolares e ii) o papel social atribuído aos diplomas escolares na estrutura ocupacional. Quanto à organização interna do sistema escolar, os autores demonstram que, quanto maior for a sua segregação escolar, maior a força dos mecanismos de 
reprodução social no seu interior. Como os autores mostram, a segregação escolar é mais forte nos sistemas escolares nacionais marcados por amplas desigualdades internas, pelo peso do sistema privado e pela primazia da livre escolha das famílias pela escola dos filhos (cf. 2012, p. 42). Quanto à influência social dos diplomas, por sua vez, os autores concluem que quanto maior o peso social e econômico dos diplomas escolares maior será a concorrência escolar e, consequentemente, maior a probabilidade das camadas mais favorecidas hegemonizarem o topo da hierarquia do sistema escolar. Assim, em suma, quanto maior a rentabilidade social dos diplomas no mercado de trabalho mais intensa a concorrência por eles, maior a hierarquização dos títulos e, consequentemente, mais intensa será a tradução das desigualdades sociais em desigualdades escolares e vice-versa (cf. 2012, p. 45ss).

O estudo comparativo de Dubet, Duru-Bellat e Vérétout (2012) permite sugerir, portanto, que a tese da reprodução, que aponta para o fato de que a expansão do ensino superior foi acompanhada pela manutenção ou mesmo aumento das suas desigualdades internas, é ainda mais válida para o caso brasileiro do que para o caso francês. Isso porque, no que concerne à organização do sistema brasileiro de ensino, não há dúvidas de que ele seja socialmente segregado em todos os níveis, de modo que as desigualdades sociais se traduzem diretamente em desigualdades escolares, processo reforçado pelo peso cada vez maior do sistema privado e pela "livre" escolha das famílias pelas instituições, inclusive superiores (cf. Castro, 2009). Essa hipótese foi confirmada recentemente por Carlos Costa Ribeiro que demonstrou que, no Brasil, “tanto recursos e características dos pais dos indivíduos quanto características institucionais determinam fortemente as desigualdades de oportunidades e o desempenho educacional" (2011, p. 78). No que concerne ao peso social dos diplomas, particularmente dos diplomas de ensino superior, é bastante consensual que, no Brasil, "a educação [superior] tem um peso decisivo na renda" do trabalho (Lima \& Abdal, 2007, p. 233). O ganho salarial associado à posse do diploma de ensino superior é o que justifica, inclusive, as altas taxas de retorno à escola, 
observada entre os trabalhadores brasileiros, sobretudo a partir dos anos 1990 (cf. Comin \& Barbosa, 2011).

Assim, o estudo da forte relação entre a expansão do ensino superior e o fortalecimento da sua estratificação interna, tanto no caso da França como de outros países, apontou para a estreita relação existente entre o aumento das desigualdades inerentes ao sistema ao longo dos últimos anos e sua diversificação interna. Nesse sentido, ao comparar a estratificação do ensino superior em quinze países, Richard Arum, Adam Gamoran e Yossit Shavit mostram que, pelo menos nos países economicamente avançados, "a expansão foi acompanhada de diferenciação" (2007, p. 1). Mesmo reconhecendo que a inclusão social tem tido efeitos democratizantes, os autores não deixam de concordar com os estudos (cf. Mare, 1981; Raftery \& Hout, 1993; Shavit \& Blossfeld, 1993) que defendem que "ao mesmo tempo em que membros das classes trabalhadoras encontram novas oportunidades de se matricularem no ensino superior, o sistema foi se diferenciando hierarquicamente de modo que essas novas oportunidades talvez tenham tido seu valor reduzido" (2007, p. 1).

A relação entre expansão e diferenciação interna do ensino superior também foi trabalhada recentemente por Brice Le Gall e Charle Soulié (2007) que, analisando o caso da França, mostraram como a recente massificação do ensino através da abertura de novas carreiras, instituições e cursos, especialmente no campo da economia e da gestão, atualiza o “conflito das faculdades", pensado, em suma, como a oposição entre o polo profissional, formado por carreiras social e economicamente valorizadas, ainda que de modo diferenciado, e o polo científico-acadêmico, baseado nas disciplinas científicas institucionalizadas que têm sido sistematicamente enfraquecidas pelo processo de massificação e diversificação em curso (cf. Gall \& Soulié, 2007). A grande contribuição do trabalho de Gall e Soulié foi pensar o processo de expansão/ diversificação à luz dos seus efeitos sobre os conflitos internos ao sistema de ensino superior, entre instituições, carreiras e cursos, que podem ser pensados como a 
contraposição entre seus dois polos essenciais. Os autores procuram mostrar como o novo fortalecimento do polo profissional está associado à crise da profissão acadêmica, com a deterioração das condições de trabalho docente e o enfraquecimento dos mecanismos de gestão colegiada (cf. 2007, p. 190ss), e ao crescimento do "espírito gestionário" que tem redefinido as condições de legitimação do exercício do poder no interior das instituições de ensino superior (cf. 2007, p.195-6).

Em síntese, esse conjunto de trabalhos sugere uma linha de interpretação para a expansão do sistema de ensino superior brasileiro em geral, e da Universidade de São Paulo, em particular, que permite supor, no caso da USP, que a expansão foi acompanhada de diferenciação interna, um processo que atualizou as hierarquias internas já existentes, produzindo efeitos importantes sobre a reprodução das elites que passam pelo topo do sistema de ensino superior paulista, representado, neste estudo, pela USP. Para analisar essa transformação, comecemos analisando o processo de diversificação interna da USP.

\subsection{A diversificação interna da USP (1960 - 2012)}

O processo de expansão da USP a partir de 1960, apresentado nas suas linhas gerais no subitem anterior, quando visto em conjunto, oculta não só uma série de diferenças internas na forma como as unidades da USP experimentaram as mudanças descritas, como uma inflexão no padrão dessa expansão a partir de 1970, quando o crescimento veio acompanhado por intenso processo de diversificação interna.

Esse processo não foi exclusivo da USP. No Brasil pós década de 1970, a expansão do ensino superior esteve diretamente associada à sua diversificação interna (cf. Ribeiro, 2002; Sampaio, 1998), em grande medida porque, como visto no capítulo anterior, a reforma universitária de 1968, ao partir de uma concepção econômica da educação para enfatizar a sua dimensão utilitária como fator de desenvolvimento, legitimou as tentativas de aproximar o 
ensino superior das demandas de mercado, particularmente voltadas para a formação de profissionais cada vez mais especializados. Esse processo resultou, em suma, na criação de novos cursos, de caráter profissionalizante, que passaram a catalisar a expansão do ensino superior brasileiro a partir da década de 1970. Considerado em perspectiva histórica, esse processo representou uma inflexão do padrão de expansão desse nível de ensino que, até 1968, esteve associado ao crescimento dos cursos pedagógicos e científicos concentrados nas Faculdades de Filosofia, Ciências e Letras, consideradas, pela Lei de Diretrizes e Bases de 1961, instituições obrigatórias em toda a estrutura universitária. A partir da década de 1970, no entanto, a expansão do ensino superior passou a depender cada vez mais da abertura de vagas em novos cursos e carreiras, marcados pela formação especializada e pelo caráter mais técnico dos seus currículos.

Nesse sentido, partindo dos dados estatísticos do MEC, é possível notar que o sistema brasileiro de ensino superior se expandiu significativamente nos anos 1960. Crescendo a uma taxa anual de 27,2\% ao longo da década, o número de alunos matriculados nesse nível de ensino passou de 93.202 em 1960 para 346.824 em 1969 (cf. MEC, 1972, p. 98). Em 1973, o número de matrículas de ensino superior chegou a 772.800 em todo o país, o que demonstra a continuidade do processo de expansão, para além da reforma universitária de 1968 (cf. MEC, 1974, p. 129) ${ }^{182}$. A manutenção do ritmo de crescimento do ensino superior brasileiro entre os anos 1960 e 1970 foi acompanhada, no entanto, por uma mudança significativa no padrão dessa expansão, sobretudo a partir de 1969.

Assim, ao longo da década de 1960, embora o crescimento do número de cursos, matrículas e vagas tenha ocorrido em praticamente todas as áreas, foi sobretudo nas áreas de filosofia, ciências e letras que essa expansão se deu de modo mais acelerado. Enquanto o número de matrículas nos cursos de direito, engenharia e medicina cresceu respectivamente

\footnotetext{
${ }^{182}$ Como bem aponta Florestan Fernandes, isso em nada alterou o caráter fundamentalmente restrito do ensino superior nos anos 1960 (cf. Fernandes, 1975, p. 33ss).
} 
$15,98 \%, 14,04 \%$ e $16,87 \%$ ao ano entre 1960 e 1969, nos cursos de filosofia, ciências e letras esse crescimento chegou a 39,46\% ao ano no mesmo período (MEC, 1972, p. 98) ${ }^{183}$. A partir do começo da década de 1970, no entanto, é possível notar que, ao lado dos cursos já existentes no ensino superior, sejam eles ligados às profissões liberais ou às carreiras acadêmicas e científicas antes concentradas nas FFCLs, surgiram uma série de novos cursos, tais como administração em comércio exterior, relações internacionais, engenharia mecânica de automóveis, engenharia de telecomunicações, zootecnia, ciência da computação, análise de sistemas, entre outros (cf. MEC, 1974, p. 123ss). Além dessas novas formações, também passaram a crescer em ritmo mais acelerado outras carreiras profissionais que, embora já existissem na década de 1960, ofereciam formações menos valorizadas socialmente, sobretudo quando comparadas às profissões liberais tradicionais, tais como, por exemplo, enfermagem, fonoaudiologia, nutrição, fisioterapia, engenharia operacional, engenharia de alimentos, agrimensura, biblioteconomia, ciências atuariais, contabilidade, comunicação social, economia doméstica, desenho industrial e turismo (cf. MEC, 1974, p. 123ss). A expansão desses cursos novos ou menos valorizados consolidou uma tendência, já visível desde a segunda metade dos anos 1960, de expansão do ensino superior ligado a carreiras profissionais não tradicionais. Essa tendência refletiu-se, inclusive, no padrão de mensuração estatística do MEC que, até 1971, concentrava os cursos de graduação do país em apenas quatorze categorias, quais sejam:

1. Administração e economia;

2. Agricultura;

3. Arquitetura e Urbanismo;

4. Artísticos;

5. Direito;

6. Enfermagem;

7. Engenharia;

8. Farmácia;

\footnotetext{
183 O processo de expansão dos cursos de filosofia, ciências e letras ao longo dos anos 1960 não é exclusivo do Brasil. Ao observar o padrão de expansão do ensino superior na França ao longo desse período, Bourdieu também observa que o crescimento desses cursos foi mais acelerado do que a expansão das profissões tradicionais, sobretudo daquelas concentradas nas chamadas escolas de elite (cf. Bourdieu, 1984 e 1989). No mesmo sentido, Gall e Soulié apontam para a inflexão do processo de expansão do ensino superior francês a partir de 1980, quando a expansão via cursos de ciências e humanidades concentrados em Paris cede lugar a uma expansão de cursos profissionais novos sediados sobretudo no interior da França (cf. 2007, p. 176ss).
} 
9. Filosofia, Ciências e Letras;

10. Medicina;

11. Medicina Veterinária;

12. Odontologia;

13. Serviço Social;

14. Outros

(cf. MEC, 1972, p. 89ss).

Em 1972, essas categorias já haviam sido desdobradas em mais de 170 novas designações de cursos, com diferentes especificações e modalidades (cf. MEC, 1974, p. 123ss). Acompanhando, ao longo dos anos 1960, o crescimento da categoria "outros", usada então para identificar os cursos novos ou menos tradicionais, é possível notar que, até 1966, esses cursos cresciam a uma taxa anual de $18,94 \%$, ou seja, na média dos outros cursos profissionais mas abaixo dos cursos de filosofia, ciências e letras. No entanto, entre 1966 e 1971, ano em que a categoria foi abandonada pelo MEC, desdobrando-se em dezenas de novas especialidades, o número de matrículas nesses cursos passou de 5.879 para 22.031 , um crescimento de $27,47 \%$ ao ano. Só entre 1969 e 1971, esses cursos cresceram quase 100\%, passando de 11.324 matrículas em 1969 para 22.031 em 1971.

A Universidade de São Paulo, que sediava a maior e mais importante Faculdade de Filosofia, Ciências e Letras do país nos anos 1960, foi um exemplo paradigmático da alteração do padrão de expansão do ensino superior a partir da reforma universitária, quando o crescimento baseado nos cursos de formação pedagógica e científica foi substituído por uma expansão ligada às novas carreiras e profissões. Nesse sentido, considerando a expansão das vagas de primeiro ano da FFCL-USP ao longo da década de 1960, é possível notar que elas passaram de 735 vagas anuais em 1960 para 2.800 vagas anuais em 1969, um crescimento de $280 \%$, três vezes maior do que o verificado no resto da USP, onde o total de vagas subiu de 1.599 para 2.904 no mesmo período, acumulando um aumento de 80\% (cf. Antunha, 1971, p. 153-4). A expansão do número de vagas da FFCL-USP refletiu-se diretamente no número de alunos matriculados na unidade que, no mesmo período, passou de 2.973 para 7.764 . Esse crescimento contínuo fez com que, em 1969, ano da fragmentação da FFCL-USP, 
aproximadamente $40 \%$ dos alunos da universidade estivessem matriculados nessa unidade, o que justificava os que a consideravam uma universidade dentro da universidade (cf. Fétizon, 1986). No entanto, a FFCL não era apenas a maior unidade da USP na década de 1960. Ela era, também, a unidade mais aberta a novos setores sociais por concentrar não só o alunado feminino da USP, como também as suas vagas de período noturno, voltadas em geral aos estudantes oriundos de setores sociais menos favorecidos (cf. Antunha, 1971, p. 155-157). É por tudo isso que, ao descrever o processo de expansão do ensino superior nos anos 1960, Heládio Antunha conclui que:

\begin{abstract}
Algumas escolas foram particularmente atingidas pelo impacto da massificação: é o caso típico da Faculdade de Filosofia, Ciências e Letras [da USP], nos últimos anos de sua existência. De um início quantitativamente modesto, a ponto de ser necessário o emprego de estímulos aos alunos (bolsas de estudo e comissionamento de professores primários), ela terminou por se transformar na maior instituição da Universidade e na maior escola de ensino superior do país (1971, p. 152).
\end{abstract}

Em consonância com as mudanças que impactaram todo o sistema de ensino superior nacional, sobretudo a partir da reforma de 1968, o padrão de expansão da USP também se alterou na década de 1970, quando a universidade passou a crescer principalmente pela criação de novas unidades e cursos, particularmente os de caráter técnico ou profissionalizante. No mesmo período, o núcleo dinâmico da expansão da USP se deslocou da capital para o interior do estado de São Paulo, o que contribuiu para preservar o caráter altamente seletivo dos cursos mais tradicionais da universidade, sediados na cidade de São Paulo, ao mesmo tempo em que fortaleceu as unidades profissionais sediadas no interior, na estrutura de poder da USP.

A tabela abaixo sistematiza o conjunto das unidades da USP hierarquizadas pelo ano de fundação, incorporação ou desmembramento, o que permite visualizar, cronologicamente, o processo de expansão da USP, através da criação de suas unidades que, na tabela, estão acompanhadas de algumas informações essenciais como nome, sigla, cidade sede, cursos de graduação oferecidos e ano de fundação, incorporação e desmembramento, este último para o 
caso de unidades que foram fundadas a partir de processos de divisão ou fragmentação de instituições preexistentes.

Tabela 5. Relação de unidades de ensino e pesquisa da USP segundo o ano de fundação, incorporação ou desmembramento e com informações sobre a localização e os principais cursos de graduação oferecidos em 2012

Unidades

Sigla

Cidade

Cursos de graduação

Ano de

fundação
Ano de incorporação

à USP ou

desmembramento

1 Faculdade de Direito

FD

São Paulo

Direito

1827

1934

Escola Politécnica

EP/ POLI

São Paulo

Engenharia

1893

1934

\begin{tabular}{|c|c|c|c|c|c|c|}
\hline 3 & $\begin{array}{l}\text { Faculdade de } \\
\text { Ciências } \\
\text { Farmacêuticas }\end{array}$ & FCF & São Paulo & Farmácia e bioquímica & 1898 & 1934 \\
\hline 4 & $\begin{array}{l}\text { Faculdade de } \\
\text { Odontologia }\end{array}$ & FO & São Paulo & Odontologia & 1898 & 1934 \\
\hline 5 & $\begin{array}{c}\text { Escola Superior de } \\
\text { Agronomia Luiz de } \\
\text { Queiróz }\end{array}$ & ESALQ & Piracicaba & $\begin{array}{l}\text { Ciências biológicas, } \\
\text { engenharia de alimentos, } \\
\text { ciências econômicas, } \\
\text { engenharia agrônoma, } \\
\text { engenharia florestal, } \\
\text { gestão ambiental e } \\
\text { licenciatura em ciências } \\
\text { agrária } \\
\end{array}$ & 1901 & 1934 \\
\hline 6 & $\begin{array}{l}\text { Faculdade de } \\
\text { Medicina }\end{array}$ & FM & São Paulo & $\begin{array}{c}\text { Fisioterapia, } \\
\text { fonoaudiologia, medicina } \\
\text { e terapia educacional }\end{array}$ & 1912 & 1934 \\
\hline 7 & $\begin{array}{l}\text { Faculdade de } \\
\text { Medicina } \\
\text { Veterinária e } \\
\text { Zootecnia }\end{array}$ & FMVZ & São Paulo & Medicina veterinária & 1919 & 1934 \\
\hline 8 & $\begin{array}{c}\text { Faculdade de Saúde } \\
\text { Pública }\end{array}$ & FSP & São Paulo & Nutrição e saúde pública & 1922 & 1934 \\
\hline
\end{tabular}


Tabela 5. Relação de unidades de ensino e pesquisa da USP segundo o ano de fundação, incorporação ou desmembramento e com informações sobre a localização e os principais cursos de graduação oferecidos em 2012 (continuação)

\begin{tabular}{|c|c|c|c|c|c|c|}
\hline & Unidades & Sigla & Cidade & Cursos de graduação & $\begin{array}{c}\text { Ano de } \\
\text { fundação }\end{array}$ & $\begin{array}{c}\text { Ano de incorporação } \\
\text { à USP ou } \\
\text { desmembramento }\end{array}$ \\
\hline 9 & $\begin{array}{l}\text { Instituto de } \\
\text { Astronomia, } \\
\text { Geofísica e Ciências } \\
\text { Atmosféricas }\end{array}$ & IAG & São Paulo & $\begin{array}{c}\text { Astronomia, bacharelado } \\
\text { em geofísica e } \\
\text { meteorologia }\end{array}$ & 1927 & 1946 \\
\hline 10 & $\begin{array}{l}\text { Faculdade de } \\
\text { Economia, } \\
\text { Administração e } \\
\text { Contabilidade }\end{array}$ & FEA & São Paulo & $\begin{array}{l}\text { Administração, ciências } \\
\text { contábeis, ciências } \\
\text { econômicas, economia } \\
\text { empresarial e } \\
\text { controladoria }\end{array}$ & 1946 & 1946 \\
\hline
\end{tabular}

Escola de

11 Engenharia de São Carlos

EESC São Carlos

Engenharia aeronáutica, engenharia ambiental, engenharia civil, engenharia de materiais e manufatura, engenharia

de mecânica e de

produção mecânica e

engenharia elétrica

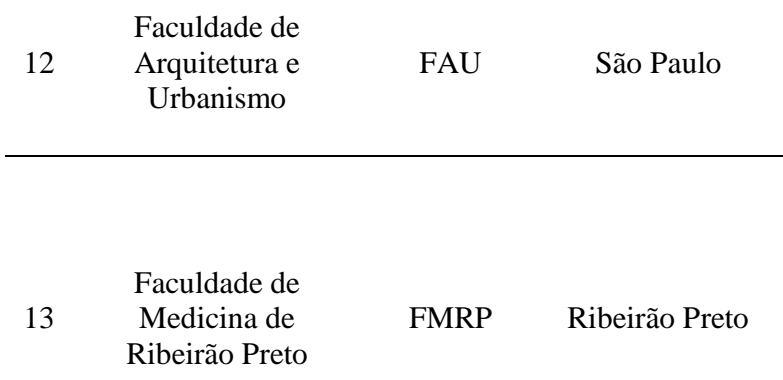

Arquitetura, urbanismo e design

Ciências biológicas, ciências médicas, fisioterapia, fonoaudiologia,

icina, terapia ocupacional e nutrição metabolismo

\begin{tabular}{|c|c|c|c|c|c|c|}
\hline 14 & $\begin{array}{c}\text { Faculdade de } \\
\text { Odontologia de } \\
\text { Bauru }\end{array}$ & FOB & Bauru & $\begin{array}{l}\text { Odontologia e } \\
\text { fonoaudiologia }\end{array}$ & 1948 & 1948 \\
\hline 15 & $\begin{array}{c}\text { Instituto } \\
\text { Oceanográfico }\end{array}$ & IO & São Paulo & Oceanografia & 1946 & 1951 \\
\hline 16 & $\begin{array}{c}\text { Escola de } \\
\text { Enfermagem }\end{array}$ & $\mathrm{EE}$ & São Paulo & $\begin{array}{l}\text { Bacharelado e } \\
\text { licenciatura em } \\
\text { enfermagem }\end{array}$ & 1942 & 1963 \\
\hline 17 & $\begin{array}{c}\text { Escola de } \\
\text { Enfermagem de } \\
\text { Ribeirão Preto }\end{array}$ & EERP & Ribeirão Preto & $\begin{array}{l}\text { Bacharelado e } \\
\text { licenciatura em } \\
\text { enfermagem }\end{array}$ & 1951 & 1964 \\
\hline
\end{tabular}


Tabela 5. Relação de unidades de ensino e pesquisa da USP segundo o ano de fundação, incorporação ou desmembramento e com informações sobre a localização e os principais cursos de graduação oferecidos em 2012 (continuação)

Unidades Sigla Cidade Cursos de graduação $\begin{gathered}\text { Ano de } \\ \text { fundação }\end{gathered} \begin{gathered}\text { Ano de incorporação } \\ \text { à USP ou } \\ \text { desmembramento }\end{gathered}$

\begin{tabular}{|c|c|c|c|c|c|c|}
\hline 18 & $\begin{array}{c}\text { Escola de } \\
\text { Comunicação e } \\
\text { Artes }\end{array}$ & ECA & São Paulo & $\begin{array}{l}\text { Artes cênicas, artes } \\
\text { plásticas, artes visuais, } \\
\text { biblioteconomia, } \\
\text { comunicação social, } \\
\text { curso superior de } \\
\text { audiovisual, educação } \\
\text { artística, } \\
\text { educomunicação, }\end{array}$ & 1966 & 1966 \\
\hline
\end{tabular}

19 Escola de Educação

Física e Esportes

EEFE

São Paulo

Esportes e educação

física

1931

1969

\begin{tabular}{cc}
\hline $20 \quad \begin{array}{c}\text { Faculdade de } \\
\text { Educação }\end{array}$ \\
\hline$\quad \begin{array}{c}\text { Faculdade de } \\
\text { Filosofia, Letras e }\end{array}$
\end{tabular}

21 Filosofia, Letras e

Ciências Humanas

FE

São Paulo

Pedagogia

1933

1969

FFLCH

São Paulo

filosofia, geografia,

história e letras

1934*

1969

(diferentes habilitações)

22 Instituto de Física

IF

São Paulo

Física

1934*

1969

$23 \quad \begin{aligned} & \text { Instituto de } \\ & \text { Geociências }\end{aligned}$

IG

São Paulo

Geologia e licenciatura

em geociências e

educação ambiental

1934*

1969

Ciência da computação, estatística, matemática

Instituto de

24 Matemática e

IME

(licenciatura e

bacharelado) e

1934*

1969

Estatística

matemática aplicada e

computacional. 
Tabela 5. Relação de unidades de ensino e pesquisa da USP segundo o ano de fundação, incorporação ou desmembramento e com informações sobre a localização e os principais cursos de graduação oferecidos em 2012 (continuação)

\begin{tabular}{|c|c|c|c|c|c|}
\hline Unidades & Sigla & Cidade & Cursos de graduação & $\begin{array}{c}\text { Ano de } \\
\text { fundação }\end{array}$ & $\begin{array}{l}\text { Ano de incorporação } \\
\text { à USP ou } \\
\text { desmembramento }\end{array}$ \\
\hline
\end{tabular}

26 Instituto de Química

IQ São Paulo licenciatura em química

Química ambiental, e química

e

\begin{tabular}{|c|c|c|c|c|c|c|}
\hline 27 & $\begin{array}{l}\text { Instituto de } \\
\text { Biociências }\end{array}$ & IB & São Paulo & Ciências biológicas & $1934 *$ & 1969 \\
\hline 28 & $\begin{array}{c}\text { Instituto de Ciências } \\
\text { Biomédicas }\end{array}$ & ICB & São Paulo & $\begin{array}{c}\text { Bacharelado em ciências } \\
\text { biomédicas e ciências } \\
\text { fundamentais para a } \\
\text { saúde }\end{array}$ & 1969 & 1969 \\
\hline 29 & $\begin{array}{c}\text { Instituto de } \\
\text { Matemática e } \\
\text { Computação de São } \\
\text { Carlos }\end{array}$ & ICMC & São Carlos & $\begin{array}{c}\text { Ciência da computação, } \\
\text { estatística, informática, } \\
\text { matemática aplica e } \\
\text { computação científica e } \\
\text { matemática }\end{array}$ & 1971 & 1971 \\
\hline 30 & $\begin{array}{c}\text { Faculdade de } \\
\text { Filosofia, Ciências e } \\
\text { Letras de Ribeirão } \\
\text { Preto }\end{array}$ & FFCLRP & Ribeirão Preto & $\begin{array}{l}\text { Bacharelado em ciência } \\
\text { da informação e da } \\
\text { documentação, física } \\
\text { médica, ciências } \\
\text { biológicas, licenciatura } \\
\text { em química, música, } \\
\text { pedagogia, psicologia e } \\
\text { química }\end{array}$ & 1959 & 1974 \\
\hline 31 & $\begin{array}{l}\text { Faculdade de } \\
\text { Ciências } \\
\text { Farmacêuticas de } \\
\text { Ribeirão Preto }\end{array}$ & FCFRP & Ribeirão Preto & Farmácia e bioquímica & 1924 & 1975 \\
\hline 32 & $\begin{array}{l}\text { Faculdade de } \\
\text { Odontologia de } \\
\text { Ribeirão Preto }\end{array}$ & FORP & Ribeirão Preto & Odontologia & 1924 & 1983 \\
\hline 33 & $\begin{array}{l}\text { Faculdade de } \\
\text { Zootecnia } \\
\text { Engenharia de } \\
\text { Alimentos }\end{array}$ & FZEA & Pirassununga & $\begin{array}{c}\text { Engenharia de alimentos, } \\
\text { engenharia de } \\
\text { biossistemas, medicina } \\
\text { veterinária e zootecnia }\end{array}$ & 1992 & 1992 \\
\hline 34 & $\begin{array}{l}\text { Instituto de Física de } \\
\text { São Carlos }\end{array}$ & IFSC & São Carlos & $\begin{array}{l}\text { Ciências físicas e } \\
\text { moleculares, física e } \\
\text { física computacional }\end{array}$ & 1971 & 1994 \\
\hline
\end{tabular}


Tabela 5. Relação de unidades de ensino e pesquisa da USP segundo o ano de fundação, incorporação ou desmembramento e com informações sobre a localização e os principais cursos de graduação oferecidos em 2012 (continuação)

\begin{tabular}{|c|c|c|c|c|c|c|}
\hline & Unidades & Sigla & Cidade & Cursos de graduação & $\begin{array}{c}\text { Ano de } \\
\text { fundação }\end{array}$ & $\begin{array}{c}\text { Ano de incorporação } \\
\text { à USP ou } \\
\text { desmembramento }\end{array}$ \\
\hline 35 & $\begin{array}{l}\text { Instituto de Química } \\
\text { de São Carlos }\end{array}$ & IQSC & São Carlos & Química & 1971 & 1994 \\
\hline 36 & $\begin{array}{l}\text { Faculdade de } \\
\text { Economia, } \\
\text { Administração e } \\
\text { contabilidade de } \\
\text { Ribeirão Preto }\end{array}$ & FEARP & Ribeirão Preto & $\begin{array}{c}\text { Administração, ciências } \\
\text { atuariais, ciências } \\
\text { contábeis, ciências } \\
\text { econômicas }\end{array}$ & 1992 & 2002 \\
\hline 37 & $\begin{array}{l}\text { Instituto de Relações } \\
\text { Internacionais }\end{array}$ & IRI & São Paulo & Relações internacionais & 2002 & 2002 \\
\hline
\end{tabular}

\begin{tabular}{|c|c|c|c|c|c|c|}
\hline 38 & $\begin{array}{c}\text { Escola de Artes, } \\
\text { Ciências e } \\
\text { Humanidades }\end{array}$ & $\mathrm{EACH}$ & São Paulo & $\begin{array}{l}\text { Ciências da atividade } \\
\text { física, gestão ambiental, } \\
\text { lazer e turismo, sistemas } \\
\text { da informação, têxtil e } \\
\text { moda, gerontologia, } \\
\text { gestão em políticas } \\
\text { públicas, licenciatura em } \\
\text { ciências da natureza, } \\
\text { marketing, obstetrícia }\end{array}$ & 2004 & 2004 \\
\hline 39 & $\begin{array}{c}\text { Escola de } \\
\text { Engenharia de } \\
\text { Lorena }\end{array}$ & EEL & Lorena & $\begin{array}{c}\text { Engenharia ambiental, } \\
\text { engenharia bioquímica, } \\
\text { engenharia de materiais, } \\
\text { engenharia de produção, } \\
\text { engenharia física, } \\
\text { engenharia industrial } \\
\text { química e engenharia } \\
\text { química }\end{array}$ & 1969 & 2006 \\
\hline 40 & $\begin{array}{l}\text { Escola de Educação } \\
\text { Física e Esportes de } \\
\text { Ribeirão Preto }\end{array}$ & EEFERP & Ribeirão Preto & Esporte e educação física & 2007 & 2007 \\
\hline 41 & $\begin{array}{l}\text { Faculdade de Direito } \\
\text { de Ribeirão Preto }\end{array}$ & FDRP & Ribeirão Preto & Direito & 2007 & 2007 \\
\hline 42 & $\begin{array}{l}\text { Instituto de } \\
\text { Arquitetura e } \\
\text { Urbanismo }\end{array}$ & IAU & São Carlos & Arquitetura e urbanismo & 2010 & 2010 \\
\hline
\end{tabular}

Fonte: Anuário Estatístico

Elaboração: Própria

*1934, data de fundação da FFCL que deu origem às diferentes unidades 
A principal função dessa tabela é explicitar que a fundação de unidades na USP se divide, grosso modo, em três grandes ciclos de expansão: I) as unidades criadas ou incorporadas até 1960, que são essencialmente unidades profissionais tradicionais sediadas sobretudo na capital do estado e marcadas pelo alto valor e prestígio social dos seus diplomas; II) as unidades criadas como feito direto da reforma universitária de 1968 que são, em síntese, unidades voltadas à formação científica e pedagógica que se originaram seja da fragmentação da FFCLUSP, seja da autonomização das disciplinas científicas das unidades tradicionais, como o caso do Instituto de Ciências Biomédicas (ICB) que agrupou as áreas básicas do curso de medicina; III) por fim, as unidades criadas a partir da década de 1970, que assumem um perfil, em geral, mais profissionalizante, concentrando-se no interior do estado de São Paulo ou, no caso de unidades sediadas em São Paulo, fora do campus central da cidade universitária, como no caso paradigmático da Escola de Artes, Ciências e Humanidades (EACH), fundada na zona leste da cidade $^{184}$

Assim, se é notável que a USP viveu um intenso processo de expansão a partir dos anos 1960 - das suas quarenta e duas unidades de ensino e pesquisa, vinte e sete foram fundadas depois de 1960 -, é igualmente significativo que, a partir dos anos 1970, essa expansão foi acompanhada pela dispersão da USP para fora do seu centro original - localizado na cidade de São Paulo e concentrado no ensino de profissões liberais, ciências e artes.

A diversificação da USP se torna ainda mais visível quando, além da fundação de novas unidades de ensino e pesquisa, considera-se também a criação de novos cursos e vagas que permitem descrever, justamente, o desenvolvimento diferencial da USP (cf. Merle, 1996). Assim, a tabela abaixo apresenta as unidades de ensino e pesquisa da USP em ordem alfabética,

${ }^{184}$ Para uma análise do processo de idealização e implementação da USP-leste, hoje denominada Escola de Artes, Ciências e Humanidades (EACH) ver Garcia \& Carlotto, 2012, 2013a e 2013b. 
com os seus respectivos cursos, incluindo os abertos e extintos a partir de $1982^{185}$. A tabela traz, ainda, informações sobre a evolução do número de vagas dos cursos e unidades da USP a partir dessa data ${ }^{186}$.

Tabela 6. Evolução dos cursos da USP por unidade de ensino e pesquisa, com indicação da progressão quinquenal do número de vagas e sua variação absoluta e percentual entre 1982 e $2010 *$

\begin{tabular}{|c|c|c|c|c|c|c|c|c|c|c|}
\hline EAC & (2004) & 1982 & 1985 & 1990 & 1995 & 2000 & 2005 & 2010 & $\begin{array}{c}\text { Variação } \\
\text { percentual } \\
\text { do } n^{\circ} \text { de }\end{array}$ & $\begin{array}{l}\text { Variação } \\
\text { absoluta } \\
\text { do } n^{\circ} \text { de }\end{array}$ \\
\hline 1 & Ciências da atividade física (2005) & $\neg$ & $\neg$ & $\neg$ & $\neg$ & $\neg$ & 60 & 60 & $\neg$ & 60 \\
\hline 2 & Gerontologia (2005) & $\neg$ & $\neg$ & $\neg$ & $\neg$ & $\neg$ & 60 & 60 & $\neg$ & 60 \\
\hline 3 & Gestão ambiental (2005) & $\neg$ & $\neg$ & $\neg$ & $\neg$ & $\neg$ & 120 & 120 & $\neg$ & 120 \\
\hline 4 & Gestão em política pública (2005) & $\neg$ & $\neg$ & $\neg$ & $\neg$ & $\neg$ & 120 & 120 & $\neg$ & 120 \\
\hline 5 & Lazer e turismo (2005) & $\neg$ & $\neg$ & $\neg$ & $\neg$ & $\neg$ & 120 & 120 & $\neg$ & 120 \\
\hline 6 & Licenciatura em ciências da natureza (2005) & $\neg$ & $\neg$ & $\neg$ & $\neg$ & $\neg$ & 120 & 120 & $\neg$ & 120 \\
\hline 7 & Marketing (2005) & $\neg$ & $\neg$ & $\neg$ & $\neg$ & $\neg$ & 120 & 120 & $\neg$ & 120 \\
\hline 8 & Obstetrícia 2005) & $\neg$ & $\neg$ & $\neg$ & $\neg$ & $\neg$ & 60 & 60 & $\neg$ & 60 \\
\hline 9 & Sistemas da informação (2005) & $\neg$ & $\neg$ & $\neg$ & $\neg$ & $\neg$ & 180 & 180 & $\neg$ & 180 \\
\hline 10 & Tecnologia têxtil e da indumentária (2005) & $\neg$ & $\neg$ & $\neg$ & $\neg$ & $\neg$ & 60 & 60 & $\neg$ & 60 \\
\hline & Total & $\neg$ & $\neg$ & $\neg$ & $\neg$ & $\neg$ & 1020 & 1020 & $\neg$ & 1020 \\
\hline
\end{tabular}

\begin{tabular}{|c|c|c|c|c|c|c|c|c|c|c|}
\hline \multicolumn{2}{|c|}{ ECA (1966) } & \multirow{2}{*}{$\begin{array}{c}1982 \\
\neg\end{array}$} & \multirow{2}{*}{$\begin{array}{c}1985 \\
\quad \neg\end{array}$} & \multirow{2}{*}{$\begin{array}{c}1990 \\
\\
\neg\end{array}$} & \multirow{2}{*}{$\begin{array}{c}1995 \\
\neg\end{array}$} & \multirow{2}{*}{$\begin{array}{c}2000 \\
15 \\
\end{array}$} & \multirow{2}{*}{$\begin{array}{r}2005 \\
\\
15\end{array}$} & \multirow{2}{*}{$\begin{array}{r}2010 \\
15\end{array}$} & \multirow{2}{*}{$\begin{array}{c}\text { Variação } \\
\text { percentual } \\
\text { do n }{ }^{\circ} \text { de } \\
\text { vagas* } \\
\neg\end{array}$} & \multirow{2}{*}{$\begin{array}{c}\text { Variação } \\
\text { absoluta } \\
\text { do } \mathbf{n}^{\circ} \text { de } \\
\text { vagas } \\
15\end{array}$} \\
\hline 1 & Artes cênicas - bacharelado (2000) & & & & & & & & & \\
\hline 2 & Artes plásticas (1996) & $\neg$ & $\neg$ & $\neg$ & $\neg$ & 30 & 30 & 30 & $\neg$ & 30 \\
\hline 3 & Biblioteconomia & 30 & 30 & 30 & 30 & 35 & 35 & 35 & $16,60 \%$ & 5 \\
\hline 4 & Comunicação social - habilitação editoração & 15 & 15 & 15 & 15 & 15 & 15 & 15 & $0,00 \%$ & 0 \\
\hline 5 & Comunicação Social - habilitação jornalismo & 45 & 45 & 45 & 45 & 50 & 60 & 60 & $37,50 \%$ & 15 \\
\hline 6 & Comunicação social - habilitação pub. e propaganda & 30 & 30 & 30 & 40 & 50 & 50 & 50 & $66,60 \%$ & 20 \\
\hline 7 & Comunicação Social - habilitação relações públicas & 15 & 15 & 15 & 20 & 50 & 50 & 50 & $233,33 \%$ & 35 \\
\hline 8 & Curso superior de audiovisual (2000) & $\neg$ & $\neg$ & $\neg$ & $\neg$ & 35 & 35 & 35 & $\neg$ & 35 \\
\hline 9 & Educação artística - habilitação artes cênicas & 20 & 20 & 25 & 25 & 10 & 10 & 10 & $-50,00 \%$ & -10 \\
\hline 10 & Música (1996) & $\neg$ & $\neg$ & $\neg$ & $\neg$ & 30 & 35 & 35 & $\neg$ & 35 \\
\hline \multirow[t]{6}{*}{11} & Turismo & 15 & 15 & 15 & 20 & 30 & 30 & 30 & $100 \%$ & 15 \\
\hline & Cinema e audiovisual & 15 & 15 & 15 & 15 & $\neg$ & $\neg$ & $\neg$ & $\neg$ & -15 \\
\hline & Educação artística - habilitação artes plásticas & 20 & 20 & 20 & 20 & $\neg$ & $\neg$ & $\neg$ & $\neg$ & -20 \\
\hline & Educação artística - habilitação música & 20 & 20 & 20 & 30 & $\neg$ & $\neg$ & $\neg$ & $\neg$ & -20 \\
\hline & Comunicação social - habilitação rádio e TV & 15 & 15 & 15 & 20 & $\neg$ & $\neg$ & $\neg$ & $\neg$ & -15 \\
\hline & Total & 170 & 170 & 175 & 195 & 350 & 365 & 365 & $114,71 \%$ & 195 \\
\hline
\end{tabular}

${ }^{185}$ Os cursos abertos depois de 1982 são acompanhados da data de abertura entre parênteses. Os cursos extintos estão em cinza. Os cursos sem informação do ano de abertura são anteriores a 1982.

${ }^{186}$ Como já foi dito, ao longo da pesquisa, só consegui ter acesso aos dados demográficos disponíveis no Anuário Estatístico. Para o número de vagas, a publicação oferece informações a partir de 1982. 
Tabela 6. Evolução dos cursos da USP por unidade de ensino e pesquisa, com indicação da progressão quinquenal do número de vagas e sua variação absoluta e percentual entre 1982 e 2010* (continuação)

\begin{tabular}{|c|c|c|c|c|c|c|c|c|c|c|}
\hline \multicolumn{2}{|c|}{ EE (1942/1963) } & \multirow{2}{*}{$\begin{array}{r}1982 \\
80\end{array}$} & \multirow{2}{*}{$\begin{array}{r}1985 \\
80\end{array}$} & \multirow{2}{*}{$\begin{array}{r}1990 \\
80\end{array}$} & \multirow{2}{*}{$\begin{array}{c}1995 \\
80\end{array}$} & \multirow{2}{*}{$\begin{array}{r}2000 \\
80\end{array}$} & \multirow{2}{*}{$\begin{array}{r}2005 \\
80\end{array}$} & \multirow{2}{*}{$\begin{array}{r}2010 \\
80\end{array}$} & \multirow[t]{2}{*}{$\begin{array}{c}\begin{array}{c}\text { Variação } \\
\text { percentual } \\
\text { do } \mathbf{n}^{\circ} \text { de } \\
\text { vagas* }\end{array} \\
0,00 \%\end{array}$} & \multirow[t]{2}{*}{$\begin{array}{c}\text { Variação } \\
\text { absoluta } \\
\text { do n }{ }^{\circ} \text { de } \\
\text { vagas } \\
0\end{array}$} \\
\hline 1 & Enfermagem & & & & & & & & & \\
\hline & Enfermagem habilitação obstetrícia (suspensa 1992) & $\neg$ & $\neg$ & 20 & $\neg$ & $\neg$ & $\neg$ & $\neg$ & $\neg$ & $\neg$ \\
\hline & Total & 80 & 80 & 100 & 80 & 80 & 80 & 80 & $\mathbf{0 , 0 0 \%}$ & $\mathbf{0}$ \\
\hline \multicolumn{2}{|c|}{ EEFE (1931/1969) } & 1982 & 1985 & 1990 & 1995 & 2000 & 2005 & 2010 & $\begin{array}{c}\text { Variação } \\
\text { percentual } \\
\text { do } n^{\circ} \text { de } \\
\text { vagas* }\end{array}$ & $\begin{array}{c}\text { Variação } \\
\text { absoluta } \\
\text { do } n^{\circ} \text { de } \\
\text { vagas }\end{array}$ \\
\hline 1 & Bacharelado em esportes (1992) & $\neg$ & $\neg$ & $\neg$ & 50 & 50 & 50 & 50 & $\neg$ & 50 \\
\hline \multirow[t]{3}{*}{2} & Educação Física - bacharelado (1992) & $\neg$ & $\neg$ & $\neg$ & 50 & 50 & 50 & 50 & $\neg$ & 50 \\
\hline & Educação Física - licenciatura & 100 & 100 & 100 & $\neg$ & $\neg$ & $\neg$ & $\neg$ & $\neg$ & -100 \\
\hline & Total & 100 & 100 & 100 & 100 & 100 & 100 & 100 & $0,00 \%$ & $\mathbf{0}$ \\
\hline \multicolumn{2}{|c|}{ EEFERP (2007) } & 1982 & 1985 & 1990 & 1995 & 2000 & 2005 & 2010 & $\begin{array}{c}\text { Variação } \\
\text { percentual } \\
\text { do } n^{\circ} \text { de } \\
\text { vagas* }^{*}\end{array}$ & $\begin{array}{c}\text { Variação } \\
\text { absoluta } \\
\text { do } n^{\circ} \text { de } \\
\text { vagas }\end{array}$ \\
\hline \multirow[t]{2}{*}{1} & Educação física (2009) & $\neg$ & $\neg$ & $\neg$ & $\neg$ & $\neg$ & $\neg$ & 60 & $\neg$ & 60 \\
\hline & Total & $\neg$ & $\neg$ & $\neg$ & $\neg$ & $\neg$ & $\neg$ & 60 & $\neg$ & 60 \\
\hline \multicolumn{2}{|c|}{ EEL $(1969 / 2006)$} & 1982 & 1985 & 1990 & 1995 & 2000 & 2005 & 2010 & $\begin{array}{c}\text { Variação } \\
\text { percentual } \\
\text { do } n^{\circ} \text { de } \\
\text { vagas* }\end{array}$ & $\begin{array}{c}\text { Variação } \\
\text { absoluta } \\
\text { do } n^{\circ} \text { de } \\
\text { vagas }\end{array}$ \\
\hline 1 & Engenharia bioquímica (2006) & $\neg$ & $\neg$ & $\neg$ & $\neg$ & $\neg$ & $\neg$ & 40 & $\neg$ & 40 \\
\hline 2 & Engenharia de materiais (2006) & $\neg$ & $\neg$ & $\neg$ & $\neg$ & $\neg$ & $\neg$ & 40 & $\neg$ & 40 \\
\hline 3 & Engenharia industrial química (2006) & $\neg$ & $\neg$ & $\neg$ & $\neg$ & $\neg$ & $\neg$ & 80 & $\neg$ & 80 \\
\hline \multirow[t]{2}{*}{4} & Engenharia química (2006) & $\neg$ & $\neg$ & $\neg$ & $\neg$ & $\neg$ & $\neg$ & 80 & $\neg$ & 80 \\
\hline & Total & $\neg$ & $\neg$ & $\neg$ & $\neg$ & $\neg$ & $\neg$ & 240 & $\neg$ & 240 \\
\hline \multicolumn{2}{|c|}{ EERP (1951/1964) } & 1982 & 1985 & 1990 & 1995 & 2000 & 2005 & 2010 & $\begin{array}{c}\text { Variação } \\
\text { percentual } \\
\text { do } \mathbf{n}^{\circ} \text { de } \\
\text { vagas* }^{*}\end{array}$ & $\begin{array}{c}\text { Variação } \\
\text { absoluta } \\
\text { do } n^{\circ} \text { de } \\
\text { vagas }\end{array}$ \\
\hline 1 & Bacharelado e licenciatura em enfermagem & $\neg$ & $\neg$ & $\neg$ & $\neg$ & $\neg$ & $\neg$ & 50 & $\neg$ & 50 \\
\hline \multirow[t]{3}{*}{2} & Enfermagem & 80 & 80 & 80 & 80 & 80 & 80 & 80 & $0,00 \%$ & 0 \\
\hline & Licenciatura em enfermagem (1992) & $\neg$ & $\neg$ & $\neg$ & 25 & $\neg$ & $\neg$ & $\neg$ & $\neg$ & $\neg$ \\
\hline & Total & 80 & 80 & 80 & 105 & 80 & 80 & 130 & $62,50 \%$ & 50 \\
\hline \multicolumn{2}{|c|}{ EESC (1948) } & 1982 & 1985 & 1990 & 1995 & 2000 & 2005 & 2010 & $\begin{array}{c}\text { Variação } \\
\text { percentual } \\
\text { do } \mathbf{n}^{\circ} \text { de } \\
\text { vagas* }^{*}\end{array}$ & $\begin{array}{c}\text { Variação } \\
\text { absoluta } \\
\text { do } n^{\circ} \text { de } \\
\text { vagas }\end{array}$ \\
\hline 1 & Arquitetura e urbanismo (1985) & $\neg$ & 30 & 30 & 30 & 30 & 30 & 45 & $\neg$ & 45 \\
\hline 2 & Engenharia aeronáutica (2002) & $\neg$ & $\neg$ & $\neg$ & $\neg$ & $\neg$ & 40 & 40 & $\neg$ & 40 \\
\hline 3 & Engenharia ambiental (2003) & $\neg$ & $\neg$ & $\neg$ & $\neg$ & $\neg$ & 40 & 40 & $\neg$ & 40 \\
\hline 4 & Engenharia civil & 180 & 60 & 60 & 60 & 60 & 60 & 60 & $-66,66 \%$ & -120 \\
\hline 5 & Engenharia de materiais e manufatura (2010) & $\neg$ & $\neg$ & $\neg$ & $\neg$ & $\neg$ & $\neg$ & 50 & $\neg$ & 50 \\
\hline 6 & Engenharia de produção mecânica (1983) & $\neg$ & 20 & 20 & 20 & 30 & 30 & 50 & $\neg$ & 50 \\
\hline 7 & Engenharia elétrica (1983) & $\neg$ & 50 & 50 & 50 & 50 & 100 & 100 & $\neg$ & 100 \\
\hline 8 & Engenharia mecânica (1986) & $\neg$ & 50 & 50 & 50 & 50 & 50 & 50 & $\neg$ & 50 \\
\hline \multirow[t]{3}{*}{9} & Engenharia mecatrônica (2003) & $\neg$ & $\neg$ & $\neg$ & $\neg$ & $\neg$ & 50 & 50 & $\neg$ & 50 \\
\hline & Engenharia da computação & $\neg$ & $\neg$ & $\neg$ & $\neg$ & $\neg$ & 50 & $\neg$ & $\neg$ & $\neg$ \\
\hline & Total & 180 & 210 & 210 & 210 & 220 & 400 & 485 & $169,00 \%$ & 305 \\
\hline
\end{tabular}


Tabela 6. Evolução dos cursos da USP por unidade de ensino e pesquisa, com indicação da progressão quinquenal do número de vagas e sua variação absoluta e percentual entre 1982 e 2010 * (continuação)

\begin{tabular}{|c|c|c|c|c|c|c|c|c|c|c|}
\hline $\mathbf{E P}$ & 3/1934) & 1982 & 1985 & 1990 & 1995 & 2000 & 2005 & 2010 & $\begin{array}{c}\text { Variação } \\
\text { percentual } \\
\text { do } n^{\circ} \text { de }\end{array}$ & $\begin{array}{l}\text { Variação } \\
\text { absoluta } \\
\text { do n }{ }^{\circ} \text { de }\end{array}$ \\
\hline 1 & Engenharia civil & 600 & 180 & 180 & 180 & $\neg$ & $\neg$ & 180 & $-70 \%$ & -420 \\
\hline 2 & Engenharia de produção (2008) & $\neg$ & $\neg$ & $\neg$ & $\neg$ & $\neg$ & $\neg$ & 70 & $\neg$ & 70 \\
\hline 3 & Engenharia elétrica (2008) & $\neg$ & $\neg$ & $\neg$ & $\neg$ & $\neg$ & $\neg$ & 210 & $\neg$ & 210 \\
\hline 4 & Engenharia mecânica (2008) & $\neg$ & $\neg$ & $\neg$ & $\neg$ & $\neg$ & $\neg$ & 110 & $\neg$ & 110 \\
\hline 5 & Engenharia mecatrônica (2008) & $\neg$ & $\neg$ & $\neg$ & $\neg$ & $\neg$ & $\neg$ & 60 & $\neg$ & 60 \\
\hline 6 & Engenharia química (2008) & $\neg$ & $\neg$ & $\neg$ & $\neg$ & $\neg$ & $\neg$ & 120 & $\neg$ & 120 \\
\hline & Engenharia elétrica & $\neg$ & 120 & 180 & 180 & $\neg$ & $\neg$ & $\neg$ & $\neg$ & $\neg$ \\
\hline & Engenharia naval & $\neg$ & 40 & 40 & 40 & $\neg$ & $\neg$ & $\neg$ & $\neg$ & $\neg$ \\
\hline & Engenharia de minas & $\neg$ & 20 & 20 & 20 & $\neg$ & $\neg$ & $\neg$ & $\neg$ & $\neg$ \\
\hline & Engenharia de produção (mecânica) & $\neg$ & 70 & 70 & 70 & $\neg$ & $\neg$ & $\neg$ & $\neg$ & $\neg$ \\
\hline & Engenharia mecânica & $\neg$ & 70 & 70 & 70 & $\neg$ & $\neg$ & $\neg$ & $\neg$ & $\neg$ \\
\hline & Engenharia mecânica - automação e sistemas & $\neg$ & 0 & 60 & 60 & $\neg$ & $\neg$ & $\neg$ & $\neg$ & $\neg$ \\
\hline & Engenharia metalúrgica & $\neg$ & 40 & 40 & 20 & $\neg$ & $\neg$ & $\neg$ & $\neg$ & $\neg$ \\
\hline & Engenharia química & $\neg$ & 60 & 60 & 60 & $\neg$ & $\neg$ & $\neg$ & $\neg$ & $\neg$ \\
\hline & Engenharia da computação - Cubatão & $\neg$ & 0 & 60 & 0 & $\neg$ & $\neg$ & $\neg$ & $\neg$ & $\neg$ \\
\hline & Engenharia de produção - Cubatão & $\neg$ & 0 & 60 & 0 & $\neg$ & $\neg$ & $\neg$ & $\neg$ & $\neg$ \\
\hline & Engenharia química - Cubatão & $\neg$ & 0 & 60 & 0 & $\neg$ & $\neg$ & $\neg$ & $\neg$ & $\neg$ \\
\hline & Engenharia de materiais (1995) & $\neg$ & 0 & 0 & 20 & $\neg$ & $\neg$ & $\neg$ & $\neg$ & $\neg$ \\
\hline & Engenharia - ciclo básico (2000) & $\neg$ & 0 & 0 & 0 & 750 & 750 & $\neg$ & $\neg$ & $\neg$ \\
\hline & Total & 600 & 600 & 900 & 720 & 750 & 750 & 750 & $25 \%$ & 150 \\
\hline ESA & $(1901 / 1934)$ & 1982 & 1985 & 1990 & 1995 & 2000 & 2005 & 2010 & $\begin{array}{c}\text { Variação } \\
\text { percentual } \\
\text { do } \mathbf{n}^{\circ} \text { de } \\
\text { vagas* }\end{array}$ & $\begin{array}{c}\text { Variação } \\
\text { absoluta } \\
\text { do } n^{\circ} \text { de } \\
\text { vagas }\end{array}$ \\
\hline 1 & Ciências biológicas (2002) & $\neg$ & $\neg$ & $\neg$ & $\neg$ & $\neg$ & 30 & 30 & $\neg$ & 30 \\
\hline 2 & Ciências dos alimentos (2001) & $\neg$ & $\neg$ & $\neg$ & $\neg$ & $\neg$ & 40 & 40 & $\neg$ & 40 \\
\hline 3 & Ciências econômicas (2001) & $\neg$ & $\neg$ & $\neg$ & $\neg$ & $\neg$ & 30 & 40 & $\neg$ & 40 \\
\hline 4 & Engenharia agronômica & 200 & 200 & 200 & 200 & 200 & 200 & 200 & $0,00 \%$ & 0 \\
\hline 5 & Engenharia florestal & 25 & 25 & 25 & 40 & 40 & 40 & 40 & $60 \%$ & 15 \\
\hline 6 & Gestão ambiental (2002) & $\neg$ & $\neg$ & $\neg$ & $\neg$ & $\neg$ & 40 & 40 & $\neg$ & 40 \\
\hline & Economia agroindustrial & $\neg$ & $\neg$ & $\neg$ & $\neg$ & 20 & $\neg$ & $\neg$ & $\neg$ & $\neg$ \\
\hline & Economia doméstica (suspenso em 1991) & 25 & 25 & 25 & $\neg$ & $\neg$ & $\neg$ & $\neg$ & $\neg$ & -25 \\
\hline & Total & 250 & 250 & 250 & 240 & 260 & 380 & 390 & $56 \%$ & 165 \\
\hline FAL & 948/1948) & 1982 & 1985 & 1990 & 1995 & 2000 & 2005 & 2010 & $\begin{array}{c}\text { Variação } \\
\text { percentual } \\
\text { do } \mathbf{n}^{\circ} \text { de } \\
\text { vagas* }\end{array}$ & $\begin{array}{c}\text { Variação } \\
\text { absoluta } \\
\text { do } n^{\circ} \text { de } \\
\text { vagas }\end{array}$ \\
\hline 1 & Arquitetura & 150 & 150 & 150 & 150 & 150 & 150 & 150 & $0,00 \%$ & 0 \\
\hline 2 & Desing (2006) & $\neg$ & $\neg$ & $\neg$ & $\neg$ & $\neg$ & $\neg$ & 40 & $\neg$ & 40 \\
\hline & Total & 150 & 150 & 150 & 150 & 150 & 150 & 190 & $26,66 \%$ & 40 \\
\hline FCF & 898/1934) & 1982 & 1985 & 1990 & 1995 & 2000 & 2005 & 2010 & $\begin{array}{c}\text { Variação } \\
\text { percentual } \\
\text { do } \text { n }^{\circ} \text { de } \\
\text { vagas* }\end{array}$ & $\begin{array}{c}\text { Variação } \\
\text { absoluta } \\
\text { do } n^{\circ} \text { de } \\
\text { vagas }\end{array}$ \\
\hline 1 & Farmácia-bioquímica & 135 & 135 & 135 & 135 & 135 & 150 & 150 & $11,11 \%$ & 15 \\
\hline & Total & 135 & 135 & 135 & 135 & 135 & 150 & 150 & $11,11 \%$ & 15 \\
\hline
\end{tabular}


Tabela 6. Evolução dos cursos da USP por unidade de ensino e pesquisa, com indicação da progressão quinquenal do número de vagas e sua variação absoluta e percentual entre 1982 e 2010* (continuação)

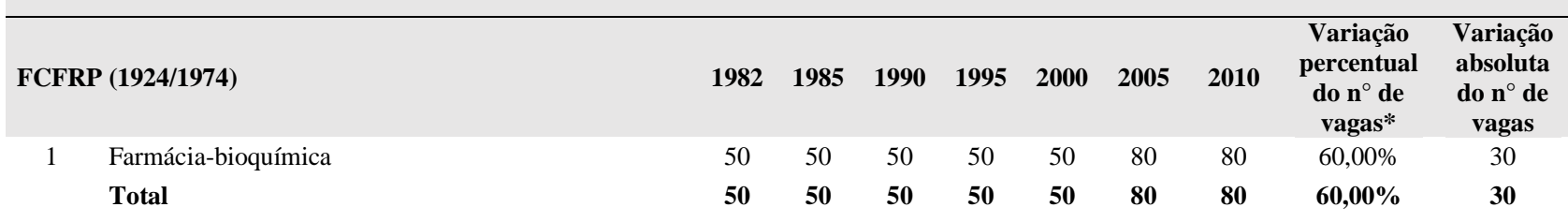

Tabela 6. Evolução dos cursos da USP por unidade de ensino e pesquisa, com indicação da progressão quinquenal do número de vagas e sua variação absoluta e percentual entre 1982 e 2010* (continuação)

\begin{tabular}{|c|c|c|c|c|c|c|c|c|c|c|}
\hline \multicolumn{2}{|c|}{ FD $(1827 / 1934)$} & \multirow{2}{*}{$\begin{array}{l}1982 \\
450\end{array}$} & \multirow{2}{*}{$\begin{array}{l}1985 \\
450\end{array}$} & \multirow{2}{*}{$\begin{array}{l}1990 \\
450\end{array}$} & \multirow{2}{*}{$\begin{array}{l}1995 \\
450\end{array}$} & \multirow{2}{*}{$\begin{array}{l}2000 \\
460\end{array}$} & \multirow{2}{*}{$\begin{array}{l}2005 \\
460\end{array}$} & \multirow{2}{*}{$\begin{array}{l}2010 \\
460\end{array}$} & \multirow{2}{*}{ 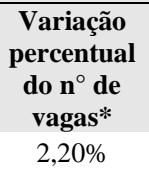 } & \multirow{2}{*}{ 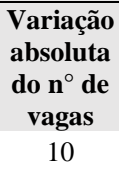 } \\
\hline 1 & Direito & & & & & & & & & \\
\hline & Total & 450 & 450 & 450 & 450 & 460 & 460 & 460 & $2,20 \%$ & 10 \\
\hline \multicolumn{2}{|c|}{ FDRP (2007) } & 1982 & 1985 & 1990 & 1995 & 2000 & 2005 & 2010 & $\begin{array}{c}\text { Variação } \\
\text { percentual } \\
\text { do } n^{\circ} \text { de } \\
\text { vagas* }^{*}\end{array}$ & $\begin{array}{c}\text { Variação } \\
\text { absoluta } \\
\text { do } n^{\circ} \text { de } \\
\text { vagas }\end{array}$ \\
\hline 1 & Direito (2007) & $\neg$ & $\neg$ & $\neg$ & $\neg$ & $\neg$ & $\neg$ & 100 & $\neg$ & 100 \\
\hline & Total & $\neg$ & $\neg$ & ᄀ & $\neg$ & $\neg$ & $\neg$ & 100 & $\neg$ & 100 \\
\hline \multicolumn{2}{|c|}{ FE $(1933 / 1969)$} & 1982 & 1985 & 1990 & 1995 & 2000 & 2005 & 2010 & $\begin{array}{c}\text { Variação } \\
\text { percentual } \\
\text { do } \mathbf{n}^{\circ} \text { de } \\
\text { vagas* }^{*}\end{array}$ & $\begin{array}{c}\text { Variação } \\
\text { absoluta } \\
\text { do } n^{\circ} \text { de } \\
\text { vagas }\end{array}$ \\
\hline \multirow[t]{2}{*}{1} & Pedagogia & 120 & 120 & 120 & 120 & 120 & 180 & 180 & $50,00 \%$ & 60 \\
\hline & Total & 120 & 120 & 120 & 120 & 120 & 180 & 180 & $\mathbf{5 0 , 0 0 \%}$ & 60 \\
\hline \multicolumn{2}{|c|}{ FEA (1946) } & 1982 & 1985 & 1990 & 1995 & 2000 & 2005 & 2010 & $\begin{array}{c}\text { Variação } \\
\text { percentual } \\
\text { do } n^{\circ} \text { de } \\
\text { vagas* }^{*}\end{array}$ & $\begin{array}{c}\text { Variação } \\
\text { absoluta } \\
\text { do } \text { n}^{\circ} \text { de } \\
\text { vagas }\end{array}$ \\
\hline 1 & Bacharelado em administração & 180 & 180 & 180 & 200 & 210 & 210 & 210 & $16,60 \%$ & 30 \\
\hline 2 & Bacharelado em ciências econômicas & 180 & 180 & 180 & 180 & 180 & 180 & 180 & $0,00 \%$ & 0 \\
\hline 3 & Bacharelado em ciências atuariais (1984) & $\neg$ & 30 & $\neg$ & $\neg$ & $\neg$ & $\neg$ & 50 & $\neg$ & 50 \\
\hline \multirow[t]{5}{*}{4} & Ciências contábeis & 90 & 90 & 120 & 140 & 150 & 150 & 150 & $66,66 \%$ & 60 \\
\hline & Economia Ribeirão Preto (1992) & $\neg$ & $\neg$ & $\neg$ & 40 & 44 & $\neg$ & $\neg$ & $\neg$ & $\neg$ \\
\hline & Administração Ribeirão Preto (1992) & $\neg$ & $\neg$ & $\neg$ & 40 & 40 & $\neg$ & $\neg$ & $\neg$ & $\neg$ \\
\hline & Ciências Contábeis Ribeirão Preto (1992) & $\neg$ & $\neg$ & $\neg$ & 40 & 40 & $\neg$ & $\neg$ & $\neg$ & $\neg$ \\
\hline & Total & 450 & 480 & 480 & 640 & 664 & 540 & 590 & $31,11 \%$ & 140 \\
\hline \multicolumn{2}{|c|}{ FEARP $(1992 / 2002)$} & 1982 & 1985 & 1990 & 1995 & 2000 & 2005 & 2010 & $\begin{array}{c}\text { Variação } \\
\text { percentual } \\
\text { do } n^{\circ} \text { de } \\
\text { vagas* }^{*}\end{array}$ & $\begin{array}{c}\text { Variação } \\
\text { absoluta } \\
\text { do } n^{\circ} \text { de } \\
\text { vagas }\end{array}$ \\
\hline 1 & Administração de empresas (1992) & $\neg$ & $\neg$ & $\neg$ & $\neg$ & $\neg$ & 45 & 105 & $\neg$ & 105 \\
\hline 2 & Bacharelado em ciências contábeis (1992) & $\neg$ & $\neg$ & $\neg$ & $\neg$ & $\neg$ & 45 & 45 & $\neg$ & 45 \\
\hline 3 & Bacharelado em ciências econômicas (1992) & $\neg$ & $\neg$ & $\neg$ & $\neg$ & $\neg$ & 45 & 45 & $\neg$ & 45 \\
\hline \multirow[t]{2}{*}{4} & Economia empresarial e controladoria (2007) & $\neg$ & $\neg$ & $\neg$ & $\neg$ & $\neg$ & $\neg$ & 70 & $\neg$ & 70 \\
\hline & Total & $\neg$ & $\neg$ & $\neg$ & $\neg$ & $\neg$ & 135 & 265 & $\neg$ & 265 \\
\hline \multicolumn{2}{|c|}{ FFCLRP (1959/1974) } & 1982 & 1985 & 1990 & 1995 & 2000 & 2005 & 2010 & $\begin{array}{c}\text { Variação } \\
\text { percentual } \\
\text { do } n^{\circ} \text { de } \\
\text { vagas* }^{*}\end{array}$ & $\begin{array}{c}\text { Variação } \\
\text { absoluta } \\
\text { do } n^{\circ} \text { de } \\
\text { vagas }\end{array}$ \\
\hline 1 & Ciência da informação e da documentação (2003) & $\neg$ & $\neg$ & $\neg$ & $\neg$ & $\neg$ & 40 & 40 & $\neg$ & 40 \\
\hline 2 & Bacharelado em física médica (2000) & $\neg$ & $\neg$ & $\neg$ & $\neg$ & 50 & 40 & 40 & $\neg$ & 40 \\
\hline 3 & Ciências biológicas & 40 & 40 & 40 & 40 & 40 & 40 & 40 & $0,00 \%$ & 0 \\
\hline 4 & Licenciatura em química (2003) & $\neg$ & $\neg$ & $\neg$ & $\neg$ & $\neg$ & 40 & 40 & $\neg$ & 40 \\
\hline
\end{tabular}


Tabela 6. Evolução dos cursos da USP por unidade de ensino e pesquisa, com indicação da progressão quinquenal do número de vagas e sua variação absoluta e percentual entre 1982 e 2010* (continuação)

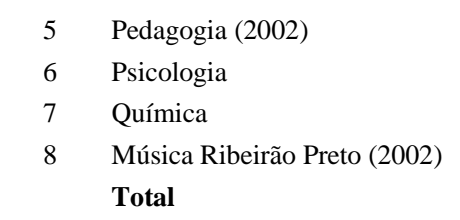

$\begin{array}{ccccccccc}\neg & \neg & \neg & \neg & \neg & 50 & 50 & \urcorner & 50 \\ 40 & 40 & 40 & 40 & 40 & 40 & 40 & 0,00 \% & 0 \\ 40 & 40 & 40 & 50 & 40 & 40 & 60 & 50,00 \% & 20 \\ \neg & \neg & \neg & \neg & \neg & 30 & 30 & \neg & 30 \\ \mathbf{1 2 0} & \mathbf{1 2 0} & \mathbf{1 2 0} & \mathbf{1 3 0} & \mathbf{9 0} & \mathbf{3 2 0} & \mathbf{3 4 0} & \mathbf{1 8 3 , 3 3 \%} & \mathbf{2 2}\end{array}$

\begin{tabular}{|c|c|c|c|c|c|c|c|c|c|c|}
\hline \multicolumn{2}{|c|}{ FFLCH (1934/1969) } & \multirow{2}{*}{$\begin{array}{l}1982 \\
850\end{array}$} & \multirow{2}{*}{$\begin{array}{l}1985 \\
850\end{array}$} & \multirow{2}{*}{$\begin{array}{l}1990 \\
850\end{array}$} & \multirow{2}{*}{$\begin{array}{l}1995 \\
875\end{array}$} & \multirow{2}{*}{$\begin{array}{l}2000 \\
849\end{array}$} & \multirow{2}{*}{$\begin{array}{l}2005 \\
849\end{array}$} & \multirow{2}{*}{$\begin{array}{l}2010 \\
849\end{array}$} & \multirow{2}{*}{ 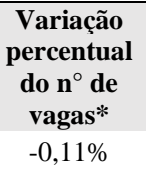 } & \multirow{2}{*}{$\begin{array}{c}\text { Variação } \\
\text { absoluta } \\
\text { do } \mathbf{n}^{\circ} \text { de } \\
\text { vagas } \\
-1\end{array}$} \\
\hline 1 & Letras - diferentes habilitações & & & & & & & & & \\
\hline 2 & Bacharelado em ciências sociais & 200 & 200 & 200 & 200 & 210 & 210 & 210 & $5 \%$ & 10 \\
\hline 3 & Bacharelado em filosofia & 160 & 160 & 160 & 160 & 170 & 170 & 170 & $6,25 \%$ & 10 \\
\hline 4 & Bacharelado em geografia & 160 & 160 & 160 & 160 & 160 & 170 & 170 & $6,25 \%$ & 10 \\
\hline \multirow[t]{2}{*}{5} & Bacharelado em história & 260 & 260 & 260 & 260 & 270 & 270 & 270 & $3,84 \%$ & 10 \\
\hline & Total & 1630 & 1630 & 1630 & 1655 & 1659 & 1669 & 1669 & $2,39 \%$ & 39 \\
\hline
\end{tabular}

\begin{tabular}{|c|c|c|c|c|c|c|c|c|c|c|}
\hline \multicolumn{2}{|c|}{ FM (1912/1934) } & \multirow{2}{*}{$\begin{array}{c}1982 \\
25\end{array}$} & \multirow{2}{*}{$\begin{array}{r}1985 \\
25\end{array}$} & \multirow{2}{*}{$\begin{array}{r}1990 \\
25\end{array}$} & \multirow{2}{*}{$\begin{array}{c}1995 \\
25\end{array}$} & \multirow{2}{*}{$\begin{array}{r}2000 \\
25\end{array}$} & \multirow{2}{*}{$\begin{array}{r}2005 \\
25\end{array}$} & \multirow{2}{*}{$\begin{array}{r}2010 \\
25\end{array}$} & \multirow{2}{*}{ 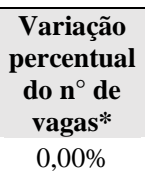 } & \multirow{2}{*}{$\begin{array}{c}\text { Variação } \\
\text { absoluta } \\
\text { do } n^{\circ} \text { de } \\
\text { vagas } \\
0\end{array}$} \\
\hline 1 & Fisioterapia & & & & & & & & & \\
\hline 2 & Fonoaudiologia & 15 & 15 & 15 & 25 & 25 & 25 & 25 & $66,60 \%$ & 10 \\
\hline 3 & Medicina & 175 & 175 & 175 & 175 & 175 & 175 & 175 & $0,00 \%$ & 0 \\
\hline \multirow[t]{2}{*}{4} & Terapia ocupacional & 25 & 25 & 25 & 25 & 25 & 25 & 25 & $0,00 \%$ & 0 \\
\hline & Total & 240 & 240 & 240 & 250 & 250 & 250 & 250 & $4,16 \%$ & 10 \\
\hline
\end{tabular}

\begin{tabular}{|c|c|c|c|c|c|c|c|c|c|c|}
\hline \multicolumn{2}{|c|}{ FMRP (1948) } & \multirow{2}{*}{$\begin{array}{c}1982 \\
\neg\end{array}$} & \multirow{2}{*}{$\begin{array}{c}1985 \\
\neg\end{array}$} & \multirow{2}{*}{$\begin{array}{c}1990 \\
\neg\end{array}$} & \multirow{2}{*}{$\begin{array}{c}1995 \\
\neg\end{array}$} & \multirow{2}{*}{$\begin{array}{l}2000 \\
100\end{array}$} & \multirow{2}{*}{$\begin{array}{l}2005 \\
100\end{array}$} & \multirow{2}{*}{$\begin{array}{l}2010 \\
100\end{array}$} & \multirow{2}{*}{$\begin{array}{c}\text { Variação } \\
\text { percentual } \\
\text { do n }{ }^{\circ} \text { de } \\
\text { vagas* }^{*} \\
\neg\end{array}$} & \multirow{2}{*}{$\begin{array}{c}\begin{array}{c}\text { Variação } \\
\text { absoluta } \\
\text { do } \mathbf{n}^{\circ} \text { de } \\
\text { vagas }\end{array} \\
100\end{array}$} \\
\hline 1 & Ciências médicas - ciclo básico (1996) & & & & & & & & & \\
\hline 2 & Fisioterapia (2003) & $\neg$ & $\neg$ & $\neg$ & $\neg$ & $\neg$ & 40 & 40 & $\neg$ & 40 \\
\hline 3 & Fonoaudiologia (2003) & $\neg$ & $\neg$ & $\neg$ & $\neg$ & $\neg$ & 30 & 30 & $\neg$ & 30 \\
\hline 4 & Nutrição e metabolismo (2003) & $\neg$ & $\neg$ & $\neg$ & $\neg$ & $\neg$ & 30 & 30 & $\neg$ & 30 \\
\hline \multirow[t]{4}{*}{5} & Terapia ocupacional (2003) & $\neg$ & $\neg$ & $\neg$ & $\neg$ & $\neg$ & 20 & 20 & $\neg$ & 20 \\
\hline & Medicina & 80 & 80 & 80 & 80 & 0 & $\neg$ & $\neg$ & $\neg$ & -80 \\
\hline & Ciências biológicas - modalidade médica & 20 & 20 & 20 & 20 & 0 & $\neg$ & $\neg$ & $\neg$ & -20 \\
\hline & Total & 100 & 100 & 100 & 100 & 100 & 220 & 220 & $120 \%$ & 220 \\
\hline \multicolumn{2}{|c|}{ FMVZ (1919/1934) } & 1982 & 1985 & 1990 & 1995 & 2000 & 2005 & 2010 & $\begin{array}{c}\text { Variação } \\
\text { percentual } \\
\text { do } \mathrm{n}^{\circ} \text { de } \\
\text { vagas* }^{*}\end{array}$ & $\begin{array}{c}\text { Variação } \\
\text { absoluta } \\
\text { do }{ }^{\circ} \text { de } \\
\text { vagas }\end{array}$ \\
\hline \multirow[t]{3}{*}{1} & Medicina veterinária & 80 & 80 & 80 & 80 & 80 & 80 & 80 & $0,00 \%$ & 0 \\
\hline & Zootecnia (transferido para FZEA em 1993) & 20 & 20 & 20 & $\neg$ & $\neg$ & $\neg$ & $\neg$ & $\neg$ & -20 \\
\hline & Total & 100 & 100 & 100 & 80 & 80 & 80 & 80 & $-20 \%$ & -20 \\
\hline \multicolumn{2}{|c|}{ FO $(1898 / 1934)$} & 1982 & 1985 & 1990 & 1995 & 2000 & 2005 & 2010 & $\begin{array}{c}\text { Variação } \\
\text { percentual } \\
\text { do } n^{\circ} \text { de } \\
\text { vagas* }^{*}\end{array}$ & $\begin{array}{c}\text { Variação } \\
\text { absoluta } \\
\text { do } n^{\circ} \text { de } \\
\text { vagas }\end{array}$ \\
\hline \multirow[t]{2}{*}{1} & Odontologia & 133 & 133 & 133 & 133 & 133 & 133 & 133 & $0,00 \%$ & 0 \\
\hline & Total & 133 & 133 & 133 & 133 & 133 & 133 & 133 & $0,00 \%$ & $\mathbf{0}$ \\
\hline
\end{tabular}


Tabela 6. Evolução dos cursos da USP por unidade de ensino e pesquisa, com indicação da progressão quinquenal do número de vagas e sua variação absoluta e percentual entre 1982 e 2010* (continuação)

\begin{tabular}{|c|c|c|c|c|c|c|c|c|c|c|}
\hline \multicolumn{2}{|c|}{ FOB (1948) } & \multirow{2}{*}{$\begin{array}{r}1982 \\
50\end{array}$} & \multirow{2}{*}{$\begin{array}{c}1985 \\
50\end{array}$} & \multirow{2}{*}{$\begin{array}{r}1990 \\
50\end{array}$} & \multirow{2}{*}{$\begin{array}{c}1995 \\
50\end{array}$} & \multirow{2}{*}{$\begin{array}{c}2000 \\
50\end{array}$} & \multirow{2}{*}{$\begin{array}{c}2005 \\
50\end{array}$} & \multirow{2}{*}{$\begin{array}{c}2010 \\
50\end{array}$} & \multirow[t]{2}{*}{ 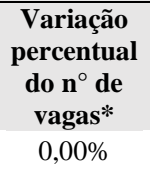 } & \multirow{2}{*}{$\begin{array}{c}\text { Variação } \\
\text { absoluta } \\
\text { do } \text { n }^{\circ} \text { de } \\
\text { vagas } \\
0\end{array}$} \\
\hline 1 & Odontologia & & & & & & & & & \\
\hline 2 & Fonoaudiologia (1990) & $\neg$ & $\neg$ & 25 & 25 & 25 & 25 & 40 & $\neg$ & 40 \\
\hline & Total & 50 & 50 & 75 & 75 & 75 & 75 & 90 & $80 \%$ & 40 \\
\hline \multicolumn{2}{|c|}{ FORP (1924/1982) } & 1982 & 1985 & 1990 & 1995 & 2000 & 2005 & 2010 & $\begin{array}{c}\text { Variação } \\
\text { percentual } \\
\text { do } n^{\circ} \text { de } \\
\text { vagas* }\end{array}$ & $\begin{array}{c}\text { Variação } \\
\text { absoluta } \\
\text { no } n^{\circ} \text { de } \\
\text { vagas }\end{array}$ \\
\hline 1 & Odontologia & 80 & 80 & 80 & 80 & 80 & 80 & 80 & $0,00 \%$ & 0 \\
\hline & Total & 80 & 80 & 80 & 80 & 80 & 80 & 80 & $0,00 \%$ & 0 \\
\hline \multicolumn{2}{|c|}{ FSP (1922/1934) } & 1982 & 1985 & 1990 & 1995 & 2000 & 2005 & 2010 & $\begin{array}{c}\text { Variação } \\
\text { percentual } \\
\text { do } n^{\circ} \text { de } \\
\text { vagas* }\end{array}$ & $\begin{array}{c}\text { Variação } \\
\text { absoluta } \\
\text { do } n^{\circ} \text { de } \\
\text { vagas }\end{array}$ \\
\hline 1 & Nutrição & 20 & 40 & 40 & 40 & 40 & 80 & 80 & $300 \%$ & 60 \\
\hline & Enfermagem em saúde pública (suspensa em 1995) & $\neg$ & $\neg$ & 20 & $\neg$ & $\neg$ & $\neg$ & $\neg$ & $\neg$ & $\neg$ \\
\hline & Total & 20 & 40 & 60 & 40 & 40 & 80 & 80 & $300 \%$ & 60 \\
\hline \multicolumn{2}{|c|}{ FZEA (1992) } & 1982 & 1985 & 1990 & 1995 & 2000 & 2005 & 2010 & $\begin{array}{c}\text { Variação } \\
\text { percentual } \\
\text { do } \mathbf{n}^{\circ} \text { de } \\
\text { vagas* }\end{array}$ & $\begin{array}{c}\text { Variação } \\
\text { absoluta } \\
\text { do } n^{\circ} \text { de } \\
\text { vagas }\end{array}$ \\
\hline 1 & Zootecnia** & $\neg$ & $\neg$ & $\neg$ & 30 & 40 & 40 & 40 & $\neg$ & 40 \\
\hline 2 & Engenharia de alimentos (2006) & $\neg$ & $\neg$ & $\neg$ & $\neg$ & $\neg$ & 100 & 100 & $\neg$ & 100 \\
\hline 3 & Engenharia de biossistemas (2009) & $\neg$ & $\neg$ & $\neg$ & $\neg$ & $\neg$ & $\neg$ & 60 & $\neg$ & 60 \\
\hline \multirow[t]{2}{*}{4} & Medicina Veterinária (2009) & $\neg$ & $\neg$ & $\neg$ & $\neg$ & $\neg$ & $\neg$ & 60 & $\neg$ & 60 \\
\hline & Total & $\neg$ & $\neg$ & $\neg$ & 30 & 40 & 140 & 260 & $\neg$ & 260 \\
\hline \multicolumn{2}{|c|}{ IAG (1927/1946) } & 1982 & 1985 & 1990 & 1995 & 2000 & 2005 & 2010 & $\begin{array}{c}\text { Variação } \\
\text { percentual } \\
\text { do n }{ }^{\circ} \text { de } \\
\text { vagas* }\end{array}$ & $\begin{array}{c}\text { Variação } \\
\text { absoluta } \\
\text { do } n^{\circ} \text { de } \\
\text { vagas }\end{array}$ \\
\hline 1 & Meteorologia & 20 & 20 & 20 & 20 & 20 & 40 & 15 & $-25 \%$ & -5 \\
\hline 2 & Geofísica (1984) & $\neg$ & 20 & 20 & 20 & 20 & 30 & 30 & $\neg$ & 20 \\
\hline \multirow[t]{2}{*}{3} & Astronomia (2009) & $\neg$ & $\neg$ & $\neg$ & $\neg$ & $\neg$ & $\neg$ & 30 & $\neg$ & 30 \\
\hline & Total & 20 & 40 & 40 & 40 & 40 & 70 & 75 & $225 \%$ & 45 \\
\hline \multicolumn{2}{|c|}{ IB (1934/ 1969) } & 1982 & 1985 & 1990 & 1995 & 2000 & 2005 & 2010 & $\begin{array}{c}\text { Variação } \\
\text { percentual } \\
\text { do } n^{\circ} \text { de } \\
\text { vagas* }\end{array}$ & $\begin{array}{c}\text { Variação } \\
\text { absoluta } \\
\text { do } n^{\circ} \text { de } \\
\text { vagas }\end{array}$ \\
\hline \multirow[t]{2}{*}{1} & Ciências biológicas & 120 & 120 & 120 & 120 & 120 & 120 & 120 & $0,00 \%$ & 0 \\
\hline & Total & 120 & 120 & 120 & 120 & 120 & 120 & 120 & $0,00 \%$ & 0 \\
\hline \multicolumn{2}{|c|}{ ICB (1969) } & 1982 & 1985 & 1990 & 1995 & 2000 & 2005 & 2010 & $\begin{array}{c}\text { Variação } \\
\text { percentual } \\
\text { do } n^{\circ} \text { de } \\
\text { vagas* }\end{array}$ & $\begin{array}{c}\text { Variação } \\
\text { absoluta } \\
\text { do } n^{\circ} \text { de } \\
\text { vagas }\end{array}$ \\
\hline \multirow[t]{2}{*}{1} & Ciências fundamentais para a saúde (2008) & $\neg$ & $\neg$ & $\neg$ & $\neg$ & $\neg$ & $\neg$ & $\neg$ & $\neg$ & $\neg$ \\
\hline & Total & $\neg$ & $\neg$ & $\neg$ & $\neg$ & $\neg$ & $\neg$ & $\neg$ & $\neg$ & $\neg$ \\
\hline
\end{tabular}


Tabela 6. Evolução dos cursos da USP por unidade de ensino e pesquisa, com indicação da progressão quinquenal do número de vagas e sua variação absoluta e percentual entre 1982 e 2010* (continuação)

\begin{tabular}{|c|c|c|c|c|c|c|c|c|c|c|}
\hline \multicolumn{2}{|c|}{ ICMC (1971) } & 1982 & 1985 & 1990 & 1995 & 2000 & 2005 & 2010 & $\begin{array}{c}\text { Variação } \\
\text { percentual } \\
\text { do } n^{\circ} \text { de } \\
\text { vagas* }\end{array}$ & $\begin{array}{c}\text { Variação } \\
\text { absoluta } \\
\text { do } n^{\circ} \text { de } \\
\text { vagas }\end{array}$ \\
\hline 1 & $\begin{array}{l}\text { Bacharelado em matemática e computação científica } \\
\text { (1999) }\end{array}$ & $\neg$ & $\neg$ & $\neg$ & $\neg$ & 10 & 25 & 25 & $\neg$ & 25 \\
\hline 2 & Matemática & 30 & 20 & 40 & 40 & 25 & 30 & 30 & $0,00 \%$ & 0 \\
\hline 3 & Bacharelado em informática (1999) & $\neg$ & $\neg$ & $\neg$ & $\neg$ & 40 & 40 & 40 & $\neg$ & 40 \\
\hline 4 & Bacharelado em estatística (2009) & $\neg$ & $\neg$ & $\neg$ & $\neg$ & $\neg$ & $\neg$ & 40 & $\neg$ & 40 \\
\hline \multirow[t]{2}{*}{5} & Bacharelado em ciência da computação (1984) & $\neg$ & 40 & 40 & 40 & 40 & 100 & 100 & $\neg$ & 100 \\
\hline & Total & 30 & 60 & 80 & 80 & 75 & 95 & 235 & $683,33 \%$ & 205 \\
\hline \multicolumn{2}{|c|}{ IF (1934/1969) } & 1982 & 1985 & 1990 & 1995 & 2000 & 2005 & 2010 & $\begin{array}{c}\text { Variação } \\
\text { percentual } \\
\text { do } n^{\circ} \text { de } \\
\text { vagas* }\end{array}$ & $\begin{array}{c}\text { Variação } \\
\text { absoluta } \\
\text { do } n^{\circ} \text { de } \\
\text { vagas }\end{array}$ \\
\hline \multirow[t]{2}{*}{1} & Física - bacharelado e licenciatura & 260 & 260 & 260 & 260 & 270 & 270 & 270 & $3,80 \%$ & 10 \\
\hline & Total & 260 & 260 & 260 & 260 & 270 & 270 & 270 & $3,80 \%$ & 10 \\
\hline \multicolumn{2}{|c|}{ IFSC (1971/1994) } & 1982 & 1985 & 1990 & 1995 & 2000 & 2005 & 2010 & $\begin{array}{c}\text { Variação } \\
\text { percentual } \\
\text { do } n^{\circ} \text { de } \\
\text { vagas* }^{*}\end{array}$ & $\begin{array}{c}\text { Variação } \\
\text { absoluta } \\
\text { do } n^{\circ} \text { de } \\
\text { vagas }\end{array}$ \\
\hline 1 & Física & 20 & 40 & 40 & 40 & 40 & 40 & 40 & $100 \%$ & 20 \\
\hline 2 & $\begin{array}{l}\text { Bacharelado em ciências físicas e biomoleculares } \\
\text { (2007) }\end{array}$ & $\neg$ & $\neg$ & $\neg$ & $\neg$ & $\neg$ & $\neg$ & 40 & $\neg$ & 40 \\
\hline \multirow[t]{3}{*}{3} & Física computacional (2007) & $\neg$ & $\neg$ & $\neg$ & $\neg$ & $\neg$ & $\neg$ & 40 & $\neg$ & 40 \\
\hline & Química (transferido para o IQSC em 1994) & 20 & 40 & 40 & $\neg$ & $\neg$ & $\neg$ & $\neg$ & $\neg$ & -20 \\
\hline & Total & 40 & 80 & 80 & 40 & 40 & 40 & 120 & $200 \%$ & 100 \\
\hline \multicolumn{2}{|c|}{ IG (1934/1969) } & 1982 & 1985 & 1990 & 1995 & 2000 & 2005 & 2010 & $\begin{array}{c}\text { Variação } \\
\text { percentual } \\
\text { do } n^{\circ} \text { de } \\
\text { vagas* }^{*}\end{array}$ & $\begin{array}{c}\text { Variação } \\
\text { absoluta } \\
\text { do } n^{\circ} \text { de } \\
\text { vagas }\end{array}$ \\
\hline 1 & Bacharelado em geologia & 50 & 50 & 50 & 50 & 50 & 50 & 50 & $0,00 \%$ & 0 \\
\hline \multirow[t]{2}{*}{2} & Lic. em geociências e educação ambiental (2004) & $\neg$ & $\neg$ & $\neg$ & $\neg$ & $\neg$ & 40 & 40 & $\neg$ & 40 \\
\hline & Total & 50 & 50 & 50 & 50 & 50 & 90 & 90 & $80 \%$ & 40 \\
\hline
\end{tabular}

Tabela 6. Evolução dos cursos da USP por unidade de ensino e pesquisa, com indicação da progressão quinquenal do número de vagas e sua variação absoluta e percentual entre 1982 e 2010* (continuação)

\begin{tabular}{|c|c|c|c|c|c|c|c|c|c|c|}
\hline \multicolumn{2}{|c|}{ IME (1934/1969) } & \multirow{2}{*}{$\begin{array}{c}1982 \\
30\end{array}$} & \multirow{2}{*}{$\begin{array}{r}1985 \\
36\end{array}$} & \multirow{2}{*}{$\begin{array}{r}1990 \\
44\end{array}$} & \multirow{2}{*}{$\begin{array}{c}1995 \\
50\end{array}$} & \multirow{2}{*}{$\begin{array}{r}2000 \\
50\end{array}$} & \multirow{2}{*}{$\begin{array}{r}2005 \\
50\end{array}$} & \multirow{2}{*}{$\begin{array}{r}2010 \\
50\end{array}$} & \multirow{2}{*}{ 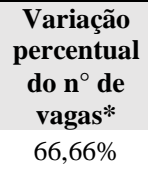 } & \multirow{2}{*}{$\begin{array}{c}\text { Variação } \\
\text { absoluta } \\
\text { no } \\
\text { período } \\
20\end{array}$} \\
\hline 1 & Bacharelado em ciência da computação & & & & & & & & & \\
\hline 3 & Estatística - bacharelado & 30 & 30 & 30 & $\neg$ & $\neg$ & 30 & 40 & $33,33 \%$ & 10 \\
\hline 3 & Matemática - bacharelado & 30 & 30 & 30 & $\neg$ & $\neg$ & 30 & 30 & $0,00 \%$ & 0 \\
\hline 4 & Matemática - licenciatura & 150 & 150 & 150 & 150 & 150 & 150 & 150 & $0,00 \%$ & 0 \\
\hline 5 & Matemática aplicada - bacharelado & 20 & 20 & 20 & $\neg$ & $\neg$ & 20 & 20 & $0,00 \%$ & 0 \\
\hline \multirow[t]{3}{*}{6} & Matemática aplicada e computacional (2002) & $\neg$ & $\neg$ & $\neg$ & $\neg$ & $\neg$ & 50 & 50 & $\neg$ & 50 \\
\hline & Matemática - ciclo básico & $\neg$ & $\neg$ & $\neg$ & 74 & 74 & $\neg$ & $\neg$ & $\neg$ & $\neg$ \\
\hline & Total & 260 & 246 & 254 & 274 & 150 & 330 & 340 & $30,76 \%$ & 80 \\
\hline \multicolumn{2}{|c|}{ IO ()1946/1951) } & 1982 & 1985 & 1990 & 1995 & 2000 & 2005 & 2010 & $\begin{array}{c}\text { Variação } \\
\text { percentual } \\
\text { do } n^{\circ} \text { de } \\
\text { vagas* }\end{array}$ & $\begin{array}{c}\text { Variação } \\
\text { absoluta } \\
\text { do } \text { n }^{\circ} \text { de } \\
\text { vagas }\end{array}$ \\
\hline \multirow[t]{2}{*}{1} & Bacharelado em oceanografia (2002) & $\neg$ & $\neg$ & $\neg$ & $\neg$ & $\neg$ & 40 & 40 & $\neg$ & 40 \\
\hline & Total & $\neg$ & $\neg$ & $\neg$ & $\neg$ & $\neg$ & 40 & 40 & $\neg$ & 40 \\
\hline
\end{tabular}


Tabela 6. Evolução dos cursos da USP por unidade de ensino e pesquisa, com indicação da progressão quinquenal do número de vagas e sua variação absoluta e percentual entre 1982 e 2010* (continuação)

\begin{tabular}{|c|c|c|c|c|c|c|c|c|c|c|}
\hline \multicolumn{2}{|c|}{ IP (1934/ 1969) } & 1982 & 1985 & 1990 & 1995 & 2000 & 2005 & 2010 & $\begin{array}{c}\text { Variação } \\
\text { percentual } \\
\text { do } \text { n }^{\circ} \text { de } \\
\text { vagas* }\end{array}$ & $\begin{array}{c}\text { Variação } \\
\text { absoluta } \\
\text { do } n^{\circ} \text { de } \\
\text { vagas }\end{array}$ \\
\hline \multirow[t]{2}{*}{1} & Psicologia & 70 & 70 & 70 & 70 & 70 & 70 & 70 & $0,00 \%$ & 0 \\
\hline & Total & 70 & 70 & 70 & 70 & 70 & 70 & 70 & $0,00 \%$ & 0 \\
\hline
\end{tabular}

\begin{tabular}{|c|c|c|c|c|c|c|c|c|c|c|}
\hline \multicolumn{2}{|c|}{ IQ (1934/1969) } & \multirow{2}{*}{$\begin{array}{c}1982 \\
\neg\end{array}$} & \multirow{2}{*}{$\begin{array}{l}1985 \\
\neg\end{array}$} & \multirow{2}{*}{$\begin{array}{l}1990 \\
\neg\end{array}$} & \multirow{2}{*}{$\begin{array}{l}1995 \\
\neg\end{array}$} & \multirow{2}{*}{$\begin{array}{l}2000 \\
\quad \neg\end{array}$} & \multirow{2}{*}{$\begin{array}{c}2005 \\
30\end{array}$} & \multirow{2}{*}{$\begin{array}{r}2010 \\
30\end{array}$} & \multirow{2}{*}{$\begin{array}{c}\text { Variação } \\
\text { percentual } \\
\text { do } \mathbf{n}^{\circ} \text { de } \\
\text { vagas* } \\
\neg\end{array}$} & \multirow{2}{*}{$\begin{array}{c}\text { Variação } \\
\text { absoluta } \\
\text { do } n^{\circ} \text { de } \\
\text { vagas } \\
30\end{array}$} \\
\hline 1 & Bacharelado em química ambiental (2003) & & & & & & & & & \\
\hline 2 & Licenciatura em química (2003) & $\neg$ & $\neg$ & $\neg$ & $\neg$ & $\neg$ & 30 & 30 & $\neg$ & 30 \\
\hline \multirow[t]{2}{*}{3} & Química & 60 & 60 & 60 & 60 & 60 & 60 & 60 & $0,00 \%$ & 0 \\
\hline & Total & 60 & 60 & 60 & 60 & 60 & 120 & 120 & $100 \%$ & 60 \\
\hline \multicolumn{2}{|c|}{ IQSC (1971/1994) } & 1982 & 1985 & 1990 & 1995 & 2000 & 2005 & 2010 & $\begin{array}{c}\text { Variação } \\
\text { percentual } \\
\text { do } n^{\circ} \text { de } \\
\text { vagas* }^{*}\end{array}$ & $\begin{array}{c}\text { Variação } \\
\text { absoluta } \\
\text { do } \text { n }^{\circ} \text { de } \\
\text { vagas }\end{array}$ \\
\hline \multirow[t]{2}{*}{1} & Química bacharelado & $\neg$ & $\neg$ & $\neg$ & 40 & 40 & 60 & 60 & $\neg$ & 40 \\
\hline & Total & $\neg$ & $\neg$ & $\neg$ & 40 & 40 & 60 & 60 & $\neg$ & 40 \\
\hline \multicolumn{2}{|c|}{ IRI (2002) } & 1982 & 1985 & 1990 & 1995 & 2000 & 2005 & 2010 & $\begin{array}{c}\text { Variação } \\
\text { percentual } \\
\text { do } n^{\circ} \text { de } \\
\text { vagas* }^{*}\end{array}$ & $\begin{array}{c}\text { Variação } \\
\text { absoluta } \\
\text { no } \\
\text { período }\end{array}$ \\
\hline \multirow[t]{2}{*}{1} & Bacharelado em relações internacionais (2002) & $\neg$ & $\neg$ & $\neg$ & $\neg$ & $\neg$ & 60 & 60 & $\neg$ & 60 \\
\hline & Total & $\neg$ & $\neg$ & $\neg$ & $\neg$ & $\neg$ & 60 & 60 & $\neg$ & 60 \\
\hline
\end{tabular}

\section{PROGRAMAS CONJUNTOS (INTERUNIDADES)}

\begin{tabular}{|c|c|c|c|c|c|c|c|c|c|c|}
\hline \multicolumn{2}{|c|}{ FFCLRP/ FMRP } & 1982 & 1985 & 1990 & 1995 & 2000 & 2005 & 2010 & $\begin{array}{c}\text { Variação } \\
\text { percentual } \\
\text { do } \mathbf{n}^{\circ} \text { de } \\
\text { vagas* }^{*}\end{array}$ & $\begin{array}{c}\text { Variação } \\
\text { absoluta } \\
\text { do } n^{\circ} \text { de } \\
\text { vagas }\end{array}$ \\
\hline \multirow[t]{2}{*}{1} & Informática biomédica (2003) & $\neg$ & $\neg$ & $\neg$ & $\neg$ & $\neg$ & 40 & 40 & $\neg$ & 40 \\
\hline & Total & $\neg$ & $\neg$ & $\neg$ & $\neg$ & $\neg$ & 40 & 40 & $\neg$ & 40 \\
\hline \multicolumn{2}{|c|}{ IFSC/ IQSC/ ICMC } & 1982 & 1985 & 1990 & 1995 & 2000 & 2005 & 2010 & $\begin{array}{c}\text { Variação } \\
\text { percentual } \\
\text { do } n^{\circ} \text { de } \\
\text { vagas* }\end{array}$ & $\begin{array}{c}\text { Variação } \\
\text { absoluta } \\
\text { do } n^{\circ} \text { de } \\
\text { vagas }\end{array}$ \\
\hline \multirow[t]{2}{*}{1} & Licenciatura em ciências exatas (1993) & $\neg$ & $\neg$ & $\neg$ & 40 & 50 & 50 & 50 & $\neg$ & 50 \\
\hline & Total & $\neg$ & $\neg$ & $\neg$ & 40 & 50 & 50 & 50 & $\neg$ & 50 \\
\hline \multicolumn{2}{|c|}{ EESC/ ICMC } & 1982 & 1985 & 1990 & 1995 & 2000 & 2005 & 2010 & $\begin{array}{c}\text { Variação } \\
\text { percentual } \\
\text { do } n^{\circ} \text { de } \\
\text { vagas* }\end{array}$ & $\begin{array}{c}\text { Variação } \\
\text { absoluta } \\
\text { do } n^{\circ} \text { de } \\
\text { vagas }\end{array}$ \\
\hline \multirow[t]{2}{*}{1} & Engenharia da computação (2009) & $\neg$ & $\neg$ & $\neg$ & $\neg$ & $\neg$ & $\neg$ & 50 & $\neg$ & 50 \\
\hline & Total & $\neg$ & $\neg$ & $\neg$ & $\neg$ & $\neg$ & $\neg$ & 50 & $\neg$ & 50 \\
\hline \multicolumn{2}{|c|}{ FEARP/ FFCLRP } & 1982 & 1985 & 1990 & 1995 & 2000 & 2005 & 2010 & $\begin{array}{c}\text { Variação } \\
\text { percentual } \\
\text { do } n^{\circ} \text { de } \\
\text { vagas* }\end{array}$ & $\begin{array}{c}\text { Variação } \\
\text { absoluta } \\
\text { do } n^{\circ} \text { de } \\
\text { vagas }\end{array}$ \\
\hline \multirow[t]{2}{*}{1} & Matemática aplicada a negócios (2009) & $\neg$ & $\neg$ & $\neg$ & $\neg$ & $\neg$ & $\neg$ & 45 & $\neg$ & 45 \\
\hline & Total & $\neg$ & $\neg$ & $\neg$ & $\neg$ & $\neg$ & $\neg$ & 45 & $\neg$ & 45 \\
\hline
\end{tabular}


Tabela 6. Evolução dos cursos da USP por unidade de ensino e pesquisa, com indicação da progressão quinquenal do número de vagas e sua variação absoluta e percentual entre 1982 e 2010 * (continuação)

\begin{tabular}{|c|c|c|c|c|c|c|c|c|c|}
\hline TOTAL USP & 1982 & 1985 & 1990 & 1995 & 2000 & 2005 & 2010 & $\begin{array}{c}\text { Variação } \\
\text { percentual } \\
\text { do } n^{\circ} \text { de } \\
\text { vagas* }\end{array}$ & $\begin{array}{c}\text { Variação } \\
\text { absoluta } \\
\text { do } n^{\circ} \text { de } \\
\text { vagas }\end{array}$ \\
\hline Unidades de ensino e pesquisa & 6268 & 6444 & 6802 & 6887 & 7125 & 9477 & 10437 & $66,51 \%$ & 4169 \\
\hline Programas conjuntos (interunidades) & 0 & 0 & 0 & 40 & 50 & 90 & 185 & $\neg$ & 185 \\
\hline Total & 6268 & 6444 & 6802 & 6927 & 7175 & 9567 & 10622 & $69,46 \%$ & 4354 \\
\hline
\end{tabular}

Fonte: Anuário Estatístico

Elaboração: própria

Observação: cursos criados depois de 1982 são acompanhados pelo ano de fundação entre parênteses. Os cursos grafados em cinza foram extintos no período.

Os dados permitem mostrar, em primeiro lugar, que os novos cursos e unidades da USP cresceram de modo contínuo a partir de 1982. Em termos quantitativos, é possível observar que as unidades criadas ou incorporadas à USP a partir de $1970^{187}$ foram as que mais abriram cursos e vagas a partir de 1982 a ponto de representar, em 2012, 28,94\% das vagas da USP. Em 1982, as novas unidades respondiam por apenas $5,10 \%$ do total de vagas. Foram essas novas unidades que protagonizaram, ainda, a criação de cursos interunidades, que surgiram no começo da década de 1990 e hoje disponibilizam, ao todo, 185 vagas de graduação, a maior parte delas no interior do estado de São Paulo.

Essa observação já aponta para um outro aspecto importante. Para além das unidades novas, apresentaram um forte dinamismo também as unidades sediadas fora da cidade de São Paulo, como a Escola de Engenharia de São Carlos (EESC), a Escola Superior de Agricultura Luiz de Queiroz (ESALQ) de Piracicaba e a Faculdade de Medicina de Ribeirão Preto (FMRP). O processo de crescimento relativamente acelerado das unidades do interior do estado fez com que o seu peso no total de vagas oferecidas pela USP aumentasse significativamente no período

\footnotetext{
187 São elas: Instituto de Matemática e Ciência da Computação de São Carlos (ICMC/1971); Faculdade de Filosofia, Ciências e Letras de Ribeirão Preto (FFCLRP/1974); Faculdade de Ciências Farmacêuticas de Ribeirão Preto (FCFRP/1975); Faculdade de Odontologia de Ribeirão Preto (FORP/1983); Faculdade de Zootecnia e Engenharia de Alimentos (FZEA/1992); Instituto de Física de São Carlos (IFSC/1994); Instituto de Química de São Carlos (IQSC/1994); Faculdade de Economia, Administração e Contabilidade de Ribeirão Preto (FEARP/2002); Instituto de Relações Internacionais (IRI/2002); Escola de Artes, Ciências e Humanidades (EACH/2004); Escola de Engenharia de Lorena (EEL/2006); Escola de Educação Física e Esportes de Ribeirão Preto (EEFERP/2007); Faculdade de Direito de Ribeirão Preto (FDRP/2007).
} 
considerado. Entre 1982 e 2010, a participação do interior no total de vagas oferecidas pela USP praticamente dobrou, passando de 15,63\% em 1982 para 30,99\% do total, em 2010. Em termos absolutos, o número de vagas variou de 980 em 1982 para 3.260 em 2010, um crescimento de $232,65 \%$. Paralelamente, as vagas sediadas na capital do estado cresceram apenas 39,22\% entre 1982 e 2010, passando de 5.288 para 7.322 vagas. Mesmo em termos absolutos, a abertura de vagas no interior foi maior do que na capital: enquanto o interior abriu 2.280 vagas, a capital inaugurou, no mesmo período, 2.034 vagas, quase metade delas concentradas na EACH, sediada na zona leste. Em síntese, ainda que as maiores unidades da USP, como a FFLCH (1669 vagas), a EACH (1020 vagas), a EP/Poli (750 vagas) e a FEA (590 vagas), permaneçam sediadas na cidade de São Paulo, existe uma clara tendência, ao longo dos últimos anos, de expansão mais acelerada das unidades do interior, o que expressa o processo de diversificação, inclusive geográfica, da instituição. Esse crescimento do interior tem reflexos sobre a estrutura de poder da USP, cujo indicador mais imediato é a unidade de origem dos reitores eleitos. Assim, dos dez reitores eleitos a partir de 1982, quatro são oriundos de unidades sediadas no interior de São Paulo ${ }^{188}$.

Outro ponto importante, que também pode ser observado na tabela anterior sobre a evolução das vagas da USP, é que os cursos criados a partir de 1982 não são apenas ligados, em geral, a novas unidades ou a unidades sediadas no interior do estado como são, também, predominantemente voltados a novas áreas de formação profissional. De modo a tornar essa informação mais visível, a tabela abaixo apresenta os cursos criados na USP a partir de 1980 segundo a unidade a que se encontram ligados, o que permite visualizar os novos cursos da USP.

\footnotetext{
${ }^{188}$ São eles: Roberto Leal Lobo e Silva (Instituto de Física de São Carlos), Adolpho José Melfi (Esalq), Suely Vilela Sampaio (Faculdade de Ciências Farmacêuticas de Ribeirão Preto) e Marco Antônio Zago (Faculdade de Medicina de Ribeirão Preto). Considerando ainda, enquanto reitor eleito pelo Conselho Universitário, o professor do Instituto de Física de São Carlos, Glaucius Oliva, preterido pelo então governador José Serra, que indicou o segundo mais votado, João Grandino Rodas, as unidades do interior elegeram cinco dos dez reitores eleitos a partir de 1982. Para os dados completos, ver tabela 11 neste mesmo capítulo.
} 
Tabela 7. Síntese dos cursos (ativos) criados a partir de 1982 com a respectiva unidade e ano de criação

Curso (ano de criação)

Ciências da atividade física (2005)

Gerontologia (2005)

Gestão ambiental (2005)

Gestão em política pública (2005)

Lazer e turismo (2005)

Licenciatura em ciências da natureza (2005)

Marketing (2005)

Obstetrícia 2005)

Sistemas da informação (2005)

10 Têxtil e moda (2005)

11 Artes cênicas - bacharelado (2000)

12 Artes plásticas (1996)

13 Curso superior de audiovisual (2000)

14 Música (1996)

15 Música Ribeirão Preto (2002)

16 Bacharelado em esportes (1992)

17 Educação Física - bacharelado (1992)

18 Educação física (2009)

19

Engenharia bioquímica (2006)

Engenharia de materiais (2006)

Engenharia industrial química (2006)

22

Engenharia química (2006)

Arquitetura e urbanismo (1985)

Engenharia aeronáutica (2002)

Engenharia ambiental (2003)

Engenharia de materiais e manufatura (2010)

Engenharia de produção mecânica (1983)

Engenharia elétrica (1983)

Engenharia mecânica (1986)
Unidade (ano de fundação)

EACH (2004)

EACH (2004)

EACH (2004)

EACH (2004)

EACH (2004)

EACH (2004)

EACH (2004)

EACH (2004)

EACH (2004)

EACH (2004)

ECA (1966)

ECA (1966)

ECA (1966)

ECA (1966)

ECA (1966)

EEFE (1969)

EEFE (1969)

EEFERP (2009)

EEL (2006)

EEL (2006)

EEL (2006)

EEL (2006)

IAU (2010)

EESC (1948)

EESC (1948)

EESC (1948)

EESC (1948)

EESC (1948)

EESC (1948) 
Tabela 7. Síntese dos cursos criados a partir de 1982 com a respectiva unidade e ano de criação (continuação)

\section{Curso (ano de criação)}

Engenharia elétrica (2008)

Engenharia mecânica (2008)

Engenharia química (2008)

Ciências biológicas (2002)

Ciências econômicas (2001)

Gestão ambiental (2002)

Desing (2006)

Direito (2008)

Pedagogia (2002)

Fisioterapia (2003)

Fonoaudiologia (2003)

Terapia ocupacional (2003)

Fonoaudiologia (1990)

Geofísica (1984)

Astronomia (2009)
Engenharia mecatrônica (2003)

Engenharia de produção (2008)

Engenharia mecatrônica (2008)

Ciências dos alimentos (2001)

Bacharelado em ciências atuariais (1984)

Administração de empresas (1992)

Bacharelado em ciências contábeis (1992)

Bacharelado em ciências econômicas (1992)

Economia empresarial e controladoria (2007)

Bac. em ciência da informação e da documentação (2003)

Bac. em ciência da informação e da documentação (2003)

Bacharelado em física médica (2000)

Licenciatura em química (2003)

Ciências médicas - ciclo básico (1996)

Nutrição e metabolismo (2003)

Engenharia de alimentos (2006)

Engenharia de biossistemas (2009)
Unidade (ano de fundação)

EESC (1948)

EP (1893)

EP (1893)

EP (1893)

EP (1893)

EP (1893)

ESALQ (1901)

ESALQ (1901)

ESALQ (1901)

ESALQ (1901)

FAU (1948)

FDRP (2007)

FEA (1946)

FEARP (2002)

FEARP (2002)

FEARP (2002)

FEARP (2002)

FFCLRP (1974)

FFCLRP (1974)

FFCLRP (1974)

FFCLRP (1974)

FFCLRP (1974)

FMRP (1948)

FMRP (1948)

FMRP (1948)

FMRP (1948)

FMRP (1948)

FOB (1948)

FZEA (1992)

FZEA (1992)

FZEA (1992)

IAG (1946)

IAG (1946) 


\begin{tabular}{|c|c|c|}
\hline \multicolumn{2}{|c|}{ Curso (ano de criação) } & \multirow{2}{*}{$\begin{array}{l}\begin{array}{l}\text { Unidade (ano de } \\
\text { fundação) }\end{array} \\
\text { ICMC (1971) }\end{array}$} \\
\hline 63 & Bacharelado em matemática e computação científica (1999) & \\
\hline 64 & Bacharelado em informática (1999) & ICMC (1971) \\
\hline 65 & Bacharelado em estatística (2009) & ICMC (1971) \\
\hline 66 & Bacharelado em ciência da computação (1984) & ICMC (1971) \\
\hline 67 & Bacharelado em ciências físicas e biomoleculares (2007) & IFSC (1994) \\
\hline 68 & Física computacional (2007) & IFSC (1994) \\
\hline 69 & Licenciatura em geociências e educação ambiental (2004) & IG (1969) \\
\hline 70 & Matemática aplicada e computacional (2002) & IME (1969) \\
\hline 71 & Bacharelado em oceanografia (2002) & IO (1951) \\
\hline 72 & Bacharelado em química ambiental (2003) & IQ (1969) \\
\hline 73 & Licenciatura em química (2003) & IQ (1969) \\
\hline 74 & Bacharelado em relações internacionais (2002) & IRI (2002) \\
\hline 75 & Ciências fundamentais aplicadas à saúde (2005) & ICB (1969) \\
\hline 76 & Informática biomédica (2003) & FFCLRP/ FMRP \\
\hline 77 & Licenciatura em ciências exatas (1993) & IFSC/ IQSC/ ICMC \\
\hline 78 & Engenharia da computação (2009) & EESC/ ICMC \\
\hline 79 & Matemática aplicada a negócios (2009) & FEARP/ FFCLRP \\
\hline 80 & Curso experimental de ciências moleculares (1992) & INTERUNIDADES \\
\hline
\end{tabular}

Fonte: Anuário Estatístico

Elaboração: própria ${ }^{189}$

A tabela acima permite enfatizar não apenas o caráter profissionalizante das carreiras criadas na USP mas, sobretudo, o predomínio do que se convencionou chamar "novas profissões". Mesmo quando os cursos criados são ligados a áreas "tradicionais", sejam elas científicas ou profissionais, eles apresentam-se como novas modalidades, mais especializadas e direcionadas. É o caso, por exemplo, da engenharia, que se desdobrou em diversas especializações como bioquímica, ambiental, aeronáutica, de materiais, de biossistemas, entre outras. A economia se tornou economia empresarial, associando-se à área de controladoria. A

${ }^{189} \mathrm{O}$ total de cursos apresentados aqui é menor do que o número indicado na tabela 3 porque, propositalmente, não estou considerando aqui a variação vespertino/noturno porque não é importante neste caso. 
matemática também se especializou, tornando-se aplicada à computação ou aos negócios. Os novos cursos de física e de química também de desdobram em novas especializações, como física médica, computacional, geofísica e química ambiental. Quando não são mais especializados, os cursos científicos criados a partir de 1982 voltam-se à formação de professores, como é possível supor pela expansão das licenciaturas, considerada por alguns, uma formação “profissionalizante". Por fim, os poucos cursos profissionais tradicionais criados nas últimas décadas localizam-se quase que exclusivamente no interior do estado. É o caso, por exemplo, do curso de direito de Ribeirão Preto, de arquitetura de São Carlos e de economia, contabilidade e administração de Ribeirão Preto.

Em síntese, enquanto as novas unidades sediadas sobretudo no interior do estado cresceram em um ritmo acelerado desde pelo menos 1982, as unidades mais tradicionais da USP, sediadas na capital, apresentaram um padrão de crescimento bem menos dinâmico. Nesse sentido, considerando os dados das tabelas 6 e 7 em conjunto, podemos notar que as unidades mais tradicionais da cidade de São Paulo, sejam elas do polo profissional ou do polo científico, praticamente não criaram novos cursos e vagas a partir de 1982 e, quando o fizeram, não foi nos seus cursos mais reconhecidos e prestigiados, que permaneceram, portanto, estagnados do ponto de vista da ampliação de vagas. É o caso paradigmático dos cursos de direito, da Faculdade de Direito do Largo São Francisco (FD), de medicina, da Faculdade de Medicina de São Paulo (FM), de odontologia, da Faculdade de Odontologia (FO), de engenharia civil, da Escola Politécnica (EP/Poli), de arquitetura, da Faculdade de Arquitetura e Urbanismo (FAU), de Economia, da Faculdade de Economia, Administração e Contabilidade (FEA) e de Psicologia, do Instituto de Psicologia (IP), que praticamente não expandiram suas vagas ao longo dos últimos trinta anos, período que, vale dizer, foi marcado pelo aumento da pressão social pela abertura de novas vagas no ensino superior público, sobretudo nas profissões liberais 
mais valorizadas socialmente (cf. Cunha, 2004; Guimarães, 2002 e 2003) ${ }^{190}$. O mesmo ocorreu, embora em menor escala, com os cursos científicos de caráter disciplinar bem definido como os cursos de física, do Instituto de Física (IF), de ciências biológicas, do Instituto de Biociências (IB), de química, do Instituto de Química (IQ), e de matemática, do Instituto de Matemática e Estatística (IME). Mesmo os cursos das áreas de humanas mais tradicionais, como história, geografia, letras, filosofia e ciências sociais da Faculdade de Filosofia, Letras e Ciências Humanas (FFLCH), pouco se expandiram, além de permanecerem como os únicos cursos disciplinares da USP sem homólogos no interior do estado ${ }^{191}$. A tabela abaixo - que apresenta os cursos já existentes em 1982, segundo o valor crescente da expansão das suas matrículas desde então - permite reconhecer com clareza esse processo que contribuiu para aumentar a concorrência nas formações mais tradicionais, elitizando ainda mais esses cursos e unidades.

\begin{tabular}{|c|c|c|c|}
\hline \multicolumn{2}{|c|}{ Curso } & \multirow{2}{*}{$\begin{array}{l}\text { Unidade } \\
\text { EP/ POLI }\end{array}$} & \multirow{2}{*}{$\begin{array}{c}\begin{array}{c}\text { Variação } \\
\text { percentual }\end{array} \\
(\mathbf{1 9 8 2}-\mathbf{2 0 1 0}) \\
-70,00 \%\end{array}$} \\
\hline 1 & Engenharia civil & & \\
\hline 2 & Engenharia civil & EESC & $-66,66 \%$ \\
\hline 3 & Educação artística - habilitação artes cênicas & ECA & $-50,00 \%$ \\
\hline 4 & Meteorologia & IAG & $-25,00 \%$ \\
\hline 5 & Letras - diferentes habilitações & FFLCH & $-0,11 \%$ \\
\hline 6 & Comunicação social - habilitação editoração & ECA & $0,00 \%$ \\
\hline 7 & Enfermagem & $\mathrm{EE}$ & $0,00 \%$ \\
\hline 8 & Enfermagem & EERP & $0,00 \%$ \\
\hline 9 & Agronomia (Engenharia agronômica) & ESALQ & $0,00 \%$ \\
\hline
\end{tabular}

\footnotetext{
${ }^{190}$ Um exemplo interessante nesse sentido ocorreu durante a criação da EACH. Enquanto idealizava a nova unidade, a equipe designada pela reitoria da USP para isso realizou uma pesquisa, nas escolas públicas da zona leste da capital interrogando os alunos sobre quais cursos eles gostariam que fossem criados na nova USP. A resposta, como era de se esperar, girou em torno das profissões liberais tradicionais, em especial medicina, engenharia e direito, consideradas, por sua antiguidade e tradição, as "profissões imperiais" brasileiras (Coelho, 1999, p.71ss).

${ }^{191}$ Praticamente todos os cursos de disciplinas mais básicas da USP possuem homólogos no interior, como física, química, ciências biológicas, matemática, estatística e mesmo pedagogia. O mesmo não ocorre com os cursos mais tradicionais da área de filosofia, letras e ciências humanas sediados na FFLCH.
} 
Tabela 8. Cursos já existentes em 1982, hierarquizados segundo a variação percentual do número de vagas no período (continuação)

\begin{tabular}{|c|c|c|c|}
\hline \multicolumn{2}{|c|}{ Curso } & \multirow{2}{*}{$\begin{array}{l}\text { Unidade } \\
\text { FAU }\end{array}$} & \multirow{2}{*}{$\begin{array}{c}\begin{array}{c}\text { Variação } \\
\text { percentual }\end{array} \\
(\mathbf{1 9 8 2}-\mathbf{2 0 1 0})\end{array}$} \\
\hline 10 & Arquitetura & & \\
\hline 11 & Economia (ciências econômicas) & FEA & $0,00 \%$ \\
\hline 12 & Biologia (ciências biológicas) & FFCLRP & $0,00 \%$ \\
\hline 13 & Psicologia & FFCLRP & $0,00 \%$ \\
\hline 14 & Fisioterapia & FM & $0,00 \%$ \\
\hline 15 & Medicina & $\mathrm{FM}$ & $0,00 \%$ \\
\hline 16 & Terapia ocupacional & FM & $0,00 \%$ \\
\hline 17 & Medicina veterinária & FMVZ & $0,00 \%$ \\
\hline 18 & Odontologia & $\mathrm{FO}$ & $0,00 \%$ \\
\hline 19 & Odontologia & FOB & $0,00 \%$ \\
\hline 20 & Odontologia & FORP & $0,00 \%$ \\
\hline 21 & Biologia (ciências biológicas) & IB & $0,00 \%$ \\
\hline 22 & Matemática & ICMC & $0,00 \%$ \\
\hline 23 & Bacharelado em geologia & IG & $0,00 \%$ \\
\hline 24 & Matemática - bacharelado & IME & $0,00 \%$ \\
\hline 25 & Matemática - licenciatura & IME & $0,00 \%$ \\
\hline 26 & Matemática aplicada - bacharelado & IME & $0,00 \%$ \\
\hline 27 & Psicologia & IP & $0,00 \%$ \\
\hline 28 & Química & IQ & $0,00 \%$ \\
\hline 29 & Direito & FD & $2,20 \%$ \\
\hline 30 & Física - bacharelado e licenciatura & IF & $3,80 \%$ \\
\hline 31 & História - bacharelado e licenciatura & FFLCH & $3,84 \%$ \\
\hline 32 & Ciências sociais - bacharelado e licenciatura & FFLCH & $5,00 \%$ \\
\hline 33 & Filosofia - bacharelado e licenciatura & FFLCH & $6,25 \%$ \\
\hline 34 & Geografia - bacharelado e licenciatura & FFLCH & $6,25 \%$ \\
\hline 35 & Farmácia-bioquímica & FCF & $11,11 \%$ \\
\hline 36 & Biblioteconomia & ECA & $16,60 \%$ \\
\hline 37 & Administração & FEA & $16,60 \%$ \\
\hline 38 & Estatística - bacharelado & IME & $33,33 \%$ \\
\hline 39 & Comunicação Social - habilitação jornalismo & ECA & $37,50 \%$ \\
\hline 40 & Pedagogia & FE & $50,00 \%$ \\
\hline 41 & Química & FFCLRP & $50,00 \%$ \\
\hline 42 & Engenharia florestal & ESALQ & $60,00 \%$ \\
\hline
\end{tabular}




\begin{tabular}{|c|c|c|c|}
\hline \multicolumn{4}{|c|}{$\begin{array}{l}\text { Tabela 8. Cursos já existentes em 1982, hierarquizados segundo a variação percentual do } \\
\text { número de vagas no período (continuação) }\end{array}$} \\
\hline \multicolumn{2}{|c|}{ Curso } & \multirow{2}{*}{$\begin{array}{l}\text { Unidade } \\
\text { USP }\end{array}$} & \multirow{2}{*}{$\begin{array}{c}\begin{array}{c}\text { Variação } \\
\text { percentual } \\
(1982-2010)\end{array} \\
66,51 \%\end{array}$} \\
\hline & Variação do total de vagas da USP & & \\
\hline 44 & Comunicação social - habilitação pub. e propaganda & ECA & $66,60 \%$ \\
\hline 45 & Fonoaudiologia & FM & $66,60 \%$ \\
\hline 46 & Ciências contábeis & FEA & $66,66 \%$ \\
\hline 47 & Ciência da computação - bacharelado & IME & $66,66 \%$ \\
\hline 48 & Turismo & $\mathrm{ECA}$ & $100,00 \%$ \\
\hline 49 & Física & IFSC & $100,00 \%$ \\
\hline 50 & Comunicação Social - habilitação relações públicas & ECA & $233,33 \%$ \\
\hline 51 & Nutrição & FSP & $300,00 \%$ \\
\hline
\end{tabular}

A tabela acima foi construída de modo a relacionar a variação percentual do número de vagas dos cursos da USP já existentes em 1982 com o crescimento do conjunto da USP entre 1982 e 2010. Essa perspectiva relacional, inerente a uma abordagem estrutural, demonstra de modo explícito como o crescimento da USP se deu, sobretudo, pela criação de novos cursos ou pela expansão de cursos em áreas profissionais relativamente novas. Nesse sentido, é possível notar que, dos 51 cursos existentes já em 1982, 43 cresceram abaixo da média da USP. Dentre os poucos que cresceram acima da média da USP, existe um forte predomínio de cursos profissionais, em especial em carreiras relativamente novas e mais especializadas, como publicidade e propaganda, fonoaudiologia, contabilidade, computação, turismo, relações públicas e nutrição. Nenhum curso já existente no começo da década de 1980 e voltado às profissões liberais tradicionais, como as que constituíam a base das estatísticas do MEC até 1971 - quais sejam, administração, economia, agricultura, arquitetura e urbanismo, direito, enfermagem, medicina, medicina veterinária, odontologia e serviço social - cresceram acima da média da USP. Dentre essas formações profissionais de prestígio, a que mais cresceu foi a 
administração, da FEA, que aumentou suas vagas em 16,6\% a partir de 1982, acompanhando um movimento geral de expansão da área de gestão/ administração, como visto no capítulo 2.

O baixo crescimento dos cursos tradicionais da USP, sediados nas unidades mais prestigiosas da cidade de São Paulo, contribuiu para aumentar a concorrências pelas suas vagas, tornando-os mais seletivos e, logo, elitizados. As duas tabelas abaixo ilustram a evolução da relação candidato/vaga para as diferentes carreiras ${ }^{192}$ da USP entre 1999 e $2009^{193}$, apresentando, ainda, as unidades hierarquizadas pelo percentual crescente de candidatos por vaga, ou seja, das menos para as mais concorridas, o que permite enxergar como elas variam em relação à média geral da USP.

\begin{tabular}{|c|c|c|c|c|}
\hline \multicolumn{5}{|c|}{$\begin{array}{l}\text { Tabela 9. Carreiras da USP hierarquizadas pela relação candidato/vaga a partir dos } \\
\text { inscritos no vestibular da Fuvest em } 1999\end{array}$} \\
\hline Nome & & Vagas & Inscritos & Relação C/V \ \\
\hline 1. & $\begin{array}{l}\text { Licenciatura em Ciências Exatas (IFSC/IQSC/ICMC - } \\
\text { São Carlos) }\end{array}$ & 40 & 126 & 3.15 \\
\hline 2. & Química (IQSC - São Carlos) & 40 & 137 & 3.43 \\
\hline 3. & Física/Meteorologia (IF/IAG - São Paulo) & 270 & 1.003 & 3.71 \\
\hline 4. & Ciências da Terra (IG - São Paulo) & 70 & 267 & 3.81 \\
\hline 5. & Filosofia (FFLCH - São Paulo) & 170 & 660 & 3.88 \\
\hline 6. & $\begin{array}{l}\text { Licenciatura em Matemática/Física (IF/IME - São } \\
\text { Paulo) }\end{array}$ & 260 & 1.074 & 4.13 \\
\hline 7. & Química (FFLCRP - Ribeirão Preto) & 50 & 222 & 4.44 \\
\hline 8. & Geografia (FFLCH - São Paulo) & 160 & 766 & 4.79 \\
\hline 9. & Letras (FFLCH - São Paulo) & 849 & 4.179 & 4.92 \\
\hline & Economia Agroindustrial (ESALQ - Piracicaba) & 20 & 113 & 5.65 \\
\hline 11. & História (FFLCH - São Paulo) & 270 & 1.526 & 5.65 \\
\hline
\end{tabular}

192 "Carreiras" é como a Fuvest denomina as opções de inscrição no vestibular. Nesse sentido, é importante notar que as carreiras nem sempre correspondem aos cursos ou às unidades, como é possível notar em alguns casos apresentados na tabela como, por exemplo, a carreira que reúne a física, do IF, e a meteorologia, do IAG. Ou a que reunia, em 1999, a engenharia da Poli e as ciências exatas do IME.

193 Não foi possível ter acesso a relação candidato/vaga para os anos anteriores a 1999, conforme é possível constatar em: < http://www.fuvest.br/>. Além disso, é preciso notas que as opções de inscrição para o vestibular da Fuvest nem sempre coincidem com os cursos da USP porque eles estão, muitas vezes, agregados por carreira de inscrição. Isso não prejudica, no entanto, a apreensão da informação essencial contida da tabela. 


\begin{tabular}{|c|c|c|c|}
\hline \multicolumn{4}{|c|}{$\begin{array}{l}\text { Tabela 9. Carreiras da USP hierarquizadas pela relação candidato/vaga a partir dos } \\
\text { inscritos no vestibular da Fuvest em } 1999 \text { (continuação) }\end{array}$} \\
\hline Nome & Vagas & Inscritos & Relação C/V 4 \\
\hline 12. Ciências Sociais (FFLCH - São Paulo) & 210 & 1.257 & 5.99 \\
\hline 13. Engenharia Agronômica (ESALQ - Piracicaba) & 200 & 1.286 & 6.43 \\
\hline 14. Química (IQ - São Paulo) & 60 & 394 & 6.57 \\
\hline 15. Engenharia Florestal (ESALQ - Piracicaba) & 40 & 285 & 7.13 \\
\hline 16. Ciências Contábeis (FEA - Ribeirão Preto) & 40 & 329 & 8.23 \\
\hline 17. Enfermagem (EE - São Paulo) & 80 & 703 & 8.79 \\
\hline 18. Engenharia Civil (EESC - São Carlos) & 60 & 531 & 8.85 \\
\hline 19. Engenharia e Ciências Exatas (EP/IME -São Paulo) & 904 & 8.609 & 9.52 \\
\hline 20. Biblioteconomia (ECA - São Paulo) & 30 & 295 & 9.83 \\
\hline 21. Economia (FEA - Ribeirão Preto) & 40 & 423 & 10.58 \\
\hline 22. Ciências Contábeis (FEA - São Paulo) & 140 & 1.544 & 11.03 \\
\hline 23. Economia (FEA - São Paulo) & 180 & 2.013 & 11.18 \\
\hline 24. Artes Cênicas - Licenciatura (ECA - São Paulo) & 10 & 112 & 11.20 \\
\hline 25. Música (ECA - São Paulo) & 30 & 338 & 11.27 \\
\hline 26. Fonoaudiologia (FOB - Bauru) & 25 & 300 & 12.00 \\
\hline 27. Pedagogia (FE - São Paulo) & 120 & 1.474 & 12.28 \\
\hline 28. Zootecnia (FZEA - Pirassununga) & 30 & 384 & 12.80 \\
\hline 29. Esporte (EEFE - São Paulo) & 50 & 660 & 13.20 \\
\hline Total de carreiras da USP & 7.429 & 101.242 & 13.63 \\
\hline 30. Odontologia (FOB - Bauru) & 50 & 688 & 13.76 \\
\hline 31. Computação (ICMC - São Carlos) & 150 & 2.095 & 13.97 \\
\hline 32. Ciências Biológicas (FM - Ribeirão Preto) & 40 & 596 & 14.90 \\
\hline 33. Artes Plásticas (ECA - São Paulo) & 30 & 449 & 14.97 \\
\hline 34. Ciências Biológicas (IB - São Paulo) & 180 & 2.717 & 15.09 \\
\hline 35. Fonoaudiologia (FM - São Paulo) & 58 & 919 & 15.84 \\
\hline 36. Farmácia - Bioquímica (FCF - São Paulo) & 135 & 2.147 & 15.90 \\
\hline
\end{tabular}


Tabela 9. Carreiras da USP hierarquizadas pela relação candidato/vaga a partir dos inscritos no vestibular da Fuvest em 1999 (continuação)

\begin{tabular}{|c|c|c|c|c|}
\hline Nome & & Vagas & Inscritos & Relação C/V 4 \\
\hline & Relações Públicas (ECA - São Paulo) & 45 & 722 & 16.04 \\
\hline 38. & Odontologia (FORP - Ribeirão Preto) & 80 & 1.347 & 16.84 \\
\hline 39. & Terapia Ocupacional (FM - São Paulo) & 55 & 943 & 17.15 \\
\hline 40. & Farmácia - Bioquímica (FCFRP - Ribeirão Preto) & 50 & 866 & 17.32 \\
\hline 41. & Engenharia (EESC - São Carlos) & 130 & 2.287 & 17.59 \\
\hline 42. & Odontologia (FO - São Paulo) & 133 & 2.484 & 18.68 \\
\hline 43. & Arquitetura (FAU - São Paulo) & 150 & 2.849 & 18.99 \\
\hline 44. & Arquitetura (EESC - São Carlos) & 30 & 585 & 19.50 \\
\hline 45. & Administração (FEA - Ribeirão Preto) & 40 & 787 & 19.68 \\
\hline 46. & Psicologia (FFCLRP - Ribeirão Preto) & 80 & 1.772 & 22.15 \\
\hline 47. & Psicologia (IP - São Paulo) & 70 & 1.734 & 24.77 \\
\hline & Cinema e Vídeo (ECA - São Paulo) & 15 & 385 & 25.67 \\
\hline & Administração (FEA - São Paulo) & 200 & 5.159 & 25.80 \\
\hline 50. & Editoração (ECA - São Paulo) & 15 & 401 & 26.73 \\
\hline & Direito (FD - São Paulo) & 460 & 12.498 & 27.17 \\
\hline & $\begin{array}{l}\text { Medicina e Ciências Médicas (FMRP - Ribeirão Preto } \\
\text { e FM - São Paulo) }\end{array}$ & 485 & 13.599 & 28.04 \\
\hline & Medicina Veterinária (FMVZ - São Paulo) & 80 & 2.255 & 28.19 \\
\hline 54. & Rádio e TV (ECA - São Paulo) & 20 & 567 & 28.35 \\
\hline & Nutrição (FM - São Paulo) & 40 & 1147 & 28.68 \\
\hline 56. & Artes Cênicas - Bacharelado (ECA/EAD - São Paulo) & 15 & 445 & 29.67 \\
\hline 57. & Jornalismo (ECA - São Paulo) & 50 & 2.277 & 45.54 \\
\hline & Fisioterapia (FM - São Paulo) & 25 & 1.164 & 46.56 \\
\hline 59. & Publicidade e Propaganda (ECA - São Paulo) & 45 & 2.545 & 56.56 \\
\hline 60. & Turismo (ECA - São Paulo) & 25 & 1.803 & 72.12 \\
\hline
\end{tabular}

Fonte: FUVEST

Elaboração: própria 


\begin{tabular}{|c|c|c|c|c|}
\hline \multicolumn{5}{|c|}{$\begin{array}{l}\text { Tabela 10. Carreiras da USP hierarquizadas pela relação candidato/vaga a partir dos } \\
\text { inscritos no vestibular da Fuvest em } 2009\end{array}$} \\
\hline Nome & & Vagas & Inscritos & Relação C/V ^ \\
\hline 1. & Música (FFCLRP - Ribeirão Preto) & 30 & 43 & 1.43 \\
\hline 2. & Licenciatura em Enfermagem (EERP - Ribeirão Preto) & 50 & 103 & 2.06 \\
\hline 3. & $\begin{array}{l}\text { Ciências da Informação e da Documentação (FFCLRP - } \\
\text { Ribeirão Preto) }\end{array}$ & 40 & 92 & 2.30 \\
\hline 4. & $\begin{array}{l}\text { Licenciatura em Geociências e Educação Ambiental (IG - } \\
\text { São Paulo) }\end{array}$ & 40 & 103 & 2.58 \\
\hline 5. & Licenciatura em Matemática e Física (IF/IME) & 260 & 711 & 2.73 \\
\hline 6. & Matemática Aplicada (FFLCRP - Ribeirão Preto) & 45 & 128 & 2.84 \\
\hline 7. & Ciências da Natureza (EACH - São Paulo) & 120 & 369 & 3.08 \\
\hline 8. & Ciências da Atividade Física (EACH - São Paulo) & 60 & 188 & 3.13 \\
\hline 9. & Licenciatura em Ciências Exatas (IFSC - São Carlos) & 50 & 158 & 3.16 \\
\hline 10. & Música (ECA - São Paulo) & 35 & 112 & 3.20 \\
\hline 11. & Matemática (ICMC - São Carlos) & 95 & 315 & 3.32 \\
\hline 12. & Química Licenciatura (FFCLRP - Ribeirão Preto) & 40 & 137 & 3.43 \\
\hline 13. & Informática Biomédica (FFCLRP/FMRP - Ribeirão Preto) & 40 & 147 & 3.68 \\
\hline 14. & Letras (FFLCH - São Paulo) & 849 & 3.234 & 3.81 \\
\hline 15. & Gerontologia (EACH - São Paulo) & 60 & 241 & 4.02 \\
\hline 16. & Gestão de Políticas Públicas (EACH - São Paulo) & 120 & 499 & 4.16 \\
\hline 17. & $\begin{array}{l}\text { Física/Meteorologia/Geofísica/Astronomia/Estatística/Matem } \\
\text { ática/ Matemática Aplicada (IF/IME/IAG - São Paulo) }\end{array}$ & 455 & 1.925 & 4.23 \\
\hline 18. & Fonoaudiologia (FOB - Bauru) & 40 & 171 & 4.28 \\
\hline 19. & Lazer e Turismo (EACH - São Paulo) & 120 & 519 & 4.33 \\
\hline 20. & Pedagogia (FE - São Paulo) & 180 & 781 & 4.34 \\
\hline 21. & Pedagogia (FFCLRP - Ribeirão Preto) & 50 & 220 & 4.40 \\
\hline 22. & Artes Plásticas (ECA - São Paulo) & 30 & 136 & 4.53 \\
\hline 23. & Física Médica (FFCLRP - Ribeirão Preto) & 40 & 182 & 4.55 \\
\hline 24. & Biblioteconomia (ECA - São Paulo) & 35 & 161 & 4.60 \\
\hline 25. & Química Licenciatura (IQ - São Paulo) & 30 & 139 & 4.63 \\
\hline
\end{tabular}




\begin{tabular}{|c|c|c|c|c|}
\hline \multicolumn{5}{|c|}{$\begin{array}{l}\text { Tabela 10. Carreiras da USP hierarquizadas pela relação candidato/vaga a partir dos } \\
\text { inscritos no vestibular da Fuvest em } 2009 \text { (continuação) }\end{array}$} \\
\hline Nome & & Vagas & Inscritos & Relação C/V \\
\hline 26. & Geografia (FFLCH - São Paulo) & 170 & 789 & 4.64 \\
\hline 27. & Fonoaudiologia (FMRP - Ribeirão Preto) & 30 & 145 & 4.83 \\
\hline 28. & Enfermagem (EERP - Ribeirão Preto) & 80 & 388 & 4.85 \\
\hline 29. & Filosofia (FFLCH - São Paulo) & 170 & 842 & 4.95 \\
\hline 30. & Educação Física (EEFERP - Ribeirão Preto) & 60 & 299 & 4.98 \\
\hline 31. & Engenharia de Biossistemas (FZEA - Pirassununga) & 60 & 313 & 5.22 \\
\hline 32. & Engenharia Industrial Química (EEL - Lorena) & 80 & 433 & 5.41 \\
\hline 33. & Ciências dos Alimentos (ESALQ - Piracicaba) & 40 & 218 & 5.45 \\
\hline 34. & Química (IQSC - São Carlos) & 60 & 332 & 5.53 \\
\hline 35 . & Esporte (EEFE- São Paulo) & 50 & 277 & 5.54 \\
\hline 36. & Engenharia Bioquímica (EEL - Lorena) & 40 & 223 & 5.58 \\
\hline 37. & Gestão Ambiental (EACH São Paulo) & 120 & 675 & 5.63 \\
\hline 38. & Química (FFCLRP - Ribeirão Preto) & 60 & 343 & 5.72 \\
\hline 39. & Ciências Sociais (FFLCH - São Paulo) & 210 & 1.228 & 5.85 \\
\hline 40. & Engenharia Agronômica (ESALQ - Piracicaba) & 200 & 1.174 & 5.87 \\
\hline 41. & Zootecnia (FZEA - Pirassununga) & 40 & 236 & 5.90 \\
\hline 42. & Engenharia de Alimentos (FEZA - Pirassununga) & 100 & 594 & 5.94 \\
\hline 43. & Terapia Ocupacional (FMRP - Ribeirão Preto) & 20 & 121 & 6.05 \\
\hline 44. & Gestão Ambiental (ESALQ - Piracicaba) & 40 & 242 & 6.05 \\
\hline 45. & Engenharia Florestal (ESALQ - Piracicaba) & 40 & 249 & 6.23 \\
\hline 46. & Química Ambiental (IQ - São Paulo) & 30 & 195 & 6.50 \\
\hline 47. & História (FFLCH - São Paulo) & 270 & 1.769 & 6.55 \\
\hline 48. & Obstetrícia (EACH - São Paulo) & 60 & 393 & 6.55 \\
\hline 49. & Fonoaudiologia (FM - São Paulo) & 25 & 178 & 7.12 \\
\hline & Engenharia de Materiais (EEL - Lorena) & 40 & 298 & 7.45 \\
\hline & Sistemas de Informação (EACH - São Paulo) & 180 & 1384 & 7.69 \\
\hline & Ciências Biomoleculares (EESC - São Carlos) & 40 & 318 & 7.95 \\
\hline
\end{tabular}




\begin{tabular}{|c|c|c|c|c|}
\hline \multicolumn{5}{|c|}{$\begin{array}{l}\text { Tabela 10. Carreiras da USP hierarquizadas pela relação candidato/vaga a partir dos } \\
\text { inscritos no vestibular da Fuvest em } 2009 \text { (continuação) }\end{array}$} \\
\hline Nome & & Vagas & Inscritos & Relação C/V \\
\hline 53. & Terapia Ocupacional (FM - São Paulo) & 25 & 200 & 8.00 \\
\hline 54. & Ciência Contábeis (FEARP - Ribeirão Preto) & 45 & 363 & 8.07 \\
\hline 55. & Odontologia (FOB - Bauru) & 50 & 405 & 8.10 \\
\hline 56. & Odontologia (FO - São Paulo) & 133 & 1.083 & 8.14 \\
\hline 57. & Oceanografia (IO - São Paulo) & 40 & 330 & 8.25 \\
\hline 58. & Informática (ICMC - São Carlos) & 40 & 331 & 8.28 \\
\hline 59. & Engenharia Elétrica e Computação (EESC - São Carlos) & 250 & 2.112 & 8.45 \\
\hline 60. & Economia (ESALQ - Piracicaba) & 40 & 341 & 8.53 \\
\hline 61. & Economia Empresarial e Controladoria-Ribeirão Preto & 70 & 614 & 8.77 \\
\hline 62. & Odontologia (FORP - Ribeirão Preto) & 80 & 703 & 8.79 \\
\hline 63. & Química Bacharelado e Licenciatura (IQ - São Paulo) & 60 & 532 & 8.87 \\
\hline 64. & Economia (FEARP - Ribeirão Preto) & 45 & 406 & 9.02 \\
\hline 65. & Marketing (EACH - São Paulo) & 120 & 1.090 & 9.08 \\
\hline 66. & Enfermagem (EE - São Paulo) & 80 & 735 & 9.19 \\
\hline 67. & Farmácia-Bioquímica (FCFRP - Ribeirão Preto) & 80 & 759 & 9.49 \\
\hline 68. & Fisioterapia (FMRP - Ribeirão Preto) & 40 & 395 & 9.88 \\
\hline 69. & Geologia (IG - São Paulo) & 50 & 502 & 10.04 \\
\hline 70. & Turismo (ECA - São Paulo) & 30 & 339 & 11.30 \\
\hline 71. & $\begin{array}{l}\text { Economia, Administração, Ciências Contábeis e Atuária } \\
\text { (FEA - São Paulo) }\end{array}$ & 590 & 6.680 & 11.32 \\
\hline 72. & Nutrição e Metabolismo (FMRP - Ribeirão Preto) & 30 & 345 & 11.50 \\
\hline & Total de carreiras da USP & 10.722 & 113.793 & 10.62 \\
\hline 73. & Farmácia-Bioquímica (FCF - São Paulo) & 150 & 1.758 & 11.72 \\
\hline 74. & Educação Física (EEFE - São Paulo) & 50 & 587 & 11.74 \\
\hline 75. & Têxtil e Moda (EACH - São Paulo) & 60 & 735 & 12.25 \\
\hline 76. & Ciências Biológicas (ESALQ - Piracicaba) & 30 & 372 & 12.40 \\
\hline 77. & Engenharia na Escola Politécnica e Computação (EP/Poli) & 800 & 10.476 & 13.10 \\
\hline
\end{tabular}




\begin{tabular}{|c|c|c|c|}
\hline \multicolumn{4}{|c|}{$\begin{array}{c}\text { Tabela 10. Carreiras da USP hierarquizadas pela relação candidato/vaga a partir dos } \\
\text { inscritos no vestibular da Fuvest em } 2009 \text { (continuação) }\end{array}$} \\
\hline Nome & Vagas & Inscritos & Relação C/V \\
\hline 78. Engenharia Química (EEL - Lorena) & 80 & 1.062 & 13.28 \\
\hline 79. Nutrição (FM - São Paulo) & 80 & 1.128 & 14.10 \\
\hline 80. Medicina Veterinária (FMVZ - São Paulo) & 140 & 1.975 & 14.11 \\
\hline 81. Editoração (ECA - São Paulo) & 15 & 212 & 14.13 \\
\hline 82. Ciências Biológicas (FFCLRP - Ribeirão Preto) & 40 & 580 & 14.50 \\
\hline 83. Engenharia (EESC - São Carlos) & 200 & 2.931 & 14.66 \\
\hline 84. Ciências Biológicas (IB - São Paulo) & 120 & 1.798 & 14.98 \\
\hline 85. Administração (FEARP - Ribeirão Preto) & 105 & 1.575 & 15.00 \\
\hline 86. Relações Públicas (ECA - São Paulo) & 50 & 794 & 15.88 \\
\hline 87. Artes Cênicas-Licenciatura (ECA - São Paulo) & 10 & 166 & 16.60 \\
\hline 88. Psicologia (FFCLRP - Ribeirão Preto) & 40 & 664 & 16.60 \\
\hline 89. Arquitetura (EESC - São Carlos) & 45 & 752 & 16.71 \\
\hline 90. Direito (FD - São Paulo) & 560 & 10.294 & 18.38 \\
\hline 91. Arquitetura (FAU - São Paulo) & 150 & 3.001 & 20.01 \\
\hline 92. Engenharia Ambiental (EESC - São Carlos) & 40 & 872 & 21.80 \\
\hline 93. Engenharia Aeronáutica (EESC - São Carlos) & 40 & 891 & 22.28 \\
\hline 94. Psicologia (IP - São Paulo) & 70 & 1.820 & 26.00 \\
\hline 95. Fisioterapia (FM - São Paulo) & 25 & 657 & 26.28 \\
\hline 96. Engenharia Civil (EESC - São Carlos) & 60 & 1.607 & 26.78 \\
\hline 97. Artes Cênicas Bacharelado (ECA/EAD - São Paulo) & 15 & 413 & 27.53 \\
\hline 98. Design (FAU - São Paulo) & 40 & 1.211 & 30.28 \\
\hline 99. Jornalismo (ECA - São Paulo) & 60 & 1.957 & 32.62 \\
\hline 100. Curso Superior do Audiovisual (ECA - São Paulo) & 35 & 1.203 & 34.37 \\
\hline 101. Ciências Médicas (FMRP - Ribeirão Preto) & 100 & 3.715 & 37.15 \\
\hline 102. Relações Internacionais (IRI - São Paulo) & 60 & 2.275 & 37.92 \\
\hline 103. Publicidade e Propaganda (ECA - São Paulo) & 50 & 2.001 & 40.02 \\
\hline 104. Medicina (FM - São Paulo) & 275 & 11.576 & 42.09 \\
\hline
\end{tabular}


Comparando os aspectos gerais do vestibular da Fuvest de 1999 e 2009, o primeiro ponto que chama a atenção é a ampliação do número de carreiras e vagas, resultado do processo de expansão e diversificação da USP analisado anteriormente: se, em 1999, eram 60 carreiras com 7.429 vagas, em 2009 eram 104 carreiras que, juntas, somavam10.722 vagas. Assim, embora o número de inscritos no vestibular tenha aumentado de 101.242 em 1999 para 113.793 em 2009, a relação candidato vaga caiu para o total de carreiras da USP, de 13,63 para 10,62, em função justamente da ampliação de vagas, resultado, sobretudo, da criação de novos cursos. No entanto, a relativa ampliação do acesso à USP, por meio da criação de novas vagas, não se traduziu imediatamente na democratização do ingresso na universidade. Para entender como se deu esse processo, é preciso considerar justamente o processo de elitização da USP.

\section{A elitização da USP (1995 - 2013)}

\subsection{A elitização da USP em termos gerais}

Como foi dito, a relativa ampliação do acesso à USP, por meio da criação de novas vagas, não se traduziu imediatamente na democratização do ingresso na universidade. Pelo contrário, considerando os dados do Questionário Socioeconômico da Fuvest, é possível notar que o crescimento do número de vagas e de inscritos no vestibular da USP entre 1999 e 2009 foi acompanhado por uma relativa elitização dos candidatos à universidade, tal como se expressa no perfil do total de inscritos no vestibular. Assim, se em 1999, 54,2\% dos inscritos no vestibular havia cursado o ensino fundamental em escola particular, em 2009, esse percentual já havia aumentado para 60,8\%. Quanto ao ensino médio, se em 1999, 63,8\% dos inscritos havia estudado no sistema privado, em 2009, esse percentual aumentou para 65,5\%. Ao mesmo tempo, a parcela de alunos que fez o ensino médio no período noturno diminuiu, passando de 16,5\% em 1999 para $11 \%$ em 2009. Os alunos que se inscreveram na Fuvest depois 
de realizar cursinho passaram de 44,6\% do total de inscritos em 1999 para 52,5\% em $2009^{194}$. Esses dados se completam pelas informações sobre a escolaridade dos pais dos inscritos na Fuvest. Entre 1999 e 2009, os candidatos ao vestibular da USP que tinham pai com ensino superior passaram de 44,3\% para 45,2\%, sendo que o percentual desses com pós-graduação também aumentou de $5,2 \%$ para $6,6 \%$. Mas foi na escolaridade das mães dos candidatos que a variação foi mais marcante. Se em 1999 apenas 36,5\% dos inscritos eram filhos de mãe com superior completo, das quais 3,0\% com pós-graduação, em 2009 esse percentual tinha subido para 45,4\%, das quais 4,9\% com pós-graduação.

A elitização dos inscritos no exame anual da Fuvest não se traduz de modo automático no perfil dos alunos aprovados na USP. Ou seja, embora os candidatos selecionados pelo vestibular, tanto em 1999 quanto em 2009, tenham um perfil em geral mais elitizado do que o total de inscritos no vestibular, comparando esses dois anos entre si, o que se observa é uma pequena democratização. Assim, ainda que o percentual de ingressantes na USP que cursou o ensino fundamental no sistema privado tenha aumentado de 65,4\% para 66,8\% entre 1999 e 2009, o percentual dos que cursaram o ensino médio privado diminuiu no mesmo período, passando de $72 \%$ para $68,5 \%$ do total. Esse declínio do percentual de estudantes oriundos do sistema privado resultou da maior parcela de estudantes do ensino médio estadual aprovada no vestibular, que passou de $19,6 \%$ em 1999, para 24,2\% do total de ingressantes em 2009. Apesar do crescimento dos egressos da escola pública aprovados na USP, o percentual dos alunos que fez cursinho subiu de 60,7\% para 68,6\% em dez anos. Além disso, embora o percentual de

\footnotetext{
${ }^{194}$ É importante notar que o aumento do percentual de alunos que realizam cursinho se observa, também, entre o percentual de aprovados no total de carreiras da USP. Assim, se em 1999, 60,7\% dos ingressantes havia realizado cursinho antes de entrar na USP, em 2009 esse percentual havia aumentado para 68,6\%. Esse crescimento, no entanto, tende a ser maior nas carreiras menos concorridas que, portanto, recebem alunos de mais baixa renda. Esse padrão permite supor que existe um novo perfil de cursinhos pré-vestibulares voltados para segmentos mais baixos da população, sejam eles de natureza beneficente, como os chamados "cursinhos populares", organizados muitas vezes pelos próprios alunos da USP, ou particular. Por outro lado, é importante notar que o fato dos cursos mais concorridos estarem sofrendo uma relativa diminuição no número de ingressantes que realiza cursinho, sobretudo a partir dos anos 2000, pode indicar que os colégios tradicionais de elite estão se adaptando para tornarem-se, eles mesmos, pré-vestibulares. Infelizmente, não encontrei estudos empíricos que permitissem comprovar essas hipóteses.
} 
alunos com pai com ensino superior completo tenha caído de 57,2\% em 1999 para 53,3\% em 2009 refletindo a abertura para alunos oriundos de famílias menos escolarizadas, o percentual de alunos cuja mãe tinha o mesmo nível de escolaridade subiu de 47,4\% para 52\% no mesmo período. O crescimento também se deu no percentual de pai e mãe com pós-graduação, que subiu de $5,3 \%$ para $8,4 \%$ no caso do pai, e de $5,3 \%$ para $6,5 \%$ no caso da mãe ${ }^{195}$.

O aumento relativo do número de egressos de escola pública aprovados na USP entre 1999 e 2009 resultou da criação de programas especiais de inclusão como o PASUSP (Programa de Avaliação Seriada da USP) e, sobretudo, o INCLUSP (Programa de Inclusão Social da USP). Implementados a partir de 2006 para enfrentar o problema da diminuição progressiva da entrada de estudantes oriundos da escola pública na USP. Esses programas, além de isentar os egressos de escola pública do pagamento da taxa de inscrição no vestibular, oferecem bônus de pontuação, proporcionais à quantidade de acertos no exame da Fuvest. A diferença entre os dois programas é que o PASUSP se volta para os alunos que ainda estão cursando o segundo grau na escola pública e que, portanto, podem prestar o vestibular da Fuvest como "treineiros" a partir do $2^{\circ}$ ano do ensino médio, acumulando pontos para o exame definitivo no ano seguinte. Já o INCLUSP é voltado para alunos que concluíram ou estão concluindo o ensino médio na escola pública e que pretendem prestar o vestibular da Fuvest. O INCLUSP se divide nas modalidades "ensino básico", para os estudantes que fizeram escola pública desde o fundamental, e "ensino médio", voltado aos que cursaram apenas o ensino médio na escola pública. Desde a sua fundação, o programa beneficia, em média, 25\% dos ingressantes anuais na USP, sendo que o pico de candidatos beneficiados pelo programa foi justamente em 2009, quando $29 \%$ dos aprovados na USP pontos do INCLUSP.

\footnotetext{
${ }^{195} \mathrm{O}$ aumento generalizado da escolaridade das mães dos ingressantes da USP, observável em praticamente todas as carreiras mas, sobretudo, nas mais abertas a novos setores sociais, indica a existência de um processo em âmbito nacional de escolarização progressiva das mulheres, inclusive com movimentos de retorno à escola.
} 
Os programas de inclusão social da USP surgiram no contexto de implementação da política de cotas nas universidades públicas federais, tanto para egressos da escola pública quanto para afrodescendentes, e foram pensados, em grande medida, como alternativa às políticas afirmativas que reservam vagas, sobretudo para afrodescendentes ${ }^{196}$. Do ponto de vista dos seus resultados, embora o programa tenha afetado o perfil dos ingressantes da USP entre 1999 e 2009, considerando um intervalo temporal mais amplo, é possível notar que o percentual de ingressantes oriundos da escola pública caiu ao invés de aumentar. Nesse sentido, o subitem a seguir busca descrever a evolução do perfil dos ingressantes em diferentes carreiras da USP, que define o processo diferencial de elitização dos estudantes da USP.

Para tentar apreender uma dinâmica de mais longo prazo e, com isso, alcançar uma descrição mais precisa da evolução do perfil dos alunos inscritos na USP, a pesquisa buscou comparar os dados do Questionário Socioeconômico da Fuvest no maior intervalo temporal possível. Assim, além de comparar 1999-2009, buscou-se comparar o intervalo 1995-2013. O ano de 1995 marcou o início da informatização do Questionário Socioeconômico sendo, portanto, o primeiro ano para o qual a Fundação publicizou seus dados. Já 2013 é o ano para o qual existem dados mais recentes processados pela Fuvest no momento de elaboração da tese. Começando pelos dados demográficos gerais, é possível notar que o percentual de afrodescendentes que ingressou na USP parece ter aumentado discretamente nos últimos anos. Embora não seja possível comparar a evolução entre 1995 e 2013, porque a questão referente à cor só foi inserida no questionário da Fuvest no ano $2000^{197}$, no período que vai de 2000 a 2013 ,

\footnotetext{
${ }^{196}$ Em editorial denominado "O novo vestibular da USP", de 14 de abril de 2008, o jornal O Estado de S. Paulo reivindicava o INCLUSP como um programa "concebido como uma alternativa ao polêmico sistema de cotas adotado pelas universidades federais" (OESP, 2008, p. 3). Em entrevista publicada na Revista Pesquisaeduca em 2011, a ex-pró-reitora de graduação da USP, Selma Garrido Pimenta, criadora do INCLUSP em 2006, argumenta que a introdução das cotas na universidade pública não resolveu a questão da inclusão do negro, como o comprova, por exemplo, o caso da Unifesp, onde, segundo ela, não existem negros suficientes para completar as cotas (cf. Faria, 2011, p.144).

${ }^{197}$ É significativo que a inclusão dessa questão tenha ocorrido no começo dos anos 2000, quando se observava um aumento progressivo das pressões sociais pela inclusão social dos afrodescendentes, particularmente no ensino superior (cf. Guimarães, 2003).
} 
o percentual dos alunos que se dizem pardos ou pretos entre os aprovados na USP aumentou de $6,7 \%$ para 9,2\%. Paralelamente, o percentual de mulheres que ingressam na USP também cresceu, passando de 39,5\%, em 1995, para 45,8\%, em 2013.

Considerando os indicadores sobre origem socioeconômica e trajetória escolar dos aprovados no vestibular em conjunto, eles apontam da USP uma relativa elitização dos ingressantes na universidade entre 1995 e 2013. Começando pelos dados de escolaridade, o percentual de estudantes que cursaram o ensino fundamental no sistema privado subiu de $55,7 \%$ para 74,6\% entre 1995 e 2013; paralelamente, os estudantes que cursaram o ensino médio particular também aumentaram de 67,3\% em 1995 para 74,2\% em 2013. No mesmo sentido, o percentual dos alunos que estudava no período noturno antes de ser aprovado no vestibular da USP caiu expressivamente, de $9,9 \%$ para $4,2 \%$. Vistos em conjunto, esses dados sugerem que “ser aprovado na USP” constitui um projeto familiar, uma vez que implica o suporte integral da família tanto no financiamento da escola privada quanto na garantia das condições necessárias à dedicação exclusiva aos estudos. Isso significa não só que essas famílias precisam ter condições econômicas suficientes para sustentar o "projeto USP" mas, também, que elas devem valorizar o estudo a ponto de dispensar parte importante da sua renda em educação. Essa observação torna-se ainda mais pertinente quando se analisa o padrão de consumo das "famílias proprietárias brasileiras" - categoria que inclui os núcleos familiares chefiados por proprietários de empresas, de imóveis residenciais, de renda de aluguel, de ativos financeiros e de conhecimento, esse último expresso em títulos de graduação e de pós-graduação (cf. Pochmann et al., 2009, p. 16-17). Segundo os dados apresentados por Pochmann e outros, considerando esse segmento, que constituía apenas $6 \%$ da população brasileira em 2003, o gasto com educação era, nesse mesmo ano, de apenas $4,6 \%$ do total da renda familiar mensal que, em termos absolutos, significava, na época, R\$ 197,00 mensais. Comparando os gastos em educação com outros gastos realizados pelas famílias proprietárias brasileiras, como habitação, 
transporte, aquisição de veículos, alimentação e assistência de saúde, é possível notar que os gastos educacionais eram, em 2003, surpreendentemente baixos. Segundo os autores, considerando só o gasto mensal desse segmento em combustível, vê-se que ele chegava a ser 10\% maior do que o gasto em educação. Levando em consideração só a Região Sudeste, o gasto com combustível entre as famílias proprietárias chegava a ser $30 \%$ maior do que o gasto em educação (cf. Pochmann et al., 2009, p. 131-143). Comparando essa informação com os dados disponíveis no estudo de Jorge Abrahão de Castro e Fábio Monteiro Vaz (2007), pode-se concluir que o padrão de gasto com educação é mais dependente dos anos de estudo do chefe de família do que do volume da propriedade ou da renda familiar propriamente dita (cf. Castro \& Vaz, 2007, p. 89).

Nesse sentido, não deve surpreender o fato de que, do total de alunos aprovados na USP em 1995, 53,4\% tinham pai com ensino superior completo e 38,7\%, mãe com o mesmo grau de escolaridade. Em 2013, esse percentual havia aumentado para 57,6\% de alunos cujo pai tinha superior completo, dos quais $20 \%$ com pós-graduação, e $58,6 \%$ de alunos cuja mãe tinha o mesmo grau de instrução, das quais 19,5\% com pós-graduação. Esses dados confirmam a tendência, observada entre 1999 e 2009, de aumento significativo tanto da escolaridade das mães quanto do percentual de pais com pós-graduação entre os estudantes ingressantes na USP.

Certamente, a relativa elitização dos novos uspianos não se deu do mesmo modo em todos os cursos da universidade. Como existe uma forte relação entre a concorrência por um determinado curso e a elitização do seu alunado, dado que os filhos de famílias com maior escolaridade e renda tendem a acumular melhores condições de enfrentar a competição pelas vagas escassas (cf. Dubet, Duru-Bellat \& Vérétout, 2012, p. 48-9), a variação da concorrência do vestibular da USP entre as diferentes áreas e carreiras ajuda a compreender a dinâmica diferencial de elitização das unidades da USP. 
Nesse sentido, voltando à comparação entre os vestibulares de 1999 e 2009, é importante notar, em primeiro lugar, que o perfil dos cursos menos procurados da USP mudou significativamente no período, como é possível observar pelas tabelas 9 e 10 apresentadas anteriormente. Se no final da década de 1990, os cursos com menor relação candidato/vaga eram de natureza acadêmico-científica, tais como licenciatura em ciências exatas, química, física e meteorologia, ciências da terra, e filosofia, todos com menos de quatro candidatos por vaga, no final da década de 2000, os cursos menos procurados da USP eram majoritariamente novas formações profissionais, sediadas sobretudo no interior do estado, tais como música, da Faculdade de Filosofia, Ciências e Letras de Ribeirão Preto (FFCLRP), licenciatura em enfermagem, da Escola de Enfermagem de Ribeirão Preto, ciência da informação e da documentação, da FFCLRP, e matemática aplicada, também da FFCLRP. Todos esses cursos, sediados no interior, contavam com pouco mais de dois candidatos por vaga em 2009. Dentre os cursos sediados na cidade de São Paulo que contavam mais ou menos com a mesma relação candidato/vaga no final dos anos 2000, estavam as licenciaturas em ciências ou, mais especificamente, i) licenciatura em geociências e educação ambiental, oferecida pelo Instituto de Geociências; ii) licenciatura em física e matemática, oferecida pelo Instituto de Física e pelo Instituto de Matemática e Estatística; e iii) licenciatura em ciências da natureza, ministrada na Escola de Artes, Ciências e Humanidades, localizada na zona leste da cidade de São Paulo.

No outro extremo, considerando os cursos mais concorridos da USP em 1999 e em 2009, a variação pode ter atingido os cursos individualmente, mas não o padrão mais geral de concorrência. Nesse sentido, é possível notar que praticamente todos os cursos profissionais mais tradicionais da USP, tais como medicina, direito, engenharia, arquitetura, psicologia, farmácia, odontologia, entre outros, contavam, tanto em 1999 quanto em 2009, com uma relação entre candidato e vaga superior à média geral da USP ${ }^{198}$. Outros cursos profissionais

\footnotetext{
198 As exceções, em 1999, foram os cursos de economia da FEA e de engenharia da Poli. Este último, no entanto, teve a sua relação candidato/vaga diminuída em 1999 porque a Fuvest agrupava, na época, as carreiras de
} 
como jornalismo, publicidade e propaganda e relações internacionais, embora não possam ser caracterizados como "tradicionais"199, também constam entre os mais procurados da universidade, o que deve refletir no perfil socioeconômico mais elevado e na trajetória escolar mais homogênea do seu corpo discente.

Considerando esses dados em conjunto, é possível concluir que a elitização do corpo discente da USP se diferenciou entre três polos principais: os novos cursos profissionais, sediados sobretudo fora da cidade universitária; os cursos acadêmico-científicos, formados pelas licenciaturas e bacharelados em currículos disciplinares, sediados tanto no interior quanto na capital; e, por fim, os cursos profissionais mais tradicionais, sediados sobretudo na capital do estado. Essa observação confirma outras análises de tipo estrutural realizadas no final dos anos 1990 (cf. Setton, 1999) ${ }^{200}$. Conforme foi visto, ainda, esses três polos tiveram uma dinâmica diferenciada de criação de vagas, com o ritmo de expansão caindo à medida que se caminha das novas profissões em direção às profissões tradicionais, passando pelos cursos acadêmico-científicos. Paralelamente, como foi possível observar pela evolução da relação

engenharia da Poli com as carreiras de matemática e estatística, do IME, que têm uma procura relativamente menor. Em 2009, as exceções foram, por sua vez, os cursos da FEA, de novo por razões metodológicas. O novo agrupamento de carreiras, promovido pela Fuvest, uniu todos os cursos da FEA, ou seja, de um lado, economia e administração - que devem contar com uma procura maior - e ciências contábeis e atuariais - que provavelmente possuem uma relação candidato/vaga menor.

199 De novo, a referência para definir os cursos "tradicionais" são as categorias usadas pelo MEC até 1971 para agrupar os cursos de ensino superior, dentre os quais as carreiras profissionais eram: administração, agronomia, arquitetura e urbanismo, direito, economia, enfermagem, engenharia, farmácia, medicina, medicina veterinária, odontologia e serviço social. Além desses, havia os cursos artísticos e de filosofia, ciências e letras.

${ }^{200}$ É interessante notar que na sua tentativa de descrever a hierarquização dos cursos de humanidades da USP no final dos anos 1990, Maria da Graça Jacinto Setton também observou a existência de três grupos principais de cursos, que ela denominou seletos, intermediários e populares, segundo a concentração de capital dos seus ingressantes (cf. Setton, 1999, p. 451ss). Para tanto, a autora também recorreu aos dados sobre a origem social e a trajetória acadêmica dos alunos ingressantes da USP por carreira, conseguidos a partir de uma pesquisa realizada com os alunos de humanidades da USP e complementados pela Fuvest. Embora a classificação construída pela autora seja um pouco distinta da que é proposta neste trabalho - sobretudo porque ela enfatizou mais a dinâmica de hierarquização dos cursos de humanidades do que o conteúdo das formações e dos diplomas oferecidos no contexto geral da universidade - é possível dizer que os dados do seu trabalho corroboram a classificação que se propõe nesta tese, de segmentar a universidade em três polos principais. Isso porque os cursos "seletos", descritos pela autora, concentram as profissões "que levam a carreiras com boas expectativas de ganho financeiro e status social" (Setton, 1999, p. 169), enquanto os cursos "intermediários" reúnem as formações disciplinares voltadas à pesquisa e os cursos "populares" levam, segundo Setton, "a carreiras pouco valorizadas no mercado de trabalho" (cf. 1999, p. 469), se aproximando assim das formações que estou denominando "técnico-profissionais". 
candidato/vaga, apesar das oscilações pontuais, existe uma tendência homóloga de variação da concorrência, que aumenta à medida que se passa dos novos cursos profissionais, aos cursos acadêmico-científicos até chegar nos cursos profissionais tradicionais.

\subsection{A elitização diferencial da USP (1995 - 2013)}

A reconstrução das hierarquias sociais que aproximam e afastam os diferentes cursos da USP, contribui de modo decisivo na compreensão do processo de elitização diferencial da universidade nos últimos anos, que define as hierarquias que estruturam, contemporaneamente, a universidade enquanto uma reunião não de cursos e carreiras, mas de unidades. Nesse sentido, no que concerne aos cursos voltados a novas profissões, é possível dizer que, ocupando a posição que há alguns anos cabia aos cursos acadêmico-científicos, eles constituem, hoje, a nova fronteira da expansão social da USP, tendendo a concentrar, portanto, os alunos oriundos dos setores sociais menos privilegiados.

É o caso, por exemplo, do curso de música de Ribeirão Preto. Criado pela ECA em 2002, como desdobramento da formação em música oferecida pela unidade de São Paulo desde 1996, o curso de música de Ribeirão Preto foi incorporado pela Faculdade de Filosofia, Ciências e Letras (FFCLRP) que, considerando o período que vai de 1982 a 2012, foi uma das unidades da USP que mais cresceu através da expansão de cursos e vagas. Assim, considerando o período que vai de 1982 a 2010, a FFCLRP aumentou suas vagas em 183,8\%. Além disso, ao lado das formações tradicionais em psicologia, química e ciências biológicas, a unidade criou os cursos de física médica, em 2000, pedagogia, em 2002, ciência da informação e da documentação e licenciatura em química, em 2003, além de incorporar o curso de música, no final dos anos 2000. Em 2009, já integrando a FFCLRP, o curso de música de Ribeirão Preto foi o menos concorrido do vestibular da USP, com apenas 1,43 candidatos por vaga. A comparação do perfil dos ingressantes do curso de música com a média dos ingressantes da USP em 2009 mostra que 
se tratam, em geral, de estudantes menos elitizados do que os ingressantes médios da USP. Considerando a sua trajetória escolar, é notável que $60,1 \%$ dos novos alunos de música da FFCLRP em 2009 eram oriundos do ensino fundamental público, enquanto a média da USP no mesmo ano foi de $28,9 \%$. Os alunos de primeiro ano de música da FFCLRP cujo pai tinha ensino superior completo eram apenas $36,6 \%$ do total em 2009, enquanto na média da USP era de 53,3\% do total. Já o percentual de alunos de música cuja mãe tinha completado o ensino superior era de $39,7 \%$ em 2009, mais de $10 \%$ a menos do que a média da USP, que era de $52 \%$.

O mesmo padrão pode ser observado no curso de licenciatura em enfermagem que, em 2009, foi o segundo menos concorrido da USP. A baixa procura fez a Escola de Enfermagem de Ribeirão Preto (EERP), responsável pelo curso, excluir, a partir de 2012, a opção de ingresso exclusivo em licenciatura, tornando-a um complemento do bacharelado em enfermagem. Analisando o perfil dos ingressantes nesse curso em 2009, ano de referência para a relação candidato/vaga observada, é possível notar, em primeiro lugar, que se tratava de um alunado essencialmente feminino: $82 \%$ dos novos alunos de licenciatura em enfermagem eram mulheres. Além disso, 64\% dos convocados para a matrícula nesse curso, em 2009, eram egressos do ensino fundamental público e 58\%, do ensino médio público. Considerando a média da USP, esses percentuais foram, no mesmo ano, de $28,9 \%$ e $30,5 \%$ respectivamente. Além disso, só $28 \%$ dos ingressantes eram filhos (ou filhas) de pai com ensino superior completo e apenas $34 \%$, de mãe com o mesmo nível de escolaridade, ao passo que para o total de ingressantes da USP em 2009, essa relação era de 53,3\% e de 52\% respectivamente. O percentual de "pardos" e "pretos" que ingressou em licenciatura em enfermagem em 2009 também foi mais alto do que a média da USP: $20 \%$ dos futuros professores de enfermagem haviam se autodeclarado "pardo" ou "preto" em 2009, 7\% a mais do que o total de alunos aprovados na USP. 
Esses dois casos indicam que os cursos menos concorridos da USP, além de serem ligados a novas formações profissionais, são, também, e por isso mesmo, relativamente mais abertos a novos setores sociais do que a média geral dos cursos da USP. Um terceiro caso que confirma essa constatação é o do bacharelado em ciência da informação e da documentação oferecido, somente no período noturno, também pela FFCLRP. O curso constitui um exemplo típico das chamadas "novas profissões universitárias", uma vez que o seu reconhecimento oficial só ocorreu em outubro de 2007, por meio de portaria 473/2007 do Conselho Estadual de Educação. Em 2009, seis anos depois de entrar em funcionamento e dois anos depois de ter sido reconhecido pelo Estado, o curso permanecia um dos menos procurados da universidade. Assim como no caso de música e de licenciatura em enfermagem, é possível notar que o grau de elitização dos ingressantes nessa carreira em 2009 era relativamente inferior à média geral da USP. Se entre o total de aprovados na USP, os percentuais de estudantes que cursaram o ensino fundamental e médio no sistema privado eram, respectivamente, $66,8 \%$ e $68,5 \%$, no caso do curso de ciência da informação e da documentação esses percentuais caíam para 50\% e 57,9\%. No caso da escolaridade máxima dos pais, se observa a mesma variação. Enquanto entre o total de alunos aprovados na USP os percentuais de pai e de mãe com ensino superior completo eram de $53,3 \%$ e de $52 \%$, no caso do curso de ciência da informação e da documentação esse percentual cai para $37,8 \%$ e 47,4\% respectivamente. Considerando o percentual de alunos com pais com pós-graduação, enquanto a média da USP em 2009 era de 8,4\% para o pai e de 6,5\% para a mãe, entre os alunos de ciência da informação e da documentação esse percentual era de apenas 5,4\% e 5,3\% respectivamente. A parcela de afrodescendentes aprovados no bacharelado da FFCLRP também foi maior: enquanto a USP aprovou apenas 2,3\% de alunos que se autoconsideravam "pretos" em 2009, o curso de ciência da informação e da documentação aprovou 7,9\% de alunos com o mesmo perfil. 
Por fim, para não limitar a análise a cursos sediados no interior do estado de São Paulo, considere-se o exemplo do curso de ciência da atividade física, criado pela EACH em 2005 e que, em 2009, também estava entre os menos procurados da USP, com apenas 3,13 candidatos por vaga. Tomando o número de egressos da escola particular em relação ao total de aprovados no curso, vê-se que ele não era apenas menor do que a média da USP como, também, menor do que a média do curso de ciência da informação e da documentação: 46,7\% e 46,6\% do total de aprovados em ciência da atividade física em 2009 cursaram o ensino fundamental e médio, respectivamente, no sistema privado, enquanto na USP esse percentual era de $66,8 \%$ e $68,5 \%$ respectivamente. Considerando a escolaridade dos pais, é possível observar o mesmo padrão: apenas 38,3\% dos alunos que ingressaram no curso de ciências da atividade física em 2009 possuíam pai com ensino superior completo, 3,3\% dos quais com pós-graduação contra 53,3\% da USP. Ao mesmo tempo, apenas 35\% desses estudantes tinham mãe com o mesmo nível de escolaridade, $1,7 \%$ das quais com pós-graduação, contra $52 \%$ dos ingressantes da USP em média. Seguindo o mesmo padrão, o percentual de "pretos" e "pardos" aprovados no curso também foi maior do que a média da USP. Além disso, enquanto no curso da EACH 18,3\% dos aprovados se autodeclaravam "pretos" ou "pardos", entre o total de aprovados da USP, como foi dito, esse percentual foi de $13,6 \%$ no mesmo ano. Considerando só os autodeclarados “pretos", enquanto a USP aprovou 2,3\% de alunos com essa característica, o curso de ciências da atividade física aprovou 8,3\% de alunos com o mesmo perfil. Esses casos servem para ilustrar o fato de que as novas formações profissionais da USP, localizadas em geral, fora da cidade universitária, seja nos campi do interior, seja na zona leste da cidade de São Paulo, ficaram de certo modo à margem do processo recente de elitização do alunado da USP, descrito 
anteriormente $^{201}$, de onde cumpriram um papel fundamental na redefinição das fronteiras da inclusão social na USP.

Por outro lado, a evolução dos cursos acadêmico-científicos da USP - atrelados, pelo seu perfil disciplinar, ao chamado regime disciplinar de produção e distribuição de conhecimento $^{202}$ - foi um pouco distinta. Embora entre 1999 e 2009, a relação candidato/vaga nas carreiras disciplinares não tenha seguido um padrão comum ${ }^{203}$, a tendência geral, quando observamos o perfil socioeconômico do alunado desses cursos, foi de uma relativa elitização, sobretudo no que concerne à escolaridade dos pais e particularmente quando se considera não apenas o lapso temporal 1999-2009, mas o intervalo mais amplo, que vai 1995 a $2013^{204}$. Assim, ainda que esses cursos permaneçam muito mais permeáveis a setores sociais menos privilegiados do que as profissões tradicionais da USP, eles não podem mais ser considerados

\footnotetext{
${ }^{201}$ Não é possível fazer uma comparação da evolução do alunado desses novos cursos profissionais entre 1999 e 2009 porque eles foram criados, como visto, depois de 2000.

${ }^{202} \mathrm{O}$ conceito de regimes de produção e distribuição de conhecimento científico, tal como formulado por Terry Shinn, busca descrever de modo empiricamente mais preciso as práticas sociais e os arranjos institucionais que definem a "ciência" como esfera relativamente autônoma e autorregulada. Segundo o autor: "O regime disciplinar [...] está baseado em departamentos disciplinares de universidades, cujo objetivo é (1) reproduzir o conhecimento disciplinar-padrão para os estudantes e (2) conduzir pesquisa original no interior da disciplina. O regime disciplinar é fortemente definido por sua orientação autorreferente. Com relação aos tópicos de pesquisa, eles são retirados do interior da disciplina e relacionam-se tanto com a história e a inércia disciplinares, como com a direção para a qual o futuro da disciplina aponta, segundo percepções dos praticantes disciplinares. A disciplina também estabelece seus critérios internos para a avaliação de seus resultados de pesquisa. Segundo as mesmas linhas, ela decide o que deve ser aprendido pelos estudantes, e em que extensão, para o estabelecimento da certificação da realização na forma de diplomas. O regime disciplinar constitui o seu próprio mercado. Os praticantes são os consumidores de suas próprias produções. $\mathrm{O}$ resultado da pesquisa está dirigido pelos pares disciplinares que avaliam, portanto, a qualidade do resultado e consomem os produtos cognitivos gerados por outros colegas disciplinares. [...] A distribuição da produção e a eventual assimilação subsequente da produção são realizadas por meio de revistas, cujo conteúdo é controlado pela disciplina" (Shinn, 2008, p. 17).
}

\footnotetext{
203 Observando as tabelas 9 e 10, é possível notar que, enquanto alguns cursos tiveram um relativo aumento da procura, com o consequente aumento da relação candidato/vaga como filosofia, história, química, física, geofísica, meteorologia e ciências da terra/geologia, outros tiveram uma relativa queda na procura e, portanto, uma redução na relação candidato/vaga como ciências biológicas (biologia), ciências sociais, letras e geografia.

${ }^{204}$ Para chegar a essa conclusão, comparei os dados dos alunos aprovados na Fuvest em 1999 e 2009, intervalo relativo à análise da relação candidato/vaga proposta e entre 1995 e 2013, intervalo no qual os dados da Fuvest estão disponíveis, nas seguintes carreiras (marcadas por uma clara identificação disciplinar): ciências sociais, filosofia, geografia, história, química São Paulo, química São Carlos, química Ribeirão Preto, física e meteorologia São Paulo, física São Carlos e ciências biológicas São Paulo, Ribeirão Preto e Piracicaba. Todos esses dados estão disponíveis em <http://www.fuvest.br/estat/> Acesso em: 16 mar. 2014.
} 
a base da hierarquia social da universidade, como o eram no momento da fundação da universidade (cf. Florestan, 1975; Limongi, 1989; Miceli, 1989).

No curso de filosofia da FFLCH, por exemplo, embora o percentual de alunos que realizaram o ensino médio no sistema privado tenha caído entre 1999 e 2009, a parcela dos que ingressaram na universidade depois de ter realizado o chamado "cursinho" subiu de $29,5 \%$ em 1999 para 47,9\% em 2009. Além disso, o grau de escolaridade atingido pelo pai e, sobretudo, pela mãe dos ingressantes em filosofia também aumentou no período. Assim, se em 1999, 44\% dos estudantes aprovados no curso de filosofia tinham pai com ensino superior completo, em 2009 esse percentual aumentou para 49,1\%. Paralelamente, se a parcela de alunos aprovados em filosofia cuja mãe tinha ensino superior completo era de 35\% em 1999, esse valor chegou a 42\% dez anos depois. Em 2013, a taxa de alunos aprovados em filosofia cuja mãe tinha ensino superior completo chegou a 52,9\%,14,7\% delas com pós-graduação completa. Comparando com os dados de 1995, quando apenas 32,8\% dos alunos aprovados em filosofia na USP tinham mãe com ensino superior completo, a evolução é bastante significativa. Apesar dessa relativa elitização, 22,5\% dos ingressantes em filosofia em 2009 se autodeclaravam ${ }^{205}$ pardos ou pretos, um percentual bastante superior à média da USP, de 13,6\%.

No curso de ciências sociais, também sediado na FFLCH, a relação candidato/vaga caiu entre 1999 e 2009. Consequentemente, a evolução do perfil dos alunos ingressantes variou, nesse mesmo período, em sentido homólogo. Ou seja, em decorrência da diminuição relativa da concorrência, o curso de ciências sociais se tornou relativamente menos elitista ao longo da década de 2000. Assim, além de um aumento dos egressos do ensino médio público, que representavam 19,4\% dos aprovados em 1999 e passaram a representar 37,8\% dos aprovados em 2009, o percentual de alunos cujo pai tinha ensino superior completo também caiu de 59,4\%

\footnotetext{
${ }^{205}$ É essencial notar que a questão sobre cor/raça no Questionário Socioeconômico da Fuvest é autodeclaratória. Sua formulação, "Entre as alternativas abaixo, qual a sua cor?", implica uma autoclassificação social que está diretamente associada à força dos movimentos de identidade, especialmente entre setores indígenas e afrodescendentes.
} 
em 1999 para 50,2\% em 2009. A porcentagem de alunos cuja mãe tinha ensino superior completo, porém, cresceu discretamente no mesmo período, passando de 55,7\% em 1999 para $56,4 \%$ em 2009. No entanto, considerando um intervalo mais amplo, que vai de 1995 a 2013, é possível observar que o curso de ciências sociais, como os demais cursos disciplinares da USP, também se elitizou ao longo das últimas duas décadas. Nesse sentido, tomando o percentual de egressos do ensino médio privado entre os aprovados em ciências sociais da USP, é possível notar que ele aumentou de 65,1\% em 1995 para 79,5\% em 2013. A porcentagem de alunos com pai com ensino superior completo também aumentou de 49,7\% em 1995 para 67,2\% em 2013. No caso dos alunos cuja mãe tem o mesmo grau de escolaridade, a variação foi homóloga, de 40,8\% em 1995 para 60,5\% em 2013.

Apesar dessa tendência geral à elitização do seu corpo discente entre 1995 e 2013, a relativa abertura do curso de ciências sociais entre 1999 e 2009 reforça a hipótese de que o grau de concorrência de um curso, que é um dos principais indicadores do valor social e econômico do seu diploma, se relaciona de modo direto com o perfil socioeconômico dos seus estudantes $^{206}$. Nesse sentido, a evolução da relação candidato/vaga e do perfil dos ingressantes dos cursos de ciências sociais e filosofia da USP, entre 1999 e 2009, testemunha a validade de uma das hipóteses essenciais da teoria estrutural do ensino superior, de que o perfil socioeconômico dos estudantes corresponde ao valor social do diploma a que pretendem, com os diplomas mais valorizados reservados aos mais favorecidos e vice-versa. Essa constatação fica mais clara quando comparamos o caso do curso de ciências sociais com o de filosofia. Enquanto a concorrência pelo curso de filosofia aumentou entre 1999 e 2009, traduzindo-se em uma relativa elitização do seu alunado, a relação candidato/vaga do curso de ciências sociais

\footnotetext{
${ }^{206}$ Lembrando que não é possível saber a variação da relação candidato/vaga entre 1995 e 2013 porque não existem dados disponíveis. No entanto, considerando a relação candidato/vaga do curso de ciências sociais de 2013, é possível notar que a relativa elitização dos ingressantes no curso entre 2009 e 2013 também corresponde a um aumento correlato da concorrência, que passou de 5,85 candidatos/vaga em 2009 para 6,21 candidatos/vaga em 2013.
} 
diminuiu no mesmo período, refletindo-se igualmente em uma relativa popularização dos seus estudantes. Nesse mesmo sentido, como em 2009, a despeito dessa evolução oposta, o curso de ciências sociais continuava a ser mais concorrido do que o de filosofia - a relação candidato/vaga do primeiro era de 5,85 e do segundo de 4,95 inscritos por vaga -, essa diferença também se traduzia no fato de que, mesmo com a relativa popularização ao longo dos anos, o alunado de ciências sociais permanecia um pouco mais elitizado do que o do curso de filosofia. Considerando, portanto, os dados do Questionário Socioeconômico da Fuvest de 2009, é possível notar que, enquanto o percentual de egressos do ensino médio privado no curso de ciências sociais era de $60,7 \%$, no de filosofia era de $58,5 \%$. Levando em conta a escolaridade dos pais, a diferença é homóloga. Enquanto 50,2\% dos estudantes de ciências sociais possuíam pai com ensino superior completo, $10,2 \%$ dos quais com pós-graduação, na filosofia esse percentual era de 49,1\%, dos quais 7,2\% com pós-graduação. Se entre os alunos de ciências sociais, 56,4\% tinham mãe com ensino superior completo, 10,8\% das quais com pós-graduação, entre os alunos de filosofia, 47,3\% possuíam mãe com o mesmo grau de escolaridade, 5,3\% das quais com pós-graduação. Os ingressantes oriundos de família com renda acima de 20 salários mínimos também eram um pouco mais numerosos nas ciências sociais do que na filosofia: $17,1 \%$ no primeiro caso, contra $16,7 \%$ no segundo. Por fim, o fato da carreira de ciências sociais ser relativamente mais concorrida do que a filosofia também se traduz no percentual relativamente menor de afrodescendentes que ingressaram no curso. Se 18,1\% dos alunos aprovados em ciências sociais em 2009 consideravam-se "pardos" e 3,9\%, "pretos", somando $22 \%$, na filosofia os autodeclarados "pardos" chegavam a 16,3\% e os "pretos", a 6,5\%, somando 22,8\%. Em suma, o exemplo da evolução desses dois cursos fundados no mesmo contexto histórico e sediados na mesma faculdade - no mesmo prédio, inclusive - ilustra de modo quase perfeito a hipótese de que o valor social do diploma - expresso na concorrência 
pelo curso que confere acesso a ele - se reflete diretamente no perfil socioeconômico e na trajetória escolar do seu alunado.

No âmbito das carreiras acadêmico-científicas é possível mobilizar, ainda, o caso dos cursos de química, cuja relação candidato/vaga foi a que mais cresceu dentre os cursos acadêmico-científicos da USP no intervalo de 1999 a 2009. Para o curso oferecido pelo Instituto de Química de São Paulo, o aumento da concorrência se refletiu, como é possível supor, na progressiva elitização dos ingressantes no curso, tanto considerando o período que vai de 1999 a 2009 quanto o intervalo temporal mais amplo que se estende de 1995 a 2013. Assim, embora o percentual de egressos do ensino médio privado tenha permanecido estável entre 1999 e 2009, os alunos que realizaram o ensino fundamental em escolas privadas passaram de $67,8 \%$ em 1999 para $85 \%$ do total de ingressantes em 2009. Além disso, a parcela dos alunos com pai e mãe detentores de diploma de ensino superior também cresceu. Se em 1999, 43,4\% dos alunos ingressantes em química tinham pai com ensino superior completo, em 2009, esse percentual chegou a 50,9\%. No mesmo período, a porcentagem de alunos cuja mãe tinha o mesmo nível de escolaridade passou de 36, $7 \%$ para 46,6\% do total. Em 2013, a tendência de aumento da escolaridade dos pais dos ingressantes de química se mantinha, notavelmente em relação às mulheres: 50,1\% dos alunos tinham pai com ensino superior completo e 55\% tinham mãe com o mesmo grau máximo de escolaridade.

A tendência à elitização pode ser observada, ainda, no curso de química do Instituto de Química de São Carlos, cujo aumento da relação candidato/vaga foi ainda maior do que o observado no curso de São Paulo. Considerando apenas o período que vai de 1995 a 2013 que, como foi dito, é o maior intervalo temporal possível de ser observado pelos dados atualmente disponibilizados pela Fuvest - vê-se que o percentual de egressos da escola pública fundamental caiu de $75,2 \%$ para $40 \%$ do total de alunos aprovados. Considerando-se os egressos do ensino médio público, o percentual caiu de 61,1\% em 1995 para 33,3\% em 2013. 
Coerentemente, a escolaridade dos pais dos ingressantes aumentou nesse mesmo período. Se em 1995, 29\% dos alunos aprovados no curso de química de São Carlos tinham pai com ensino superior completo, em 2013 esse percentual aumentou para 58,3\%, 20\% dos quais com pósgraduação. O percentual de alunos cuja mãe possuía o mesmo nível de escolaridade também cresceu, passando de 22,1\%, em 1995, para 40,1\%, em $2013,11,7 \%$ das quais com pósgraduação.

Sobre a evolução do perfil socioeconômico dos ingressantes nos cursos acadêmicocientíficos da USP, vale a pena observar, ainda, o caso dos cursos de ciências biológicas. Entre todos os cursos disciplinares da USP, os cursos de ciências biológicas são, pelo menos desde 1999, os mais concorridos. Na verdade, tanto em 1999 quanto em 2009, os cursos de biologia foram os únicos voltados sobretudo à formação científica cuja relação candidato/vaga ficou acima da média geral da USP, conforme é possível observar pelas tabelas 9 e 10. O fato da biologia ser um curso relativamente mais concorrido se reflete diretamente no perfil do seu alunado, em geral mais elitizado do que o de outros cursos acadêmico-científicos da USP. Considerando, portanto, o caso do curso de ciências biológicas do Instituto de Biociências de São Paulo, que é o mais antigo curso de biologia da universidade e que, tanto em 1999 quanto em 2009, foi o curso disciplinar mais concorrido da USP, é possível notar que, do ponto de vista da evolução do perfil socioeconômico e escolar do seu alunado, o curso seguiu o padrão de relativa elitização, assim como observado em outros cursos acadêmico-científicos da USP. Desse modo, entre 1999 e 2009, acompanhando a relativa diminuição da concorrência pelas suas vagas, o perfil dos estudantes ingressantes na biologia se popularizou, à semelhança do que ocorreu com as ciências sociais no mesmo período. O percentual de egressos do ensino fundamental privado, por exemplo, caiu de 75,2\% em 1999 para 68,1\% em 2009. Os egressos do ensino médio privado também caíram de $84,1 \%$ para $74,0 \%$ do total no mesmo período. De modo esperado, a porcentagem de estudantes cujo pai tinha ensino superior completo também 
diminuiu, de 65,1\% em 1999 para 61,3\% em 2009. Já os alunos cuja mãe tinha ensino superior completo, acompanhando uma tendência geral da USP e do país, conforme já observado, aumentou discretamente no mesmo período, passando de 57,4\% em 1999 para 58,9\% em 2009. No entanto, à semelhança do que ocorreu em outros cursos, tal como exposto até aqui, a popularização relativa observada entre 1999 e 2009 é uma tendência temporalmente circunscrita que não se confirma no intervalo mais amplo, que vai de 1995 a 2013. Desse modo, embora o curso tenha se popularizado entre 1999 e 2009, entre 1995 e 2013 o que se observa, na verdade, é uma tendência à elitização do seu alunado. Assim, se na metade dos anos 1990, $55,9 \%$ dos aprovados em ciências biológicas tinham realizado o ensino fundamental em escola privada, em 2013 esse percentual chegava a 73,3\% do total de aprovados. Os que realizaram o ensino médio no sistema privado, por sua vez, passaram de $64,8 \%$ para $75,0 \%$ do total de aprovados no mesmo período. O percentual de alunos cujo pai é altamente escolarizado também cresceu de 51,6\% para 64,9\%. Considerando-se a evolução da escolaridade das mães dos ingressantes em biologia, é possível notar que a parcela de estudantes cuja mãe tem superior completo saltou de 34,8\% em 1995 para 64,9\% em 2013.

A análise do polo acadêmico-científico se completa com o olhar sobre os cursos de licenciatura em ciências que estavam, em 2009, entre os menos concorridos da USP, ao lado das novas profissões, sediadas sobretudo fora da cidade universitária. Tomando como exemplo as novas licenciaturas - como a licenciatura em química, oferecida pela FFCLRP desde 2003, a licenciatura em geociências e educação ambiental, oferecida pelo IG desde 2004, e a licenciatura em ciências da natureza, oferecida pela EACH desde 2005 -, é visível que elas possuem um alunado bem menos elitizado do que o corpo discente da USP como um todo, bem como menos elitizado do que os cursos acadêmico-científicos voltados não só à formação de professores, mas também de pesquisadores. Para considerar apenas dois indicadores significativos, tomo, primeiro, a escolaridade paterna. É possível notar que o percentual de 
alunos cujo pai tinha ensino superior completo entre os ingressantes de 2009 era de 30,0\% na licenciatura em química, 35,9\% na licenciatura em geociências e educação ambiental, e de 50,4\% na licenciatura em ciências da natureza. A média entre os alunos da USP no mesmo ano foi de 53,3\%, como já foi dito. Nos cursos acadêmico-científicos já analisados, como filosofia, ciências sociais, química São Paulo, química São Carlos e ciências biológicas, esse mesmo percentual foi de $49,1 \%, 50,2 \%, 50,5 \%, 44,1 \%$ e $61,3 \%$ respectivamente. Paralelamente, considerando o ingresso de alunos afrodescendentes, esses cursos também são significativamente mais abertos do que a média da USP: 25\% dos ingressantes da licenciatura em química de Ribeirão Preto se diziam "pardos" ou "pretos". Entre os ingressantes da licenciatura em geociências e educação ambiental e da licenciatura em ciências da natureza, esse percentual foi de $28,2 \%$ e de $14,4 \%$ respectivamente. Esses percentuais de afrodescendentes entre o total de ingressantes são, no geral, não só maiores do a média observada na USP $(13,6 \%)$, como maiores do que o percentual que se verifica nos cursos acadêmico-científicos analisados anteriores, especialmente nas ciências exatas, como química São Paulo (10,0\%), química São Carlos (10,0\%) e ciências biológicas (11,3\%). Nas ciências sociais e filosofia, os afrodescendentes representaram, em 2009, $18,1 \%$ e 22,5\% dos ingressantes, como já foi dito.

O caráter mais popular não é exclusivo das novas licenciaturas em ciências. Cursos de formação de professores mais consolidados como a licenciatura em ciências exatas, oferecido pelo Instituto de Física de São Carlos (IFSC) em parceria com o Instituto de Ciências Matemáticas e Computação (ICMC) sediado na mesma cidade, e a licenciatura em física e matemática, do Instituto de Física (IF) e de Matemática e Estatística (IME) de São Paulo, assumem a mesma característica. No primeiro caso, apenas $38 \%$ dos estudantes tinham pai com ensino superior completo, no segundo, mais popular ainda, apenas $28,5 \%$ dos ingressantes contavam com pai com formação superior. O percentual de alunos "pardos" e "pretos" também 
era mais alta do que a média: entre os futuros professores de ciências exatas aprovados em São Carlos, 16\% se declaravam "pardos" ou "pretos" e entre os futuros professores de física e matemática formados em São Paulo, 25,9\% assumiam essa característica.

É possível dizer, portanto, que ao lado das novas profissões, sobretudo de caráter técnico, as carreiras dedicadas à formação de professores de ciências constituem uma das principais portas de entrada de novos setores sociais na Universidade de São Paulo. Considerados em conjunto, no entanto, os cursos acadêmico-científicos passaram a ocupar um lugar intermediário na estrutura da USP, ainda abaixo das profissões tradicionais mas agora acima dos novos cursos profissionais.

Para entender a validade dessa observação, é preciso analisar, por fim, a evolução do perfil dos alunos ingressantes nos cursos profissionais tradicionais, voltados à formação de profissionais liberais cujo diploma assegura não só uma remuneração mais alta, como também acesso a posições econômica, administrativas e politicamente mais elevadas. Antes de tudo, é preciso reconhecer que analisar a evolução do perfil social do alunado desses cursos, à semelhança do que foi feito para os acadêmico-científicos, é uma operação complicada porque o padrão de agrupamento dessas carreiras pela Fuvest variou significativamente ao longo do tempo. Tome-se o caso do curso de direito, por exemplo. Se em 1999, estavam incluídos nessa carreira apenas os ingressantes da Faculdade de Direito do Largo São Francisco, em 2009 a Fuvest incluiu, para efeito das estatísticas disponibilizadas, o curso de direito da Faculdade de Direito de Ribeirão Preto. No caso dos cursos de Medicina e Ciências Médicas se deu o oposto. Se em 1999 a Fuvest agrupava os alunos da Faculdade de Medicina de São Paulo e de Ribeirão Preto em uma única carreira, a partir de 2009 a Fundação segmentou esses cursos em duas carreiras distintas, o que igualmente dificulta a comparação. O mesmo ocorreu com os cursos da Faculdade de Economia, Administração e Contabilidade, que passaram a ser agrupados em uma única carreira a partir de 2009. Os cursos de engenharia da Poli também sofreram alteração 
na forma como a Fuvest considera essa carreira. Em 1999, as engenharias de São Paulo eram computadas juntamente com os cursos de ciências exatas do IME, o que deixou de ser feito a partir de 2008. Considerando essa variação, a melhor forma de descrever a evolução do perfil do alunado desses cursos foi selecionar os cursos em que a variação foi menos intensa e mobilizar o maior intervalo temporal possível, de modo a captar sobretudo os movimentos tendenciais mais importantes. Embora a solução não seja perfeita, e a análise geral desses dados demande cautela, optamos por mantê-la pelo que ela revela, ainda que de modo indicativo, sobre a evolução do perfil do alunado dos cursos profissionais tradicionais da USP, que formam, como se verá, o seu polo dominante.

Nesse sentido, considere-se, em primeiro lugar, a evolução dos cursos de medicina de São Paulo e de ciências médicas de Ribeirão Preto $^{207}$ que, como resultado de uma tendência de aumento da concorrência pelas suas vagas nos últimos anos ${ }^{208}$, tornaram-se, em 2014, os dois cursos mais concorridos da USP com 58,57 e 62,91 candidatos por vaga respectivamente. Considerando a evolução do perfil dos seus ingressantes entre 1995 e 2013, apesar do leve aumento do número de egressos da escola pública entre os aprovados - eram 12,6\% do total de aprovados em 1995 para os dois cursos passando para 18,9\% no caso da medicina de São Paulo e 16\%, no caso da de Ribeirão Preto -, a escolaridade dos pais seguiu a tendência oposta: se em 1995, 73,9\% dos alunos tinham pai com ensino superior completo, em 2013 esse percentual cresceu para 77,4\%, no caso da medicina de São Paulo, apesar de ter diminuído para 72,0\% no caso de Ribeirão Preto. Os alunos cuja mãe tinha ensino superior completo também aumentaram significativamente nos dois cursos ao longo desse período, passando de 56,1\%, em 1995, para

\footnotetext{
${ }^{207}$ Em 1996, a FMRP substituiu o seu curso de "medicina" por um curso de "ciências médicas". Essa inflexão que testemunha o perfil historicamente mais científico dessa Faculdade não implicou um afastamento em relação à profissão médica, uma vez que o curso, mesmo com outro nome, continua sendo um curso de medicina.

${ }^{208}$ Em 1999, os cursos de ciências médicas e medicina contavam com 28,68 candidatos por vaga. Em 2009, esse valor já tinha subido para 35,68. Em 2013, a Medicina São Paulo contava com 56,43 candidatos por vaga e a medicina Ribeirão Preto com 45,45 candidatos por vaga.
} 
76\% na FM (São Paulo) e 73\% na FMRP (Ribeirão) em 2013. Os alunos ingressantes em medicina da USP não são apenas oriundos de famílias que têm, em média, maior escolaridade. Em comparação com a média da USP, esses alunos possuem, também, maior renda familiar. Assim, 37,1\% dos ingressantes do curso de medicina de São Paulo e 26,0\% do curso de medicina de Ribeirão Preto vêm de famílias cuja renda é maior do que 15 salários mínimos, enquanto, entre o total de ingressantes na USP, apenas 20,7\% estão nessa mesma faixa de renda. O percentual de "pardos" e "pretos" que ingressam nos dois cursos mais concorridos da USP também é menor do que a média da universidade. Em 2013, apenas um ingressante do curso de medicina da Faculdade de Medicina de São Paulo e um ingressante do curso de medicina da Faculdade de Medicina de Ribeirão Preto se autodeclararam como "pretos" no Questionário socioeconômico da Fuvest, o que correspondia a uma média de $0,5 \%$ do total de ingressantes. Já os autodeclarados "pardos" aprovados nos cursos de medicina da USP em 2013 representavam 6,2\% do total no caso da medicina São Paulo e 10,0\% do total no caso da medicina de Ribeirão Preto - ambos percentuais mais baixos do que a USP. Por fim, se houve um aspecto em que o perfil dos estudantes de medicina da USP se diversificou no período observado foi no sexo dos ingressantes, com uma tendência discreta à feminização da carreira ao longo dos últimos anos. Assim, se em 1995 os homens representavam 69,8\% dos alunos aprovados em medicina da USP, seja em São Paulo seja em Ribeirão Preto, em 2013 esse percentual caiu para 58,5\% dos aprovados em medicina na capital e 65,0\% dos aprovados no interior, o que comprova o predomínio de homens entre os futuros médicos formados pela USP.

O predomínio dos alunos do sexo masculino também se observa nos dois cursos de direito da USP. Em 1995, 59,3\% dos aprovados em direito eram homens. Em 2013, considerando as Faculdades de Direito de São Paulo e de Ribeirão Preto conjuntamente, esse percentual caiu discretamente, chegando a 57\%. Além do aumento do percentual de mulheres ter sido menor do que a verificada nos cursos de medicina, a elitização dos alunos de direito da 
USP quando comparados aos de medicina, foi ainda maior. Em síntese, se em 1995, 79,1\% dos ingressantes de direito eram alunos de escola privada, em 2013 esse percentual cresceu para 85,6\%. A escolaridade dos pais também aumentou. Na metade dos anos 1990, 70,9\% dos estudantes de primeiro ano de direito da USP eram filhos de pai com ensino superior completo, enquanto em 2013 esses estudantes representavam 72\% do total, 27,3\% dos quais eram filhos de pai com pós-graduação. À semelhança do que ocorreu com outros cursos, a variação da escolaridade da mãe foi ainda mais marcante: em 1995, 59,6\% dos ingressantes em direito possuíam mãe com ensino superior completo, enquanto em 2013, esse percentual que chegou a $75 \%$ do total. Dessas mães com diploma de ensino superior, 27,5\% possuíam, também, pósgraduação. O perfil altamente escolarizado das famílias dos estudantes de direito da USP se traduz na superioridade da sua renda: 41,4\% dos estudantes ingressantes no curso em 2013 eram oriundos de famílias cuja renda era de mais do que 15 salários mínimos, o dobro do percentual observado para a USP como um todo.

Por fim, é possível considerar o exemplo dos cursos de engenharia da Escola Politécnica, um dos mais tradicionais da USP. Assim como nos cursos de medicina e de direito, e de modo ainda mais acentuado, os ingressantes da Poli são majoritariamente homens, ainda que esse percentual também venha caindo ao longo do tempo. Assim, se em 1995, 89,2\% dos aprovados na carreira de "engenharia e ciências exatas" eram homens, em 2013 esse percentual para os cursos de "engenharia da Escola Politécnica" caiu para 78,2\% do total. O predomínio de homens nas chamadas profissões imperiais (Coelho, 1999) da USP reforça uma das conclusões do estudo de Maria da Graça Setton sobre a hierarquização das carreiras da área de humanas da USP, no qual a autora observa "uma acentuada tendência dos homens escolherem os cursos classificados como seletos" (1999, p. 469), ou seja, marcados por um predomínio de alunos oriundos de famílias de alto capital cultural e econômico e que preparam para posições social, política e economicamente dominantes (cf. Setton, 1999). 
Voltando à análise dos cursos da Escola Politécnica, apesar da relativa abertura do ponto de vista demográfico, o perfil social e econômico dos ingressantes da Poli se tornou mais homogêneo ao longo dos últimos anos, resultado de um processo de elitização semelhante ao que impactou as outras profissões tradicionais da USP. Nesse sentido, o percentual de ingressantes da Poli que cursaram o ensino fundamental na escola privada passou de $74,3 \%$ em 1995 para $88,8 \%$ em 2013. Já os que cursaram o ensino médio na escola privada cresceram de $78,2 \%$ para $80,8 \%$ do total no mesmo período. A parcela dos alunos ingressantes cujo pai tinha ensino superior completo também aumentou de $69,1 \%$, em 1995 , para $73,3 \%$, em $2013,26,6 \%$ dos quais possuindo pós-graduação completa. O percentual de alunos cuja mãe tinha a mesma escolaridade aumentou de 50,2\% para 73,8\% no mesmo período, $24 \%$ das quais com pósgraduação completa. Paralelamente, em 2013, o percentual de alunos que, ingressando na Poli, se autodeclaravam "pardos" e "pretos" foi de 7,6\%, metade do percentual verificado para o conjunto da USP. Outro dado importante, o percentual de alunos oriundos de famílias com renda maior do que 15 salários mínimos foi de $36,6 \%$, mais ou menos o mesmo percentual dos estudantes de medicina de São Paulo e significativamente maior do que a média da USP, que foi de $20,7 \%$ em 2013.

Em síntese, essa longa análise sobre a variação do perfil social dos ingressantes em carreiras paradigmáticas da USP permite mostrar que, ao longo dos últimos anos, em consequência do aumento da concorrência pelo ingresso na universidade, o perfil dos estudantes da USP se elitizou, resultando em uma universidade consideravelmente homogênea, onde a maior parte dos seus estudantes são brancos, egressos de escola privada e oriundos de famílias com alta renda e alta escolaridade. No entanto, essa tendência à elitização do corpo discente, bem como a homogeneidade social que ela produz, não se expressa da mesma forma em todos os cursos e carreiras da universidade. Ao contrário, existem clivagens importantes, relacionadas ao valor social dos diplomas oferecidos pelos diferentes cursos e ao perfil socioeconômico dos 
estudantes para eles selecionados que, determinando as proximidades e distâncias entre as diferentes unidades da USP, definem, em essência, a sua estrutura social.

Nesse sentido, ao analisar os processos de expansão, diversificação e elitização da Universidade de São Paulo nos últimos anos, foi possível constatar que esses movimentos tendências gerais, que são determinantes na histórica recente da instituição, não se desenvolveram do mesmo modo nos diferentes cursos, carreiras e unidades da universidade. $\mathrm{Na}$ verdade, foi possível observar três padrões claramente distintos de evolução, a partir dos quais é possível definir os três polos principais da USP, nos quais se distribuem as suas diferentes unidades. São eles:

I) Polo profissional tradicional. Constituído pelas faculdades da USP que reúnem principalmente os cursos de graduação voltados à formação de profissionais cujo diploma tem um alto valor econômico e social, o que se reflete no caráter essencialmente elitizado do seu alunado. Justamente pelo seu recrutamento social elevado, são espaços de formação e de socialização de elites sociais, políticas e econômicas de São Paulo. O núcleo desse polo é formado pelas faculdades profissionais concentradas na capital do estado e fundadas antes de 1934 ou, em menor medida, antes de 1960, quais sejam:

- Faculdade de Direito (1827)

- Escola Politécnica (1893)

- Faculdade de Ciências Farmacêuticas (1898)

- Faculdade de Odontologia (1898)

- Faculdade de Medicina (1912)

- Faculdade de Medicina Veterinária e Zootecnia (1911)

- Faculdade de Saúde Pública (1919)

- Faculdade de Economia e Contabilidade (1931)

- Faculdade de Arquitetura e Urbanismo (1948) 
Para além desse "núcleo duro", podem ser incluídas nesse polo as faculdades profissionais sediadas fora da cidade de São Paulo e/ou fundadas depois dos anos 1960 mas que, igualmente, voltam-se à formação de profissionais valorizados socialmente, tais como:

- Escola de Agricultura Luiz de Queiróz (1901)

- Faculdade de Odontologia de Bauru (1948)

- Faculdade de Medicina de Ribeirão Preto (1948)

- Escola de Engenharia de São Carlos (1948)

- Escola de Comunicação e Artes (1966)

- Instituto de Psicologia (1969)

- Faculdade de Ciências Farmacêuticas de Ribeirão Preto (1924/1975)

- Faculdades de Odontologia de Ribeirão Preto (1924/1982)

- Faculdade de Economia, Administração e Contabilidade de Ribeirão Preto (2002)

- Instituto de Relações Internacionais (2002)

- Escola de Engenharia de Lorena (2006)

- Faculdade de Direito de Ribeirão Preto (2007)

- Instituto de Arquitetura e Urbanismo de São Carlos (2010)

Juntas, essas unidades compõem o polo profissional tradicional da USP. É importante notar que denominar esse polo de "profissional" não implica afirmar que as unidades que o compõem se dediquem exclusivamente à formação profissional. Ao contrário, é amplamente reconhecido que essas unidades possuem uma tradição de pesquisa e de formação em pósgraduação bastante consolidadas. Por outro lado, em relação a outras unidades, especialmente do polo que estamos denominando acadêmico-científico, é a importância da formação de profissionais que as distingue sendo, portanto, no âmbito da estrutura, isso que as distingue. É dessa perspectiva relacional, também, que se pode afirmar que essas unidades hegemonizam o 
poder institucional da universidade, como é possível notar pela tabela 11, que sintetiza os reitores da USP, e suas respectivas unidades de origem, eleitos ou nomeados entre 1934 e 2014.

As exceções na tabela confirmam, de certo modo, a regra, de predomínio das áreas profissionais tradicionais. O professor José Goldemberg, apesar de ser titular do Instituto de Física da USP, prestou concurso originalmente para a Escola Politécnica, onde lecionou até a reforma universitária de 1969, quando todas as cadeiras de física da universidade foram reunidas em um único instituto. O professor Roberto Leal Lobo e Silva, do Instituto de Física de São Carlos, é engenheiro de formação, apesar de ter feito doutorado em física e lecionar na área. O professor Ruy Laurenti, vice-reitor em exercício da USP durante 1993, é formado em medicina pela FMUSP, onde fez também a sua pós-graduação, antes de ingressar na Faculdade de Saúde Pública. O professor Flávio Fava de Moraes, titular do Instituto de Ciências Biomédicas, fez graduação da Faculdade de Odontologia de São Paulo e realizou toda a sua carreira de pesquisa na Faculdade de Medicina, onde exerce, hoje, o cargo de diretor da Fundação Faculdade de Medicina.

Paralelamente, as unidades profissionais tradicionais são, ainda, as que, a despeito do progressivo aumento do percentual de professores trabalhando em regime de RDIDP, possuem o menor percentual relativo de docentes em dedicação exclusiva, segundo dados de 2010. A tabela 12, apresenta as unidades de ensino e pesquisa da USP segundo o percentual de professores em regime de dedicação exclusiva em relação à média da universidade. 
Tabela 11. Reitores da USP entre 1934 e 2014, com a respectiva unidade de vinculação

\begin{tabular}{|c|c|c|}
\hline Reitor da USP & Período & Unidade de vinculação \\
\hline Reinaldo Porchat & $1934-1937$ & Faculdade de Direito \\
\hline Lúcio Martins Rodrigues & $1938-1939$ & Escola Politécnica \\
\hline Domingos Rubião Alves Meira & $1939-1941$ & Faculdade de Medicina \\
\hline Jorge Americano & $1941-1946$ & Faculdade de Direito \\
\hline Antônio de Almeida Prado & $1946-1947$ & Faculdade de Medicina \\
\hline Benedito Montenegro & $1947-1947$ & Faculdade de Medicina \\
\hline Lineu Prestes & $1947-1949$ & Faculdade de Odontologia \\
\hline Miguel Reale & $1949-1950$ & Faculdade de Direito \\
\hline Luciano Gualberto & $1950-1951$ & Faculdade de Medicina \\
\hline Ernesto de Morais Leme & $1951-1953$ & Faculdade de Direito \\
\hline José Melo Morais & $1954-1955$ & Escola Superior de Agricultura Luiz de Queiroz \\
\hline Alípio Correia Neto & $1955-1957$ & Faculdade de Medicina \\
\hline Gabriel de Teixeira Carvalho & $1957-1960$ & Faculdade de Medicina Veterinária e Zootecnia \\
\hline Antônio Barros de Ulhôa Cintra & $1960-1963$ & Faculdade de Medicina \\
\hline Luiz Antônio da Gama e Silva & $1963-1969$ & Faculdade de Direito \\
\hline Mário Guimarães Ferri* & $1967-1968$ & Faculdade de Filosofia, Ciências e Letras \\
\hline Hélio Lourenço de Oliveira* & $1968-1969$ & Faculdade de Medicina de Ribeirão Preto \\
\hline Alfredo Buzaid & $1969-1969$ & Faculdade de Direito \\
\hline Miguel Reale & $1969-1973$ & Faculdade de Direito \\
\hline Orlando Marques de Paiva & $1973-1979$ & Faculdade de Medicina Veterinária e Zootecnia \\
\hline Waldir Muniz Oliva & $1978-1982$ & Instituto de Matemática e Estatística \\
\hline Antônio Hélio Guerra Vieira & $1983-1986$ & Escola Politécnica \\
\hline José Goldemberg & $1986-1990$ & Instituto de Física \\
\hline Roberto Leal Lobo e Silva & $1990-1993$ & Instituto de Física e Química de São Carlos \\
\hline Ruy Laurenti* & $1993-1993$ & Faculdade de Saúde Pública \\
\hline Flávio Fava de Moraes & $1993-1997$ & Instituto de Ciências Biomédicas \\
\hline Jacques Marcovitch & $1997-2001$ & Faculdade de Economia e Administração \\
\hline Adolpho José Melfi & $2001-2005$ & Escola Superior de Agricultura Luiz de Queiroz \\
\hline Suely Vilela Sampaio & $2005-2009$ & $\begin{array}{l}\text { Faculdade de Ciências Farmacêuticas de } \\
\text { Ribeirão Preto }\end{array}$ \\
\hline João Grandino Rodas & $2010-2014$ & Faculdade de Direito \\
\hline Marco Antônio Zago & $2014-2018 * *$ & Faculdade de Medicina de Ribeirão Preto \\
\hline
\end{tabular}

Fonte: Motoyama, 2006

Elaboração própria
* Vice-reitores em exercício
** Data prevista para o fim do mandato 
Tabela 12. Unidades de ensino e pesquisa da USP hierarquizadas segundo o percentual de docentes em regime de dedicação exclusiva (2010)

Unidades de ensino e pesquisa

Faculdade de Direito

Faculdade de Medicina

Faculdade de Odontologia

Faculdade de Arquitetura e Urbanismo

Faculdade de Direito de Ribeirão Preto

Faculdade de Economia, Administração e Contabilidade

Instituto de Psicologia

Escola Politécnica

Instituto de Relações Internacionais

Escola de Educação Física e Esportes

Escola de Comunicação e Artes

Universidade de São Paulo (total)

Faculdade de Odontologia de Ribeirão Preto

Faculdade de Odontologia de Bauru

Faculdade de Saúde Pública

Faculdade de Ciências Farmacêuticas

Escola de Artes, Ciências e Humanidades

Faculdade de Economia, Administração e Contabilidade de R.P.

Instituto de Química de São Carlos

Escola de Engenharia de São Carlos

Instituto de Ciências Biomédicas

Instituto de Matemática e Estatística

Instituto de Geociências

Faculdade de Ciências Farmacêuticas de Ribeirão Preto

Faculdade de Educação

Faculdade de Medicina de Ribeirão Preto

Instituto de Física de São Carlos

Escola Superior de Agronomia Luiz de Queiróz

Escola de Enfermagem

Faculdade de Filosofia, Ciências e Letras de Ribeirão Preto

Instituto de Física

Faculdade de Filosofia, Letras e Ciências Humanas

Instituto de Ciência Matemática e Computação de São Carlos

Instituto de Astronomia, Geofísica e Ciências Atmosféricas

Escola de Enfermagem de Ribeirão Preto

Faculdade de Medicina Veterinária e Zootecnia

Instituto de Biociências

Escola de Educação Física e Esportes de Ribeirão Preto

Faculdade de Zootecnia Engenharia de Alimentos

Instituto Oceanográfico

Instituto de Química

Escola de Engenharia de Lorena

Instituto de Arquitetura e Urbanismo
Percentual de docentes em dedicação exclusiva (2010)

$12,65 \%$

$42,16 \%$

$48,05 \%$

$60,00 \%$

$61,53 \%$

$69,02 \%$

$73,33 \%$

$75,87 \%$

$83,33 \%$

$84,09 \%$

$84,31 \%$

$\mathbf{8 4 , 7 3 \%}$

$85,41 \%$

$85,47 \%$

$86,46 \%$

$90,10 \%$

$94,26 \%$

$94,31 \%$

$94,33 \%$

$95,02 \%$

$95,10 \%$

$95,16 \%$

$95,23 \%$

$96,11 \%$

$96,23 \%$

$97,03 \%$

$97,36 \%$

$97,48 \%$

$97,59 \%$

$97,79 \%$

$97,93 \%$

$98,14 \%$

$98,50 \%$

$98,63 \%$

$98,95 \%$

$98,99 \%$

$99,09 \%$

$100,00 \%$

$100,00 \%$

$100,00 \%$

$100,00 \%$

$\mathrm{s} / \mathrm{d}$

$\mathrm{s} / \mathrm{d}$

Fonte: Anuário Estatístico

Elaboração: própria 
Analisados em conjunto, esses dois dados mostram que as unidades do polo profissional tradicional - que poderiam também ser chamadas, em função do perfil do seu alunado e da formação que oferecem, de "escolas de elite" - concentram não só o poder político da USP como, também, os canais de comunicação diretos que a universidade estabelece com outros espaços sociais, particularmente o Estado e o mercado, como é possível depreender a partir dos baixos índices de dedicação exclusiva à docência e à pesquisa verificados entre seus professores, que indicam uma forte inserção social do seu corpo docente, seja em outros espaços profissionais do mercado de trabalho, seja em órgãos de controle econômico, político e social, especialmente no aparelho de Estado. É esse índice de “integração social”, que em geral traduz uma "adesão à ordem dominante", que aproxima o polo profissional da USP do que Bourdieu denominou, na sua análise sobre o campo universitário francês, de "poder temporal" concentrado pelo "polo mundano" da universidade (cf. Bourdieu, 1984, p. 99ss). Ainda segundo o autor, esse polo é marcado por uma distância menor em relação aos poderes e espaços socialmente dominantes e, consequentemente, por um grau de autonomia social também inferior em relação a eles, sobretudo quando comparado ao outro polo essencial do campo universitário, constituído pelas disciplinas intelectuais e científicas, voltadas à produção de conhecimento e à produção de produtores de conhecimento. É nesse sentido que, também na USP, ao polo profissional tradicional contrapõe-se um "polo acadêmico-científico", sistematizado a seguir.

II) Polo acadêmico-científico. Composto pelas unidades voltadas à formação científica e pedagógica, fundadas sobretudo entre 1934 e 1968, no geral com sede em São Paulo, o polo acadêmico-científico reúne as unidades relativamente mais abertas a novos setores sociais em comparação com o polo profissional tradicional. Paralelamente, esse polo reúne, também, as disciplinas e áreas marcadas por um grau de autonomia universitária relativamente maior, dado 
não só pela inserção social mais frágil dos seus alunos e docentes como, também, pelo seu compromisso com a construção de condições institucionais para que a atividade científica, expressa no chamado regime disciplinar, possa funcionar em condições de relativa autonomia $^{209}$. No caso da USP, o núcleo do polo acadêmico-científico reúne, em primeiro lugar, as unidades que compunham a antiga FFCL, fundada em 1934 e fragmentada em 1969. São elas:

- Instituto de Física (1934/1969)

- Instituto de Química (1934/1969)

- Instituto de Biociências (1934/1969)

- Instituto de Matemática e Estatística (1934/1969)

- Instituto de Geociências (1934/1969)

- Faculdade de Filosofia, Letras e Ciências Humanas (1934/1969)

- Faculdade de Educação

Além disso, compõem esse polo outras unidades de vocação científica, embora não vinculadas originalmente à FFCL, tais como:

- Instituto Oceanográfico (1946/1951)

- Instituto de Astronomia, Geofísica e Ciências Atmosféricas (1927/1946)

- Instituto de Ciências Biomédicas (1949)

- Instituto de Ciências Matemáticas e Computação (1971)

- Instituto de Física de São Carlos (1971/1994)

- Instituto de Química de São Carlos (1971/1994)

\footnotetext{
${ }^{209}$ Como procurei mostrar em pesquisa anterior, a história da institucionalização da ciência no país é inseparável da atuação de cientistas brasileiros, especialmente ligados às ciências exatas, sobretudo à física, na constituição de condições para que a ciência possa funcionar com um grau de autonomia mínimo, dado pelo predomínio da avaliação por pares, por canais de comunicação próprios e mecanismos institucionais de autocontrole dos cientistas sobre o desenvolvimento da ciência, ainda que essas instâncias de autogoverno sejam essencialmente hierarquizadas (cf. Carlotto, 2013).
} 
Para descrever a composição desse polo é preciso reconhecer a existência de unidades de ensino e pesquisa marcadas por uma forte ambiguidade. É o caso, por exemplo, da Faculdade de Educação (1934/1969) que, embora tenha uma vocação profissional dada pela ênfase na formação de professores, pedagogos e administradores escolares, preserva-se próxima do polo acadêmico-científico justamente pela peculiaridade da formação que oferece, de natureza acadêmica e pela construção de um campo forte de pesquisas educacionais. Ou ainda, de algumas áreas da Escola de Comunicação e Artes (1966), ligadas ao estudo e à pesquisa cultural e artística, que se diferenciam da vocação profissional da maior parte dos cursos da unidade. Ou mesmo a Escola de Artes, Ciências e Humanidades, prevista para ser um espaço de expansão da formação profissional de caráter mais técnico, revela, quando vista de perto, uma série de disputas internas pela afirmação de um perfil mais acadêmico, que testemunham a força dos padrões e práticas predominantes nas unidades do polo científico da universidade, nas quais a maioria dos seus professores foi formada (cf. Garcia \& Carlotto, 2012 e 2013a).

Na verdade, uma análise que se concentrasse na compreensão da organização interna das diferentes unidades da USP certamente encontraria ambiguidades e contraposições homólogas em todas elas. Nesse sentido, por exemplo, seria possível citar o caso da Faculdade de Medicina de Ribeirão Preto que, embora voltada à formação profissional em medicina, assumiu, desde a sua fundação, um perfil mais científico em função da intervenção direta da Fundação Rockfeller que financiou a criação da unidade, definindo padrões e práticas (cf. Marinho, 2001). Esse perfil científico se reflete de modo paradigmático na nomeação do seu curso de medicina, chamado de curso "ciências médicas", como já foi visto. No mesmo sentido, da própria Faculdade de Filosofia, Letras e Ciências Humanas - maior unidade da USP - vive constantemente sob o impacto de tensões entre concepções de ensino e pesquisa, ligadas muitas vezes às posições sociais e institucionais dos seus portadores, que atingem não só a unidade 
como um todo, mas praticamente todos os seus cursos, departamentos e áreas (cf. Arantes, 1994; Jackson, 2007; Keineirt \& Silva, 2010; Pulici, 2008; Rodrigues, 2011). A constatação da complexidade social e acadêmica da USP não invalida a abordagem estrutural que está sendo proposta por este trabalho, que envolve relacionar e hierarquizar, no âmbito da USP, as unidades de ensino e pesquisa, consideradas como uma totalidade mais ou menos coesa. Ao contrário, é próprio do método estrutural ser capaz de revelar princípios essenciais de hierarquização social, econômica, política e cultural que marcam, de modo sucessivo, os espaços e subespaços sociais. Em síntese, demonstrar a existência de uma contraposição principal - de natureza econômica, social, política e acadêmica - entre um polo profissional e um polo científico-acadêmico no interior da USP, vista então como um espaço social estruturado, não impede - antes supõe - a constatação de outras polarizações dentro dos subcampos que compõem esse espaço, tais como o subcampo profissional e o subcampo acadêmico-científico, e mesmo dentro das diferentes unidades de ensino e pesquisa, elas mesmas marcadas por polarizações e disputas importantes. É nesse sentido que Bourdieu, ao analisar o campo universitário francês, e encontrando uma oposição essencial entre o valor social e econômico dos diplomas superiores e o perfil socioeconômico dos estudantes que ingressam nas diferentes carreiras, vai concluir que "essa oposição cardinal é reencontrada no interior de cada um dos subespaços do campo universitário que correspondem aos grandes setores do campo do poder" (Bourdieu, 1989, p. 205).

É justamente reconhecendo uma hierarquização fundamental no interior do subcampo profissional, que separa e diferencia as unidades profissionalizantes da USP, que proponho a existência de um terceiro polo, constituído pelas unidades voltadas sobretudo às novas formações profissionais, em geral, de caráter mais especializado e pelas unidades dedicadas à formação de profissões consolidadas que assumem, no entanto, um perfil mais técnico. Optei por denominar esse polo de técnico-profissional justamente por reconhecer que, além de ser 
voltado à formação de profissionais, os cursos assim classificados destacam-se pelo perfil mais especializado da sua formação. Implícito no movimento, de reconhecer a existência de um terceiro polo na USP, está o pressuposto de que a contraposição entre concepção e execução ou, em outras palavras, entre uma formação voltada ao exercício do controle social e uma formação voltada à execução técnica de funções especializadas (cf. Bourdieu, 1989; Boltanski, 1982; Bolstanski \& Chiapello, 1999; Pichon, 2008), que fratura o campo profissional, é mais importante dos que as inúmeras diferenças que atingem o interior do campo acadêmicocientífico, como as que separam as áreas científicas de humanas, biológicas e exatas, ou as que opõem os cursos laboratoriais e não laboratoriais ou, mais recentemente, as que diferenciam os cursos disciplinares das formações multi, trans ou interdisciplinares.

III) Polo técnico-profissional. Como foi dito, o polo técnico-profissional é composto, sobretudo, pelas novas unidades que concentram os cursos profissionalizantes de caráter mais especializado e pelas unidades da USP mais antigas que, no entanto, se voltam para a formação de profissionais mais técnicos. O caráter socialmente dominado das formações profissionais oferecidas por essas unidades se reflete claramente no perfil do seu alunado, marcadamente mais popular e mais feminino do que o das outras unidades profissionais. No caso da USP, as unidades que compõem o polo profissional dominado ou técnico-profissional são:

- Escola de Enfermagem (1942/1963)

- Escola de Enfermagem de Ribeirão Preto (1951/1964)

- Escola de Educação Física e Esportes (1969)

- Faculdade de Filosofia, Ciências e Letras de Ribeirão Preto (1959/1974)

- Faculdade de Zootecnia e Engenharia de Alimentos (1992)

- Escola de Artes, Ciências e Humanidades (2004)

- Escola de Educação Física e Esportes de Ribeirão Preto (2007) 
Dentre essas unidades, as que se formaram depois de 1970 contribuíram para dinamizar, como foi visto, a expansão da USP através da abertura de novos cursos e vagas. Paralelamente, as unidades formadas antes de 1970, embora tenham permanecido praticamente estagnadas do ponto de vista da abertura de cursos e vagas, continuam sendo um dos principais espaços de inclusão social da USP, pelo fato de se abrirem para novos setores sociais, função que compartilham com o polo acadêmico-científico e que as diferencia das profissões tradicionais. É importante notar que o agrupamento de unidades da USP em função do perfil especializado ou técnico da formação profissional que elas oferecem certamente será objeto de protestos e estranhamentos, sobretudo por parte daqueles que, no interior dessas instituições, atuam para afirmá-las essencialmente enquanto espaços de produção de conhecimento e formação geral. No entanto, esse tipo de reação, mais do que sugerir a fraqueza da análise proposta revela, na verdade, a sua força. O caráter fortemente pejorativo que assumem, no interior da USP, designações como "especializado", "profissional médio" e "técnico" revelam, de modo exemplar, a força das hierarquias sociais que estruturam a USP e que se traduzem, portanto, em esquemas categoriais como os que opõem, no âmbito da universidade, a "formação geral" à “formação técnica”, os “dirigentes” aos "especialistas”, a "concepção" à “execução". A análise da estrutura social da universidade, que permite compreende a força e o significado desses esquemas categoriais, é o tema do próximo item. 


\title{
3. Dominantes e dominados no contexto universitário: a estrutura social da USP
}

\begin{abstract}
O campo universitário reproduz, na sua estrutura, o campo do poder que, através da sua ação própria de seleção e inculcação, ajuda a reproduzir estruturalmente. É, na verdade, no seu e pelo seu funcionamento enquanto espaço de diferença entre posições (e, ao mesmo tempo, entre as disposições de seus ocupantes) que se realiza, para além de toda intervenção das consciências e das vontades individuais ou coletivas, a reprodução do espaço de posições diferenciais que são constitutivas do campo do poder. Como mostra claramente a análise de correspondência, as diferenças que separam as faculdades e as disciplinas, tal como é possível defini-las através das propriedades dos seus professores, apresentam uma estrutura homóloga àquela do campo do poder no seu conjunto: as faculdades temporalmente dominadas, faculdades de ciências, e, em menor grau, faculdades de letras, se opõem às faculdades socialmente dominantes, sob esse aspecto, praticamente idênticas, [como as] faculdades de direito e de medicina, por todo um conjunto de diferenças econômicas, culturais e sociais, onde se reconhece o essencial do que constitui a oposição, no seio do campo do poder, entre a fração dominante e a fração dominada (Bourdieu, 1984, p. 62).
\end{abstract}

Ao descrever o campo universitário francês, tanto em Homo Academicus (1984) quanto em La noblesse d'état (1989), Pierre Bourdieu reconhece a importância da contraposição entre um polo dominado, formado pelas carreiras científicas e certas formações profissionais como letras, e um polo dominante, constituído pelas profissões socialmente valorizadas, tais como direito e medicina. $\mathrm{O}$ autor reconhece, ainda, que essa oposição acadêmica traduz, nos seus próprios termos, diferenças de ordem social, econômica e cultural que também separam essas faculdades e seus egressos no espaço exterior à universidade. Por fim, o autor procura mostrar como a tradução de diferenças sociais, culturais e econômicas em diferenças acadêmicas, cuja origem é externa à universidade, é, em geral, obliterada na crença na meritocracia, que ajuda a reproduzir as estruturas essenciais do campo do poder, conceito que designa, em síntese, as posições de controle social, cultural, político e econômico. Essas proposições específicas sobre o papel social da universidade na reprodução das estruturas de poder, que são uma expressão particular da tese da reprodução que enfatiza a função conservadora do sistema escolar, partem de uma operação analítica que busca observar a estrutura social da universidade, expressa nas hierarquias que afastam e aproximam as suas diferentes unidades de ensino e pesquisa, segundo 
o perfil socioeconômico dos seus membros. É justamente essa a intenção da presente seção, que busca, através da análise da estrutura social da USP, descrever a tradução de hierarquias sociais em hierarquias acadêmicas.

No entanto, antes de entrar na análise propriamente dita, é preciso sistematizar de que maneira foram construídos os dados que constituem o seu fundamento. A Universidade de São Paulo tem, como foi dito, duas instâncias principais de produção de dados públicos: o Anuário Estatístico, que sintetiza informações de vários órgãos e sistemas centralizados, e o Questionário socioeconômico da Fuvest, que permite conhecer, anualmente, o perfil social, cultural, demográfico e econômico dos ingressantes nas diferentes carreiras da USP. Nenhuma dessas duas instâncias permite acessar o perfil socioeconômico do corpo docente da USP, nem mesmo do seu corpo discente de pós-graduação. Nesse sentido, a reconstrução da estrutura social da USP foi feita, neste trabalho, através das informações sociais sobre o corpo discente de graduação, disponibilizadas anualmente pela Fuvest, quando necessário e possível, complementadas por informações disponíveis no Anuário Estatístico da USP. Essa opção pelo alunado de graduação resultou, portanto, de razões puramente práticas: não existem informações públicas ${ }^{210}$, atuais, sobre o perfil socioeconômico dos professores, funcionários e estudantes de pós-graduação da USP. A restrição da análise ao perfil socioeconômico dos estudantes de graduação não é, no entanto, um empecilho. Ao contrário, é importante notar que o perfil dos alunos que "escolhem" e são "escolhidos" para ingressar em um determinado curso de graduação constitui informação privilegiada sobre a estrutura social da instituição, porque a composição social desse alunado, mais do que o perfil dos docentes e dos pós-graduandos,

\footnotetext{
${ }^{210}$ Digo públicas porque é possível que a Comissão Especial de Regime de Trabalho (CERT) tenha informações socioeconômicas e demográficas mais completas sobre o corpo docente da USP, mas elas não são divulgadas, tal como é possível observar pelo Anuário, que sintetiza todas as informações públicas sobre o corpo docente, discente e funcional da USP. Além disso, a antiga Coordenadoria de Saúde e Assistência Social (Coseas), hoje Superintendência de Assistência Social (SAS), também tem informações mais precisas sobre o corpo discente de graduação e pós-graduação, especialmente os que recorrem à assistência social. Eu solicitei acesso a esses dados para saber, por exemplo, qual a distribuição das vagas das moradias estudantis por unidades da USP, mas os dados não foram disponibilizados.
} 
relaciona-se diretamente com o valor diferencial dos diplomas oferecidos pelas diferentes unidades e, portanto, com o recrutamento social específico estabelecido pelo aumento da concorrência pelas suas vagas. Assim, apesar de limitado, trata-se do melhor indicador para reconstruir a estrutura social da USP porque permite acessar, de uma só vez, as hierarquias sociais internas e externas à universidade.

Além disso, é preciso lembrar que os dados do Questionário da Fuvest são gerados, originalmente, por "carreira", que é a categoria que a Fundação, como entidade relativamente autônoma ${ }^{211}$, utiliza para diferenciar as opções de inscrição no vestibular. Como já foi dito, as carreiras não correspondem de modo direto aos cursos de graduação da USP, nem às suas unidades de origem. Por exemplo, a carreira denominada "direito", como visto, reúne atualmente dois cursos distintos, sediados em duas unidades diferentes, a FD e a FDRP. Ou, ainda, o caso da carreira chamada "administração, economia, contabilidade e ciências atuariais" que agrega todos os cursos da FEA, São Paulo, em uma única opção de inscrição, diferenciada por modalidade. No entanto, o objetivo desta tese é analisar a hierarquia da USP por unidade de ensino e pesquisa, uma vez que são elas que constituem a fração essencial do poder universitário, expresso, por exemplo, na composição dos seus órgãos deliberativos máximos, nas formas essenciais de distribuição de recursos, de organização das avaliações internas e de estruturação dos procedimentos de gestão interna da universidade. Não por acaso, a unidade é a principal categoria que organiza a publicação de dados do Anuário Estatístico da USP desde a sua criação em 1987. Isso impôs a necessidade de intervir nos dados estatísticos originalmente disponibilizados pela Fuvest, no sentido de desagrupar as informações por carreiras, reagrupando-as por unidades universitárias. Essa operação foi feita, a pedido da pesquisadora,

\footnotetext{
${ }^{211}$ Como já foi dito no capítulo 2, a Fundação Universitária para o Vestibular foi criada pela USP, composta de um Conselho Curador, formado por membros nomeados pelo reitor da USP, e uma Diretoria Executiva, formada pelo Conselho. Apesar da relação intrínseca com a reitoria, a Fuvest tem autonomia financeira e de gestão e, como se sabe, é responsável inclusive pela seleção para cursos externos à USP, tais como para a Academia de Polícia do Estado de São Paulo e para a Faculdade de Medicina da Santa Casa de Misericórdia de São Paulo.
} 
pela equipe estatística da Fuvest ${ }^{212}$. No entanto, por mudanças no sistema de coleta e processamento dos dados, a Fuvest só disponibilizou esses dados, reagrupados por unidade, a partir do ano 2000. Para garantir o controle sobre variações ocasionais e apreender possíveis dinâmicas temporais relevantes, solicitei à Fundação que fizesse o reprocessamento dos dados para os anos 2000, 2005, 2010 e 2012. Depois de analisar sistematicamente essa série de dados, contatou-se que, embora tenha havido um progressivo processo de elitização do corpo discente da USP, conforme já analisado, as relações hierárquicas entre os três polos principais da USP nesse período permaneceram praticamente intocadas, reforçando a ideia de que as mudanças no interior do campo universitário, embora produzam variações mais ou menos importantes, não atingem a sua estrutura geral, dada pelo sistema de relações entre as diferentes unidades universitárias, que pode ser descrito, portanto, como um "invariante estrutural" (Bourdieu, 1989, p. 266ss).

Para ilustrar a conservação das relações entre as unidades da USP, é interessante considerar, por exemplo, a variável escolaridade da mãe que, como visto anteriormente, foi uma das que mais se alterou ao longo dos últimos anos na USP. As tabelas apresentadas nas páginas seguintes hierarquizam as unidades da USP pelo percentual decrescente de alunos ingressantes cuja mãe tem ensino superior completo, incluindo pós-graduação. Em destaque, apresento a média da USP, o que permite enxergar claramente de que modo as unidades que se distribuem no interior de uma hierarquia que distingue, grosso modo, as unidades socialmente dominantes, com alunos oriundos de famílias mais escolarizadas, das unidades socialmente dominadas, com ingressantes oriundos de contextos familiares escolarmente menos privilegiados.

\footnotetext{
${ }^{212}$ Esse trabalho não teria sido possível sem a autorização da vice-diretora executiva da Fuvest na época, Maria Thereza Fraga Rocco. Igualmente imprescindível foi o trabalho e a dedicação de Renan de Cerqueira Leite, responsável pelo processamento estatístico dos dados do Questionário Socioeconômico da Fuvest, a quem agradeço, mais uma vez, pelo intenso trabalho de reagrupamento dos dados da Fuvest para os fins desta pesquisa e por todos os esclarecimentos e auxílios prestados ao longo do processo de construção desta análise.
} 


\begin{tabular}{|c|c|c|c|c|c|c|c|c|}
\hline \multicolumn{9}{|c|}{$\begin{array}{l}\text { Questionário socioeconômico da Fuvest (2000) } \\
\text { "Qual o grau de instrução mais alto que sua mãe obteve?" } \\
\text { pelo percentual de ingressantes em } 2000 \text { cuja mãe realizou o ensino superior completo }\end{array}$} \\
\hline Unidades & $\begin{array}{l}\text { Não } \\
\text { frequentou } \\
\text { a escola ou } \\
\text { primário } \\
\text { incomp. }\end{array}$ & $\begin{array}{l}\text { Ens. Fund. } \\
\text { Incomp. }\end{array}$ & $\begin{array}{l}\text { Ens. Fund. } \\
\text { completo }\end{array}$ & $\begin{array}{c}\text { Ensino } \\
\text { médio } \\
\text { incomp. }\end{array}$ & $\begin{array}{c}\text { Ensino } \\
\text { médio } \\
\text { completo }\end{array}$ & $\begin{array}{c}\text { Ens. } \\
\text { Superior } \\
\text { incomp. }\end{array}$ & $\begin{array}{l}\text { Ens. } \\
\text { Superior } \\
\text { completo } \\
\downarrow\end{array}$ & $\begin{array}{l}\text { Das quais, } \\
\text { com pós- } \\
\text { graduação }\end{array}$ \\
\hline Faculdade de Medicina de Ribeirão Preto & $0,0 \%$ & $2,5 \%$ & $3,3 \%$ & $4,9 \%$ & $13,9 \%$ & $5,7 \%$ & $69,7 \%$ & $9,8 \%$ \\
\hline Faculdade Arquitetura e Urbanismo & $1,3 \%$ & $4,6 \%$ & $1,3 \%$ & $2,6 \%$ & $15,0 \%$ & $6,5 \%$ & $68,6 \%$ & $11,1 \%$ \\
\hline Instituto de Psicologia & $2,7 \%$ & $1,4 \%$ & $6,8 \%$ & $4,1 \%$ & $11,0 \%$ & $5,5 \%$ & $68,5 \%$ & $4,1 \%$ \\
\hline Faculdade de Medicina & $0,8 \%$ & $5,3 \%$ & $2,7 \%$ & $3,8 \%$ & $14,4 \%$ & $8,7 \%$ & $64,3 \%$ & $8,0 \%$ \\
\hline Faculdade de Direito & $2,3 \%$ & $3,8 \%$ & $4,5 \%$ & $1,7 \%$ & $19,2 \%$ & $4,9 \%$ & $63,5 \%$ & $7,2 \%$ \\
\hline Escola Politécnica & $0,9 \%$ & $4,7 \%$ & $3,2 \%$ & $2,9 \%$ & $15,1 \%$ & $11,1 \%$ & $62,2 \%$ & $6,4 \%$ \\
\hline Faculdade de Saúde Pública & $4,0 \%$ & $0,0 \%$ & $0,0 \%$ & $4,0 \%$ & $14,0 \%$ & $16,0 \%$ & $62,0 \%$ & $8,0 \%$ \\
\hline Faculdade de Odontologia de Ribeirão & $0,9 \%$ & $7,1 \%$ & $2,7 \%$ & $3,6 \%$ & $19,6 \%$ & $8,0 \%$ & $58,0 \%$ & $1,8 \%$ \\
\hline Instituto de Biociências & $0,0 \%$ & $8,8 \%$ & $1,4 \%$ & $6,1 \%$ & $14,2 \%$ & $12,2 \%$ & $57,4 \%$ & $9,5 \%$ \\
\hline Faculdade de Ciências Farmacêuticas & $0,7 \%$ & $6,2 \%$ & $5,5 \%$ & $4,8 \%$ & $18,5 \%$ & $8,9 \%$ & $55,5 \%$ & $2,1 \%$ \\
\hline Escola de Comunicação e Artes & $1,6 \%$ & $10,9 \%$ & $3,6 \%$ & $4,9 \%$ & $15,9 \%$ & $7,6 \%$ & $55,5 \%$ & $7,3 \%$ \\
\hline Escola de Engenharia de São Carlos & $0,3 \%$ & $9,2 \%$ & $5,4 \%$ & $4,1 \%$ & $16,9 \%$ & $9,2 \%$ & $54,9 \%$ & $6,4 \%$ \\
\hline Escola Superior de Agricultura Luiz de Queiróz & $1,2 \%$ & $5,8 \%$ & $4,3 \%$ & $4,9 \%$ & $21,9 \%$ & $8,8 \%$ & $53,2 \%$ & $4,9 \%$ \\
\hline Faculdade de Odontologia & $2,7 \%$ & $6,8 \%$ & $4,1 \%$ & $2,7 \%$ & $23,0 \%$ & $9,5 \%$ & $51,4 \%$ & $4,7 \%$ \\
\hline Universidade de São Paulo (total geral) & $3,5 \%$ & $9,4 \%$ & $4,7 \%$ & $4,3 \%$ & $17,8 \%$ & $8,9 \%$ & $51,3 \%$ & $5,4 \%$ \\
\hline Faculdade de Economia, Administração e Contabilidade & $3,5 \%$ & $8,2 \%$ & $5,0 \%$ & $3,3 \%$ & $17,2 \%$ & $11,5 \%$ & $51,3 \%$ & $5,8 \%$ \\
\hline Faculdade de Odontologia de Bauru & $2,0 \%$ & $3,9 \%$ & $2,9 \%$ & $3,9 \%$ & $28,4 \%$ & $7,8 \%$ & $51,0 \%$ & $2,9 \%$ \\
\hline Instituto de Física de São Carlos & $2,9 \%$ & $8,7 \%$ & $2,9 \%$ & $5,8 \%$ & $14,5 \%$ & $14,5 \%$ & $50,7 \%$ & $7,2 \%$ \\
\hline Faculdade de Medicina Veterinária e Zootecnia & $4,2 \%$ & $8,4 \%$ & $6,3 \%$ & $2,1 \%$ & $20,0 \%$ & $8,4 \%$ & $50,5 \%$ & $8,4 \%$ \\
\hline Faculdade de Ciências Farmacêuticas de Ribeirão & $1,5 \%$ & $9,2 \%$ & $4,6 \%$ & $9,2 \%$ & $20,0 \%$ & $6,2 \%$ & $49,2 \%$ & $3,1 \%$ \\
\hline Escola de Educação Física e Esportes & $1,7 \%$ & $6,0 \%$ & $7,8 \%$ & $6,9 \%$ & $20,7 \%$ & $9,5 \%$ & $47,4 \%$ & $4,3 \%$ \\
\hline Instituto de Geociências & $3,6 \%$ & $12,7 \%$ & $5,5 \%$ & $5,5 \%$ & $18,2 \%$ & $10,9 \%$ & $43,6 \%$ & $3,6 \%$ \\
\hline Faculdade de Filosofia, Ciências e Letras de Ribeirão & $4,7 \%$ & $7,0 \%$ & $4,7 \%$ & $5,6 \%$ & $24,3 \%$ & $10,3 \%$ & $43,5 \%$ & $2,8 \%$ \\
\hline Instituto de Ciências Matemáticas e Computação & $3,0 \%$ & $11,3 \%$ & $4,4 \%$ & $4,9 \%$ & $20,7 \%$ & $12,3 \%$ & $43,3 \%$ & $2,5 \%$ \\
\hline Faculdade de Zootecnia e Engenharia de Alimentos & $4,2 \%$ & $8,3 \%$ & $4,2 \%$ & $8,3 \%$ & $22,2 \%$ & $9,7 \%$ & $43,1 \%$ & $5,6 \%$ \\
\hline Instituto de Química & $3,9 \%$ & $10,5 \%$ & $6,6 \%$ & $6,6 \%$ & $19,7 \%$ & $10,5 \%$ & $42,1 \%$ & $3,9 \%$ \\
\hline Faculdade de Economia, Administração e Cont. de Ribeirão & $4,5 \%$ & $16,7 \%$ & $3,8 \%$ & $5,1 \%$ & $23,1 \%$ & $6,4 \%$ & $40,4 \%$ & $5,8 \%$ \\
\hline Instituto de Matemática e Estatística & $6,9 \%$ & $15,4 \%$ & $7,4 \%$ & $6,9 \%$ & $18,9 \%$ & $4,9 \%$ & $39,7 \%$ & $3,4 \%$ \\
\hline Instituto de Astronomia, Geociências e Ciências Atmosférica & $3,8 \%$ & $11,3 \%$ & $5,7 \%$ & $7,5 \%$ & $24,5 \%$ & $7,5 \%$ & $39,6 \%$ & $3,8 \%$ \\
\hline Instituto de Química de São Carlos & $0,0 \%$ & $18,8 \%$ & $5,8 \%$ & $2,9 \%$ & $23,2 \%$ & $11,6 \%$ & $37,7 \%$ & $1,4 \%$ \\
\hline Faculdade de Filosofia, Letras e Ciências Humanas & $8,5 \%$ & $17,0 \%$ & $6,1 \%$ & $5,0 \%$ & $20,0 \%$ & $8,4 \%$ & $35,0 \%$ & $4,4 \%$ \\
\hline Instituto de Física & $8,6 \%$ & $19,6 \%$ & $8,3 \%$ & $4,6 \%$ & $17,5 \%$ & $7,1 \%$ & $34,4 \%$ & $4,0 \%$ \\
\hline Escola de Enfermagem de Ribeirão Preto & $7,2 \%$ & $18,6 \%$ & $10,3 \%$ & $10,3 \%$ & $13,4 \%$ & $7,2 \%$ & $33,0 \%$ & $1,0 \%$ \\
\hline Faculdade de Educação & $9,4 \%$ & $12,6 \%$ & $11,8 \%$ & $7,1 \%$ & $20,5 \%$ & $7,1 \%$ & $31,5 \%$ & $1,6 \%$ \\
\hline Instituto de Física de São Carlos & $14,4 \%$ & $26,7 \%$ & $7,8 \%$ & $8,9 \%$ & $14,4 \%$ & $3,3 \%$ & $24,4 \%$ & $1,1 \%$ \\
\hline Escola de Enfermagem & $7,0 \%$ & $19,0 \%$ & $10,0 \%$ & $15,0 \%$ & $25,0 \%$ & $5,0 \%$ & $19,0 \%$ & $5,0 \%$ \\
\hline
\end{tabular}

Fonte: Questionário Socioeconômico da Fuvest

Elaboração: própria 
Questionário socioeconômico da Fuvest (2005)

Questão "Qual o grau de instrução mais alto que sua mãe obteve?"

Tabela 14. Unidades hierarquizadas pelo percentual de ingressantes em 2005 cuja mãe realizou o ensino superior completo

\begin{tabular}{|c|c|c|c|c|c|c|c|c|}
\hline Unidades & $\begin{array}{c}\text { Não } \\
\text { frequentou } \\
\text { a escola ou } \\
\text { primário } \\
\text { incomp. } \\
\end{array}$ & $\begin{array}{c}\text { Ens. Fund. } \\
\text { incomp. }\end{array}$ & $\begin{array}{l}\text { Ens. Fund. } \\
\text { completo }\end{array}$ & $\begin{array}{c}\text { Ensino } \\
\text { médio } \\
\text { incomp. }\end{array}$ & $\begin{array}{c}\text { Ensino } \\
\text { médio } \\
\text { comp. }\end{array}$ & $\begin{array}{c}\text { Ens. } \\
\text { Superior } \\
\text { incomp. }\end{array}$ & $\begin{array}{c}\text { Ens. } \\
\text { Superior } \\
\text { completo } \\
\downarrow\end{array}$ & $\begin{array}{l}\text { Das quais, } \\
\text { com pós- } \\
\text { graduação }\end{array}$ \\
\hline Faculdade de Arquitetura e Urbanismo & $0,7 \%$ & $1,3 \%$ & $1,3 \%$ & $2,6 \%$ & $11,9 \%$ & $6,6 \%$ & $75,5 \%$ & $9,9 \%$ \\
\hline Instituto de Psicologia & $0,0 \%$ & $1,4 \%$ & $4,3 \%$ & $4,3 \%$ & $10,0 \%$ & $11,4 \%$ & $68,6 \%$ & $11,4 \%$ \\
\hline Faculdade de Medicina & $2,8 \%$ & $1,2 \%$ & $1,6 \%$ & $1,6 \%$ & $16,0 \%$ & $8,4 \%$ & $68,4 \%$ & $10,0 \%$ \\
\hline Faculdade de Direito & $3,3 \%$ & $3,7 \%$ & $2,6 \%$ & $1,8 \%$ & $15,8 \%$ & $6,8 \%$ & $66,0 \%$ & $12,9 \%$ \\
\hline Escola Politécnica & $1,7 \%$ & $1,2 \%$ & $2,3 \%$ & $2,3 \%$ & $15,5 \%$ & $11,6 \%$ & $65,3 \%$ & $6,6 \%$ \\
\hline Faculdade de Medicina Veterinária e Zootecnia & $0,0 \%$ & $2,5 \%$ & $3,8 \%$ & $1,3 \%$ & $18,8 \%$ & $8,8 \%$ & $65,0 \%$ & $2,5 \%$ \\
\hline Escola de Engenharia de São Carlos & $2,0 \%$ & $2,0 \%$ & $2,2 \%$ & $2,0 \%$ & $19,2 \%$ & $11,1 \%$ & $61,5 \%$ & $8,2 \%$ \\
\hline Escola de Esportes e Educação Física & $4,1 \%$ & $3,1 \%$ & $5,1 \%$ & $3,1 \%$ & $13,3 \%$ & $10,2 \%$ & $61,2 \%$ & $6,1 \%$ \\
\hline Faculdade de Odontologia de Ribeirão Preto & $3,8 \%$ & $1,3 \%$ & $2,5 \%$ & $1,3 \%$ & $26,3 \%$ & $7,5 \%$ & $57,5 \%$ & $3,8 \%$ \\
\hline Faculdade de Zootecnia e Engenharia de Alimentos & $2,1 \%$ & $3,5 \%$ & $2,1 \%$ & $2,8 \%$ & $19,9 \%$ & $12,8 \%$ & $56,7 \%$ & $4,3 \%$ \\
\hline Faculdade de Ciências Farmacêuticas de Ribeirão Preto & $3,8 \%$ & $2,5 \%$ & $3,8 \%$ & $2,5 \%$ & $21,3 \%$ & $10,0 \%$ & $56,3 \%$ & $0,0 \%$ \\
\hline Faculdade de Odontologia de Bauru & $4,0 \%$ & $6,7 \%$ & $5,3 \%$ & $4,0 \%$ & $14,7 \%$ & $9,3 \%$ & $56,0 \%$ & $2,7 \%$ \\
\hline Faculdade de Economia e Administração & $5,0 \%$ & $5,2 \%$ & $4,7 \%$ & $3,9 \%$ & $15,9 \%$ & $9,7 \%$ & $55,5 \%$ & $7,4 \%$ \\
\hline Escola de Comunicação e Artes & $5,2 \%$ & $3,0 \%$ & $4,1 \%$ & $3,3 \%$ & $15,6 \%$ & $13,4 \%$ & $55,3 \%$ & $5,8 \%$ \\
\hline Faculdade de Medicina de Ribeirão Preto & $4,3 \%$ & $2,3 \%$ & $2,7 \%$ & $3,5 \%$ & $23,7 \%$ & $8,9 \%$ & $54,5 \%$ & $5,8 \%$ \\
\hline Faculdade de Odontologia & $4,5 \%$ & $6,1 \%$ & $6,1 \%$ & $4,5 \%$ & $19,7 \%$ & $8,3 \%$ & $50,8 \%$ & $3,0 \%$ \\
\hline Faculdade de Ciências Farmacêuticas & $2,7 \%$ & $5,4 \%$ & $4,1 \%$ & $4,1 \%$ & $21,6 \%$ & $11,5 \%$ & $50,7 \%$ & $2,7 \%$ \\
\hline Faculdade de Saúde Pública & $7,6 \%$ & $2,5 \%$ & $3,8 \%$ & $5,1 \%$ & $21,5 \%$ & $8,9 \%$ & $50,6 \%$ & $7,6 \%$ \\
\hline Escola Superior de Agronomia Luiz de Queiroz & $5,3 \%$ & $3,7 \%$ & $3,7 \%$ & $6,1 \%$ & $21,6 \%$ & $10,8 \%$ & $48,8 \%$ & $5,8 \%$ \\
\hline Universidade de São Paulo (total geral) & $6,9 \%$ & $6,0 \%$ & $4,6 \%$ & $4,4 \%$ & $20,2 \%$ & $9,5 \%$ & $48,3 \%$ & $5,6 \%$ \\
\hline Instituto de Biociências & $2,5 \%$ & $3,3 \%$ & $7,5 \%$ & $5,8 \%$ & $25,0 \%$ & $9,2 \%$ & $46,7 \%$ & $5,8 \%$ \\
\hline Instituto de Geociências & $8,0 \%$ & $4,5 \%$ & $6,8 \%$ & $2,3 \%$ & $25,0 \%$ & $8,0 \%$ & $45,5 \%$ & $3,4 \%$ \\
\hline Faculdade de Filosofia, Letras e Ciências Humanas & $9,4 \%$ & $8,6 \%$ & $5,2 \%$ & $5,5 \%$ & $19,5 \%$ & $9,2 \%$ & $42,5 \%$ & $5,2 \%$ \\
\hline Faculdade de Economia e Administração de Ribeirão Preto & $2,2 \%$ & $6,7 \%$ & $5,9 \%$ & $8,1 \%$ & $22,2 \%$ & $12,6 \%$ & $42,2 \%$ & $5,2 \%$ \\
\hline Instituto de Astronomia, Geofísica e Ciências Atmosféricas & $8,7 \%$ & $5,8 \%$ & $5,8 \%$ & $7,2 \%$ & $23,2 \%$ & $7,2 \%$ & $42,0 \%$ & $2,9 \%$ \\
\hline Instituto de Oceanografia & $2,6 \%$ & $5,1 \%$ & $0,0 \%$ & $5,1 \%$ & $17,9 \%$ & $28,2 \%$ & $41,0 \%$ & $7,7 \%$ \\
\hline Escola de Enfermagem & $7,5 \%$ & $6,3 \%$ & $6,3 \%$ & $11,3 \%$ & $21,3 \%$ & $8,8 \%$ & $38,8 \%$ & $3,8 \%$ \\
\hline Instituto de Ciências Matemáticas e Computação & $5,2 \%$ & $8,8 \%$ & $8,8 \%$ & $5,7 \%$ & $26,8 \%$ & $7,7 \%$ & $37,1 \%$ & $1,5 \%$ \\
\hline Faculdade de Educação & $12,8 \%$ & $12,3 \%$ & $3,9 \%$ & $2,8 \%$ & $21,2 \%$ & $10,6 \%$ & $36,3 \%$ & $5,6 \%$ \\
\hline Faculdade de Filosofia, Ciências e Letras de Ribeirão Preto & $9,0 \%$ & $9,6 \%$ & $5,1 \%$ & $5,1 \%$ & $27,2 \%$ & $9,3 \%$ & $34,9 \%$ & $2,4 \%$ \\
\hline Instituto de Química & $10,9 \%$ & $8,4 \%$ & $8,4 \%$ & $3,4 \%$ & $26,9 \%$ & $7,6 \%$ & $34,5 \%$ & $3,4 \%$ \\
\hline Instituto de Matemática e Estatística & $9,8 \%$ & $9,1 \%$ & $6,1 \%$ & $5,5 \%$ & $25,3 \%$ & $9,8 \%$ & $34,5 \%$ & $3,0 \%$ \\
\hline Escola de Artes, Ciências e Humanidades & $14,9 \%$ & $10,1 \%$ & $6,9 \%$ & $7,1 \%$ & $21,6 \%$ & $7,7 \%$ & $31,7 \%$ & $4,0 \%$ \\
\hline Escola de Comunicação e Artes de Ribeirão Preto & $13,8 \%$ & $17,2 \%$ & $0,0 \%$ & $3,4 \%$ & $34,5 \%$ & $0,0 \%$ & $31,0 \%$ & $6,9 \%$ \\
\hline Escola de Enfermagem de Ribeirão Preto & $12,5 \%$ & $7,5 \%$ & $2,5 \%$ & $1,3 \%$ & $36,3 \%$ & $10,0 \%$ & $30,0 \%$ & $1,3 \%$ \\
\hline Instituto de Física & $13,7 \%$ & $11,9 \%$ & $8,1 \%$ & $6,7 \%$ & $27,4 \%$ & $5,2 \%$ & $27,0 \%$ & $2,2 \%$ \\
\hline Instituto de Física de São Carlos & $14,4 \%$ & $10,0 \%$ & $6,7 \%$ & $5,6 \%$ & $30,0 \%$ & $7,8 \%$ & $25,6 \%$ & $3,3 \%$ \\
\hline Instituto de Química de São Carlos & $8,3 \%$ & $5,0 \%$ & $5,0 \%$ & $3,3 \%$ & $26,7 \%$ & $26,7 \%$ & $25,0 \%$ & $3,3 \%$ \\
\hline
\end{tabular}

Fonte: Questionário Socioeconômico da Fuvest

Elaboração: própria 


\begin{tabular}{|c|c|c|c|c|c|c|c|c|}
\hline \multicolumn{9}{|c|}{$\begin{array}{l}\text { Questionário socioeconômico da Fuvest (2010) } \\
\text { o "Qual o grau de instrução mais alto que sua mãe obteve?" } \\
\text { pelo percentual de ingressantes em } 2010 \text { cuja mãe realizou o ensino superior completo }\end{array}$} \\
\hline Unidades & $\begin{array}{c}\text { Não } \\
\text { frequentou } \\
\text { a escola ou } \\
\text { primário } \\
\text { incomp. } \\
\end{array}$ & $\begin{array}{l}\text { Fundamen } \\
\text { tal } \\
\text { incompleto }\end{array}$ & $\begin{array}{l}\text { Fundamen } \\
\text { tal } \\
\text { completo }\end{array}$ & $\begin{array}{l}\text { Ensino } \\
\text { médio } \\
\text { incompleto }\end{array}$ & $\begin{array}{c}\text { Ensino } \\
\text { médio }\end{array}$ & $\begin{array}{c}\text { Ens. } \\
\text { Superior } \\
\text { incompleto }\end{array}$ & $\begin{array}{l}\text { Ens. } \\
\text { Superior } \\
\text { completo } \\
\downarrow\end{array}$ & $\begin{array}{l}\text { Das quais, } \\
\text { com pós- } \\
\text { graduação }\end{array}$ \\
\hline Faculdade de Arquitetura e Urbanismo & $0,5 \%$ & $0,5 \%$ & $2,1 \%$ & $2,1 \%$ & $10,5 \%$ & $8,9 \%$ & $75,3 \%$ & $15,3 \%$ \\
\hline Faculdade de Direito & $2,2 \%$ & $1,5 \%$ & $1,3 \%$ & $1,5 \%$ & $10,7 \%$ & $9,6 \%$ & $73,3 \%$ & $12,0 \%$ \\
\hline Escola Politécnica & $0,9 \%$ & $1,2 \%$ & $1,2 \%$ & $2,0 \%$ & $13,5 \%$ & $8,4 \%$ & $72,8 \%$ & $7,3 \%$ \\
\hline Faculdade de Direito de Ribeirão Preto & $1,0 \%$ & $1,0 \%$ & $0,0 \%$ & $0,0 \%$ & $18,4 \%$ & $7,1 \%$ & $72,4 \%$ & $13,3 \%$ \\
\hline Instituto de Relações Internacionais & $0,0 \%$ & $3,3 \%$ & $0,0 \%$ & $5,0 \%$ & $11,7 \%$ & $8,3 \%$ & $71,7 \%$ & $10,0 \%$ \\
\hline Instituto de Psicologia & $2,9 \%$ & $1,4 \%$ & $0,0 \%$ & $4,3 \%$ & $11,4 \%$ & $8,6 \%$ & $71,4 \%$ & $12,9 \%$ \\
\hline Instituto de Biociências & $0,8 \%$ & $2,5 \%$ & $3,3 \%$ & $3,3 \%$ & $13,3 \%$ & $10,0 \%$ & $66,7 \%$ & $11,7 \%$ \\
\hline Faculdade de Medicina & $2,0 \%$ & $1,6 \%$ & $2,4 \%$ & $0,8 \%$ & $19,6 \%$ & $7,6 \%$ & $66,0 \%$ & $8,8 \%$ \\
\hline Faculdade de Economia e Administração & $3,1 \%$ & $1,7 \%$ & $1,9 \%$ & $2,6 \%$ & $18,2 \%$ & $9,0 \%$ & $63,6 \%$ & $9,0 \%$ \\
\hline Escola de Engenharia de São Carlos & $2,3 \%$ & $2,3 \%$ & $1,5 \%$ & $2,1 \%$ & $21,9 \%$ & $8,7 \%$ & $61,3 \%$ & $10,2 \%$ \\
\hline Faculdade de Medicina Veterinária e Zootecnia & $3,8 \%$ & $2,5 \%$ & $0,0 \%$ & $3,8 \%$ & $18,8 \%$ & $10,0 \%$ & $61,3 \%$ & $3,8 \%$ \\
\hline Escola de Comunicação e Artes & $3,6 \%$ & $3,0 \%$ & $2,2 \%$ & $1,6 \%$ & $22,2 \%$ & $7,1 \%$ & $60,3 \%$ & $8,5 \%$ \\
\hline Escola de Esportes e Educação Física & $1,0 \%$ & $2,0 \%$ & $1,0 \%$ & $4,0 \%$ & $21,0 \%$ & $11,0 \%$ & $60,0 \%$ & $7,0 \%$ \\
\hline Faculdade de Odontologia de Ribeirão Preto & $3,8 \%$ & $3,8 \%$ & $3,8 \%$ & $1,3 \%$ & $18,8 \%$ & $8,8 \%$ & $60,0 \%$ & $6,3 \%$ \\
\hline Faculdade de Odontologia & $3,8 \%$ & $2,3 \%$ & $3,0 \%$ & $1,5 \%$ & $27,1 \%$ & $5,3 \%$ & $57,1 \%$ & $7,5 \%$ \\
\hline Faculdade de Medicina de Ribeirão Preto & $2,7 \%$ & $3,2 \%$ & $1,8 \%$ & $3,2 \%$ & $25,9 \%$ & $6,4 \%$ & $56,8 \%$ & $5,0 \%$ \\
\hline Escola Superior de Agronomia de Luiz de Queiroz & $3,3 \%$ & $3,3 \%$ & $1,5 \%$ & $2,6 \%$ & $22,9 \%$ & $9,5 \%$ & $56,8 \%$ & $6,4 \%$ \\
\hline Instituto de Oceanografia & $2,6 \%$ & $2,6 \%$ & $2,6 \%$ & $5,1 \%$ & $23,1 \%$ & $7,7 \%$ & $56,4 \%$ & $7,7 \%$ \\
\hline Faculdade de Saúde Pública & $2,5 \%$ & $1,3 \%$ & $1,3 \%$ & $2,5 \%$ & $28,8 \%$ & $7,5 \%$ & $56,3 \%$ & $6,3 \%$ \\
\hline Escola de Engenharia de Lorena & $1,7 \%$ & $2,5 \%$ & $3,0 \%$ & $5,5 \%$ & $22,9 \%$ & $8,5 \%$ & $55,9 \%$ & $6,8 \%$ \\
\hline Faculdade de Economia e Administração de Ribeirão & $2,6 \%$ & $4,2 \%$ & $4,2 \%$ & $3,4 \%$ & $19,2 \%$ & $10,6 \%$ & $55,8 \%$ & $5,7 \%$ \\
\hline Faculdade de Ciências Farmacêuticas & $2,0 \%$ & $2,7 \%$ & $2,7 \%$ & $1,3 \%$ & $26,7 \%$ & $9,3 \%$ & $55,3 \%$ & $6,0 \%$ \\
\hline Universidade de São Paulo (total geral) & $4,5 \%$ & $3,9 \%$ & $3,3 \%$ & $3,5 \%$ & $21,7 \%$ & $9,2 \%$ & $\mathbf{5 3 , 9 \%}$ & $\mathbf{7 , 0 \%}$ \\
\hline Faculdade de Zootecnia e Engenharia de Alimentos & $3,5 \%$ & $1,2 \%$ & $2,7 \%$ & $2,7 \%$ & $26,6 \%$ & $10,9 \%$ & $52,3 \%$ & $4,3 \%$ \\
\hline Instituto de Química de São Carlos & $8,3 \%$ & $1,7 \%$ & $0,0 \%$ & $1,7 \%$ & $25,0 \%$ & $11,7 \%$ & $51,7 \%$ & $6,7 \%$ \\
\hline Escola de Esportes e Educação Física de Ribeirão Preto & $1,7 \%$ & $8,5 \%$ & $1,7 \%$ & $1,7 \%$ & $25,4 \%$ & $10,2 \%$ & $50,8 \%$ & $10,2 \%$ \\
\hline Faculdade de Odontologia de Bauru & $2,2 \%$ & $4,5 \%$ & $5,6 \%$ & $3,4 \%$ & $22,5 \%$ & $13,5 \%$ & $48,3 \%$ & $5,6 \%$ \\
\hline Faculdade de Filosofia, Letras e Ciências Humanas & $6,7 \%$ & $6,7 \%$ & $4,1 \%$ & $4,4 \%$ & $20,6 \%$ & $9,5 \%$ & $48,0 \%$ & $7,9 \%$ \\
\hline Instituto de Geociências & $10,0 \%$ & $6,7 \%$ & $5,6 \%$ & $3,3 \%$ & $20,0 \%$ & $8,9 \%$ & $45,6 \%$ & $5,6 \%$ \\
\hline Instituto de Astronomia, Geofísica e Ciências Atmosféricas & $10,8 \%$ & $1,4 \%$ & $6,8 \%$ & $2,7 \%$ & $23,0 \%$ & $10,8 \%$ & $44,6 \%$ & $8,1 \%$ \\
\hline Faculdade de Ciências Farmacêuticas de Ribeirão Preto & $3,8 \%$ & $3,8 \%$ & $3,8 \%$ & $3,8 \%$ & $28,8 \%$ & $12,5 \%$ & $43,8 \%$ & $7,5 \%$ \\
\hline Instituto de Ciências Matemáticas e Computação & $5,5 \%$ & $4,1 \%$ & $4,1 \%$ & $5,0 \%$ & $28,6 \%$ & $9,5 \%$ & $43,2 \%$ & $3,2 \%$ \\
\hline Escola de Artes, Ciências e Humanidades & $6,8 \%$ & $4,5 \%$ & $4,3 \%$ & $5,4 \%$ & $26,6 \%$ & $10,1 \%$ & $42,4 \%$ & $3,7 \%$ \\
\hline Instituto de Matemática e Estatística & $8,8 \%$ & $6,4 \%$ & $4,8 \%$ & $5,5 \%$ & $25,2 \%$ & $9,1 \%$ & $40,3 \%$ & $5,5 \%$ \\
\hline Escola de Enfermagem & $3,8 \%$ & $8,8 \%$ & $6,3 \%$ & $2,5 \%$ & $27,5 \%$ & $11,3 \%$ & $40,0 \%$ & $2,5 \%$ \\
\hline Instituto de Química & $5,8 \%$ & $5,8 \%$ & $5,8 \%$ & $5,8 \%$ & $26,7 \%$ & $10,0 \%$ & $40,0 \%$ & $4,2 \%$ \\
\hline Faculdade de Educação & $9,4 \%$ & $3,9 \%$ & $7,2 \%$ & $6,1 \%$ & $27,2 \%$ & $8,3 \%$ & $37,8 \%$ & $3,3 \%$ \\
\hline Escola de Enfermagem de Ribeirão Preto & $9,2 \%$ & $6,9 \%$ & $6,2 \%$ & $5,4 \%$ & $28,5 \%$ & $7,7 \%$ & $36,2 \%$ & $0,8 \%$ \\
\hline Instituto de Física de São Carlos & $9,8 \%$ & $6,7 \%$ & $4,9 \%$ & $6,1 \%$ & $22,7 \%$ & $14,7 \%$ & $35,0 \%$ & $3,7 \%$ \\
\hline Instituto de Física & $7,8 \%$ & $7,4 \%$ & $8,6 \%$ & $5,2 \%$ & $29,0 \%$ & $7,8 \%$ & $34,2 \%$ & $4,8 \%$ \\
\hline Faculdade de Filosofia, Ciências e Letras de Ribeirão & $5,2 \%$ & $6,2 \%$ & $7,0 \%$ & $5,2 \%$ & $31,9 \%$ & $10,6 \%$ & $33,8 \%$ & $2,9 \%$ \\
\hline Escola de Comunicação e Artes de Ribeirão Preto & $10,0 \%$ & $16,7 \%$ & $10,0 \%$ & $3,3 \%$ & $33,3 \%$ & $10,0 \%$ & $16,7 \%$ & $0,0 \%$ \\
\hline
\end{tabular}

Fonte: Questionário Socioeconômico da Fuvest

Elaboração: própria 


\begin{tabular}{|c|c|c|c|c|c|c|c|}
\hline \multicolumn{8}{|c|}{$\begin{array}{l}\text { Questionário socioeconômico da Fuvest (2012) } \\
\text { io "Qual o grau de instrução mais alto que sua mãe obteve?" }\end{array}$} \\
\hline Unidades & $\begin{array}{c}\text { Não } \\
\text { frequentou } \\
\text { a escola ou } \\
\text { primário } \\
\text { incomp. } \\
\end{array}$ & $\begin{array}{l}\text { Ens. Fund. } \\
\text { completo }\end{array}$ & $\begin{array}{l}\text { Ensino } \\
\text { médio } \\
\text { incompleto }\end{array}$ & $\begin{array}{l}\text { Ensino } \\
\text { médio } \\
\text { completo }\end{array}$ & $\begin{array}{c}\text { Ens. } \\
\text { Superior } \\
\text { incompleto }\end{array}$ & $\begin{array}{l}\text { Ens. } \\
\text { Superior } \\
\text { completo } \\
\downarrow\end{array}$ & $\begin{array}{l}\text { Das quais, } \\
\text { com pós- } \\
\text { graduação }\end{array}$ \\
\hline Instituto de Oceanografia & $2,6 \%$ & $0,0 \%$ & $5,1 \%$ & $5,1 \%$ & $10,3 \%$ & $76,9 \%$ & $12,8 \%$ \\
\hline Faculdade de Direito & $4,1 \%$ & $1,1 \%$ & $1,3 \%$ & $10,9 \%$ & $6,5 \%$ & $76,1 \%$ & $11,5 \%$ \\
\hline Faculdade de Arquitetura e Urbanismo & $2,6 \%$ & $1,1 \%$ & $1,1 \%$ & $14,2 \%$ & $5,3 \%$ & $75,8 \%$ & $16,8 \%$ \\
\hline Escola Politécnica & $2,2 \%$ & $1,6 \%$ & $1,9 \%$ & $12,7 \%$ & $7,0 \%$ & $74,7 \%$ & $12,1 \%$ \\
\hline Instituto de Relações Internacionais & $1,7 \%$ & $1,7 \%$ & $1,7 \%$ & $13,3 \%$ & $8,3 \%$ & $73,3 \%$ & $10,0 \%$ \\
\hline Instituto de Psicologia & $8,6 \%$ & $2,9 \%$ & $1,4 \%$ & $10,0 \%$ & $8,6 \%$ & $68,6 \%$ & $15,7 \%$ \\
\hline Faculdade de Direito de Ribeirão Preto & $2,1 \%$ & $3,1 \%$ & $2,1 \%$ & $17,7 \%$ & $8,3 \%$ & $66,7 \%$ & $10,4 \%$ \\
\hline Faculdade de Economia, Administração e Contabilidade & $5,5 \%$ & $2,4 \%$ & $2,2 \%$ & $16,2 \%$ & $8,7 \%$ & $65,0 \%$ & $11,1 \%$ \\
\hline Escola de Engenharia de São Carlos & $5,4 \%$ & $1,9 \%$ & $1,5 \%$ & $20,6 \%$ & $5,8 \%$ & $64,8 \%$ & $10,4 \%$ \\
\hline Faculdade de Odontologia & $7,5 \%$ & $2,3 \%$ & $3,0 \%$ & $17,3 \%$ & $5,3 \%$ & $64,7 \%$ & $7,5 \%$ \\
\hline Instituto de Ciências Biomédicas* & $2,6 \%$ & $2,6 \%$ & $0,0 \%$ & $23,1 \%$ & $7,7 \%$ & $64,1 \%$ & $2,6 \%$ \\
\hline Faculdade de Medicina & $6,0 \%$ & $3,6 \%$ & $2,4 \%$ & $15,3 \%$ & $10,0 \%$ & $62,7 \%$ & $8,4 \%$ \\
\hline Escola de Educação Física e Esportes & $5,0 \%$ & $0,0 \%$ & $1,0 \%$ & $23,0 \%$ & $10,0 \%$ & $61,0 \%$ & $4,0 \%$ \\
\hline Instituto de Biociências & $3,4 \%$ & $4,2 \%$ & $1,7 \%$ & $21,8 \%$ & $8,4 \%$ & $60,5 \%$ & $9,2 \%$ \\
\hline Faculdade de Medicina Veterinária e Zootecnia & $2,5 \%$ & $3,8 \%$ & $5,0 \%$ & $22,5 \%$ & $7,5 \%$ & $58,8 \%$ & $6,3 \%$ \\
\hline Escola de Comunicação e Artes & $8,9 \%$ & $3,3 \%$ & $2,8 \%$ & $17,6 \%$ & $8,9 \%$ & $58,5 \%$ & $10,2 \%$ \\
\hline Escola de Engenharia de Lorena & $5,1 \%$ & $1,7 \%$ & $3,7 \%$ & $25,4 \%$ & $6,0 \%$ & $58,1 \%$ & $4,0 \%$ \\
\hline Faculdade de Odontologia de Ribeirão Preto & $2,6 \%$ & $6,6 \%$ & $3,9 \%$ & $17,1 \%$ & $13,2 \%$ & $56,6 \%$ & $3,9 \%$ \\
\hline Faculdade de Ciências Farmacêuticas & $6,8 \%$ & $1,4 \%$ & $5,4 \%$ & $22,3 \%$ & $10,1 \%$ & $54,1 \%$ & $6,1 \%$ \\
\hline Universidade de São Paulo (total geral) & $9,0 \%$ & $3,3 \%$ & $3,4 \%$ & $22,4 \%$ & $8,0 \%$ & $\mathbf{5 3 , 9 \%}$ & $7,2 \%$ \\
\hline Instituto de Arquitetura e Urbanismo de São Carlos & $4,4 \%$ & $4,4 \%$ & $4,4 \%$ & $20,0 \%$ & $13,3 \%$ & $53,3 \%$ & $15,6 \%$ \\
\hline Faculdade de Zootecnia e Engenharia de Alimentos & $7,6 \%$ & $1,6 \%$ & $6,4 \%$ & $25,2 \%$ & $6,0 \%$ & $53,2 \%$ & $5,2 \%$ \\
\hline Faculdade de Medicina de Ribeirão Preto & $7,8 \%$ & $4,1 \%$ & $2,3 \%$ & $26,9 \%$ & $6,8 \%$ & $52,1 \%$ & $5,0 \%$ \\
\hline Faculdade de Economia e Administração de Ribeirão Preto & $7,3 \%$ & $2,3 \%$ & $3,1 \%$ & $29,1 \%$ & $6,5 \%$ & $51,7 \%$ & $4,2 \%$ \\
\hline Instituto de Química de São Carlos & $10,3 \%$ & $5,2 \%$ & $5,2 \%$ & $24,1 \%$ & $3,4 \%$ & $51,7 \%$ & $8,6 \%$ \\
\hline Escola Superior de Agricultura Luiz de Queiroz & $8,6 \%$ & $3,1 \%$ & $3,9 \%$ & $27,2 \%$ & $6,8 \%$ & $50,3 \%$ & $5,2 \%$ \\
\hline Instituto de Química & $13,6 \%$ & $2,5 \%$ & $2,5 \%$ & $23,7 \%$ & $7,6 \%$ & $50,0 \%$ & $5,9 \%$ \\
\hline Escola de Educação Física e Esportes de Ribeirão Preto & $8,6 \%$ & $1,7 \%$ & $1,7 \%$ & $27,6 \%$ & $12,1 \%$ & $48,3 \%$ & $1,7 \%$ \\
\hline Faculdade de Filosofia, Letras e Ciências Humanas & $13,2 \%$ & $4,5 \%$ & $4,5 \%$ & $22,2 \%$ & $8,8 \%$ & $46,9 \%$ & $7,4 \%$ \\
\hline Instituto de Matemática de Estatística & $14,8 \%$ & $4,2 \%$ & $4,5 \%$ & $24,0 \%$ & $6,5 \%$ & $46,0 \%$ & $4,7 \%$ \\
\hline Faculdade de Odontologia de Bauru & $9,4 \%$ & $4,7 \%$ & $5,9 \%$ & $27,1 \%$ & $7,1 \%$ & $45,9 \%$ & $5,9 \%$ \\
\hline Instituto de Física de São Carlos & $12,9 \%$ & $4,3 \%$ & $3,1 \%$ & $25,8 \%$ & $8,6 \%$ & $45,4 \%$ & $3,7 \%$ \\
\hline Escola de Enfermagem & $6,3 \%$ & $5,1 \%$ & $5,1 \%$ & $31,6 \%$ & $7,6 \%$ & $44,3 \%$ & $2,5 \%$ \\
\hline Faculdade de Educação & $16,9 \%$ & $4,5 \%$ & $3,4 \%$ & $21,5 \%$ & $9,6 \%$ & $44,1 \%$ & $2,8 \%$ \\
\hline Instituto de Geociências & $11,2 \%$ & $3,4 \%$ & $3,4 \%$ & $30,3 \%$ & $7,9 \%$ & $43,8 \%$ & $6,7 \%$ \\
\hline Instituto de Ciências Matemáticas e Computação & $11,0 \%$ & $4,1 \%$ & $2,3 \%$ & $33,3 \%$ & $5,9 \%$ & $43,4 \%$ & $8,2 \%$ \\
\hline Faculdade de Saúde Pública & $13,4 \%$ & $5,0 \%$ & $4,2 \%$ & $25,2 \%$ & $9,2 \%$ & $42,9 \%$ & $4,2 \%$ \\
\hline Faculdade de Ciências Farmacêuticas de Ribeirão Preto & $6,5 \%$ & $2,6 \%$ & $2,6 \%$ & $35,1 \%$ & $10,4 \%$ & $42,9 \%$ & $1,3 \%$ \\
\hline Instituto de Astronomia, Geofísica e Ciências Atmosféricas & $10,7 \%$ & $5,3 \%$ & $5,3 \%$ & $26,7 \%$ & $9,3 \%$ & $42,7 \%$ & $4,0 \%$ \\
\hline Faculdade de Filosofia, Ciências e Letras de Ribeirão Preto & $13,9 \%$ & $4,3 \%$ & $4,6 \%$ & $29,0 \%$ & $7,4 \%$ & $40,8 \%$ & $2,6 \%$ \\
\hline Escola de Artes, Ciências e Humanidades & $11,6 \%$ & $4,3 \%$ & $4,8 \%$ & $27,8 \%$ & $10,7 \%$ & $40,8 \%$ & $4,1 \%$ \\
\hline Instituto de Física & $17,5 \%$ & $6,3 \%$ & $3,7 \%$ & $30,6 \%$ & $10,4 \%$ & $31,3 \%$ & $3,4 \%$ \\
\hline Escola de Enfermagem de Ribeirão Preto & $16,3 \%$ & $5,4 \%$ & $5,4 \%$ & $41,9 \%$ & $7,0 \%$ & $24,0 \%$ & $4,7 \%$ \\
\hline
\end{tabular}

Fonte: Questionário Socioeconômico da Fuvest

Elaboração: própria 
As tabelas permitem mostrar, portanto, que embora a taxa de egressos cuja mãe tem ensino superior completo possa ter aumentado progressivamente ao longo dos últimos anos tanto para a média geral da USP quanto para as suas diferentes unidades, a relação entre as unidades socialmente dominantes e as unidades socialmente dominadas não se alterou nesse período, sendo marcada pela contraposição entre faculdades profissionais tradicionais e faculdades acadêmico-científicas ou técnico-profissionais. O mesmo se observa para outras variáveis significativas, tais como percentual de egressos cujo pai tem ensino superior completo, percentual de egressos de escola pública, percentual de pardos e negros, percentual de mulheres, percentual de ingressantes com alta renda familiar e percentual de ingressantes que exerce atividade remunerada. Em todos esses casos, considerando os anos de 2000, 2005, 2010 e 2012, é possível observar que variações pontuais não impactam de modo decisivo os invariantes estruturais da USP, pensados como o padrão de relação objetiva entre seus três polos fundamentais.

Partindo disso, e considerando as limitações de espaço, optou-se por apresentar, aqui, apenas os dados referentes ao ano de 2012. Essa escolha não se deve apenas ao fato de se tratar do ano mais recente para o qual a Fuvest disponibilizou suas estatísticas reagrupadas por unidades mas, sobretudo, por ser, dentre os anos disponíveis, o que oferece o questionário mais completo $^{213}$ e a relação de unidades da USP mais ampla ${ }^{214}$. A análise proposta, apesar de refletir "um estado da estrutura" (Bourdieu, 1989, p.185), busca revelar "os mecanismos profundos que

\footnotetext{
${ }^{213}$ O Questionário Socioeconômico da Fuvest se alterou ao longo do tempo. A exclusão ou inclusão de variáveis reflete a evolução de questões e temas sociais ou mudanças no perfil da amostra. Assim, a partir de 2000, a Fuvest incluiu, por pressões internas e sobretudo externas à universidade, a pergunta referente à raça ou cor autodeclaradas. A partir de 1997, o questionário passou a perguntar sobre a ocupação do pai e da mãe. Em 2005, provavelmente em função do fato de que a amostra se tornava cada vez mais homogênea, de modo que era preciso encontrar novas formas de diferenciação, incluiu-se a pergunta referente à renda.

${ }^{214}$ Como foi visto, a USP criou sete novas unidades na década de 2000, sendo que a mais recente delas, o Instituto de Arquitetura e Urbanismo sediado em São Carlos, foi criado em 2010 e incorporou o primeiro vestibular da Fuvest em 2011, de modo que, dentre os anos que temos disponíveis, só 2012 apresenta a configuração atual da USP, com as suas 42 unidades. Além disso, o Instituto de Ciências Biomédicas inaugurou seu curso de graduação no final dos anos 2010, passando a figurar no Questionário Socioeconômico da Fuvest também recentemente.
} 
asseguram a perpetuação e a transformação estrutural, permitindo ir além da ilusão da contingência", ilusão essa que faz com que a análise, presa às "curiosidades do dia a dia", possa ignorar "as substituições funcionais" e os "equivalentes estruturais" (Bourdieu, 1989, p. 165).

Nesse sentido, partindo para a análise propriamente dita, é interessante começar pelos dados sobre a trajetória escolar dos estudantes da USP. As próximas tabelas posicionam as unidades da USP em relação a quatro variáveis referentes à escolaridade dos ingressantes nas diferentes unidades em 2012, são elas: i) onde realizou o ensino fundamental; ii) onde realizou o ensino médio; iii) que tipo de ensino médio realizou; e iv) em que período.

Em primeiro lugar, essa série de tabelas revela que, independentemente da variável em questão, a relação entre as unidades da USP se desenha quase sempre do mesmo modo, ou seja, pela oposição entre um polo dominante, formado em geral pelas faculdades profissionais tradicionais, e um polo dominado, formado tanto pelas unidades acadêmico-científicas quanto pelas unidades técnico-profissionais. Mesmo que possa haver variações pontuais, elas não são suficientemente importantes para invalidar a força da oposição essencial entre dominantes e dominados no contexto da instituição.

Ao considerar os dados relativos ao ensino fundamental dos aprovados na USP, é possível supor que o percentual de egressos do ensino privado seja um indicador do grau de elitização das diferentes unidades e, portanto, da estrutura social da USP. Assim, considerando o ápice dessa estrutura, formado, no caso, pelas unidades em que mais de $80 \%$ dos ingressantes estudou no ensino fundamental privado, encontramos as unidades tradicionais ou voltadas às formações profissionais valorizadas, tais como: o Instituto de Relações Internacionais, a Escola Politécnica, a Faculdade de Arquitetura e Urbanismo, a Faculdade de Direito, a Faculdade de Economia, Administração e Contabilidade, a Faculdade de Direito de Ribeirão Preto. Dessas seis escolas, somente a última não está sediada na cidade de São Paulo. No outro extremo, considerando as unidades cujo percentual de egressos da escola privada é menor do que $60 \%$, 
encontramos somente unidades acadêmico-científicas ou técnico-profissionais. São elas, nessa ordem: a Faculdade de Educação, o Instituto de Química de São Carlos, a Escola de Artes, Ciências e Humanidades, a Faculdade de Filosofia, Letras e Ciências Humanas, o Instituto de Ciências Matemáticas e Computação, o Instituto de Geociências, o Instituto de Matemática e Estatística, a Escola de Esportes e Educação Física de Ribeirão Preto, a Faculdade de Filosofia de Ribeirão Preto, o Instituto de Física de São Carlos, o Instituto de Física e a Escola de Enfermagem de Ribeirão Preto. Quanto aos dados relativos ao ensino médio, os pressupostos analíticos são os mesmos e os resultados encontrados na tabela são consistentes com os dados relativos ao ensino fundamental. Assim, embora possa haver uma pequena variação nas unidades específicas que estão no topo e na base da tabela, essa variação não altera a contraposição essencial entre o polo profissional tradicional, representando as profissões liberais socialmente valorizadas, e os polos acadêmico-científico e técnico-profissional que compartilham as posições inferiores da estrutura social da USP, expressa, no caso, pelas condições de acesso ao ensino médio privado.

O tipo de ensino médio realizado - que se divide principalmente entre comum, técnico, magistério e supletivo -, embora não possa ser considerado um indicador direto do grau de elitização das suas unidades, contribui para exemplificar o perfil altamente homogêneo da USP, que seleciona praticamente a totalidade dos seus estudantes no ensino médio comum, voltado a uma formação geral, sem conteúdo técnico ou profissionalizante, com função, portanto, propedêutica. Ainda assim, algumas poucas unidades, ligadas às áreas exatas, têm um canal de acesso à USP garantido pelo ensino técnico, que pode constituir uma opção para os alunos que precisam trabalhar enquanto cursam o ensino médio. Nesse mesmo sentido, os dados sobre o percentual de ingressantes na USP que estudaram no período noturno, e que tinham, portanto, possibilidade de trabalhar em tempo integral e estudar, são ainda mais significativos. Enquanto nas unidades profissionais tradicionais praticamente inexistem estudantes egressos do período 
noturno, as unidades que recebem um percentual um pouco maior desses estudantes são ou acadêmico-científicos ou técnico-profissionais.

\author{
Questionário socioeconômico da Fuvest (2012) \\ Questão "Onde você realizou o Ensino Fundamental?"
}

Tabela 17. Unidades hierarquizadas em ordem decrescente segundo o percentual de ingressantes que cursaram o ensino fundamental, integralmente ou na maior parte, em escola particular

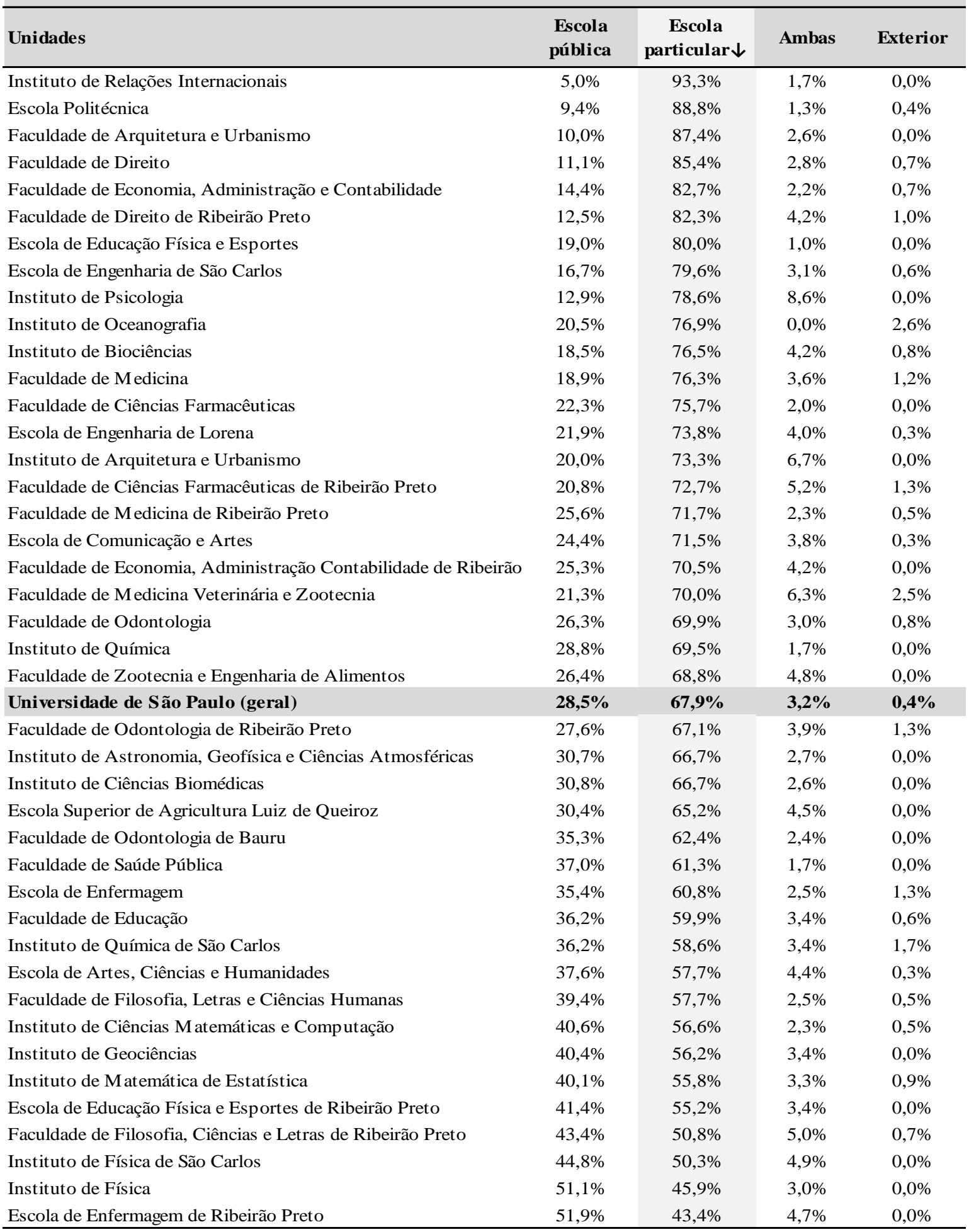

Fonte: Questionário Socioeconômico da Fuvest

Elaboração: própria 


\begin{tabular}{|c|c|c|c|c|}
\hline \multicolumn{5}{|c|}{$\begin{array}{c}\text { Questionário socioeconômico Fuvest (2012) } \\
\text { Questão "Onde você realizou o Ensino Médio?" }\end{array}$} \\
\hline Unidades & $\begin{array}{l}\text { Escola } \\
\text { pública }\end{array}$ & $\begin{array}{c}\text { Escola } \\
\text { particular } \\
\downarrow \\
\end{array}$ & Ambas & Exterior \\
\hline Faculdade de Direito de Ribeirão Preto & $11,5 \%$ & $87,5 \%$ & $0,0 \%$ & $1,0 \%$ \\
\hline Escola Politécnica & $15,0 \%$ & $84,6 \%$ & $0,3 \%$ & $0,1 \%$ \\
\hline Faculdadade de Arquitetura e Urbanismo & $14,7 \%$ & $84,2 \%$ & $0,5 \%$ & $0,5 \%$ \\
\hline Faculdade de Odontologia de Ribeirão Preto & $17,1 \%$ & $82,9 \%$ & $0,0 \%$ & $0,0 \%$ \\
\hline Instituto de Psicologia & $17,1 \%$ & $82,9 \%$ & $0,0 \%$ & $0,0 \%$ \\
\hline Faculdade de Ciências Farmacêuticas de Ribeirão Preto & $18,2 \%$ & $80,5 \%$ & $0,0 \%$ & $1,3 \%$ \\
\hline Faculdade de Direito & $19,8 \%$ & $80,2 \%$ & $0,0 \%$ & $0,0 \%$ \\
\hline Escola de Engenharia de São Carlos & $19,8 \%$ & $80,0 \%$ & $0,2 \%$ & $0,0 \%$ \\
\hline Faculdade de Economia e Administração de Ribeirão Preto & $19,2 \%$ & $79,7 \%$ & $1,1 \%$ & $0,0 \%$ \\
\hline Instituto de Oceanografia & $20,5 \%$ & $79,5 \%$ & $0,0 \%$ & $0,0 \%$ \\
\hline Faculdade de Economia e Administração & $20,3 \%$ & $78,8 \%$ & $0,3 \%$ & $0,5 \%$ \\
\hline Faculdade de Zootecnia e Engenharia de Alimentos & $23,2 \%$ & $76,8 \%$ & $0,0 \%$ & $0,0 \%$ \\
\hline Escola de Educação Física e Esportes & $24,0 \%$ & $76,0 \%$ & $0,0 \%$ & $0,0 \%$ \\
\hline Instituto de Relações Internacionais & $25,0 \%$ & $75,0 \%$ & $0,0 \%$ & $0,0 \%$ \\
\hline Instituto de Biociências & $23,5 \%$ & $74,8 \%$ & $0,0 \%$ & $1,7 \%$ \\
\hline Faculdade de Medicina & $24,5 \%$ & $74,7 \%$ & $0,0 \%$ & $0,8 \%$ \\
\hline Escola de Engenharia de Lorena & $25,9 \%$ & $73,8 \%$ & $0,3 \%$ & $0,0 \%$ \\
\hline Faculdade de Medicina de Ribeirão Preto & $26,5 \%$ & $73,5 \%$ & $0,0 \%$ & $0,0 \%$ \\
\hline Instituto de Aquitetura e Urbanismo de São Carlos & $26,7 \%$ & $73,3 \%$ & $0,0 \%$ & $0,0 \%$ \\
\hline Faculdade de Odontologia de Bauru & $25,9 \%$ & $72,9 \%$ & $1,2 \%$ & $0,0 \%$ \\
\hline Escola Superior de Agrononomia Luiz de Queiroz & $28,8 \%$ & $70,4 \%$ & $0,3 \%$ & $0,5 \%$ \\
\hline Instituto de Química de São Carlos & $31,0 \%$ & $69,0 \%$ & $0,0 \%$ & $0,0 \%$ \\
\hline Faculdade de Medicina Veterinária e Zootecnia & $31,3 \%$ & $68,8 \%$ & $0,0 \%$ & $0,0 \%$ \\
\hline Escola de Comunicação e Artes & $30,5 \%$ & $68,7 \%$ & $0,5 \%$ & $0,3 \%$ \\
\hline Faculdade de Ciências Farmacêuticas & $31,8 \%$ & $68,2 \%$ & $0,0 \%$ & $0,0 \%$ \\
\hline Universidade de São Paulo (geral) & $31,6 \%$ & $67,8 \%$ & $0,4 \%$ & $0,2 \%$ \\
\hline Faculdade de Odontologia & $34,6 \%$ & $63,9 \%$ & $0,0 \%$ & $1,5 \%$ \\
\hline Escola de Enfermagem & $36,7 \%$ & $63,3 \%$ & $0,0 \%$ & $0,0 \%$ \\
\hline Faculdade de Filosofia, Ciências e Letras de Ribeirão Preto & $36,9 \%$ & $62,1 \%$ & $0,5 \%$ & $0,5 \%$ \\
\hline Instituto de Química & $38,1 \%$ & $61,9 \%$ & $0,0 \%$ & $0,0 \%$ \\
\hline Instituto de Ciências Biomédicas & $38,5 \%$ & $61,5 \%$ & $0,0 \%$ & $0,0 \%$ \\
\hline Instrituto de Ciências Matemáticas e Computação & $38,8 \%$ & $61,2 \%$ & $0,0 \%$ & $0,0 \%$ \\
\hline Instituto de Física de São Carlos & $38,7 \%$ & $60,7 \%$ & $0,6 \%$ & $0,0 \%$ \\
\hline Instituto de Astronomia, Geofísica e Ciências Atmosféricas & $38,7 \%$ & $60,0 \%$ & $0,0 \%$ & $1,3 \%$ \\
\hline Faculdade de Educação & $39,5 \%$ & $59,3 \%$ & $0,6 \%$ & $0,6 \%$ \\
\hline Faculdade de Saúde Pública & $41,2 \%$ & $58,0 \%$ & $0,8 \%$ & $0,0 \%$ \\
\hline Instituto de Matemática de Estatística & $41,5 \%$ & $57,9 \%$ & $0,3 \%$ & $0,3 \%$ \\
\hline Faculdade de Filosofia, Letras e Ciências Humanas & $42,4 \%$ & $56,8 \%$ & $0,7 \%$ & $0,1 \%$ \\
\hline Escola de Educação Física e Esportes de Ribeirão Preto & $44,8 \%$ & $55,2 \%$ & $0,0 \%$ & $0,0 \%$ \\
\hline Escola de Enfermagem de Ribeirão Preto & $44,2 \%$ & $55,0 \%$ & $0,8 \%$ & $0,0 \%$ \\
\hline Instituto de Geociências & $47,2 \%$ & $52,8 \%$ & $0,0 \%$ & $0,0 \%$ \\
\hline Escola de Artes, Ciências e Humanidades & $46,8 \%$ & $52,2 \%$ & $0,9 \%$ & $0,1 \%$ \\
\hline Instituto de Física & $49,6 \%$ & $49,6 \%$ & $0,7 \%$ & $0,0 \%$ \\
\hline
\end{tabular}

Fonte: Questionário Socioeconômico da Fuvest

Elaboração: própria 


\begin{tabular}{|c|c|c|c|c|c|}
\hline $\begin{array}{l}\text { Questinário sc } \\
\text { Questão "Que tipc }\end{array}$ & $\begin{array}{l}\text { nômico da Fu } \\
\text { sino Médio ve }\end{array}$ & $\begin{array}{l}\text { (2012) } \\
\text { realizou?" }\end{array}$ & & & \\
\hline Unidades & Comum $\downarrow$ & Técnico & Magistério & Supletivo & Outro \\
\hline Faculdade de Direito de Ribeirão Preto & $99,0 \%$ & $1,0 \%$ & $0,0 \%$ & $0,0 \%$ & $0,0 \%$ \\
\hline Faculdade de Ciências Farmacêuticas de Ribeirão Preto & $97,4 \%$ & $2,6 \%$ & $0,0 \%$ & $0,0 \%$ & $0,0 \%$ \\
\hline Faculdade de Odontologia de Ribeirão Preto & $97,4 \%$ & $1,3 \%$ & $0,0 \%$ & $0,0 \%$ & $1,3 \%$ \\
\hline Faculdade de Medicina de Ribeirão Preto & $97,3 \%$ & $2,7 \%$ & $0,0 \%$ & $0,0 \%$ & $0,0 \%$ \\
\hline Instituto de Psicologia & $97,1 \%$ & $2,9 \%$ & $0,0 \%$ & $0,0 \%$ & $0,0 \%$ \\
\hline Faculdade de Economia e Administração de Ribeirão Preto & $96,9 \%$ & $2,7 \%$ & $0,0 \%$ & $0,0 \%$ & $0,4 \%$ \\
\hline Escola de Educação Física e Esportes de Ribeirão Preto & $96,6 \%$ & $1,7 \%$ & $0,0 \%$ & $1,7 \%$ & $0,0 \%$ \\
\hline Faculdade de Medicina & $96,0 \%$ & $3,6 \%$ & $0,0 \%$ & $0,4 \%$ & $0,0 \%$ \\
\hline Faculdadade de Arquitetura e Urbanismo & $95,3 \%$ & $4,7 \%$ & $0,0 \%$ & $0,0 \%$ & $0,0 \%$ \\
\hline Faculdade de Filosofia, Ciências e Letras de Ribeirão Preto & $95,2 \%$ & $3,6 \%$ & $0,0 \%$ & $1,0 \%$ & $0,2 \%$ \\
\hline Faculdade de Odontologia de Bauru & $94,1 \%$ & $4,7 \%$ & $0,0 \%$ & $1,2 \%$ & $0,0 \%$ \\
\hline Faculdade de Zootecnia e Engenharia de Alimentos & $94,0 \%$ & $6,0 \%$ & $0,0 \%$ & $0,0 \%$ & $0,0 \%$ \\
\hline Faculdade de Economia e Administração & $93,8 \%$ & $5,1 \%$ & $0,2 \%$ & $0,9 \%$ & $0,0 \%$ \\
\hline Escola de Enfermagem de Ribeirão Preto & $93,8 \%$ & $3,9 \%$ & $0,0 \%$ & $2,3 \%$ & $0,0 \%$ \\
\hline Instituto de Física de São Carlos & $93,3 \%$ & $6,1 \%$ & $0,0 \%$ & $0,6 \%$ & $0,0 \%$ \\
\hline Escola de Educação Física e Esportes & $93,0 \%$ & $7,0 \%$ & $0,0 \%$ & $0,0 \%$ & $0,0 \%$ \\
\hline Escola Politécnica & $92,5 \%$ & $6,9 \%$ & $0,0 \%$ & $0,1 \%$ & $0,5 \%$ \\
\hline Instituto de Biociências & $92,4 \%$ & $5,9 \%$ & $0,0 \%$ & $0,8 \%$ & $0,8 \%$ \\
\hline Instituto de Ciências Biomédicas & $92,3 \%$ & $5,1 \%$ & $2,6 \%$ & $0,0 \%$ & $0,0 \%$ \\
\hline Faculdade de Direito & $92,2 \%$ & $6,5 \%$ & $0,7 \%$ & $0,4 \%$ & $0,2 \%$ \\
\hline Instituto de Relações Internacionais & $91,7 \%$ & $8,3 \%$ & $0,0 \%$ & $0,0 \%$ & $0,0 \%$ \\
\hline Escola de Engenharia de São Carlos & $91,5 \%$ & $8,1 \%$ & $0,0 \%$ & $0,0 \%$ & $0,4 \%$ \\
\hline Escola de Enfermagem & $91,1 \%$ & $6,3 \%$ & $0,0 \%$ & $1,3 \%$ & $1,3 \%$ \\
\hline Faculdade de Odontologia & $91,0 \%$ & $6,8 \%$ & $0,8 \%$ & $0,8 \%$ & $0,8 \%$ \\
\hline Escola de Comunicação e Artes & $90,8 \%$ & $8,7 \%$ & $0,0 \%$ & $0,3 \%$ & $0,3 \%$ \\
\hline Escola Superior de Agrononomia Luiz de Queiroz & $90,8 \%$ & $8,1 \%$ & $0,0 \%$ & $0,5 \%$ & $0,5 \%$ \\
\hline Universidade de São Paulo (geral) & $\mathbf{9 0 , 5 \%}$ & $7,9 \%$ & $0,3 \%$ & $0,9 \%$ & $\mathbf{0 , 3 \%}$ \\
\hline Faculdade de Medicina Veterinária e Zootecnia & $90,0 \%$ & $10,0 \%$ & $0,0 \%$ & $0,0 \%$ & $0,0 \%$ \\
\hline Faculdade de Ciências Farmacêuticas & $89,9 \%$ & $8,8 \%$ & $0,7 \%$ & $0,0 \%$ & $0,7 \%$ \\
\hline Instituto de Química & $89,0 \%$ & $11,0 \%$ & $0,0 \%$ & $0,0 \%$ & $0,0 \%$ \\
\hline Instituto de Aquitetura e Urbanismo de São Carlos & $88,9 \%$ & $11,1 \%$ & $0,0 \%$ & $0,0 \%$ & $0,0 \%$ \\
\hline Faculdade de Filosofia, Letras e Ciências Humanas & $88,2 \%$ & $8,3 \%$ & $0,8 \%$ & $1,9 \%$ & $0,7 \%$ \\
\hline Instituto de Química de São Carlos & $87,9 \%$ & $10,3 \%$ & $1,7 \%$ & $0,0 \%$ & $0,0 \%$ \\
\hline Instrituto de Ciências Matemáticas e Computação & $87,7 \%$ & $11,4 \%$ & $0,0 \%$ & $0,5 \%$ & $0,5 \%$ \\
\hline Instituto de Geociências & $87,6 \%$ & $10,1 \%$ & $2,2 \%$ & $0,0 \%$ & $0,0 \%$ \\
\hline Escola de Artes, Ciências e Humanidades & $87,0 \%$ & $10,7 \%$ & $0,3 \%$ & $1,8 \%$ & $0,1 \%$ \\
\hline Faculdade de Saúde Pública & $86,6 \%$ & $10,1 \%$ & $0,8 \%$ & $1,7 \%$ & $0,8 \%$ \\
\hline Escola de Engenharia de Lorena & $86,3 \%$ & $13,7 \%$ & $0,0 \%$ & $0,0 \%$ & $0,0 \%$ \\
\hline Faculdade de Educação & $85,9 \%$ & $7,3 \%$ & $3,4 \%$ & $2,3 \%$ & $1,1 \%$ \\
\hline Instituto de Matemática de Estatística & $83,1 \%$ & $14,2 \%$ & $0,6 \%$ & $2,1 \%$ & $0,0 \%$ \\
\hline Instituto de Oceanografia & $82,1 \%$ & $15,4 \%$ & $0,0 \%$ & $0,0 \%$ & $2,6 \%$ \\
\hline Instituto de Física & $81,3 \%$ & $15,3 \%$ & $0,0 \%$ & $3,4 \%$ & $0,0 \%$ \\
\hline Instituto de Astronomia, Geofísica e Ciências Atmosféricas & $76,0 \%$ & $20,0 \%$ & $1,3 \%$ & $2,7 \%$ & $0,0 \%$ \\
\hline
\end{tabular}

Fonte: Questionário Socioeconômico da Fuvest

Elaboração: própria 


\begin{tabular}{|c|c|c|c|c|}
\hline $\begin{array}{r}\text { Questionário socioecor } \\
\text { Questão "Em que período você reali } \\
\text { Tabela 20. Unidades hierarquizadas pelo percentual cre } \\
\text { período }\end{array}$ & $\begin{array}{l}\text { co da Fu } \\
\text { seus estud } \\
\text { te de ing } \\
\text { irno }\end{array}$ & $\begin{array}{l}\text { Ensino Médi } \\
\text { antes que cur }\end{array}$ & Im o ensi & aédio no \\
\hline Unidades & Diurno & Noturno $\downarrow$ & Integral & Ambos \\
\hline Faculdade de Ciências Farmacêuticas de Ribeirão Preto & $90,9 \%$ & $0,0 \%$ & $9,1 \%$ & $0,0 \%$ \\
\hline Faculdade de Direito de Ribeirão Preto & $90,6 \%$ & $0,0 \%$ & $9,4 \%$ & $0,0 \%$ \\
\hline Faculdade de Odontologia de Ribeirão Preto & $96,1 \%$ & $0,0 \%$ & $3,9 \%$ & $0,0 \%$ \\
\hline Instituto de Ciências Biomédicas & $89,7 \%$ & $0,0 \%$ & $10,3 \%$ & $0,0 \%$ \\
\hline Instituto de Psicologia & $82,9 \%$ & $0,0 \%$ & $17,1 \%$ & $0,0 \%$ \\
\hline Instituto de Química de São Carlos & $81,0 \%$ & $0,0 \%$ & $19,0 \%$ & $0,0 \%$ \\
\hline Instituto de Relações Internacionais & $85,0 \%$ & $0,0 \%$ & $15,0 \%$ & $0,0 \%$ \\
\hline Faculdadade de Arquitetura e Urbanismo & $82,1 \%$ & $1,1 \%$ & $16,8 \%$ & $0,0 \%$ \\
\hline Escola Politécnica & $80,2 \%$ & $1,1 \%$ & $18,2 \%$ & $0,5 \%$ \\
\hline Faculdade de Medicina & $89,6 \%$ & $1,6 \%$ & $8,4 \%$ & $0,4 \%$ \\
\hline Instituto de Biociências & $84,0 \%$ & $1,7 \%$ & $13,4 \%$ & $0,8 \%$ \\
\hline Escola de Engenharia de Lorena & $80,1 \%$ & $1,7 \%$ & $17,4 \%$ & $0,9 \%$ \\
\hline Escola de Engenharia de São Carlos & $83,3 \%$ & $1,9 \%$ & $14,4 \%$ & $0,4 \%$ \\
\hline Instituto de Aquitetura e Urbanismo de São Carlos & $82,2 \%$ & $2,2 \%$ & $15,6 \%$ & $0,0 \%$ \\
\hline Faculdade de Odontologia de Bauru & $78,8 \%$ & $2,4 \%$ & $16,5 \%$ & $2,4 \%$ \\
\hline Escola de Enfermagem & $91,1 \%$ & $2,5 \%$ & $6,3 \%$ & $0,0 \%$ \\
\hline Faculdade de Direito & $83,9 \%$ & $3,3 \%$ & $12,8 \%$ & $0,0 \%$ \\
\hline Escola de Educação Física e Esportes de Ribeirão Preto & $91,4 \%$ & $3,4 \%$ & $3,4 \%$ & $1,7 \%$ \\
\hline Faculdade de Economia e Administração & $82,9 \%$ & $3,6 \%$ & $13,3 \%$ & $0,2 \%$ \\
\hline Faculdade de Zootecnia e Engenharia de Alimentos & $87,6 \%$ & $3,6 \%$ & $8,8 \%$ & $0,0 \%$ \\
\hline Faculdade de Economia e Administração de Ribeirão Preto & $87,0 \%$ & $3,8 \%$ & $9,2 \%$ & $0,0 \%$ \\
\hline Escola Superior de Agrononomia Luiz de Queiroz & $80,6 \%$ & $3,9 \%$ & $14,9 \%$ & $0,5 \%$ \\
\hline Faculdade de Ciências Farmacêuticas & $82,4 \%$ & $4,1 \%$ & $13,5 \%$ & $0,0 \%$ \\
\hline Escola de Comunicação e Artes & $83,7 \%$ & $4,3 \%$ & $11,2 \%$ & $0,8 \%$ \\
\hline Faculdade de Odontologia & $81,2 \%$ & $4,5 \%$ & $13,5 \%$ & $0,8 \%$ \\
\hline Faculdade de Medicina de Ribeirão Preto & $87,2 \%$ & $4,6 \%$ & $8,2 \%$ & $0,0 \%$ \\
\hline Escola de Enfermagem de Ribeirão Preto & $89,9 \%$ & $4,7 \%$ & $4,7 \%$ & $0,8 \%$ \\
\hline Escola de Educação Física e Esportes & $85,0 \%$ & $5,0 \%$ & $10,0 \%$ & $0,0 \%$ \\
\hline Faculdade de Medicina Veterinária e Zootecnia & $86,3 \%$ & $5,0 \%$ & $8,8 \%$ & $0,0 \%$ \\
\hline Instituto de Oceanografia & $82,1 \%$ & $5,1 \%$ & $12,8 \%$ & $0,0 \%$ \\
\hline Universidade de São Paulo (geral) & $82,0 \%$ & $5,6 \%$ & $11,4 \%$ & $0,9 \%$ \\
\hline Faculdade de Filosofia, Ciências e Letras de Ribeirão Preto & $88,2 \%$ & $6,0 \%$ & $5,3 \%$ & $0,5 \%$ \\
\hline Instituto de Astronomia, Geofísica e Ciências Atmosféricas & $76,0 \%$ & $6,7 \%$ & $16,0 \%$ & $1,3 \%$ \\
\hline Instituto de Geociências & $77,5 \%$ & $6,7 \%$ & $15,7 \%$ & $0,0 \%$ \\
\hline Escola de Artes, Ciências e Humanidades & $82,8 \%$ & $7,6 \%$ & $8,2 \%$ & $1,4 \%$ \\
\hline Instrituto de Ciências Matemáticas e Computação & $78,5 \%$ & $7,8 \%$ & $12,8 \%$ & $0,9 \%$ \\
\hline Faculdade de Saúde Pública & $81,5 \%$ & $9,2 \%$ & $7,6 \%$ & $1,7 \%$ \\
\hline Instituto de Química & $75,4 \%$ & $9,3 \%$ & $14,4 \%$ & $0,8 \%$ \\
\hline Faculdade de Filosofia, Letras e Ciências Humanas & $78,2 \%$ & $9,6 \%$ & $9,9 \%$ & $2,2 \%$ \\
\hline Instituto de Física de São Carlos & $77,9 \%$ & $11,0 \%$ & $10,4 \%$ & $0,6 \%$ \\
\hline Instituto de Matemática de Estatística & $78,0 \%$ & $11,9 \%$ & $8,0 \%$ & $2,1 \%$ \\
\hline Faculdade de Educação & $71,2 \%$ & $12,4 \%$ & $13,6 \%$ & $2,8 \%$ \\
\hline Instituto de Física & $72,4 \%$ & $19,0 \%$ & $6,7 \%$ & $1,9 \%$ \\
\hline
\end{tabular}

Fonte: Questionário Socioeconômico da Fuvest

Elaboração: própria 
As tabelas relativas à escolaridade dos ingressantes da USP, vistas em conjunto, revelam a força da contraposição essencial que estrutura a instituição, entre unidades profissionais tradicionais, de recrutamento social elevado, e unidades voltadas à formação de docentes, cientistas ou profissionais de perfil técnico, de recrutamento social um pouco mais aberto. Mas além disso, as tabelas revelam a homogeneidade social da USP, sobretudo no seu polo dominante, que é praticamente fechado a estudantes com uma trajetória escolar menos linear, especialmente em função da necessidade de conciliar trabalho e estudo. Isso distingue as tendências observadas na USP do movimento que marca o ensino superior brasileiro como um todo, que vem crescendo a taxas elevadas nos últimos anos em função do ingresso de “estudantes trabalhadores", o que explica o predomínio de estudantes que frequentam o ensino superior no período noturno.

Nesse sentido, analisando dados recentes sobre a evolução do perfil dos estudantes de ensino superior no Brasil como um todo, Alvaro Comin e Rogério Barbosa mostraram que 75\% das matrículas de ensino superior em 2008 concentravam-se no sistema privado, a maioria delas no período noturno, de modo que a maior parte dos seus estudantes cursava universidade trabalhando em tempo integral (cf. 2011). Essa constatação levou os autores a concluir que os novos estudantes de ensino superior brasileiro são, essencialmente, "indivíduos já há muito inseridos no mercado de trabalho, que retornam aos estudos em proporção cada vez maior, não raro após uma trajetória de interrupções nos estudos ou atraso escolar” (2011, p. 79) Nesse caso, portanto, ao invés da escola conduzir os estudantes ao mercado de trabalho, é o mercado de trabalho que fornece condições, sobretudo materiais, para que os trabalhadores possam voltar a estudar, sobretudo no sistema privado e no período noturno.

Essa transformação geral no perfil dos estudantes de ensino superior brasileiro reflete de modo aparentemente paradoxal na USP. O percentual de ingressantes na universidade que exercem atividade profissional remunerada caiu de $28,6 \%$, em 1997, ano em que a pergunta 
passou a ser incluída no Questionário Socioeconômico da Fuvest, para 17,9\% em 2013. Em

2012, ano de referência para a nossa análise, o percentual de ingressantes da USP que exerciam atividade profissional foi de $23,9 \%$, só $11 \%$ deles em tempo integral, conforme tabela abaixo.

\begin{tabular}{|c|c|c|c|c|c|}
\hline \multicolumn{6}{|c|}{$\begin{array}{l}\text { Questionário socioeconômico da Fuvest (2012) } \\
\text { Questão "Você exerce atualmente atividade remunerada?" } \\
\text { Tabela 21. Unidades hierarquizadas segundo o percentual decrescente de ingressantes que não exercem nenhum tipo de atividade } \\
\text { remunerada }\end{array}$} \\
\hline Unidades & $\begin{array}{c}\text { Não } \\
\text { Trabalha } \\
\downarrow\end{array}$ & $\begin{array}{c}\text { Eventualme } \\
\text { nte }\end{array}$ & $\begin{array}{c}\text { Meio } \\
\text { período }\end{array}$ & $\begin{array}{c}\text { Tempo semi- } \\
\text { integral }\end{array}$ & $\begin{array}{c}\text { Tempo } \\
\text { integral }\end{array}$ \\
\hline Instituto de Arquitetura e Urbanismo de São Carlos & $95,6 \%$ & $2,2 \%$ & $2,2 \%$ & $0,0 \%$ & $0,0 \%$ \\
\hline Instituto de Ciências Biomédicas & $94,9 \%$ & $0,0 \%$ & $2,6 \%$ & $0,0 \%$ & $2,6 \%$ \\
\hline Escola Politécnica & $94,7 \%$ & $2,8 \%$ & $1,6 \%$ & $0,4 \%$ & $0,4 \%$ \\
\hline Faculdade de Odontologia de Ribeirão Preto & $92,1 \%$ & $2,6 \%$ & $1,3 \%$ & $1,3 \%$ & $2,6 \%$ \\
\hline Instituto de Relações Internacionais & $91,7 \%$ & $1,7 \%$ & $1,7 \%$ & $5,0 \%$ & $0,0 \%$ \\
\hline Faculdade de Medicina & $91,2 \%$ & $3,6 \%$ & $1,2 \%$ & $0,4 \%$ & $3,6 \%$ \\
\hline Faculdade de Odontologia & $91,0 \%$ & $1,5 \%$ & $0,0 \%$ & $3,8 \%$ & $3,8 \%$ \\
\hline Faculdade de Ciências Farmacêuticas de Ribeirão Preto & $90,9 \%$ & $2,6 \%$ & $0,0 \%$ & $2,6 \%$ & $3,9 \%$ \\
\hline Escola de Engenharia de São Carlos & $90,8 \%$ & $4,6 \%$ & $2,1 \%$ & $1,0 \%$ & $1,5 \%$ \\
\hline Faculdade de Direito de Ribeirão Preto & $90,6 \%$ & $3,1 \%$ & $3,1 \%$ & $0,0 \%$ & $3,1 \%$ \\
\hline Faculdade de Medicina de Ribeirão Preto & $90,4 \%$ & $4,6 \%$ & $2,3 \%$ & $0,5 \%$ & $2,3 \%$ \\
\hline Faculdade de Zootecnia e Engenharia de Alimentos & $90,4 \%$ & $5,2 \%$ & $1,6 \%$ & $1,6 \%$ & $1,2 \%$ \\
\hline Escola de Engenharia de Lorena & $90,0 \%$ & $4,8 \%$ & $1,4 \%$ & $1,1 \%$ & $2,6 \%$ \\
\hline Faculdade de Arquitetura e Urbanismo & $90,0 \%$ & $6,3 \%$ & $0,5 \%$ & $1,1 \%$ & $2,1 \%$ \\
\hline Faculdade de Medicina Veterinária e Zootecnia & $88,8 \%$ & $2,5 \%$ & $1,3 \%$ & $2,5 \%$ & $5,0 \%$ \\
\hline Escola de Enfermagem de Ribeirão Preto & $88,4 \%$ & $1,6 \%$ & $5,4 \%$ & $1,6 \%$ & $3,1 \%$ \\
\hline Faculdade de Ciências Farmacêuticas & $87,8 \%$ & $2,7 \%$ & $2,0 \%$ & $2,7 \%$ & $4,7 \%$ \\
\hline Faculdade de Odontologia de Bauru & $87,1 \%$ & $2,4 \%$ & $3,5 \%$ & $3,5 \%$ & $3,5 \%$ \\
\hline Instituto de Química de São Carlos & $86,2 \%$ & $5,2 \%$ & $0,0 \%$ & $0,0 \%$ & $8,6 \%$ \\
\hline Instituto de Psicologia & $85,7 \%$ & $11,4 \%$ & $2,9 \%$ & $0,0 \%$ & $0,0 \%$ \\
\hline Instituto de Biociências & $84,9 \%$ & $8,4 \%$ & $1,7 \%$ & $3,4 \%$ & $1,7 \%$ \\
\hline Escola Superior de Agricultura Luiz de Queiroz & $84,6 \%$ & $4,7 \%$ & $3,7 \%$ & $1,8 \%$ & $5,2 \%$ \\
\hline Faculdade de Direito & $84,1 \%$ & $3,0 \%$ & $2,0 \%$ & $1,7 \%$ & $9,1 \%$ \\
\hline Escola de Educação Física e Esportes de Ribeirão Preto & $81,0 \%$ & $3,4 \%$ & $8,6 \%$ & $3,4 \%$ & $3,4 \%$ \\
\hline Faculdade de Economia, Administração e Contabilidade de Ribeirão & $80,5 \%$ & $6,1 \%$ & $3,4 \%$ & $1,1 \%$ & $8,8 \%$ \\
\hline Instituto de Oceanografia & $79,5 \%$ & $10,3 \%$ & $2,6 \%$ & $0,0 \%$ & $7,7 \%$ \\
\hline Faculdade de Economia, Administração e Contabilidade & $78,5 \%$ & $4,3 \%$ & $2,4 \%$ & $2,7 \%$ & $12,1 \%$ \\
\hline Instituto de Ciências Matemáticas e Computação & $78,1 \%$ & $9,1 \%$ & $1,4 \%$ & $2,7 \%$ & $8,7 \%$ \\
\hline Instituto de Química & $77,1 \%$ & $5,9 \%$ & $0,8 \%$ & $5,1 \%$ & $11,0 \%$ \\
\hline Universidade de São Paulo (total geral) & $76,1 \%$ & $6,0 \%$ & $3,4 \%$ & $3,4 \%$ & $11,1 \%$ \\
\hline Faculdade de Filosofia, Ciências e Letras de Ribeirão Preto & $75,8 \%$ & $6,7 \%$ & $4,6 \%$ & $2,2 \%$ & $10,8 \%$ \\
\hline Instituto de Física de São Carlos & $74,8 \%$ & $6,1 \%$ & $1,8 \%$ & $2,5 \%$ & $14,7 \%$ \\
\hline Instituto de Astronomia, Geofísica e Ciências Atmosféricas & $74,7 \%$ & $8,0 \%$ & $0,0 \%$ & $6,7 \%$ & $10,7 \%$ \\
\hline Instituto de Geociências & $70,8 \%$ & $3,4 \%$ & $4,5 \%$ & $6,7 \%$ & $14,6 \%$ \\
\hline Faculdade de Saúde Pública & $68,1 \%$ & $3,4 \%$ & $5,9 \%$ & $8,4 \%$ & $14,3 \%$ \\
\hline Escola de Educação Física e Esportes & $68,0 \%$ & $13,0 \%$ & $5,0 \%$ & $7,0 \%$ & $7,0 \%$ \\
\hline Faculdade de Filosofia, Letras e Ciências Humanas & $54,2 \%$ & $9,2 \%$ & $6,6 \%$ & $6,9 \%$ & $23,2 \%$ \\
\hline Instituto de Matemática de Estatística & $51,9 \%$ & $7,4 \%$ & $4,5 \%$ & $6,5 \%$ & $29,7 \%$ \\
\hline Instituto de Física & $51,5 \%$ & $7,5 \%$ & $6,3 \%$ & $6,7 \%$ & $28,0 \%$ \\
\hline Faculdade de Educação & $50,3 \%$ & $6,2 \%$ & $6,2 \%$ & $10,2 \%$ & $27,1 \%$ \\
\hline
\end{tabular}

Fonte: Questionário Socioeconômico da Fuvest

Elaboração: própria 
Apesar da taxa de aprovação na USP de alunos que se dividiam entre o trabalho e o estudo ser baixa em praticamente todas as unidades, existe uma variação significativa entre as unidades que formam o polo profissional tradicional, que em geral recebem menos de $10 \%$ de alunos que trabalham, e as unidades do polo acadêmico-científico, como no caso da Faculdade de Filosofia, Letras e Ciências Humanas, do Instituto de Matemática e Estatística, do Instituto de Física e da Faculdade de Educação, todas unidades sediadas em São Paulo e que recebem quase $50 \%$ de estudantes que exercem atividade remunerada antes de ingressar na universidade.

Os dados sobre escolaridade e atividade profissional dos ingressantes indicam, como já foi dito, que os estudantes da USP, sobretudo os que enxergam na universidade um espaço de formação profissional, apresentam uma trajetória fortemente homogênea, que pressupõe a frequência ao ensino privado, de tipo "comum", no período diurno e com dedicação exclusiva aos estudos. Essa trajetória pressupõe o suporte material direto das suas famílias que assumem o projeto de "passar na USP" como um objetivo essencialmente familiar. Nesse sentido, para analisar o perfil diferenciado das famílias dos ingressantes nas diferentes unidades da USP, é preciso olhar para indicadores tais como escolaridade do pai e da mãe, situação profissional do pai e da mãe e renda familiar. A tabela de escolaridade da mãe já foi apresentada e não será reinserida aqui. A situação profissional dos pais é apresentada de dois modos distintos, primeiro, as unidades são hierarquizadas segundo o percentual de ingressantes cujo pai ou mãe é "proprietário de empresa de médio e grande porte" e, a seguir, as mesmas unidades são hierarquizadas segundo o percentual de alunos aprovados que são filhos de "profissionais liberais". Por fim, as unidades são hierarquizadas segundo a renda familiar, o que constitui um indicador de elitização por excelência. 


\begin{tabular}{|c|c|c|c|c|c|c|c|c|}
\hline \multicolumn{9}{|c|}{$\begin{array}{l}\text { Questão "Qual o grau de instrução mais alto que seu pai obteve?" } \\
\text { Tabela 22. Unidades hierarquizadas segundo o percentual de ingressantes com pai que realizou pós-graduação }\end{array}$} \\
\hline Unidades & $\begin{array}{l}\text { Não } \\
\text { frequentou } \\
\text { a escola }\end{array}$ & $\begin{array}{l}\text { Ensino } \\
\text { fundam. } \\
\text { incompleto }\end{array}$ & $\begin{array}{l}\text { Ensino } \\
\text { fundam. } \\
\text { completo }\end{array}$ & $\begin{array}{c}\text { Ensino } \\
\text { médio } \\
\text { incompleto }\end{array}$ & $\begin{array}{l}\text { Ensino } \\
\text { médio } \\
\text { completo }\end{array}$ & $\begin{array}{c}\text { Ensino } \\
\text { superior } \\
\text { incompleto }\end{array}$ & $\begin{array}{c}\text { Ens. } \\
\text { Superior } \\
\text { completo } \\
\downarrow\end{array}$ & $\begin{array}{l}\text { Dos quais, } \\
\text { com pós- } \\
\text { graduação }\end{array}$ \\
\hline Escola Politécnica & $0,1 \%$ & $2,8 \%$ & $0,9 \%$ & $2,0 \%$ & $10,1 \%$ & $9,3 \%$ & $74,7 \%$ & $15,8 \%$ \\
\hline Faculdade de Direito & $0,2 \%$ & $5,0 \%$ & $1,5 \%$ & $1,7 \%$ & $10,0 \%$ & $8,5 \%$ & $73,0 \%$ & $13,7 \%$ \\
\hline Instituto de Oceanografia & $0,0 \%$ & $5,1 \%$ & $0,0 \%$ & $2,6 \%$ & $12,8 \%$ & $7,7 \%$ & $71,8 \%$ & $2,6 \%$ \\
\hline Instituto de Relações Internacionais & $0,0 \%$ & $5,0 \%$ & $1,7 \%$ & $1,7 \%$ & $11,7 \%$ & $8,3 \%$ & $71,7 \%$ & $21,7 \%$ \\
\hline Instituto de Psicologia & $0,0 \%$ & $7,1 \%$ & $1,4 \%$ & $2,9 \%$ & $14,3 \%$ & $2,9 \%$ & $71,4 \%$ & $14,3 \%$ \\
\hline Faculdade de Arquitetura e Urbanismo & $0,0 \%$ & $4,2 \%$ & $1,1 \%$ & $1,6 \%$ & $15,8 \%$ & $7,4 \%$ & $70,0 \%$ & $14,2 \%$ \\
\hline Faculdade de Direito de Ribeirão Preto & $0,0 \%$ & $4,2 \%$ & $2,1 \%$ & $2,1 \%$ & $12,5 \%$ & $9,4 \%$ & $69,8 \%$ & $21,9 \%$ \\
\hline Faculdade de Economia, Administração e Contabilidade & $0,2 \%$ & $6,2 \%$ & $3,6 \%$ & $2,1 \%$ & $11,5 \%$ & $10,4 \%$ & $66,2 \%$ & $12,3 \%$ \\
\hline Escola de Engenharia de São Carlos & $0,2 \%$ & $5,8 \%$ & $2,1 \%$ & $3,8 \%$ & $17,7 \%$ & $6,5 \%$ & $64,0 \%$ & $11,9 \%$ \\
\hline Instituto de Biociências & $0,0 \%$ & $3,4 \%$ & $3,4 \%$ & $2,5 \%$ & $18,5 \%$ & $9,2 \%$ & $63,0 \%$ & $8,4 \%$ \\
\hline Instituto de Arquitetura e Urbanismo de São Carlos & $0,0 \%$ & $8,9 \%$ & $4,4 \%$ & $8,9 \%$ & $11,1 \%$ & $4,4 \%$ & $62,2 \%$ & $13,3 \%$ \\
\hline Escola de Educação Física e Esportes & $0,0 \%$ & $5,0 \%$ & $1,0 \%$ & $8,0 \%$ & $14,0 \%$ & $11,0 \%$ & $61,0 \%$ & $9,0 \%$ \\
\hline Faculdade de Medicina & $0,4 \%$ & $5,6 \%$ & $1,6 \%$ & $2,4 \%$ & $16,1 \%$ & $13,3 \%$ & $60,6 \%$ & $13,3 \%$ \\
\hline Faculdade de Odontologia de Ribeirão Preto & $0,0 \%$ & $2,6 \%$ & $2,6 \%$ & $2,6 \%$ & $27,6 \%$ & $6,6 \%$ & $57,9 \%$ & $3,9 \%$ \\
\hline Faculdade de Odontologia & $1,5 \%$ & $9,8 \%$ & $3,0 \%$ & $2,3 \%$ & $18,8 \%$ & $9,0 \%$ & $55,6 \%$ & $6,8 \%$ \\
\hline Faculdade de Ciências Farmacêuticas & $0,7 \%$ & $9,5 \%$ & $3,4 \%$ & $3,4 \%$ & $14,2 \%$ & $13,5 \%$ & $55,4 \%$ & $10,1 \%$ \\
\hline Escola de Comunicação e Artes & $0,3 \%$ & $10,2 \%$ & $5,1 \%$ & $2,0 \%$ & $16,5 \%$ & $10,9 \%$ & $55,0 \%$ & $10,9 \%$ \\
\hline Escola de Engenharia de Lorena & $0,3 \%$ & $6,0 \%$ & $2,6 \%$ & $4,8 \%$ & $23,9 \%$ & $8,0 \%$ & $54,4 \%$ & $6,0 \%$ \\
\hline Faculdade de Economia, Administração e Cont. de Ribeirão & $0,0 \%$ & $7,7 \%$ & $1,9 \%$ & $3,8 \%$ & $21,1 \%$ & $11,1 \%$ & $54,4 \%$ & $9,6 \%$ \\
\hline Faculdade de Medicina Veterinária e Zootecnia & $0,0 \%$ & $5,0 \%$ & $5,0 \%$ & $6,3 \%$ & $13,8 \%$ & $16,3 \%$ & $53,8 \%$ & $7,5 \%$ \\
\hline Faculdade de Ciências Farmacêuticas de Ribeirão Preto & $0,0 \%$ & $7,8 \%$ & $1,3 \%$ & $2,6 \%$ & $24,7 \%$ & $10,4 \%$ & $53,2 \%$ & $7,8 \%$ \\
\hline Universidade de São Paulo (total geral) & $0,6 \%$ & $10,1 \%$ & $3,7 \%$ & $3,9 \%$ & $19,8 \%$ & $9,5 \%$ & $52,5 \%$ & $8,9 \%$ \\
\hline Faculdade de Medicina de Ribeirão Preto & $0,5 \%$ & $8,2 \%$ & $1,4 \%$ & $5,5 \%$ & $23,7 \%$ & $10,5 \%$ & $50,2 \%$ & $5,5 \%$ \\
\hline Instituto de Química & $1,7 \%$ & $15,3 \%$ & $3,4 \%$ & $1,7 \%$ & $21,2 \%$ & $6,8 \%$ & $50,0 \%$ & $10,2 \%$ \\
\hline Instituto de Ciências Matemáticas e Computação & $2,3 \%$ & $9,1 \%$ & $5,5 \%$ & $1,8 \%$ & $26,9 \%$ & $6,8 \%$ & $47,5 \%$ & $5,9 \%$ \\
\hline Faculdade de Zootecnia e Engenharia de Alimentos & $0,0 \%$ & $9,6 \%$ & $4,8 \%$ & $4,8 \%$ & $23,6 \%$ & $10,0 \%$ & $47,2 \%$ & $5,6 \%$ \\
\hline Escola Superior de Agricultura Luiz de Queiroz & $0,0 \%$ & $10,2 \%$ & $5,0 \%$ & $3,7 \%$ & $24,1 \%$ & $10,2 \%$ & $46,9 \%$ & $8,9 \%$ \\
\hline Instituto de Ciências Biomédicas & $0,0 \%$ & $2,6 \%$ & $7,7 \%$ & $7,7 \%$ & $23,1 \%$ & $12,8 \%$ & $46,2 \%$ & $5,1 \%$ \\
\hline Faculdade de Filosofia, Letras e Ciências Humanas & $1,5 \%$ & $14,2 \%$ & $5,4 \%$ & $4,2 \%$ & $19,7 \%$ & $9,7 \%$ & $45,3 \%$ & $8,0 \%$ \\
\hline Escola de Educação Física e Esportes de Ribeirão Preto & $0,0 \%$ & $15,5 \%$ & $3,4 \%$ & $1,7 \%$ & $24,1 \%$ & $12,1 \%$ & $43,1 \%$ & $5,2 \%$ \\
\hline Instituto de Química de São Carlos & $1,7 \%$ & $6,9 \%$ & $1,7 \%$ & $5,2 \%$ & $25,9 \%$ & $15,5 \%$ & $43,1 \%$ & $5,2 \%$ \\
\hline Instituto de Física de São Carlos & $0,6 \%$ & $13,5 \%$ & $8,6 \%$ & $3,1 \%$ & $23,9 \%$ & $7,4 \%$ & $42,9 \%$ & $6,7 \%$ \\
\hline Escola de Artes, Ciências e Humanidades & $0,7 \%$ & $15,0 \%$ & $3,9 \%$ & $6,3 \%$ & $24,1 \%$ & $7,9 \%$ & $42,1 \%$ & $4,1 \%$ \\
\hline Faculdade de Educação & $0,6 \%$ & $14,7 \%$ & $2,8 \%$ & $5,6 \%$ & $25,4 \%$ & $9,6 \%$ & $41,2 \%$ & $6,8 \%$ \\
\hline Instituto de Matemática de Estatística & $0,3 \%$ & $16,9 \%$ & $5,0 \%$ & $5,6 \%$ & $22,0 \%$ & $9,8 \%$ & $40,4 \%$ & $6,2 \%$ \\
\hline Faculdade de Odontologia de Bauru & $0,0 \%$ & $10,6 \%$ & $4,7 \%$ & $4,7 \%$ & $32,9 \%$ & $7,1 \%$ & $40,0 \%$ & $9,4 \%$ \\
\hline Instituto de Astronomia, Geofísica e Ciências Atmosféricas & $0,0 \%$ & $8,0 \%$ & $10,7 \%$ & $8,0 \%$ & $24,0 \%$ & $9,3 \%$ & $40,0 \%$ & $5,3 \%$ \\
\hline Instituto de Geociências & $0,0 \%$ & $14,6 \%$ & $2,2 \%$ & $5,6 \%$ & $24,7 \%$ & $13,5 \%$ & $39,3 \%$ & $7,9 \%$ \\
\hline Faculdade de Filosofia, Ciências e Letras de Ribeirão Preto & $0,5 \%$ & $12,5 \%$ & $4,6 \%$ & $5,3 \%$ & $29,3 \%$ & $10,1 \%$ & $37,9 \%$ & $3,4 \%$ \\
\hline Faculdade de Saúde Pública & $2,5 \%$ & $15,1 \%$ & $3,4 \%$ & $1,7 \%$ & $22,7 \%$ & $16,8 \%$ & $37,8 \%$ & $5,9 \%$ \\
\hline Escola de Enfermagem & $0,0 \%$ & $13,9 \%$ & $2,5 \%$ & $6,3 \%$ & $34,2 \%$ & $10,1 \%$ & $32,9 \%$ & $1,3 \%$ \\
\hline Instituto de Física & $0,0 \%$ & $20,1 \%$ & $7,1 \%$ & $4,9 \%$ & $25,4 \%$ & $10,4 \%$ & $32,1 \%$ & $6,0 \%$ \\
\hline Escola de Enfermagem de Ribeirão Preto & $1,6 \%$ & $17,8 \%$ & $8,5 \%$ & $4,7 \%$ & $32,6 \%$ & $7,8 \%$ & $27,1 \%$ & $4,7 \%$ \\
\hline
\end{tabular}

Fonte: Questionário Socioeconômico da Fuvest

Elaboração: própria 


\begin{tabular}{|c|c|c|c|c|c|c|c|c|c|}
\hline Tabela 23. Unidades hierarquizad & $\begin{array}{r}\text { Question } \\
\text { Questão "Qual } \\
\text { las segundo o } \mathrm{p}\end{array}$ & $\begin{array}{l}\text { nário socioecon } \\
\text { lé a situação pr } \\
\text { percentual de i }\end{array}$ & $\begin{array}{l}\text { ômico da } \\
\text { rofissional } \\
\text { ngressant }\end{array}$ & $\begin{array}{l}\text { Fuvest (2012) } \\
\text { atual de seu po } \\
\text { es com pai pro }\end{array}$ & ai?" & rande ou $\mathrm{m}$ & édia empresa & & \\
\hline Unidades & $\begin{array}{l}\text { Proprietário } \\
\text { de empresa } \\
\text { grande ou } \\
\text { média }\end{array}$ & $\begin{array}{c}\text { Proprietário } \\
\text { de micro ou } \\
\text { pequena } \\
\text { empresa }\end{array}$ & $\begin{array}{c}\text { Func. } \\
\text { público }\end{array}$ & $\begin{array}{c}\text { Profissional } \\
\text { Liberal }\end{array}$ & $\begin{array}{l}\text { Func. } \\
\text { empresa } \\
\text { privada ou } \\
\text { estatal }\end{array}$ & Rentista & Aposentado & $\begin{array}{l}\text { Não exerce } \\
\text { atividade } \\
\text { remunerada }\end{array}$ & Outras \\
\hline Escola Superior de Agricultura Luiz de Queiroz & $5,2 \%$ & $21,5 \%$ & $7,6 \%$ & $18,3 \%$ & $30,1 \%$ & $0,5 \%$ & $7,3 \%$ & $1,0 \%$ & $8,4 \%$ \\
\hline Instituto de Oceanografia & $5,1 \%$ & $12,8 \%$ & $20,5 \%$ & $12,8 \%$ & $25,6 \%$ & $0,0 \%$ & $10,3 \%$ & $0,0 \%$ & $12,8 \%$ \\
\hline Instituto de Relações Internacionais & $5,0 \%$ & $13,3 \%$ & $10,0 \%$ & $18,3 \%$ & $36,7 \%$ & $0,0 \%$ & $5,0 \%$ & $0,0 \%$ & $11,7 \%$ \\
\hline Faculdade de Economia, Administração e Contabilidade & $3,4 \%$ & $18,8 \%$ & $7,4 \%$ & $19,8 \%$ & $28,5 \%$ & $0,5 \%$ & $10,4 \%$ & $4,4 \%$ & $6,7 \%$ \\
\hline Faculdade de Arquitetura e Urbanismo & $3,2 \%$ & $16,8 \%$ & $13,7 \%$ & $21,6 \%$ & $30,0 \%$ & $1,1 \%$ & $3,7 \%$ & $2,6 \%$ & $7,4 \%$ \\
\hline Faculdade de Direito de Ribeirão Preto & $3,1 \%$ & $10,4 \%$ & $19,8 \%$ & $28,1 \%$ & $22,9 \%$ & $0,0 \%$ & $6,3 \%$ & $2,1 \%$ & $7,3 \%$ \\
\hline Faculdade de Economia, Administração e Contabilidade de RP & $2,7 \%$ & $22,2 \%$ & $10,7 \%$ & $18,0 \%$ & $27,2 \%$ & $0,8 \%$ & $9,2 \%$ & $2,7 \%$ & $6,5 \%$ \\
\hline Instituto de Astronomia, Geofísica e Ciências Atmosféricas & $2,7 \%$ & $12,0 \%$ & $2,7 \%$ & $25,3 \%$ & $29,3 \%$ & $0,0 \%$ & $13,3 \%$ & $6,7 \%$ & $8,0 \%$ \\
\hline Faculdade de Direito & $2,6 \%$ & $15,2 \%$ & $14,8 \%$ & $23,7 \%$ & $24,1 \%$ & $0,9 \%$ & $7,6 \%$ & $3,3 \%$ & $7,8 \%$ \\
\hline Faculdade de Ciências Farmacêuticas de Ribeirão Preto & $2,6 \%$ & $20,8 \%$ & $10,4 \%$ & $18,2 \%$ & $29,9 \%$ & $0,0 \%$ & $10,4 \%$ & $2,6 \%$ & $5,2 \%$ \\
\hline Escola Politécnica & $2,6 \%$ & $19,8 \%$ & $10,8 \%$ & $19,0 \%$ & $34,1 \%$ & $1,8 \%$ & $5,0 \%$ & $1,9 \%$ & $5,1 \%$ \\
\hline Escola de Engenharia de São Carlos & $2,3 \%$ & $19,4 \%$ & $15,4 \%$ & $17,3 \%$ & $31,3 \%$ & $0,4 \%$ & $6,7 \%$ & $1,9 \%$ & $5,4 \%$ \\
\hline Faculdade de Medicina de Ribeirão Preto & $2,3 \%$ & $14,6 \%$ & $13,7 \%$ & $26,9 \%$ & $29,2 \%$ & $0,0 \%$ & $8,7 \%$ & $1,8 \%$ & $2,7 \%$ \\
\hline Faculdade de Odontologia & $2,3 \%$ & $16,5 \%$ & $5,3 \%$ & $21,8 \%$ & $27,1 \%$ & $0,8 \%$ & $13,5 \%$ & $4,5 \%$ & $8,3 \%$ \\
\hline Instituto de Ciências Matemáticas e Computação & $1,8 \%$ & $14,2 \%$ & $15,5 \%$ & $15,5 \%$ & $27,4 \%$ & $0,0 \%$ & $12,3 \%$ & $2,3 \%$ & $11,0 \%$ \\
\hline Instituto de Matemática de Estatística & $1,8 \%$ & $8,0 \%$ & $11,6 \%$ & $16,6 \%$ & $28,2 \%$ & $0,9 \%$ & $14,5 \%$ & $6,2 \%$ & $12,2 \%$ \\
\hline Universidade de São Paulo (geral) & $1,7 \%$ & $15,1 \%$ & $10,7 \%$ & $19,1 \%$ & $29,6 \%$ & $0,6 \%$ & $9,9 \%$ & $3,8 \%$ & $9,4 \%$ \\
\hline Escola de Educação Física e Esportes de Ribeirão Preto & $1,7 \%$ & $12,1 \%$ & $15,5 \%$ & $20,7 \%$ & $20,7 \%$ & $0,0 \%$ & $8,6 \%$ & $10,3 \%$ & $10,3 \%$ \\
\hline Instituto de Biociências & $1,7 \%$ & $16,8 \%$ & $9,2 \%$ & $20,2 \%$ & $33,6 \%$ & $0,8 \%$ & $2,5 \%$ & $4,2 \%$ & $10,9 \%$ \\
\hline Faculdade de Zootecnia e Engenharia de Alimentos & $1,6 \%$ & $16,8 \%$ & $12,0 \%$ & $18,0 \%$ & $33,2 \%$ & $0,4 \%$ & $8,4 \%$ & $2,8 \%$ & $6,8 \%$ \\
\hline Instituto de Psicologia & $1,4 \%$ & $12,9 \%$ & $8,6 \%$ & $27,1 \%$ & $31,4 \%$ & $0,0 \%$ & $8,6 \%$ & $2,9 \%$ & $7,1 \%$ \\
\hline Faculdade de Odontologia de Ribeirão Preto & $1,3 \%$ & $18,4 \%$ & $11,8 \%$ & $31,6 \%$ & $27,6 \%$ & $0,0 \%$ & $3,9 \%$ & $0,0 \%$ & $5,3 \%$ \\
\hline Faculdade de Medicina Veterinária e Zootecnia & $1,3 \%$ & $15,0 \%$ & $7,5 \%$ & $22,5 \%$ & $32,5 \%$ & $0,0 \%$ & $7,5 \%$ & $5,0 \%$ & $8,8 \%$ \\
\hline Instituto de Física de São Carlos & $1,2 \%$ & $8,6 \%$ & $15,3 \%$ & $11,0 \%$ & $33,7 \%$ & $0,0 \%$ & $11,7 \%$ & $5,5 \%$ & $12,9 \%$ \\
\hline Faculdade de Filosofia, Ciências e Letras de Ribeirão Preto & $1,2 \%$ & $14,6 \%$ & $11,3 \%$ & $20,9 \%$ & $30,7 \%$ & $0,5 \%$ & $9,1 \%$ & $3,6 \%$ & $8,2 \%$ \\
\hline Faculdade de Odontologia de Bauru & $1,2 \%$ & $22,4 \%$ & $14,1 \%$ & $27,1 \%$ & $14,1 \%$ & $0,0 \%$ & $8,2 \%$ & $2,4 \%$ & $10,6 \%$ \\
\hline Escola de Engenharia de Lorena & $1,1 \%$ & $15,7 \%$ & $14,8 \%$ & $17,1 \%$ & $33,3 \%$ & $0,6 \%$ & $7,7 \%$ & $2,8 \%$ & $6,8 \%$ \\
\hline Instituto de Geociências & $1,1 \%$ & $12,4 \%$ & $12,4 \%$ & $21,3 \%$ & $22,5 \%$ & $0,0 \%$ & $14,6 \%$ & $7,9 \%$ & $7,9 \%$ \\
\hline Escola de Comunicação e Artes & $1,0 \%$ & $15,0 \%$ & $11,5 \%$ & $18,1 \%$ & $28,0 \%$ & $0,8 \%$ & $9,9 \%$ & $5,1 \%$ & $10,7 \%$ \\
\hline Escola de Educação Física e Esportes & $1,0 \%$ & $16,0 \%$ & $7,0 \%$ & $15,0 \%$ & $40,0 \%$ & $0,0 \%$ & $7,0 \%$ & $6,0 \%$ & $8,0 \%$ \\
\hline Faculdade de Filosofia, Letras e Ciências Humanas & $1,0 \%$ & $12,4 \%$ & $8,9 \%$ & $18,0 \%$ & $27,2 \%$ & $0,6 \%$ & $14,3 \%$ & $4,6 \%$ & $13,1 \%$ \\
\hline Faculdade de Saúde Pública & $0,8 \%$ & $12,6 \%$ & $6,7 \%$ & $17,6 \%$ & $26,1 \%$ & $0,0 \%$ & $14,3 \%$ & $6,7 \%$ & $15,1 \%$ \\
\hline Faculdade de Medicina & $0,8 \%$ & $12,9 \%$ & $10,0 \%$ & $25,7 \%$ & $30,9 \%$ & $1,6 \%$ & $9,2 \%$ & $4,0 \%$ & $4,8 \%$ \\
\hline Instituto de Física & $0,7 \%$ & $8,6 \%$ & $9,0 \%$ & $13,8 \%$ & $31,0 \%$ & $0,4 \%$ & $16,4 \%$ & $3,4 \%$ & $16,8 \%$ \\
\hline Faculdade de Ciências Farmacêuticas & $0,7 \%$ & $20,3 \%$ & $10,1 \%$ & $19,6 \%$ & $33,1 \%$ & $0,0 \%$ & $8,8 \%$ & $3,4 \%$ & $4,1 \%$ \\
\hline Escola de Artes, Ciências e Humanidades & $0,6 \%$ & $12,8 \%$ & $8,8 \%$ & $18,7 \%$ & $31,7 \%$ & $0,0 \%$ & $10,4 \%$ & $5,6 \%$ & $11,4 \%$ \\
\hline Faculdade de Educação & $0,6 \%$ & $15,3 \%$ & $7,9 \%$ & $16,4 \%$ & $23,2 \%$ & $1,1 \%$ & $15,3 \%$ & $2,8 \%$ & $17,5 \%$ \\
\hline Escola de Enfermagem & $0,0 \%$ & $20,3 \%$ & $7,6 \%$ & $13,9 \%$ & $32,9 \%$ & $0,0 \%$ & $8,9 \%$ & $3,8 \%$ & $12,7 \%$ \\
\hline Escola de Enfermagem de Ribeirão Preto & $0,0 \%$ & $12,4 \%$ & $16,3 \%$ & $13,2 \%$ & $32,6 \%$ & $0,0 \%$ & $7,8 \%$ & $5,4 \%$ & $12,4 \%$ \\
\hline Instituto de Arquitetura e Urbanismo de São Carlos & $0,0 \%$ & $33,3 \%$ & $8,9 \%$ & $15,6 \%$ & $28,9 \%$ & $0,0 \%$ & $4,4 \%$ & $2,2 \%$ & $6,7 \%$ \\
\hline Instituto de Ciências Biomédicas & $0,0 \%$ & $17,9 \%$ & $10,3 \%$ & $25,6 \%$ & $38,5 \%$ & $0,0 \%$ & $0,0 \%$ & $2,6 \%$ & $5,1 \%$ \\
\hline Instituto de Química & $0,0 \%$ & $9,3 \%$ & $9,3 \%$ & $12,7 \%$ & $35,6 \%$ & $0,8 \%$ & $9,3 \%$ & $7,6 \%$ & $15,3 \%$ \\
\hline Instituto de Química de São Carlos & $0,0 \%$ & $12,1 \%$ & $12,1 \%$ & $24,1 \%$ & $22,4 \%$ & $0,0 \%$ & $10,3 \%$ & $3,4 \%$ & $15,5 \%$ \\
\hline
\end{tabular}

Fonte: Questionário Socioeconômico da Fuvest

Elaboração: própria 


\begin{tabular}{|c|c|c|c|c|c|c|c|c|c|}
\hline \multicolumn{10}{|c|}{$\begin{array}{l}\text { Questionário socioeconômico da Fuvest (2012) } \\
\text { Questão "Qual é a situação profissional atual de seu pai?" } \\
\text { s hierarquizadas segundo o percentual de ingressantes com pai profissional liberal }\end{array}$} \\
\hline Unidades & $\begin{array}{c}\text { Proprietário } \\
\text { de empresa } \\
\text { grande ou } \\
\text { média }\end{array}$ & $\begin{array}{c}\text { Proprietário } \\
\text { de micro ou } \\
\text { pequena } \\
\text { empresa }\end{array}$ & $\begin{array}{c}\text { Func. } \\
\text { público }\end{array}$ & $\begin{array}{l}\text { Profissional } \\
\text { Liberal } \\
\downarrow\end{array}$ & $\begin{array}{c}\text { Func. } \\
\text { empresa } \\
\text { privada ou } \\
\text { estatal } \\
\end{array}$ & Rentista & Aposentado & $\begin{array}{l}\text { Não exerce } \\
\text { atividade } \\
\text { remunerada }\end{array}$ & Outras \\
\hline Faculdade de Odontologia de Ribeirão Preto & $1,3 \%$ & $18,4 \%$ & $11,8 \%$ & $31,6 \%$ & $27,6 \%$ & $0,0 \%$ & $3,9 \%$ & $0,0 \%$ & $5,3 \%$ \\
\hline Faculdade de Direito de Ribeirão Preto & $3,1 \%$ & $10,4 \%$ & $19,8 \%$ & $28,1 \%$ & $22,9 \%$ & $0,0 \%$ & $6,3 \%$ & $2,1 \%$ & $7,3 \%$ \\
\hline Instituto de Psicologia & $1,4 \%$ & $12,9 \%$ & $8,6 \%$ & $27,1 \%$ & $31,4 \%$ & $0,0 \%$ & $8,6 \%$ & $2,9 \%$ & $7,1 \%$ \\
\hline Faculdade de Odontologia de Bauru & $1,2 \%$ & $22,4 \%$ & $14,1 \%$ & $27,1 \%$ & $14,1 \%$ & $0,0 \%$ & $8,2 \%$ & $2,4 \%$ & $10,6 \%$ \\
\hline Faculdade de Medicina de Ribeirão Preto & $2,3 \%$ & $14,6 \%$ & $13,7 \%$ & $26,9 \%$ & $29,2 \%$ & $0,0 \%$ & $8,7 \%$ & $1,8 \%$ & $2,7 \%$ \\
\hline Faculdade de Medicina & $0,8 \%$ & $12,9 \%$ & $10,0 \%$ & $25,7 \%$ & $30,9 \%$ & $1,6 \%$ & $9,2 \%$ & $4,0 \%$ & $4,8 \%$ \\
\hline Instituto de Ciências Biomédicas & $0,0 \%$ & $17,9 \%$ & $10,3 \%$ & $25,6 \%$ & $38,5 \%$ & $0,0 \%$ & $0,0 \%$ & $2,6 \%$ & $5,1 \%$ \\
\hline Instituto de Astronomia, Geofísica e Ciências Atmosférica: & $2,7 \%$ & $12,0 \%$ & $2,7 \%$ & $25,3 \%$ & $29,3 \%$ & $0,0 \%$ & $13,3 \%$ & $6,7 \%$ & $8,0 \%$ \\
\hline Instituto de Química de São Carlos & $0,0 \%$ & $12,1 \%$ & $12,1 \%$ & $24,1 \%$ & $22,4 \%$ & $0,0 \%$ & $10,3 \%$ & $3,4 \%$ & $15,5 \%$ \\
\hline Faculdade de Direito & $2,6 \%$ & $15,2 \%$ & $14,8 \%$ & $23,7 \%$ & $24,1 \%$ & $0,9 \%$ & $7,6 \%$ & $3,3 \%$ & $7,8 \%$ \\
\hline Faculdade de Medicina Veterinária e Zootecnia & $1,3 \%$ & $15,0 \%$ & $7,5 \%$ & $22,5 \%$ & $32,5 \%$ & $0,0 \%$ & $7,5 \%$ & $5,0 \%$ & $8,8 \%$ \\
\hline Faculdade de Odontologia & $2,3 \%$ & $16,5 \%$ & $5,3 \%$ & $21,8 \%$ & $27,1 \%$ & $0,8 \%$ & $13,5 \%$ & $4,5 \%$ & $8,3 \%$ \\
\hline Faculdade de Arquitetura e Urbanismo & $3,2 \%$ & $16,8 \%$ & $13,7 \%$ & $21,6 \%$ & $30,0 \%$ & $1,1 \%$ & $3,7 \%$ & $2,6 \%$ & $7,4 \%$ \\
\hline Instituto de Geociências & $1,1 \%$ & $12,4 \%$ & $12,4 \%$ & $21,3 \%$ & $22,5 \%$ & $0,0 \%$ & $14,6 \%$ & $7,9 \%$ & $7,9 \%$ \\
\hline Faculdade de Filosofia, Ciências e Letras de Ribeirão & $1,2 \%$ & $14,6 \%$ & $11,3 \%$ & $20,9 \%$ & $30,7 \%$ & $0,5 \%$ & $9,1 \%$ & $3,6 \%$ & $8,2 \%$ \\
\hline Escola de Educação Física e Esportes de Ribeirão Preto & $1,7 \%$ & $12,1 \%$ & $15,5 \%$ & $20,7 \%$ & $20,7 \%$ & $0,0 \%$ & $8,6 \%$ & $10,3 \%$ & $10,3 \%$ \\
\hline Instituto de Biociências & $1,7 \%$ & $16,8 \%$ & $9,2 \%$ & $20,2 \%$ & $33,6 \%$ & $0,8 \%$ & $2,5 \%$ & $4,2 \%$ & $10,9 \%$ \\
\hline Faculdade de Economia, Administração e Contabilidade & $3,4 \%$ & $18,8 \%$ & $7,4 \%$ & $19,8 \%$ & $28,5 \%$ & $0,5 \%$ & $10,4 \%$ & $4,4 \%$ & $6,7 \%$ \\
\hline Faculdade de Ciências Farmacêuticas & $0,7 \%$ & $20,3 \%$ & $10,1 \%$ & $19,6 \%$ & $33,1 \%$ & $0,0 \%$ & $8,8 \%$ & $3,4 \%$ & $4,1 \%$ \\
\hline Universidade de São Paulo (total geral) & $1,7 \%$ & $15,1 \%$ & $10,7 \%$ & $19,1 \%$ & $29,6 \%$ & $0,6 \%$ & $9,9 \%$ & $3,8 \%$ & $9,4 \%$ \\
\hline Escola Politécnica & $2,6 \%$ & $19,8 \%$ & $10,8 \%$ & $19,0 \%$ & $34,1 \%$ & $1,8 \%$ & $5,0 \%$ & $1,9 \%$ & $5,1 \%$ \\
\hline Escola de Artes, Ciências e Humanidades & $0,6 \%$ & $12,8 \%$ & $8,8 \%$ & $18,7 \%$ & $31,7 \%$ & $0,0 \%$ & $10,4 \%$ & $5,6 \%$ & $11,4 \%$ \\
\hline Instituto de Relações Internacionais & $5,0 \%$ & $13,3 \%$ & $10,0 \%$ & $18,3 \%$ & $36,7 \%$ & $0,0 \%$ & $5,0 \%$ & $0,0 \%$ & $11,7 \%$ \\
\hline Escola Superior de Agricultura Luiz de Queiroz & $5,2 \%$ & $21,5 \%$ & $7,6 \%$ & $18,3 \%$ & $30,1 \%$ & $0,5 \%$ & $7,3 \%$ & $1,0 \%$ & $8,4 \%$ \\
\hline Faculdade de Ciências Farmacêuticas de Ribeirão Preto & $2,6 \%$ & $20,8 \%$ & $10,4 \%$ & $18,2 \%$ & $29,9 \%$ & $0,0 \%$ & $10,4 \%$ & $2,6 \%$ & $5,2 \%$ \\
\hline Escola de Comunicação e Artes & $1,0 \%$ & $15,0 \%$ & $11,5 \%$ & $18,1 \%$ & $28,0 \%$ & $0,8 \%$ & $9,9 \%$ & $5,1 \%$ & $10,7 \%$ \\
\hline Faculdade de Filosofia, Letras e Ciências Humanas & $1,0 \%$ & $12,4 \%$ & $8,9 \%$ & $18,0 \%$ & $27,2 \%$ & $0,6 \%$ & $14,3 \%$ & $4,6 \%$ & $13,1 \%$ \\
\hline Faculdade de Economia, Administração e Cont. de RP & $2,7 \%$ & $22,2 \%$ & $10,7 \%$ & $18,0 \%$ & $27,2 \%$ & $0,8 \%$ & $9,2 \%$ & $2,7 \%$ & $6,5 \%$ \\
\hline Faculdade de Zootecnia e Engenharia de Alimentos & $1,6 \%$ & $16,8 \%$ & $12,0 \%$ & $18,0 \%$ & $33,2 \%$ & $0,4 \%$ & $8,4 \%$ & $2,8 \%$ & $6,8 \%$ \\
\hline Faculdade de Saúde Pública & $0,8 \%$ & $12,6 \%$ & $6,7 \%$ & $17,6 \%$ & $26,1 \%$ & $0,0 \%$ & $14,3 \%$ & $6,7 \%$ & $15,1 \%$ \\
\hline Escola de Engenharia de São Carlos & $2,3 \%$ & $19,4 \%$ & $15,4 \%$ & $17,3 \%$ & $31,3 \%$ & $0,4 \%$ & $6,7 \%$ & $1,9 \%$ & $5,4 \%$ \\
\hline Escola de Engenharia de Lorena & $1,1 \%$ & $15,7 \%$ & $14,8 \%$ & $17,1 \%$ & $33,3 \%$ & $0,6 \%$ & $7,7 \%$ & $2,8 \%$ & $6,8 \%$ \\
\hline Instituto de Matemática de Estatística & $1,8 \%$ & $8,0 \%$ & $11,6 \%$ & $16,6 \%$ & $28,2 \%$ & $0,9 \%$ & $14,5 \%$ & $6,2 \%$ & $12,2 \%$ \\
\hline Faculdade de Educação & $0,6 \%$ & $15,3 \%$ & $7,9 \%$ & $16,4 \%$ & $23,2 \%$ & $1,1 \%$ & $15,3 \%$ & $2,8 \%$ & $17,5 \%$ \\
\hline Instituto de Arquitetura e Urbanismo de São Carlos & $0,0 \%$ & $33,3 \%$ & $8,9 \%$ & $15,6 \%$ & $28,9 \%$ & $0,0 \%$ & $4,4 \%$ & $2,2 \%$ & $6,7 \%$ \\
\hline Instituto de Ciências Matemáticas e Computação & $1,8 \%$ & $14,2 \%$ & $15,5 \%$ & $15,5 \%$ & $27,4 \%$ & $0,0 \%$ & $12,3 \%$ & $2,3 \%$ & $11,0 \%$ \\
\hline Escola de Educação Física e Esportes & $1,0 \%$ & $16,0 \%$ & $7,0 \%$ & $15,0 \%$ & $40,0 \%$ & $0,0 \%$ & $7,0 \%$ & $6,0 \%$ & $8,0 \%$ \\
\hline Escola de Enfermagem & $0,0 \%$ & $20,3 \%$ & $7,6 \%$ & $13,9 \%$ & $32,9 \%$ & $0,0 \%$ & $8,9 \%$ & $3,8 \%$ & $12,7 \%$ \\
\hline Instituto de Física & $0,7 \%$ & $8,6 \%$ & $9,0 \%$ & $13,8 \%$ & $31,0 \%$ & $0,4 \%$ & $16,4 \%$ & $3,4 \%$ & $16,8 \%$ \\
\hline Escola de Enfermagem de Ribeirão Preto & $0,0 \%$ & $12,4 \%$ & $16,3 \%$ & $13,2 \%$ & $32,6 \%$ & $0,0 \%$ & $7,8 \%$ & $5,4 \%$ & $12,4 \%$ \\
\hline Instituto de Oceanografia & $5,1 \%$ & $12,8 \%$ & $20,5 \%$ & $12,8 \%$ & $25,6 \%$ & $0,0 \%$ & $10,3 \%$ & $0,0 \%$ & $12,8 \%$ \\
\hline Instituto de Química & $0,0 \%$ & $9,3 \%$ & $9,3 \%$ & $12,7 \%$ & $35,6 \%$ & $0,8 \%$ & $9,3 \%$ & $7,6 \%$ & $15,3 \%$ \\
\hline Instituto de Física de São Carlos & $1,2 \%$ & $8,6 \%$ & $15,3 \%$ & $11,0 \%$ & $33,7 \%$ & $0,0 \%$ & $11,7 \%$ & $5,5 \%$ & $12,9 \%$ \\
\hline
\end{tabular}

Fonte: Questionário Socioeconômico da Fuvest

Elaboração: própria 


\begin{tabular}{|c|c|c|c|c|c|c|c|c|c|}
\hline \multicolumn{10}{|c|}{$\begin{array}{l}\text { Questionário socioeconômico da Fuvest (2012) } \\
\text { tão "Qual é a situação profissional atual da sua mã }\end{array}$} \\
\hline Unidades & $\begin{array}{c}\text { Proprietária } \\
\text { de empresa } \\
\text { grande ou } \\
\text { média }\end{array}$ & $\begin{array}{c}\text { Proprietária } \\
\text { de micro ou } \\
\text { pequena } \\
\text { empresa }\end{array}$ & $\begin{array}{l}\text { Func. } \\
\text { pública }\end{array}$ & $\begin{array}{l}\text { Profissional } \\
\text { liberal }\end{array}$ & $\begin{array}{c}\text { Func. de } \\
\text { empresa } \\
\text { privada ou } \\
\text { estatal }\end{array}$ & Rentista & Aposentada & $\begin{array}{l}\text { Não exerce } \\
\text { atividade } \\
\text { remunerada }\end{array}$ & Outras \\
\hline Instituto de Oceanografia & $5,1 \%$ & $2,6 \%$ & $25,6 \%$ & $10,3 \%$ & $17,9 \%$ & $0,0 \%$ & $10,3 \%$ & $15,4 \%$ & $12,8 \%$ \\
\hline Faculdade de Odontologia & $3,0 \%$ & $6,0 \%$ & $13,5 \%$ & $21,8 \%$ & $24,8 \%$ & $0,8 \%$ & $8,3 \%$ & $18,8 \%$ & $3,0 \%$ \\
\hline Faculdade de Direito de Ribeirão Preto & $2,1 \%$ & $6,3 \%$ & $27,1 \%$ & $15,6 \%$ & $16,7 \%$ & $5,2 \%$ & $7,3 \%$ & $18,8 \%$ & $1,0 \%$ \\
\hline Instituto de Ciências Matemáticas e Computação & $1,8 \%$ & $5,9 \%$ & $17,8 \%$ & $8,2 \%$ & $21,0 \%$ & $0,5 \%$ & $9,1 \%$ & $22,4 \%$ & $13,2 \%$ \\
\hline Escola Politécnica & $1,8 \%$ & $9,7 \%$ & $12,5 \%$ & $20,1 \%$ & $24,3 \%$ & $0,4 \%$ & $7,0 \%$ & $20,1 \%$ & $4,2 \%$ \\
\hline Escola Superior de Aagricultura Luiz de Queiroz & $1,6 \%$ & $9,9 \%$ & $17,5 \%$ & $13,1 \%$ & $20,4 \%$ & $0,5 \%$ & $5,5 \%$ & $20,9 \%$ & $10,5 \%$ \\
\hline Faculdade de Economia e Administração & $1,4 \%$ & $9,7 \%$ & $14,5 \%$ & $17,1 \%$ & $21,2 \%$ & $1,2 \%$ & $10,3 \%$ & $17,6 \%$ & $7,0 \%$ \\
\hline Instituto de Astronomia, Geofísica e Ciências Atmosféricas & $1,3 \%$ & $6,7 \%$ & $10,7 \%$ & $12,0 \%$ & $30,7 \%$ & $0,0 \%$ & $8,0 \%$ & $28,0 \%$ & $2,7 \%$ \\
\hline Faculdade de Zootecnia e Engenharia de Alimentos & $1,2 \%$ & $8,0 \%$ & $19,6 \%$ & $10,4 \%$ & $19,6 \%$ & $0,4 \%$ & $8,0 \%$ & $23,6 \%$ & $9,2 \%$ \\
\hline Instituto de Geociências & $1,1 \%$ & $2,2 \%$ & $20,2 \%$ & $7,9 \%$ & $20,2 \%$ & $2,2 \%$ & $15,7 \%$ & $23,6 \%$ & $6,7 \%$ \\
\hline Faculdade de Arquitetura e Urbanismo & $1,1 \%$ & $13,2 \%$ & $16,3 \%$ & $20,5 \%$ & $20,5 \%$ & $0,5 \%$ & $5,8 \%$ & $17,4 \%$ & $4,7 \%$ \\
\hline Escola de Engenharia de São Carlos & $1,0 \%$ & $9,2 \%$ & $23,1 \%$ & $15,4 \%$ & $20,4 \%$ & $0,2 \%$ & $5,6 \%$ & $18,5 \%$ & $6,5 \%$ \\
\hline Escola de Engenharia de Lorena & $0,9 \%$ & $10,0 \%$ & $20,2 \%$ & $15,4 \%$ & $19,9 \%$ & $0,6 \%$ & $5,4 \%$ & $19,7 \%$ & $8,0 \%$ \\
\hline Escola de Enfermagem de Ribeirão Preto & $0,8 \%$ & $7,8 \%$ & $18,6 \%$ & $6,2 \%$ & $27,9 \%$ & $0,0 \%$ & $5,4 \%$ & $19,4 \%$ & $14,0 \%$ \\
\hline Faculdade de Economia, Administração e Cont. de Ribeirão & $0,8 \%$ & $10,7 \%$ & $15,3 \%$ & $17,2 \%$ & $21,5 \%$ & $0,4 \%$ & $10,0 \%$ & $20,7 \%$ & $3,4 \%$ \\
\hline Faculdade de Ciências Farmacêuticas & $0,7 \%$ & $6,1 \%$ & $17,6 \%$ & $12,8 \%$ & $25,0 \%$ & $0,0 \%$ & $8,8 \%$ & $24,3 \%$ & $4,7 \%$ \\
\hline Universidade de São Paulo & $0,7 \%$ & $8,2 \%$ & $16,3 \%$ & $14,6 \%$ & $21,0 \%$ & $0,7 \%$ & $10,2 \%$ & $21,0 \%$ & $7,4 \%$ \\
\hline Instituto de Física de São Carlos & $0,6 \%$ & $6,7 \%$ & $21,5 \%$ & $11,0 \%$ & $21,5 \%$ & $0,6 \%$ & $8,0 \%$ & $23,9 \%$ & $6,1 \%$ \\
\hline Faculdade de Medicina & $0,4 \%$ & $9,6 \%$ & $16,5 \%$ & $19,7 \%$ & $20,9 \%$ & $0,0 \%$ & $7,2 \%$ & $20,1 \%$ & $5,6 \%$ \\
\hline Instituto de Física & $0,4 \%$ & $5,6 \%$ & $15,3 \%$ & $15,3 \%$ & $14,9 \%$ & $0,0 \%$ & $16,0 \%$ & $20,5 \%$ & $11,9 \%$ \\
\hline Faculdade de Filosofia, Letras e Ciências Humanas & $0,2 \%$ & $6,7 \%$ & $14,4 \%$ & $12,8 \%$ & $20,7 \%$ & $0,7 \%$ & $14,4 \%$ & $21,6 \%$ & $8,4 \%$ \\
\hline Faculdade de Filosofia, Ciências e Letras de Ribeirão Preto & $0,2 \%$ & $8,4 \%$ & $18,2 \%$ & $12,0 \%$ & $20,9 \%$ & $0,0 \%$ & $8,2 \%$ & $25,4 \%$ & $6,7 \%$ \\
\hline Escola de Educação Física e Esportes & $0,0 \%$ & $12,0 \%$ & $17,0 \%$ & $10,0 \%$ & $25,0 \%$ & $1,0 \%$ & $12,0 \%$ & $17,0 \%$ & $6,0 \%$ \\
\hline Escola de Educação Física e Esportes de Ribeirão Preto & $0,0 \%$ & $8,6 \%$ & $22,4 \%$ & $8,6 \%$ & $20,7 \%$ & $1,7 \%$ & $8,6 \%$ & $15,5 \%$ & $13,8 \%$ \\
\hline Faculdade de Ciências Farmacêuticas de Ribeirão Preto & $0,0 \%$ & $15,6 \%$ & $16,9 \%$ & $9,1 \%$ & $11,7 \%$ & $0,0 \%$ & $7,8 \%$ & $29,9 \%$ & $9,1 \%$ \\
\hline Faculdade de Direito & $0,0 \%$ & $9,6 \%$ & $18,0 \%$ & $21,3 \%$ & $17,0 \%$ & $1,5 \%$ & $10,2 \%$ & $18,9 \%$ & $3,5 \%$ \\
\hline Faculdade de Educação & $0,0 \%$ & $5,1 \%$ & $11,9 \%$ & $14,1 \%$ & $19,2 \%$ & $0,6 \%$ & $17,5 \%$ & $23,2 \%$ & $8,5 \%$ \\
\hline Faculdade de Medicina de Ribeirão Preto & $0,0 \%$ & $11,9 \%$ & $11,4 \%$ & $16,0 \%$ & $21,5 \%$ & $0,0 \%$ & $6,8 \%$ & $22,8 \%$ & $9,6 \%$ \\
\hline Faculdade de Medicina Veterinária e Zootecnia & $0,0 \%$ & $10,0 \%$ & $17,5 \%$ & $17,5 \%$ & $23,8 \%$ & $0,0 \%$ & $8,8 \%$ & $20,0 \%$ & $2,5 \%$ \\
\hline Faculdade de Odontologia de Bauru & $0,0 \%$ & $8,2 \%$ & $17,6 \%$ & $21,2 \%$ & $16,5 \%$ & $0,0 \%$ & $8,2 \%$ & $22,4 \%$ & $5,9 \%$ \\
\hline Faculdade de Odontologia de Ribeirão Preto & $0,0 \%$ & $7,9 \%$ & $25,0 \%$ & $19,7 \%$ & $18,4 \%$ & $1,3 \%$ & $5,3 \%$ & $19,7 \%$ & $2,6 \%$ \\
\hline Faculdade de Saúde Pública & $0,0 \%$ & $7,6 \%$ & $12,6 \%$ & $11,8 \%$ & $20,2 \%$ & $2,5 \%$ & $15,1 \%$ & $21,0 \%$ & $9,2 \%$ \\
\hline Instituto de Arquitetura e Urbanismo de São Carlos & $0,0 \%$ & $13,3 \%$ & $6,7 \%$ & $8,9 \%$ & $31,1 \%$ & $0,0 \%$ & $8,9 \%$ & $28,9 \%$ & $2,2 \%$ \\
\hline Instituto de Biociências & $0,0 \%$ & $10,9 \%$ & $17,6 \%$ & $16,8 \%$ & $21,0 \%$ & $0,0 \%$ & $8,4 \%$ & $19,3 \%$ & $5,9 \%$ \\
\hline Instituto de Ciências Biomédicas & $0,0 \%$ & $5,1 \%$ & $15,4 \%$ & $23,1 \%$ & $20,5 \%$ & $0,0 \%$ & $15,4 \%$ & $20,5 \%$ & $0,0 \%$ \\
\hline Instituto de Matemática de Estatística & $0,0 \%$ & $5,0 \%$ & $13,1 \%$ & $12,5 \%$ & $21,7 \%$ & $1,5 \%$ & $17,2 \%$ & $21,7 \%$ & $7,4 \%$ \\
\hline Instituto de Psicologia & $0,0 \%$ & $7,1 \%$ & $14,3 \%$ & $25,7 \%$ & $12,9 \%$ & $1,4 \%$ & $12,9 \%$ & $18,6 \%$ & $7,1 \%$ \\
\hline Instituto de Química & $0,0 \%$ & $7,6 \%$ & $16,9 \%$ & $8,5 \%$ & $24,6 \%$ & $1,7 \%$ & $5,1 \%$ & $24,6 \%$ & $11,0 \%$ \\
\hline Instituto de Química de São Carlos & $0,0 \%$ & $3,4 \%$ & $20,7 \%$ & $12,1 \%$ & $24,1 \%$ & $0,0 \%$ & $10,3 \%$ & $15,5 \%$ & $13,8 \%$ \\
\hline Instituto de Relações Internacionais & $0,0 \%$ & $8,3 \%$ & $15,0 \%$ & $26,7 \%$ & $23,3 \%$ & $1,7 \%$ & $6,7 \%$ & $8,3 \%$ & $10,0 \%$ \\
\hline
\end{tabular}

Fonte: Questionário Socioeconômico da Fuvest

Elaboração: própria 


\begin{tabular}{|c|c|c|c|c|c|c|c|c|c|}
\hline \multicolumn{10}{|c|}{$\begin{array}{l}\text { Questionário socioeconômico da Fuvest (2012) } \\
\text { Questão "Qual é a situação profissional atual da sua mãe?" } \\
\text { hierarquizadas segundo o percentual de ingressantes com mãe profissional liberal }\end{array}$} \\
\hline Unidades & $\begin{array}{l}\text { Proprietária } \\
\text { de empresa } \\
\text { grande ou } \\
\text { média }\end{array}$ & $\begin{array}{l}\text { Proprietári } \\
\text { a de micro } \\
\text { ou pequena } \\
\text { empresa }\end{array}$ & $\begin{array}{c}\text { Func. } \\
\text { pública }\end{array}$ & $\begin{array}{c}\text { Profissional } \\
\text { liberal } \\
\downarrow\end{array}$ & $\begin{array}{l}\text { Func. de } \\
\text { empresa }\end{array}$ & Rentista & Aposentada & $\begin{array}{l}\text { Não exerce } \\
\text { atividade } \\
\text { remunerada }\end{array}$ & Outras \\
\hline Instituto de Relações Internacionais & $0,0 \%$ & $8,3 \%$ & $15,0 \%$ & $26,7 \%$ & $23,3 \%$ & $1,7 \%$ & $6,7 \%$ & $8,3 \%$ & $10,0 \%$ \\
\hline Instituto de Psicologia & $0,0 \%$ & $7,1 \%$ & $14,3 \%$ & $25,7 \%$ & $12,9 \%$ & $1,4 \%$ & $12,9 \%$ & $18,6 \%$ & $7,1 \%$ \\
\hline Instituto de Ciências Biomédicas & $0,0 \%$ & $5,1 \%$ & $15,4 \%$ & $23,1 \%$ & $20,5 \%$ & $0,0 \%$ & $15,4 \%$ & $20,5 \%$ & $0,0 \%$ \\
\hline Faculdade de Odontologia & $3,0 \%$ & $6,0 \%$ & $13,5 \%$ & $21,8 \%$ & $24,8 \%$ & $0,8 \%$ & $8,3 \%$ & $18,8 \%$ & $3,0 \%$ \\
\hline Faculdade de Direito & $0,0 \%$ & $9,6 \%$ & $18,0 \%$ & $21,3 \%$ & $17,0 \%$ & $1,5 \%$ & $10,2 \%$ & $18,9 \%$ & $3,5 \%$ \\
\hline Faculdade de Odontologia de Bauru & $0,0 \%$ & $8,2 \%$ & $17,6 \%$ & $21,2 \%$ & $16,5 \%$ & $0,0 \%$ & $8,2 \%$ & $22,4 \%$ & $5,9 \%$ \\
\hline Faculdade de Arquitetura e Urbanismo & $1,1 \%$ & $13,2 \%$ & $16,3 \%$ & $20,5 \%$ & $20,5 \%$ & $0,5 \%$ & $5,8 \%$ & $17,4 \%$ & $4,7 \%$ \\
\hline Escola Politécnica & $1,8 \%$ & $9,7 \%$ & $12,5 \%$ & $20,1 \%$ & $24,3 \%$ & $0,4 \%$ & $7,0 \%$ & $20,1 \%$ & $4,2 \%$ \\
\hline Faculdade de Odontologia de Ribeirão Preto & $0,0 \%$ & $7,9 \%$ & $25,0 \%$ & $19,7 \%$ & $18,4 \%$ & $1,3 \%$ & $5,3 \%$ & $19,7 \%$ & $2,6 \%$ \\
\hline Faculdade de Medicina & $0,4 \%$ & $9,6 \%$ & $16,5 \%$ & $19,7 \%$ & $20,9 \%$ & $0,0 \%$ & $7,2 \%$ & $20,1 \%$ & $5,6 \%$ \\
\hline Faculdade de Medicina Veterinária e Zootecnia & $0,0 \%$ & $10,0 \%$ & $17,5 \%$ & $17,5 \%$ & $23,8 \%$ & $0,0 \%$ & $8,8 \%$ & $20,0 \%$ & $2,5 \%$ \\
\hline Faculdade de Economia, Administração e Cont. de Ribeirão & $0,8 \%$ & $10,7 \%$ & $15,3 \%$ & $17,2 \%$ & $21,5 \%$ & $0,4 \%$ & $10,0 \%$ & $20,7 \%$ & $3,4 \%$ \\
\hline Faculdade de Economia, Administração e Contabilidade & $1,4 \%$ & $9,7 \%$ & $14,5 \%$ & $17,1 \%$ & $21,2 \%$ & $1,2 \%$ & $10,3 \%$ & $17,6 \%$ & $7,0 \%$ \\
\hline Instituto de Biociências & $0,0 \%$ & $10,9 \%$ & $17,6 \%$ & $16,8 \%$ & $21,0 \%$ & $0,0 \%$ & $8,4 \%$ & $19,3 \%$ & $5,9 \%$ \\
\hline Faculdade de Medicina de Ribeirão Preto & $0,0 \%$ & $11,9 \%$ & $11,4 \%$ & $16,0 \%$ & $21,5 \%$ & $0,0 \%$ & $6,8 \%$ & $22,8 \%$ & $9,6 \%$ \\
\hline Faculdade de Direito de Ribeirão Preto & $2,1 \%$ & $6,3 \%$ & $27,1 \%$ & $15,6 \%$ & $16,7 \%$ & $5,2 \%$ & $7,3 \%$ & $18,8 \%$ & $1,0 \%$ \\
\hline Escola de Engenharia de São Carlos & $1,0 \%$ & $9,2 \%$ & $23,1 \%$ & $15,4 \%$ & $20,4 \%$ & $0,2 \%$ & $5,6 \%$ & $18,5 \%$ & $6,5 \%$ \\
\hline Escola de Engenharia de Lorena & $0,9 \%$ & $10,0 \%$ & $20,2 \%$ & $15,4 \%$ & $19,9 \%$ & $0,6 \%$ & $5,4 \%$ & $19,7 \%$ & $8,0 \%$ \\
\hline Instituto de Física & $0,4 \%$ & $5,6 \%$ & $15,3 \%$ & $15,3 \%$ & $14,9 \%$ & $0,0 \%$ & $16,0 \%$ & $20,5 \%$ & $11,9 \%$ \\
\hline Universidade de São Paulo (total geral) & $0,7 \%$ & $8,2 \%$ & $16,3 \%$ & $14,6 \%$ & $21,0 \%$ & $0,7 \%$ & $10,2 \%$ & $21,0 \%$ & $\mathbf{7 , 4 \%}$ \\
\hline Faculdade de Educação & $0,0 \%$ & $5,1 \%$ & $11,9 \%$ & $14,1 \%$ & $19,2 \%$ & $0,6 \%$ & $17,5 \%$ & $23,2 \%$ & $8,5 \%$ \\
\hline Escola Superior de Agricultura Luiz de Queiroz & $1,6 \%$ & $9,9 \%$ & $17,5 \%$ & $13,1 \%$ & $20,4 \%$ & $0,5 \%$ & $5,5 \%$ & $20,9 \%$ & $10,5 \%$ \\
\hline Faculdade de Ciências Farmacêuticas & $0,7 \%$ & $6,1 \%$ & $17,6 \%$ & $12,8 \%$ & $25,0 \%$ & $0,0 \%$ & $8,8 \%$ & $24,3 \%$ & $4,7 \%$ \\
\hline Faculdade de Filosofia, Letras e Ciências Humanas & $0,2 \%$ & $6,7 \%$ & $14,4 \%$ & $12,8 \%$ & $20,7 \%$ & $0,7 \%$ & $14,4 \%$ & $21,6 \%$ & $8,4 \%$ \\
\hline Instituto de Matemática de Estatística & $0,0 \%$ & $5,0 \%$ & $13,1 \%$ & $12,5 \%$ & $21,7 \%$ & $1,5 \%$ & $17,2 \%$ & $21,7 \%$ & $7,4 \%$ \\
\hline Instituto de Química de São Carlos & $0,0 \%$ & $3,4 \%$ & $20,7 \%$ & $12,1 \%$ & $24,1 \%$ & $0,0 \%$ & $10,3 \%$ & $15,5 \%$ & $13,8 \%$ \\
\hline Instituto de Astronomia, Geofísica e Ciências Atmosféricas & $1,3 \%$ & $6,7 \%$ & $10,7 \%$ & $12,0 \%$ & $30,7 \%$ & $0,0 \%$ & $8,0 \%$ & $28,0 \%$ & $2,7 \%$ \\
\hline Faculdade de Filosofia, Ciências e Letras de Ribeirão Preto & $0,2 \%$ & $8,4 \%$ & $18,2 \%$ & $12,0 \%$ & $20,9 \%$ & $0,0 \%$ & $8,2 \%$ & $25,4 \%$ & $6,7 \%$ \\
\hline Faculdade de Saúde Pública & $0,0 \%$ & $7,6 \%$ & $12,6 \%$ & $11,8 \%$ & $20,2 \%$ & $2,5 \%$ & $15,1 \%$ & $21,0 \%$ & $9,2 \%$ \\
\hline Instituto de Física de São Carlos & $0,6 \%$ & $6,7 \%$ & $21,5 \%$ & $11,0 \%$ & $21,5 \%$ & $0,6 \%$ & $8,0 \%$ & $23,9 \%$ & $6,1 \%$ \\
\hline Faculdade de Zootecnia e Engenharia de Alimentos & $1,2 \%$ & $8,0 \%$ & $19,6 \%$ & $10,4 \%$ & $19,6 \%$ & $0,4 \%$ & $8,0 \%$ & $23,6 \%$ & $9,2 \%$ \\
\hline Instituto de Oceanografia & $5,1 \%$ & $2,6 \%$ & $25,6 \%$ & $10,3 \%$ & $17,9 \%$ & $0,0 \%$ & $10,3 \%$ & $15,4 \%$ & $12,8 \%$ \\
\hline Escola de Educação Física e Esportes & $0,0 \%$ & $12,0 \%$ & $17,0 \%$ & $10,0 \%$ & $25,0 \%$ & $1,0 \%$ & $12,0 \%$ & $17,0 \%$ & $6,0 \%$ \\
\hline Faculdade de Ciências Farmacêuticas de Ribeirão Preto & $0,0 \%$ & $15,6 \%$ & $16,9 \%$ & $9,1 \%$ & $11,7 \%$ & $0,0 \%$ & $7,8 \%$ & $29,9 \%$ & $9,1 \%$ \\
\hline Instituto de Arquitetura e Urbanismo de São Carlos & $0,0 \%$ & $13,3 \%$ & $6,7 \%$ & $8,9 \%$ & $31,1 \%$ & $0,0 \%$ & $8,9 \%$ & $28,9 \%$ & $2,2 \%$ \\
\hline Escola de Educação Física e Esportes de Ribeirão Preto & $0,0 \%$ & $8,6 \%$ & $22,4 \%$ & $8,6 \%$ & $20,7 \%$ & $1,7 \%$ & $8,6 \%$ & $15,5 \%$ & $13,8 \%$ \\
\hline Instituto de Química & $0,0 \%$ & $7,6 \%$ & $16,9 \%$ & $8,5 \%$ & $24,6 \%$ & $1,7 \%$ & $5,1 \%$ & $24,6 \%$ & $11,0 \%$ \\
\hline Instituto de Ciências Matemáticas e Computação & $1,8 \%$ & $5,9 \%$ & $17,8 \%$ & $8,2 \%$ & $21,0 \%$ & $0,5 \%$ & $9,1 \%$ & $22,4 \%$ & $13,2 \%$ \\
\hline Instituto de Geociências & $1,1 \%$ & $2,2 \%$ & $20,2 \%$ & $7,9 \%$ & $20,2 \%$ & $2,2 \%$ & $15,7 \%$ & $23,6 \%$ & $6,7 \%$ \\
\hline Escola de Enfermagem de Ribeirão Preto & $0,8 \%$ & $7,8 \%$ & $18,6 \%$ & $6,2 \%$ & $27,9 \%$ & $0,0 \%$ & $5,4 \%$ & $19,4 \%$ & $14,0 \%$ \\
\hline
\end{tabular}

Fonte: Questionário Socioeconômico da Fuvest

Elaboração: própria 


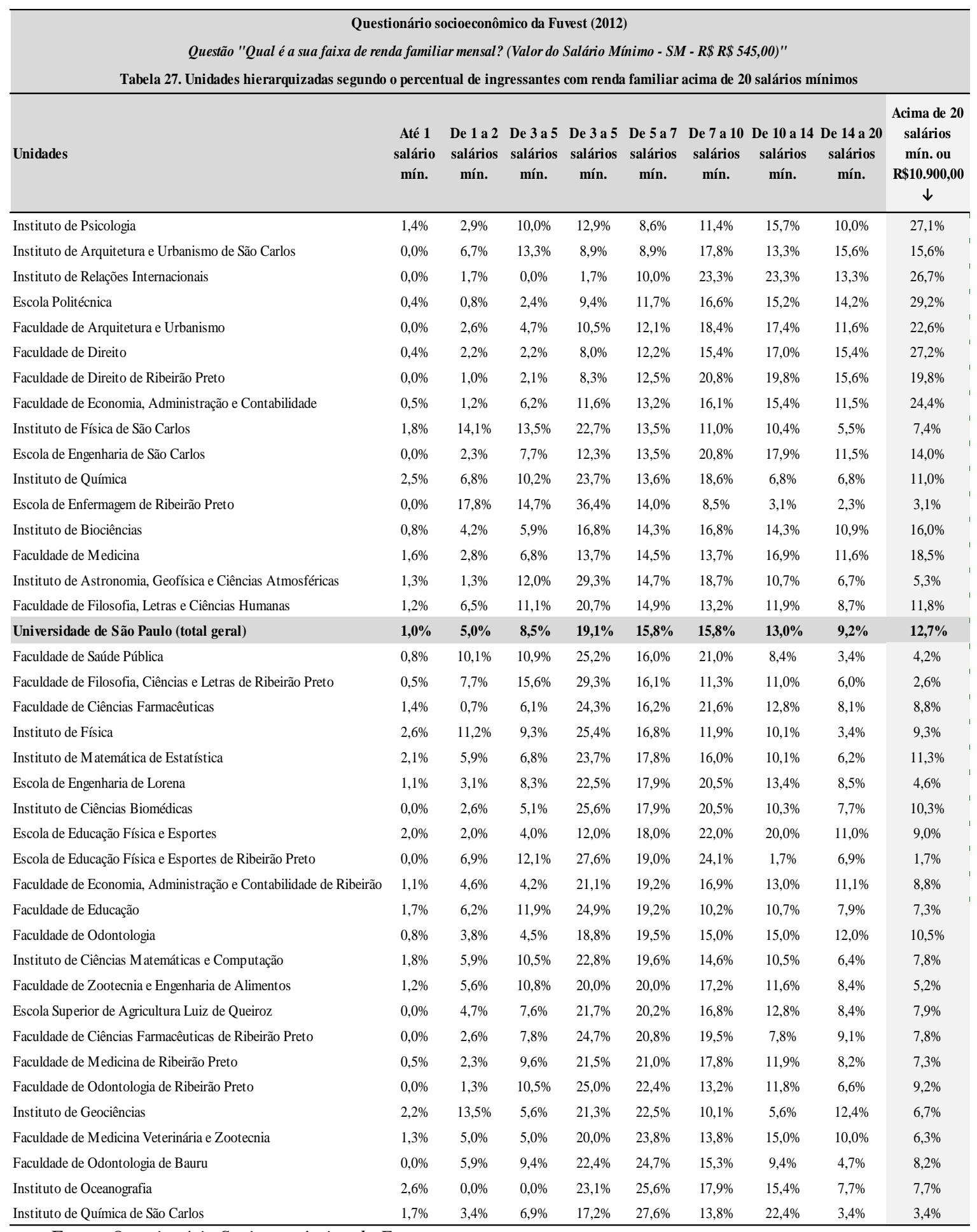

Fonte: Questionário Socioeconômico da Fuvest

Elaboração: própria 
As tabelas acima apresentam resultados muito significativos. Em primeiro lugar, é possível observar que a contraposição essencial entre o polo dominante e os polos dominados da universidade se revela de modo ainda mais marcante quando o que está em questão é o perfil socioeconômico das famílias dos estudantes da USP. Ainda assim, as tabelas revelem especificidades que merecem ser observadas.

Em primeiro lugar, considerando a escolaridade do pai, comparada com a escolaridade da mãe, apresentada na tabela 16 , é possível notar que as unidades com mais $70 \%$ dos ingressantes com pai e mãe com ensino superior completo são praticamente as mesmas: Escola Politécnica, Faculdade de Direito, Instituto de Oceanografia e Instituto de Relações Internacionais. A Faculdade de Arquitetura e Urbanismo, o Instituto de Psicologia e a Faculdade de Direito de Ribeirão Preto podem ser incluídas nesse grupo, uma vez que mais de $70 \%$ dos seus ingressantes têm ou o pai ou a mãe com ensino superior completo. Juntas, essas unidades reúnem a elite cultural da USP, se por elite cultural se compreender os portadores de diploma de ensino superior. Incluindo nessa relação o dado sobre o percentual de alunos cujos pais têm pós-graduação, presente nas duas tabelas, essas unidades também se destacam, o que sugere que se trata de portadores de diplomas de graduação relativamente valorizados, uma vez que conferem acesso a programas de pós-graduação. Considerando a oposição entre as unidades que estão acima e abaixo da média da USP nas duas tabelas, é possível notar, ainda, que as unidades voltadas à formação profissional possuem, em geral, um alto percentual de estudantes oriundos de famílias de alta escolarização. A principal oposição, nesse caso, não se configura exatamente entre o polo profissional-tradicional e o polo acadêmico-científico, mas no interior do próprio polo profissional, como o comprova a presença de unidades que concentram cursos técnico-profissionais na base da tabela, como a Faculdade de Filosofia, Ciências e Letras de Ribeirão Preto, a Escola de Artes, Ciências e Humanidades e as Escolas de Enfermagem de São 
Paulo e Ribeirão Preto que, juntamente com o Instituto de Física, estão entre as que possuem o menor percentual de alunos oriundos de famílias altamente escolarizadas. Por fim, dois casos “desviantes" são a presença do Instituto de Oceanografia entre as unidades com pais de mais alta escolaridade e da Faculdade de Saúde Pública entre as unidades com menor percentual de filhos de diplomados pelo ensino superior. A variação, por ser pontual, não invalida a força das relações essenciais entre os polos da USP, expressas nas duas tabelas analisadas.

Os dados relativos à situação profissional dos pais também são muito significativos. Considerando, primeiro, a ocupação paterna, é possível dizer que, embora entre os estudantes da USP como um todo o percentual de filhos de grandes ou médios proprietários não seja tão expressivo, a diferença entre as unidades parece ser relevante. Assim, tomando-se as unidades que concentram o maior percentual de filhos de proprietários, é possível encontrar um padrão: são instituições que tradicionalmente preparam "herdeiros" para assumirem os negócios de família. Primeiro e em lugar de destaque, a Escola Superior de Agricultura Luiz de Queiroz, a ESALq, que historicamente constitui um espaço de formação das elites agrárias proprietárias do estado de São Paulo. Depois dela, o novo Instituto de Relações Internacionais, que possibilita a formação de profissionais voltados às relações exteriores, seja no Estado, como uma preparação à carreira diplomática, seja no mercado, em posições ligadas ao comércio exterior. Na sequência vem a Faculdade de Economia, Administração e Contabilidade, que também concentra um percentual de filhos de proprietários mais alto do que a média. Aliás, como apontam Pochmann et al. e conforme já foi dito, os cursos de administração, economia, ciências atuariais e contabilidade estão entre os cursos mais frequentados pelos "empregadores" brasileiros, que constitui uma fração importante dos proprietários nacionais (cf. 2009, p. 87). Além desses, o curso de direito também merece destaque (cf. Pochmann et al., 2009, p. 87). Não por acaso, portanto, a Faculdade de Direito de Ribeirão Preto também recebe um alto 
percentual de "futuros proprietários". Juntamente com essas, a Faculdade de Arquitetura e Urbanismo e, de novo, o Instituto de Oceanografia também merecem destaque.

Passando de uma análise mais pontual para uma visão mais geral da tabela, a oposição essencial entre as profissões tradicionais e as outras é marcante mais uma vez. Nesse sentido, com exceção do recém-criado curso de Arquitetura de São Carlos, as unidades que são completamente preteridas pelos filhos de famílias proprietárias ou são técnico-profissionais, como o caso das Escolas de Enfermagem, ou são acadêmico-científicas, como no caso dos Institutos de Química de São Paulo e São Carlos e o Instituto de Ciências Biomédicas. O ICB, no entanto, reaparece no topo da tabela quando as unidades da USP são hierarquizadas pelo percentual de alunos cujo pai é profissional liberal. Ao lado do ICB, outras unidades que também formam para as profissões de saúde, como as Faculdades de Medicina, de Odontologia e, em certo sentido, o Instituto de Psicologia, concentram os filhos de profissionais liberais.

A tabela que apresenta a distribuição das unidades da USP pelo percentual de alunos ingressantes cuja mãe é grande ou média proprietária expressa, antes de mais nada, uma desigualdade de gênero: as mães dos alunos da USP têm bem menos chance de serem proprietárias do que os pais, tal como é possível depreender pelo grande número de unidades que não recebeu nenhum aluno cuja mãe é “dona de empresa de grande ou médio porte”. Mas, para além disso, embora essa seja, de todas, a tabela que apresente maior variação na hierarquia entre as unidades, com os polos algo embaralhados, a oposição essencial entre profissões socialmente reconhecidas e carreiras acadêmicas, científicas ou técnicas, ainda assim, se mantém. Por outro lado, ao hierarquizar as unidades pelo percentual de aprovados no vestibular cuja mãe é profissional liberal, na tabela seguinte, a estrutura retoma a rigidez observada em praticamente todas as outras variáveis.

Aliás, se existe uma variável que revela a rigidez da estrutura social da USP - pensada como as relações objetivas que aproximam e afastam seus polos essenciais - essa variável é a 
renda familiar, indicador por excelência do grau de elitização do corpo discente, conforme é possível observar pela tabela 27.

Ao hierarquizar as unidades pelo percentual decrescente de ingressantes cuja renda é maior do que vinte salários mínimos ou, em valores da época, R\$10.900,00, é possível observar o polo dominante da USP se delinear com clareza. Ele agrupa as faculdades profissionais tradicionais, sediadas sobretudo, embora não exclusivamente, na cidade de São Paulo, nessa ordem: Escola Politécnica, Faculdade de Direito, Instituto de Psicologia, Instituto de Relações Internacionais, Faculdade de Economia e Administração, Faculdade de Arquitetura e Urbanismo, Faculdade de Direito de Ribeirão Preto, Faculdade de Medicina, Instituto de Biologia, Instituto de Arquitetura e Urbanismo e Escola de Engenharia de São Carlos. Note-se que as únicas unidades do interior que estão entre as unidades mais elitizadas da USP, do ponto de vista do percentual de ingressantes com alta renda familiar, são unidades voltadas a profissões tradicionais, ou seja, Direito, Arquitetura e Engenharia. Por outro lado, a presença do Instituto de Biologia entre as unidades com maior percentual de alunos de alta renda já indica que, em relação à renda familiar, os cursos acadêmico-científicos ocupam uma posição intermediária, ou seja, abaixo das unidades profissionais tradicionais, mas acima do polo técnico-profissional, que de novo aparece na base da tabela representado pela Escola de Enfermagem, pela Faculdade de Filosofia, Ciências e Letras e pela Escola de Esportes e Educação Física, as três sediadas em Ribeirão Preto.

Essa estrutura geral, que tem em um extremo as unidades profissionais tradicionais sediadas na capital e no outro as unidades técnico-profissionais sediadas no interior do estado de São Paulo, com os cursos acadêmico-científicos ocupando uma posição intermediária, reflete sobretudo a hierarquização das unidades pela renda familiar, escolaridade e situação profissional dos pais. No entanto, quando a dimensão em questão é o percentual de alunos afrodescendentes que ingressam na universidade, a capital se mostra relativamente mais aberta 
do que o interior do estado, e o polo acadêmico-científico, mais democrático do que os outros

dois polos profissionais, conforme é possível enxergar na tabela 28, posicionada a seguir. Por

outro lado, o percentual de indígenas que ingressam na universidade é absolutamente insignificante em praticamente todas as unidades da USP.

\begin{tabular}{|c|c|c|c|c|c|c|}
\hline \multicolumn{7}{|c|}{$\begin{array}{l}\text { Questionário socioeconômico FUVEST (2012) } \\
\text { Questão "Entre as alternativas abaixo, qual é a sua cor? (branca, preta, amarela, parda, indígena)" } \\
\text { Tabela 28. Unidades hierarquizadas segundo o percentual crescente de ingressantes que se declara de cor "parda" ou "preta" }\end{array}$} \\
\hline Unidades & Branca & Preta & Parda & $\begin{array}{c}\text { Pardos e } \\
\text { Pretos }\end{array}$ & Amarela & Indígena \\
\hline Faculdade de Ciências Farmacêuticas de Ribeirão Preto & $88,3 \%$ & $0,0 \%$ & $3,9 \%$ & $3,9 \%$ & $7,8 \%$ & $0,0 \%$ \\
\hline Faculdade de Odontologia de Ribeirão Preto & $93,4 \%$ & $0,0 \%$ & $3,9 \%$ & $3,9 \%$ & $2,6 \%$ & $0,0 \%$ \\
\hline Faculdadade de Arquitetura e Urbanismo & $77,4 \%$ & $1,6 \%$ & $2,6 \%$ & $4,2 \%$ & $18,4 \%$ & $0,0 \%$ \\
\hline Faculdade de Direito de Ribeirão Preto & $91,7 \%$ & $2,1 \%$ & $3,1 \%$ & $5,2 \%$ & $3,1 \%$ & $0,0 \%$ \\
\hline Instituto de Aquitetura e Urbanismo de São Carlos & $88,9 \%$ & $0,0 \%$ & $6,7 \%$ & $6,7 \%$ & $4,4 \%$ & $0,0 \%$ \\
\hline Instituto de Ciências Biomédicas & $79,5 \%$ & $2,6 \%$ & $5,1 \%$ & $7,7 \%$ & $12,8 \%$ & $0,0 \%$ \\
\hline Faculdade de Economia e Administração de Ribeirão Preto & $87,7 \%$ & $1,1 \%$ & $6,9 \%$ & $8,0 \%$ & $4,2 \%$ & $0,0 \%$ \\
\hline Escola Superior de Agrononomia Luiz de Queiroz & $88,0 \%$ & $3,1 \%$ & $5,0 \%$ & $8,1 \%$ & $3,9 \%$ & $0,0 \%$ \\
\hline Instituto de Psicologia & $85,7 \%$ & $2,9 \%$ & $5,7 \%$ & $8,6 \%$ & $5,7 \%$ & $0,0 \%$ \\
\hline Faculdade de Medicina Veterinária e Zootecnia & $77,5 \%$ & $1,3 \%$ & $7,5 \%$ & $8,8 \%$ & $13,8 \%$ & $0,0 \%$ \\
\hline Escola Politécnica & $74,9 \%$ & $1,3 \%$ & $7,5 \%$ & $8,9 \%$ & $16,0 \%$ & $0,1 \%$ \\
\hline Faculdade de Medicina de Ribeirão Preto & $87,2 \%$ & $0,9 \%$ & $8,2 \%$ & $9,1 \%$ & $3,7 \%$ & $0,0 \%$ \\
\hline Instituto de Biociências & $82,4 \%$ & $0,0 \%$ & $9,2 \%$ & $9,2 \%$ & $8,4 \%$ & $0,0 \%$ \\
\hline Faculdade de Odontologia de Bauru & $87,1 \%$ & $1,2 \%$ & $8,2 \%$ & $9,4 \%$ & $3,5 \%$ & $0,0 \%$ \\
\hline Faculdade de Economia e Administração & $75,2 \%$ & $0,7 \%$ & $9,2 \%$ & $9,9 \%$ & $14,9 \%$ & $0,0 \%$ \\
\hline Instituto de Relações Internacionais & $83,3 \%$ & $1,7 \%$ & $8,3 \%$ & $10,0 \%$ & $6,7 \%$ & $0,0 \%$ \\
\hline Escola de Educação Física e Esportes de Ribeirão Preto & $84,5 \%$ & $0,0 \%$ & $10,3 \%$ & $10,3 \%$ & $3,4 \%$ & $1,7 \%$ \\
\hline Faculdade de Direito & $82,4 \%$ & $0,9 \%$ & $10,0 \%$ & $10,9 \%$ & $6,7 \%$ & $0,0 \%$ \\
\hline Escola de Engenharia de São Carlos & $82,1 \%$ & $1,5 \%$ & $9,8 \%$ & $11,3 \%$ & $6,3 \%$ & $0,4 \%$ \\
\hline Faculdade de Ciências Farmacêuticas & $75,0 \%$ & $2,0 \%$ & $9,5 \%$ & $11,5 \%$ & $13,5 \%$ & $0,0 \%$ \\
\hline Instituto de Física de São Carlos & $82,8 \%$ & $2,5 \%$ & $9,2 \%$ & $11,7 \%$ & $5,5 \%$ & $0,0 \%$ \\
\hline Faculdade de Medicina & $73,9 \%$ & $2,4 \%$ & $9,6 \%$ & $12,0 \%$ & $12,9 \%$ & $1,2 \%$ \\
\hline Escola de Enfermagem & $81,0 \%$ & $2,5 \%$ & $10,1 \%$ & $12,7 \%$ & $6,3 \%$ & $0,0 \%$ \\
\hline Faculdade de Filosofia, Ciências e Letras de Ribeirão Preto & $83,9 \%$ & $3,4 \%$ & $9,4 \%$ & $12,7 \%$ & $3,1 \%$ & $0,2 \%$ \\
\hline Faculdade de Odontologia & $70,7 \%$ & $3,0 \%$ & $9,8 \%$ & $12,8 \%$ & $16,5 \%$ & $0,0 \%$ \\
\hline Faculdade de Zootecnia e Engenharia de Alimentos & $80,0 \%$ & $4,0 \%$ & $8,8 \%$ & $12,8 \%$ & $7,2 \%$ & $0,0 \%$ \\
\hline Escola de Engenharia de Lorena & $80,9 \%$ & $2,6 \%$ & $10,3 \%$ & $12,8 \%$ & $6,3 \%$ & $0,0 \%$ \\
\hline Faculdade de Saúde Pública & $76,5 \%$ & $2,5 \%$ & $10,9 \%$ & $13,4 \%$ & $10,1 \%$ & $0,0 \%$ \\
\hline Universidade de São Paulo & $78,3 \%$ & $2,6 \%$ & $11,2 \%$ & $13,8 \%$ & $7,6 \%$ & $0,2 \%$ \\
\hline Instrituto de Ciências Matemáticas e Computação & $81,3 \%$ & $4,1 \%$ & $10,0 \%$ & $14,2 \%$ & $4,6 \%$ & $0,0 \%$ \\
\hline Escola de Comunicação e Artes & $79,1 \%$ & $3,3 \%$ & $11,7 \%$ & $15,0 \%$ & $5,9 \%$ & $0,0 \%$ \\
\hline Instituto de Química & $76,3 \%$ & $3,4 \%$ & $11,9 \%$ & $15,3 \%$ & $7,6 \%$ & $0,8 \%$ \\
\hline Instituto de Oceanografia & $84,6 \%$ & $5,1 \%$ & $10,3 \%$ & $15,4 \%$ & $0,0 \%$ & $0,0 \%$ \\
\hline Instituto de Química de São Carlos & $74,1 \%$ & $1,7 \%$ & $13,8 \%$ & $15,5 \%$ & $10,3 \%$ & $0,0 \%$ \\
\hline Instituto de Astronomia, Geofísica e Ciências Atmosféricas & $73,3 \%$ & $0,0 \%$ & $17,3 \%$ & $17,3 \%$ & $9,3 \%$ & $0,0 \%$ \\
\hline Faculdade de Filosofia, Letras e Ciências Humanas & $77,4 \%$ & $4,0 \%$ & $14,8 \%$ & $18,8 \%$ & $3,4 \%$ & $0,4 \%$ \\
\hline Escola de Educação Física e Esportes & $76,0 \%$ & $1,0 \%$ & $18,0 \%$ & $19,0 \%$ & $5,0 \%$ & $0,0 \%$ \\
\hline Escola de Enfermagem de Ribeirão Preto & $78,3 \%$ & $3,9 \%$ & $15,5 \%$ & $19,4 \%$ & $2,3 \%$ & $0,0 \%$ \\
\hline Escola de Artes, Ciências e Humanidades & $72,5 \%$ & $4,2 \%$ & $15,2 \%$ & $19,4 \%$ & $7,7 \%$ & $0,4 \%$ \\
\hline Instituto de Matemática de Estatística & $68,2 \%$ & $3,6 \%$ & $16,0 \%$ & $19,6 \%$ & $11,9 \%$ & $0,3 \%$ \\
\hline Instituto de Física & $72,8 \%$ & $3,4 \%$ & $20,1 \%$ & $23,5 \%$ & $3,0 \%$ & $0,7 \%$ \\
\hline Faculdade de Educação & $68,9 \%$ & $4,5 \%$ & $19,8 \%$ & $24,3 \%$ & $5,1 \%$ & $1,7 \%$ \\
\hline Instituto de Geociências & $66,3 \%$ & $4,5 \%$ & $20,2 \%$ & $24,7 \%$ & $9,0 \%$ & $0,0 \%$ \\
\hline
\end{tabular}

Fonte: Questionário Socioeconômico da Fuvest

Elaboração: própria 
Por fim, a tabela a seguir apresenta a hierarquia entre as diferentes unidades da USP a partir do percentual decrescente de homens que ingressam nos seus cursos de graduação, ou seja, das unidades mais "masculinas" para as mais "femininas". Nesse caso, a oposição essencial não é entre os polos profissional tradicional, acadêmico-científico e técnicoprofissional mas entre as grandes áreas da universidade: ciências exatas, em um extremo, biológicas, no outro, com as ciências humanas ocupando uma posição intermediária.

\begin{tabular}{|c|c|c|}
\hline \multicolumn{3}{|c|}{$\begin{array}{c}\text { Questionário socioeconômico da Fuvest (2012) } \\
\text { Questão "Qual o seu sexo?" } \\
\text { Tabela 29. Unidades hierarquizadas segundo o percentual decrescente de ingressantes } \\
\text { homens }\end{array}$} \\
\hline Unidades & $\begin{array}{l}\text { Percentual de } \\
\text { mulheres }\end{array}$ & $\begin{array}{c}\text { Percentual de } \\
\text { homens }\end{array}$ \\
\hline Escola Politécnica & $16,4 \%$ & $83,6 \%$ \\
\hline Instituto de Física & $18,7 \%$ & $81,3 \%$ \\
\hline Instituto de Ciências Matemáticas e Computação & $20,1 \%$ & $79,9 \%$ \\
\hline Escola de Engenharia de São Carlos & $21,9 \%$ & $78,1 \%$ \\
\hline Escola de Educação Física e Esportes de Ribeirão Preto & $24,1 \%$ & $75,9 \%$ \\
\hline Instituto de Matemática de Estatística & $25,5 \%$ & $74,5 \%$ \\
\hline Instituto de Física de São Carlos & $26,4 \%$ & $73,6 \%$ \\
\hline Escola de Educação Física e Esportes & $28,0 \%$ & $72,0 \%$ \\
\hline Instituto de Astronomia, Geofísica e Ciências Atmosféricas & $30,7 \%$ & $69,3 \%$ \\
\hline Faculdade de Economia e Administração & $33,0 \%$ & $67,0 \%$ \\
\hline Faculdade de Economia e Administração de Ribeirão Preto & $36,8 \%$ & $63,2 \%$ \\
\hline Instituto de Química & $38,1 \%$ & $61,9 \%$ \\
\hline Instituto de Geociências & $38,2 \%$ & $61,8 \%$ \\
\hline Faculdade de Direito & $41,5 \%$ & $58,5 \%$ \\
\hline Escola de Engenharia de Lorena & $43,0 \%$ & $57,0 \%$ \\
\hline Universidade de São Paulo & $46,5 \%$ & $53,5 \%$ \\
\hline Instituto de Química de São Carlos & $46,6 \%$ & $53,4 \%$ \\
\hline Escola Superior de Agricultura Luiz de Queiroz & $47,4 \%$ & $52,6 \%$ \\
\hline Instituto de Biociências & $49,6 \%$ & $50,4 \%$ \\
\hline Faculdade de Filosofia, Ciências e Letras de Ribeirão Preto & $50,4 \%$ & $49,6 \%$ \\
\hline Faculdade de Direito de Ribeirão Preto & $51,0 \%$ & $49,0 \%$ \\
\hline Faculdade de Filosofia, Letras e Ciências Humanas & $51,6 \%$ & $48,4 \%$ \\
\hline Escola de Artes, Ciências e Humanidades & $53,4 \%$ & $46,6 \%$ \\
\hline Escola de Comunicação e Artes & $55,5 \%$ & $44,5 \%$ \\
\hline Faculdade de Medicina & $56,2 \%$ & $43,8 \%$ \\
\hline Instituto de Relaç̃̃es Internacionais & $56,7 \%$ & $43,3 \%$ \\
\hline Instituto de Ciências Biomédicas & $59,0 \%$ & $41,0 \%$ \\
\hline Instituto de Oceanografia & $64,1 \%$ & $35,9 \%$ \\
\hline Faculdade de Arquitetura e Urbanismo & $64,7 \%$ & $35,3 \%$ \\
\hline Faculdade de Medicina de Ribeirão Preto & $68,0 \%$ & $32,0 \%$ \\
\hline Instituto de Psicologia & $68,6 \%$ & $31,4 \%$ \\
\hline Faculdade de Zootecnia e Engenharia de Alimentos & $68,8 \%$ & $31,2 \%$ \\
\hline Faculdade de Odontologia de Ribeirão Preto & $69,7 \%$ & $30,3 \%$ \\
\hline Faculdade de Ciências Farmacêuticas & $70,9 \%$ & $29,1 \%$ \\
\hline Faculdade de Odontologia & $73,7 \%$ & $26,3 \%$ \\
\hline Instituto de Arquitetura e Urbanismo de São Carlos & $75,6 \%$ & $24,4 \%$ \\
\hline Faculdade de Educação & $75,7 \%$ & $24,3 \%$ \\
\hline Faculdade de Medicina Veterinária e Zootecnia & $78,8 \%$ & $21,3 \%$ \\
\hline Faculdade de Saúde Pública & $81,5 \%$ & $18,5 \%$ \\
\hline Faculdade de Odontologia de Bauru & $82,4 \%$ & $17,6 \%$ \\
\hline Escola de Enfermagem de Ribeirão Preto & $87,6 \%$ & $12,4 \%$ \\
\hline Faculdade de Ciências Farmacêuticas de Ribeirão Preto & $88,3 \%$ & $11,7 \%$ \\
\hline Escola de Enfermagem & $91,1 \%$ & $8,9 \%$ \\
\hline
\end{tabular}

Fonte: Questionário Socioeconômico da Fuvest

Elaboração: própria 
As tabelas analisadas até aqui só revelam o seu sentido forte quando vistas como uma série, em que as variações ocasionais vão perdendo importância diante da reiteração da oposição essencial que define os polos principais da estrutura da USP. É, em síntese, a operação essencial da análise estrutural que busca depurar os dados disponíveis em busca das contraposições essenciais que configuram os espaços sociais como espaços estruturados que traduzem diferenças sociais em diferenças específicas - universitárias, no caso - naturalizando, assim, as relações sociais de dominação.

Uma vez definida, nas suas linhas gerais, a estrutura social que opõe, na USP, dominantes e dominados, é preciso se voltar para o interior do campo dominante para entender como ele se constitui como um espaço privilegiado de formação e socialização das elites acadêmicas e políticas que, em grande medida, assumem as estruturas de governo da USP, definindo o sentido geral da sua transformação. É essencialmente esse o objetivo do quarto e último capítulo desta tese. 


\title{
Capítulo 4. Escolas de elite, escolas de poder: a socialização no polo dominante e o discurso da gestão como violência simbólica
}

\begin{abstract}
A violência simbólica é essa coerção que se institui por intermédio da adesão que o dominado não pode deixar de conceder ao dominante (portanto, à dominação), quando dispõe, para pensá-lo e para pensar a si mesmo, ou melhor, para pensar a sua relação com ele, somente de instrumentos de conhecimentos comuns e que fazem essa relação aparecer como natural, pelo fato de serem, na verdade, a forma incorporada da estrutura da relação de dominação; ou, em outros termos, quando os esquemas que ele mobiliza para se perceber e para se apreciar, ou para perceber e apreciar os dominantes (elevado/baixo, masculino/feminino, branco/negro etc.), constituem o produto da incorporação das estruturas assim naturalizadas, de que seu ser social é produto (Bourdieu, 1997, p. 204).
\end{abstract}

Vistos em conjunto, os movimentos descritos estatisticamente no capítulo anterior, de expansão, diversificação, elitização e manutenção da estrutura social da Universidade de São Paulo, revelam que, conforme observado em outros países, as faculdades que ocupavam as posições socialmente dominantes na estrutura universitária antes da reforma de 1968 conseguiram, apesar de todas as transformações ocorridas, não apenas manter como aprofundar o seu padrão elevado de recrutamento social. Esse processo, consequência da padronização do vestibular, do aumento da concorrência, da orientação dos novos setores sociais para as chamadas novas profissões e da resistência a políticas mais profundas de inclusão social, como as ações afirmativas, resultou no aumento da distância que separa os polos principais da universidade, opondo dominantes e dominados no seu interior.

No caso específico da USP, a polaridade estrutural que foi mantida e atualizada ao longo das últimas décadas situa, de um lado, as faculdades profissionais tradicionais - concentradas sobretudo na cidade de São Paulo, marcadas por um recrutamento escolar altamente seletivo e social fortemente elevado voltando-se, portanto, à formação de profissionais destinados a atuar em posições de comando e poder, portanto, como elite dirigente - e, de outro, as faculdades $e$ institutos voltados à formação científica e à formação de profissionais de menor prestígio social - ambas relativamente abertas a setores sociais menos favorecidos, como estudantes de 
escola pública, filhos de famílias de baixa escolaridade e baixa renda e, em menor medida, afrodescendentes, que são formados para exercer atividades ligadas ao ensino e à pesquisa ou para executar funções de natureza técnica e especializada.

É, portanto, à luz dessa estrutura social que se deve analisar o processo de difusão do discurso gerencial na USP, que se estabeleceu como um referencial a partir do qual o problema do governo acadêmico é concebido e equacionado no interior da instituição pelo conjunto dos seus membros, oriundos de diferentes polos. Em outras palavras, é preciso entender o discurso da gestão como um sistema de classificação que, traduzindo relações de dominação em categorias cognitivas, terminou por se impor ao conjunto da universidade que, assumindo e naturalizando essa linguagem, experimentou um movimento típico de violência simbólica, em que os conhecimentos disponíveis para pensar o mundo, ou, no caso, o governo desse mundo, são apenas aqueles mais adequados à perspectiva dos seus setores dominantes. Mas antes de analisar em que medida as categorias do discurso gerencial, e a forma como ele é percebido pelos dirigentes da USP, reflete a visão inerente ao seu polo dominante, é preciso compreender um pouco melhor o funcionamento desse mesmo polo onde, vale lembrar, foi formada e socializada a maior parte dos professores que têm exercido posições de governo na universidade, a partir das quais promovem a sua reforma organizacional.

Nesse sentido, o presente capítulo parte da constatação, demonstrada no capítulo anterior, de que não obstante a expansão da USP ao longo dos últimos anos, seu polo dominante tornou-se ainda mais fechado. Essa constatação ganha ainda mais importância quando consideramos que a homogeneidade constitui um elemento fundamental do processo social de produção e reprodução de elites políticas, administrativas e econômicas através da universidade. É, portanto, por oferecer uma socialização ancorada na homogeneidade social e por desempenhar como função essencial a formação de elites dirigentes que é possível supor a existência de uma homologia estrutural entre as faculdades profissionais tradicionais da USP, 
sediadas sobretudo na cidade de São Paulo e voltadas à formação das elites paulistas, e as grandes escolas francesas, sediadas sobretudo em Paris e voltadas à educação das elites metropolitanas da França. Partindo disso, foi possível mobilizar as análises de Bourdieu sobre a formação escolar das elites francesas para pensar a socialização no interior do polo dominante da USP. Em síntese, é esse movimento que marca o primeiro e o segundo item deste capítulo, voltados à análise da socialização no polo dominante da universidade, que se torna ainda mais relevante no contexto em que essas elites universitárias se fortalecem, política e socialmente, a partir da alteração das bases de legitimação do exercício do poder, com a crise da política e a consequente emergência de dispositivos e espaços cada vez mais técnicos de ação e de decisão. O terceiro e último item deste capítulo busca analisar uma expressão desse movimento de tecnicização da política a partir da expansão do saber gerencial na USP, enfatizando como esse processo é percebido e avaliado por dirigentes egressos de diferentes polos da universidade. Esse movimento permite demonstrar, justamente, como a linguagem gerencial se impôs como uma referência essencial a partir da qual se pensa e se disputa a organização do governo acadêmico da USP.

\section{Escolas de poder, escolas de elite: a socialização para o controle e a produção social de uma elite dirigente}

No seu livro La noblesse d'état, grandes écoles et esprit de corps, uma das questões centrais de Bourdieu é entender, como o próprio título sugere, de que maneira as escolas de elite formam quadros dirigentes que se concebem e se comportam enquanto uma "nobreza de estado", ou seja, enquanto lideranças, sobretudo no plano político-administrativo, vocacionadas e legitimadas para o exercício do poder. Para tanto, além de analisar as grandes escolas do ponto de vista da sua história estrutural (cf. 1989, p. 183ss), o autor dedica uma parte inteira do seu 
livro, intitulada justamente $A$ ordenação $o^{215}$, à análise do processo social de produção dessa “nobreza” pelo ensino superior, através da socialização nas chamadas “escolas de poder” (cf. Bourdieu, 1989, p. 277-8).

O primeiro passo da análise bourdieusiana consiste em mostrar que as ações pedagógicas, ao exercerem suas funções técnicas, notadamente o ensino de saberes e competências especializadas, acabam exercendo, simultaneamente, funções simbólicas cujo significado essencial é de natureza social. No caso das ações pedagógicas voltadas à preparação para posições dominantes, ou seja, para o exercício do poder, a sua dimensão especificamente técnica - que define a organização do processo de ensino/aprendizagem - produz, acima de tudo, um movimento social de "exclusão ritual”, pelo qual se opera "uma ação de consagração, um rito de instituição visando a produção de um grupo separado e sagrado" (Bourdieu, 1989, p. 102).

Assim, mobilizando exemplos de escolas de elite situadas em diferentes contextos históricos-nacionais, Bourdieu conclui que o que há de comum, em todas elas, é a existência de "provas de iniciação" 216 que pressupõem tanto a "reclusão" quanto a "ascese" como rotina de preparação (cf. 1989, p. 102). Essas provas assumem diferentes formatos ao longo da história, mas a sua expressão contemporânea mais comum são os exames de admissão, tais como as provas de ingresso, os concursos acadêmicos e os vestibulares que, justamente pelo alto grau de concorrência e o consequente esforço demandado, acabam promovendo, desde a seleção dos

\footnotetext{
${ }^{215}$ O livro de Bourdieu, A nobreza de estado, tem cinco partes: I) "As formas escolares de classificação"; II) "A ordenação"; III) "O campo das grandes escolas e sua transformação"; IV) "O campo do poder e suas transformações"; V) "Poder de Estado e poder sobre o Estado". A parte intitulada "A ordenação", analisada mais sistematicamente neste item, se divide em três capítulos: i) "A produção de uma nobreza"; ii) Um rito de instituição"; iii) “As ambiguidades da competência” (cf. Bourdieu, 1989).

${ }^{216}$ No francês, o termo usado pelo autor é épreuve initiatique (Bourdieu, 1989, p. 102), que tem o sentido explícito de provas de seleção ou testes de aptidão. No entanto, o uso do termo initiatique, que remete à ideia de "iniciação", é usado pelo autor para reforçar o sentido ritual dessas provas de seleção que, justamente como os rituais de iniciação, promovem mudanças de ordem simbólica na percepção dos que enfrentam as provas e provações.
} 
ingressantes, as práticas ascéticas e o distanciamento social que constituem a base da formação escolar das elites.

Partindo disso, Bourdieu vai enfatizar a alquimia social existente em toda a sanção escolar promovida por essas provas de seleção que legitimam a exclusão social que promovem, ao serem conhecidas e reconhecidas como eleição legítima, não só pelos que dispensa mas, sobretudo, pelos que seleciona. Uma vez eleitos pela seleção, esses "alunos excelentes" passam a se sentir portadores de uma legitimidade que os autoriza, subjetivamente antes de mais nada, a exercer funções de comando, direção e controle. É por essa operação que se produz o reconhecimento social da excelência que está na base da produção social de uma "nobreza" escolar:

[...] o processo de ruptura social e de segregação que institui, como um grupo separado, um conjunto de eleitos cuidadosamente selecionados engendra, por si mesmo, um capital simbólico cujo valor é tanto mais importante quanto mais o grupo assim constituído for restrito e exclusivo. O monopólio, quando reconhecido, se converte em nobreza (Bourdieu, 1989, p. 109-110).

É precisamente essa consagração socialmente reconhecida e legitimada, promovida pela seleção escolar, que faz com que a aprovação nos exames de admissão tenha um significado social parecido com o das ordenações religiosas. No entanto, de novo, o essencial é o efeito que esse processo social exerce sobre os próprios "ordenados", que passam a se enxergar e a se sentir como um grupo à parte. Nas palavras de Bourdieu:

[...] a sanção escolar realiza a operação social por excelência que consiste em produzir seres à parte, separados e sagrados, pelo único fato de fazer ser conhecida e reconhecida por todos a fronteira que os coloca fora do [âmbito] comum, de tornar pública e notória, garantida pelo consensus omnium, a distinção que os consagra, e de determinar por isso entre os eleitos a conversão à crença que os leva a se (re)conhecer como diferentes (Bourdieu, 1989, p. 141).

Como uma ordem quase religiosa, a nobreza escolar dos "excelentes" compartilha o valor simbólico, materializado nos títulos e diplomas das escolas de elite, de pertencer a um grupo de eleitos, ou, para ser mais precisa, de selecionados. Esse pertencimento ao grupo faz com que todos se beneficiem "magicamente" das realizações coletivas e individuais de cada 
membro individual do grupo. É como se, depois de enfrentar a provação comum de ser testado e aprovado por uma grande escola, eles passassem a formar um único corpo social, não só pela maneira como são vistos socialmente mas, sobretudo, pela forma como se enxergam enquanto um grupo unido e coeso, a despeito das suas discordâncias e cisões internas. Para entender a produção desse corps e desse esprit de corps, ou seja, dessa coesão e desse sentimento de unidade que define de modo marcante as escolas de elite, Bourdieu vai analisar os traços comuns do processo de socialização nesses espaços.

Seguindo uma inspiração antropológica ${ }^{217}$, Bourdieu vai mostrar que, desde os seus cursos preparatórios, as escolas de elite funcionam como verdadeiras "instituições sociais totais". A noção busca enfatizar a potência socializadora dessas instituições escolares que reúnem, em um espaço socialmente separado e altamente controlado, jovens ainda em período de formação, muito parecidos pelas suas características sociais e escolares (cf. 1989, p. 104). Pela socialização intensa e prolongada, inerente ao ensino superior, esse corpo homogêneo passa a ter quase todas as dimensões da sua vida associadas e condicionadas pela experiência escolar: dos rituais de iniciação $0^{218}$ às cerimônias de instituição ${ }^{219}$, das festas individuais às

\footnotetext{
${ }^{217}$ É interessante notar que no seu artigo sobre a violência simbólica, Gérard Mauger vai enfatizar que os estudos de inspiração etnográfica promovem uma inflexão nos estudos de sociologia do sistema escolar na medida em que deixam de priorizar "a pedagogia explícita na sociogênese do habitus" para enfatizar o processo de incorporação de categorias de percepção e avaliação que ocorre em uma dimensão muito mais implícita (Mauger, 2006, p. 96). Na verdade, a análise da Noblesse d'etat deixa claro que Bourdieu pretende incorporar à análise do sistema escolar todos os pressupostos da etnografia da sociedade kabyla, sintetizados em Le sens pratique (cf. Bourdieu, 1980). Isso fica explícito, justamente, nessa análise das condições de ensino/aprendizado que, implicitamente, transmitem toda uma visão de mundo.

${ }^{218}$ Os "rituais de iniciação" mais conhecidos e contestados são os chamados "trotes" que, por se basearem, no geral, em processos de subjugação física e moral, são descritos por alguns autores como um "processo de integração sadomasoquista" que, tolerado pelas universidades e instituições de ensino superior, buscam naturalizar o exercício da "subserviência e da humilhação que passam a ser consideradas normais" (Zuin, 2002, p. 246; 2011). Mas além dos trotes, existem outros rituais como as aulas inaugurais, as palestras de apresentação do curso, as "calouradas" e festas que marcam a recepção dos novos integrantes do corps.

${ }^{219}$ As "cerimônias de instituição", por sua vez, são aquelas que marcam justamente a instituição do corps, ou seja, a formalização social da sua existência. As cerimônias mais famosas são as formaturas, as colações de grau, os juramentos e os outros eventos que marcam a formação no ensino superior. É interessante que tanto os rituais de iniciação quanto as cerimônias de instituição tendem a ser mais importantes justamente no polo profissional tradicional, como é possível observar claramente no caso da USP.
} 
celebrações coletivas, dos amigos aos parceiros amorosos, dos preceptores aos adversários, das atividades culturais às práticas esportivas, do estudo à militância política e institucional. São instituições que, portanto, por incentivar e proporcionar a imersão social, que constitui o essencial da chamada "experiência universitária", promovem e reforçam a coesão que é a sua base e o seu produto. Essa operação pressupõe a "reclusão seletiva", que implica selecionar "os melhores" e colocá-los em um espaço social "separado", o que:

[..] tem por efeito a produção de um grupo social muito homogêneo, cuja homogeneidade acaba sendo ainda mais reforçada pela socialização mútua que resulta do contato contínuo e prolongado dos condiscípulos. Ao limitar assim o espaço social de outras frequentações possíveis, a reclusão seletiva contribui para limitar as chances de más alianças [mésalliances] (no sentido amplo) e isso de modo durável, porque, através das ligações afetivas que se formam com uma força particular durante a adolescência, ela predetermina os atos posteriores de cooptação (Bourdieu, 1989, p. 104).

As análises do autor permitem conferir, portanto, novo estatuto à homogeneidade social das escolas de elite. Mais do que um resultado indesejado de um processo de seleção escolar altamente concorrido, trata-se de um dos pressupostos da preparação de elites, uma vez que permite controlar o contexto de socialização desses jovens, evitando "desvios" e “contaminações”, de ordem social, intelectual ou ideológica (cf. Bourdieu, 1989, p. 109) ${ }^{220}$. A abordagem revela assim que, em termos sociais, o essencial na escola de elite está para além dos conteúdos que são ensinados. São a situação de aprendizagem e o contexto mais amplo de socialização escolar que fazem com que esse espaço social, em que a homogeneidade de origem soma-se a uma socialização prolongada altamente controlada, produza e reforce uma "cultura comum, no sentido antropológico do termo" (1989, p. 110). Essa cultura é mais do que o conteúdo dos saberes e técnicas que os alunos aprendem juntos, sendo constituída pelos:

[...]imponderáveis das maneiras e do comportamento, as expressões típicas da gíria escolar, condensações de valores cristalizados, os usos da língua, as brincadeiras, as

\footnotetext{
${ }^{220}$ Em outro momento do livro, Bourdieu vai falar em "má frequentação". Segundo ele: "Melhor do que as reuniões, os bailes e outras instituições que buscam circunscrever um espaço para encontros aprovados, o algoritmo de classificação escolar, através dos grupos de condiscípulos socialmente homogêneos que produz, favorece a aproximação entre semelhantes e, sobretudo, tende a excluir as 'más-frequentações' que envolvem sempre a ameaça das más alianças e que são mais prováveis onde o trabalho escolar de seleção é menos avançado" (Bourdieu, 1989, p. 258).
} 
formas de postar o corpo e a voz, de rir e de se relacionar com os outros, sobretudo com os pares, que fundamenta e sustenta ao longo do tempo a conivência imediata, bem mais profunda do que a simples solidariedade de interesses compartilhados, entre os condiscípulos [...] (Bourdieu, 1989, p. 110-1).

Essa cultura comum, forjada em um ambiente social homogeneizado e homogeneizante, contribui para que a experiência social nas escolas de elite seja marcada por uma profunda "harmonia" que, vivida como algo quase miraculoso, ajuda a explicar porque seus egressos rememoram os "tempos de escola", em geral, com profunda "nostalgia", que testemunha justamente o "encantamento afetivo" que une os membros dessa elite escolar e que nasce:

[...] de poder se amar e se admirar nos seus semelhantes, constituindo um dos fundamentos, juntamente com o conformismo lógico associado à homogeneidade das estruturas mentais, disso que se denomina esprit de corps: esse sentimento de solidariedade com o grupo [que] repousa, na verdade, sobre a comunidade de esquemas de percepção, apreciação, pensamento e ação que funda a conivência reflexa dos inconscientes bem orquestrados (Bourdieu, 1989, p. 112) 221 .

Nesse sentido, são esses esquemas de percepção, apreciação, pensamento e ação que definem o modo de codificar, classificar, conceber e intervir no mundo, que os alunos das escolas de elite compartilham antes da experiência escolar, pela sua origem social comum, e que é reforçada e legitimada pela escola, incluindo a de ensino superior, que prepara esses estudantes para as posições socialmente dominantes de onde provêm, pela posição social das suas famílias. É a “mágica social” de produção de agentes dominantes capazes de, dispostos a e motivados para ocupar posições de controle, coordenação e comando que pressupõem e reforçam um certo "esquema cognitivo" que está implícito na própria organização do processo de ensino/aprendizagem.

\footnotetext{
${ }^{221}$ Bourdieu se inspira claramente em Émile Dukheim e Marcel Mauss para falar em "conformismo lógico". No seu famoso artigo sobre as formas elementares de classificação, esses autores vão descrever o conformismo lógico como o processo pelo qual a sociedade estrutura as categorias mais elementares do entendimento. Segundo os autores: "A sociedade não foi simplesmente um modelo a partir do qual o pensamento classificatório teria trabalhado; foram os seus próprios quadros que serviram de enquadramento para o sistema [classificatório]. As primeiras categorias lógicas foram categorias sociais (Durkheim \& Mauss, 1903, p. 42-43; grifo meu). Nota-se, portanto, como o problema do fundamento social das categorias de pensamento é compartilhado por toda a teoria social.
} 
Nesse sentido, o mais interessante da análise bourdieusiana sobre as escolas de ensino superior voltadas à formação de elites, sobretudos as elites político-administrativas, é mostrar como as práticas sociais e escolares pressupostas pelo exame de admissão, tais como a ascese, o distanciamento social, a ruptura afetiva, os exercícios repetitivos, a disciplina estrita e o autocontrole, vão ser cotidianamente repostas no interior dessas escolas pela ação pedagógica, determinando as suas “condições de aprendizagem". Assim, ao analisar as classes preparatórias que conferem acesso ao ápice do sistema de ensino superior francês, Bourdieu vai mostrar que o essencial nesses espaços, e que define a continuidade com as grandes escolas e as afasta de outras instituições de ensino superior como as faculdades de ciências e letras, é a existência de mecanismos constantes de controle e de estímulo que impõem aos alunos "uma sucessão ininterrupta de atividades escolares intensivas, rigorosamente regradas e controladas, tanto em relação ao momento quanto ao ritmo em que são realizadas" (Bourdieu, 1989, p. 112). Esse controle estrito da aprendizagem implica um distanciamento social, expresso na ruptura de outros laços sociais, que é uma das bases práticas da percepção de que se vive um processo de ordenação quase religiosa. Assim, a busca constante pela "excelência" é, em si, a principal forma de produzir "excelentes" que se percebem e são percebidos enquanto tais.

Essa reclusão seletiva - expressa de modo extremo nos internatos, mas igualmente presente no ensino em tempo integral e nas grades escolares repletas de atividades curriculares e extracurriculares - assume uma função social, que não se limita aos seus objetivos propriamente pedagógicos: além de garantir a homogeneidade e a coesão do grupo pelo controle estrito das suas atividades, a função social dessa disciplina pedagógica baseada na proliferação de tarefas e na cobrança de resultados é, basicamente, ensinar uma "organização rigorosa do trabalho intensivo" (1989, p. 112), que passa a ser uma base para a avaliação de si e dos outros. Nessa chave, o essencial de todo o ensino, inclusive do ensino de elite, está menos no conteúdo do que é ensinado e mais na situação social em que esse ensino acontece e em que se inscrevem, 
tacitamente, todos os padrões essenciais que se quer transmitir. É por isso que o autor vai afirmar que, na organização da ação pedagógica das escolas de elite, “é toda uma definição da cultura e do trabalho intelectual que se impõe através da organização mesma do trabalho, em particular por intermédio da subordinação da aprendizagem aos imperativos da urgência" (Bourdieu, 1989, p. 113).

Essa "urgência" se manifesta, pedagogicamente, no enorme volume de conteúdo obrigatório que precisa ser incorporado em pouco tempo, e cuja aquisição é avaliada constantemente através de provas, exames e exercícios. Essa situação, em que conteúdos sistematizados estão sob avaliação constante, faz com que os alunos tanto incorporem o valor da produtividade, que entendem ser maior nas suas escolas do que nas faculdades de letras e ciências (cf. 1989, p.114), quanto naturalizem a competição acadêmica, que passa a ser vista como um apelo a um realismo análogo ao "da existência cotidiana", em contraposição à percepção oposta, do universo escolar como um espaço "de lazer, de gratuidade, de finalidade sem fim" (1989, p. 177), que predomina, justamente, entre "os improdutivos" que, mantendo uma outra relação com o conhecimento e a cultura, não precisam atender com urgência aos imperativos da realização.

O apelo do "jogo sério", enquanto elemento fundamental da formação de "homens sérios", portanto dispostos a e capazes, de assumir posições sociais que envolvem grandes responsabilidades, faz com que as escolas superiores de elite - muito mais do que as faculdades de filosofia, ciências e letras - compartilhem um certo "culto ao esporte", que expressa e reforça a "vontade de vencer" que esses alunos também manifestam em outras esferas da vida. Nesses espaços de formação de "homens de ação", as práticas esportivas, como uma das atividades extraescolares mais centrais, incorporam os mesmos princípios da ação pedagógica que, para formar para o exercício do poder, devem se centrar no controle estrito dos resultados tendo em vista produzir: 
[...] a propensão e a aptidão a um uso intensivo do tempo, que constituem sem nenhuma dúvida uma vantagem considerável na competição escolar (notadamente nas situações de concurso) e também, mais tarde, nas lutas pela existência profissional mas também que vão de par com uma relação instrumental, pragmática, por vezes estritamente calculista, com a cultura e com o trabalho intelectual (Bourdieu, 1989, p. 117).

Assim, portanto, a "lógica da urgência" (Bourdieu, 1989, p. 117), que é o princípio de toda a ação pedagógica das escolas de elite, é justamente o que faz com elas sejam, em contraposição às instituições que preparam para as atividades intelectuais, de docência e/ou de pesquisa, espaços de preparação de "homens de ação", voltados ao exercício do poder. Como descreve Bourdieu:

Assim, tudo concorre para fazer das escolas de elite verdadeiras escolas de quadros [dirigentes]: a subordinação da aprendizagem à pressão da urgência e o enquadramento estrito e contínuo do trabalho são moldados para inculcar essa relação com a cultura, ao mesmo tempo dócil e segura, que predispõe mais ao exercício do poder do que à prática da pesquisa e que se evoca quando se fala em "cultura geral". Essa arte de mobilizar instantaneamente todos os recursos disponíveis e deles tirar o melhor proveito [...] e a segurança estatutária que acompanha esse controle compõem, sem dúvida, o primeiro escalão das "virtudes do chefe" que são sancionadas e consagradas por todas as grandes escolas e que predispõem, na verdade, mais aos cálculos pragmáticos e disciplinados da decisão resoluta do que às audácias e rupturas da pesquisa científica e artística (Bourdieu, 1989, p. 118).

Mas não é apenas à prática insubordinada da pesquisa - predominante no polo acadêmico-científico da universidade - que a formação das escolas de elite, enquanto escolas de poder, se opõe. É também às formações técnicas, voltadas à "pura execução", uma vez que:

[...] a "cultura geral" é também essa relação confiante com os saberes especializados, particulares, parcelados, e com seus detentores, que dão o sentimento de ter tido acesso ao fundamento verdadeiro, à ciência, matriz de todas as técnicas particulares, deixadas aos simples agentes de execução (Bourdieu, 1989, p. 119).

Essa posição ambígua, de especialistas que desprezam a especialização, de cientistas que não podem se entregar às aventuras e desventuras da ciência, de técnicos que devem se opor à pura técnica, é o que define a relação igualmente ambivalente que esses futuros "líderes" estabelecem com a cultura. Desse modo, eles buscam se colocar ao lado "da inteligência, do pensamento, do desinteresse, do refinamento, da cultura" para se distinguir do homem comum, do "povo" (Bourdieu, 1989, p. 120), mas reorientam-se para o lado "da força, da ação, da 
virilidade, do pragmatismo, da eficácia" quando precisam se opor "aos intelectuais e artistas" e, sobretudo, “à definição propriamente intelectual da inteligência, como espírito crítico, distanciado do poder ou, simplesmente, como erudição, scholarship, pesquisa" (Bourdieu, 1989, p. 120).

Isso demonstra que é sobretudo na relação de distinção com outros polos do campo universitário, especificamente, o polo científico e o polo da formação técnica, que a ação pedagógica das escolas superiores de elite releva o seu sentido social mais profundo, enquanto um "estilo de trabalho", um "sistema de disposições" e "de visões de mundo" (1989, p. 132). No caso francês, a principal oposição que Bourdieu analisa é a que separa as escolas de poder e as escolas intelectuais, em especial, as grandes escolas de preparação científica e as faculdades de filosofia, ciências e letras, que recusam os princípios essenciais da ação pedagógica inerente à formação de quadros dirigentes, valorizando a lassidão curricular, a autonomia do aluno, a liberdade acadêmica, o tempo livre para o estudo e para a pesquisa desinteressada e o inconformismo intelectual e social (cf. 1989, p. 139ss). Essa relação de "desinteresse", "liberdade" e "autonomia" em relação ao conhecimento e à produção de conhecimento é radicalmente oposta às "práticas ascéticas" que marcam, como foi dito, a organização institucional e a ação pedagógica das escolas de elite, em que prevalece o regime de urgência que induz a uma relação pragmática e instrumental com o conhecimento ${ }^{222}$. Mas esses princípios pedagógicos revelam, justamente nessa contraposição, seu sentido mais profundo, de preparação de homens para o exercício do poder, o que pressupõe, acima de tudo, a disposição para controlar a si mesmo:

Em outras palavras, se todas as escolas destinadas a reproduzir a "elite" têm em comum a imposição de práticas ascéticas, a começar pelos exercícios que são necessários para adquirir uma cultura formal afastada da vida, é sem dúvida porque, como observa Durkheim, o asceticismo "é parte integrante de toda a cultura humana"

\footnotetext{
${ }^{222}$ Empiricamente, Bourdieu baseia tal constatação nos dados de um questionário aplicado entre alunos do ensino superior francês. $\mathrm{O}$ autor observa que entre os alunos que se preparam para as grandes escolas, $65 \%$ destacam a sua "aptidão para trabalhar rápido" enquanto apenas $15 \%$ enfatizam a sua habilidade para "trabalhar em profundidade", relação diametralmente oposta às frequências observadas entre os alunos das faculdades de ciências e letras (Bourdieu, 1989, p. 124).
} 
e que os que pretendem assegurar-se o monopólio do sagrado e da excelência humana devem passar por essa "escola necessária em que o homem se forma e se molda, onde ele adquire as qualidades do desinteresse e da dureza" próprias para afirmar seu controle sobre a natureza, quer dizer - mas não é mais Durkheim que o diz - sobre os que não sabem controlar a própria natureza. "Eu sou mestre de mim mesmo, assim como do universo", profissão de fé ética em que o dominante justifica a seus próprios olhos sua dominação, invocando sua capacidade natural de dominar a própria natureza. A aquisição da cultura é, nesse sentido, um ritual de luto, destinado a matar o velho homem, nesse caso, o jovem homem, com suas paixões, seus desejos, em uma palavra, a sua natureza (Bourdieu, 1989, p. 154).

É tendo em vista o sentido social mais profundo das práticas ascéticas que fundamentam a preparação das elites para o exercício de um poder que pressupõe o controle de si, dos outros e da natureza, que Bourdieu mostra ser possível compreender porque justamente os alunos de elite são submetidos aos tratamentos mais "rudes" (cf. Bourdieu, 1989, p. 154), impostos por uma dura disciplina física e mental, de exercícios acadêmicos, práticos e esportivos intensos e contínuos que, na verdade, se revela um fim em si mesmo, uma forma de fomentar "a pura obediência à regra" (cf. 1989, p. 154). O pressuposto pedagógico revelado por Bourdieu não deixa de ser aparentemente paradoxal: os que se destinam a mandar devem aprender, antes de tudo, a obedecer. Mas a obediência, nesse caso, é principalmente em relação à própria ordem social que estabelece as hierarquias estruturais que precisam ser reconhecidas como legítimas, não só pelos dominados mas também pelos dominantes que, justamente pela sua posição privilegiada na estrutura social, reúnem possibilidades mais concretas e imediatas de transformação dessa mesma ordem. A questão essencial, portanto, é sobre as condições sociais de manutenção da ordem social, pergunta que marca parte importante da teoria social crítica na segunda metade do século XX.

É por isso que, ao analisar a formação escolar e social dos dominantes como um elemento constitutivo da conservação e da reprodução das relações sociais, Bourdieu insiste tanto no fato de que a "consagração das elites" é, antes de tudo, um processo de conversão, o que justifica a mobilização constante, pelo autor, de termos originalmente religiosos como “ordenação", “consagração", "participação mágica" e “difusão de crenças". Nessa chave, a 
lógica inerente à formação de elite, de uma "concorrência permanente" que submete seus alunos à provação constante e ao esforço desmesurado, se revela essencial na conversão que faz com que os diplomados por essas escolas "se identifiquem completamente à identidade social que os consagra" (1989, p. 153). É fundamental reconhecer, portanto, que as relações sociais de dominação, inclusive as constituídas pela formação escolar diferenciada, retiram sua força não só das distâncias objetivas que estabelecem mas, sobretudo, das distâncias subjetivas que constroem pela imposição de crenças e condutas "próprias a justificar, tanto aos seus próprios olhos como dos outros, a sua distinção" (Bourdieu, 1989, p. 157).

Essa longa exposição dos capítulos de La noblesse d'état dedicados à formação escolar das elites para o exercício do poder serve de inspiração para pensar alguns aspectos do processo de socialização acadêmica inerente às escolas profissionais da USP que, como foi dito, ocupam um lugar estruturalmente homólogo às grandes escolas francesas analisadas por Bourdieu ${ }^{223}$.É esse movimento essencial que define o segundo item deste capítulo, dedicado à análise do processo de socialização do polo dominante da USP, voltado, como veremos, à formação de elites dirigentes do estado de São Paulo.

\section{A produção social de elites dirigentes: socialização e homogeneidade do polo dominante da USP}

É bastante consolidada, na literatura sobre as origens históricas da USP, a interpretação de que o projeto de criação de uma universidade em São Paulo nos anos 1930 tinha, como

\footnotetext{
${ }^{223}$ Essa homologia estrutural não significa, de modo algum, dizer que os dois sistemas de ensino superior são idênticos. Além de todas as diferenças de ordem legal e institucional, o ensino superior francês, do ponto de vista social, distingue-se radicalmente do brasileiro pela existência de setores da aristocracia cultural que faz com que a oposição entre o que autor denomina de capital cultural e capital econômico seja essencial, ou seja, o autor fala, o tempo todo, em setores culturalmente dominantes e economicamente dominados e setores economicamente dominantes mas culturalmente dominados. No caso do Brasil em geral e da USP em particular, não foi possível encontrar essa oposição tão clara, tanto que, como visto, o polo dominante da USP, formado pelas Faculdades profissionais tradicionais, se distingue por ser econômica e culturalmente dominante, entendendo cultura, nesse caso, no sentido restrito de escolaridade dos pais.
} 
objetivo principal, a formação de uma elite dirigente capaz de reconduzir os paulistas às posições dominantes no aparelho de Estado, particularmente no plano federal, por meio da construção de uma nova "liderança" intelectual (cf. Antunha, 1971; Cardoso, 1982; Fétizon, 1986; Hey \& Catani, 2006; Limongi, 1989; Miceli, 1989; Motoyama, 2006). O fim da hegemonia dos bacharéis da Faculdade de Direito de São Paulo na presidência da República pela ascensão de Getúlio Vargas ao poder e a debacle contundente das tropas de São Paulo na "Revolução" Constitucionalista de 1932 foram o motivo explícito para a consolidação do projeto de criação de um novo centro de formação superior no estado. Como bem observa Sergio Miceli: "os dirigentes da oligarquia paulista atribuem as derrotas sofridas em 1930 e 1932 à carência de quadros especializados e, escorados nesse diagnóstico, passam a condicionar suas pretensões de mando no plano federal à criação de novos instrumentos de luta" (2001, p. 101). Esses "novos instrumentos de luta" foram, justamente, as instituições de ensino e pesquisa, em especial a Universidade de São Paulo e a sua Faculdade de Filosofia, Ciências e Letras. Sob esse ponto de vista, torna-se compreensível que a USP tenha criado um brasão d'armas. Se tratava, de fato, de uma instituição "armada" e disposta a "vencer pela ciência", tal como foi subscrito ao seu brasão.

Pelo projeto original da USP, a FFCL, como nova unidade, além de constituir-se idealmente como centro da universidade, deveria substituir as faculdades preexistentes, em especial, as de Direito, Medicina e Engenharia, na formação e socialização de uma nova elite dirigente, distinta por sua base científica (cf. Cardoso, 1982; Limongi, 1989). No entanto, se a função original da Faculdade de Filosofia, Ciências e Letras, que está na raiz do atual polo acadêmico-científico da USP, era formar as elites do estado de São Paulo (Limongi, 1989) transformando-as em “quadros dirigentes" (Hey \& Catani, 2006), esse objetivo não se cumpriu como esperado. A falência do projeto original da USP se deu pela confluência de dois fatores principais. Primeiro, a formação eminentemente acadêmica e científica oferecida pelos cursos 
da FFCL ministrados por professores europeus, treinados e socializados em padrões rigorosos de trabalho intelectual, não atraiu alunos da elite paulista e paulistana, a quem se destinavam, originalmente, os cursos da nova universidade. Consequentemente, a baixa procura pelos novos cursos obrigou a FFCL a se abrir para setores sociais até então excluídos do ensino superior, em especial imigrantes e mulheres, através do comissionamento de professores e professoras da escola pública e de uma política mais ou menos sistemática de bolsas de estudo para os interessados nas novas carreiras (cf. Blay \& Lang, 2004; Limongi, 1989). Essa relativa democratização social subverteu completamente o projeto original da FFCL e da USP. Nesse sentido, depois de analisar a composição social das primeiras turmas da FFCL e das turmas de direito e engenharia da Faculdade de Direito e da Escola Politécnica, Fernando Limongi conclui:

\begin{abstract}
Se a FFCL foi imaginada por seus mentores como se destinando às elites de São Paulo, independentemente do objetivo confiado a seus formandos, os dados já apresentados, por preliminares que sejam, indicam que a face da faculdade criada foi rapidamente assumindo feições muito diferentes das imaginadas. Os alunos que se encaminhavam para a FFCL e para as faculdades profissionais já existentes tinham perfis sociais claramente distintos. Para estas últimas, encaminhavam-se os filhos da elite, os possuidores de diplomas secundários obtidos nas melhores escolas, aqueles que saíam diretamente do secundário para a faculdade. Alunos deste tipo são raros na FFCL. Se o objetivo da FFCL era se constituir em uma alternativa às escolas existentes para formar "elites", se, portanto, pretendia concorrer com estas, os anos iniciais da vida da FFCL acumulam sinais do fracasso das suas pretensões. Os filhos da elite continuaram a se encaminhar para as mesmas faculdades que seus pais e estas faculdades continuaram a ser responsáveis pela formação das "elites" (Limongi, 1989, p. 166).
\end{abstract}

Assim, desde a sua fundação, a USP vive fraturada pelo valor diferencial dos seus diplomas, que determina a concorrência igualmente diferenciada pelos seus cursos e unidades e, através dela, a composição social distinta do seu alunado. Mas o que é determinante nesse processo é que, por seguir formando os setores sociais de elite, as escolas profissionais tradicionais da USP hegemonizaram, também, a função de formação dos quadros dirigentes, destinados a exercer posições de comando, coordenação e controle no plano econômico, administrativo, político e até mesmo cultural. Por outro lado, a FFCL, incorporando setores sociais menos privilegiados, tornou-se um espaço sobretudo de formação de acadêmicos e 
cientistas, que protagonizaram, ao longo do século $\mathrm{XX}$, as disputas pela institucionalização da ciência brasileira como um espaço relativamente autônomo, como o comprova a atuação da FFCL na construção da SBPC, da Fapesp e de outros órgãos de fomento à ciência como o CNPq (cf. Fernandes, 1990; Schwartzman, 1979).

Da perspectiva teórica que é adotada nesta tese, para se compreender por que as faculdades profissionais da USP permaneceram responsáveis pela formação de quadros para atuar sobretudo fora da universidade enquanto a Faculdade de Filosofia, Ciências e Letras, desdobrada depois de 1969 em diferentes institutos e faculdades, assumiu a função de formar cientistas e professores para atuar particularmente dentro de instituições acadêmicas, sejam elas escolas, faculdades ou universidades, é impensável sem a compreensão dos setores sociais a que se destinam. Nesse sentido, o presente trabalho reconhece a validade de interpretações sociológicas sobre a história da USP, da sua Faculdade de Filosofia, Ciências e Letras e das faculdades profissionais tradicionais fundadas antes dela, que apontam a importância dessa mesma relação entre a origem social e o destino ocupacional do seu alunado (cf. Adorno, 1988; Cardoso, 1982; Fernandes, 1975 e 1984; Hey \& Catani, 2006; Limongi, 1989; Miceli, 1989; Mota, 2005; Nadai, 1981; Schwarcz, 1993).

Portanto, pensando especificamente nas faculdades profissionais tradicionais da USP, é possível dizer que, enquanto "escolas de elite”, elas são, igualmente, “escolas de poder”. Desse modo, assumem um lugar estruturalmente homólogo ao polo dominante das grandes écoles francesas que, segundo Pierre Bourdieu, também se constituem simultaneamente como escolas de elite e de poder porque são, justamente, "instituições encarregadas de conferir uma formação e uma consagração àqueles que são chamados a entrar no campo do poder, de onde, na maioria das vezes, já provêm" (1989, p. 109). É à luz dessa homologia que vamos analisar o processo de socialização no interior de três escolas icônicas do polo profissional tradicional da 
universidade: a Faculdade de Direito, a Escola Politécnica e a Faculdade de Medicina, formadas antes da USP.

\subsection{A "imensa e poderosa família" das arcadas: socialização na Faculdade de Direito da USP}

A mais antiga e tradicional de todas as escolas profissionais da USP, a Faculdade de Direito do Largo São Francisco, foi concebida explicitamente para operar como uma "escola de poder" voltada à formação das elites brasileiras. No contexto pós-colonial, o desejo de afirmação da autonomia política e cultural do novo país, bem como a necessidade prática de constituir as estruturas jurídico-administrativas do aparelho de Estado $^{224}$, levou à criação, em 1827, da Academia de Direito de Olinda ${ }^{225}$, voltada às elites do norte e nordeste, e da Academia de Direito de São Paulo, aberta sobretudo às elites do sul, sudeste e centro-oeste ${ }^{226}$, as quais se mantiveram, durante todo o Império, como a principal referência do ensino superior brasileiro.

Em seu trabalho sobre o ensino jurídico no Brasil, Venancio Filho apresenta todo um quadro que nos permite esboçar os padrões gerais de socialização que marcaram, historicamente, os cursos jurídicos no país, e em São Paulo particularmente. Segundo o autor, o traço essencial dos cursos de direito no século XIX era a "má qualidade do ensino", que já aparecia "logo nos primeiros anos", levando o governo a fazer advertências públicas "sobre a

\footnotetext{
${ }^{224}$ Segundo Venancio Filho, o despreparo das elites políticas nacionais no âmbito jurídico ficou explícito na Constituinte de 1823 quando "com exceção de três ou quatro deputados que revelaram alguma familiaridade com as instituições jurídicas [...], a maioria só inculcou manter relações assíduas com os clássicos de Roma. Sabiam de cor o seu Virgílio ou o seu Lucrécio mas em assuntos jurídicos, não eram dos mais firmes, nem das mais substanciosas as suas noções" (Venancio Filho, 2004, p. 15).

${ }^{225}$ Fundada originalmente em Olinda, a Academia de Direito pernambucana foi transferida para Recife em 1854 (cf. Schwarcz, 1993, p. 146; Venancio Filho, 2004, p. 68).

${ }^{226}$ A localização dos cursos jurídicos no Brasil gerou enorme polêmica porque cada deputado reivindicava a Faculdade para a sua província, mas a posição de se criar uma faculdade no nordeste, Olinda no caso, e em São Paulo prevaleceu, a lei para a criação dos cursos jurídicos no Brasil foi aprovada e a lei final sancionada por D. Pedro I em 11 de agosto de 1827. A lei que cria os cursos jurídicos no Brasil foi transcrita na íntegra por Venancio Filho (cf. 2004, p. 28-9).
} 
incúria e desleixo de alguns lentes" (Venancio Filho, 2004, p. 49). Ao que tudo indica, os professores que compuseram o corpo docente das duas academias não possuíam uma formação muito especializada, padecendo, com raras exceções, de deficiências importantes. Do ponto de vista do ensino, as aulas eram diárias e as provas, orais e semanais, o que instituiu uma rotina relativamente sistemática de avaliações. No entanto, a comparação entre os estudantes ingressantes e os formados nos primeiros anos de funcionamento da escola ${ }^{227}$ sugere que a aprovação ao longo do curso era quase automática e a sua seletividade, extremamente alta (cf. Venancio Filho, 2004, p. 49ss). Essa alta taxa de aprovação se relaciona diretamente à cultura estudantil vigente nas acadêmicas de direito do século XIX, de não aceitação das avaliações rigorosas, sobretudo as com reprovação. Nesse sentido, em um relatório de 1836 sobre o quadro de "indisciplina" do curso de direito de Olinda, é possível observar em que termos se dava essa recusa de toda e qualquer forma de avaliação efetiva:

\begin{abstract}
Estudantes vadios e mal-educados (que nunca faltam em corporação tão numerosa), vendo os lentes, que além de pobres, não os podem chamar a seus deveres, pouco ou nada respeitam, e era uma coisa muito originária e comezinha, desde a criação desta Academia, ouvir-se todos os dias este ou aquele estudante dizer em público que daria uma bofetada, uma facada, etc. ao lente que ousasse deitar-lhe um "R"; e o mais é que o medo de tais ameaças tem concorrido, em grande parte, para serem aprovados [..] (2004, p. 54).
\end{abstract}

Além desse exemplo, que aponta para a importância da hierarquia entre pobres e ricos que opunha alunos e professores do curso, o autor dá outros que demonstram o quanto o ambiente das Academias de Direito de Olinda e São Paulo era marcado por relações de caráter violento. Assim, além de brigas entre os próprios professores, existem relatos de tensões e agressões entre os próprios estudantes e entre os estudantes e os professores (cf. Venancio Filho, 2004, p. 47ss). Tudo isso levou, ao longo do século XIX, a uma proliferação de códigos de conduta, decretos e reformas que proibiam "injúrias, ameaças ou violências de qualquer

\footnotetext{
${ }^{227}$ Dos 33 alunos aprovados no curso de direito de São Paulo, 27 se formaram em 1832. Em Recife, dos 41 alunos que ingressaram em Recife, 41 se formaram quatro anos depois, embora não exatamente os mesmos (cf. Venancio Filho, 2004, p. 52-3)
} 
natureza" dentro e fora da sala de aula (cf. Venancio Filho, 2004, p.56). Dentre essas, a reforma mais importante foi a de 1854, que impôs regras para garantir a assiduidade dos professores, a frequência obrigatória e o cumprimento estrito de códigos disciplinares que previam até mesmo o encarceramento dos estudantes que "perturbassem a ordem escolar" (Venancio Filho, 2004, p. 66ss). Todo esse rigor, no entanto, não durou muito, em especial no que tange à obrigatoriedade da presença em sala de aula. Isso porque, em 1879, a chamada Reforma do Ensino Livre, de inspiração positivista, eliminou a obrigatoriedade da frequência escolar, liberalizou o ingresso no ensino superior e a abertura de novos cursos, reinstaurando o que muitos consideravam uma "lassidão" acadêmica e disciplinar (Venancio Filho, 2004, p. 75ss).

Todo esse quadro contribui para mostrar que o essencial do ensino jurídico, durante todo o período imperial e republicano, não foi o ensino, mas sim a "vida acadêmica" pautada justamente no isolamento e na homogeneidade do corpo estudantil. Vale a pena acompanhar, dessa perspectiva, o depoimento de um estudante da Academia de Direito de Olinda que descreve como era essa vida estudantil dos futuros bacharéis:

\footnotetext{
A nossa vida em Olinda era completamente escolástica. Concorria para isso a isolação [sic] da velha cidade, limitada em número de estudantes, sem recursos nem distrações. [...] Socialmente, as ideias, os hábitos e o espírito da corporação formavam para os acadêmicos uma existência à parte. Dominávamos completamente a cidade a título de corpo acadêmico (Venancio Filho, 2004, p. 57).
}

Na Academia de Direito de São Paulo, conhecida no século XIX como "a cidade acadêmica", a situação não era muito distinta, com a existência de uma intensa vida acadêmicoestudantil que determinou o que viria a ser chamado, pelos próprios estudantes, de "espírito das arcadas". Para exemplificar esse ambiente, Venancio Filho mobiliza o exemplo de Ruy Barbosa que "ao chegar em São Paulo para cursar o quarto ano, em 1864, escreve a seu primo Albino José de Oliveira, [para dizer que está] 'engolfado na vida acadêmica"'. Ainda segundo o autor, parece ser a caracterização de 'vida acadêmica' a melhor descrição do ambiente dos cursos 
jurídicos e das atividades que desempenhavam os estudantes nos cinco anos que eram, por assim dizer, o cursus honorum da vida política do século XIX (Venancio Filho, 2004, p. 130).

O fato de se constituir como um curso de política rendeu à Academia de São Paulo, no século XIX, o carinhoso apelido de "antessala do parlamento" até porque, desde os seus primeiros anos, ela se dedicava a formar um estudante "feito para vida exterior, para a política, destinado a ser um homem de ação, para viver em um meio que o aplaudisse e o elevasse" (Venancio Filho, 2004, p. 135). Mas essa escola de poder era, ao mesmo tempo e pour cause, uma escola de elite, o que se expressa na alta seletividade de seus estudantes, como o prova o caráter praticamente obrigatório das chamas "cartas de recomendação", de ministros ou outros ocupantes de cargos importantes do Estado brasileiro, para o ingresso nas arcadas. Por outro lado, como afirma um relato da época:

[...] sem ter cartas e recomendações de ministros, ou sem ter se servido delas, é necessário passar vigílias, renunciar a tudo quanto é divertimento, estar preocupado em todos os momentos pelos estudos, e isso só o pode fazer quem vê sua triste posição, quem reconhece ser necessário fazer semelhantes sacrifícios (cf. Venancio Filho, 2004, p. 61).

Mas esse padrão de ruptura social produzido pela necessidade de se dedicar aos estudos, que Bourdieu descreve como um isolamento seletivo baseado em práticas ascéticas, não era, no entanto, a única forma de ruptura social promovida pela Academia de Direito de São Paulo como um pressuposto para a formação de um esprit de corps específico. Igualmente importante era a boemia, experienciada como uma "vida fictícia", que passava pelas repúblicas 228

\footnotetext{
${ }^{228}$ No Brasil, as casas estudantis ganharam o nome de "repúblicas" durante o Império porque, em tese, elas se organizavam internamente de modo "democrático", com seus coabitantes votando democraticamente a organização interna da casa num prenúncio da forma de governo que defendiam para o país, a república (cf. Venancio Filho, 2004, p. 131-2). Não deixa de ser significativo, desse ponto de vista, que as casas estudantis recebiam o nome de "repúblicas democráticas" a despeito do fato de cada estudante manter, consigo, um escravo doméstico cedido pela família. Essa "subclasse acadêmica", formada pelos escravos, dispensava, entre si, um tratamento semelhante ao de seus "senhores-moços", tratando-se por "calouro" e "veterano" e dividindo tarefas segundo essa hierarquia. A tradição vigente na época era que, uma vez diplomado, o bacharel alforriava seu escravo como uma forma de reconhecimento e comemoração. Na perspectiva desses estudantes, a relação de hierarquia senhor/escravo poderia ser facilmente superada porque, com essa decisão, "perdia-se o escravo, mas conservava-se o amigo" (cf. Venancio Filho, 2004, p. 131-2).
} 
democráticas", pelos clubes e associações e pelas sociedades secretas e seus rituais ${ }^{229}$. É por isso que, "ser estudante de Direito era, pois, sobretudo, dedicar-se ao jornalismo, fazer literatura, especialmente a poesia, consagrar-se ao teatro, ser bom orador, participar dos grêmios literários e políticos, das sociedades secretas e das lojas maçônicas" (Venancio Filho, 2004, p. 136).

Não é difícil entender, portanto, porque o prestígio social dos bacharéis advinha "menos do curso em si, ou da profissão stricto sensu, e mais da carga simbólica e das possibilidades políticas que se apresentavam ao profissional de direito" (Schwarcz, 1993, p. 142). Ou seja, como "sinônimo de prestígio social” e "marca de poder político" (Schwarcz, 1993, p. 142), os bacharéis se tornaram a figura máxima da intelligentsia local, responsável tanto pela construção política das estruturas burocráticas do Estado brasileiro quanto pela elaboração de interpretações locais sobre o país. Assim, como resultado do projeto de “criar elites próprias de pensamento e direção política", o bacharel se converteu "no grande intelectual da sociedade local, chamando a atenção o ecletismo das ideias e o pragmatismo" da sua formação (Schwarcz, 1993, p. 142).

Em direção semelhante caminha a análise de Sérgio Adorno, ao afirmar que o essencial da preparação dos futuros bacharéis, que o sociólogo designa pela imagética expressão “aprendizes de poder”, estava para além do conteúdo jurídico ensinado, das doutrinas e teorias do direito formuladas, ou mesmo da relação didática estabelecida concretamente em sala de aula (cf. Adorno, 1988, p. 92-3). Como o autor expõe, foi sobretudo "por uma vida acadêmica agitada e controvertida" (1988, p. 94), marcada pela boemia, pela militância política, pela vida literária e associativa, pelo jornalismo estudantil e por outros expedientes não propriamente

\footnotetext{
${ }^{229}$ É bastante documentada a existência de sociedade secretas nas faculdades de direito, medicina e engenharia de São Paulo (cf. Venancio Filho, 2004, p. 150). No entanto, sem dúvida, a mais famosa e importante delas é a chamada "Bucha" que reunia os estudantes da Academia de Direito de São Paulo, em torno de rituais, auxílios e ideais liberais, republicanos e abolicionistas. Pelos trabalhos que existem, é possível dizer que a "Bucha" foi um espaço fundamental de socialização das elites políticas do Império e da República tendo passado por ela presidentes, deputados e ministros de Estado (cf. Adorno, 1988; Barbuy \& Martins, 1998; Venancio Filho, 2004).
} 
escolares, mas inerentes à vida na escola, que se deu a profissionalização desses bacharéis.

Contudo a importância da socialização externa à sala de aula na produção social dos quadros político-administrativos do Império não minimiza a centralidade da sanção escolar na legitimação social desses bacharéis. Foi a escola como instância de homogeneização social e política que permitiu manter a coesão do Estado Nacional recém-criado. Como observa Sérgio Adorno:

\begin{abstract}
As escolas de Direito foram criadas efetivamente para atender às necessidades burocráticas do Estado Nacional em emergência. Nesse sentido, privilegiou-se a formação política, em lugar de uma formação exclusivamente jurídica. Particularmente no caso de São Paulo, foram recrutados, para os mais altos cargos do Estado, bacharéis cuja carreira profissional se dispersou pelas diversas instâncias do legislativo e do executivo - como senadores, deputados, presidentes de conselho e presidentes de província, diplomatas etc. - e, em menor expressão, pela magistratura e pelo magistério. Conforme apontam os principais analistas que estudaram as relações entre os intelectuais, a elite política e o Estado brasileiro nessa sociedade pósindependência, desde cedo a educação elegeu-se como mecanismo político-ideológico de recrutamento dos agentes incumbidos da direção dos negócios públicos. Ela não apenas representou veículo de diferenciação social frente à imensa maioria da população desprovida da propriedade, pobre e analfabeta; a educação superior, além do mais, possibilitou a homogeneização política da elite, pois que as relações de parentesco e de amizade, consolidadas nos primórdios da emancipação nacional, não responderam por si só aos anseios de um país, de imensas proporções territoriais, que se pretendia manter coeso (Adorno, 1988, p. 141-2).
\end{abstract}

É impossível não reconhecer que Adorno dialoga, nessa passagem, com uma das hipóteses centrais do sociólogo José Murilo de Carvalho, para quem a experiência escolar compartilhada, proporcionada pela forte homogeneidade de trajetórias escolares das elites coloniais brasileiras, que estudavam quase sem variação no curso de direito de Coimbra, foi um dos fatores essenciais para a manutenção da integridade territorial, da coesão política e da ordem social no contexto pós-independência, sobretudo quando comparada à fragmentação, ao radicalismo e à evolução política da América espanhola (cf. Carvalho, 1987). Nessa chave, a formação das elites imperiais pelas Academias de Direito de Recife e, sobretudo, de São Paulo, no período que se segue à independência política do Brasil, pode ser considerada uma continuação da tradição colonial de forte homogeneidade de trajetórias escolares e, não por acaso, como mostra Sérgio Adorno, a organização curricular do curso de direito paulista 
mimetizou quase que integralmente ${ }^{230}$ a organização curricular do curso de direito de Coimbra (cf. Adorno, 1988, p. 95).

Mas não foi apenas no período colonial e imperial que a socialização de elites pelo ensino de direito foi central para a formação de quadros político-administrativos. Mesmo com o processo de descentralização política e com a ascensão dos militares-engenheiros e dos médicos, é amplamente reconhecido que a vida política da Primeira República foi praticamente hegemonizada por egressos da Academia de Direito de São Paulo (cf. Schwarcz, 1993; Martins \& Barbuy, 1998; Venancio Filho, 2004). De fato, desde o movimento abolicionista e a campanha pela proclamação da República os acadêmicos de São Paulo se destacavam na vida política nacional. O movimento republicano e federalista também é forjado nesses espaços, inclusive com a concorrência das já mencionadas sociedades secretas. Por isso, com o fim do período imperial, os bacharéis de São Paulo ganharam destaque no cenário político, ao mesmo tempo em que o estado de São Paulo tornava-se o centro dinâmico da economia brasileira. A importância adquirida por São Paulo e pelos paulistas, sobretudo no período republicano, se expressa na imagem que os acadêmicos do Largo São Francisco passam a projetar de si mesmos, enquanto "uma verdadeira caravana portadora de Luzes para todo o país", como é possível ler nas páginas da Revista da Faculdade de Direito de São Paulo no começo do século XX (cf. Schwarcz, 1993, p. 177). Se São Paulo deve conduzir a nação, são os portadores da "sciencia da justiça" que devem protagonizar essa liderança. Não por acaso, tal Revista especializada é fruto

[...] da associação entre a hipotética proeminência da profissão e a apregoada "superioridade inata paulista" [...] Assim, enquanto a província paulista aparece caracterizada de forma sempre diferenciada: "São Paulo mantém a aureola do seu papel civilizador como 'alma mater' do nosso ensino jurídico, de nossa sciencia da justiça”, a justiça surge como prática imparcial, responsável pelo caminho que retiraria o país da barbárie e o encaminharia rumo à civilização (Schwarcz, 1993, p. 177).

\footnotetext{
${ }^{230}$ A única inovação foi a criação de uma cadeira de Economia Política, no quinto ano, que era em geral ocupada por “docentes de notoriedade" (cf. Adorno, 1988, p. 96).
} 
Essa percepção da superioridade dos acadêmicos paulistas testemunha a força simbólica do pertencimento àquele “centro de 'eleitos' especialmente treinados para a condução dos destinos da nação" (Schwarcz, 1993, p. 178). E de fato, entre 1894, quando é eleito o bacharel paulista Prudente de Moraes, primeiro presidente civil do Brasil, até 1930, quando Getúlio Vargas assume o lugar de outro acadêmico paulista, Júlio Prestes, a Faculdade de Direito elegeu dez presidentes da República, nessa ordem: Prudente de Moraes (1894-1898); Campos Salles (1898-1902); Rodrigues Alves (1902-1906); Affonso Penna (1906-1909); Wenceslau Braz (1914-1918) Delfim Moreira (1919); Arthur Bernardes (1922-1926), Washington Luís (19261930); e Júlio Prestes (1930).

Nesse sentido, os acadêmicos da São Francisco operaram, desde o fim do período imperial, como os "artífices da nova ordem", a ordem republicana, cuja política controlavam não só através de grande parte dos presidentes eleitos, como por meio de figuras centrais da vida política brasileira, de apoio ou de oposição à ordem, como mostram Martins \& Barbuy (1998). Mesmo com a emergência de novas escolas paulistas de ensino superior durante a Primeira República, como a Escola Superior de Agricultura, a Faculdade de Odontologia, a Faculdade de Farmácia e, sobretudo, a Escola Politécnica e a Faculdade de Medicina (cf. Nadai, 1981) e a evidente nacionalização da vida política brasileira, a Faculdade de Direito de São Paulo permaneceu um espaço importante de formação política, sobretudo, como já havia apontado Sérgio Adorno, por meio de espaços de socialização que extravasam as salas de aula. Nesse sentido, formaram-se na Faculdade de Direito José Linhares, que assumiu a presidência da República entre 1945 e 1946, Nereu Ramos, que ocupou o cargo de novembro de 1955 a janeiro de 1956, e Jânio Quadros, que foi eleito Presidente da República em 1960, assumindo em 1961 e renunciando nesse mesmo ano. Isso sem contar toda a influência desses mesmos bacharéis no poder judiciário e legislativo. 
O predomínio dos "bacharéis" na vida política brasileira, no Império e na Primeira República, é um tema constante nas análises de interpretação do Brasil. Raymundo Faoro, por exemplo, fala em um "governo de bacharéis", marcado por uma lógica de autorreprodução baseada no controle sobre a educação, já que "o governo preparava escolas para criar letrados e bacharéis que se incorporavam à burocracia, regulando a educação, de acordo com seus fins" (Faoro, 1958, p. 224). Esse processo dava origem a uma verdadeira "aristocracia togada" que fazia do bacharel-jurista o "universal dos cargos" (Faoro, 1958, p. 221). Roque Spencer Maciel de Barros vai além, associando o prestígio do bacharel ao desprestígio do trabalho manual em uma sociedade escravocrata, o que fazia com que o bacharelismo fosse "nesta época final do Império, um ideal de vida. $\mathrm{O}$ trabalho manual não seduz ninguém numa sociedade escravocrata e o senhor rural já perdeu o seu prestígio aos olhos de uma juventude urbanizada que refina os seus costumes" (Barros, 1959, p. 203). O tema aparece, ainda, em outros intérpretes do Brasil como Gilberto Freire (cf. 2006), Sérgio Buarque de Holanda (cf. 1972) e Florestan Fernandes (2006).

Do começo do século XX até hoje, um dos espaços estratégicos de formação dessa elite política é, sem dúvida, o Centro Acadêmico XI de Agosto, ou simplesmente o “Onze”, fundado em 1903 como resultado "da atividade acadêmica da Faculdade durante quase todo o século XIX” (Centro Acadêmico XI de Agosto, 2003, p.8). No livro oficial de comemoração do centenário do XI de Agosto, é possível encontrar uma descrição sobre a sua fundação que é exemplar não só do lugar que o centro ocupa na sociedade brasileira, desde a sua fundação, bem como do imaginário que acompanha a sua valorização pelos próprios estudantes:

O Onze nasce cercado de grande prestígio. Para a inauguração, primeiro evento noturno da história da Faculdade, suas dependências são especialmente iluminadas, em uma época em que a luz elétrica ainda não estava difundida. Diversas autoridades compareceram e outras enviaram mensagens de apoio e congratulações [...]. A Faculdade era um celeiro de líderes. As vitoriosas campanhas pela abolição da escravatura e pela República haviam contado com a decisiva participação dos estudantes (Centro Acadêmico XI de Agosto, 2003, p. 14-5). 
No mesmo sentido, ao recontar a história do Centro, o bacharel Armando Marcondes Machado Júnior destaca que ele se constitui essencialmente, como:

[...] uma escola formadora de homens públicos no Brasil, e que tem a glória de ver saídos do seu quadro associativo três presidentes da República, onze governadores do Estado e cinco prefeitos da Capital, além de um contingente imenso que integrou e integra os poderes no plano federal, estadual e municipal, neste e demais estados (1988, p. 3).

Se Machado Júnior estivesse escrevendo não em 1988 mas em 2013, poderia incluir na sua lista pelo menos mais um Senador do estado de São Paulo, Aloysio Nunes Ferreira, eleito presidente do XI de Agosto em 1967 e senador da República por São Paulo em 2010, e mais um prefeito da capital, Fernando Haddad, eleito presidente do Onze em 1985 e prefeito da capital em 2012, o que indica que, a despeito das inúmeras mudanças sofridas tanto pela Faculdade quanto pela vida política brasileira ao longo dos anos, a escola continua sendo um centro importante de formação de lideranças políticas, sobretudo através de espaços de socialização que estão para além da grade curricular stricto sensu.

É importante notar que a importância desses espaços de socialização externos à sala de aula na Faculdade de Direito é um dos elementos que explica porque os setores mais diversos da faculdade se unem no culto quase mítico às "arcadas", como é chamado, com afeto, o pátio interno do antigo convento franciscano que permanece, até hoje, um dos principais núcleos da socialização acadêmica da faculdade. A força simbólica da imagem das "arcadas" é tão significativa que o nome tornou-se, por metonímia, sinônimo literário da Faculdade de Direito, como pode ser observado nos incontáveis - o adjetivo, nesse caso, é mais preciso do que parece - textos e livros dedicados às Histórias e tradições das Arcadas (Marchi, 2011), às Memórias das Arcadas (Grola, 2009), às Recordações das Arcadas (Lôbo, 1953), ao Espírito das Arcadas (Pati, 1950), às Arcadas na política brasileira (Dallari, 2003) e assim por diante. Ainda marcando a importância desse pátio interno, “Arcadas" é o título da Associação dos Antigos Alunos da Faculdade de Direito da Universidade de São Paulo, fundada em 1931, da Fundação 
de Apoio à Faculdade de Direito da USP, reformada em 2012, e de um dos livros mais importantes sobre a história da Faculdade de Direito da USP, escrito por Ana Luiza Martins e Heloísa Barbuy, em 1998, intitulado Arcadas: história da Faculdade de Direito da Universidade de São Paulo, Largo São Francisco (1827-1992). A importância desse "pátio interno" enquanto espaço de criação de laços, de homogeneização de hábitos, disposições, visões e concepções de mundo, em suma, de coesão social foi sintetizada de forma contundente por Goffredo da Silva Telles Júnior que no seu discurso do cinquentenário da sua turma de 1945 da Faculdade concluiu, em verso: "o que as arcadas unem a vida não separa” (Telles Júnior, 1995).

Goffredo da Silva Telles Júnior é autor, ainda, da famosa Carta aos Brasileiros, de 1977, chamada de "manifesto de repúdio da ditadura e de exaltação ao "Estado de direito já"” (cf. Telles Júnior, 2007). A carta representou um dos marcos do fortalecimento da luta contra a ditadura militar brasileira no final da década de 1970, alcançando, rapidamente, enorme repercussão pelo seu significado simbólico e político, de um manifesto assinado por nomes representativos da Faculdade de Direito da USP que, reivindicando o discurso jurídico, voltouse publicamente contra o regime justamente no aniversário de 150 anos dos cursos jurídicos no país. Os primeiros parágrafos da carta, que identifica os egressos da Faculdade de Direito como uma "poderosa família", testemunha a "força da tradição" e da "coesão" que marca, simbolicamente, o culto da Faculdade de Direito, à direita e à esquerda, como uma escola de elite e de poder (cf. Bourdieu, 1989, p. 111):

Das Arcadas do Largo de São Francisco, do Território Livre da Academia de Direito de São Paulo, dirigimos a todos os brasileiros esta Mensagem de Aniversário, que é a Proclamação de Princípios de nossas convicções políticas. Na qualidade de herdeiros do patrimônio recebido de nossos maiores, ao ensejo do Sesquicentenário dos Cursos Jurídicos no Brasil, queremos dar o testemunho, para as gerações futuras, de que os ideais do Estado de Direito, apesar da conjuntura da hora presente, vivem e atuam, hoje como ontem, no espírito vigilante da nacionalidade. Queremos dizer, sobretudo aos moços, que nós aqui estamos e aqui permanecemos, decididos, como sempre, a lutar pelos Direitos Humanos, contra a opressão de todas as ditaduras. Nossa fidelidade de hoje aos princípios basilares da Democracia é a mesma que sempre existiu à sombra das Arcadas: fidelidade indefectível e operante, que escreveu as Páginas da Liberdade, na História do Brasil. Estamos certos de que esta Carta exprime 
o pensamento comum de nossa imensa e poderosa Família formada, durante um século e meio, na Academia do Largo de São Francisco, na Faculdade de Direito de Olinda e Recife, e nas outras grandes Faculdades de Direito do Brasil. Família indestrutível, espalhada por todos os rincões da Pátria, e da qual já saíram, na vigência de Constituições democráticas, dezessete Presidentes da República (Telles Júnior, 2007).

Mas se o traço marcante do processo de socialização escolar e política dos alunos da Faculdade de Direito do Largo São Francisco é o fato dele ocorrer sobretudo nesse ambiente acadêmico mais amplo, como é possível depreender da importância que esse espaço ampliado desempenha na memória escolar dos "franciscanos"231, o mesmo não ocorre em outras unidades análogas, como a Faculdade de Medicina e a Escola Politécnica, cuja identidade é dada pelo ensino de habilidades e competências altamente especializadas.

${ }^{231}$ É interessante notar que o fato das escolas voltadas à formação de elites conseguirem produzir grupos sociais relativamente homogêneos e coesos - ou seja, corps dotados de esprit, como diz Bourdieu (1989) ou "poderosas famílias" como sintetizou a carta escrita por Goffredo Telles Júnior (2007) - se expressa claramente na existência de designações para esses conjuntos conhecidas e reconhecidas publicamente. É o caso, por exemplo, do termo "franciscanos", que designa os alunos e egressos da Faculdade de Direito, ou da palavra "politécnicos", que nomeia o alunado da Escola Politécnica, ou ainda, da expressão "filhos de Arnaldo", que identificou, por longo tempo, os alunos da Faculdade de Medicina de São Paulo. São exemplos nesse mesmo sentido o termo "esalquiano", que identifica o aluno da Esalq e, mais recentemente, o termo "feano" para nomear o estudante da FEA. Em todos esses casos, os corpos escolares se reconhecem e são reconhecidos socialmente por essas designações. Por outro lado, é bem mais raro encontrar nomeações semelhantes para as faculdades e escolas que não exercem essa mesma função, de produção de elites mais ou menos coesas voltadas ao exercício do poder (cf. Bourdieu, 1989), tais como as unidades do polo acadêmico-científico e técnico-profissional. Assim, embora todos possam ser identificados como "uspianos", designação por si mesma dotada de alta carga simbólica e amplo reconhecimento social, a mobilização de rótulos particulares para identificar os egressos dessas escolas, estruturalmente dominadas, tende a ser feita por agentes externos assumindo, em geral, sentidos pejorativos, como exemplifica a pronúncia "Fefeleche" da sigla da Faculdade de Filosofia, Letras e Ciências Humanas, criada pelo polo tradicional para marcar, depreciativamente, a suposta origem nordestina de seu alunado e o uso mais recente do termo "fefelechentos" para designar, sobretudo em blogues neoconservadores, os alunos da Faculdade. É sociologicamente fascinante como o polo dominante, investido da paulistanidade, escolhe marcar a sua diferença em relação aos alunos da FFLCH associando-os aos nordestinos, num espelhamento claro da experiência social na capital paulista. Internamente, certos setores da Faculdade adotam essa pronúncia, em um movimento de reversão do sentido pejorativo e de afirmação positiva de suas origens sociais mais populares. Paralelamente, outros setores rejeitam essa nova pronúncia mantendo o tradicional "Efe-efe-ele-ce-agá" ou tentam manter o uso do nome de "Faculdade de Filosofia", invocando uma tradição intelectual específica, fundada no reconhecimento da autoridade da competência especializada e sem ligação com o poder político. A inexistência de autodenominações consensuais e de sentido honroso incontroverso por parte das faculdades e institutos do polo acadêmico-científico e do polo técnico-profissional é apenas uma expressão visível de um traço mais profundo que é o relativo desapego ao culto da tradição que, nessas escolas, não exerce a mesma função que nas unidades profissionais tradicionais. Não por acaso, como foi dito do capítulo 1, o volume de trabalhos historiográficos sobre essas unidades dominadas é escasso, bem como a simbologia associada ao seu passado que se expressa, por exemplo, na existência de hinos, odes, marcos arquitetônicos, datas simbólicas, associações de alunos e ex-alunos, brasões, bandeiras e flâmulas. 


\section{2. "Formando engenheiros e líderes": a socialização na Escola Politécnica}

A criação da Escola Politécnica de São Paulo, no final do século XIX, foi uma reação crítica direta ao predomínio do "bacharelismo" da Faculdade de Direito, considerado pouco preparado para assumir os desafios técnicos impostos pelo processo de modernização industrial e urbana em curso na Primeira República. Nesse sentido, como observa Elza Nadai:

Se o Império criou uma burocracia centrada no bacharelismo, a República a considerava pouco eficiente para compor seu aparelho de Estado. Ela queria uma nova burocracia que se distinguisse pela competência, que se responsabilizasse pelos novos desafios que a "modernidade" traria, enfim, ansiava pela melhoria qualitativa do seu estamento burocrático (1981, p. 62).

Segundo a autora, datam da época da fundação da Escola Politécnica as contraposições simbólicas entre a imagem do bacharel em direito, "espírito jurisprudente, chicanista, trapalhão e maquiavélico", e a do politécnico, "verdadeiro, exato, justo, rigoroso", versado nos mistérios “das mais difíceis ciências” (cf. Nadai, p. 1981, p. 62-3). Para ilustrar essa disputa simbólica, a historiadora retoma artigos da época, de estilo combativo, como o publicado pelo polemista Zózimo Barros no Diário Popular em 1891:

Não é de hoje que escrevo contra o domínio quasi exclusivo de uma classe - dos bachareis em preponderancia, a qual, salvas excepções que sei respeitar, de sciencia possue o academico pergaminho oficial, que habilita annualmente, centenas e centenas de homens, a pretenderem quasi todos os empregos publicos neste paiz, desde porteiros de secretarias até diplomatas e ministros de marinha, finanças e obras públicas (Nadai, 1981, p. 63; ortografia original mantida).

A desconstrução da hegemonia simbólica dos bacharéis e a tentativa de afirmar socialmente outras formações profissionais, notadamente a formação de engenheiro, testemunha a emergência de uma nova escala de valores e imperativos práticos que legitimam o exercício do poder a partir da competência técnica (cf. Gomes et al., 1994). Atende a essa mudança cultural e objetiva, a criação de uma "escola superior de mathematicas e sciencias applicadas às artes e industrias", denominada originalmente de "Escola Polytechnica de S. 
Paulo", contando com os cursos de engenharia civil, engenharia industrial, engenharia agrícola e curso anexo de artes mecânicas (cf. São Paulo, 1893, n.p.; ortografia original mantida) ${ }^{232}$.

Quando a Escola Politécnica de São Paulo foi inaugurada, no ano seguinte, a notícia foi amplamente saudada pela imprensa paulista da época, que via na escola um espaço de formação de quadros voltados à modernização da estrutura industrial, ferroviária e comunicacional do estado de São Paulo (cf. Nadai, 1981, p. 66). Nesse sentido, o reconhecimento da validade dos cursos oferecidos pela Escola em todo território nacional ocorreu já em 1900, mesmo com a escola não respeitando o modelo oficial de ensino de engenharia, representado pela Escola Politécnica do Rio de Janeiro (cf. Nadai, 1981, p. 84).

Isso porque, se a organização curricular da Faculdade de Direito seguiu de perto a do curso de direito de Coimbra, a da Escola Politécnica de São Paulo baseou-se diretamente na escola homônima de Paris ${ }^{233}$ e na Technische Hochschule de Zurique. A valorização dessas escolas superiores de engenharia, que os idealizadores da Poli, formados no exterior e responsáveis pela elaboração do projeto da nova escola, conheciam e reconheciam como portadoras "da mais avançada concepção de escola técnica” (Nadai, 1981, p. 71), foi essencialmente o que os fez desprezar os modelos de ensino superior em engenharia até então existentes no país, em especial na Escola Politécnica do Rio de Janeiro e na Escola de Minas de Ouro Preto. O essencial do modelo europeu de escola técnica admirado pelos engenheiros paulistas era fornecer, nas palavras de Victor da Silva Freire Júnior, "um sólido preparo matemático", moldado por "trabalhos de laboratório" capazes de preparar os alunos para a "passagem difícil do abstrato ao concreto, que se apresenta em todos os problemas industriaes"

\footnotetext{
${ }^{232}$ O texto integral da lei $n^{\circ} 191 / 1983$ que "approva o regulamento que organiza a Escola Polytechnica de São Paulo" está disponível no arquivo digital da Assembleia Legislativa do Estado de São Paulo em: $<$ http://www.al.sp.gov.br/repositorio/legislacao/lei/1893/lei-191-24.08.1893.html>. Acesso em 17 de mar. 2014.

${ }^{233}$ Não é demais lembrar que a École Polytechnique de Paris, que serviu de inspiração à Escola Politécnica de São Paulo, é uma das grandes écoles analisadas por Bourdieu em La noblesse d'état (cf. 1989).
} 
(apud Nadai, 1981, p. 71-2; ortografia original mantida). A ideia essencial do projeto pedagógico original da Escola Politécnica era, portanto, submeter intensa formação matemática, dedicada ao desenvolvimento do pensamento lógico, racional e abstrato, a um treinamento laboratorial voltado ao pragmatismo necessário à resolução de problemas concretos.

Segundo José Carlos Barreto de Santana, a valorização de um ensino prático que submetesse a ciência abstrata à ciência aplicada, pela importação do modelo de ensino técnico da Technische Hochschule, foi resultado direto da passagem de Antônio Francisco de Paula Souza, principal idealizador da Escola Politécnica e seu diretor por quase um quarto de século $^{234}$, pela Eidgenössische Technische Hochschule de Zurique, entre 1861 e 1863 (cf. Santos, 1985, p. 47), e pela Technische Hochschule de Karlsruhe, na Alemanha, onde se formou em 1865 (cf. Santana, 1996, p. 312). A importação desse modelo de escola técnica superior, e o consequente predomínio de um ensino voltado à aplicação prática do conhecimento, não impediu que escola buscasse fornecer uma ampla formação geral, que superasse "a fragmentária e deficitária formação secundária do aluno" (Nadai, 1981, p. 85).

Do ponto de vista da organização pedagógica, esse projeto didático foi implementado através da criação de um curso preparatório, fundamental, ao qual se seguia o ensino propriamente superior, com uma intensa grade curricular de cinco anos baseada em física experimental, álgebra superior, geometria analítica e descritiva, trigonometria, cálculo diferencial e integral, mecânica analítica, entre outras (cf. São Paulo, 1893, n.p.). A essa grade curricular extensa e intensiva somava-se a realização de exercícios práticos, tais como "levantamentos topográficos e geodésicos, projetos de arquitetura, visitas a fábricas, a estabelecimentos agrícolas, a obras em construção tanto na capital quanto no interior" (Nadai,

\footnotetext{
${ }^{234}$ Francisco de Paula Souza dirigiu a Escola Politécnica desde a sua fundação, em 1893, até a sua morte, em 1917. Pelo caráter vitalício da sua direção é muitas vezes comparado a Arnaldo Vieira de Carvalho, o Dr. Arnaldo, que também dirigiu a Faculdade de Medicina da sua fundação, em 1912, à sua morte em 1920 (cf. Campos, 1954).
} 
1981, p. 73). Essas atividades práticas aconteciam tanto no período letivo quanto nas férias, o que indica que a socialização escolar dos alunos da Poli, pelo menos durante os seus primeiros anos de funcionamento, era marcado, nos moldes das escolas de elite francesas nas quais, de certo modo, se inspirava, por um grande volume de trabalho cotidiano e por uma convivência prolongada que não se interrompia sequer no recesso escolar.

A alta seletividade e a longa permanência no ambiente escolar, outro traço diferencial das escolas de elite, também era valorizada na Politécnica de São Paulo. Assim, se por efeito da legislação, em um primeiro momento, a escola não exigia deliberadamente a frequência às aulas e se abria a alunos ouvintes, de assiduidade fluida, logo de início a instituição criou "vários artifícios para reter o aluno e valorizar sua presença na escola: desde o oferecimento de um prêmio ao melhor aluno regularmente matriculado - bolsa de estudo no estrangeiro ou emprego em alguma repartição técnica do Estado - até critérios diferentes de avaliação escolar" (Nadai, 1981$, p. 76$)^{235}$

Ao longo dos seus primeiros anos de funcionamento, a Escola Politécnica sofreu uma série de reformas curriculares e organizacionais que buscavam ajustar o seu projeto original. Inicialmente, ela mantinha dois tipos de cursos profissionais: cursos superiores, voltados à formação em engenharia em diferentes modalidades como civil, industrial e agrícola e, posteriormente, arquitetônica e elétrica (cf. Nadai, 1981, p. 79); e cursos especiais de nível médio, dedicados à formação de “contadores, agrimensores, engenheiros geógrafos, maquinistas e mecânicos", aos quais se somou, no começo do século XX e no bojo da importação dos primeiros modelos gerenciais para o Brasil, um curso novo, voltado à formação de "condutores de trabalho" (cf. Nadai, 1981, p. 80).

\footnotetext{
235 Pela tabela de frequência dos alunos aos diferentes cursos da Poli, apresentada pela autora, é possível concluir que essas medidas obtinham sucesso porque a frequência em todos os cursos, com exceção dos engenheiros eletricistas, ficava acima de 70\% (cf. Nadai, 1981, p. 102).
} 
A reforma sofrida pela instituição em 1910, que marca a sua forma mais moderna, eliminou esses cursos especiais de nível médio, concentrando-se em formações de nível superior, voltadas aos problemas da industrialização e da urbanização. Isso significou a eliminação da formação em engenharia agrícola, uma vez que o curso já existia na Escola Superior de Agricultura. A partir dessa reforma, as formações oferecidas pela escola limitaramse aos cursos de engenharia civil, arquitetura, engenharia elétrica e engenharia química, todos de cinco anos cada.

Somou-se a essa reforma as disposições da lei Rivadavia Corrêa ${ }^{236}$, de 1911, que essencialmente eliminou os exames de admissão, gerando uma relativa massificação do nível superior no começo dos anos 1910, à qual os politécnicos, juntamente com os responsáveis por outras escolas superiores públicas de São Paulo, reagiram de imediato, procurando "brecar, de várias maneiras, o processo de expansão desmesurada do ensino, processo esse que nunca esteve nas cogitações de nenhum de seus idealizadores" (Nadai, 1981, p. 85). Nesse sentido, a Câmara dos Deputados de São Paulo, sob pressão da Escola Politécnica, da recém-criada Faculdade de Medicina e de setores da Esalq e da Faculdade de Direito, reagiu à lei federal e, contrariando-a, estabeleceu, em 1913, regras mais rígidas para o ingresso na escola, tornando o exame de admissão mais difícil e seletivo (cf. Nadai, 1981, p. 88ss).

A rigidez do processo seletivo para o ingresso na Escola Politécnica fez com que Elza Nadai, considerando a origem social dos alunos da instituição até 1930, concluísse "que o aluno que frequentou a Poli foi sobretudo aquele oriundo da classe dominante e que dificilmente elementos da classe média a ela tiveram acesso" (1981, p. 104-5). Paralelamente, considerando o destino social dos seus egressos, a autora vai concluir que eles "ocuparam posições de

\footnotetext{
${ }^{236}$ A Lei Rivadavia Corrêa, que faz referência ao seu idealizador, Rivadavia da Cunha Corrêa, é como ficou conhecida a "Lei Orgânica do Ensino Superior e do Ensino Fundamental da República" sancionada pelo Decreto de Hermes da Fonseca ${ }^{\circ} 8.659$ de 1911. O essencial da lei, de inspiração positivista, foi estabelecer a total liberdade de ensino no país, o que possibilitou a abertura de instituições de ensino superior pela iniciativa privada, além de eliminar a exigência de exames de admissão para as instituições oficiais para os diplomados de ginásios oficiais, a maioria deles elevada a essa categoria pela mesma lei (cf. Barros, 1959).
} 
destaque na sociedade civil, além de fazer o mesmo na sociedade política - seja em postos técnicos do Estado, seja em político-administrativos" (1981, p. 106).

Enquanto um espaço novo de formação de "homens de ação", inspirados no ideal pragmático e utilitário de ciência como instrumento de dominação da natureza, a Escola Politécnica se compreendia, na passagem do século XIX para o século XX, como um "agente do progresso", como fica explícito no discurso proferido pelo orador da sua primeira turma, de novo citado por Elza Nadai:

[...] a Escola Polytechnica de São Paulo será indubitavelmente um dos factores mais poderosos e efficazes do nosso progresso intellectual e material [...] são essas conquistas pacificas do homem sobre a natureza bruta que o tornaram nobre, altivo e digno do logar que occupa na série zoológica. A Escola Polytechnica foi fundada para dar à mocidade esses meios de acção, essas armas poderosas que tudo conquistam e submettem e que fazem do homem um semideus (1981, p. 110; ortografia original mantida).

Esse ideal de controle se manifestava de modo paradigmático na organização disciplinar da escola, concentrada nas mãos do seu diretor. Conforme estabelecia o seu primeiro regimento, o poder de funcionar como uma "policia no recinto do edificio do estabelecimento, procedendo pelo modo prescripto neste regulamento contra os que perturbarem a ordem, e empregando ao mesmo tempo a maior vigilancia na manutenção dos bons costumes" (São Paulo, 1893, n.p.; ortografia original mantida). No mesmo sentido, à Congregação competia "prestar todo o auxilio ao director para que se mantenha no estabelecimento um excellente regimen disciplinar e para que a policia academica seja exercida com a maxima regularidade" (São Paulo, 1893, n.p.; ortografia original mantida). O regulamento trazia, ainda, um capítulo intitulado "da policia academica", no qual se inserem vinte artigos detalhando sistematicamente o controle disciplinar, que deveria se exercer em todos os espaços acadêmicos, dentro e fora da sala de aula $^{237}$. Não por acaso, portanto, a Escola Politécnica de São Paulo foi o primeiro

\footnotetext{
${ }^{237}$ O capítulo intitulado "Da polícia acadêmica" está disponível na íntegra, juntamente com a lei nº191/1893, no arquivo digital da Assembleia Legislativa do Estado de São Paulo, em: $<$ http://www.al.sp.gov.br/repositorio/legislacao/lei/1893/lei-191-24.08.1893.html>. Acesso em 17 mar. 2014.
} 
estabelecimento de ensino superior do país a tornar o serviço militar obrigatório, negando-se a conferir grau aos alunos que não fossem reservistas (cf. Nadai, 1981, p. 99).

Por todo o exposto acima, conclui-se que a organização pedagógica da Escola Politécnica nos seus primeiros anos de funcionamento era, de certa maneira, antípoda à da Faculdade de Direito. Assim, se na primeira o traço distintivo era a valorização estrita da disciplina, inclusive militar, na segunda os "rigores legais pareciam ter pouca eficácia enquanto poder intimidativo [uma vez que] desde a fundação dos cursos jurídicos, queixavam-se as autoridades dirigentes da academia que a indisciplina turvava o aprendizado" (Adorno, 1988, p. 118). Enquanto a Escola Politécnica mantinha uma grade intensiva de ciências exatas, considerada determinante na formação dos seus estudantes, na Faculdade de Direito "parece pouco provável que a estrutura curricular tenha sido eficaz do ponto de vista pedagógico" (Adorno, 1988, p. 103). Se na escola de engenharia valorizava-se a presença exigindo assiduidade às aulas e premiando as boas notas (Nadai, 1981, p. 76), na Faculdade de Direito, "a [baixa] assiduidade do corpo docente caminhava, par a par, com a do corpo discente, mesmo porque burlar a rotina de aferição da presença constituía-se ousadia estudantil que atribuía júbilo a seu autor" (Adorno, 1988, p. 112). A despeito dessas oposições, que revelam dois estilos escolares distintos, é possível encontrar nas duas escolas princípios que demarcam seu funcionamento enquanto espaços de formação de elites para o exercício do poder, conforme analisado por Pierre Bourdieu (1989).

Em primeiro lugar, o caráter altamente seletivo do seu recrutamento que reunia, em um espaço social relativamente separado da sociedade - um "território livre", como se autodenominava a Faculdade de Direito -, um grupo socialmente homogêneo de jovens que, se reconhecendo e sendo reconhecido como um conjunto de "eleitos”, viverá um intenso e longo processo de socialização no interior dessas instituições. Esse processo tanto pode privilegiar espaços acadêmicos externos à sala de aula, onde se valoriza o inconformismo e a irreverência, 
quanto estar concentrado na situação de aprendizado propriamente dita, marcada pela valorização do rendimento e do controle estrito. Mesmo assim, o que as distingue é a produção de um grupo coeso, que se sente motivado, preparado e legitimado, justamente pela experiência vivida no interior da instituição, a exercer funções de direção no âmbito político e administrativo. A força da tradição e dos rituais de instituição - tal como expresso na importância das formaturas, das festas típicas, das associações de alunos e ex-alunos, dos discursos oficiais entre outros - testemunha esse sentido geral compartilhado.

Embora os cursos de engenharia da Escola Politécnica - assim como o de direito, da Faculdade de Direito - tenham sofrido inúmeras transformação ao longo da década, é possível identificar algumas continuidades que derivam, essencialmente, da permanência da sua função enquanto escola formadora de elites dirigentes em diferentes níveis. Nesse sentido, é significativo quem ainda hoje, no discurso oficial da escola, esteja presente o reconhecimento da função essencialmente política da formação oferecida nessa "escola de poder". Nesse sentido, no logotipo atual da escola, é possível ler a inscrição "Escola Politécnica da Universidade de São Paulo: formando engenheiros e líderes" (Escola Politécnica, 2014, n.p. $)^{238}$. Na sua página oficial, na definição do "perfil” da escola, é possível ler que:

\begin{abstract}
A Escola Politécnica da Universidade de São Paulo (Poli/USP) tem mais de um século de história, formando gerações de engenheiros que têm se destacado não só em suas especialidades profissionais, mas também na vida política do País e na administração de empresas e de órgãos públicos. Fundada em 1893, a então denominada Escola Politécnica de São Paulo foi incorporada à USP em 1934; hoje ela é referência nacional e considerada a mais completa faculdade de Engenharia da América Latina (Escola Politécnica, 2014, n.p.).
\end{abstract}

A grade curricular da Escola, embora tenha mudado significativamente, continua baseada em um primeiro ciclo, denominado hoje ciclo básico, de duração de um ano, composto por sete disciplinas no primeiro semestre e oito no segundo, o que implica a organização do

${ }^{238}$ Para mais detalhes, ver: < http://www.poli.usp.br/ >. Acesso em: 17 mar. 2014. 
curso em tempo integral. As disciplinas são, basicamente, de ciências exatas, com destaque, hoje como nos seus primeiros anos de funcionamento, para o ensino de matemática e física, expresso em disciplinas como álgebra linear I e II, cálculo diferencial e integral I e II, cálculo numérico, física geral e experimental para a engenharia I e II, e laboratórios de física I e II. O ciclo básico de engenharia, que confere acesso às dezessete modalidades de cursos de engenharia da Poli, é considerado a fase mais difícil do curso, quando ocorre a maior parte das desistências e trancamentos, dado o enorme volume de conteúdo e a intensa rotina de avaliações $^{239}$. As notas do ciclo básico são a referência elementar para uma classificação interna, que franqueia o acesso aos diversos cursos da Poli. Por isso, a regra do ciclo básico é a competição e o trabalho intensivo e repetitivo realizado em curtos espaços de tempo, exatamente como Bourdieu observa nas escolas de elite francesa. Nesse sentido, é interessante acompanhar a descrição de um estudante que, tendo desistido do curso da Poli, resolveu explicitar, em um jornal de grande circulação de São Paulo, as suas razões:

\begin{abstract}
Em 2002, comecei a cursar engenharia na Escola Politécnica da Universidade de São Paulo. Tinha passado os últimos dois anos do colegial obcecado por notas e vestibular. O colégio onde fiz o ensino médio, o Agostiniano Mendel, estimulava os alunos a estudarem para as provas através de rankings de classificação, que serviam para definir em qual sala cada um ficaria. Entrei completamente no jogo. Raramente conversava com amigos fora do colégio, saía pouco, dificilmente pesquisava assuntos não relacionados ao vestibular, sentia culpa por estar perdendo um tempo precioso. [...]. Na Poli, as semanas de prova guiavam as vidas dos alunos. Todos entravam no ciclo básico e, de acordo com a sua classificação, escolhiam as especialidades. Ou seja, a competitividade do colegial seguia. Eu nunca tinha tirado uma nota vermelha na vida até a primeira prova de álgebra linear. Percebi que jamais seria um dos primeiros do ranking e me sentia cada vez mais desmotivado. As coletâneas de provas de anos anteriores, vendidas no xerox do grêmio, eram muito disseminadas. Estudávamos através delas, muitas vezes sem saber de onde surgiam fórmulas e técnicas. O objetivo era passar nas provas, não aprender. Era tão grande a pressão por notas, e as disciplinas tão desconexas, que trapacear era algo natural (Crema, 2012, p. 3).
\end{abstract}

Mas não é apenas a rotina intensiva de trabalho, que estimula um domínio rigoroso do tempo e a competição entrepares, que favorece as analogias entre a organização da Escola

\footnotetext{
${ }^{239}$ É comum encontrar nos "guias de estudante" e de "carreira" destinados aos alunos que pretendem cursar a Poli advertências sobre a extrema dificuldade dessa primeira fase. Ver, por exemplo: <http://www.guiadacarreira.com.br/artigos/educacao/escola-politecnica-usp/>. Acesso em: 21 de abr. 2014.
} 
Politécnica e das escolas francesas de formação de elites voltadas ao exercício do poder. A centralidade das práticas esportivas, que é um outro traço marcante da formação de elite para o exercício do controle e do autocontrole, também é um elemento importante da socialização dos politécnicos da USP. Nesse sentido, ao apresentar "a vida acadêmica da Poli" na sua página oficial, a escola coloca em lugar de destaque a A.A.A.P - Associação Atlética Acadêmica Politécnica - que, desde 1955, representa oficialmente a escola em competições e campeonatos esportivos. A página oficial da Atlética da Poli, por sua vez, traz, como mensagem de abertura, a foto de uma pequena carta, escrita em próprio punho e datada de 19 de janeiro de 1993, em que o então senador Mario Covas, ex-aluno da Escola, afirma:

Na mesma medida em que a Escola Politécnica forma o profissional, é o esporte que desenvolve no homem os principais aspectos do seu caráter. É onde se aprende a ganhar e perder, é onde se pratica, o tempo todo, a solidariedade, é onde se cultua o respeito pelo oposto. A AAAP faz isso: ela ajuda a melhorar o ser humano. Por isso ela é indispensável e útil (AAAP, 2013).

Ao reivindicar para o esporte a missão de desenvolver "os principais aspectos do caráter do homem", a AAAP expressa o significado social das práticas esportivas nesse contexto de socialização de elites. É bastante emblemático, dessa perspectiva, que a principal competição disputada pela Atlética da Poli, o Interusp, que em 2014 completa 30 anos de existência, só reúna o núcleo duro das escolas profissionais tradicionais da USP, quais sejam: a Faculdade de Direito, a Escola Politécnica, a Faculdade de Economia e Administração, a Faculdade de Medicina de Ribeirão Preto, a Faculdade de Odontologia, a Faculdade de Ciências Farmacêuticas, a Escola Superior de Agricultura e a Faculdade de Medicina de São Paulo. Excluídas da competição mais prestigiosa da USP, algumas unidades do polo acadêmicocientífico e as unidades profissionais menos tradicionais de São Paulo criaram uma competição paralela que denominaram BIFE, porque fundada pelo Instituto de Biologia, Instituto de Matemática e Estatística, Faculdade de Arquitetura e Urbanismo e Escola de Comunicação e Artes. Hoje a competição reúne pelo menos dez unidades, são elas: além das quatro fundadoras, 
a Faculdade de Filosofia, Letras e Ciências Humanas, o Instituto de Física, a Faculdade de Medicina Veterinária e Zootecnia, o Instituto de Psicologia e o Instituto de Química. É a estrutura geral da USP se reproduzindo na organização das suas competições esportivas ${ }^{240}$.

Ainda no que concerne às práticas esportivas, é pertinente registrar que, das vinte e oito edições do Interusp realizadas até 2012, sete foram vencidas pela Escola Politécnica e vinte e uma pela Faculdade de Medicina de São Paulo $^{241}$, que é considerada, então, nesse âmbito, a maior "potência" das competições esportivas da USP desde a sua consolidação e expansão a partir dos anos $1960^{242}$. É sobre ela que voltamos, agora, o nosso olhar.

\section{3. "Uma classe poderosa, preparada e coesa": a socialização na Faculdade de Medicina}

A Faculdade de Medicina e Cirurgia de São Paulo, hoje denominada Faculdade de Medicina da Universidade de São Paulo, compõe, ao lado da Escola Politécnica, da Escola Superior de Agricultura Luiz de Queiroz, da Faculdade de Odontologia e da Faculdade de Farmácia da USP, o conjunto de faculdades profissionais fundadas pelo estado de São Paulo na Primeira República, como parte de um amplo projeto político de consolidação e organização no ensino superior paulista (cf. Nadai, 1981, p. 248). Essas instituições, somadas à Faculdade

\footnotetext{
${ }^{240}$ A presente pesquisa não se aprofundou no estudo das Atléticas e das competições esportivas da USP, mas é importante notar que se trata de um campo de estudos ainda não explorado pela sociologia e que, assim como os trotes e as festas, constitui um dos espaços essenciais de socialização dessas elites.

${ }^{241}$ A edição de 2013, realizada na cidade de São Roque, terminou sem um vencedor oficial, segundo informações do Jornal do Campus Ver: <http://www.jornaldocampus.usp.br/index.php/tag/interusp/ > .

${ }^{242}$ Embora não existam muitos estudos sobre o tema, é possível observar que a proliferação das Associações Atléticas foi incentivada durante a ditadura militar como uma forma de deslegitimar o movimento estudantil de caráter "ideológico" (cf. Cunha, 2007c, p. 54ss). Nesse sentido, a famosa Lei Suplicy Lacerda, Lei n ${ }^{\circ}$.464/1964, que "dispõe sobre os órgãos de representação dos estudantes", vedou aos órgãos de representação estudantil realizar "qualquer ação, manifestação ou propaganda de caráter político-partidário, bem como incitar, promover ou apoiar as ausências coletivas aos trabalhos escolares" (Brasil, 1964, n.p.). Paralelamente, era autorizada a organização de atividades de "caráter cívico, social, cultural, técnico, artístico e desportivo visando à complementação e ao aprimoramento da formação universitária" (Brasil, 1964, n.p.). Além disso, uma das leis complementares à Lei da Reforma Universitária de 1968, o decreto $n^{\circ} 705$ de 25 de julho de 1969 , tornou "obrigatória a prática da educação física em todos os níveis e ramos de escolarização, com predominância esportiva no ensino superior" (Brasil, 1969, p. 136).
} 
de Direito, de origem imperial, constituem o núcleo duro das escolas de elite da USP, voltadas à formação de profissionais altamente valorizados e que recrutam seus alunos entre os setores mais favorecidos da população de São Paulo e, em menor medida, do resto do país. A definição da Faculdade de Medicina como uma "escola de poder" pode parecer estranha ao senso comum dado que, enquanto um grupo profissional que se volta à questão da saúde individual, os médicos teriam uma atuação mais restrita do que os engenheiros e advogados, engajados diretamente em práticas de intervenção social, necessárias à constituição do Estado moderno. No entanto, uma rápida reconstrução da história da medicina no Brasil desmente tal perspectiva.

Os dois primeiros cursos de medicina no país, com sede no Rio de Janeiro e em Salvador $^{243}$, surgiram em 1808 , no bojo de uma série de transformações sociais, culturais e políticas associadas à chegada da família real ao Brasil. Até então, a inexistência quase absoluta de médicos na colônia ${ }^{244}$ favorecia a difusão de práticas tradicionais não autorizadas pelo poder estabelecido, tais como herbalistas de origem africana ou indígena, curandeiros, parteiras, sangradores, cirurgiões-barbeiros, boticários, dentre outras ocupações não oficializadas que constituíam a regra da prática médica no país (cf. Schwarcz, 1993, p. 192-3). Mesmo os "médicos práticos" ou "protomédicos" que conseguiam a licença para atuar sob a fiscalização dos cirurgiões-mores do Reino "não passavam de iniciantes, geralmente mestiços, analfabetos e cuja atuação não levava a qualquer posição de prestígio social” (Schwarcz, 1993, p. 192).

\footnotetext{
${ }^{243}$ Segundo Luiz Antonio Cunha, o ensino médico surgiu no país em 1808, com a criação das cadeiras de Anatomia e Cirurgia no Rio de Janeiro e na Bahia, que foram os embriões dos cursos de medicina, cirurgia, obstetrícia, farmácia e odontologia no país. Essas formações foram oferecidas inicialmente nas chamadas Academias de Medicina e Cirurgia. Em 1832, uma primeira reforma transformou as Academias da Bahia e do Rio de Janeiro em Faculdades de Medicina e Cirurgia sediadas nas respectivas cidades. Por pressão da recém-criada Sociedade de Medicina, inspirada na sua congênere de Paris, foi se elevando o grau de exigência dos exames de admissão e ampliando os currículos, sobretudo para o curso de medicina. Em 1884, uma nova reforma caminhou no mesmo sentido, com as Faculdades de Medicina autorizadas a oferecer cursos de ciências médicas e cirúrgicas, de 8 anos, Farmácia, de 3 anos, Obstetrícia e Ginecologia, de 2 anos, e Odontologia, de 3 anos. Nesse momento, final do século XIX, já existiam cursos de farmácia separados das faculdades de medicina, concorrendo diretamente com elas (cf. Cunha, 2007a, p. 91ss).

${ }^{244}$ Lilia Schwarcz relata que em 1789, uma carta do vice-rei do Brasil, Luiz de Vasconcelos, à metrópole alegava só existirem, em toda a colônia, quatro médicos credenciados (cf. Schwarcz, 1993, p. 192-3)
} 
Essa posição essencialmente dominada da medicina na estrutura ocupacional do Brasil colônia vai mudar radicalmente no período imperial, a partir da afirmação do monopólio profissional da prática médica e da medicina como mecanismo de intervenção social.

Durante todo o Império, continuaram existindo no Brasil apenas os dois cursos de medicina criados em 1808. No entanto, em 1832, por pressão da recém-criada Sociedade de Medicina do Rio de Janeiro, oficializada em 1835 como Academia Imperial de Medicina, esses dois cursos isolados se transformaram nas Faculdades de Medicina e Cirurgia do Rio de Janeiro e da Bahia. Essa mesma reforma assegurou "o monopólio legal de prestação de serviços médicos" para os portadores de diploma em medicina, concedido exclusivamente por essas duas faculdades (Coelho, 1999, p. 124). Assim, a famosa Lei de 03 de outubro de 1832, que criou as faculdades de medicina no país, definiu o monopólio profissional sobre a prática médica nos seguintes termos:

Art. 12. Os que obtiverem o titulo de Doutor em Medicina pelas Faculdades do Brazil poderão exercer em todo o Imperio indistictamente qualquer dos ramos da arte de curar. Art. 13. Sem titulo conferido, ou approvado pelas ditas Faculdades, ninguem poderá curar, ter botica, ou partejar, emquanto disposições particulares, que regulem o exercicio da Medicina, não providenciarem a este respeito. Não são comprehendidos nesta disposição os Medicos, Cirurgiões, Boticarios, e Parteiras, legalmente autorizados em virtude de Lei anterior (Brasil, 1832, n.p.; ortografia original mantida)

A monopolização da "arte de curar" pelos médicos formados em instituições oficiais ocorreu no momento em que, segundo Edmundo Coelho, os saberes médicos ainda possuíam uma base cognitiva relativamente frágil ${ }^{245}$. Segundo o autor, "sem referências mais sólidas, cada médico improvisava seu próprio método alterando-o ao sabor de observações superficiais e pouco sistemáticas, aplicando tratamentos inspirados pelo mais raso empirismo" (1999, p.

\footnotetext{
${ }^{245}$ No seu trabalho sobre as profissões imperiais - medicina, engenharia e direito -, Edmundo Coelho apresenta uma descrição detalhada das práticas médicas defendidas pelos membros da Academia Imperial de Medicina na sua publicação oficial, mostrando a fragilidade da sua base empírica e teórica - um pretendia tratar todas as doenças cuja manifestação era recorrente com o mesmo remédio que descrevia como "vencedor da periodicidade", outro atribua o tétano à variação entre calor e frio, outro, ainda, recomendava a aplicação de sanguessugas a bebês recémnascidos que apresentassem febre. Ao fim, o autor conclui: "Examinando tais matérias nos Annaes de Medicina Brasiliense, órgão oficial da Academia Imperial, o leitor terminará com a desconfortável impressão de que os médicos - os de maior cultura e prestígio - não tinham a mais longínqua noção do que faziam, procedendo com uma absurda dose de arrogância e irresponsabilidade" (Coelho, 1999, p. 108-9).
} 
107). A fragilidade do conhecimento médico não impediu, no entanto, a realização dos “ambiciosos projetos profissionais" desse setor privilegiado da elite imperial, que se organizou de modo sistemático para garantir o monopólio do tratamento de doenças e enfermidades aos portadores do diploma de "doutor" em medicina (cf. Coelho, 1999, p. 106ss).

Embora tenha sido a medicina individual o foco principal da disputa pela afirmação do monopólio do saber médico, uma vez que era sobre ela que incidia a maior concorrência de outros saberes e práticas não regulamentados, exercidos por botânicos, homeopatas, farmacêuticos, dentistas, curandeiros e parteiras, Edmundo Coelho é preciso ao reconhecer que a pressão pela profissionalização da medicina partiu, na verdade, de um outro campo de conhecimento médico, representado pela medicina social. Esse outro campo era formado, sobretudo, pelos higienistas e sanitaristas que, contando com bases científicas mais sólidas, a microbiologia, e um circuito de conhecimento mais internacionalizado, tendo como centro irradiador Paris, reunia cada vez mais os médicos provenientes das famílias mais ricas e influentes, muitos formados no exterior, que começavam a enxergar na profissão médica uma carreira de prestígio (cf. Coelho, 1999, p. 105ss). Mas para afirmar o prestígio da medicina, essa nova elite profissional se afirmava como "científica" e buscava se distinguir tanto dos "médicos práticos", como os obstetras, cirurgiões e homeopatas, quanto dos profissionais auxiliares, como os boticários e os farmacêuticos, para não falar naqueles que eles rotulavam de "charlatões", ou seja, as parteiras, curandeiros, herbalistas, barbeiros e sangradores que eram considerados, então, um caso de polícia. Foi justamente essa nova elite médica, ligada às práticas que resultavam da microbiologia (cf. Almeida, 2003), que liderou a organização da Sociedade de Medicina do Rio de Janeiro, inspirada na Académie de Medicine de Paris e, a partir dela, pressionou o Estado para acabar com a "anarquia" que reinava sobre as práticas médicas e "que deixava em mãos leigas o que cabe à competência de profissionais" (Coelho, 1999, p. 119). Foi justamente a Sociedade de Medicina que redigiu a lei de 1832, que instituiu 
o monopólio profissional na área médica, pressionando o Estado a aprová-la, pelos canais de acesso ao poder franqueados aos membros da elite imperial.

A atração que a medicina social passou a exercer sobre certos setores da elite imperial não pode ser interpretada sem se levar em consideração o novo lugar, social e político, que o conhecimento médico passou a ocupar a partir da sua transformação em prática de intervenção e controle social, em um processo denominado, pela literatura inspirada nos trabalhos de Michel Foucault (cf. 1988), de "medicalização da sociedade" (cf. Almeida, 2003; Machado et al., 1978; Mota, 2005; Nadai, 1981; Schwarcz, 1993). Em termos gerais, esse processo pode ser descrito, como:

[...] a penetração da medicina na sociedade que incorpora o meio urbano como alvo da reflexão e da prática médicas, e a situação da medicina como apoio científico indispensável ao exercício de poder do Estado. [...] A transformação do objeto da medicina significa fundamentalmente um deslocamento da doença para a saúde. Não é mais a ação direta e lacunar sobre a doença como assistência isolada e específica que move o projeto médico. O 'médico político' deve dificultar ou impedir o aparecimento da doença, lutando, ao nível das suas causas, contra tudo o que na sociedade pode intervir no bem-estar físico e moral (Machado et al., 1978, p.155).

A transição da ênfase de uma medicina individual para uma medicina social implicou uma ampliação significativa das práticas médicas, que deixaram de ser um conjunto de saberes que orientam apenas técnicas isoladas e pontuais de intervenção sobre o doente, para se tornar um dispositivo de saber-poder voltado à intervenção social necessária à promoção da saúde pública. Até porque "se a sociedade, por sua desorganização e mal funcionamento, é causa de doença, a medicina deve refletir e atuar sobre seus componentes naturais, urbanísticos e institucionais visando a neutralizar todo perigo possível” (Machado et al., 1978, p.155), seja esse perigo de natureza física ou moral, natural ou política, individual ou social. Essas mudanças, fortalecidas pelo impacto teórico e prático da microbiologia, marcam a transformação da medicina em uma estratégia de poder fundamental à ação do Estado no começo dos processos de urbanização e industrialização, pressupondo tanto o controle das populações, com a disciplina de corpos e hábitos (cf. Foucault, 1988; 2004; 2010), quanto dos 
territórios urbanos, com as intervenções necessárias à higienização, gentrificação e urbanização das cidades (cf. Chalhoub, 2001; Carvalho, 1987; Mota, 2005; Rago, 1987). Com a emergência desse novo lugar político e social do saber médico, os seus portadores passaram "a reivindicar a instituição da 'medicina política', com a sua 'polícia médica', e com esta, uma parcela do poder do estado" (Coelho, 1999, p. 112). De fato, é possível notar que “o higienismo abria [...] o caminho para cargos na administração pública, desejáveis não apenas como fonte de renda mas também como uma espécie de participação vicária no poder” (Coelho, 1999, p. 112).

Mas é fundamental reconhecer que essa forma de intervenção política foi marcada de modo decisivo pela estrutura social em que se desenvolveu. Como instrumento monopolizado pela elite branca que conseguia acessar os bancos dos cursos médicos superiores, que agora detinham o monopólio profissional sobre as práticas de intervenção corporal, higiênica e sanitárias, a medicina social tornou-se, acima de tudo, um instrumento de controle social. Foi por isso que o foco da ação sanitarista voltou-se principalmente à enorme população afrodescendente de escravos e ex-escravos que constituía a principal fonte da miscigenação nacional considerada, a partir da influência das perspectivas eugenistas no século XIX, a principal doença da nação (cf. Schwarcz, 1993). Ou, ainda, aos trabalhadores imigrantes igualmente pobres que se concentravam em regiões circunscritas dos centros urbanos, tais como os cortiços, favelas e bairros operários que, considerados "insalubres" ou "anti-higiênicos", tornaram-se alvo de constante intervenção (cf. Almeida, 2003; Mota, 2005). Tanto os escravos e ex-escravos quanto, mais tarde, o proletariado imigrante eram considerados setores sociais que precisavam ser mantidos sob estrito controle por representarem uma ameaça à ordem pública pelas suas formas de auto-organização pouco compreendidas e aceitas, sejam elas as manifestações religiosas e culturais dos afrodescendentes, sistematicamente perseguidas a partir do final do século XIX, sejam as primeiras organizações operárias, anarquistas e socialistas igualmente perseguidas a partir do começo do século XX. 
Nesse sentido, embora as primeiras iniciativas sanitaristas e higienistas tenham se iniciado no período imperial, o poder político da medicina se fortaleceu sobretudo a partir da Proclamação da República e da intensificação dos processos de industrialização e urbanização que pressupunham uma atuação mais sistemática das formas de controle e organização da população. No entanto, embora a afirmação das práticas médico-sanitárias seja muitas vezes atribuída aos "processos modernizadores republicanos em contraposição à inércia dos tempos imperiais" (Almeida, 2003, p. 48), a historiografia mais contemporânea tem procurado escapar de uma visão tão estanque desses dois períodos da história brasileira (cf. Almeida, 2003; Mota, 2005). E isso não só porque a medicina no período imperial também foi marcada por relativa diversidade de saberes e práticas que incluíam, como visto, a microbiologia e a concepção bacteriológica (cf. Almeida, 2003, p. 48ss), mas sobretudo pelo fato de que a elite médica foi parte integrante do movimento republicano e, com a vitória política deste, passou a assumir uma posição de destaque na nova ordem, atribuindo a si mesmo um sentido essencialmente positivo, de força "modernizadora".

Nessa chave, assumem novo significado as observações de José Murilo de Carvalho, ao enfatizar as raízes elitistas do movimento republicano, sobre a sistemática oposição entre os estudantes de medicina e a população negra da Bahia e do Rio de Janeiro. Segundo ele, mesmo que os republicanos tenham procurado restringir os negros que recusavam a República "a capoeiras baderneiros manipulados pela polícia" (cf. Carvalho, 1987, p. 30), o essencial é que:

\footnotetext{
Permanece o fato de que os republicanos não conseguiram a adesão dos setores pobres da população, sobretudo dos negros. O próprio Silva Jardim, ao acompanhar o Conde d'Eu em sua viagem ao norte do país em 1889, experimentaria mais uma vez a ira da população negra. Por ele e pela República, manifestaram-se apenas os estudantes da Faculdade de Medicina local (Carvalho, 1987, p. 30; grifo meu).
}

A oposição entre a população pobre, particularmente os afrodescendentes, e a elite intelectualizada republicana, especialmente os médicos, manteve-se depois da Proclamação da República, com o movimento de perseguição aos capoeiras, aos bicheiros, aos cortiços e às 
favelas, ganhando expressão marcante na chamada "Revolta da Vacina" que, ainda segundo Carvalho, pode ter sido "em parte alicerçada na antipatia pelo novo regime" (Carvalho, 1987, p. 31). Essa oposição foi particularmente forte, ainda, no âmbito municipal, cujo governo, transformado em mera instância administrativa, foi esvaziado da sua função política e representativa. Ainda segundo Carvalho,

[...] o fato era agravado pela frequente nomeação de prefeitos e chefes de polícia totalmente alheios à vida da cidade. Abria-se, então, do lado do governo, o caminho para o autoritarismo, que na melhor das hipóteses poderia ser um autoritarismo ilustrado, baseado na competência, real ou presumida, de técnicos. Não por acaso, muitos dos chefes de governo municipal no período em foco foram médicos ou engenheiros (1987, p. 35; grifo meu).

A transformação da medicina e da engenharia em práticas de intervenção técnico-sociais e, consequentemente, em fonte de legitimação da atuação do Estado, fortaleceu a disputa entre entres esses grupos profissionais, ciosos do seu conhecimento científico e especializado, e os bacharéis, orgulhosos da sua formação mais humanista e eclética. No entanto, pela força que o processo de medicalização da sociedade alcançou, especialmente com a difusão da perspectiva eugenista no final do século XIX (cf. Schwarcz, 1993), foi sobretudo pelos médicos que a hegemonia dos bacharéis passou a ser ameaçada (cf. Adorno, 1988). Lilia Schwarcz, que se dedicou à análise do impacto do eugenismo em diferentes áreas intelectuais e profissionais, descreve esse conflito entre médicos e bacharéis como uma disputa pela liderança do processo de construção nacional, operado durante o período republicado. Reivindicando para si as posições de liderança e concepção, cada grupo profissional atribuía ao outro uma função relativamente rebaixada de assessoria técnica aos processos essenciais de condução e concepção da "nação", o que mostra o papel estrutural desempenhado pela oposição cognitiva entre os ideais de concepção/execução, de formação geral/formação técnica, que ainda hoje marcam a USP:

Quando contrastado com as faculdades de direito, com a fala do bacharel, o discurso médico ganha mais outra conotação. Trata-se agora de perceber a existência de uma querela - mais ou menos formalizada - acerca das áreas de saber, projetos profissionais ou mesmo formas diversas de conceber o país. Na ótica médica o 
objetivo era curar um país enfermo, tendo como base um projeto médico-eugênico, amputando a parte gangrenada do país, para que restasse uma população de possível "perfectibilidade". O "homem de direito" seria um assessor que colocaria sob forma de lei o que o perito médico já diagnosticara e com o tempo traria de tratar. Nas faculdades de direito, as posições praticamente se invertem: cabia ao jurista codificar e dar uma forma unificada ao país, sendo o médico entendido como um técnico que auxiliaria no bom desempenho desses profissionais das leis (Schwarcz, 1993, p. 190).

Foi nesse contexto histórico, de consolidação do monopólio profissional sobre as práticas médicas e de fortalecimento da medicina como mecanismo de intervenção política e social que ganhou força o projeto de criação de uma faculdade de medicina em São Paulo após a Proclamação da República. Como procurou mostrar Elza Nadai, a descentralização política promovida no período republicano favoreceu a constituição de um projeto paulista de ensino superior que determinou a fundação de um conjunto de faculdades profissionais entre 1889 e 1930 inspiradas por uma ideologia do progresso que ressaltava a importância de colocar o conhecimento "a serviço da modernização" (cf. Nadai, 1981, p. 52). Nesse processo, paradoxalmente, a Faculdade de Medicina e Cirurgia foi a primeira das instituições de ensino superior a ser criada no estado, mas uma das últimas a ser efetivamente implementada.

De fato, em 1891, logo após a aprovação da Constituição Estadual de São Paulo, o então governador da província, Américo Brasiliense, professor catedrático da Faculdade de Direito, sancionou a Lei n¹9/1891 que criava a "Academia de Medicina, Cirurgia e Farmácia de São Paulo”. Essa lei, no entanto, não foi implementada imediatamente porque, dias depois da sua sanção, mudanças no cenário político nacional levaram o bacharel de São Paulo ao Supremo Tribunal Federal, marcando uma descontinuidade importante no governo paulista. Assim, embora tivesse sido legalmente criada nos primeiros anos da República, a Faculdade de Medicina e Cirurgia de São Paulo só foi implementada, de fato, vinte e um anos depois, em 1912, quando um outro catedrático da Faculdade de Direito, Francisco de Paula Rodrigues Alves, enquanto "presidente de São Paulo", sancionou a Lei 1.357/1912, estabelecendo finalmente a "Academia de Medicina, Cirurgia e Farmácia de São Paulo", agora denominada 
"Faculdade de Medicina e Cirurgia de São Paulo". Nesse interregno, inúmeros projetos de criação de um curso de medicina no estado se sucederam no debate parlamentar e público, resultando, inclusive, na fundação de uma universidade privada, denominada Universidade de São Paulo, em 1911, tendo como núcleo central um curso de medicina (cf. Mota, 2004).

A explicação para esse longo intervalo entre a criação legal e a implementação efetiva da Faculdade de Medicina de São Paulo, bem como para a proliferação de projetos de criação de um curso médico no estado, reside em uma disputa de fundo que, já visível no final do século XIX, viria a marcar o campo da política educacional paulista ao longo de todo século XX, com repercussões ainda atuais. Essa disputa opunha aqueles que consideravam que a educação deveria ser atribuição do Estado em todos os níveis, inclusive no superior, aos que, por outro lado, defendiam liberar a instrução superior à iniciativa privada, concentrando os esforços estatais apenas na educação básica (cf. Barros, 1959; Nadai, 1981). Essa contraposição entre ensino superior público e privado manifestou-se, nesse primeiro momento, na oposição entre a reivindicação do ensino oficial, organizado e financiado pelo Estado, e a defesa da liberdade de ensino, que favorecia os empreendimentos privados no âmbito educacional. Mais do que qualquer outra formação profissional, a medicina paulista permaneceu refém dessa oposição. E isso porque a existência de uma rede relativamente consolidada de serviços médico-sanitários no Estado ${ }^{246}$ fez com que a instalação de um curso médico fosse considerada menos prioritária do que a criação de cursos como engenharia e agronomia, mais ligados às necessidades econômicas e à ideologia do progresso da burguesia paulista (cf. Nadai, 1981, p.272). Essa resistência dos parlamentares paulistas em priorizar a formação médica foi potencializada pelo

\footnotetext{
${ }^{246}$ Desde o período imperial, São Paulo formava médicos, oriundos sobretudo da elite cafeeira do interior do Estado, na Faculdade de Medicina do Rio de Janeiro, não raro com estudos no exterior. É o caso, por exemplo, de Arnaldo Vieira de Carvalho, oriundo de uma família de cafeicultores de Campinas. Ou de Emílio Ribas, natural de Pindamonhangaba, herdeiro de uma fazenda de café. Ou ainda de Ovídio Pires de Campos, substituto de Arnaldo Vieira de Carvalho na direção da Faculdade de Medicina, que também era oriundo de uma família de cafeicultores.
} 
fato do corpo médico paulista não estar, na época, unido em torno de projeto comum de curso médico (cf. Nadai, 1981).

Essa divisão se explicitou de modo marcante em 1911 quando, aproveitando a liberalização do ensino promovida pela Lei Rivadavia Corrêa, um grupo liderado por um médico positivista ${ }^{247}$, Eduardo Augusto Guimarães, criou a Universidade de São Paulo (cf Mota, 2004; Nadai, 1981). Essa primeira USP era uma instituição privada de ensino superior que oferecia, já no seu primeiro ano de funcionamento, cursos de direito, medicina, engenharia, belas-artes, comércio, odontologia e farmácia (cf. Mota, 2004, p.214). A formação em medicina, originando-se de um curso pré-existente de farmácia, já era então a carreira mais concorrida e recebeu, em 1911, 376 alunos de primeiro ano (cf. Nadai, 1981, p. 269). Essa instituição, até pelo caráter audacioso da ideia de criar de uma universidade que, como instituição privada, não estivesse sob controle direto do Estado, provocou uma forte reação dos críticos da liberdade de ensino. Paralelamente, reagiram também os médicos, sobretudo os melhores posicionados socialmente que se ligavam, portanto, às associações profissionais que consideravam uma afronta submeter o currículo de medicina a um conselho formado por farmacêuticos. Segundo um texto irônico da época, citado por André Mota, os médicos não aceitavam que o corpo docente do curso de medicina fosse “"...] escolhido, escovado, preparado e diplomado por um comitê de farmacêuticos oficiosos e intrometidos em seara alheia" (Mota, 2004, p. 215). Também repudiavam, igualmente, a rapidez com que a nova instituição foi idealizada e implementada, o que resultava, segundo eles, em um curso pouco estruturado e, sobretudo, pouco representativo das visões "da classe":

Rapidamente, expeditamente, sem entraves, fez-se a Faculdade do pé para a mão, sem conferências fastidiosas com as corporações que representam a intelectualidade médica, sem enervantes observações e empeços [sic], sem necessidade mesmo de entente com os Hospitais, de cujo serviço dependem todas as Faculdades Médicas (Bacellar apud Mota, 2004, p. 215).

\footnotetext{
${ }^{247}$ Como aponta Elza Nadai (cf. 1981), os positivistas eram os principais defensores da liberdade de ensino e da organização de escolas pela iniciativa privada.
} 
Diante da necessidade de reagir à faculdade privada de medicina de 1911, o corpo médico de São Paulo também criou a sua faculdade "rapidamente, expeditamente e sem entraves”. Já em 1912, liderados por Arnaldo Vieira de Carvalho, “crítico severo da liberdade de ensino" (Nadai, 1981, p. 270), e por intervenção de outro crítico da Lei Rivadavia Corrêa, o presidente estadual Rodrigues Alves, criou-se a Faculdade de Medicina e Cirurgia de São Paulo que, como instituição oficial e pública, portanto, de maior prestígio, inviabilizou a existência da primeira USP, com o seu curso privado de medicina (cf. Mota, 2004).

É interessante notar que, reagindo à permissividade da Lei Rivadavia Corrêa, que possibilitou a criação de instituições privadas como a Universidade de São Paulo de 1911, os fundadores da Faculdade de Medicina de São Paulo passaram a buscar soluções para aspectos da lei que limitavam o seu projeto, de fornecer um ensino de "alto nível". O principal empecilho, para os idealizadores da nova Faculdade, era a já referida eliminação da obrigatoriedade do exame de admissão que, segundo o próprio Rodrigues Alves, possibilitou o ingresso de "moços não sabendo ler corretamente o português, escrevendo uma linguagem inçada de solecismos imperdoáveis; nas demais matérias, a mesma ignorância” (Nadai, 1981, p. 287).

A solução para contornar esse problema foi mobilizar um rigoroso e complicado sistema de avaliação, inspirado totalmente no da Escola Politécnica (cf. Nadai, 1981, p. 284), somado à exigência estrita de frequência obrigatória e um código disciplinar rigoroso. Juntos, esses dispositivos de ação pedagógica e disciplinar resultaram em "porcentagens elevadíssimas de reprovações" (cf. Nadai, 1981, p. 288) que contribuíram para desempenhar a função dos exames de admissão de "garantir a formação de classes homogêneas e de bom rendimento" (Nadai, 1981, p.286, grifo meu $)^{248}$.

\footnotetext{
${ }^{248}$ Segundo dados apresentados por Elza Nadai, considerando-se a primeira turma, dos 180 ingressantes no começo de 1913, sobraram apenas setenta e oito, uma vez que cinquenta foram eliminados por falta e cinquenta e dois por decisão do então diretor Arnaldo Vieira de Carvalho que insistiu em punir atos de indisciplina, mesmo sob protestos legais (cf. 1981, p. 291).
} 
Uma versão interessante desse processo de seleção e eliminação interno à escola encontra-se em Ernesto de Souza Campos que, enquanto egresso da Escola Politécnica, compôs a primeira turma da Faculdade de Medicina e Cirurgia de São Paulo, marcada por intensos protestos contra os rigorosos expedientes de avaliação e, consequentemente, eliminação (cf. Campos, 1954, p. 354ss). O autor narra em detalhes essa história, descrevendo a sua participação sempre na segunda pessoa do plural:

\begin{abstract}
O professor Xavier, recebendo as provas, estudou-as minuciosamente. Não lhe foi difícil separar o joio do trigo. E o joio era muito mais abundante do que o trigo; este, aliás, bem raro. Resultou dessa circunstância que a grande massa da turma ficou classificada abaixo da nota cinco. [...] Proclamados os resultados daqueles dois exames, romperam reclamações. Edmundo Xavier ficou firme. [...] Dr. Arnaldo sustentou-o neste propósito. Rompeu então o tumulto. Sucediam-se vaias que impediam o professor Xavier de ministrar as aulas. [...] Nesse momento, Dr. Arnaldo chamou-nos especialmente, em seu gabinete, para mostrar provas de má qualidade. Teve este gesto, porque havíamos conquistado a nota máxima naquele conjunto tão maltratado. Vimos, de fato, várias provas inconcebíveis, em que até o nosso idioma era horrivelmente maltratado [...]. Foram inúteis todos os esforços para recolher ao aprisco as ovelhas desgarradas. Arnaldo viu-se obrigado a fechar a escola. A clínica do Dr. Xavier foi depredada. Certa vez em que o professor referido se encontrava no prédio da Escola de Comércio, não podia sair diante de ameaças de agressão. Arnaldo, informado pelo telefone, apareceu sozinho, penetrou no Hall e expulsou os turbulentos. E saiu acompanhando o Dr. Xavier, sem que os estudantes que se achavam no Largo de São Francisco dissessem uma só palavra, tal a atmosfera de respeito que emanava da sua pessoa. [...] Infelizmente, na eliminação, foram sacrificados alguns bons elementos. Era impossível, porém, um critério seguro, tal a confusão que se estabeleceu [...] Por outro lado, a sua descrição mostra como foram árduos os primeiros momentos da nova instituição de ensino. Felizmente, aí estava, com as responsabilidades de direção, a alma forte e inatacável de Arnaldo Vieira de Carvalho (Campos, 1954, p. 352-4).
\end{abstract}

A frequente observação sobre o domínio da língua portuguesa sugere que os principais atingidos por essa seleção rigorosa foram os filhos de imigrantes. E, de fato, o resultado desse processo de seleção - que sob o véu dos critérios meritocráticos, oculta uma seleção econômica e social - foi não só a drástica redução das turmas como a sua progressiva homogeneização. Assim, dos cento e oitenta ingressantes da primeira turma de 1913, apenas vinte se formaram em 1919, sendo apenas duas mulheres. Além disso, nessa primeira turma, "não aparecia nenhum [formando] que ostentasse sobrenome de origem estrangeira" (Nadai, 1981, p. 299). A partir da segunda, turma, porém, novos sobrenomes, inclusive estrangeiros, da burguesia 
industrial paulista começaram a aparecer, timidamente, entre os egressos (cf. Nadai, 1981, p. 299).

A partir da sua consolidação institucional, no final da década de 1910, a Faculdade de Medicina passou a estabelecer um intenso contato, sob a forma de convênios, com a Fundação Rockfeller, conforme já analisado. Esses convênios resultaram na ampliação da estrutura física do ensino médico paulista, com a criação de um Instituto de Higiene anexo à Faculdade, que hoje compõe a Faculdade de Saúde Pública da USP, a reforma da sede da Faculdade, a implementação do Hospital das Clínicas e, na década de 1940, a fundação de uma nova Faculdade de Medicina em Ribeirão Preto, também ligada à USP (cf. Campos, 1954; Marinho, 2001; Nadai, 1981). No entanto, embora a ênfase das análises sobre a atuação da Fundação Rockfeller recaia sobre a criação dessa infraestrutura física, tão ou mais importantes foram as mudanças científico-pedagógicas implementadas por pressão da fundação.

Dentre essas mudanças destaca-se, em primeiro lugar, a hierarquização das disciplinas entre "fundamentais" e "complementares", sendo as primeiras as que pressupunham a atuação de professores em tempo integral e as segundas, voltadas para a clínica, seguiam abertas a professores de tempo parcial. Essa oposição, que expressa a oposição fundamental observada no âmbito da universidade como um todo entre um polo profissional tradicional e um polo científico, foi de enorme importância na história da faculdade e está na raiz tanto da crise vivida durante os anos 1960, com a pressão por reformas internas à Faculdade dando origem a perseguições de natureza política (cf. Adusp, 2004; Cunha, 2007c; Motta, 2014), quanto da criação do Instituto de Ciências Biomédicas pela reforma universitária de 1969, que reuniu as disciplinas básicas dos cursos de medicina e de outras profissões da saúde. Além dessa divisão entre disciplinas fundamentais e complementares, a Fundação Rockfeller impôs, também, um exame vestibular baseado não só em conhecimentos biológicos, mas também "em física, 
química, história natural, além da aprovação nas matérias que constituíam o curso ginasial do Colégio Pedro II" (Nadai, 1981, p. 304).

Foi a partir de todo esse processo que a Faculdade de Medicina se afirmou como uma "escola de elite", no duplo sentido do termo, de uma escola voltada à preparação de profissionais que passam a ocupar posições de poder, e de uma instituição dedicada à formação de alunos oriundos das elites, sobretudo, de São Paulo ${ }^{249}$. Essas duas dimensões são, da perspectiva da teoria da reprodução, inseparáveis, porque a transformação da medicina em uma profissão de elite resultou da e na exclusão tanto de outros grupos profissionais, através da afirmação do monopólio profissional, quanto de outros setores sociais, através de diversos mecanismos de exclusão internos ao curso. Esse processo é igualmente inseparável da afirmação da medicina como um mecanismo de intervenção social essencialmente ligado à atuação do Estado em um contexto de industrialização, urbanização e migração que pressupõe transformar a população em problema e objeto de governo (cf. Foucault, 2004). É nessa chave que se pode interpretar o significativo discurso do Dr. Arnaldo Vieira de Carvalho, fundador e diretor da Faculdade de Medicina, em 1918 - não por acaso, na inauguração do curso de Clinica Gynecologica que constitui, na sua origem, um saber masculino de intervenção sobre o corpo feminino -, marcando a força das estruturas sociais essenciais de dominação:

Também vós, meus jovens colegas, constituis uma classe poderosa, quando preparada e coesa. No actual momento, tendes sobre todas as outras classes nacioanes uma imensa vantagem; o domínio médico, vosso domínio, portanto, é ardentemente desejado pela população do Brasil. Pois, de outra forma se não compreende o facto de - na terra de Santa Cruz - scientistas e ignorantes, mestres e discipulos, letrados e analphabetos, politicos e indiferentes, proclamarem a invalidez nacional, classificarem a patria de immenso hospital, de trecho pestilento da America, cujo saneamento urgente imploram afflictos, como se pedissem vida e pão para filhos famintos. Todos reduzem nossos variados problemas nacionaes a uma só coisa - ao restalecimento da saúde da nação (Carvalho, 1921, p. 253; ortografia original mantida). ${ }^{250}$

\footnotetext{
${ }^{249}$ Não custa mencionar que, assim como a eleição para a prefeitura de São Paulo de 2012 opôs ex-alunos da Faculdade de Direito e da Escola Politécnica, ao que tudo indica, a eleição para o governo do Estado de São Paulo de 2014 será polarizada por dois egressos da Faculdade de Medicina da USP: Alexandre Padilha, do Partido dos Trabalhadores, que formado na Unicamp realizou sua pós-graduação da FMUSP, e Geraldo Alckmin, graduado por essa mesma escola.

${ }^{250}$ Esta citação aparece também na abertura do capítulo de Elza Nadai sobre a fundação da Faculdade de Medicina
} 
A preocupação com a preparação e a coesão dos estudantes de medicina marca de modo decisivo a organização e o desenvolvimento dos cursos médicos que, até hoje, estão entre os mais valorizados e, portanto, mais concorridos e elitizados cursos de graduação da USP. Nesse sentido, embora a formação médica tenha evoluído de modo radical ao longo de todo o século XX e começo do XXI, com a emergência de novos saberes, novas práticas e principalmente novas tecnologias de intervenção, organização e diagnóstico, resultando na crescente especialização desse campo profissional, do ponto de vista estrutural, é possível propor uma linha de continuidade entre o significado social da homogeneidade construída pelos mecanismos de avaliação e seleção implementados pela Faculdade nas primeiras décadas do século XX e, atualmente, pelo moderno vestibular da Fuvest. Não por acaso, ainda hoje, a faculdade segue incorporando a "sólida formação geral" e a "formação básica profunda" como um dos seus objetivos pedagógicos principais, distinguindo-se, ou procurando distinguir-se, da formação médica especializada que estaria, da perspectiva estrutural, vetada às "escolas de elite".

Partindo dessa análise da história e dos padrões de socialização das três principais faculdades profissionais tradicionais da USP, é possível sustentar a hipótese de que se tratam, essencialmente, de escolas de elite que são, ao mesmo tempo, escolas de poder na medida em que se voltam para setores social e economicamente privilegiados da população paulista para prepará-los para posições de poder das quais, em geral, já provêm por seus laços familiares (cf. Bourdieu, 1989). Esse processo de reprodução social de elites dirigentes por meio do ensino superior é inseparável do processo de tecnicização da política através da afirmação de novos saberes de intervenção que, enquanto dispositivos de saber-poder, transformam, especialmente por meio da ação de instituições estatais, os objetos e espaços sobre os quais incidem. É exatamente esse o caso do saber gerencial de inspiração econômica que, como visto no segundo

e Cirurgia (cf. Nadai, 1981, p. 247). 
capítulo desta tese, se afirmou como um novo regime de verdade, munido de dispositivos de intervenção social, através de processos de circulação internacional de conhecimentos e de elites portadoras desses conhecimentos. Não é o caso de repetir toda a análise do processo pelo qual o saber gerencial assumiu, juntamente com a economia, "uma situação privilegiada no seio das elites político-administrativas" (Motta, 1994, p. 82) no Brasil a partir da segunda metade do século XX. Importa apenas destacar que é possível observar uma linha de continuidade entre os saberes jurídicos, hegemônicos no Império, o saber especializado da engenharia e da medicina, na Primeira República, e o novo saber econômico-gerencial que, desde a segunda metade do século XX, tornou-se social e politicamente predominante no aparelho de Estado, produzindo efeitos sobre a organização das universidades. A emergência, difusão e afirmação desse novo conhecimento contribuiu para fortalecer o polo profissional tradicional da universidade não apenas no Brasil como em outros países como França, Canadá e Estados Unidos (cf. Bourdieu, 1989; Freitag, 1995; Readings, 1996).

O terceiro e último item deste capítulo parte da análise do perfil geral dos dirigentes da USP para mostrar em que medida eles provêm do polo profissional tradicional e como eles contribuíram para afirmar o saber gerencial na USP, contribuindo para tecnicizar espaços de discussão e deliberação no interior da universidade. O capítulo se encerra com uma análise das categorias de julgamento, percepção e apreciação que esses dirigentes mobilizam para pensar o governo da USP em geral e a expansão do discurso gerencial em particular.

\section{O discurso da gestão como violência simbólica: o novo vocabulário das disputas sobre as formas de governo na USP}

Como foi dito, o último item deste capítulo busca analisar a imposição do discurso gerencial na USP como uma forma de violência simbólica em que as categorias de percepção, julgamento e ação inerentes ao polo dominante da universidade acabaram se impondo, como 
algo natural e necessário, para o conjunto da comunidade uspiana, especialmente o seu corpo de dirigentes, que passou a pensar o problema do governo acadêmico a partir das categorias disponibilizadas pelo discurso gerencial. Nesse sentido, é possível dizer que a questão que orienta esta seção não difere, substancialmente, da questão que procurei responder no segundo capítulo deste trabalho, ou seja, como o discurso gerencial pôde se impor na USP a despeito das resistências explicitadas pelos próprios dirigentes universitários? No entanto, se no segundo capítulo o esforço foi para analisar a gestão como um dispositivo de saber-poder que se difundiu por meio de processos de conversão invisível, de reformas organizacionais centralizadoras e de implementação de dispositivos técnico-materiais, neste capítulo final, a intenção é pensar a gestão como um sistema de classificação afinado com as categorias de visão e avaliação inerentes aos setores dominantes da universidade, vinculados ao seu polo profissional tradicional, cujo núcleo duro é formado, como visto, pela Faculdade de Direito, Escola Politécnica e Faculdade de Medicina de São Paulo.

Para tanto, essa parte final da tese se divide em três subitens. O primeiro analisa os dados elementares da trajetória de três categorias de dirigentes da USP - os reitores, como líderes institucionais, os coordenadores da Codage, como experts em gestão, e os pró-reitores, como especialistas acadêmicos - demonstrando, entre eles, o predomínio de trajetórias ligadas ao polo profissional tradicional da USP. O segundo subitem descreve, em linhas gerais, como o discurso gerencial foi se difundindo como uma visão específica no âmbito central da universidade, através da implantação de mecanismos de gestão e de reformas organizacionais, sobretudo a partir de 1988. O último subitem deste capítulo se volta para as categorias que os dirigentes da USP - entrevistados ao longo da pesquisa - mobilizam para avaliar a expansão do discurso gerencial e a própria organização do governo acadêmico. Explicitando as diferenças de avaliação e julgamento entre o polo profissional tradicional, dominante, e o polo acadêmicocientífico, minoritário, a intenção é mostrar como, no fim das contas, até mesmo as críticas à 
reestruturação da universidade e do seu governo a partir do discurso da gestão passaram a ser formuladas nos seus próprios termos, em um exemplo paradigmático de violência simbólica.

\subsection{Os dirigentes centrais da USP: a hegemonia do polo profissional tradicional}

No capítulo anterior, ao apresentar um perfil geral dos três polos essenciais da USP, eu procurei mostrar como o polo profissional tradicional, social e economicamente dominante na universidade, também hegemonizava os espaços de poder da instituição, tal como era possível observar a partir de uma listagem sumária dos seus reitores desde $1934^{251}$. Retomando essa questão e considerando não apenas a vinculação dos reitores da USP, que denominei de lideranças institucionais, mas também dos seus experts em gestão, que ocuparam a direção da Codage, hoje Vice-reitoria Executiva de Administração (VREA), e dos seus especialistas acadêmicos, que assumiram as pró-reitorias universitárias a partir de 1988, é possível notar que o polo profissional tradicional, de fato, hegemoniza os espaços de poder da universidade, em particular aqueles mais diretamente envolvidos na implementação do conhecimento gerencial, ou seja, a Codage/VREA e a reitoria. A tabela abaixo apresenta os dirigentes da USP que assumiram, entre 1934 e 2014, os cargos de reitor, coordenador da Codage/VREA e pró-reitor, com informações sobre o período de permanência no cargo, a unidade de vinculação e o curso de graduação realizado.

${ }^{251}$ Para mais detalhes, ver a tabela 11 no terceiro capítulo desta tese. 
Tabela 30. Dirigentes da USP (reitores, pró-reitores e coordenadores gerais de administração) segundo período no cargo, faculdade de origem e formação

Reitores da USP (1934 - 2010)

\begin{tabular}{|c|c|c|c|}
\hline Dirigente & $\begin{array}{l}\text { Período no } \\
\text { cargo }\end{array}$ & $\begin{array}{l}\text { Unidade de } \\
\text { vinculação }\end{array}$ & $\begin{array}{c}\text { Formação na } \\
\text { graduação }\end{array}$ \\
\hline Reinaldo Porchat & 1934-1937 & FD & Direito \\
\hline Lúcio Martins Rodrigues & 1938-1939 & POLI & Engenharia \\
\hline Domingos Rubião Meira & 1939-1941 & FM & Medicina \\
\hline Jorge Americano & 1941-1946 & FD & Direito \\
\hline Antônio de Almeida Prado & $1946-1947$ & FM & Medicina \\
\hline Benedito Montenegro & 1947 & FM & Medicina \\
\hline Lineu Prestes & 1947-1949 & FO & Farmácia; Direito \\
\hline Miguel Reale & 1949-1950 & FD & Direito \\
\hline Luciano Gualberto & 1950-1951 & FM & Medicina \\
\hline Ernesto Moraes Leme & 1951-1953 & FD & Direito \\
\hline José de Mello Moraes & 1954-1955 & ESALQ & Agronomia \\
\hline Alípio Correia Neto & 1955-1957 & FM & Medicina \\
\hline Gabriel Sylvestre de Teixeira de Carvalho & $1957-1960$ & FMVZ & Medicina Veterinária \\
\hline Antonio Barros de Ulhôa Cintra & 1960-1963 & FM & Medicina \\
\hline Luiz Antonio Gama e Silva & 1963-1969 & FD & Direito \\
\hline Mario Guimarães Ferri & $1967-1968$ & FFCL & Botânica \\
\hline Hélio Lourenço de Oliveira & 1968-1969 & FMRP & Medicina \\
\hline Alfredo Buzaid & 1969-1973 & FD & Direito \\
\hline Miguel Reale & $1970-1973$ & FD & Direito \\
\hline Orlando Marques Paiva & 1973-1979 & FMVZ & Medicina Veterinária \\
\hline Waldir Muniz Oliva & 1978-1982 & IME & Engenharia \\
\hline Antônio Hélio Guerra Vieira & 1983-1986 & POLI & Engenharia \\
\hline José Goldemberg & 1986-1990 & IF & Física \\
\hline Roberto Leal Lobo e Silva & 1990-1993 & IFSC & Engenharia \\
\hline Ruy Laurenti & 1993 & FSP & Medicina \\
\hline Flávio Fava de Moraes & 1993-1997 & ICB & Odontologia \\
\hline Jacques Marcovitch & $1997-2001$ & FEA & Administração \\
\hline Adolpho José Melfi & 2001-2005 & ESALQ & Geologia \\
\hline Suely Vilela Sampaio & 2005-2009 & FCFRP & Farmácia \\
\hline João Grandino Rodas & 2010-2014 & FD & Direito \\
\hline Marco Antonio Zago & 2014-2018 & FMRP & Medicina \\
\hline
\end{tabular}


Tabela 30. Dirigentes da USP (reitores, pró-reitores e coordenadores gerais de administração) segundo período no cargo, faculdade de origem e formação (continuação)

Diretores da Codage, hoje Vice-reitoria Executiva de Administração (1973 - 2014)

\begin{tabular}{lccc}
\hline \multicolumn{1}{c}{ Dirigente } & $\begin{array}{c}\text { Período no } \\
\text { cargo }\end{array}$ & $\begin{array}{c}\text { Unidade de } \\
\text { vinculação }\end{array}$ & $\begin{array}{c}\text { Formação na } \\
\text { graduação }\end{array}$ \\
\hline Fausto Haroldo Ribeiro & $1973-1982$ & FD & Direito \\
Sérgio Baptista Zacarelli & $1982-1986$ & POLI / FEA & Engenharia \\
André Ricciardi Cruz & 1986 & FFCLRP & Economia \\
Fábio Prado & 1986 & FD & Direito \\
Elisa Wolynec & $1986-1988$ & IF & Física \\
Joaquim Engler & $1988-1991$ & ESALQ & Agronomia \\
Hélio Nogueira da Cruz & $1991-2001$ & FEA & Economia \\
José Roberto Drugowich de Felício & $1992-1993$ & FFCLRP & Física \\
Douglas Wagner Franco & $2006-2007$ & IQSC & Química \\
Dante Pinheiro Martinelli & $2007-2009$ & FEARP & Administração \\
Antonio Roque Dechen & $2010-2014$ & ESALQ & Agronomia \\
\hline
\end{tabular}

Pró-reitores de graduação (1988 - 2014)

\begin{tabular}{|c|c|c|c|}
\hline Dirigente & $\begin{array}{c}\text { Período no } \\
\text { cargo }\end{array}$ & $\begin{array}{l}\text { Unidade de } \\
\text { vinculação }\end{array}$ & $\begin{array}{c}\text { Formação na } \\
\text { graduação }\end{array}$ \\
\hline Luiz de Queiróz Orsini & $1988-1990$ & POLI & Engenharia \\
\hline Celso de Rui Beisiegel & $1990-1993$ & FE & Pedagogia \\
\hline Vítor Manoel de Souza Lima & 1993 & POLI & Engenharia \\
\hline Carlos Alberto Barbosa Dantas & 1993-1997 & IME & Física \\
\hline Vítor Manoel de Souza Lima & 1993 & POLI & Engenharia \\
\hline Ada Pellegrini Grinover & $1997-2001$ & FD & Direito \\
\hline Sônia Penin & $2001-2005$ & $\mathrm{FE}$ & Pedagogia \\
\hline Selma Pimenta Guarrido & $2005-2010$ & $\mathrm{FE}$ & Pedagogia \\
\hline Telma Tenório Zorn & $2010-2014$ & $\mathrm{ICB}$ & Medicina \\
\hline \multicolumn{4}{|c|}{ Pró-reitores de pós-graduação (1988 - 2014) } \\
\hline Dirigente & $\begin{array}{l}\text { Período no } \\
\text { cargo }\end{array}$ & $\begin{array}{l}\text { Unidade de } \\
\text { vinculação }\end{array}$ & $\begin{array}{l}\text { Formação na } \\
\text { graduação }\end{array}$ \\
\hline Oswaldo Ubríaco Lopes & $1989-1990$ & $\mathrm{ICB}$ & Medicina \\
\hline Franco Maria Lajolo & $1990-1993$ & FCF & Farmácia \\
\hline Moacyr Antônio Mestriner & 1993 & FMRP & Medicina \\
\hline José Adolfo Mefi & $1993-1997$ & ESALQ & Geologia \\
\hline Hector Francisco Terenzi & $1998-2001$ & FFCLRP & Ciências Biológicas \\
\hline
\end{tabular}


Tabela 30. Dirigentes da USP (reitores, pró-reitores e coordenadores gerais de administração) segundo período no cargo, faculdade de origem e formação (continuação)

Pró-reitores de pós-graduação (1988 - 2014)

\begin{tabular}{|c|c|c|c|}
\hline Dirigente & $\begin{array}{c}\text { Período no } \\
\text { cargo }\end{array}$ & $\begin{array}{l}\text { Unidade de } \\
\text { vinculação }\end{array}$ & $\begin{array}{c}\text { Formação na } \\
\text { graduação }\end{array}$ \\
\hline Suely Sampaio Vilela & $2001-2005$ & FCFRP & Farmácia \\
\hline Armando Corbani Ferraz & $2005-2010$ & IF & Física \\
\hline Vahan Agopyran & $2010-2014$ & POLI & Engenharia \\
\hline \multicolumn{4}{|c|}{ Pró-reitores de pesquisa (1988 - 2014) } \\
\hline Dirigente & $\begin{array}{l}\text { Período no } \\
\text { cargo }\end{array}$ & $\begin{array}{l}\text { Unidade de } \\
\text { vinculação }\end{array}$ & $\begin{array}{c}\text { Formação na } \\
\text { graduação }\end{array}$ \\
\hline Erney Plessmand de Camargo & $1988-1993$ & ICB & Medicina \\
\hline Geraldo Gomes Serra & 1993 & FAU & Arquitetura \\
\hline Hugo Aguirre Armelin & 1994-1998 & IQ & Ciências Biológicas \\
\hline Hernan Chaimovich Guralnik & $1998-2002$ & IQ & Bioquímica \\
\hline Luiz Nunes de Oliveira & $2002-2006$ & IFSC & Física \\
\hline Mayana Zatz & $2006-2010$ & ICB & Ciências Biológicas \\
\hline Marco Antonio Zago & $2010-2014$ & FMRP & Medicina \\
\hline
\end{tabular}

Pró-reitores de cultura e extensão (1988 - 2014)

\begin{tabular}{lccc}
\hline \multicolumn{1}{c}{ Dirigente } & $\begin{array}{c}\text { Período no } \\
\text { cargo }\end{array}$ & $\begin{array}{c}\text { Unidade de } \\
\text { origem }\end{array}$ & $\begin{array}{c}\text { Formação na } \\
\text { graduação }\end{array}$ \\
\hline Ruy Laurenti & $1988-1993$ & FSP & Medicina \\
João Alexandre Costa Barbosa & 1993 & FFLCH & Letras \\
Jacques Marcovitch & $1993-1997$ & FEA & Administração \\
Sebastião Timo-Iaria & 1997 & ICB & Medicina \\
Moacyr da Silva & 1997 & FO & Odontologia \\
Adilson Avansi de Abreu & $1997-2005$ & FFCLH & Geografia \\
Sedi Hirano & $2006-2008$ & FFLCH & Ciências Sociais \\
Ruy Alberto Corrêa Altafim & $2008-2010$ & POLI & Engenharia \\
Maria Arminda Nascimento Arruda & $2010-2014$ & FFLCH & Ciências Sociais
\end{tabular}

Fonte: Motoyama, 2006 para dados até 2005. Levantamento próprio para anos seguintes. Elaboração: própria

Observação: No momento de realização da pesquisa, o Coordenador da

Codage e os pró-reitores da nova gestão não haviam sido confirmados

A tabela acima permite mostrar, em síntese, que os dirigentes diretamente envolvidos na circulação do conhecimento gerencial na USP, quais sejam, os reitores da USP e seus experts 
em gestão, são predominantemente oriundos do polo profissional tradicional da universidade, cujo núcleo duro são a Faculdades de Direito, a Faculdade de Medicina e a Escola Politécnica, todas fundadas antes da USP e situadas na cidade de São Paulo. Por outro lado, as diferentes pró-reitorias, que reúnem os especialistas acadêmicos em ensino, pesquisa e cultura e extensão, são ocupadas, em geral, por dirigentes que apresentam trajetórias acadêmicas mais diversificadas. Nesse sentido, além de professores oriundos do polo profissional tradicional, entre os pró-reitores da USP é possível encontrar um percentual considerável de dirigentes que se vinculam, integral ou parcialmente, ao polo do acadêmico-científico da universidade. Tentando descrever esse predomínio do polo profissional tradicional nos postos de comando da universidade, o gráfico abaixo sistematiza os dados da tabela 30, apresentando o percentual de dirigentes oriundos dos diferentes polos da universidade entre reitores, diretores da Codage/VREA e pró-reitores.

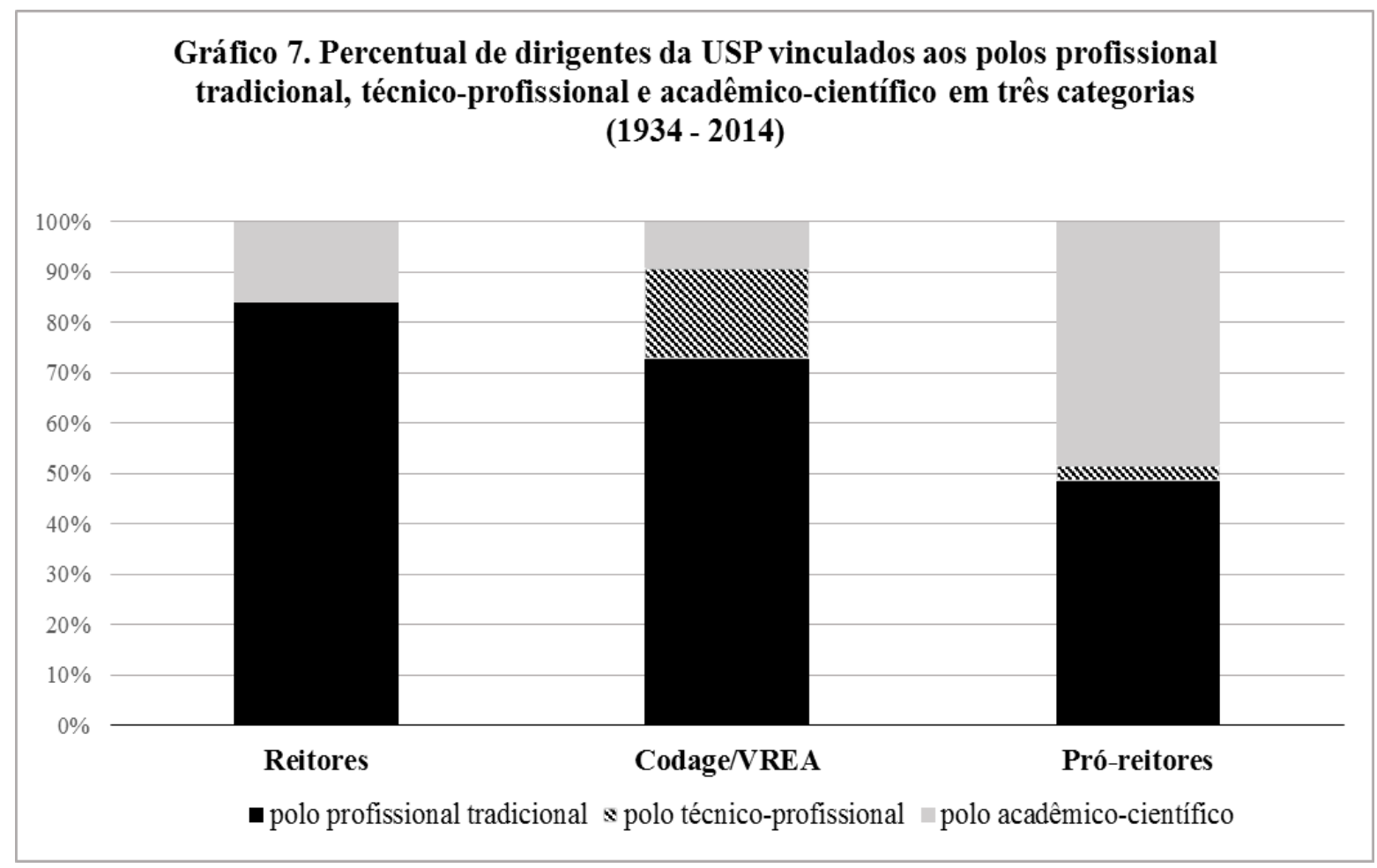

Fonte: Motoyama, 2006 para dados até 2005. Levantamento próprio para anos seguintes. Elaboração: própria

Observação: A Coordenadoria de Administração Geral (Codage) tornou-se Vice-reitoria Executiva de Administração (VREA) em 2012 
Tomando, em primeiro lugar, o exemplo dos reitores da USP, que representam a posição de poder mais importante da universidade, é possível observar que entre os dirigentes que ocuparam a reitoria de 1934 até hoje aproximadamente $80 \%$ eram vinculados, como docentes, ao polo profissional tradicional. Analisando em conjunto os dados do gráfico 9 e da tabela 30, é possível concluir, ainda, que entre os reitores que ocuparam essa posição depois da reforma universitária de 1968, tal percentual não varia significativamente, ou seja, em torno de $80 \%$ deles eram provenientes do polo profissional tradicional. Se o foco recair sobre os últimos 30 anos, ou seja, sobre o período pós-redemocratização, esse percentual decai um pouco, porque "apenas" $60 \%$ dos reitores da USP eram institucionalmente ligados ao polo profissional tradicional. Embora esse dado possa sugerir que o predomínio desse polo esteja se enfraquecendo na universidade, os dados mais recentes mostram o contrário. Asssim, nos últimos 20 anos, todos os dirigentes que assumiram a reitoria da USP eram vinculados ao polo profissional tradicional, o que reforça a ideia de que o predomínio político desse polo na direção da instituição constitui um exemplo de "invariante estrutural" na universidade (cf. Bourdieu, 1989).

No caso dos responsáveis pela Codage, hoje Vice-Reitoria Executiva de Administração, o predomínio de docentes vinculados ao polo profissional tradicional também é significativo: mais de $70 \%$ dos ocupantes desse cargo, entre 1973 e 2014, eram professores do polo profissional tradicional. Além disso, é possível destacar, entre esses experts em gestão, a presença de professores ligados ao polo técnico-profissional da universidade que, como visto, cresceu de modo contínuo nas últimas décadas abrigando as chamadas "novas profissões". Ainda sobre o órgão responsável pela administração geral da USP, vale notar que dentre os três cargos analisados nesta tese, esse é o que apresenta a menor participação de docentes vinculados ao polo acadêmico-científico, que reúne as faculdades e institutos voltados sobretudo à formação de professores e pesquisadores. Isso reforça a hipótese de que existe, de fato, uma 
espécie de dissintonia entre o núcleo duro da difusão do discurso gerencial na USP, formado originalmente pelos órgãos executivos de administração geral (Codage/VREA), e o polo acadêmico-científico da universidade.

Por fim, em relação às pró-reitorias da USP, é possível dizer que elas são os espaços de poder, no âmbito central da universidade, mais abertos ao polo acadêmico-científico e, não por acaso, como visto no capítulo 2, acaba recebendo dirigentes mais refratários aos processos de conversão ao discurso gerencial. Em suma, o gráfico 7 mostra que aproximadamente metade dos pró-reitores da USP, que ocuparam esse cargo a partir da sua criação, em 1988, eram professores vinculados ao polo acadêmico-científico, com destaque, entre os pró-reitores de graduação, para os professores ligados à Faculdade de Educação; entre os pró-reitores de cultura e extensão, para docentes da Faculdade de Filosofia, Letras e Ciências Humanas; e, entre os pró-reitores de pesquisa, de professores ligados aos institutos de ciências exatas e biomédicas.

Levando em consideração não só a vinculação institucional dos dirigentes da USP, ou seja, em que unidade eles atuaram durante a sua carreira universitária mas, também, o curso de graduação que eles realizaram, mais uma vez, o predomínio do polo profissional tradicional, em especial do seu núcleo duro, formado pelos cursos de medicina, direito e engenharia, se destaca. Esse predomínio pode ser observado nos três gráficos abaixo que apresentam os principais cursos de graduação realizados pelo conjunto dos dirigentes da USP - listados na tabela 30 - que ocuparam cargos, primeiro, entre 1934 e 1968, depois, de 1968 a 2014 e, por fim, considerando todo o período, de 1934 a 2014. 


\section{Gráfico 8. Distribuição dos cursos de graduação realizados pelos dirigentes da USP (1934-1968)}

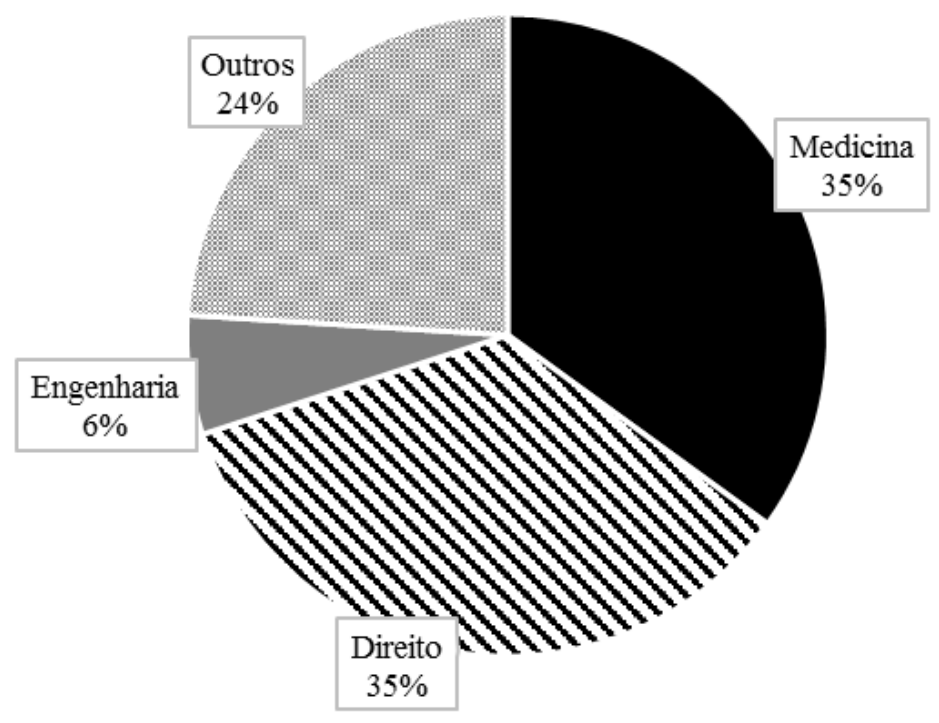

Fonte: Motoyama, 2006 para dados até 2005. Levantamento próprio para anos seguintes. Elaboração: própria

\section{Gráfico 9. Distribuição dos cursos de graduação realizado pelos} dirigentes da USP (1968 - 2014)

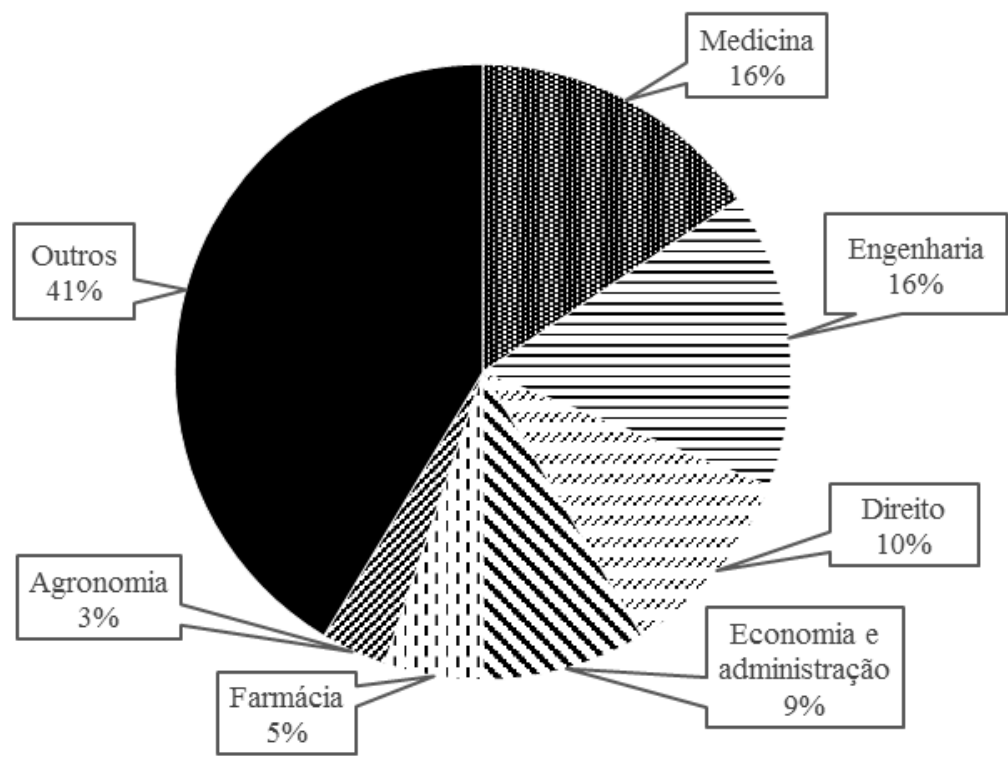

Fonte: Motoyama, 2006 para dados até 2005. Levantamento próprio para anos seguintes. Elaboração: própria 


\section{Gráfico 10. Distribuição dos cursos de graduação realizados pelos dirigentes da USP (1934 - 2014)}

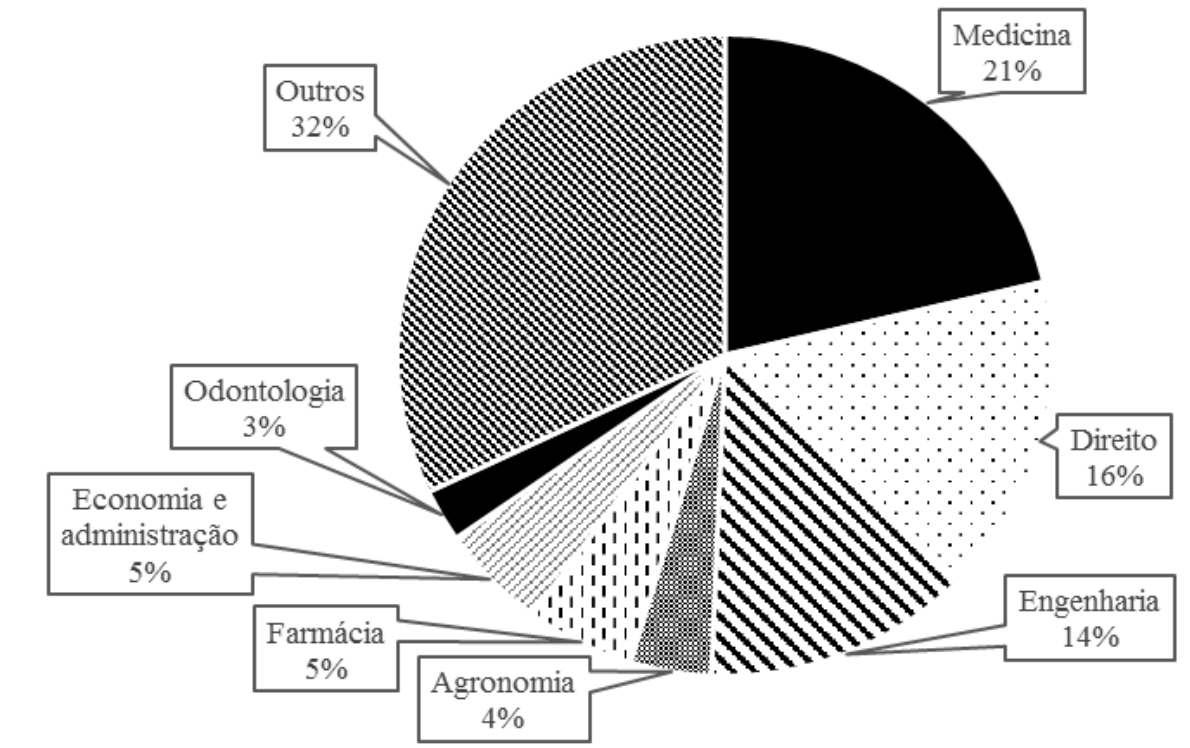

Fonte: Motoyama, 2006 para dados até 2005. Levantamento próprio para anos seguintes. Elaboração: própria

Vistos em conjunto, os gráficos 8, 9 e 10 mostram que, na maior parte das vezes, os dirigentes da USP se formaram em profissões liberais tradicionais, especialmente medicina, direito e engenharia, com destaque também para outras profissões como economia, administração, agronomia, odontologia e farmácia. Considerando a variação das profissões tradicionais realizadas pelos professores que se tornaram dirigentes da USP ao longo do tempo, é possível notar que, até 1968, eles eram fundamentalmente médico, advogados ou engenheiros e que, a partir de então, esse lugar passou a ser ocupado, também, por economistas e administradores, o que explicita, como visto, a ascensão desses novos conhecimentos como saberes de Estado conforme apontam, por exemplo, as análises sobre a afirmação de engenheiros, economistas e administradores como "novas elites burocráticas" (cf. Gomes, 1994).

Nesse sentido, considerando o predomínio dessas profissões liberais tradicionais entre os dirigentes da USP, incluindo reitores, pró-reitores e coordenadores de administração que 
assumiram cargos a partir de 1968, é possível concluir que 50\% deles eram formados em apenas cinco profissões, quais sejam: medicina, direito, engenharia, economia e administração. Considerando só os reitores e diretores de administração, esse percentual é ainda maior: $60 \%$ das lideranças institucionais e dos seus experts em gestão, que assumiram cargos na direção central da USP depois de 1968, eram formados em um desses cinco cursos, o que mostra a relação intrínseca entre a difusão do saber gerencial, ocorrida nesse período, e a atuação de professores oriundos do polo profissional tradicional, especialmente das faculdades da USP que funcionam, ao mesmo tempo, como "escolas de poder" (cf. Bourdieu, 1989). Isso porque, considerando os dirigentes que ocuparam cargos na direção central da universidade depois de 1968, é possível dizer que mais de $80 \%$ deles se formaram na própria USP, em especial na Faculdades de Direito, na Faculdade de Medicina e na Escola Politécnica, instuições cujo padrão de socialização analisamos na primeira parte deste capítulo. Em síntese, os lugares institucionais associados à expansão do conhecimento gerencial da USP, ou seja, a reitoria, como instância decisória máxima, e a Coordenadoria Geral de Administração, hoje Vice-reitoria de Administração, como órgão responsável pela implementação de programas e práticas gerenciais na USP, foram ocupados por professores oriundos do polo profissional tradicional, formado por escolas que, justamente, preparam seus alunos para o exercício do poder.

Antes de analisar os caminhos que esse conhecimento seguiu na universidade nos últimos 30 anos, é importante considerar um último dado, bastante significativo, sobre o perfil dos dirigentes da USP. Como é possível observar pelo gráfico 11, abaixo, entre os dirigentes uspianos, especialmente reitores e coordenadores de administração, não existe apenas um predomínio de professores vinculados ao polo profissional tradicional da universidade. Igualmente importante é o predomínio masculino que, embora observável em todos os níveis, incluindo as pró-reitorias, é visivelmente mais forte nesse núcleo duro de expansão do conhecimento gerencial, ou seja, a reitoria e a Codage/VREA. 


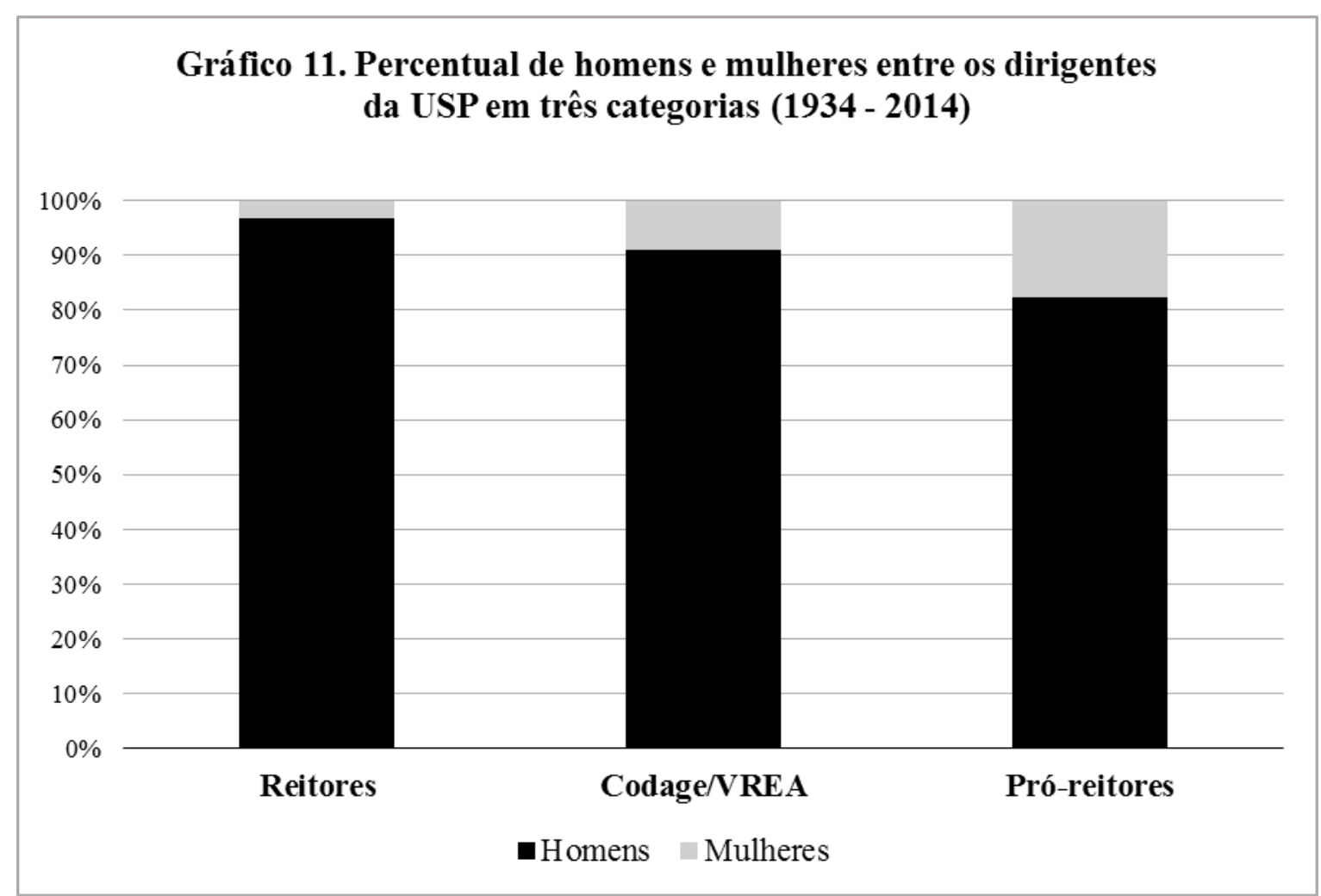

Fonte: Motoyama, 2006 para dados até 2005. Levantamento próprio para anos seguintes.

Elaboração: própria

O amplo predomínio de homens entre os dirigentes máximos da USP está associado não só à tendência social geral de sub-representação das mulheres em cargos de poder como, igualmente, ao perfil das unidades de origem desses dirigentes, ligadas ao polo profissional tradicional. Como visto no capítulo anterior, essas unidades ocupam uma posição estruturalmente dominante na universidade não só em função do seu padrão de recrutamento social, econômica e escolarmente elevado mas, também, pelo perfil essencialmente masculino do seu alunado, ainda hoje predominante, em particular nos cursos de direito, engenharia e medicina da USP.

Em suma, os dados apresentados ao longo desta seção mostram como o polo profissional tradicional estruturalmente dominante na universidade é, também e pour cause, o polo politicamente dominante, prevalecendo especialmente nas posições de poder diretamente envolvidas na difusão do discurso gerencial e das suas categorias através da implantação de 
reformas organizacionais, de programas especiais de avaliação e de outros expedientes que apresentamos, sinteticamente, no item a seguir.

\subsection{O processo de imposição do discurso gerencial: reformas, programas e especialistas}

O segundo capítulo desta tese procurou analisar, em termos gerais, o processo de centralização do poder na USP a partir da reforma universitária de 1968-1969. O foco analítico, nesse caso, era a criação de órgãos executivos no âmbito da reitoria da USP cujo resultado geral foi um empoderamento do poder executivo central da universidade ao longo dos últimos cinquenta anos. Tomando esse processo de centralização como pressuposto, o objetivo desta seção é descrever sumariamente a difusão do discurso gerencial que está na base de um novo processo de fortalecimento da reitoria da USP, especialmente a partir da reforma estatutária de 1988, que criou condições institucionais para a orientação e normatização das atividades de ensino, pesquisa e extensão da universidade.

Assim, partindo da análise da primeira gestão reitoral do período democrático ${ }^{252}$, que se estende de 1986 a 1990, é possível identificar claramente a difusão de princípios gerenciais, seja na implementação de dispositivos técnico-materiais de gestão, seja na legitimação de dirigentes que se apresentavam como portadores desse conhecimento específico. Quanto à implementação de dispositivos de gestão, é possível dizer que esse período, que coincide com a aprovação da autonomia financeira das universidades estaduais paulistas, foi palco: i) da criação de instrumentos fundamentais de accountability, em especial, como visto, do Anuário Estatístico, que inaugurou a coleta e a sistematização centralizada de dados estatísticos sobre

\footnotetext{
${ }^{252}$ Neste trabalho, como dito, optei por não identificar os dirigentes acadêmicos pelos seus nomes próprios, mas sim pelos seus atributos sociais relevantes para a presente análise. Essa opção é de natureza metodológica e não busca ocultar nomes e identidades.
} 
toda a USP; ii) da fundação de órgão para a definição de diretrizes e estratégias de planejamento, tais como as Pró-reitorias, a Comissão de Planejamento e o Grupo de Planejamento Setorial aprovados no novo Estatuto; iii) do uso sistemático da informática como instrumento de centralização e normatização de procedimentos gerenciais; e iv) do esboço das primeiras iniciativas de avaliação do corpo docente, inclusive com capítulos controversos como a famigerada "lista dos improdutivos" 253 . Quanto à importância adquirida pelos portadores de saberes gerenciais, ela se expressa, de modo paradigmático, no fato do reitor ter assumido a direção da universidade depois de passar alguns anos na presidência de uma empresa, na época pública, legitimando-se também por essa experiência específica de gestão. Ou ainda, no fato da diretoria da Coordenadoria de Administração Geral (Codage) ter sido entregue, em um primeiro momento, a uma professora da USP que atuava, simultaneamente, na universidade e em uma empresa de desenvolvimento de "soluções de gestão" para instituições ligadas ao governo, e às áreas de saúde e educação ${ }^{254}$. Ao deixar a reitoria para atuar no ramo empresarial da gestão, essa professora foi substituída por outro expert em gestão que, além de pós-graduação na área de produtividade agrícola, tinha uma formação específica na área de gestão acadêmica, realizada nos Estados Unidos durante os anos 1970. Esse expert, que já participava do processo de elaboração do orçamento da universidade desde 1983 e da coordenação do Anuário Estatístico desde 1987, assumiu a coordenação da Codage em 1988, onde permaneceu até 1991,

\footnotetext{
${ }^{253}$ A "lista dos improdutivos" foi divulgada pela reitoria em 1988, com o nome dos professores que, segundo informações do Sistema Integrado de Bibliotecas da USP (SIBI/USP), não haviam publicado trabalhos científicos no biênio 1985-1986. Não só pelo seu significado geral, mas também pelos seus erros internos, a lista gerou enorme polêmica. Até pelo impacto desse acontecimento específico, existem outros trabalhos que abordam ou tangenciam essa primeira gestão reitoral do período democrático os quais enfatizam a importância de concepções de avaliação e controle, ligadas às diretrizes gerenciais (cf. Cardoso, 2001; Chauí, 2001; Hey, 2008; Silva, 1999; Paula, 2000). Atualmente, existe uma pesquisa de mestrado sendo realizada no Departamento de Sociologia da USP, por Aline Chiaramonte, sobre a chamada "lista dos improdutivos".

${ }^{254}$ A Techne é uma empresa fundada por "profissionais da universidade de São Paulo" em 1982, com sede em São Paulo e presente em diversos estados brasileiros. Seus principais clientes são instituições governamentais, educacionais e de saúde pública para as quais desenvolve softwares de "gestão de capital humano no setor público", "controle acadêmico", "gestão escolar" e "gestão da saúde pública em estados e municípios". Para mais detalhes ver $<$ http://www.techne.com.br $>$ Acesso em 21 de abr. 2014.
} 
sendo que na Comissão de Orçamento e Patrimônio da USP e na coordenação do Anuário

Estatístico ele permaneceu, pelo menos até o começo de 2014, quando encerrei a presente

pesquisa. Por fim, acompanhando a trajetória do então vice-reitor, é possível notar que ele

integrava, pelo seu cargo na reitoria, redes internacionais de discussão e deliberação sobre o

ensino superior, em que o tema da gestão acadêmica, com seus expedientes de avaliação,

racionalização e planejamento, ganhava lugar de destaque, conforme já analisado.

Na gestão seguinte, que se estende de 1990 a 1993, foi justamente esse vice-reitor que

assumiu o cargo máximo da universidade, mostrando a importância que foram adquirindo os

conhecimentos especializados sobre gestão universitária na escolha do reitor da USP, até então

selecionado quase que exclusivamente pelas suas relações políticas externas à universidade ${ }^{255}$.

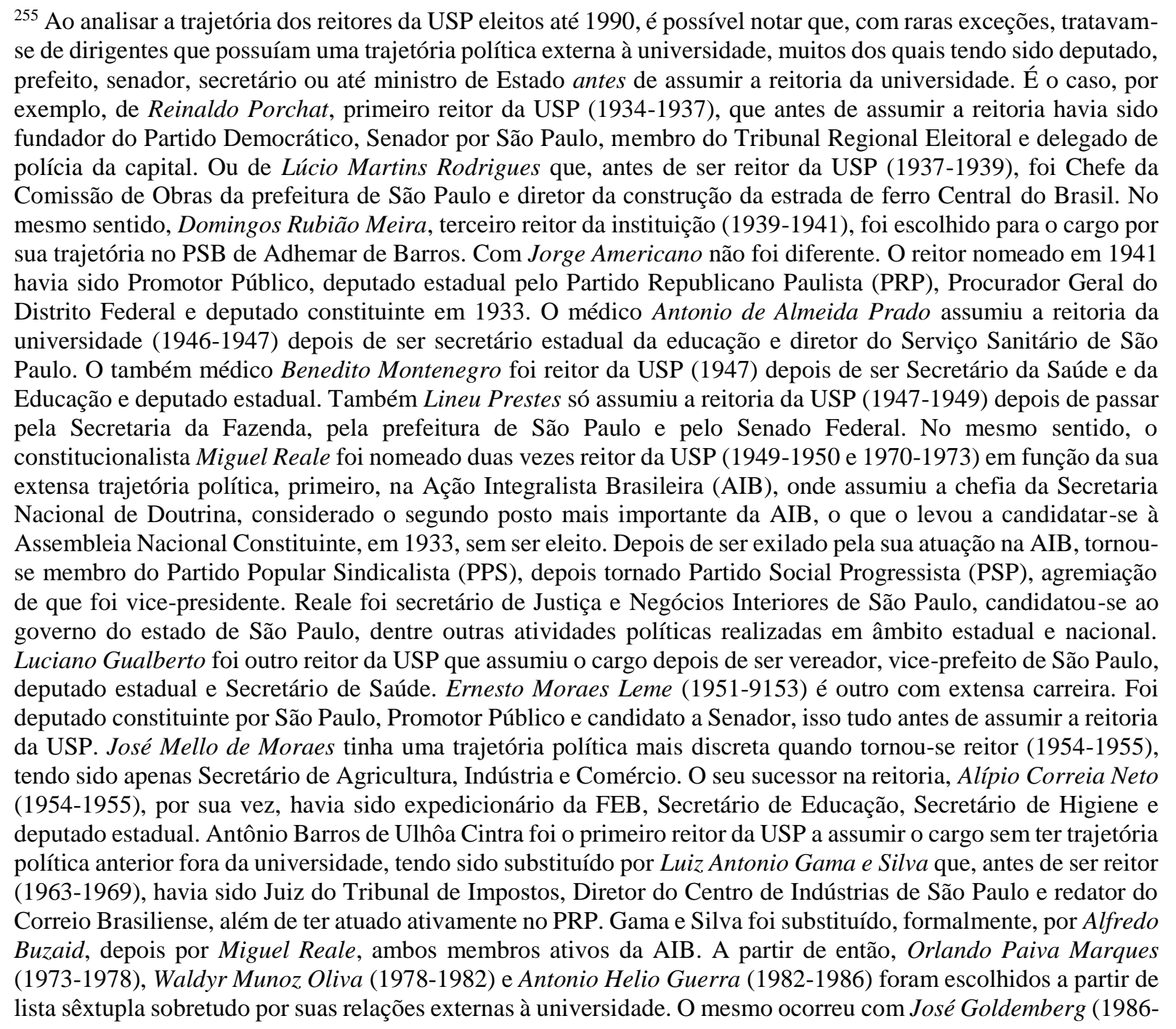


Nesse sentido, essa reitoria que se inicia em 1993 pode ser considerada, em grande medida, uma gestão de continuidade, de modo que também foi possível observar, nesse período, o fortalecimento do discurso gerencial seja no papel desempenhado pelos experts em gestão, seja na manutenção e criação de instrumentos de gestão. Vale notar que o novo reitor, pela intensificação da sua participação em redes internacionais de dirigentes de ensino superior, foi se tornando, aos poucos, um grande especialista no tema da "gestão acadêmica", o que possibilitou que ele, alguns anos depois de renunciar à reitoria da USP em 1993, fundasse uma empresa de consultoria em gestão que é, até hoje, no campo empresarial, uma das mais importantes referências no tema do país ${ }^{256}$.

Durante a sua gestão, foi designado para a Codage, órgão administrativo que vai ganhando proeminência, outro expert em gestão, dessa vez ligado à Faculdade de Economia e Administração. Esse economista permaneceu à frente do órgão entre 1990 e 1992, retornando no final de 1993 para conservar-se no cargo até 2001, quando assumiu a vice-reitoria da USP em outra trajetória significativa da valorização do conhecimento gerencial, como saber específico, no âmbito central da USP. Do ponto de vista da implantação de dispositivos de gestão, foi durante esse período que se criou, no âmbito da Codage, a Comissão Permanente de Avaliação (CPA) com o objetivo de "planejar, acompanhar e avaliar o desenvolvimento das atividades acadêmicas da universidade" (USP, 1992, n.p.). A CPA foi um marco na história da USP por ter formalizado, pela primeira vez, um procedimento de avaliação institucional que, com o apoio do Banco Interamericano de Desenvolvimento (BID) - que, além de obras de infraestrutura, financiava projetos específicos de "modernização administrativa" - conseguiu

1990), primeiro reitor do período democrático, que mantinha relações políticas próximas com o então governador, Franco Montoro.

${ }^{256}$ A Lobo \& Associados Consultoria é parte do Grupo Lobo que reúne, além dessa empresa de consultoria, o Instituto Lobo para o Desenvolvimento da Educação, da Ciência e da Tecnologia e a Lobo Organização Empresarial. Juntas, essas organizações atuam na "elaboração de projetos, análises, acompanhamento, sugestões e benchmarking" na área educacional. Para mais detalhes, ver: < http://www.institutolobo.org.br/ >. Acesso em: 21 de abr. 2014. 
avaliar todos os 210 departamentos então existentes na universidade, mobilizando, para isso, centenas de pessoas, incluindo 421 assessores externos, 132 deles estrangeiros. Como resultado mais significativo da consolidação da avaliação institucional, cada departamento e, por consequência, cada unidade da USP, foi obrigado a produzir um Plano de Metas Quinquenais que passou a servir de referência para a sua relação com o poder central, sobretudo no que tange à contratação docente e ao financiamento de obras de infraestrutura, estabelecendo uma linguagem comum de planos, metas e resultados (cf. USP, 2005).

A reitoria consecutiva, eleita no final de 1993, em meio a uma crise institucional aberta pela renúncia do reitor precedente, apesar de se colocar como uma gestão de oposição, manteve a opção de valorizar o saber gerencial, tanto através do fortalecimento dos experts em gestão quanto da manutenção dos dispositivos técnico-materiais necessários à implementação e ao fortalecimento das rotinas gerenciais. Justamente por isso, o reitor da época optou por recolocar na direção da Codage o já referido especialista ligado à FEA que, pela sua formação econômica, dominava plenamente a linguagem gerencial, o que permitiu que ele se mantivesse à frente da área administrativa da USP, como dito, até 2001, quando se tornou vice-reitor da USP, cargo que ocupou de 2001 a 2005 e de 2010 a 2014. Mas a gestão que se inicia em 1993, além de fortalecer os experts em gestão, deu continuidade aos trabalhos da Comissão Permanente de Avaliação, às iniciativas de planejamento integral e setorial, ao desenvolvimento do Anuário Estatístico e à mobilização da informática como instrumento de coleta e sistematização de informações estatísticas, avaliação e gestão. Além disso, criou, em 1996, no bojo do Programa Permanente de Qualidade e Produtividade do Governo do estado de São Paulo, a Comissão de Gestão da Qualidade e da Produtividade da USP que, de 1996 a 2005, exerceu enorme influência, através de atividades de "sensibilização e motivação da comunidade universitária para se integrar ao programa [de qualidade e produtividade]" (USP, 2005, p. 22). Esse programa levou à criação de 39 comissões de qualidade e produtividade em diferentes unidades da USP, 
à realização de mais de uma dezena de encontros e seminários de qualidade e produtividade, à publicação de manuais, à produção de sínteses de indicadores e ao apoio de dezenas de projetos locais, incluindo a criação de um Centro de Educação Continuada na Escola Politécnica, que fundou um MBA em Gestão e Tecnologias da Qualidade, responsável pela formação de dezenas de funcionários da USP (cf. USP, 2005, p. 21ss).

As duas gestões reitorais que se sucederam, de 1998 a 2001 e de 2001 a 2005, podem ser consideradas, em grande medida, desdobramentos da gestão eleita em 1993, não só porque os seus reitores eram diretamente ligados ao seu quadro político mas, sobretudo, porque é possível observar uma continuidade, pelo menos no plano da gestão, de pessoas e programas. Assim, nesse período, o responsável pelo Anuário Estatístico da universidade permaneceu o mesmo, o responsável pela Coordenadoria de Administração Geral permaneceu o mesmo, os programas essenciais de avaliação institucional, promovidos pela Comissão Permanente de Avaliação, e de promoção da produtividade e da qualidade, promovidos pela Comissão de Gestão da Qualidade e da Produtividade, também se mantiveram os mesmos.

É, portanto, a reitoria eleita em 2005 que marca uma inflexão no âmbito da gestão da USP, expressa de modo mais imediato no abandono dos programas ligados à Codage, em especial as atividades da Comissão Permanente de Avaliação e da Comissão de Gestão da Qualidade e da Produtividade. Mas a decisão de suspender, mesmo que temporariamente, esses programas específicos não significou um enfraquecimento do discurso gerencial e uma diminuição do seu impacto na USP. Pelo contrário, a partir dos documentos produzidos por essa reitoria entre 2006 e 2009, é possível notar que a visão gerencial ganhou ainda mais importância na USP nesse período, passando a determinar não só a reestruturação das chamadas "atividadesmeio", ou seja, das rotinas de avaliação, controle e gestão, mas também e principalmente, a definição dos objetivos das "atividades-fim", através de um desenho mais estrito e centralizado de diretrizes e metas para o ensino, a pesquisa e a extensão. Esse período pode ser considerado, 
portanto, o início de um novo processo de fortalecimento da gestão que, pressupondo todo o longo processo de centralização e difusão da gestão como dispositivo de saber-poder analisado anteriormente, pôde se realizar como modelo organizacional pleno, o que significou projetar a universidade como uma organização, valorizando a liderança executiva, o planejamento estratégico e outros expedientes semelhantes ${ }^{257}$.

Como resultado desse processo de fortalecimento da gestão como modelo organizacional, a Comissão de Planejamento, prevista no Estatuto de 1988 e com membros indicados pelo reitor ${ }^{258}$, ganhou importância em detrimento da Codage, agora identificada a um planejamento de curto e médio prazo, considerado menos importante (cf. USP, 2009a, p. 68). O pressuposto, explicitado pela nova reitoria, era de que a definição de diretrizes e metas de longo prazo, o chamado planejamento institucional estratégico, deveria ser prioridade do poder central, determinando toda a ação do aparato administrativo de apoio com seus dispositivos técnicos de gestão, tais como os instrumentos de avaliação, de controle de qualidade e de incentivo à produtividade (cf. USP, 2009a). Data dessa época, portanto, a decisão de fomentar e sistematizar a discussão sobre os "desafios futuros da USP", cujo resultado mais propagandeado foi um seminário institucional intitulado "USP 2034, planejando o futuro" (cf. USP, 2009b) que deu origem a publicação homônima, coordenada pela Comissão de

\footnotetext{
${ }^{257}$ É interessante notar, dessa perspectiva, que o projeto da Escola de Artes, Ciências e Humanidades, a chamada USP-leste, desenhado e implementado nesse momento, seguiu de perto um modelo organizacional tal como procurei analisar, com Sylvia Garcia, em artigo intitulado "Tensões e contradições do conceito de organização aplicado à universidade: o caso da criação da USP-leste" (Garcia \& Carlotto, 2013b). A defesa do projeto, no âmbito da universidade, caminhou no sentido de apresentar a concepção da nova unidade como um modelo para o conjunto da universidade, dada a sua incorporação de tendências internacionais, incluindo, como pretendemos demonstrar, tendências de gestão acadêmica (cf. Garcia \& Carlotto, 2013b, p. 670).

${ }^{258}$ É interessante notar que o Regimento Geral da USP de 1990 acrescentou, às atribuições estatutárias do(a) reitor(a) da USP, o poder de "I - designar, para a Comissão de Planejamento (CP), Comissão Especial de Regimes de Trabalho (CERT) e Comissão de Cooperação Internacional (CCInt), os membros e respectivos presidentes; designar o secretário geral, o consultor jurídico chefe, o presidente do Grupo de Planejamento Setorial (GPS) e os coordenadores das várias coordenadorias; III - designar os superintendentes dos Órgãos Complementares, bem como dirigentes e membros dos demais órgãos vinculados à Reitoria" (USP, 1990, p. 5). Esse poder de nomeação conferido ao reitor fez com que as comissões de planejamento criadas pela Reforma de 1987-1988 passassem a representar as diretrizes de governo dos reitores e não a perspectiva do Conselho Universitário, ainda mantido como órgão máximo da USP mas cada vez mais enfraquecido nas suas atribuições.
} 
Planejamento, com o objetivo de:

[...] diagnosticar os principais desafios que se apresentam para a Universidade moderna e para a USP em particular, bem como delinear os cenários projetados para o futuro e os possíveis posicionamentos da Instituição para a construção da sua visão de futuro, no contexto do Sistema de Ensino Superior e de Ciência, Tecnologia e Inovação do Estado e do país (USP, 2009a, p. 69).

Na prática, a valorização dessas comissões de planejamento institucional, setorial e estratégico, com membros designados pelo reitor, aprofundou ainda mais o processo de enfraquecimento dos órgãos colegiados em diferentes níveis, instaurando a hegemonia da reitoria, como órgão executivo, na definição da política universitária na USP. Esse fortalecimento dos executivos universitários, vale lembrar, já era uma intenção da Reforma de 1968 que, na USP, resultou nos primeiros órgãos de planejamento e coordenação no âmbito central. Do mesmo modo, a Reforma de 1987-1988 também contribuiu para aprofundar esse processo, com a criação das pró-reitorias e de novas comissões executivas de planejamento e gestão. Ainda assim, é possível dizer que foi somente a partir dos anos 2000 que esse modelo organizacional, que concentra a elaboração de diretrizes e normas no âmbito central da universidade, de fato ganhou força. Isso se expressa de modo paradigmático no aprofundamento do processo de normatização das atividades de graduação, pós-graduação, pesquisa e extensão universitária através da reforma e expansão dos regimentos internos, da criação de programas especiais de intervenção e da implementação de rotinas centralizadas de avaliação. É à luz desse processo histórico de centralização que se deve compreender, portanto, as reformas organizacionais, descritas formalmente como iniciativas de "descentralização", que marcam a segunda metade da década de 2000 e a primeira metade da década de 2010 na USP.

Analisadas nessa chave, essas iniciativas de "descentralização administrativa" se revelam, na verdade, um novo instrumento para a expansão dos órgãos e serviços gerenciais, antes concentrados na administração central, para os diferentes campi e unidades, sem que isso implicasse o abandono dos mecanismos centralizados de planejamento, coordenação, controle 
e avaliação. Essa tendência fica explícita quando analisamos o processo de "descentralização" que conduziu, em 2008, à substituição das prefeituras pelas coordenadorias de campi. Na sua forma original, as prefeituras de campi constituíam órgãos autônomos, ligados à reitoria, que administravam a questão do espaço físico nos diferentes campi da USP. A partir da “descentralização" de 2008, as coordenadorias de campi ampliaram suas atribuições, tornandose suporte para a atuação mais direta da reitoria no interior do Estado. Isso se expressa de modo marcante no fato de que, no âmbito das coordenadorias de campi, foram criados setores regionais dos diferentes órgãos da reitoria como a Consultoria Jurídica (CJ), a Comissão de Cooperação Internacional (CCint), a Coordenadoria de Espaço Físico (Coesf), a Coordenadoria de Assistência Social (Coseas) e a Coordenadoria de Comunicação Social (CCS), sem que sua direção geral tivesse sido descentralizada. Assim, além de funcionar como suporte para a extensão do aparato administrativo central para os diferentes campi, as Coordenadorias foram, também, integradas a um órgão central, chamado Diretoria Administrativa do Gabinete da Reitoria, que se tornou responsável por coordenar, padronizar e avaliar as ações e procedimentos desses diferentes órgãos.

Finalmente, é importante notar que a gestão reitoral que se inicia em 2010 encerrandose em 2014, apesar de representar formalmente uma ruptura com o período anterior, aprofundou ainda mais o processo de expansão das estruturas gerenciais da USP. Em síntese, é um momento em que se buscou unir tanto a tendência predominante até 2006, de identificar o fortalecimento da capacidade de gestão universitária à profissionalização das rotinas de controle e avaliação, com a promoção da qualidade e da produtividade, quanto a tendência, predominante no período seguinte, de definir o potencial de gestão como capacidade centralizada de coordenação e planejamento estratégico de médio e longo prazo. Por certo, essas duas tendências não são excludentes, mas representaram, até 2010, ênfases distintas. Nesse sentido, observando em linhas gerais o período 2010-2014, é possível observar tanto iniciativas para desenvolver a 
capacidade de controle e avaliação da reitoria quanto tentativas de estabelecer diretrizes e metas para o planejamento de médio e longo prazo.

No que tange ao desenvolvimento dos dispositivos de controle e avaliação, além da retomada, com força, das iniciativas mais importantes da Comissão Permanente de Avaliação, como o Ciclo de Avaliação Institucional, um dos marcos essenciais desse processo foi a aprovação de uma nova carreira docente, cuja progressão passou a ser condicionada a mecanismos de avaliação do desempenho individual. Ou mesmo a nova carreira de funcionários, igualmente submetida a ferramentas de avaliação de resultados. Nesse mesmo sentido, a reforma organizacional realizada pela resolução $\mathrm{n}^{\circ} 6.061$, publicada pelo então reitor em 27 de fevereiro de 2012, representa um outro exemplo de expansão da estrutura gerencial. Alterando a organização da reitoria da USP prevista pelo Estatuto de 1988 e pela já mencionada reforma de 2008, a resolução afirmava:

O Reitor da Universidade de São Paulo, usando de suas atribuições legais, com fundamento no art. 42, IX, do Estatuto, tendo em vista o deliberado pelo Conselho Universitário, em sessão realizada em 23 de fevereiro de 2012, baixa a seguinte resolução: Artigo $1^{\circ}$ - O artigo 34 do Estatuto, baixado pela Resolução $n^{\circ} 3461$, de 07 de outubro de 1988 e alterado pela Resolução 5492/2008, passa a ter a seguinte redação:

Art. 34 - A Reitoria, órgão que superintende todas as atividades universitárias, com sede na Cidade Universitária “Armando de Salles Oliveira”, é exercida pelo Reitor e compreende:

I Gabinete do Reitor;

II Pró-Reitorias;

III Secretaria Geral;

IV Procuradoria Geral;

V Vice-Reitoria Executiva de Administração;

VI Superintendência de Assistência Social;

VI A Superintendência do Espaço Físico;

VI-B Superintendência de Tecnologia da Informação;

VII Grupo de Planejamento Setorial;

VIII Prefeitura dos Campi e do Quadrilátero Saúde/Direito;

IX Superintendência Jurídica;

X Comissão de Planejamento;

XI Comissão Especial de Regimes de Trabalho;

XII Vice-Reitoria Executiva de Relações Internacionais;

XIII Superintendência de Comunicação Social;

XIV Superintendência de Saúde;

XV Superintendência de Gestão Ambiental;

XVI Superintendência de Relações Institucionais;

XVII Superintendência de Segurança (USP, 2012, n.p.). 
A transformação de parte das Coordenadorias em Superintendências, a fundação de uma

Procuradoria Jurídica e, principalmente, a criação de Vice-reitorias Executivas de

Administração e de Relações Internacionais podem ser interpretados como exemplos da tentativa de fortalecer ainda mais a capacidade de gestão da reitoria, através da estruturação interna dos seus órgãos de planejamento, coordenação, execução e controle. Esse fortalecimento da direção executiva central foi antecedido pela tentativa de estabelecer diretrizes claras para o médio e longo prazo, tal como sistematizado pelo primeiro Plano de Desenvolvimento Institucional da USP, formulado e aprovado no âmbito da Comissão Permanente de Avaliação em 2011, tendo em vista o quinquênio 2012-2017. Na introdução ao documento, o seu contexto de aprovação é descrito nos seguintes termos:

A presente versão do Plano de Desenvolvimento Institucional (PDI) da USP inscrevese nos esforços atuais dessa comunidade universitária em olhar criticamente a sua história, diagnosticar o presente e seus desafios, projetando, numa perspectiva estratégica, o seu futuro próximo, em consonância com o movimento da sociedade brasileira e da civilização atual, de maneira a mobilizar as forças atuantes e responsáveis pela instituição em direção a novas superações e a dar publicidade às ações desenvolvidas. Neste texto foram utilizados diversos documentos já formulados a respeito da USP e de sua história, assim como incorporadas contribuições provenientes de especialistas nos temas tratados (USP, 2011, p. 5; grifo meu).

Em suma, o Plano de Desenvolvimento Institucional buscou sintetizar a "missão e a visão" 259 da universidade, tendo em vista definir o seu "projeto de futuro". Segundo o documento, a missão da USP seria, tal como previsto pelo Estatuto de 1988:

I - Promover e desenvolver todas as formas de conhecimento, por meio do ensino e da pesquisa;

II - Ministrar o ensino superior visando à formação de pessoas capacitadas ao exercício da investigação e do magistério em todas as áreas do conhecimento, bem como à qualificação para as atividades profissionais;

III - Estender à sociedade serviços indissociáveis das atividades de ensino e de pesquisa. (USP, 2011, p. 17).

\footnotetext{
259 O trinômio "missão-visão-valores", que às vezes aparece apenas como o binômio "missão-visão", é uma ferramenta de gestão formulada a partir das teorias organizacionais de gestão estratégica ou da gestão estratégica de resultados que afirmam, em síntese, que o sucesso de uma organização depende da sua capacidade de construir uma visão clara da sua missão e valores que inspire seus funcionários a atuarem em uma mesma direção de modo coeso e harmônico. Além de ser um componente motivacional, a tentativa de explicitar a visão, a missão e os valores de uma organização é fundamental para a sua ação estratégica de futuro já que: “A reflexão estratégica [...] trata-se de um processo compreensivo que inclui desde os condicionantes do comportamento, especialmente dos executivos organizacionais até a efetiva clarificação da visão, da missão e das políticas organizacionais" (Caravantes et al., 2004, p. 96).
} 
Já a visão da USP, ou seja, o que seu projeto de futuro seria:

Tornar-se uma universidade de classe mundial, fortemente enraizada em nossa história, contribuindo para o desenvolvimento socioeconômico e sustentável do país e respondendo de maneira crescentemente qualificada e inovadora aos anseios da sociedade contemporânea, comprometida com o avanço da ciência, da tecnologia e da cultura para a melhoria da qualidade de vida (USP, 2011, p. 17).

Partindo desse esforço de explicitar a missão e a visão da USP, o Plano de Desenvolvimento Institucional buscou estabelecer tanto "objetivos e metas" para as áreas de atuação acadêmica - o "ensino de excelência", a "pesquisa com compromisso social" e a “cultura para o desenvolvimento pessoal e transformação social” (USP, 2011, p. 18ss) - quanto "metas e ações" de apoio à realização dessas "atividades-fim" (USP, 2011, p. 24ss). Os objetivos e metas estabelecidos pelo PDI são bastante detalhados e incluem:

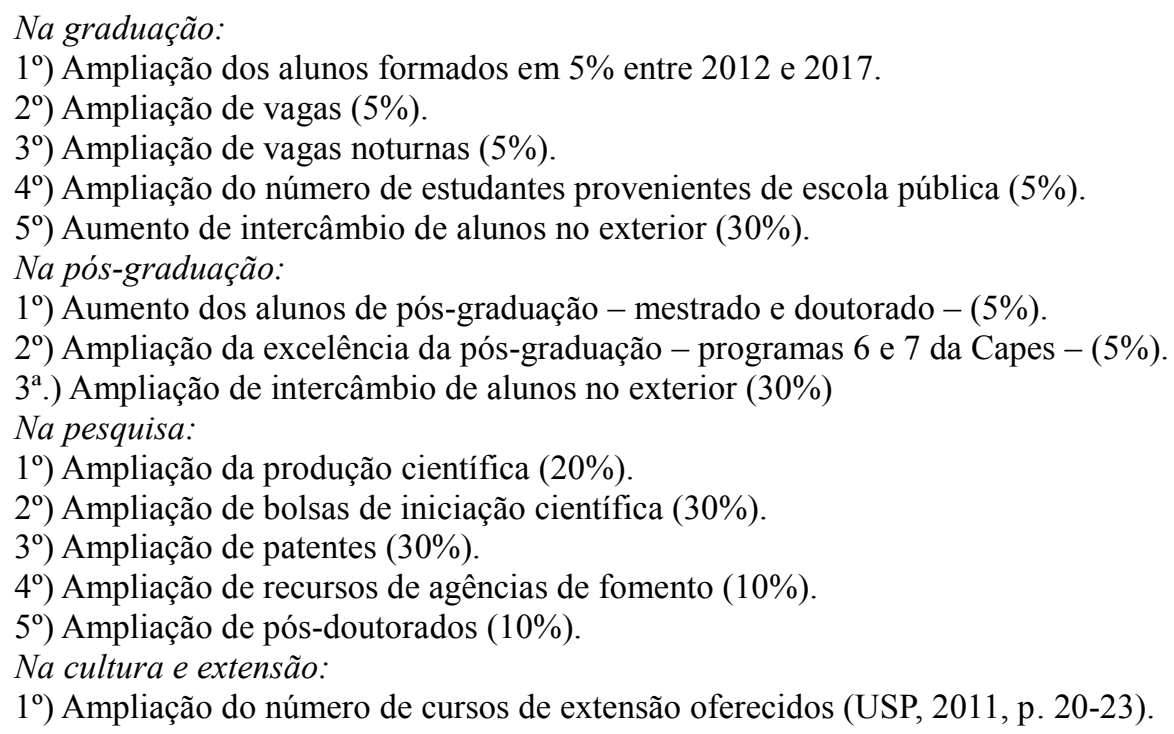

Para realizar esses objetivos e metas, o PDI desenhou uma série de ações específicas para o fortalecimento da "internacionalização", do "planejamento financeiro e orçamentário", da "capacidade de gestão", da "política de apoio ao estudante" e da "avaliação e acompanhamento do desenvolvimento institucional" (cf. USP, 2011, p. 24ss). É interessante que ao descrever o surgimento do Plano de Desenvolvimento Institucional, o então presidente da Comissão Permanente de Avaliação, em entrevista concedida a mim na reitoria da USP, 
descreve um longo processo que surge com os primeiros ciclos de avaliação, passa pelo Anuário

Estatístico e culmina no Plano:

Pois é, na avaliação institucional das unidades e departamentos, aquela ideia de estabelecer uma linguagem comum, com um plano de metas que definisse exatamente o que eles queriam nas áreas de graduação, pós-graduação, pesquisa, cultura e extensão aparecia com força. A história da qualidade implica um arranjo em que existe um indicador para cada coisa a que você se refere, isso fazia parte da gestão da qualidade. E isso se reflete no Anuário Estatístico, tanto que as primeiras páginas do Anuário têm uma síntese de indicadores. Isso foi uma contribuição nossa, da Comissão Permanente de Avaliação. E os indicadores passam a fazer parte da linguagem comum. Então, nos planos de metas, se você for ver, tem números. E agora, mais recentemente, nós fizemos o PDI [Plano de Desenvolvimento Institucional], não sei se você sabe disso, mas é o primeiro plano, propriamente dito, com indicadores quantitativos estabelecidos para um certo horizonte de tempo, até 2017, para toda a USP. Vamos crescer 5\%. Não é um, nem dez, nem duzentos... Tem um número lá, queremos fazer tantos alunos, tantas moradias, tantos intercâmbios internacionais, tanta evasão. Quer dizer, passa da retórica genérica, para metas precisas. Eu entendo que, em termos de planejamento, é um passo decisivo. Agora ganhamos em termos de transparência, em termos de diálogo, ou seja, $5 \%$ de crescimento é pouco, as unidades vão ter que negociar para ver qual vai ser atendida ou quais que vão ser atendidas, e é uma negociação bastante objetivada, com os números. Na minha visão, é um avanço importante. O pessoal da Unicamp esteve comigo e eles ficaram impressionados com a precisão. E é um documento denso, não é retórica vazia.

Segundo ele existe, portanto, uma linha de continuidade e, em certo sentido, de progressão, que vai das primeiras formas de avaliação institucional desenvolvidas no âmbito da Comissão Permanente de Avaliação no começo dos anos 1990, mobilizando as estatísticas que surgem mais ou menos nesse momento, até o Plano de Desenvolvimento Institucional, projetado para toda a USP. O principal resultado desse longo processo de expansão do discurso gerencial na USP, com o consequente desenvolvimento de um aparato técnico para as atividades de gestão foi o aumento da participação dos órgãos centrais e dos projetos especiais, atividades integradas e programas de expansão centralizados na alíquota "outras despesas", que exclui os gastos com pessoal, como é possível observar na tabela 31, abaixo. 
Tabela 31. Distribuição do orçamento da USP, na alíquota "outras despesas", que exclui o gasto em pessoal (1986 - 2012)

\begin{tabular}{|c|c|c|c|c|c|}
\hline & $\begin{array}{c}\text { Unidades de } \\
\text { ensino e } \\
\text { pesquisa }\end{array}$ & $\begin{array}{c}\text { Institutos } \\
\text { especializados, } \\
\text { museus e } \\
\text { hospitais }\end{array}$ & $\begin{array}{l}\text { Órgãos } \\
\text { centrais }\end{array}$ & $\begin{array}{c}\text { Projetos } \\
\text { especiais, } \\
\text { atividades } \\
\text { integradas e } \\
\text { programas de } \\
\text { expansão } \\
\end{array}$ & $\begin{array}{c}\text { Outros (inclui } \\
\text { sentenças } \\
\text { judiciais e } \\
\text { transferência } \\
\text { de exercício) }\end{array}$ \\
\hline 1986 & $17,40 \%$ & $6,30 \%$ & $27,70 \%$ & $32,30 \%$ & $16,30 \%$ \\
\hline 1987 & $18,67 \%$ & $11,01 \%$ & $31,18 \%$ & $31,63 \%$ & $7,51 \%$ \\
\hline 1988 & $12,84 \%$ & $7,79 \%$ & $20,84 \%$ & $56,08 \%$ & $2,47 \%$ \\
\hline 1989 & $9,39 \%$ & $9,07 \%$ & $22,74 \%$ & $56,11 \%$ & $2,69 \%$ \\
\hline 1990 & $10,51 \%$ & $14,07 \%$ & $15,41 \%$ & $52,62 \%$ & $7,40 \%$ \\
\hline 1991 & $12,25 \%$ & $8,50 \%$ & $13,44 \%$ & $61,66 \%$ & $4,15 \%$ \\
\hline 1992 & $11,39 \%$ & $6,28 \%$ & $20,97 \%$ & $56,85 \%$ & $4,50 \%$ \\
\hline 1993 & $13,61 \%$ & $5,17 \%$ & $11,82 \%$ & $39,71 \%$ & $29,29 \%$ \\
\hline 1994 & $16,40 \%$ & $5,89 \%$ & $10,45 \%$ & $48,48 \%$ & $18,78 \%$ \\
\hline 1995 & $19,16 \%$ & $5,57 \%$ & $10,50 \%$ & $62,39 \%$ & $2,39 \%$ \\
\hline 1996 & $18,05 \%$ & $4,35 \%$ & $8,92 \%$ & $60,04 \%$ & $8,64 \%$ \\
\hline 1997 & $16,22 \%$ & $4,18 \%$ & $6,84 \%$ & $48,77 \%$ & $24,00 \%$ \\
\hline 1998 & $16,51 \%$ & $7,93 \%$ & $7,17 \%$ & $52,74 \%$ & $15,65 \%$ \\
\hline 1999 & $11,91 \%$ & $5,59 \%$ & $4,49 \%$ & $43,46 \%$ & $34,46 \%$ \\
\hline 2000 & $10,52 \%$ & $4,38 \%$ & $4,18 \%$ & $30,62 \%$ & $50,00 \%$ \\
\hline 2001 & $15,76 \%$ & $8,07 \%$ & $6,91 \%$ & $38,32 \%$ & $30,94 \%$ \\
\hline 2002 & $18,90 \%$ & $13,39 \%$ & $7,01 \%$ & $53,18 \%$ & $7,91 \%$ \\
\hline 2003 & $23,28 \%$ & $16,72 \%$ & $7,33 \%$ & $49,34 \%$ & $3,30 \%$ \\
\hline 2004 & $11,91 \%$ & $5,70 \%$ & $8,35 \%$ & $37,87 \%$ & $36,16 \%$ \\
\hline 2005 & $17,74 \%$ & $9,10 \%$ & $8,64 \%$ & $64,52 \%$ & $0,00 \%$ \\
\hline 2006 & $18,47 \%$ & $9,70 \%$ & $9,66 \%$ & $62,17 \%$ & $0,00 \%$ \\
\hline 2007 & $18,18 \%$ & $11,19 \%$ & $8,43 \%$ & $59,57 \%$ & $2,63 \%$ \\
\hline 2008 & $16,54 \%$ & $10,45 \%$ & $14,23 \%$ & $55,42 \%$ & $3,36 \%$ \\
\hline 2009 & $19,72 \%$ & $11,22 \%$ & $13,40 \%$ & $51,47 \%$ & $4,19 \%$ \\
\hline 2010 & $20,01 \%$ & $9,36 \%$ & $10,36 \%$ & $56,75 \%$ & $0,07 \%$ \\
\hline 2011 & $19,93 \%$ & $7,70 \%$ & $24,38 \%$ & $46,99 \%$ & $1,00 \%$ \\
\hline 2012 & $19,72 \%$ & $6,36 \%$ & $33,78 \%$ & $39,35 \%$ & $0,20 \%$ \\
\hline
\end{tabular}

Fonte: Anuário Estatístico (1987-2013)

Elaboração: própria 
A tabela mostra, em suma, que embora a participação das instâncias centrais na parcela do orçamento da USP definido como "outras despesas" - que exclui o gasto fixo com pessoal mas reúne os investimentos em manutenção, projetos e infraestrutura - possa ter variado significativamente ao longo dos últimos anos, em função de sentenças judiciais e de déficits orçamentários que obrigam a transferências de exercício de um ano para outro, o movimento tendencial mais importante aponta para um aumento do volume e do percentual do orçamento executado no âmbito central.

Nesse sentido, é possível notar que, não obstante a expansão das unidades de ensino e pesquisa da USP nos últimos anos, conforme analisado no capítulo anterior, a sua participação "nas outras despesas" da USP não aumentou na mesma proporção. Apesar das intensas variações anuais, seja em função da centralização da execução orçamentária (1986-1993), seja como resultado do agravamento de crises orçamentárias (1999 - 2001), é possível notar que a participação das unidades de ensino e pesquisa permaneceu a maior parte do tempo na faixa de $15 \%$ a $20 \%$ do montante do orçamento referente a "outras despesas", que inclui manutenção, infraestrutura e investimentos. Por outro lado, a participação dos chamados "órgãos centrais", dedicados essencialmente às atividades de gestão e planejamento, aumentou, ainda que de modo descontínuo, a partir de 1986 e, sobretudo, 2008, quando começam as reformas organizacionais inspiradas em modelos de gestão organizacional que buscam fortalecer a capacidade de "planejamento estratégico" da universidade, chegando a representar 33\% do orçamento da USP em 2012, excluído, de novo, os gastos com pessoal. Além do orçamento executado diretamente pelos "órgãos centrais", também representam gastos centralizados os chamados "projetos especiais, atividades integradas e programas de expansão" que, excluindo o gasto em pessoal, responderam, em média, por metade do orçamento da USP ao longo dos anos 1990 e 2000. Foi por meio desses projetos, atividades e programas, definidos centralmente, que os órgãos executivos centrais da USP conseguiram exercer pressão para normatizar as atividades de 
ensino, pesquisa e extensão através de programas ligados à reitoria e às pró-reitorias (cf. Pereira, 2008).

Mas talvez o dado mais relevante da tabela 31 seja o fato de que, considerando em conjunto as unidades de ensino e pesquisa e os institutos especializados, hospitais e museus que, juntos, concentram a realização das chamadas "atividades fim" da universidade, é possível notar que, desde a década de 1980, eles consomem, em média, apenas um terço do orçamento da USP relativo a outras despesas. Por outro lado, os órgãos centrais e os projetos centralizados respondem por dois terços da execução orçamentária. Isso não significa, evidentemente, que todo o gasto executado pela esfera central tenha sido consumida nela mesma. No entanto, indica que, em larga medida, a decisão sobre como e onde realizar esses gastos, atendendo a uma definição de prioridades, é controlada, na USP, pelo âmbito central.

A tabela 32, a seguir, apresenta a distribuição do orçamento global da USP, incluindo o “gasto em pessoal” e as “outras despesas”. É possível notar, em resumo, que apesar do processo de expansão da USP nos últimos anos, no qual a reitoria, através da centralização do orçamento e da mobilização de suplementação orçamentária ${ }^{260}$, induziu a criação de novos cursos e unidades, a participação percentual das unidades de ensino e pesquisa no orçamento global da USP não aumentou substancialmente, sobretudo se considerarmos que o salto ocorrido em 1998 refere-se apenas à mudança de classificação do gasto com aposentadorias. Isso significa, portanto, que se houve um aumento do gasto das unidades, incluindo com isso o gasto com salários e aposentadorias, nos últimos anos ele ocorreu na mesma proporção do aumento dos gastos dos órgãos centrais e dos projetos especiais e atividades integradas que seguem concentrando em torno de um terço do orçamento global da USP.

\footnotetext{
${ }^{260}$ A Escola de Artes, Ciências e Humanidades, que foi a maior unidade da USP criada depois de 1968, contou com suplementação orçamentária oferecida, na época, por Geraldo Alckmin, então à frente do Governo do estado de São Paulo (cf. Garcia \& Carlotto, 2012 e 2013a, 2013b).
} 


\begin{tabular}{|c|c|c|c|c|c|}
\hline & $\begin{array}{c}\text { Unidades de } \\
\text { ensino e } \\
\text { pesquisa }\end{array}$ & $\begin{array}{c}\text { Institutos } \\
\text { especializados, } \\
\text { museus e } \\
\text { hospitais }\end{array}$ & $\begin{array}{l}\text { Órgãos } \\
\text { centrais }\end{array}$ & $\begin{array}{c}\text { Projetos } \\
\text { especiais, } \\
\text { atividades } \\
\text { integradas e } \\
\text { programas de } \\
\text { expansão }\end{array}$ & $\begin{array}{c}\text { Outros (inclui } \\
\text { inativos entre } \\
1990 \text { e 1997) }\end{array}$ \\
\hline 1986 & $51,40 \%$ & $6,90 \%$ & $16,60 \%$ & $7,80 \%$ & $17,20 \%$ \\
\hline 1987 & $54,00 \%$ & $7,78 \%$ & $19,25 \%$ & $7,06 \%$ & $11,91 \%$ \\
\hline 1988 & $54,90 \%$ & $8,55 \%$ & $20,27 \%$ & $14,66 \%$ & $1,62 \%$ \\
\hline 1989 & $54,94 \%$ & $9,14 \%$ & $20,32 \%$ & $14,63 \%$ & $0,98 \%$ \\
\hline 1990 & $48,44 \%$ & $10,26 \%$ & $14,13 \%$ & $11,08 \%$ & $16,10 \%$ \\
\hline 1991 & $46,02 \%$ & $9,52 \%$ & $12,59 \%$ & $15,66 \%$ & $14,48 \%$ \\
\hline 1992 & $43,84 \%$ & $9,39 \%$ & $15,65 \%$ & $13,69 \%$ & $17,42 \%$ \\
\hline 1993 & $48,74 \%$ & $9,36 \%$ & $13,74 \%$ & $6,07 \%$ & $22,09 \%$ \\
\hline 1994 & $48,20 \%$ & $9,28 \%$ & $12,78 \%$ & $7,11 \%$ & $22,63 \%$ \\
\hline 1995 & $47,86 \%$ & $9,59 \%$ & $12,99 \%$ & $8,90 \%$ & $20,66 \%$ \\
\hline 1996 & $49,25 \%$ & $10,06 \%$ & $10,27 \%$ & $8,13 \%$ & $22,20 \%$ \\
\hline 1997 & $44,55 \%$ & $9,58 \%$ & $12,49 \%$ & $7,72 \%$ & $25,66 \%$ \\
\hline 1998 & $64,65 \%$ & $11,17 \%$ & $13,54 \%$ & $8,19 \%$ & $2,44 \%$ \\
\hline 1999 & $62,19 \%$ & $10,47 \%$ & $12,47 \%$ & $8,30 \%$ & $6,57 \%$ \\
\hline 2000 & $59,09 \%$ & $9,72 \%$ & $11,79 \%$ & $7,36 \%$ & $12,04 \%$ \\
\hline 2001 & $63,06 \%$ & $10,79 \%$ & $12,73 \%$ & $7,39 \%$ & $6,03 \%$ \\
\hline 2002 & $64,86 \%$ & $11,77 \%$ & $12,83 \%$ & $9,19 \%$ & $1,36 \%$ \\
\hline 2003 & $67,12 \%$ & $12,32 \%$ & $13,00 \%$ & $6,73 \%$ & $0,83 \%$ \\
\hline 2004 & $61,86 \%$ & $10,17 \%$ & $12,96 \%$ & $7,67 \%$ & $7,34 \%$ \\
\hline 2005 & $64,95 \%$ & $10,77 \%$ & $13,26 \%$ & $10,24 \%$ & $0,78 \%$ \\
\hline 2006 & $66,92 \%$ & $11,10 \%$ & $13,40 \%$ & $8,58 \%$ & $0,00 \%$ \\
\hline 2007 & $67,50 \%$ & $11,43 \%$ & $13,51 \%$ & $7,24 \%$ & $0,32 \%$ \\
\hline 2008 & $66,29 \%$ & $11,15 \%$ & $13,84 \%$ & $8,22 \%$ & $0,50 \%$ \\
\hline 2009 & $66,75 \%$ & $11,20 \%$ & $13,61 \%$ & $7,80 \%$ & $0,64 \%$ \\
\hline 2010 & $67,09 \%$ & $10,71 \%$ & $12,82 \%$ & $8,83 \%$ & $0,55 \%$ \\
\hline 2011 & $65,49 \%$ & $10,75 \%$ & $15,69 \%$ & $7,90 \%$ & $0,17 \%$ \\
\hline 2012 & $62,18 \%$ & $11,03 \%$ & $18,66 \%$ & $8,33 \%$ & $0,16 \%$ \\
\hline
\end{tabular}

Fonte: Anuário Estatístico (1987-2013)

Elaboração: própria

Observação: Até 1998 o pagamento de inativos era contabilizado como "outros" 
Do ponto de vista desta tese, essas duas tabelas, que apresentam a distribuição do orçamento da USP, interessam na medida em que ajudam a descrever os processos de centralização e de fortalecimento dos órgãos executivos centrais da USP, que se expressam, grosso modo, no volume de gastos executados pelos "órgãos centrais" e pelos "projetos especiais, atividades integradas e programas de expansão" igualmente centralizados. Esses dados reforçam a ideia de que a partir da reforma universitária de 1987-1988, no bojo de processos que remontam aos anos 1950, quando a importação do conhecimento em gestão recrudesce no país, o discurso gerencial se difundiu na USP, especialmente no âmbito do chamado "poder central", determinando a implantação de reformas, dispositivos e rotinas de gestão que alteraram a forma do governo acadêmico da universidade, que se tornou mais centralizado, mais forte e mais técnico.

Esse processo de transformação do governo acadêmico da USP, que traz consequências em termos do controle profissional do trabalho docente, não é, porém, independente da estrutura social da universidade. Ao contrário, a difusão do discurso e das práticas de gestão na universidade contribuiu para e se favoreceu do fortalecimento do polo dominante da instituição - formado pelas suas unidades profissionais tradicionais - e das suas categorias essenciais orientadas para o controle, a disciplina, a produtividade e os imperativos da urgência, tal como determinado pelo padrão de socialização das escolas de elite e de poder, na USP e fora dela. O último item deste capítulo procura mostrar, justamente, como as categorias essenciais do discurso da gestão se afinam com as categorias hegemônicas do polo dominante da USP, cuja visão de passado e de futuro, o perfil social dos seus alunos e os marcos do processo de socialização foram analisados ao longo dos quatro capítulos desta tese. 


\subsection{Categorias de avaliação do governo acadêmico: o discurso da gestão como violência simbólica}

Este último item tem como objetivo geral mostrar de que maneira o processo de imposição do discurso gerencial pode ser pensado não só como a afirmação de um novo regime de verdade, imbuído de dispositivos técnico-materiais próprios, mas também como um movimento de violência simbólica, em que as categorias afinadas com a perspectiva do polo dominante da universidade se impõem de modo quase natural. Para tanto, ele se divide em quatro tópicos. O primeiro procura analisar como as categorias de avaliação do discurso gerencial refletem oposições estruturais marcantes no âmbito da USP, o que possibilita pensar o ideal elementar do discurso gerencial, de centralização da visão e do planejamento institucional no âmbito central, à luz da estrutura social. Os dois tópicos seguintes seguem essa mesma inspiração estrutural para mostrar como a valorização das novas formas de avaliação externa e da liderança institucional individual também se afinam com o ideário do polo dominante da USP, refletindo suas categorias. Por fim, o último tópico, dedicado às críticas à mudança do governo acadêmico da USP a partir do fortalecimento da gestão, procura mostrar como a imposição do discurso gerencial fez com que até mesmo os seus críticos passassem a mobilizar os seus termos, em um movimento típico de violência simbólica.

\subsubsection{O olhar a partir "de cima": a capacidade de visão e o planejamento à luz da estrutura social}

A aprovação do Plano de Desenvolvimento Institucional da USP no âmbito da Comissão Permanente de Avaliação em 2011 e a reforma organizacional realizada pela reitoria no ano seguinte podem ser considerados o ponto culminante de um longo esforço, protagonizado pelo âmbito central da universidade, para fortalecer os dispositivos de gestão atrelando-os a um planejamento institucional de longo prazo, ele mesmo expressão de uma concepção gerencial. 
Essa concepção defende, essencialmente, que o desenvolvimento estratégico de uma instituição, vista enquanto "organização", deve ser determinado por diretrizes estabelecidas a partir "de cima".

A expressão "de cima" revelou, ao longo da pesquisa, possuir um significado social mais profundo do que sugere o seu sentido imediato, de designação dos órgãos centrais da universidade. O postulado da gestão estratégica de que os executivos centrais, ocupados por lideranças institucionais, devem estabelecer a partir de "cima" a "missão", os "valores" e, principalmente, a "visão" de uma organização implica aceitar o pressuposto de que aqueles que ocupam postos de direção, por estarem em posições "mais altas" da hierarquia de poder são capazes, por isso mesmo, de "ver mais longe".

No caso da USP, como visto, essa hierarquia de poder reflete claramente uma hierarquia social que tem, no seu ápice, as faculdades profissionais tradicionais voltadas à formação de elites dirigentes socializadas para exercerem funções de comando, direção e coordenação política, o que as afasta, como visto, tanto das unidades voltadas para a formação acadêmicocientífica mais estrita quanto das unidades técnico-profissionais que formam especialistas em funções mais técnicas associadas, então, às atividades de execução. Essa hierarquia social se exprime claramente na relação de homologia estabelecida, no plano cognitivo, entre oposições de natureza social entre concepção/execução, mando/obediência, dirigentes/dirigidos e as dicotomias cognitivas de alto/baixo, elevado/rasteiro, maior/menor, central/periférico que marcam os discursos dos dirigentes da USP entrevistados ao longo desta pesquisa.

Foi justamente com base nessas oposições sociais, traduzidas em oposições cognitivas, que os dirigentes da USP, não obstante terem participado ativamente do longo processo de imposição do discurso gerencial e de suas ferramentas na universidade, recusam a administração e a gestão associando-as a atividades de mera execução que, por isso mesmo, ocupam uma posição "mais baixa" na hierarquia de saberes e práticas. Isso fica explícito, por 
exemplo, na fala do dirigente 64, que se formou na Faculdade de Medicina da USP no final dos anos 1950, tornando-se professor dessa Faculdade no começo dos anos 1960, aí permanecendo até ser transferido, pela Reforma Universitária de 1968-1969, para o Instituto de Ciências Biomédicas, o ICB. Depois de ser diretor de unidade e, como tal, compor o Conselho Universitário, tornou-se o primeiro pró-reitor de pós-graduação da USP já em 1988. Ao avaliar o lugar da administração, como ciência específica, o professor afirma:

[Resposta] Onde você colocar o nível mais baixo, põe embaixo a administração [...] Você não pode transformar setores de auxílio em centro. A administração, é claro, tem que fazer_uma porção de coisas: ela tem que administrar, resolver questões, mas não mandar. Foi por isso que na reforma do estatuto da USP, de 1988, que coincidiu com a Constituinte, com a imagem do autoritarismo ainda muito forte, começou aquela história de limitar o poder do reitor. Foi, então, que um conselheiro disse uma coisa excelente: "Bom, mas o reitor tem que 'reitorar', ele tem que ter algum poder porque senão...".

Em outro trecho, logo a seguir, ele expõe de modo ainda mais claro essa oposição entre as tarefas de administração, associadas aos "funcionários”, esse "povo dos Recursos Humanos”, e as funções de controle e mando, que devem ser desempenhadas pelos dirigentes universitários:

[...] Eu tive um problema seríssimo. Quando eu fui diretor do ICB, eu não tinha sido nem mesmo chefe de departamento. Então, na primeira semana, eu me isolei e li o estatuto, os regimentos todos, até o regimento dos funcionários. Porque muitas vezes, a chefe da seção de pessoal, aquele povo dos Recursos Humanos, dizia: "Ah, não, é assim que deve funcionar". E você, como Diretor, não tinha autoridade para desdizer. Então isso era muito comum na universidade.

[Pergunta] Os funcionários mandarem?

[Resposta] É. Por exemplo, antigamente, o secretário geral era um sujeito que tinha um bigodão, boa gente, mas era ele que mandava. Ele conhecia tudo, trocava o reitor, mas ele está lá há 20 anos! Então essa inversão não dá [...] Quer dizer, então você terminar nas mãos da administração, sendo que deve ser o contrário, você é que reúne a informação.

A oposição essencial que transparece no discurso do dirigente 64 é, portanto, entre as funções de concepção e de comando, que devem ser concentradas pelos professores universitários em cargos de direção, e as funções de execução e obediência, que devem ser atribuídas aos funcionários, incluindo os ligados à administração, dentre os quais os de "Recursos Humanos" que, para exercer tal função, adquiriram conhecimentos específicos de gestão. É interessante que, implícito nesse movimento, está uma recusa, que aparece de modo 
recorrente nas minhas entrevistas, sobretudo entre os professores formados ou vinculados ao polo profissional tradicional, a atribuir uma capacidade inerente de liderança e direção àqueles que adquiriram conhecimentos formais para tanto. Mais importante, segundo eles, são os saberes tácitos adquiridos no seu processo de formação, tais como a capacidade de agir rápido e sobre pressão, a intuição, o bom senso e o discernimento, este último privilégio dos que possuem um "nível intelectual elevado". Essa valorização de saberes tácitos mostra a importância da socialização desses dirigentes nas escolas de poder da USP onde, como visto, eles aprendem justamente a exercer essas funções de comando, controle e direção. Nesse sentido, é significativo que o dirigente 64, formado na Faculdade de Medicina da USP, atribui a sua capacidade para assumir postos de direção justamente ao fato de ser médico:

[Pergunta] Mas na sua experiência toda de “administrador”, assim, entre aspas, ou seja, na sua experiência em postos de direção, não teve nenhum conhecimento específico que te ajudou?

[Resposta] Talvez o fato de eu ser médico. O médico é um bom administrador porque ele toma decisões. Certas ou erradas. Aliás, o reitor da minha época era assim: ele tomava decisões na hora, não ficava protelando. O médico-geral, o cirurgião, que trabalha em pronto-socorro, tem que tomar decisões, não adianta ficar protelando. Isso faz a coisa andar: "Ah, mas deu errado". Paciência! Volta aqui e vai para lá, mas a coisa tem que andar. Fora essa experiência, nenhum outro conhecimento me ajudou.

No mesmo sentido, a dirigente 54, formada na Faculdade de Direito da USP no final dos anos 1950, também atribui a sua capacidade para "atividades político-administrativas" não a conhecimentos formalizados, adquiridos pelo estudo, descrito enquanto "preparação organizacional", mas a uma habilidade tácita que atribui à "mera intuição":

[Pergunta] Mas, por exemplo, professora, quando a senhora, em 1984, se tornou Chefe de Departamento na Faculdade de Direito. Que experiências a ajudaram a desempenhar aquela atividade político-administrativa?

[Resposta] Mera intuição.

[Pergunta] Intuição?

[Resposta] Mera intuição. Eu não tinha nenhum preparo organizacional.

De modo semelhante, o dirigente 24, formado na Faculdade de Medicina da USP, ao comentar a sua experiência de acompanhar, como vice-diretor da FSP, uma outra médica especializada em administração hospitalar que, na época, encontrava-se na diretoria da unidade, 
atribui a capacidade de administrar ao "bom senso":

[Pergunta] E o que o senhor aprendeu na sua experiência com essa diretora?

[Resposta] Na verdade, eu dizia sempre para ela: "professora, eu não sei administrar". E ela dizia: "administrar é questão de bom senso. Se você tiver bom senso, você administra".

[Pergunta] Mas professor, uma questão que pra mim é bem importante. Essa diretora que tinha uma larga experiência, trabalhando e pesquisando a administração hospitalar mas, ao mesmo tempo, ela afirma que administração é questão de mero "bom senso". O que significa dizer que não precisa ter nenhum conhecimento especializado. Qual é a sua visão sobre isso? Precisa ter conhecimentos especializados?

[Resposta] Precisa. Pois é, eu acho que precisa, mas com muito bom senso. [Risos]. [...] Porque realmente, com bom senso, você sabe, você decide.

É nessa chave que podemos compreender, por sua vez, a oposição que marca a fala do dirigente 22, que se formou em física da Faculdade de Filosofia, Ciências e Letras da USP, mas se tornou professor da Escola Politécnica antes de ser transferido para o novo Instituto de Física, na Reforma de 1968-1969. Depois de atuar como diretor do Instituto e assumir cargos de direção fora da universidade, o dirigente retornou à USP para ser o primeiro reitor do período democrático. Ao avaliar o lugar que a administração ocupou na sua gestão, o ex-reitor recorre a um esquema categorial que também associa as noções de alto e o baixo à oposição entre concepção/execução, direção/obediência:

[Pergunta] Professor, alguns dizem que o senhor colocou a administração em um lugar mais discreto. O senhor concorda com essa visão?

[Resposta] É, é o que eu disse para você: você escolhe diretores pelo discernimento, e discernimento é só para pessoas de nível intelectual elevado. E importante é você começar a escolher um bom burocrata. Burocratas são para fazer coisas. O reitor precisa dirigir. Quer dizer, eu tenho uma visão baixa da administração. Quer dizer, não baixa no sentido de desrespeitosa.

[Pergunta] Na sua opinião, qual é o papel da administração?

[Resposta] Ah, é viabilizar as ideias que os dirigentes têm. Digo, os diretores, os próreitores e reitores.

Fica explícito, portanto, que na visão dos dirigentes da USP, a sua função essencial deve ser, justamente, conceber as grandes diretrizes da universidade, desempenhando, assim, uma função de "planejamento", o que eles podem fazer justamente por habilidades que eles não aprenderam formalmente, tais como a sua capacidade de visão, o seu bom senso, a sua intuição e o seu discernimento. Mas na medida em que o meu trabalho de campo avançava e a recusa 
dos dirigentes à "administração", como conhecimento e como prática, ia se mostrando recorrente, eu passei a achar que esse padrão de resposta, que atribuía à administração um lugar essencialmente inferior, era determinado justamente pelo enunciado da minha pergunta que, ao invés de mencionar o conhecimento em "gestão", falava explicitamente em "administração" 261. Essa sugestão foi confirmada durante uma entrevista realizada com um ex-reitor da USP que, por ser formado em administração de empresas, dominava profundamente a linguagem gerencial e seus significados. Segundo ele, a oposição entre "gestão" e "administração", embora insignificante do ponto de vista teórico, acaba assumindo, no “imaginário desta comunidade específica", a USP, uma diferença simbólica essencial, sintetizada por ele nos seguintes termos:

\begin{abstract}
[Pergunta] Professor indo para as últimas questões, mais especificas. Existe uma discussão muito grande, um pouco retórica e um pouco científica, da diferença entre administração e gestão. O senhor vê pertinência nessa oposição?

[Resposta] Na parte simbólica, sim. Se você for para discussão científica, não. Você vai ver que essas palavras são sinônimos. Mas, em como isso é tratado no imaginário desta comunidade específica que você está estudando, a resposta é sim. A palavra administração, por estar associada à administração pública, ou mesmo à administração de empresa, ou ao administrador, envolve toda uma origem: o administrador vem do capataz, do individuo que administrava fazendas, era um mero executor. Era um operador. A palavra gestão, vem de gestare, ao mesmo tempo de gerir, mas de gestar no sentido de criar, de constituir, ela transmite mais a função do gestor. Então, são palavras que muitos utilizam como sinônimos, mas na palavra administrar há mais o traço executor. E na palavra gerir, há uma palavra que transmite mais a figura do dirigente, de dirigir, portanto, de ter a visão, de ter a leitura estratégica, de lidar com a inovação. Enquanto que o administrador é um executor. É por isso que se fala "gestão de projetos" e não "administração de projetos", apesar de "administração de projetos" também existir. Agora, é uma questão que você levanta, até pelo seu convívio com o tema. Poucas pessoas cultivam essa diferença. Eu, claramente, sou sensível a ela porque tive que transitar da área de administração, no sentido restrito, para a gestão.
\end{abstract}

Ao tentar explicar a diferença entre "administração" e "gestão", o dirigente 26 explicita de modo paradigmático todo um conjunto de oposições sociais, significativas no âmbito da USP, e que têm, como base, a valorização das funções de coordenação e comando que só podem ser exercidas por aqueles que "têm a visão" e, portanto, "a leitura estratégica” da organização

\footnotetext{
${ }^{261}$ As palavras "gestão" e "administração", apesar de serem usadas como sinônimos por parte importante dos entrevistados, possuem uma diferença que remete, justamente, 'a oposição essencial entre concepção/execução que define uma oposição categorial essencial no contexto da USP. Para mais detalhes, ver capítulo 2, em que trabalhamos a evolução desses dois termos.
} 
estando, por isso, preparados para dirigi-la. Essa explicação da diferença entre "administração" e "gestão", ao trazer para o primeiro plano o esquema categorial que sustenta a recusa, pelos dirigentes da USP, da administração como conjunto de conhecimentos explícitos e práticas sistematizadas, ajuda a compreender, inclusive, porque a própria "gestão", quando associada a funções meramente executivas, também acaba sendo recusada. Assim, por exemplo, o dirigente 37, que é professor de economia da FEA, tendo assumido, por longo tempo, a direção da Codage, implementando os programas da Comissão Permanente de Avaliação e da Comissão de Qualidade e Produtividade e assumindo a coordenação do Plano de Desenvolvimento Institucional, trata a "gestão" e a "administração" como sinônimos, associando-os, sem distinção, às atividades de execução descritas, de novo, como "mais baixas", "mais rasteiras" e associadas a "coisas menores":

\begin{abstract}
[Pergunta]Professor, na sua opinião, qual o lugar da gestão, como corpo de conhecimento e como prática, na universidade?

[Resposta] Gerente é alguém que trabalha em dadas condições mais ou menos estáveis e faz funcionar, tem uma envergadura mais baixa. E é preciso de gerentes...

[Pergunta] Uma envergadura mais o que?

[Resposta] Mais baixa, mais rasteira. Então, tem que trabalhar. O sujeito tem que chegar, estar adequado, com as coisas funcionando bem, tem que ter as rotinas normais. A teoria da administração é mais de gerência do que de inovação. [...]... Veja, a palavra inovação, nessas áreas, vem do Schumpeter e hoje ela se banalizou. Hoje se usa inovação para tudo, qualquer curso de qualquer coisa fala de inovação, e os administradores se apropriaram dessa palavra, mas a empobreceram muito. Falam de coisas menores, não das de grande envergadura. Não falam daquela questão que eu colocava para você: $\mathrm{O}$ que é que gera avanço de conhecimento, o que é que gera grandes inovações? [...] Isso é muito mais complicado e, na verdade, a literatura que trata sobre isso na ótica que eu gosto mais, ela tem historiadores, tem economistas, de vez em quando passa um administrador, mas com voo baixo. Tem sucesso relativo e depois desaparece. Os grandes autores não desaparecem. Eu estou falando de gente que tem muitos anos aí, de grande contribuição. Então veja, eu estou falando de um nivel mais alto, eu estou querendo grandes resultados.
\end{abstract}

Vistos em conjunto, essas falas de dirigentes da USP, formados ou vinculados ao polo profissional tradicional da universidade, revelam, em primeiro lugar, a força dos esquemas categoriais que traduzem a estrutura social interna à universidade que opõe, justamente, a formação de elites dirigentes à formação de cientistas, professores e técnicos especialistas. Nesse sentido, elas demonstram, ainda, que o ideal do modelo gerencial, de concentrar nos 
executivos centrais as funções de planejamento e controle, não pode ser separado, na universidade, dos ideais mais gerais que inspiram o seu polo dominante. Por fim e como resultado disso, essas falam explicitam que a recusa da "gestão" e da "administração" como saber formalizado na definição dos rumos do governo da USP deve ser pensada, também, à luz dessa estrutura social.

Assim, voltando a uma das questões centrais desta tese, cabe de novo perguntar como foi possível que o conhecimento gerencial determinasse toda uma reestruturação do governo da USP se seus dirigentes, responsáveis por essas mudanças, recusam veementemente esses conhecimentos? Por um lado, como visto, isso foi possível porque a gestão se impôs na USP como um novo regime de verdade, se quisermos, como um dispositivo de saber-poder que pressupôs longos processos de conversão, reformas organizacionais e a implementação de instrumentos concretos que, juntos, acabaram estabelecendo a gestão como linguagem comum e inescapável. Mas não foi só isso. A gestão pôde se impor na USP, também, porque suas concepções elementares se afinam perfeitamente às categorias e visões do polo dominante da universidade que, por meio da gestão, conseguiu impor suas categorias como "naturais". Para demonstrar essa afinidade entre as categorias da gestão e as visões do polo dominante da USP selecionamos dois exemplos paradigmáticos: por um lado, a valorização da avaliação externa como um mecanismo para assegurar uma universidade de resultados; por outro, a valorização da liderança individual que resulta, em síntese, no enfraquecimento dos órgãos colegiados.

\subsubsection{A valorização da avaliação externa: a universidade de resultados}

Como visto anteriormente, as escolas de elite assumem como um dos pilares da relação de ensino/aprendizado, a competição escolar subordinada aos imperativos da urgência. Isso se manifesta de modo paradigmático no enorme volume de conteúdo, que precisa ser absorvido em pouco tempo, sob avaliação constante, o que incentiva processos internos de competição e 
concorrência. Ao basear a relação de ensino/aprendizado e, portanto, a própria socialização escolar na avaliação constante, na concorrência generalizada e no regime de urgência as escolas de elite incentivam uma relação essencialmente instrumental com o conhecimento, pela qual esse passa a valer pelos seus resultados práticos, em uma oposição explícita à relação de gratuidade e desinteresse material que predomina, em geral, no polo oposto, formado pelas unidades e faculdades voltadas à formação de pesquisadores e professores (cf. Bourdieu, 1989).

Partindo dessa contraposição cabe lembrar que, no primeiro capítulo desta tese, ao tratar da visão de universidade que predominava na chamada "história oficial" da USP, procurei mostrar como essa visão era essencialmente pragmática e utilitária correspondendo, assim, aos ideais que orientaram a criação, pela burguesia paulista em ascensão no período republicano, das escolas profissionalizantes de ensino superior que estão na raiz do polo dominante da USP, responsável justamente por essa história oficial, formulada nos espaços de poder hegemonizados, como visto, pelo polo profissional tradicional. Foi justamente contra essa visão pragmática que se voltou o Movimento pela Reforma Universitária, durante os anos 1950 e 1960, formulando um projeto de universidade que colocava a pesquisa como base do ensino, opondo-se frontalmente à opção, até então predominante, de privilegiar, como função essencial da universidade, a formação profissional. A derrota desse projeto, encampado particularmente pelo polo acadêmico-científico, resultou na inflexão do padrão de expansão da USP, que passou a crescer sobretudo pela abertura de novos cursos profissionalizantes, pautados mais ainda por uma visão pragmática de conhecimento.

É à luz dessa longa história, em que o polo dominante conseguiu impor uma visão essencialmente pragmática de formação universitária e de produção de conhecimento que se deve buscar compreender a força dos discursos em torno da função e da missão social da universidade, que se expressam de modo marcante na defesa de formas externas de avaliação, associadas diretamente ao discurso gerencial. Essas novas avaliações, que buscam impor na 
universidade uma "cultura de resultados", afirma-se contra o "caráter corporativo" das formas de avaliação historicamente consolidadas na instituição acadêmica. Foi nesse sentido que, ao longo dos últimos anos, procurou-se legitimar diferentes formas de avaliação, em geral externas ao corpo docente, que tomaram como objeto não só o desempenho dos próprios professores, como também o rendimento dos alunos, a produtividade dos departamentos e unidades e a qualidade dos cursos de graduação e programas de pós-graduação. Essas avaliações, antes hegemonizadas por docentes universitários que mantinham, assim, um controle de tipo profissional sobre a própria atividade, passaram a ser realizadas por gestores profissionais, por consultores externos, locais e estrangeiros, por ranqueamentos universitários, nacionais e internacionais, ou, ainda, pelos próprios alunos vistos agora como "clientes". Em todos esses casos, o objetivo é elaborar dados quantitativos que possam servir para estabelecer hierarquias, metas e comparações, aferindo claramente a produção de resultados e, através disso, "a contribuição social da universidade".

É essa afinidade entre uma visão essencialmente pragmática de conhecimento e as concepções gerenciais de avaliação do trabalho acadêmico que explicam a facilidade com que essas novas formas de avaliação foram aceitas pelos dirigentes da universidade, oriundos do polo dominante da universidade e, a partir da sua ação em órgãos centrais de direção, impostas para o conjunto da universidade. Essa afinidade é explicitada, por exemplo, pelo dirigente 26, formado em administração na FEA e, por isso, portador de uma visão essencialmente gerencial de universidade. Ao falar da sua relação com o dirigente 21 que, oriundo da Escola Politécnica, tornou-se reitor da USP no começo dos anos 1980, o dirigente afirma que, não obstante as diferenças políticas que os afastavam, havia uma "afinidade em relação às prioridades da universidade", ou seja, à "gestão de resultados":

A minha posição na época [anos 1980] era uma posição um pouco ambígua. De um lado, pelo fato de eu ser ligado à gestão e à administração, eu estava muito próximo da cultura da Escola Politécnica. No entanto, pela minha visão política geral, eu era oposto ao reitor da época e à Escola Politécnica, de onde ele provinha. Mas havia essa afinidade com relação às prioridades da universidade. Então, ele e eu acabamos nos 
entendendo muito bem, por sermos pessoas comprometidas com a gestão de resultados.

Essa "cultura de resultados", a princípio tímida na universidade, acabou se impondo passando a determinar, ainda segundo o dirigente 26 , um conjunto de políticas acadêmicas, implementadas ao longo dos últimos anos:

Nós, na universidade, sempre temos muitos dados e números sobre processos. Processos no sentido dos meios necessários [para a nossa atividade]. Mas temos pouco dados sobre os resultados. [...] Um exemplo de dado sobre resultado, na universidade, é o tempo que o aluno demora para se formar. E foi a partir daí que vieram as várias decisões ligadas a esse tema. Uma decisão muito dura que tivemos que tomar, já na época em que eu era diretor, foi evitar que os alunos estivessem inscritos simultaneamente em mais de um curso. [...] Mas depois, essa ênfase em resultados se expandiu e passou a influenciar, inclusive, a criação de cursos novos. A pró-reitora de graduação, [formada na Faculdade de Direito da USP], absorveu essa ideia e, então, toda a proposta de expansão foi dada em torno de prioridades, de números, de custos de alocação. O então diretor da Codage já tinha essa sensibilidade, porque ele vinha da área financeira. Então, eu acho que essa cultura de resultados acabou prevalecendo.

Um outro exemplo de afinidade entre a "cultura de resultados" e uma "visão pragmática" de universidade aparece também na fala do dirigente 23 , formado em engenharia no começo dos anos 1960. Ao explicar como ele procurou criar, no interior da sua unidade, uma cultura da avaliação por desempenho, ele explicita que esse movimento era inseparável da valorização de projetos práticos que não se limitam ao ideal de ciência e conhecimento abstrato, refletindo-se em desenvolvimento:

Então, por exemplo, todo professor que fosse conversar comigo tinha que trazer o currículo com as publicações dos últimos cinco anos [risos]. O professor pedia uma entrevista e a secretária já dizia: "o professor pede que o senhor leve o seu currículo com as publicações”. Então já começava colocando uma pressão assim. E eu lutei muito para a gente poder fazer projetos práticos. Então, por exemplo, defendi muita gente que, às vezes, academicamente era considerada de "segundo nível", mas que tinha um grande componente de inovação. Esse pessoal, eu protegi muito. Tanto que se criaram vários grupos de ciência aplicada. Esses eu defendi, mesmo que eles fossem muito atacados, porque eles faziam coisas de impacto, coisas importantes. Eu sempre tive isso na cabeça. Eu acho que a ciência, ela tem que trazer conhecimento abstrato, conhecimento pelo conhecimento, mas também ela tem que se refletir em desenvolvimento.

É interessante notar que esse mesmo dirigente 23, que acabou se tornando um grande especialista em gestão universitária e, por conseguinte, em avaliação acadêmica, acredita que a

USP nunca conseguiu realizar um processo de avaliação "para valer", justamente por 
resistências internas à universidade que, por uma espécie de desvio corporativo, impede a universidade de "expor a si própria":

[Resposta] Avaliação, para mim, é um negócio para valer! É um negócio penoso, importante, inevitável. Inevitável para uma instituição que quer crescer e ser internacional. Não dá só para bombear. [...] a USP não tem coragem de abrir suas feridas, então ela nunca vai resolver isso.

[Pergunta] Em que sentido, professor?

[Resposta] A USP não se expõe a si própria. A USP não se expõe. Você acha que a USP vai fazer um levantamento para dizer que há professores ruins, por exemplo, na Química? Oito professores na Química são super mal-avaliados pelos alunos, por exemplo. Você acha que a USP fará isso algum dia? Nunca! Nunca! Então, a avaliação está perdida porque se você não pode criticar, você não pode fazer avaliação. Avaliação em que está tudo bom? Está tudo maravilhoso? Então, é o que eu falo para você: a USP é uma instituição que bombeia! Bombear tem um papel? Tem! Estimular, financiar, apoiar, tudo isso joia! Eu acho que é muito certo. Mas tem que ter uma outra parte também, que é a parte de saber se aquilo que está sendo feito tem eficácia.

É também a resistências internas à universidade, especialmente por parte dos professores que não querem ser avaliados, que a dirigente 54 - formada na Faculdade de Direito e pró-reitora de graduação nos anos 1990 - atribui o fracasso das suas iniciativas para impor uma avaliação do corpo docente pelos alunos:

[Pergunta] E na sua pró-reitoria ainda alguma política que nós não citamos aqui que a senhora gostaria de ter implementado ou que a senhora tenha implementado? [Resposta] Nós fizemos muito encontro, muito seminário para aperfeiçoar o ensino da graduação. Essa foi uma atividade muito intensa. Fizemos também seminários para avaliação. Avaliação foi um ponto extremamente importante, tanto a avaliação dos docentes pelos alunos como a auto-avaliação. Nós não conseguimos efetivamente mudar a avaliação pelos alunos [...] Por resistência dos professores, resistência à mudança. Aliás as minhas dificuldades como pró-reitora vieram sempre mais dos professores do que dos alunos [...], porque os professores não querem ser avaliados.

É interessante que essa mesma dirigente, ao definir o que constitui, na sua perspectiva, uma "gestão eficiente" da universidade, explicita a sua visão pragmática de conhecimento que, mais uma vez, mostra a sua afinidade com a concepção gerencial de avaliação porque, em ambos os casos, o que está em jogo é uma crítica a um ideal mais estrito de autonomia, visto como corporativo:

[Pergunta] Professora, como a senhora definiria uma gestão eficiente? Porque hoje tem uma discussão muito forte sobre isso, não é?

[Resposta] Nesse caso, depende do papel que você confere à Universidade. Eu acho que falta um pouco de eficiência às nossas universidades. A todas as universidades, não é só à USP. Eficiência em relação ao corpo social, em termos de entrosamento 
com o corpo social. Um pouco também na pesquisa, porque a nossa pesquisa é muito dirigida a temas científicos, mas que não interessam a ninguém. [...] Sabe, você examinar no microscópio um inseto e descobrir que ele tem um sistema reprodutor de um jeito ou de outro, pode até ser que indiretamente que esses estudos sejam úteis. Mas eu vejo pouca utilidade, tanto que eu gosto muito de ler a revista Pesquisa da FAPESP porque ela realmente mostra o que deve ser uma pesquisa útil. Nós nunca tivemos, no Brasil, um grande prêmio de pesquisa. Por que? Porque nossas pesquisas são excelentes, mas não se ligam às demandas sociais. [...] Eu acho que a universidade seria mais eficiente se se ligasse mais socialmente, culturalmente e politicamente à sociedade, e interagisse mais com a sociedade. Eu acho a universidade muito encastelada. Muito olhando para si mesma e não para fora.

Essa crítica à autonomia acadêmica também está presente de modo marcante no discurso do dirigente 59, formado na Faculdade de Arquitetura e Urbanismo da USP, uma unidade que, apesar de vinculada ao polo profissional tradicional da universidade, praticamente não está presente nas suas estruturas de governo. Ao ser perguntado sobre o lugar que a avaliação ocupa na universidade, o arquiteto, que foi pró-reitor de pesquisa da USP, relata um acontecimento que testemunha os embates que, no começo dos anos 1990, ainda marcavam a universidade em torno da afirmação da necessidade de um certo modelo de avaliação:

Bom, eu acho que você tocou em um ponto interessante porque, de fato, de repente, a palavra de ordem passou a ser "avaliação". Tanto que, no meu departamento, criouse uma linha de pesquisa, que permanece até hoje, que é a avaliação pós-ocupação dos imóveis. Então há toda essa questão da avaliação e é algo necessário. Eu me lembro, inclusive, de ter dito uma frase que me valeu um prestígio muito grande com alguns professores e o ódio de outros. Em um dado momento, quando eu estava à frente do Conselho de Pesquisa, alguns professores começaram a protestar contra a avaliação, apontando problemas. Eles tinham razão, tinha problema mesmo na avaliação de desempenho, mas eles não sabiam como colocar a questão, de modo que dava a impressão de que eles eram contra a avaliação. E no aceso da discussão eu saí com uma frase, dizendo: "Eu não teria coragem de avaliar os meus alunos se eu não me dispusesse a ser avaliado também". Se você cunha uma frase dessas no calor da discussão causa um impacto enorme.

Essa posição, de afirmar a importância da avaliação passando por cima de críticas pertinentes que eram então apresentadas, testemunha o esforço que foi feito, no âmbito da administração central da USP e no bojo da expansão dos dispositivos de gestão acadêmica analisados anteriormente, para afirmar novos modelos de avaliação que conseguissem vencer o que esses dirigentes consideravam como barreiras de uma "universidade encastelada". Mas não apenas a recusa da avaliação externa que é considerada, pelo dirigente 59, como uma expressão 
injustificada de corporativismo. Também as diferentes formas de autogoverno devem ser vistas nessa mesma chave:

\begin{abstract}
Uma vez uns alunos de graduação entraram em minha sala e me perguntaram: "O senhor é a favor ou contra a eleição direta para reitor?". E eu respondi, para a surpresa deles: "Eu sou a favor. A nossa diferença certamente está no colégio eleitoral. Porque eu acho que os alunos e os professores deveriam ser proibidos de votar, não é? Porque quem está pagando a festa é o povo do estado de São Paulo. Então, se o povo do Estado de São Paulo for votar para a eleição direta, eu sou a favor. Agora, vocês e nós, que estamos ganhando aqui - porque vocês estão ganhando tanto quanto os professores ganham - esses não podem votar, entendeu? Porque isso é uma safadeza". Eu sempre digo, para o americano soa como alguma coisa imoral que nosso sistema de governo seja assim, ou seja, que a gente eleja o nosso chefe, eles olham e pensam, "que mamata é essa?".
\end{abstract}

A defesa da restrição da autonomia universitária, expressa em formas externas de avaliação e eleição de dirigentes, é vista, sobretudo pelos docentes do polo profissional tradicional, como algo natural e desejável. É essa posição que defende o dirigente 64 formado, como dito, na Faculdade de Medicina da USP. O trecho é interessante porque explicita, na voz dos próprios dirigentes da universidade, a homologia entre a USP e as grandes escolas francesas que orienta as análises deste capítulo:

Uma vez eu participei de um debate no Instituto de Estudos Avançados, e percebi que havia uma turma que não queria mais elaborar a lista tríplice, eles queriam escolher sozinhos o reitor. Eu então disse: "Sinto discordar. Mas essa soberania eu acho que a universidade não tem" [...]. De fato, eu nunca achei que a universidade devesse ter uma autonomia plena. Aliás, você vê que, em Harvard, tem um Conselho [externo] que reúne personalidades, ele tem dinheiro e tudo. Quer dizer, essa história de que cada membro da universidade vota, não é por aí o caminho das pedras. Tanto que você tem o caso da universidade francesa, que acabou sendo um pouco esculhambada. $\mathrm{O}$ Napoleão tanto achava isso que criou as grandes escolas, que não têm nada a ver com a universidade, e de onde saiu a elite intelectual francesa. Depois a Escola Politécnica daqui foi copiada da francesa [...]. Então, essa história de democracia na universidade é o problema e o fim dela.

Em síntese, é possível dizer que a defesa gerencial de formas externas de avaliação descritas também como formas não corporativas de avaliação porque não realizadas pelos próprios docentes universitários - e eleição - expressa na valorização da intervenção governamental da escolha dos dirigentes máximos da USP - encontra paralelos importantes com as concepções predominantes no polo dominante da universidade, não só de defesa de um ideal mais pragmático de conhecimento, mas também de uma crítica aos princípios de 
autogoverno acadêmico e de defesa, mais ou menos radicais, da autonomia universitária. Mas além disso, é possível apontar uma afinidade entre a valorização do comando individual pelo polo dominante da universidade e as concepções gerenciais que defendem a centralização da direção das organizações em pequenos órgãos executivos comandados por lideranças individuais.

\subsubsection{A valorização da liderança individual: a universidade centralizada}

Assim, uma outra marca importante desse processo, em que a visão gerencial se beneficia e reforça as categorias inerentes ao polo dominante da universidade, é a difusão de um novo termo para designar os ocupantes de cargos executivos na USP, sobretudo os seus reitores: eles são, cada vez mais, identificados como líderes ou lideranças, tal como inspirado pelo novo vocabulário da gestão. De fato, como visto, uma das primeiras vezes que a noção de liderança aparece associada aos reitores brasileiros foi no relatório de Rudolph Atcon, Rumo a uma reestruturação das universidades brasileiras, em que o consultor norte-americano descreve os dirigentes universitários da década de 1960 como "uma nova geração de líderes" (cf. Atcon, 1966, p.77-8). No entanto, a valorização da capacidade individual de liderança, expressa em posturas e atitudes determinadas, não surge com o discurso da gestão. Como visto no primeiro capítulo desta tese, não é raro encontrar descrições do caráter de liderança individual assumida por dirigentes importantes da história da USP e das suas unidades isoladas. Nesse sentido, vale a pena retomar, agora em nova perspectiva, as biografias de caráter consagrador mobilizadas por Ernesto de Souza Campos no seu livro sobre a história da USP. Assim, sobre o ex-diretor da Faculdade de Medicina da USP, Arnaldo Vieira de Carvalho, Campos afirma:

Mas o que caracterizava especialmente a figura social e profissional de Arnaldo era seu atrativo pessoal. Refletia-se na inconfundivel atitude de comando, revelada nas deliberações rápidas e incisivas, na nobreza e na dignidade dos seus atos, nos gestos moderados e cortantes, no seu feitio de estimular os estudiosos e até na sua 
indumentária sempre correta (Campos, 1954, p. 346; grifos meus).

Ainda sobre o fundador da Faculdade de Medicina de São Paulo, o autor sintetiza:

Possuindo excepcional envergadura moral, dotado de grande inteligência, senhor de uma cultura vastíssima, adquirida pelo trato constante dos livros, tinha Dr. Arnaldo a seu serviço, extraordinárias qualidades de energia e decisão. Tinha, além do mais, o "physique du role". Estas circunstâncias transpareciam no seu porte elegante, na caracterização marcante da fisionomia e refletia-se até no andar, e no fraseado cortante e rápido. Verdadeiro condutor de homens era também, na sua profissão, o "primus interpares". Não será demasia dizer-se que lucrou a escola, em se ter protelado a sua criação, só pelo fato de conseguir oportunidade de uma tal orientação (Campos, 1954, p. 349; grifos meus).

Nesse mesmo sentido, sobre o então diretor da Escola Politécnica, Antônio Francisco

de Paula Souza, Ernesto de Souza Campos afirma:

A Escola Politécnica também sofreu alguns tropeços nos albores da sua organização, mas ali também havia um homem de têmpera de aço: Antônio Francisco de Paula Souza. Inflexível, prestigioso, manteve a linha de disciplina a ponto de conferir àquela casa de ensino o nome carinhoso de escolinha Paula Souza (Campos 1954, p. 355).

A valorização da firmeza da postura pessoal de liderança acadêmicas também aparece na avaliação do reitor da USP, à época:

Ocorreram também perturbações graves de disciplina na recém-fundada Faculdade de Arquitetura e Urbanismo. Além da greve, permitida legalmente, surgiram reclamações contrárias à disciplina hierárquica. A firmeza do Magnífico Reitor Ernesto de Moraes Leme repôs a instituição na estrada real (Campos, 1954, p. 355).

É evidente que, hoje, o conteúdo apreciado na liderança acadêmica mudou. Mas permanece a valorização de atitudes individuais, ligadas à capacidade de tomar decisões, de agir sem protelar, de enfrentar resistências quando necessário e de superar desafios ${ }^{262}$. Nesse sentido, ao longo do meu trabalho de campo, sobretudo nas entrevistas com dirigentes, a valorização da capacidade de liderança individual apareceu com considerável frequência,

\footnotetext{
${ }^{262}$ Como visto, a valorização da noção de liderança está associada ao processo de socialização escolar voltado à formação de "homens de ação". Cabe notar que o novo regimento de pós-graduação da USP inseriu o desenvolvimento da "capacidade de liderança" dentre os objetivos da pós-graduação da universidade, o que dividiu o Conselho Universitário da USP durante a aprovação do referido regimento. Atualmente, o primeiro artigo do regimento afirma: "A Pós-Graduação stricto sensu, voltada para a geração do conhecimento, destina-se à formação de docentes, pesquisadores e profissionais com amplo domínio de seu campo do saber e capacidade de liderança e inovação" (USP, 2013, n.p.).
} 
sobretudo em relação aos cargos executivos, especialmente os reitores. Nessa chave, podemos considerar a fala do dirigente 23 , por exemplo, que, como dito, foi diretor de unidade nos anos 1980 e reitor da USP nos anos 1990. Ao descrever porque decidiu apoiar a candidatura do reitor que o antecedeu, de quem tornou-se vice-reitor, ele afirma:

Eu achava que a USP precisava ter um reitor que fosse uma liderança internacionalmente reconhecida, em termos científicos, inclusive. Então, quando ele se apresentou como candidato, eu decidi apoiá-lo porque nós precisávamos ter alguém com nome, com prestígio e que sabia o que é fazer ciência, para que a USP entrasse em um rumo menos doméstico. [...] Enfim, era toda uma equipe, mas ele era o nome, a liderança, não é?

O reitor a que ele se refere, o dirigente 22 , também enxerga a capacidade de liderança como uma qualidade importante dos ocupantes do governo da USP. Ao comentar sobre qual é, na sua opinião, o papel dos órgãos colegiados, ele explicita que, a despeito da sua importância, eles não devem substituir "a liderança". O trecho como um todo é muito interessante porque já aponta a existência de uma outra afinidade, aparentemente improvável, entre as categorias do discurso gerencial moderno e os valores políticos da esquerda revolucionária, da primeira metade do século XX, relação que, contemporaneamente, tem sido objeto de trabalhos no campo da historiografia (cf. Cohen, 2013a e 2013b) ${ }^{263}$. Em síntese, o ex-reitor afirma:

Os órgãos colegiados... [pausa] eles são importantes por causa da diversidade de opiniões. Mas acontece, como você pode ler nos meus artigos, que eu sou uma pessoa que não acredita nas massas, eu acredito na liderança. Na sua área, a sociologia, Marx acha que o progresso da humanidade é feito pelas massas e pelos fatores econômicos, não é? Mas a verdade é que se não tivesse tido Lenine não teria revolução nenhuma. A importância de líderes que captam o momento histórico e fazem as coisas que são necessárias é uma questão que não está resolvida pelas ciências sociais até hoje [...]. $\mathrm{Eu}$ acredito que a liderança é absolutamente insubstituível. "Ah, não, mas são as condições sociais que criam os líderes!". Não sei.

Essa afinidade eletiva entre os ideais do discurso revolucionário, que valoriza vanguardas e líderes, e as categorias da teoria gerencial moderna é importante para entender alguns

\footnotetext{
${ }^{263}$ Em 2013, Yves Cohen publicou o livro "Le siècle des chefs: une histoire transnationale du commandement et de l'autorité (1891-1940)" (cf. Cohen, 2013a). No mesmo ano, traduzi um texto do autor justamente sobre o significado da figura do "chefe" no discurso político do século XX, em diferentes expressões nacionais como o discurso gerencial norte-americano, a cultura revolucionária soviética, o movimento nazista alemão e a psicologia experimental francesa (cf. Cohen, 2013b).
} 
paradoxos, especialmente ligados ao papel dos dirigentes enraizados no polo acadêmicocientífico e marcados por uma trajetória política de esquerda, no recrudescimento da linguagem e das rotinas gerenciais na USP, a partir do final dos anos 1980. Um exemplo paradigmático, nesse sentido, é o do dirigente 58. Formado na Faculdade de Medicina da USP no final dos anos 1950, o dirigente 58 tornou-se professor assistente de um departamento básico dessa Faculdade no começo dos anos 1960, desenvolvendo, nesse contexto, atividades de ensino e pesquisa na área de parasitologia. Por sua reconhecida militância política, especialmente no Partido Comunista, e pela sua ligação com as áreas "científicas" da FMUSP, o dirigente foi um dos primeiros professores da USP a ser cassado pelo regime militar, em lista elaborada pela própria Faculdade, ainda em $1964^{264}$. Ao longo dos anos 1980, depois de desenvolver a sua carreira acadêmica nos Estados e na Unifesp, o dirigente 58 voltou à USP para se tornar, então, professor do ICB, tendo sido chamado para assumir a pró-reitoria de pesquisa da universidade no final dos anos 1980. Mesmo formulando duras críticas, como se verá, à centralização e à avaliação gerencial, o dirigente 58 acaba corroborando, indiretamente, o processo de centralização do governo acadêmico que resulta da imposição dessa visão gerencial ao criticar a burocracia e defender o papel das lideranças individuais:

O reitor, na época, era muito de tomar decisões. Ele gostava de tomar decisões, não é? Inclusive até hoje [...]. Mas eu o admiro exatamente por isso, ou seja, burocracia não era com ele. [...] Então ele era absolutamente contra normas e regulamentos. Se ele pudesse, ele dissolvia o Conselho Universitário, provavelmente seria chamado de tirano, mas ele não gostava desse entrave, ele queria era fazer as coisas.

Essa oposição aos órgãos colegiados, que o dirigente 58 atribui ao reitor da sua época, é uma constante nas entrevistas com os dirigentes oriundos do polo profissional tradicional e, como visto anteriormente, é uma das bases do processo de centralização do poder na USP ao longo dos últimos anos, com base na valorização de órgãos executivos centrais. Vale a pena

\footnotetext{
${ }^{264}$ Para detalhes sobre o processo de perseguição política no interior da FMUSP ver o relatório especial da Adusp sobre o "controle ideológico na USP" que afirma que as cassações da Faculdade de Medicina privilegiaram professores de esquerda e, sobretudo, ligados às áreas básicas ou científicas da unidade (cf. Adusp, 2004).
} 
acompanhar, nesse sentido, o modelo de gestão universitária defendido pelo dirigente 23 , em que não só a autonomia para as diferentes áreas deve ser restrita aos limites do planejamento centralizado como, também, os órgãos colegiados mais amplos e representativos devem ser substituídos por pequenos órgãos executivos:

[Pergunta] Professor, para terminar, eu queria fazer uma pergunta bem rápida. A própria literatura sobre gestão reconhece a existência de uma tensão entre, digamos, uma gestão moderna que é centralizada nos órgãos executivos, como o senhor defendeu, e uma gestão, eu não vou dizer descentralizada, mas muito calcada nos órgãos colegiados.

[Resposta] É verdade. Eu vejo muito bem, eu acho que é isso mesmo. Quem melhor resolve o curso de física é o físico, não será o reitor, porque o reitor não sabe de áreas específicas. Mas as grandes linhas são dadas de cima. Agora, ele não pode entrar na ponta. Então, o planejamento tem que ser o planejamento das grandes linhas e a autonomia na ponta para, dentro do planejamento, fazer o que é certo. Mas sempre dentro de uma orientação geral [...]. Então eu acho que esse é o papel da reitoria: dar as grandes linhas.

[Pergunta] Claro, entendi. E aí, essa "ponta", digamos, seriam os órgãos colegiados na sua visão?

[Resposta] Seriam os órgãos colegiados? Não, seria um gestor que vai ouvir uma comunidade. [...] Na verdade, eu sempre pensei em órgãos muito executivos. E eu sempre defendi que você precisa ter pequenos órgãos executivos e órgãos de aconselhamento político amplos. Então, da mesma forma, eu acho que a pró-reitoria deveria ser uma coisa pequenininha, enxuta e ter um Conselho que ela ouvisse para estabelecer a política, não para estabelecer decisão do cotidiano [...]. Ou seja, a próreitoria tem que ter autonomia para executar as políticas do Conselho. Então, no Estatuto de 1988, isso ficou mal feito. O Conselho ficou muito grande por causa dessa questão de todo mundo querer participar e tal e coisa, e acabou ficando meio executivo, e aí ficou torto.

A ideia de que a direção da universidade deve ser feita por um executivo forte, tal como expresso também na valorização da liderança individual, aparece igualmente na fala do dirigente 36. O trecho é interessante porque associa a noção de liderança à dedicação intensa, quando não exclusiva, ao posto de direção, contrapondo-a a uma atitude, vista como potencialmente "perigosa", de diretores que assumem a gestão universitária apenas transitoriamente. Nessa oposição, transparece a importância da autonomização do governo universitário e seus efeitos sobre a organização da profissão acadêmica, em termos da separação entre controle e execução expressa na divisão entre aqueles responsáveis pelas atividades de docência e pesquisa e aqueles responsáveis pela sua coordenação: 
Eu vejo inúmeros diretores que reclamam do ônus dos cargos de direção dizendo "Eu assumi isso, mas a minha meta é continuar sendo professor e pesquisador, e essa atividade é marginal". Dessa posição surgem os perigos: ele delega suas funções a pessoas menos qualificadas, às vezes os assistentes técnico-administrativos, dentre os quais alguns são muito bons mas outros, nem tanto. Então, se não houver uma liderança do diretor, dificulta muito. Você vê a execução orçamentária de certas unidades, é muito ruim. Quer dizer, faltou ali a presença de um diretor atuante.

Ao apontar o "perigo" subjacente à atuação daqueles que, assumindo cargos de direção, preservam a "meta [de] continuar sendo professor e pesquisador", o dirigente 36 anuncia um padrão de diferenciação que se mostrou essencial no interior do corpo de dirigentes que estou analisando. Diferentes processos, dentre os quais destacamos a expansão do conhecimento gerencial com seus efeitos em termos de conversão de dirigentes, centralização de poder e implantação de novos dispositivos de gestão, contribuíram para complexificar e autonomizar as funções de direção no interior da universidade, especialmente no seu nível central. Como resultado desse processo, é cada vez mais raro, sobretudo para reitores, como lideranças institucionais, e para os coordenadores administrativos, como experts em gestão, não se dedicar exclusivamente às funções de direção e, mais do que isso, retornar às atividades de ensino e pesquisa depois da sua passagem pela direção central da universidade. Esse padrão de trajetória, em que as atividades de gestão constituem uma via de mão única, contrasta com outro, observado sobretudo entre os dirigentes formados ou vinculados ao polo acadêmico-científico que, depois da sua passagem pelos postos de direção, retornaram completamente para as suas atividades pregressas de ensino e pesquisa. Não por acaso, serão esses os principais críticos ao processo de transformação do governo acadêmico na USP, a partir da influência do conhecimento gerencial, como é possível observar no subitem a seguir que encerra este capítulo. 


\subsubsection{Crítica e resistência nos limites da gestão: a universidade gerenciada}

O presente capítulo, como dito, se encerra com uma análise das críticas formuladas por dirigentes oriundos do polo acadêmico-científico às mudanças ocorridas no governo acadêmico da USP a partir do fortalecimento da gestão, como conhecimento e como prática, especialmente em termos de centralização do poder na universidade e de imposição de novas formas de governo e avaliação do trabalho acadêmico.

Antes de apresentar de modo mais sistemático essas críticas, é interessante notar que, ao contrário das entrevistas realizadas com dirigentes do polo profissional tradicional, que ocorreram predominantemente em espaços de direção tais como gabinetes, presidências, conselhos, coordenações e chefias, todas as entrevistas de dirigentes oriundos do polo acadêmico-científico da USP foram concedidas em ambientes de trabalho, ou seja, em salas de professores. Durante essas entrevistas, não raro, ocorreram interrupções de alunos, funcionários e professores para tratar de assuntos acadêmicos como horário de aulas, data de entrega de trabalhos, disponibilidade para participação em bancas e prazos para submissão de artigos. Essa diferença no contexto de entrevista é um indício importante de como o lugar do campo universitário em que se formam ou ao qual se vinculam os seus dirigentes é um determinante dos limites e possibilidades das suas trajetórias institucionais, especialmente em termos de ruptura ou permanência em cargos de coordenação, controle e direção.

Mas esse enraizamento em diferentes polos da universidade parece determinar, também, a percepção que os dirigentes da USP têm das mudanças que impactaram o governo acadêmico da universidade. Nesse sentido, enquanto entre os dirigentes do polo profissional tradicional, como visto, predomina a defesa tanto das novas formas de avaliação quanto do processo de centralização através da definição de diretrizes a partir "de cima" e de fortalecimento dos órgãos 
executivos em detrimento dos órgãos colegiados, entre os dirigentes ligados ao polo acadêmicocientífico, a visão que predomina é sobretudo crítica a esses mesmos processos.

Essa crítica segue, sobretudo, três padrões que parecem corresponder a três períodos em que esses dirigentes se formaram. Em primeiro lugar, estão aqueles que sempre foram críticos do discurso da gestão e, por conseguinte, críticos às mudanças que ele promoveu não se identificando, de modo algum, com elas. É o caso, sobretudo, daqueles professores que se formaram nos anos 1950, associando-se de modo mais intenso a padrões tradicionais de trabalho acadêmico. Em uma segunda posição estão aqueles que chegaram a defender, em algum momento da sua trajetória, os modelos de centralização e avaliação inerentes ao discurso gerencial mas que, hoje, se arrependeram de tal posição diante do que eles enxergam como o resultado final desse processo. No geral, os professores que assumem essa posição se formaram nos anos 1960 e passaram a atuar como docentes universitários depois da reforma de 1968. Por fim, estão aqueles que, não obstante manterem-se críticos às mudanças que o discurso gerencial promove, em termos de alteração das formas de governo e de controle do trabalho acadêmico, usam as próprias categorias gerenciais para formular essa crítica e tentar desenhar novos caminhos para a universidade. Nesse caso, tratam-se especialmente dos dirigentes ligados ao polo acadêmico-científico que ingressaram na universidade depois da reforma de 1968-1969, tornando-se docentes universitários posteriormente ao início do processo de difusão do discurso gerencial, o que talvez ajude a explicar porque eles precisaram traduzir as posições históricas desse polo na "nova" linguagem da gestão.

Como um exemplo do primeiro caso, podemos citar o já mencionado dirigente 58 que, apesar de ter se formado em medicina na USP no final dos anos 1950, desenvolveu toda a sua trajetória universitária subsequente no polo acadêmico-científico, onde se tornou um pesquisador internacionalmente reconhecido. Ao analisar o desenvolvimento dos regulamentos centrais, comparando a sua gestão na pró-reitoria de pesquisa entre o final dos anos 1980 e o 
começo dos anos 1990 com o que ele entende ser o modelo predominante hoje, o dirigente expõe seus questionamentos:

[Pergunta] Professor, pensando na criação das pró-reitorias nesse momento, o que significa a tentativa de dirigir a pesquisa a partir desse lugar, que é a administração central da universidade, que tem culturas de pesquisa muito diversas? Até onde a administração central pode ir?

[Resposta] Olha, no meu tempo era o seguinte: não interferir em nada. A função do órgão central é ajudar. Então ao invés do órgão te dizer: "você tem que fazer isso, isso e aquilo", é o contrário, ele deve perguntar: "Onde é que eu posso ajudar?" E essa orientação central não dá certo para um cientista. Se alguém vier falar para mim o que eu tenho que fazer, é bobagem, é perda de tempo. Eu quero um administrador para quem eu possa falar: "Eu estou precisando disso". Então, quando eu fui pró-reitor de pesquisa, era assim e tenho absoluta consciência disso. Eu não estou falando para você por falar. Eu agi assim.

[Pergunta] É muito interessante o senhor estar falando isso, porque quando o senhor comentou que era contra a burocracia, a primeira coisa que o senhor disse foi "eu não vou ficar criando estatuto", a sensação que eu tive é que o senhor estava apresentando uma recusa de qualquer tentativa de normatizar as atividades acadêmicas, incluindo a pesquisa, a partir desse centro. É isso mesmo?

[Resposta] É. O estatuto da pró-reitoria de pesquisa no meu tempo tinha duas páginas e uns quinze artigos apenas. E todos artigos inócuos: era só para organizar a reunião do Conselho de Pesquisa. Não interferia em nada nas atividades de pesquisa. Na mesma época, o regulamento da pós-graduação tinha, no máximo, uns 30 artigos. [...] Veja hoje, o regulamento de pós-graduação que acabou de ser aprovado tem um número absurdo de artigos, acho que tinha mais de trezentos. Não foi culpa do atual pró-reitor, ele foi herdando isso, porque cada um que chega resolve regulamentar um pouco mais [...]. No meu tempo, regulamentar a graduação, a pós-graduação, a pesquisa? De jeito nenhum! A ideia era "deixa correr..." [...] e transferir a responsabilidade para quem deve tê-la, os professores, e não para um artigo de regulamento [...]. Então é autonomia quase que total. [...] Outro dia eu lembrei, o reitor da minha época tinha uma frase ótima. Ele sempre dizia "Se derem o deserto do Saara para o governo central administrar, em 5 anos vai faltar areia." A administração tende a se consumir em si mesma. Ela começa a criar mecanismos, papéis e você fica preso nesse emaranhado. O resultado é que você perde o fim da universidade, ou seja, a pesquisa, a extensão e o ensino.

Além de criticar o processo de centralização ligado à tentativa de estabelecer diretrizes e normas para a o ensino, a pesquisa e a extensão, o dirigente 58 também critica as novas formas de avaliação, em geral centralizadas, que segundo ele resultam necessariamente na imposição de critérios de uma área sobre a outra.

[Pergunta] Mas, por exemplo, quando se começou a pensar em remunerar professor por desempenho.

[Resposta] Isso é bobagem!! Bobagem, bobagem! Eu já falei sobre isso [...] Uma universidade é uma universidade. Você tem professor de educação física, tem professor de religião etc. Como é que você vai avaliar? Quantos trabalhos publicou o professor de educação física? Quantos padre-nossos rezou o professor de religião? Então você tem que respeitar a característica de universal da universidade. Quando o pessoal começou a fazer essas avaliações, inclusive eu, no meu conselho, o que você tinha, sempre, era a predominância dos critérios de um setor sobre os outros. E os setores mais fortes, em produção científica, são os da física, da bioquímica e da 
química. Então, os critérios de avaliação da universidade passaram a ser o número de trabalhos publicados. Então você cria, com isso, um bias muito grande na avaliação da universidade. E não era isso o que nós pensávamos que era avaliação.

É interessante que, na sua análise, o dirigente 58 dá a entender que, durante o período em que esteve à frente da pró-reitoria de pesquisa, participou da implantação de políticas das quais, no fundo, discorda. Essa posição, que aponta para um certo "paradoxo das consequências", é ainda mais marcante no discurso de outros professores do polo acadêmicocientífico que assumiram posições de direção no âmbito central da universidade por um certo período. É o caso, por exemplo, do dirigente 52, formado na FFCL nos anos 1960, tornando-se, primeiro, professor catedrático dessa unidade e, depois da Reforma de 1968-1969, professor titular do Instituto de Matemática e Estatística. Tendo se formado e atuado sempre no polo acadêmico-científico da USP, o dirigente passou alguns anos no âmbito central, mais precisamente quando assumiu a pró-reitoria de graduação no começo dos anos 1990, depois de ter participado da Reforma do Estatuto de 1987-1988, como membro do Conselho Universitário. É interessante como na entrevista concedida a mim no IME, ele mencionou espontaneamente o problema do "gigantismo técnico-burocrático" para o qual ele considera ter contribuído ao participar da reforma do Estatuto de 1987-1988. É nesse sentido que ele esboça uma "autocrítica" à sua contribuição para a criação de uma "máquina burocrática" na USP:

[...] E outra coisa que eu acho importante e não sei se você vai perguntar, é o papel da modernização administrativa. Eu acho que houve certa modernização administrativa, mas houve um gigantismo também da parte técnico-burocrática. [...] O que acontece? Os anos de ditadura foram os anos em que se lutou para sobreviver. E depois veio a democratização, mas uma coisa meio fantasiosa, quer dizer, [...] dava a impressão de que a gente podia tudo. E nós fizemos uma reforma do estatuto na USP, de que eu participei, coordenando a comissão de graduação. No entanto, fazendo uma autocrítica, eu acho que nós criamos uma máquina burocrática, ampliamos a máquina burocrática. Esse é o ponto central.

[Pergunta] Esse gigantismo que o senhor diz é o crescimento da administração central?

[Resposta] Não só central, nas unidades também. Porque, na medida em que, por exemplo, você introduziu métodos computacionais para organizar a informação, gerir, etc., não se criou uma descentralização. $O$ âmbito central continuou estanque e mantendo os mesmos órgãos e passando a ter muitas atividades duplicadas. Então eu tenho a impressão de que se você comparar, fizer um levantamento do gasto da USP em administração vai ver que ele aumentou muito desde então. 
Uma percepção muito semelhante acompanha o discurso do dirigente 50, que tem uma trajetória praticamente homóloga a do dirigente 52, formando-se na FFCL nos anos 1960 e passando a atuar, como docente, em uma das unidades criadas pela Reforma de 1968-1969, no caso, a Faculdade de Educação. Assim como o dirigente 50, o dirigente 52 assumiu a próreitoria de graduação nos seus primeiros anos de funcionamento, no começo da década de 1990 e também do mesmo modo que o dirigente 52 , retornou às suas atividades de ensino e pesquisa depois de deixar o cargo na pró-reitoria. Ao analisar a sua participação na direção da Faculdade de Educação, quando ajudou na implementação de uma linha de pesquisa sobre avaliação educacional no começo dos anos 1990, ele também explicita um certo "arrependimento" porque, nas suas palavras, "o que eu pensava e o que surgiu como produto dessa linha de pesquisa foram coisas completamente diferentes".

[...] O começo da minha gestão na direção da Faculdade foi um pouco conflituoso. Eu consegui resolver problemas difíceis. Mas eu tinha um projeto, que podia não agradar a muitos colegas, mas era um projeto de elevação da qualidade, de promoção da Faculdade em um sentido, assim, digamos, acadêmico.

[Pergunta] Que tipo de propostas o senhor tinha?

[Resposta] Colocar em discussão, na Faculdade, um projeto de pesquisas. Eu trouxe uma linha de pesquisa para cá, da Fundação Carlos Chagas, na área de avaliação. [...] Mas isso caminhou para um sentido muito diferente do que eu imaginava. Naquela época, estava começando essa promoção da avaliação [ênfase], a linha de promoção da avaliação. O que eu pensava e o que surgiu como produto dessa linha de pesquisa foram coisas completamente diferentes!!

[Pergunta] Em que sentido, professor?

[Resposta] No sentido de que a gente poderia ter se tornado um corpo institucional voltado para o ensino e realizando pesquisas significativas em educação. A avaliação foi nos transformando em, vamos dizer - eu falo isso em tese, não é? -, mas em indivíduos voltados para produzir mais uma linha no Currículo Lattes. Você localiza facilmente muitos colegas, na universidade, que têm um Currículo Lattes com duzentas, trezentas páginas, não é? Hoje é um ideal. Mas se os programas institucionais e sua realização fossem o foco da coisa, isso seria diferente. A avaliação foi, na minha modesta opinião e não sei se vou continuar pensando assim, mas a minha impressão é de que houve uma transposição, pura e simples, de alguma coisa que funciona em pesquisas de laboratório para um universo onde o artesanato sempre predominou.

A análise das críticas formuladas pelos dirigentes ligados ao polo acadêmico-científico

da universidade não se completa sem, antes, olharmos para aqueles que, incorporando a linguagem da gestão, formulam suas críticas nos próprios termos do discurso gerencial, 
testemunhando o processo de violência simbólica marcado pela imposição dessas categorias como as únicas possíveis para se pensar o problema do governo acadêmico.

É o caso, marcante, do dirigente 62, formado no Instituto de Física de São Carlos nos anos 1970, onde atuou como professor universitário depois de fazer sua pós-graduação nos Estados Unidos. Ao ser convidado para assumir a pró-reitoria de pesquisa no começo dos anos 2000, com exceção da sua experiência como Coordenador Adjunto da Fapesp, o dirigente 62 não tinha muita experiência em cargos de direção, o que o levou a procurar uma literatura especializada sobre gestão acadêmica para ajudá-lo nessa função. Depois da sua passagem pela administração central o professor retornou às suas atividades de ensino e pesquisa, tendo sido eleito para o Conselho Universitário como representante dos professores titulares. Foi nessa posição que participou ativamente das discussões mais recentes sobre a reforma do estatuto da USP, especialmente a alteração do processo de eleição do reitor. Segundo ele, o grande problema da universidade, hoje, é que ela não tem um "bom sistema de tomada de decisões coletivas", ou seja, ela não tem "uma boa governança". Para ele, a solução para esse problema é a descentralização do poder e o fortalecimento dos órgãos colegiados, começando pelos Conselhos de Departamento. Em síntese, é a posição histórica do polo acadêmico-científico mas, agora, formulada em novos termos:

[Pergunta] É interessante, professor, porque o senhor descreve a Fapesp como uma escola, uma escola onde o senhor aprendeu muita coisa. O que o senhor aprendeu ali? Pergunto isso porque em outra entrevista sua, eu li que o senhor descreve a Fapesp como um sistema administrativo que funciona bem. Eu queria que o senhor explorasse um pouco melhor isso.

[Resposta] Está bem, perfeito. Porque esse é o ponto que eu acho o mais importante de tudo isso. O que eu mais aprendi lá, e depois aprendi em outros lugares, é que você tem que ter um bom sistema de tomada de decisões. Isso é o que as pessoas chamam de governança, que não é administração, é bem mais amplo do que administração, e a Fapesp tem um sistema bom de governança. [...] Então, quando eu estava na Fapesp, todo mundo achava que eu tinha poder, mas eu não tinha poder algum. Eu não tinha poder de decisão. Eu não podia aprovar o projeto de um amigo, nem que eu quisesse. Ninguém tem esse poder. Essa estrutura de decisão, que leva em conta a opinião de várias pessoas, conseguindo chegar a uma conclusão, isso é o que existe na Fapesp. No entanto, a USP não tem isso, e o resultado é que ela não tem capacidade de tomar decisões coletivas. Decisões individuais todo mundo sabe tomar, mas se você tiver que decidir uma questão que depende de cinco opiniões diferentes, a USP não sabe e não tem como fazer. E essa é a raiz de todos os problemas que ela está enfrentando. Isso foi a principal coisa que eu aprendi lá na Fapesp: você precisa ter um bom sistema 
de tomada de decisões. De maneira que eu acho que a USP está muito mal estruturada nesse ponto.

[Pergunta] Mas é interessante o senhor comentar isso porque, em tese, a universidade tem um sistema que permitiria tomar essas decisões, que são os órgãos colegiados.

[Resposta] É, em tese.

[Pergunta] E na sua opinião, o que é que acontece com os colegiados? Qual deveria ser a função dos órgãos colegiados? Por que eles não exercem essa governança, como o senhor falou?

[Resposta] Muito bem, está certo. Essa é a questão chave. Tem razões diferentes e, na USP, existem unidades diferentes com realidades diferentes. A USP é formada de unidades. Hoje, são 42 unidades. Ela é, portanto, uma federação de 42 unidades e cada uma tem uma cultura completamente diferente, então você não pode generalizar. Uma coisa que eu falar, relativa ao meu Instituto, de maneira alguma se pode achar que vai valer para a Faculdade de Filosofia.

[Pergunta] De fato, são estruturas diferentes, por exemplo, a taxa de dedicação exclusiva varia de $100 \%$ a $30 \%$.

[Resposta] Exatamente! Então, uma coisa que para um é perfeitamente normal, para o outro já não é. Bem, isso tudo para dizer que, na universidade, deveríamos começar olhando para as congregações e, talvez, mesmo para os conselhos departamentais. $\mathrm{O}$ que acontece nas congregações, por exemplo? Os diretores têm medo de perder o poder. O diretor vê a congregação como uma coisa meio chata que ele precisa, de alguma maneira, contornar. Varia de unidade para unidade, em algumas isso é mais intenso e em outras menos. Eu acho que a Faculdade de Filosofia seria o lugar onde a congregação tem maior poder dentro da universidade, mas nos outros lugares a congregação é bem mais fraca. Além disso, a relação que existe entre o diretor e as congregações é, em geral, ruim. O diretor não aproveita aquilo que a congregação deveria oferecer para ele. [...] Nós temos que ter um sistema para discutir e decidir. Vamos supor que, hoje, tivéssemos que discutir as cotas. Então, como vamos resolver o problema das cotas? Está aberta a discussão, uma pessoa fala, a outra fala, e o presidente do conselho está anotando. No fim, ele diz: muito bem, todo mundo falou, quem quis falar falou e, em síntese, o que foi dito é isso, isso e isso. Vocês concordam? Às vezes alguém levanta: não foi levado em conta isso e aquilo. Muito bem, vamos corrigir, e no fim chegava-se a uma conclusão que é uma conclusão emanada do conselho. Como todo mundo participou daquilo, todos apoiam. Essa eu acho que é a maneira correta de fazer as coisas e isso deveria começar nos departamentos e ir para cima até chegar ao Conselho Universitário. [...] Eu sou um pouco pessimista sobre a solução disso no longo prazo, a menos que apareça alguém, algum Reitor ou coisa assim, que tome para si a tarefa de mudar esse problema. Acho que essa seria uma tarefa para um reitor passar quatro anos só tentando resolver essa dificuldade que a universidade tem, mas se os dirigentes executivos acharem que isso é uma coisa boa, vai continuar assim.

Em síntese, o discurso desse dirigente, que esteve envolvido de modo mais direto nas disputas mais recentes pelos rumos da universidade, preserva a visão histórica do polo em que se formou a atuou, o polo acadêmico-científico, o que se mostra como um outro invariante estrutural da universidade. Assim, se o polo social e politicamente dominante da universidade, formado pelas faculdades profissionais tradicionais, defende que as diretrizes gerais para o funcionamento da USP, incluindo a dinâmica do seu governo acadêmico, devem ser definidas a partir "de cima", o que pode ser entendido como uma metáfora da própria posição na estrutura 
social da universidade, o polo social e politicamente dominado da USP, formado sobretudo pelas suas unidades acadêmico-científicas, defende justamente o contrário, um governo acadêmico que se estruture de baixo para cima, dando espaço para a preservação de uma certa diversidade de estilos de ensino, pesquisa e extensão.

Mas o mais interessante, sociologicamente, é observar como houve um descolamento, que podemos chamar cognitivo, nesse embate. Na posição atual do polo acadêmico-científico, a defesa da democratização e da descentralização da universidade parece estar sendo traduzida no ideal "da boa governança", um termo que emana diretamente do discurso gerencial mais moderno (cf. Grün, 2003). Não parece ser demais afirmar que se trata, portanto, de um caso típico de violência simbólica, "essa coerção que se institui por intermédio da adesão que o dominado não pode deixar de conceder ao dominante (portanto, à dominação), quando dispõe, para pensá-lo e para pensar a si mesmo [...] somente de instrumentos de conhecimentos comuns e que fazem essa relação aparecer como natural, pelo fato de serem, na verdade, a forma incorporada da estrutura da relação de dominação" (Bourdieu, 1997, p. 204). Esse movimento de violência simbólica, que impôs a gestão como uma linguagem compartilhada por diferentes setores da universidade, sugere que os processos sociais de dominação, através da transformação das categorias dominantes em categorias "universais", concorrem para definir os limites do pensável e do impensável circunscrevendo, com isso, o terreno mesmo das disputas políticas em torno das formas de organização social. 


\section{Conclusão}

A universidade, enquanto instituição social, está em constante transformação. Não é por acaso que o caráter essencialmente dinâmico da instituição universitária é reconhecido como uma das dimensões mais essenciais da sua história. Nas palavras de Christophe Charle e Jacques Verger: "desde a sua origem, a universidade sempre pareceu estar à espera de uma nova reforma" (1996, p. 57). No mesmo sentido, segundo Björn Wittrock: “a universidade é, juntamente com a Igreja, a mais antiga dentre todas as instituições macrossociais contemporâneas mas, apesar disso, pode-se dizer que ela é, também, a mais inovadora" (1993, p. 303).

Mas, se conforme sugerem esses autores, o dinamismo foi um traço importante da instituição universitária ao longo de toda a sua história, ou seja, desde o seu surgimento como corporação medieval, também é certo que a emergência da universidade moderna marca uma clara intensificação desse processo. Isso porque foi a sua transformação em uma instituição central da sociedade capitalista moderna - tanto pela sua contribuição para o desenvolvimento econômico por meio da geração, direta ou indireta, de tecnologias industriais e da formação de mão-de-obra especializada quanto pelo seu papel central na consolidação e na profissionalização das elites dirigentes - que tornou a reforma universitária uma questão central para o Estado e para a "sociedade".

É nesse sentido que até a primeira metade do século XX praticamente todos os países fundaram ou reformaram suas universidades, na maior parte das vezes, inspirados no chamado "modelo alemão", cujo cerne era a união entre as funções de ensino e pesquisa e a consolidação de um modelo institucional baseado na autonomia e no autogoverno acadêmico. Dentre os países que reformaram ou expandiram o seu sistema universitário nesse período podemos citar, além da própria Alemanha, os Estados Unidos, a Inglaterra, a Escócia, o Japão, a Rússia, a França, a Áustria, a Hungria, a Suíça, a Espanha, a Itália e, em certa medida, o próprio Brasil, 
que fundou suas primeiras universidades - em particular, a Universidade do Brasil e a Universidade de São Paulo - a partir de 1920.

Em visão panorâmica, as reformas que marcaram a história da universidade até esse momento encerravam uma ambiguidade fundamental. Se, por um lado, elas expressavam as respostas dadas, pela universidade, às pressões para que ela se adaptasse à constante transformação da estrutura social, ocupacional e produtiva da sociedade, por outro, essas mesmas reformas guardavam, por trás das mudanças implementadas, um impulso essencialmente conservador. Nesse sentido, ao mesmo tempo em que procurava se acomodar aos "novos tempos", a universidade buscava preservar o seu funcionamento tradicional. Nesse sentido, as análises sobre a transformação da instituição universitária na passagem para a sociedade moderna são quase unânimes ao apontar a importância da preservação de características fundamentais do seu modelo tradicional, em especial, dos seus mecanismos internos de autogoverno que compunham o núcleo da sua dinâmica institucional, enquanto corporação medieval, e da sua forma específica de organização do trabalho, enquanto estrutura profissional moderna. Nas palavras de Etzkowitz, Webster e Healey:

Como instituição de origem medieval, voltada para a conservação, renovação e transmissão de conhecimento, a universidade manteve suas características originais mesmo quando expandiu o seu alcance para abarcar novas missões. A continuidade da universidade reside na história do seu desenvolvimento: cada nova tarefa envolveu um esforço no sentido de que ela preservasse um objetivo prévio (1998, p. 1).

Ou ainda, segundo Paul Gerbod:

Pode parecer que a autonomia da administração universitária foi seriamente restringida, em muitos países, por uma série de constrangimentos externos dos quais o surgimento do Estado foi apenas mais um. No entanto, em todos os lugares, as universidades continuaram a encarnar, em algum grau, sua tradição histórica de autogoverno. Essa autonomia está fundada no princípio corporativo. O seu modo de aplicação varia de acordo com o Estado e a universidade. Não obstante, nós podemos definir uma série de características comuns às universidades [...]. $\mathrm{Na}$ base desse sistema estão os conselhos em que os membros da corporação elegem representantes e decidem todas as questões universitárias (2004, p. 118-9).

O historiador Walter Rüegg vai além e atribui o próprio "sucesso do espírito científico" europeu à confluência entre a valorização da liberdade moderna de ensino e pesquisa e a 
preservação dessa organização medieval das universidades:

Quais foram as razões para o sucesso do espírito científico? Uma comparação entre o modelo francês, alemão e britânico nos leva a uma surpreendente conclusão: o sucesso do espírito científico cresce à medida que o modelo adapta a autonomia corporativa da universidade tradicional à liberdade dos seus membros em ensinar, estudar e pesquisar. A maior conquista de Humboldt e seu conselheiro, Schleiermacher, foi a rejeição do modelo francês de colégios profissionais e de modernização da estrutura medieval da universidade (2004, p. 14).

Em síntese, é possível dizer que a história da instituição universitária foi marcada, até a primeira metade do século $\mathrm{XX}$, por constantes reformas que, na tentativa de conciliar conservação e mudança, adquiriam um caráter de constante aggiornamiento. Essa dialética entre conservação e mudança estava ancorada, essencialmente, nos mecanismos sociais e institucionais que conferiam autonomia relativa à instituição universitária. Em outras palavras: pelo seu funcionamento institucional específico - expresso no fato da universidade ter preservado uma estrutura de autogoverno baseada em órgãos colegiados que asseguravam sua autonomia relativa- as universidades foram, por longo tempo, instituições nas quais as pressões da sociedade, entenda-se, dos seus grupos sociais, classes e frações de classe, incidiam de forma mediada.

É à luz desse quadro histórico que se torna possível compreender porque as reformas universitárias realizadas a partir da segunda metade do século XX implicaram uma novidade tão grande e um impacto tão profundo. Essa nova onda de reformas - que emergiu, de início, como uma reação às pressões democratizantes dos movimentos universitários de 1968 - atingiu justamente o âmago da estrutura institucional histórica da universidade, ou seja, as suas diferentes formas de autogoverno. Para resumir em poucas palavras, essas reformas se baseiam em um discurso gerencial, pretensamente científico, para promover o fortalecimento, a profissionalização e a autonomização dos executivos acadêmicos, esvaziando o governo colegiado e alterando completamente as bases do exercício do poder na universidade.

A importância dessa mudança é tão grande que mobiliza, atualmente, parte importante da literatura nacional e internacional sobre a mudança universitária. Na chave da sociologia do 
trabalho, alguns autores descrevem esse processo como uma crise da profissão acadêmica, mostrando como ela implica a perda de controle dos professores universitários sobre a própria atividade (cf. Kogan, 1999; Rhoades \& Sporn, 2002; Tappe \& Palfreyman, 2002). A tradição marxista enfatiza os efeitos desse processo em termos da precarização do trabalho, sugerindo uma crescente "proletarização" do corpo docente (cf. Martins, 1998; Rhoades, 1996, 1998). A perspectiva weberiana mobiliza o conceito de "burocratização", apontando, no entanto, o seu caráter disfuncional (cf. Gornitzka, Larsen \& Svein, 1998; Roberts \& Donahue, 2000). A abordagem institucionalista denuncia o esvaziamento dos órgãos colegiados como espaços de tomada de decisão, condenando a emergência de novos experts que passam por cima das especificidades acadêmicas, gerando tensões e contradições nessas instituições (cf. Musselin, 2005, 2007; Friedberg \& Musselin, 1992). No Brasil, como visto ao longo deste trabalho, também são muitas as análises que se voltam para os impactos da difusão do discurso gerencial sobre a reorganização das universidades a partir dos anos 1960 (cf. Cardoso, 2001; Chauí, 2001; Cunha, 2007c; Fávero, 2001; Garcia, 2001; Motta, 2014; Silva, 1998). Além dessa literatura sobre a expansão do discurso gerencial na universidade, multiplicam-se as análises que enfatizam o papel crucial da gestão - como linguagem, forma de conhecimento, visão de mundo e arsenal de normas, procedimentos e práticas - na reorganização das instituições sociais modernas, da escola à empresa, dos movimentos sociais aos partidos políticos, das creches aos hospitais, das ONGs ao Estado. Em todos esses espaços, a gestão, como uma nova forma de organizar o "governo dos homens", estaria ajudando a definir uma nova estrutura social e, com ela, novas formas de subjetividade (cf. Boltanski, 1982; Boltanski \& Chiapello, 1999; Dardot \& Laval, 2010; Ogien, 1995).

Partindo dessa ampla literatura, a presente pesquisa procurou oferecer uma contribuição específica à análise da transformação das universidades contemporâneas e à compreensão da difusão do discurso gerencial, através de um estudo de caso que buscou unir a perspectiva 
histórica estrutural de Pierre Bourdieu (cf. 1980, 1984, 1989) à abordagem construtivista do papel das formações discursivas na construção social da realidade inspirada em Michel Foucault (cf. 2004, 2010, 2011). Nesse sentido, esta pesquisa investigou o processo de imposição do discurso gerencial, como uma matriz de práticas e de visões de mundo, expressa em uma nova linguagem, à luz da estrutura social de uma instituição específica, a Universidade de São Paulo. A tese essencial que procurei demonstrar é que o discurso gerencial conseguiu se impor na USP pela ação do seu polo dominante, formado pelas unidades profissionais tradicionais que conseguiram, justamente pela sua posição, social e politicamente dominante, impor sua visão específica de universidade e de governo acadêmico. Ao longo dos quatro capítulos que compõem este trabalho, o leitor pôde acompanhar o desenvolvimento desta tese através de alguns movimentos analíticos cujas conclusões principais apresento, sumariamente, a seguir.

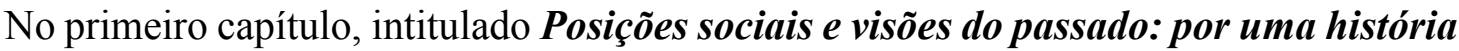
estrutural da USP, procurei defender, na prática, a opção analítica pela história estrutural mostrando como o seu pressuposto essencial, de que existe uma relação entre estruturas sociais e estruturas cognitivas, contribui para entender a própria disputa que, na USP, opõe distintas visões sobre o seu passado. Para tanto, analisei as três principais linhas de reconstrução histórica da USP, mostrando como cada uma delas corresponde a uma posição específica no interior da instituição.

A primeira dessas linhas, que chamei de história oficial, representa os trabalhos escritos a partir de posições social e politicamente dominantes na universidade, hegemonizadas por egressos do polo profissional tradicional, cujo núcleo duro são as faculdades de direito, engenharia e medicina fundadas nos antes de 1934. Não por acaso, portanto, a visão de passado inerente a essas histórias expressa alguns pressupostos desse polo dominante, em particular, a consagração de lideranças institucionais, provenientes, em geral, de setores da elite paulista, e a valorização do caráter utilitário do conhecimento, expresso no ideal de ciência a serviço do 
desenvolvimento, industrial e urbano. São, em resumo, trabalhos que entendem a história em uma chave finalista, como uma sucessão de fatos e feitos, de caráter essencialmente individual. Essa visão faz com que eles enxerguem a história da USP, portanto, como uma trajetória coerente e bem sucedida projetada e conduzida por "grandes homens" de "ampla visão". Esses pressupostos implicam, nessa linha de "história oficial", a opção metodológica de privilegiar os relatos individuais, tal como expresso na defesa que fazem da chamada "história oral".

Partindo da crítica a essa primazia do relato individual, procurei defender, teoricamente, a opção pela história estrutural, como uma expressão específica da sociologia histórica que, reconhecendo as relações de múltipla determinação existentes entre ação e estrutura, consegue explicar as transformações institucionais para além da mera factualidade. Nesse sentido, procurei argumentar que a abordagem estrutural, além de iluminar o significado social mais amplo das transformações institucionais, é capaz de revelar, ainda, o sentido social mais profundo das diferentes visões sobre o passado da universidade.

Para comprovar a validade desse argumento, o capítulo segue mostrando como, no caso da USP, no extremo oposto da "história oficial" estaria uma "história dos vencidos", formada por trabalhos de filosofia e história da educação que, representando uma posição essencialmente dominada no interior da universidade, incorporam a defesa do projeto original da USP que, como eles apontam, nunca se realizou uma vez que, inspirado no modelo alemão, encontrou resistências instransponíveis do polo profissional tradicional, formado por unidades inspiradas no modelo francês de grandes escolas profissionais e independentes. Em síntese, esses estudos do campo da educação defendem que os princípios da integração, da autonomia e do desinteresse deveriam constituir a base da universidade e, não por acaso, revelam-se críticos do seu percurso histórico.

Esse primeiro capítulo se encerra com a análise de uma terceira linha de reconstrução histórica, formada justamente pelos trabalhos que pretenderam fazer uma história estrutural da 
USP, mostrando a relação entre as diferentes visões de educação, de conhecimento e de universidade que marcam a instituição e a sua estrutura social. São, em síntese, os trabalhos realizados na área das ciências sociais que, apesar de se ligarem a uma posição social e politicamente dominada, conseguem, pelo desenvolvimento de condições institucionais específicas, afirmar-se como cientificamente dominantes, sobretudo em relação aos estudos do campo da educação, o que se expressa, essencialmente, no seu padrão de publicação, marcadamente contrastante com os padrões predominantes nos outros dois extremos. Assim, enquanto os trabalhos de "história dos vencidos" foram produzidos sobretudo como teses acadêmicas que não alcançaram publicação mais ampla, os trabalhos de história estrutural foram todos publicados por editoras acadêmicas de grande circulação, em edições manuseáveis e acessíveis, reforçando o seu caráter de obra de referência, instrumento de estudo e pesquisa. Esses dois padrões contrastam, ainda, com o padrão de publicação que define a chamada "história oficial", que resulta em compêndios extensos e luxuosos, com circulação restrita e diversas formas de apoio institucional.

São os diferentes trabalhos de história estrutural que apontaram, de modo quase unânime, que a USP se divide, historicamente, entre dois grandes polos constituídos, de um lado, pelas unidades profissionais que se voltam à formação de elites dirigentes e, de outro, pelas unidades acadêmico-científicas que se destinam à formação de professores e pesquisadores para atuar dentro e fora da universidade.

Partindo dessa estruturação geral, o capítulo procurou, ainda, interpretar, à luz dessa estrutura social, um dos símbolos mais importantes da USP, o seu brasão d'armas que, nos últimos anos, vem ganhando cada vez mais destaque no cotidiano da instituição. Ao eleger como seu emblema máximo a imagem clássica de São Paulo apóstolo sentado sobre um trono elevado, portando uma espada na mão esquerda e um livro na mão direita, o brasão da USP expressa, simbolicamente, na hierarquia implícita entre o lado esquerdo e o lado direito da 
imagem, a hierarquia social da USP que situa, de um lado, as escolas profissionais voltadas à formação de elites dirigentes, e, de outro, as unidades acadêmico-científicas dedicadas à formação de elites intelectuais. Essa oposição, entre o poder, representado pela espada, e a atividade intelectual, representada pelo livro, é marcante também em outros contextos históricos e nacionais, o que sugere se tratar, em síntese, de um desses invariantes estruturais da universidade que, não obstante suas sucessivas reformas, está constantemente se atualizando.

Para saber se essa oposição entre cursos profissionais e cursos acadêmico-científicos permanecia um modelo válido para pensar a transformação contemporânea da universidade, a pesquisa mostrou ser preciso mobilizar um conjunto de estatísticas gerais sobre a USP, em especial, os dados produzidos pelo Anuário Estatístico e pelo Questionário Socioeconômico da Fuvest. No entanto, essas duas instâncias produtoras de estatísticas gerais sobre a USP se revelaram, ao longo da pesquisa, como resultados do processo de transformação do governo acadêmico, pela incidência do saber gerencial, que esta pesquisa procurava interrogar. Por isso, ao invés de seguir diretamente para a análise desses dados, achei necessário acrescentar um segundo capítulo, chamado Posições sociais e visões de futuro: a emergência da universidade como objeto de gestão, cujo objetivo final era mostrar como a emergência de estatísticas sobre a USP como um todo, ao longo dos anos 1980, resultou de um longo processo de transformação da universidade em objeto de gestão.

Para tanto, iniciei esse capítulo com uma apresentação sumária dos estudos de inspiração construtivista que buscam explicar, justamente, como saberes especializados, em especial, os que se estruturam como regimes de verdade que legitimam e definem dispositivos técnico-materiais de intervenção social, acabam contribuindo para a construção social da realidade, como no caso da transformação da universidade em objeto de gestão, a partir da emergência do discurso gerencial como saber específico. Partindo desse quadro teórico geral, procurei mostrar que a constatação dessa transformação da universidade pela gestão ganhou, 
na literatura internacional, uma interpretação comum: ela aparece, em geral, associada às reformas do Estado que ocorreram, na Europa e nos Estados Unidos, a partir do final dos anos 1970, como resultado do fortalecimento do novo regime neoliberal. Porém, como procurei enfatizar neste capítulo, ao olharmos para o modo como esse mesmo processo se desenvolve na universidade latino-americana, não é difícil perceber que se trata, na verdade, de um processo que se iniciou, aqui, algumas décadas antes. Assim, analisando o processo de importação/exportação do conhecimento gerencial à luz de uma análise estrutural da circulação internacional de saberes e práticas procurei mostrar como os países latino-americanos funcionaram, no caso da reforma gerencial da universidade, como um "terreno de experimentação" de formas mais radicais de mobilização dos saberes gerenciais. Nesse sentido, ao invés de analisar o processo de transformação da universidade pressupondo a oposição clássica entre centro e periferia, em que o Brasil, numa eterna mimese social, incorporaria mudanças implementadas sempre antes na Europa e nos Estados Unidos, procurei enfatizar não só a especificidade da reforma universitária brasileira dos anos 1960, como o seu aparente protagonismo. Foi para demonstrar isso que reconstruí a história do processo de importação do saber gerencial no Brasil, a partir do final do século XIX, mostrando como as transformações da política externa norte-americana para a América Latina, no contexto de Guerra Fria, representaram uma inflexão importante nesse processo, ao tornar a exportação de saberes especializados, incluindo o saber gerencial, uma política de Estado.

O capítulo parte desse quadro geral para analisar as disputas em torno da reforma universitária que, a partir dos anos 1950 opuseram, dentro e fora da USP, as faculdades voltadas à formação acadêmico-científica e as faculdades voltadas à formação profissional tradicional. O capítulo reconstrói esse embate para mostrar como o seu desfecho foi determinado tanto por essa inflexão da política externa norte-americana nos anos 1950 quanto pelo golpe militar dos anos 1960, que criou novas condições institucionais para a difusão do saber gerencial e da visão 
econômica da educação que lhe é inerente. Assim, procurei demonstrar como a proposta de reforma universitária formulada pelo polo acadêmico-científico que buscava, através do fortalecimento do autogoverno, tornar a pesquisa a base da universidade fortalecendo a sua autonomia, gerou uma reação de setores então dominantes, no campo universitário e político, no sentido de construir uma proposta alternativa de reforma, baseada justamente em modelos administrativos modernos, que prescreviam o fortalecimento e a profissionalização dos órgãos executivos acadêmicos e a subordinação da universidade aos imperativos do desenvolvimento, a partir da difusão de cursos mais profissionalizantes. É a partir desse sentido geral que podemos compreender porque apesar de incorporar, em parte, as propostas do polo acadêmico-científico da universidade a reforma de 1968 não foi considerada, por ele, propriamente uma vitória.

Para encerrar esse segundo capítulo, voltei-me para os impactos dessa reforma universitária inspirada no discurso gerencial na USP. A intenção foi mostrar de que maneira a gestão se impôs, na universidade, como um novo regime de verdade ancorado em dispositivos técnico-materiais aparentemente neutros, independentemente dos interesses e das resistências dos próprios dirigentes da instituição. Para isso, analisei três processos centrais que resultaram da emergência da gestão como um saber aplicado à universidade. Em primeiro lugar, tratei da “conversão invisível” dos dirigentes da USP ao conhecimento gerencial, através de processos formais e informais de formação em gestão. Analisando a trajetória dos dirigentes que compunham a minha amostra - formada por reitores, pró-reitores e diretores administrativos que assumiram cargos no governo central da USP a partir de 1986 - fui obrigada a diferenciar três grupos dirigentes que se relacionavam a três padrões de conversão igualmente distintos: i) os experts, que assumiram a gestão, ou os saberes relacionados, como seu tema de pesquisa, beneficiando-se, assim, dos programas norte-americanos de apoio à difusão do saber gerencial nos anos 1960 e 1970; ii) as lideranças institucionais, em especial os reitores da USP que, pela sua trajetória, passaram a conviver intensamente com especialistas em gestão e a circular em 
redes internacionais de discussão e normatização do ensino superior em que a gestão passou a ser, cada vez mais, um tema crítico; e, por fim, iii) os especialistas acadêmicos, representados particularmente pelos pró-reitores, que não só apresentam uma trajetória institucional mais diversificada como se mostram, em geral, mais indiferentes ou distantes dos processos de conversão ao discurso da gestão. Um segundo impacto da gestão na USP que procurei analisar foi a centralização do poder, através do fortalecimento do executivo acadêmico nas sucessivas reformas promovidas a partir de 1968, sempre no sentido de ampliar os órgãos da reitoria, fortalecendo seu poder de ação e esvaziando, consequentemente, o governo colegiado cuja base são os conselhos departamentais. Por fim, encerro o capítulo analisando a emergência das estatísticas universitárias na USP, cujas instâncias produtoras, em especial, o Anuário Estatístico e a Fuvest resultaram do e fortaleceram o processo de centralização do poder na universidade, contribuindo para efetivar a capacidade de gestão do chamado "poder central".

Foi justamente com base nessas estatísticas universitárias que desenvolvi o terceiro capítulo desta tese, A transformação estrutural da USP: dominantes e dominados no contexto universitário, cujo foco foram os movimentos de expansão, diversificação, elitização e atualização da estrutura social da USP a partir de 1968, considerando os dados disponíveis. Assim, na primeira parte desse capítulo enfatizei a crescente expansão que marcou a USP nas últimas décadas, através do aumento do número de alunos, cursos, programas, unidades, publicações e, em menor medida, professores, o que sugere, como indiquei, que a USP se tornou, ao longo dos anos, uma instituição não só maior como, também, mais "eficiente", como previsto pela reforma universitária de 1968. Essa expansão universitária foi determinada, por sua vez, por um processo igualmente importante de diversificação interna que aumentou tanto o peso das unidades localizadas fora da cidade de São Paulo quanto a importância dos cursos voltados para as novas profissões, de caráter mais técnico. A análise do processo de expansão e diversificação da USP revelou, portanto, que os novos cursos técnico-profissionais, que 
dinamizaram a expansão da universidade nos últimos cinquenta anos, voltam-se sobretudo para setores sociais mais vulneráveis, representando, ao lado dos cursos acadêmico-científicos, uma pequena porta de entrada desses setores na universidade pública. Por outro lado, os cursos profissionais tradicionais, que praticamente não expandiram suas vagas ao longo dos últimos trinta anos, tornaram-se, por isso mesmo, mais concorridos e mais elitizados.

Essa conclusão ficou explícita na segunda parte desse capítulo sobre a estrutura social da USP, dedicada ao processo de elitização que impactou, de modo diferencial, os cursos e unidades da universidade a partir da segunda metade dos anos 1990, quando os dados da Fuvest passaram a ser publicados. Resumidamente, a minha intenção foi mostrar de que maneira, com o aumento da concorrência no seu exame de ingresso, a USP passou a sofrer um processo de elitização crescente que, no entanto, variou de modo significativo segundo o valor social dos seus diplomas, portanto, o grau de concorrência dos seus diferentes cursos. A consequência principal desse processo foi que a expansão da USP, que representou em parte um processo de democratização, implicou, ao mesmo tempo, um aumento da sua desigualdade interna o que, vale dizer, não é uma especificidade da USP, como demonstram outros estudos, sobretudo internacionais, sobre as consequências da expansão quantitativa do ensino superior nas últimas décadas.

Partindo dessa análise dos processos de expansão, diversificação e elitização da USP e constatando que eles variavam segundo três padrões claramente distintos de evolução, consegui identificar os três polos principais que estruturam, hoje, a USP, aproximando e afastando as suas diferentes unidades. São eles:

I) Polo profissional tradicional. Constituído pelas unidades da USP, em geral, as mais antigas, voltadas às formações profissionais socialmente valorizadas e que, através de um padrão elevado de concorrência, selecionam alunos oriundos de setores dominantes, social, econômica e escolarmente. Seu núcleo duro é formado, como dito, pela Faculdade de Direito, 
Faculdade de Medicina, Escola Politécnica e, em certa medida, pela Faculdade de Economia e Administração.

II) Polo acadêmico-científico. Composto pelas unidades voltadas à formação científica e pedagógica, fundadas sobretudo entre 1934 e 1968, no geral com sede em São Paulo, sendo marcadas por um grau relativamente maior de autonomia e abertura a setores sociais mais vulneráveis.

III) Polo técnico-profissional. Formado principalmente pelas unidades fundadas nos anos 1970 que concentram os novos cursos profissionalizantes de caráter mais especializado e pelas unidades da USP mais antigas que, no entanto, se voltam para formações profissionais mais técnicas.

Considerando esses três polos, cujo significado social depende estritamente da relação que eles estabelecem entre si, encerrei o capítulo analisando os dados da Fuvest sobre os ingressantes na USP em 2012, que permitem mostrar como as unidades da USP se hierarquizam segundo diferentes indicadores sociais, tais como trajetória escolar, escolaridade dos pais, renda familiar, proporção de homens e mulheres e proporção de afrodescentes. Os dados mostraram em resumo, que segundo praticamente todos esses indicadores, a estrutura social da USP opõe, de um lado, as faculdades profissionais tradicionais - concentradas sobretudo na cidade de São Paulo, marcadas por um recrutamento escolar e social altamente seletivo e fortemente elevado voltando-se, portanto, à formação de profissionais destinados a atuar em posições de comando e poder, portanto, como elite dirigente - e, de outro, as faculdades e institutos voltados à formação científica e à formação de profissionais de menor prestígio social - ambas relativamente abertas a setores sociais menos favorecidos, como estudantes de escola pública, filhos de famílias de baixa escolaridade e baixa renda e, em menor medida, afrodescendentes, que são formados para exercer atividades ligadas ao ensino e à pesquisa ou para executar funções de natureza técnica e especializada. 
Assumindo essa estrutura social geral, no quatro e último capítulo desta tese, chamado Escolas de elite, escolas de poder: a socialização no polo dominante e o discurso da gestão como violência simbólica retomei a análise do processo de difusão do discurso gerencial na USP, agora sob nova perspectiva, ou seja, mostrando como ele opera como um sistema de classificação que, traduzindo relações de dominação em categorias cognitivas, terminou por se impor ao conjunto da universidade em um movimento típico de violência simbólica, no qual os conhecimentos disponíveis para pensar o mundo são apenas aqueles mais afinados à perspectiva dos seus setores dominantes.

Para demonstrar essa proposição, que constitui o cerne desta tese, comecei construindo um marco teórico para analisar o processo de socialização nas escolas de elite que, voltadas à formação de dirigentes, funcionam ao mesmo tempo como escolas de poder. Assumindo uma relação de homologia estrutural entre as grandes escolas francesas e as faculdades profissionais tradicionais da USP, retomei a análise que Pierre Bourdieu desenvolveu, no seu livro La noblesse d'état, grandes écoles et esprit de corps (1989), sobre o processo de produção social de "homens de ação" pelo ensino superior, desde a preparação para os exames de ingresso até o apelo das práticas esportivas, passando pelas formas de avaliação, a ação pedagógica e a organização da relação ensino/aprendizado.

Foi à luz desse referencial que procurei reconstruir alguns marcos essenciais do processo de socialização no polo dominante da USP, em especial na Faculdade de Direito, na Escola Politécnica e na Faculdade de Medicina, espaços tradicionalmente voltados para a formação de "homens de ação". O meu esforço essencial, nesse caso, foi mostrar como essas escolas se construíram e se reafirmaram como espaços de formação de elites dirigentes dispostas, legitimadas e preparadas para o exercício do poder.

Nesse sentido, não deve surpreender a informação de que a grande maioria dos dirigentes da USP, em especial, seus reitores e diretores administrativos é oriunda desse polo 
profissional tradicional que, como procurei mostrar ao longo da tese, é historicamente dominante na USP, tanto em termos sociais quanto em termos políticos. São esses dirigentes formados sobretudo na Faculdade de Direito, na Escola Politécnica, na Faculdade de Medicina e, em menor medida, na Faculdade de Economia e Administração - que vão liderar o processo de difusão do discurso gerencial na universidade, através de ações e programas específicos de gestão, conforme a reconstrução histórica que eu apresentei, sumariamente, na sequência desse capítulo. A última seção do capítulo dedicou-se às categorias que os dirigentes da USP mobilizam para avaliar a própria gestão, mostrando como elas traduzem, em termos cognitivos, oposições sociais que marcam a instituição, em especial a oposição entre concepção/execução, dirigentes/dirigidos, comando/obediência. Essas categorias explicam a valorização da "capacidade de visão" e da "habilidade para o planejamento" daqueles que, ocupando as posições mais altas da estrutura social, ocupam também posições elevadas na hierarquia de poder. Prosseguindo com essa análise, e mobilizando, mais uma vez, trechos das entrevistas realizadas com dirigentes da USP, mostrei como elementos centrais do discurso da gestão, em especial, a valorização de formas externas de avaliação, a crítica da autonomia corporativa e a valorização da liderança individual se afinam à visão de universidade e de governo universitário do seu polo dominante, conforme procurei demonstrar desde o primeiro capítulo desta tese. Por fim, ao analisar as críticas ao processo de transformação da universidade pelo discurso gerencial por parte dos poucos dirigentes oriundos do polo acadêmico-científico da USP, sugeri que essa crítica segue três padrões distintos, que correspondem, por sua vez, ao momento de ingresso na universidade, e que vão desde a recusa total do discurso da gestão até a tradução da defesa da posição histórica do polo acadêmico-científico, de gestão colegiada e descentralizada, nos termos da linguagem gerencial, representando um caso típico de violência simbólica, em que as categorias do polo dominante se impõem como necessárias e naturais. 
Em síntese, ao analisar, de uma perspectiva estrutural, o processo de difusão do discurso gerencial na USP e os seus efeitos para a transformação dessa instituição específica, esta tese foi capaz de revelar aspectos importantes tanto do processo de mudança das universidades contemporâneas quanto da dinâmica de expansão da gestão enquanto uma nova linguagem, que define possibilidades de conhecimento, pensamento e ação. Em especial, a pesquisa mostrou que nenhum desses processos é independente da estrutura social em que se desenvolve, o que significa dizer que as relações de dominação que definem as instituições como espaços sociais estruturados são absolutamente decisivas para a dinâmica de mudança institucional, para o processo de circulação de conhecimentos e para o sucesso dos esforços para impor determinadas visões de mundo. Além disso, a pesquisa possibilitou mostrar, ainda, que essa estrutura social tem, pelo menos no caso da Universidade de São Paulo, uma tendência extremamente forte à autoconservação, e isso a despeito das inúmeras reformas e mudanças que incidiram sobre a instituição ao longo das últimas décadas. Nesse sentido se, por um lado, este trabalho reforça os estudos que apontam que a reforma da universidade que se inicia a partir dos anos 1960 representa uma inflexão sem precedentes na história dessa instituição, que sempre se reformou conservando os seus mecanismos de autogoverno, por outro, ele sugere que essa mesma reforma, no caso estudado aqui, apesar de atingir o núcleo do funcionamento institucional da universidade, não altera, no essencial, a sua estrutura social interna. Portanto, nesse caso, se a universitas semper reformanda é a própria condição da universidade, é apenas no limite das suas relações sociais internas, que parecem constituir, por sua vez, uma structura semper immutabile.

Mas, como todo estudo de caso, esta pesquisa talvez contribua mais com perguntas do que propriamente com respostas e, por isso, termino esta tese com algumas delas. Seria possível mobilizar a estrutura social da USP, em especial a oposição entre polo profissional tradicional e polo acadêmico-científico, para pensar outras disputas marcantes no interior da instituição? 
Essa oposição pode funcionar como matriz de práticas em sentido mais amplo, para além da posição em relação à própria universidade? O fortalecimento crescente do polo técnicoprofissional trará impactos importantes sobre essa oposição primordial? Se sim, em que sentido? Se não, por quê? Em que medida seria possível pensar o processo de transformação de outras instituições de ensino superior no Brasil à luz do movimento que ocorreu na Universidade de São Paulo? A estrutura social dessas instituições encontra paralelos com a estruturação social observada na USP? Essa estrutura interna é sempre determinante para os processos de transformação dessas instituições? Como essa estrutura incide no interior das unidades, cursos e polos específicos da universidade, determinando processos internos de tensão e disputa? A difusão do conhecimento gerencial e os processos que ela determinou ocorreram com a mesma intensidade em outras instituições de ensino superior ou foi uma especificidade da USP? Como as universidades e faculdades criadas depois da reforma universitária dos anos 1960 lidaram com o processo de difusão da gestão? A determinação estrutural do processo de circulação do discurso gerencial constitui um modelo para pensar a sua imposição em outras instituições sociais? Como se dá essa relação nos processos de reforma do Estado e de reestruturação produtiva inspirados pelo discurso gerencial? Seria possível pensar essa estrutura social para além da estratificação entre dominantes e dominados, mobilizando para tanto uma teoria de classes que pressupõe, para além de tensões, contradições sociais? Essas são algumas dentre as muitas questões que este trabalho permite formular, o que demonstra a potencialidade da sociologia histórica estrutural na análise de processos contemporâneos de transformação social, em particular, de transformação das universidades. 


\section{Referências}

A.A.A.P., AsSociaÇÃo AtlÉtiCA ACADÊMICA PolitéCNICA. Texto do ex-governador Mário Covas Sobre a AAAP. São Paulo: AAAP, n.p., 2013. Disponível em < http://www.atleticapoliusp.com.br/> Acesso em: 21 abr. 2014.

ABRAMS, Philip. Historical sociology. Ithaca: Cornell University Press, 1982.

Abrucio, Fernando Luiz; Pedroti, Paula \& PÓ, Marcus Vinicius. A formação da burocracia brasileira: a trajetória e o significado das reformas administrativas. In: LOUREIRO, Maria Rita; ABRUCIO, Fernando Luiz \& PACHECO, Regina Silva. (Orgs.). Burocracia e política no Brasil: desafios para a ordem democrática no século XXI. Rio de Janeiro: Editora da FGV, 2010. p. 27-71.

ADORNO, Sérgio. Os aprendizes do poder: o bacharelismo liberal na política brasileira. Rio de Janeiro: Paz e Terra, 1988.

AdORnO, Theodor W. \& HORKHEIMER, Max. Dialética do esclarecimento: fragmentos filosóficos. Rio de Janeiro: Jorge Zahar, 1985.

AdusP. AsSOCIAÇÃo dOS DocenteS DA USP. Controle ideológico na USP (1964-1978). São Paulo: Adusp, 2004.

AiU. Association InTERnATIONALE DES Universites. Statuts de l'association internationale des universités. Paris: AIU, 1950.

. Rapport Annuel 2010. Paris: AIU, 2010.

. Rapport Annuel 2012. Paris: AIU, 2012.

ALBERTONI, Ettore. Gaetano mosca y la formacion del elitismo politico contemporaneo. Cidade do México: Fondo de Cultura Econômica, 1992.

Alcadipani, Rafael \& Bertero, Carlos Osmar. Guerra Fria e ensino do management no Brasil: o caso da FGV-EAESP. Revista de Administração de Empresas, v. 52, n. 3, p. 28499, 2012.

AlCKMIN, Geraldo. História de quem fez história. In: OBA, Rosana. Universidade de São Paulo, seus reitores e seus símbolos. Um pouco da história. São Paulo: Edusp, 2006, p. 13-14.

AlmeIDA, Ana Maria. O assalto à educação pelos economistas. Tempo Social, v. 20, n. 1, p. 163-78, 2008.

AlmeIDA, Marta de. República dos invisíveis: Emílio Ribas, microbiologia e saúde pública em São Paulo (1898-1917). Bragança Paulista: EDUSF, 2003.

AltAFIM, Ruy Alberto Corrêa \& Silva, Maria Aparecida de Andrade. 50 anos da EESC: um olhar no passado visando ao futuro. São Carlos: Escola de Engenharia de São Carlos, 2004.

Alves, Marcio Moreira. Beabá dos [acordos] MEC-Usaid. Rio de Janeiro: Edições Gernasa, 1968.

Americano, Jorge. A Universidade de São Paulo: dados, problemas e planos. São Paulo: Empresa Revista dos Tribunais, 1947. 
AndRADE, José Aluysio Reis de. Autonomia para a licenciatura. In: Bernardo, Maristela Veloso Campos. (Org.). Pensando a educação: ensaios sobre a formação do professor e a política educacional. São Paulo: Editora da Unesp, 1989. p.107-12.

ANSOFF, Igor. Strategic management. Classic edition. New York: Palgrave Macmillan, 2007.

Antunha, Heladio Cesar Gonçalves. Universidade de São Paulo: fundação e reforma. 1971, 252f. Tese (Doutorado em Educação). Faculdade de Educação, Universidade de São Paulo, São Paulo, 1971.

. A instrução pública no Estado de São Paulo: a reforma de 1920. São Paulo: Faculdade de Educação, 1976.

ARANTES, Paulo Eduardo. Um departamento francês de ultramar. Estudos sobre a formação da cultura filosófica uspiana (uma experiência nos anos 60). São Paulo: Paz e Terra, 1994.

ARUM, Richard; GAMORAn, Adam \& SHAVIT, Yossi. More inclusion than diversion: expansion, differentiation and markets structures in higher education. In: ARUM, Richard; GAMORAN, Adam \& ShaVIT, Yossi. Stratification in higher education: a comparative study. Stanford: Stanford University Press, 2007. p. 1-35.

AtCon, Rudolph. La universidad latinoamericana: clave para un enfoque conjunto del desarollo coordinado social, económico y educativo en la America Latina. Bogotá: ECO, p. 37-39, mai/jul. 1963.

- Rumo à reformulação estrutural da universidade brasileira. Rio de Janeiro: MEC/DESU, 1966. 1970.

Manual sobre o planejamento integrado do campus universitário. Brasília: CRUB, . Administração integral da universidade. Rio de Janeiro: MEC/PREMESU, 1974.

AUBERT, Francis Henrik. Projeto memória da Faculdade de Filosofia. Informe: Informativo da Faculdade de Filosofia, Letras e Ciências Humanas - USP, n. 31, p. 4-5, 2002.

AzeVEdo, Fernando de. A educação pública em S. Paulo: problemas e discussões; inquérito para O Estado de S. Paulo em 1926. São Paulo: Companhia Editora Nacional, 1937.

BAlConi, Margherita; Brusoni, Stefano \& OrSEnIGO, Luigi. In defense of the linear model: an essay. Research Policy, n. 39, p. 1-13, 2010.

BARros, Amon Narciso de \& CARrIERI, Alexandre de Pádua. Ensino superior em administração entre os anos 1940 e 1950: uma discussão a partir dos acordos de cooperação Brasil-Estados Unidos. Cadernos EBAPE, v. 11, n. 2, p. 256-73, 2013.

BARros, Roque Spencer Maciel. Ilustração brasileira e a ideia de universidade. São Paulo: s.n., 1959.

BENEVIDES, Maria Vitória. 64, um golpe de classe? Lua Nova, n. 58, p. 255-61, 2003.

BENSAUDE-VINCENT, Bernadette. Les vertiges de la technoscience: façonner le monde atome par atome. Paris: La Découverte, 2009. 
Blay, Eva \& LANG, Alice Beatriz. Mulheres na USP: horizontes que se abrem. São Paulo: Associação Editorial Humanitas, 2004.

BleIKLIE, Ivar \& Kogan, Maurice. Organization and governance of universities. Higher Education Policy, v. 20, p. 477-93, 2007.

BolTANSKI, Luc. America, America... Le plan Marshall et l'importation du management. Actes de la Recherche en Sciences Sociales, v. 38, p. 19-41, 1981.

Les cadres: la formation d'un groupe social. Paris: Les Éditions de Minuit, 1982.

BoltANSKI, Luc \& CHIAPELlo, Ève. Le nouvel esprit du capitalisme. Paris: Gallimard, 1999.

BONTEMPI JÚNIOR, Bruno. A educação brasileira e a sua periodização: vestígio de uma identidade disciplinar. Revista Brasileira de História da Educação, n. 5, p. 43-68, 2003.

. O ensino e a pesquisa em história da educação brasileira na cadeira de filosofia e história da educação (1933-1962). História da Educação, n. 21, p. 79-105, 2007.

. Do Instituto de Educação à Faculdade de Filosofia da Universidade de São Paulo. Cadernos de Pesquisa, v. 41, n. 142, p. 188-207, 2011.

. O país, a ciência e o engenheiro nos Anuários da Escola Politécnica (1900-1947). In: Congresso Brasileiro de História da Educação, VII, 2013, Campo Grande, Grupos de

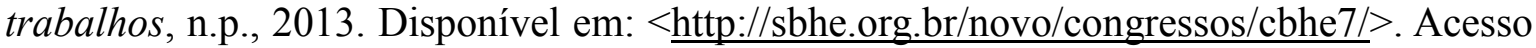
em: 02 abr. 2014.

BORRERO, Alfonso. The university as an institution today: topics for reflection. Paris: Unesco, 1993.

Bourdieu, Pierre. Le sens pratique. Paris: Les Éditions de Minuit, 1980.

. Homo academicus. Paris: Les Éditions de Minuit, 1984.

. L'illusion biographique. Actes de la Recherche en Sciences Sociales, v. 62-63, p. 69-72, 1986.

- Variations et invariants. Éléments pour une histoire structurale du champ des grandes écoles. Actes de la Recherche en Sciences Sociales, n. 70, p. 3-30, 1987. 1989.

La noblesse d'état. Grandes écoles et esprit de corps. Paris: Les Éditions de Minuit,

. Raisons pratiques. Sur la theorie de l'action. Paris: Éditions du Seuil, 1994.

. Esquisse d'une theorie de la pratique. Precedé de trois études d'ethnologie kabyle. Paris: Éditions du Seuil, 2000.

. Language et pouvoir symbolique. Paris: Éditions du Seuil, 2001.

. Les conditions sociales de la circulation internationale des idées. Actes de la Recherche en Sciences Sociales, n. 145, p. 3-8, 2002.

. Para uma sociologia da ciência. Lisboa: Edições 70, 2004a.

Os usos sociais da ciência: para uma sociologia do campo científico. São Paulo: Editora Unesp, $2004 b$. 
. Meditações pascalianas. Rio de Janeiro: Bertrand Brasil, 2007.

. A distinção. Crítica social do julgamento. São Paulo/Porto Alegre: Edusp /Zouk, 2008.

BOURDIEU, Pierre \& PASSERON, Jean Claude. La reproduction. Éléments pour une théorie du système d'enseignement. Paris: Les Éditions de Minuit, 1970.

Bourdieu, Pierre \& Saint Martin, Monique de. Agrégation et ségrégation. Le champ des grandes écoles et le champ du pouvoir. Actes de la Recherche en Sciences Sociales, n. 69, p. 2-50, 1987.

Bourdieu, Pierre \& Wacquant, Loïc. Sur les ruses de la raison impérialiste. Actes de la Recherche en Sciences Sociales. v. 121-122, p. 109-18, 1998.

BRASIL. Lei de 03 de outubro de 1832. Dá nova organização às actuaes Academias Medicocirurgicas das cidades do Rio de Janeiro e Bahia. Coleção de leis do Império, Rio de Janeiro, n.p., 1832. Disponível em:< http://www2.camara.leg.br/legin/fed/lei_sn/1824-1899/lei37274-3-outubro-1832-563716-publicacaooriginal-87775-pl.html>. Acesso em: 21 abr. 2014.

Decreto lei n. 6693 de 14 de julho de 1944. Dispõe sobre a criação de uma entidade que se ocupará do estudo da organização racional do trabalho e do preparo de pessoal para as administrações pública e privada. Diário Oficial da União, Brasília, DF, 1944. Disponível em: < http://legis.senado.gov.br/legislacao/ListaPublicacoes.action?id=4877>. Acesso em 21 de abr. 2014.

. Acordo Básico de Cooperação Técnica Entre o Brasil e os EE.UU. América. 19 de dezembro de 1950. Disponível em: <http://dai-mre.serpro.gov.br/atosinternacionais/bilaterais/1950/b_39/> Acesso em: 21 de abr. 2014.

Acordo Sobre Programas de Serviços Técnicos Especiais entre o Governo dos Estados Unidos da América e o Governo dos Estados Unidos do Brasil. Rio de Janeiro, 30 de maio de 1953. Disponível em $<$ http://dai-mre.serpro.gov.br/atosinternacionais/bilaterais/1953/b_17/>. Acesso em 21 de abr. 2014.

. Lei n 4.464 de 09 de novembro de 1964 (Lei Suplicy Lacerda). Dispõe sobre os Órgãos de Representação dos Estudantes e dá outras providências. Diário Oficial da União, Brasília, DF, 11 de novembro 1964.

Decreto n ${ }^{\circ}$ 62.024, de 29 de Dezembro de 1967. Institui Comissão Especial para propor medidas relacionadas com os problemas estudantis. Diário Oficial da União, Brasília, DF, 30 de dezembro de 1967.

Relatório da Equipe de Assessoria ao planejamento do ensino superior. EAPES. Acordo MEC-Usaid. Brasília: MEC, 1968a.

- Reforma universitária: relatório do Grupo de Trabalho criado pelo decreto $n^{\circ}$ 62.937/68. Brasília: Governo Costa e Silva, 1968b.

. Relatório da Comissão Especial criada pelo decreto $n^{\circ}$ 62.024. Brasília: Governo Costa e Silva, 1968c.

Reforma universitária: leis, decretos-leis, decretos, portarias, pareceres, resoluções. Brasília: Governo Costa e Silva, 1969.

Brener, Jayme \& Cesar, Chester Luiz Galvão. (Ed.). A casa de Higeia o percurso da 
Faculdade de Saúde Pública de São Paulo, 1918-2010. São Paulo: Ex Libris, 2010.

Brosan, George et al. Patterns and policies in higher education. London: Penguin Books, 1971.

Brown H. S. \& MAYEW, L. B. Ensino superior americano. Rio de Janeiro: Edições Bloch, 1967.

Bueno, Maria Sylvia Simões. O Banco Mundial e modelos de gestão educativa para a América Latina. Cadernos de Pesquisa, v. 34, n. 122, p. 445-66, 2004.

BuRCHELL, Graham (Org.). The Foucault effect: studies in governmentality. London: Harvester Wheatsheaf, 1991.

Buzzoni, Henrique D'Aragona (Org.). Arcadas no tempo da ditadura. São Paulo: Saraiva, 2007.

BRUnSSON, Nils \& SAHLIN-ANDERSSON, Kerstin. Constructing organizations. The example of public sector reform. Organization Studies, v. 21, n. 4, p. 21-46, 2000.

ÇALISKAN, Koray \& CALlON, Michel. Economization, part 1: shifting attention from the economy towards processes of economization. Economy and Society, v. 38, n. 3, p. 369-98, 2009.

CALlON, Michel. Éléments pour une sociologie de la traduction. La domestication des coquilles Saint-Jacques et des marins-pêcheurs das la baile de Saint-Brieuc. L'Anne Sociologique, v. 36, n. esp., p. 169-208, 1986.

Introduction: the embeddedness of economic markets in economies. In: . (Org.). The laws of the markets. London: Blackwell Plublishers/The Sociological Review, 1998a. p. $1-57$.

. An essay on framing and overflowing: economic externalities revisited by sociology. In: . (Org.). The laws of the markets. London: Blackwell Plublishers/The Sociological Review, 1998b. p. 244-69.

. Défense et illustrations des recherches sur la science. In: JURDANT, B. (Org.). Impostures scientifiques. Les malentendus de l'affaire Sokal. Paris: Alliage/La Découvert, 1998c. p. 25367.

What does mean to say that economics is performative? Papiers de Recherche du Centre de Sociologie de l'Innovation, n. 5, p. 1-58, 2006.

An essay on the growing contribution of economic markets to the proliferation of the social. Theory, Culture \& Society, v. 24, p.139-63, 2007.

CAllon, Michel \& LATOuR, Bruno. (Orgs.). La science telle qu'elle se fait. Une anthologie de la sociologie des sciences de langue anglaise. Paris: La Découvert, 1991.

CAMPos, Ernesto de Souza. A história da Universidade de São Paulo. São Paulo: Universidade de São Paulo, 1954.

CANDIDO, Antônio. Prefácio. In: MiCeli, Sergio. Intelectuais à brasileira. São Paulo: Companhia das Letras, 2001, p. 71-5.

CARAVANTES, Geraldo et al. Gestão estratégica de resultados: construindo o futuro. São Paulo: Editora Age, 2004. 
CARdoso, Irene. A universidade da comunhão paulista. São Paulo: Cortez, 1982.

. Memorial para concurso de Livre-Docência (parte). São Paulo: Faculdade de Filosofia, Letras e Ciências Humanas, 1999.

. Para uma crítica do presente. São Paulo: Editora 34, 2001.

CARlotto, Maria Caramez. Reflections on the historical, epistemological, and social meaning of technoscience. Scientiae Studia, v. 10, n. spe, p. 129-39, 2012.

. Veredas da mudança na ciência brasileira. Discurso, institucionalização e práticas no cenário contemporâneo. São Paulo: Scientiae Studia; Editora 34, 2013.

CARVAlHO, Arnaldo Vieira de. Lição inaugural do curso de clinica gynecologica. Boletim da Sociedade de Medicina e Cirurgia de São Paulo, n. esp, p. 253-54, 1921.

CARVAlho, José Murilo de. Os bestializados: o Rio de Janeiro e a República que não foi. São Paulo: Companhia das Letras, 1987. . A construção da ordem: a elite imperial. Rio de Janeiro: Civilização Brasileira, 2003.

. A formação das almas: o imaginário da República no Brasil. São Paulo: Companhia das Letras, 2012.

CAsassus, Juan. A reforma educacional na América Latina no contexto da globalização. Cadernos de Pesquisa, v. 114, p. 2-28, 2001.

CASTRO, Alberto Pereira de. IPT/POLI antecedentes históricos, realidade e perspectivas futuras. São Paulo: Escola Politécnica da USP,1982.

CASTRO, João Abrahão de. Evolução e desigualdade na educação brasileira. Educação $e$ Sociedade, v. 30, n. 108, p. 673-97, 2009.

CASTRO, Jorge Abrahão \& VAZ, Fábio Monteiro. Gastos das famílias com educação. In: SiLveIRA, Fernando Gaiger et al. (Orgs.). Gasto e consumo das famílias brasileiras contemporâneas. Brasília: IPEA, 2007. p. 77-104.

Celeste filho, Macioniro. A constituição da Universidade de São Paulo e a reforma universitária da década de 1960. São Paulo: Editora Unesp, 2013.

Centro Acadêmico XI De agosto. A heroica pancada: Centro Acadêmico XI de Agosto, 100 anos de luta. São Paulo: Memojus, 2003.

Charle, Christophe. La république des universitaires, 1970-1940. Paris: Édititions du Seuil, 1994.

. Les références étrangères des universitaires. Actes de la Recherche en Sciences Sociales, n. 148, p. 8-19, 2003.

Les elites de la republique. Paris: Fayard, 2006.

Charle, Christophe \& Soulie, Charles (Orgs.). Les ravages de la "modernisation" universitaire en Europe. Paris: Éditions Syllepse, 2007.

Charle, Christophe \& Verger, Jacques. História das universidades. São Paulo: Editora da 
Universidade Estadual Paulista, 1996.

CHAUÍ, Marilena. Escritos sobre a universidade. São Paulo: Editora Unesp, 2001.

Chalhoub, Sidney. Cidade febril: cortiços e epidemias na Corte Imperial. São Paulo: Cia das Letras, 2001.

Clark, Burton. Creating entrepreneurial universities: organizational pathways of transformation. Paris/Oxford: IAU/Elsevier Science, 1998.

CodATo, Adriano \& PerissinotTo, Renato. Marxismo e elitismo: dois modelos antagônicos de análise social? Revista Brasileira de Ciências Sociais, v. 24, n. 71, p. 143-95, 2009.

Coelho, Edmundo Campos. Profissões imperiais no Brasil: medicina, engenharia e advocacia no Rio de Janeiro, 1822-1930. Rio de Janeiro: Record, 1999.

COHEN, Yves. Le siècle des chefs. Une histoire transnationale du commandement et de l'autorité (1891-1940). Paris: Éditions Amsterdam, 2013a.

O conjunto significativo da figura do chefe (França, Alemanha, União Soviética e Estados Unidos, 1980-1942). Revista Fevereiro, n. 5, n.p., 2013 b.

COMIN, Alvaro \& BARBOSA, Alexandre. Trabalhar para estudar: sobre a pertinência da noção de transição escola-trabalho no Brasil. Novos Estudos, n. 91, p. 75-95, 2001.

Cooke, Bill. The management of the (third) world. Organization, v. 11, n. 5, p. 603-29, 2004.

. Managerialism as knowing and making Latin America: international development management and World Bank interventions. In: FARIA, A. \& GuEdES, A. (Orgs.). International management and international relations. A critical perspective from Latin America. London: Routledge, 2010. p. 161-84.

Cooke, Bill; Mills, A. \& Kelley, E. S. Situating Maslow in Cold War America: a recontextualization of management theory. Group \& Organization Management, v. 30, n. 2, p. 129-52, 2006.

CPDOC. Centro de Pesquisa e Documentação de História Contemporânea do Brasil. Dicionário histórico-biográfico brasileiro. Verbete IBAD. São Paulo: CPDOC, n.p., 2004. Disponível em < http://www.fgv.br/cpdoc>. Acesso em : 21 de abr. 2014.

Crema, Jagotá. Como desisti da Escola Politécnica. Folha de S. Paulo, p. 3, 16 mar. 2012. Disponível em: <http://www1.folha.uol.com.br/fsp/opiniao/31488-como-desisti-da-escolapolitecnica.shtml>. Acesso em 21 abr. 2014.

CunHA, Luiz Antônio. A universidade temporã: o ensino superior da colônia à era de Vargas. São Paulo: Editora da Unesp, 2007a.

. A universidade crítica: o ensino superior na república populista. São Paulo: Editora da Unesp, $2007 b$.

. A universidade reformanda: o golpe de 1964 e a modernização do ensino superior. São Paulo: Editora da Unesp, 2007c. 
CunHA, Marcia. Do planejamento à ação focalizada. IPEA e a construção de uma abordagem de tipo econômico da pobreza. 2012, 272f. Tese (Doutorado em Sociologia). Faculdade de Filosofia, Letras e Ciências Humanas, Universidade de São Paulo, São Paulo, 2012.

CURADO, Isabela Baleeiro. O desenvolvimento dos saberes administrativos em São Paulo: uma análise histórica. 2001. 205f. Tese (Doutorado em Administração). Escola de Administração de Empresas de São Paulo, Fundação Getúlio Vargas, São Paulo, 2001.

Cytrynowicz, Roney \& Cytrynowicz, Monica Musatti. Poli-Elétrica, 100 anos de liderança. São Paulo: Riemma, 2011.

DALlARI, Dalmo. As Arcadas na política brasileira. In: BITTAR, Eduardo Carlos Bianca (Org.). História do direito brasileiro: leituras da ordem jurídica nacional. São Paulo: Atlas, 2003.

DANIlA, Arthur Hirschfeld (Coord.). Centro Acadêmico Oswaldo Cruz: a história dos estudantes da Faculdade de Medicina da Universidade de São Paulo. São Paulo: Centro Acadêmico Oswaldo Cruz, 2009.

DARDOT, Pierre \& LAVAL, Christian. La nouvelle raison du monde: essai sur la société néolibérale. Paris: La Découverte, 2010.

DESROSIERES, Alain. La politique des grands nombres. Histoire de la raison statistique. Paris: La Découberte/Syros, 1993.

DeZAlay, Yves. Multinationales de l'expertise et "dépérissement de l'État". Actes de la Recherche en Sciences Sociales. v. 96-97, p. 3-20, 1993.

Dezalay, Yves \& Garth, Bryant. Le "Washington consensus". Actes de la Recherche en Sciences Sociales, n. 121-122, p. 3-22, 1998.

\& _ _ L L La mondialization des guerres de palais. Paris: Seuil, 2002.

$\&$ \&_. Les usages nationaux d'une science "globale" : la diffusion de nouveaux paradigmes économiques comme stratégie hégémonique et enjeu domestique dans les champs nationaux de reproduction des élites d'État. Sociologie du Travail, v. 48, p. 308-29, 2006.

DILL, David \& SPORN, Barbara. The implications of a postindustrial environment for the university: an introduction. In: DILL, David \& SPORN,,Barbara (Orgs.). Emerging patterns of social demand and university reform: through a glass darkly. London: Pergamon Press, 1995.

DonZELOT, Jacques. The poverty of political culture. Ideol. Conscious., v. 5, p. 73-86, 1979.

Drahos, Peter \& BraithwaIte, John. "Une hégémonie de la connaissance". Les enjeux des débats sur la propriété intellectuelle. Actes de la Recherche en Sciences Sociales, n. 151-152, p. 68-79, 2004.

DREIFUSS, René Armand. 1964 a conquista do Estado: ação política, poder e golpe de classe. Petrópolis: Vozes, 1981.

DroRI, Gili S. et al (Orgs.). Globalization and organization. Oxford: Oxford University Press, 2006. 
Dubet, François; Duru-Bellat, Marie \& Veretout, Antoine. As desigualdades escolares antes e depois da escola : organização escolar e influência dos diplomas. Sociologias, v. 14, n. 29, p. 22-70, 2012.

DURKHEIM, Émile. Formes elementaires de la vie religieuse. Paris: P.U.F, 1960.

DURKHEIM, Émile \& MAUSS, Marcel. De quelques formes de classification - contribution à l'étude des représentations collectives. Année Sociologique, n. 6, p. 1-72, 1903.

Escola Politécnica. Formando engenheiros e líderes. São Paulo: Escola Politécnica, n.p., 2014. Disponível em: < http://www.poli.usp.br/pt/a-poli.html>. Acesso em: 21 de abr. 2014.

Etzkowitz, Henry; Webster, Andrew \& Haley, Peter. Capitalizing knowledge: new intersections of industry and Academia. Albany: State University of New York Press, 1998.

EuRIAT, Michel \& THÉlot, Claude. Le recrutement social de l'élite scolaire en France. Evólution des inegalités de 1950 à 1990. Revue Française de Sociologie, n. 36, p. 403-13, 1995.

EYAL, Gil. For a sociology of expertise: the social origins of the autism epidemic. American Journal of Sociology, v. 118, n. 4, p. 863-907, 2013.

EyAL, Gil \& BuchHolz, Larissa. From the sociology of intellectuals to the sociology of interventions. The Annual Review of Sociology, v. 36, p. 117-37, 2010.

EyAL, Gil \& POK, Grace. From a sociology of professions to a sociology of expertise. Working Paper for Columbia University, 2011.

FAORO, Raymundo. Os donos do poder. Porto Alegre: Editora Globo, 1958.

FARIA, Lenilda Rêgo Albuquerque. Entrevista com Selma Garrido Pimenta. Revista eletrônica Pesquisaeduca, v. 3, n. 5, p. 129-53, 2011.

FARIA, Lina Rodrigues de. Saúde e política, a Fundação Rockefeller e seus parceiros em São Paulo. Rio de Janeiro: Fundação Oswaldo Cruz, 2007.

FÁVERO, Maria de Lourdes de Albuquerque. Da universidade "modernizada" à universidade disciplinada: Atcon e Meira Mattos. São Paulo: Cortez, 1991.

Da cátedra universitária ao departamento: subsídios para discussão. In: SGUISSARDI, Valdemar \& SILVA JÚNIOR, João Reis (Org.). Educação superior: análise e perspectivas de pesquisa. São Paulo: Xamã, 2001, p. 223-30.

. A universidade no Brasil: das origens à Reforma de 1968. Educar, n. 28, p. 17-36, 2006.

FERnANDes, Ana Maria. A construção da ciência no Brasil e a SBPC. Brasília: Editora da Universidade de Brasília: Anpocs, 1990.

FERNANDES, Florestan. Universidade brasileira: reforma ou revolução. São Paulo: Alfa-ômega, 1975.

. A questão da USP. São Paulo: Brasiliense, 1984. 2006.

. A revolução burguesa no Brasil: ensaio de interpretação sociológica. São Paulo: Globo, 
FERREIRA, Fábio Vizeu. Management no Brasil em perspectiva histórica: o projeto do IDORT nas décadas de 1930 e 1940. Tese (Doutorado em Administração). 2008. 254f. Escola de Administração de Empresas de São Paulo, Fundação Getúlio Vargas, São Paulo, 2008.

FERreirA, Mariana Toledo. A institucionalização da pesquisa em genética no Brasil e seus pesquisadores: um estudo do Centro de Estudos do Genoma Humano da USP. 2013. 191f. Dissertação (Mestrado em Sociologia). Faculdade de Filosofia, Letras e Ciências Humanas, Universidade de São Paulo, São Paulo, 2013.

FÉTIZON, Beatriz Alexandrina de Moura. Subsídios para o estudo da Universidade de São Paulo. 1986. Tese (Doutorado em Educação). Faculdade de Educação, Universidade de São Paulo, São Paulo, 1986. 3 v.

FICHER, Sylvia. Ensino e profissão: o curso de engenheiro-arquiteto da Escola Politécnica de São Paulo. s.1.; s.n., 1995. 2v.

Os arquitetos da Poli, ensino e profissão em São Paulo. São Paulo: Edg, 2005.

FISCHER, Tânia. $O$ ensino da administração pública no Brasil, os ideais do desenvolvimento e as dimensões da racionalidade. 1984. Tese (Doutorado em Administração). Faculdade de Economia, Administração e Contabilidade, Universidade de São Paulo, São Paulo, 1984.

FORMAN, Paul. The primacy of science in modernity, of the technology in the postmodernity, and of ideology in the history of technology. History and Technology, v. 23, n.1, p. 1-152, 2007.

FÓRUM DE PRÓ-REITORES DE GRADUAÇÃO DAS UNIVERSIDADES BRASILEIRAS. Do pessimismo da razão para o otimismo da vontade: referências para a construção dos projetos pedagógicos nas IES brasileiras. Curitiba: ForGRAD, 1999.

FOUCAUlT, Michel. Surveiller et punir. Naissance de la prison. Paris: Gallimard, 1975.

La naissance de la clinique. Paris: Presses Universitaires de France, 1988.

. Em defesa da sociedade. São Paulo: Martins Fontes, 1999.

. La naissance de la biopolitique. Paris: Gallimard, 2004.

. L'archéologie du savoir. Paris: Gallimard, 2010.

A ordem do discurso. Aula inaugural no Collège de France pronunciada em 2 de dezembro de 1970. São Paulo: Edições Loyola, 2011.

FRANK, John David \& MEYER, John. Worldwide expansion and change in the university. In: KRÜCKEN, Georg; KOSMÜTZKY, Anna \& TORKA, Marc. Towards a multiversity? Universities between global trends and national traditions. Bielefeld: Transcript Velag, 2006. p. 19-44.

FREITAG, Michel. Le naufrage de l'université et autres essais d'épistémologie politique. Québec/Paris: Nuit Blanche Éditeur/La Découvert, 1995.

FREIRE, Gilberto. Sobrados e mucambos. Decadência do patriarcado rural e desenvolvimento do urbano. São Paulo: Global, 2006.

FriedBerg, Erhard \& Musselin, Christine (Coord.). Le gouvernment des universités: perspectives comparatives. Paris: L'Harmattan, 1991. 
GALISON, Peter. Image and logic, a material culture of microphysics. Chicago: University of Chicago Press, 1997.

Gall, Brice Le \& Soulie, Charles. Massification, professionnalisation, réforme du gouvernement des universités et actualisation du conflit des facultés en France. In: CHARLE, Christophe \& Soulie, Charles (Orgs.). Les ravages de la "modernisation" universitaire en Europe. Paris: Éditions Syllepse, 2007. p.173-208.

GASPARI, Elio. A ditadura envergonhada. São Paulo: Companhia das Letras, 2002

GARCiA, Afrânio. Les intellectuels et la conscience nationale au Brésil. Actes de la Recherche en Sciences Sociales, n. 98, p. 20-33, 1993.

La construction interrompue : Celso Furtado, la guerre froide et le développement du Nordeste. Actes de la Recherche en Sciences Sociales, n. 121-122, p. 52-61, 1998.

GARCIA, Sandrine \& POUPEAU, Frank. La mesure de la "démocratisation" scolaire. Actes de la Recherche en Sciences Sociales, n. 149, p. 74-87, 2003.

GARCiA, Sylvia Garcia. A questão da universidade e a formação em ciências sociais. Tempo social, v. 21, n. 1, p. 123-40, 2000.

GARCIA, Sylvia Garcia \& CARLOTto, Maria Caramez. Institutional specificity and organizational change: A case of university social engagement in Brazil. In: PINHEIRO, R.; BENNEWORTH, P. \& JONES, G. (Ed.). Universities and regional development: a critical assessment of tensions and contradictions. London \& New York: Routledge, Taylor and Francis, 2012. p. 124-40.

. Tensões e contradições do conceito de organização aplicado à universidade: o caso da criação da USP-Leste. Avaliação, v. 18, p. 657-684, 2013a.

- A expansão do ensino superior e o controle profissional do trabalho docente: o caso da implementação da USP-Leste. In: Congresso Latino-Americano de Estudos do Trabalho, 2013, São Paulo. ANAIS Congresso Latino-Americano de Estudos do Trabalho, 2013b.

GERBOD, Paul. Resources and management. In: RÜEGG, Walter (Org.). A history of the university in Europe: universities in the nineteenth and early twentieth century. Cambridge: Cambridge Univertsity Press, 2004.

GianNOTTI, José Arthur. Universidade em ritmo de barbárie. São Paulo: Brasiliense, 1987.

GINGRAS, Yves. Un air de radicalisme. Actes de la Recherche en Sciences Sociales, v. 108, p. 3-18, 1995.

. Les formes spécifiques de l'internationalité du champ scientifique. Actes de la Recherche en Sciences Sociales, n. 141-142, p. 31-45, 2002.

Idées d'université: enseignement, recherche et innovation. Actes de la Recherche en Sciences Sociales, n. 148, p. 3-7, 2003.

GoDIN, Benoit. Technological gaps: an important episode in the construction of S\&T statistics. Technology in Society, v. 24, p. 387-413, 2002.

The emergence of S\&T indicators: why did governments supplement statistics with indicators? Research Policy, v. 32, p. 679-91, 2003. 
. The new economy: what the concept owes to the OECD. Research Policy, v. 33, p. 67990, 2004a.

. The obsession for competitiveness and its impact on statistics: the construction of hightechnology indicators. Research Policy, v. 33, p. 1217-29, 2004 b.

The linear model of innovation. The historical construction of an analytical framework. Science, Technology \& Human Values, v. 31, n. 6, p. 639-67, 2006.

Gelfand, M. A. Universities libraries for developing countries. Paris: Unesco, 1968. Disponível em: <http://unesdoc.unesco.org/images/0000/000007/000714eo.pdf $>$ Acesso em: 21.Abr.2014.

Gomes, Angela de Castro (coord.). Engenheiros e economistas: novas elites burocráticas. Rio de Janeiro: Editora FGV, 1994.

Gomes, Celso de Barros. Geologia USP: 50 anos. São Paulo: Edusp/IGC, 2007.

Gomes, Celso de Barros. (Org.). USP leste: a expansão da universidade de oeste para o leste. São Paulo: Edusp, 2005.

GORNITZKA, Âse \& LARSEN, Ingvild. Towards professionalisation? Restructuring of administrative work force in universities. Higher Education, v. 47, n. 4, p. 455-71, 2004.

GornitzKa, Âse; SveIn, Kyvik \& LARSEN, Ingvild. The bureaucratization of universities. Minerva, v. 36, p. 21-47, 1998.

Grola, Diego Amorim. A memória das Arcadas. Construção material, simbólica e ideológica do edifício da Faculdade de Direito do Largo São Francisco. São Paulo: FDUSP, 2009.

GRÜN, Roberto. A revolução dos gerentes brasileiros. Tese (Doutorado em Ciências Sociais). 1990. 320f. Instituto de Filosofia e Ciências Humanas, Universidade Estadual de Campinas, Campinas, 1990.

. Atores e ações na construção da governança corporativa brasileira. Revista Brasileira de Ciências Sociais, v.18, n. 52, p. 139-161, 2003.

Convergência das elites e inovações financeiras: a governança corporativa no Brasil. Revista Brasileira de Ciências Sociais, v. 20, n. 58, p. 67-90, 2005.

Guimarães, Antônio da Palma. Arnaldo Vieira de Carvalho. Biografia e crítica. São Paulo: Universidade de São Paulo, 1967. 2v.

Guimarães, Carlos Eduardo. Filosofia, lógica e educação. In: NAGLE, Jorge (Org.). Educação e linguagem. São Paulo: Edarte, 1976. p. 99-144.

Guimarães, Antônio Sérgio. Acesso de negros às universidades públicas. Cadernos de Pesquisa, n. 118, p. 247-68, 2003.

HABERMAS, Jürgen. Técnica e ciência como “ideologia”. Lisboa: Edições 70, 2001.

HACKETT, Edward. Science as a Vocation in the 1990s: The changing organizational culture of academic science. Journal of Higher Education, v. 61, n. 3, p. 241-79, 1990.

HAFFERTY, Frederic W. \& Light, Donald W. Professional dynamics and the changing nature of 
medical work. Journal of Health and Social Behavior, Extra issue, p. 132-53, 1995.

HEDMO, T. et al. Is an organizational field of higher education emerging? Management education as an early example. In: KRÜCKEN, Georg et al. (Eds.). Towards a multiversity? Universities between global trends and national traditions. Bielefeld: Transcript Velag, 2006, p. 154-75.

HENDERSON, Algo. La formation des administrateurs d'université. Paris: UNESCO, 1972.

HenKel, Mary. Government, evaluation and change. London: Jessica Kingsley Publishers, 1991.

. Academic identities and policy change in higher education. London: Jessica Kingsley Publishers, 2000.

HERMIDA, Jorge Fernando. O Plano Nacional de Educação (Lei10.172), de 9 de janeiro de 2001. Educar, n. 27, p. 239-58, 2006.

Hey, Ana Paula. Esboço de uma sociologia do campo acadêmico. A educação superior no Brasil. São Carlos: Edufscar, 2008.

HEY, Ana Paula \& CATANI, Afrânio. A USP e a formação de quadros dirigentes. In: MoROSONI, Marília (Org.). A universidade no Brasil: concepções e modelos. Brasília: INEP, 2006. p. 295-312.

HIRANO, Sedi. Espaço memória: atividades a serem desenvolvidas pela nossa Faculdade para comemorar seus 70 anos. Informe: Informativo da Faculdade de Filosofia, Letras e Ciências Humanas, n. 3, p. 12-3, 2003.

HoHENDHAL, Peter Uwe. Humboldt revisitado: educação liberal, reforma universitária e a oposição à universidade neoliberal. Revista Fevereiro, n. 6, n.p., 2013.

Holanda, Sérgio Buarque. História geral da civilização brasileira: o Brasil monárquico. Rio de Janeiro: Difusão Europeia do Livro, 1972.

HorKHEIMER, Max. Teoria tradicional e teoria crítica. In: HoRKHEIMER, Max. Os pensadores: Textos escolhidos. São Paulo: Abril Cultural, 1980.

Hоттоіs, Gilbert. Le signe et la technique: la philosophie à l'épreuve de la technique. Paris: Aubier, 1984.

HouAISs, Antônio. Dicionário Houaiss da língua portuguesa. Lisboa: Instituto Houaiss/ Temas e Debates, 2003.

INEP. Educação Superior Brasileira 1991-2004: São Paulo. Brasília: INEP, 2006.

Instituto De Administração. Guia da Universidade de São Paulo. São Paulo, Instituto de Administração, 1951.

IPES. Instituto de Pesquisas e Estudos Sociais. A educação que nos convém. Fórum realizado em outubro/novembro de 1968. Rio de Janeiro: APEC Editora, 1969.

INGERSOLL, Richard. Who controls teachers' work?: Power and accountability in America's schools. Cambridge, MA: Harvard University Press, 2003. 
JACKSON, Luiz Carlos. Gerações pioneiras na sociologia paulista (1934-1969). Tempo Social, v. 19, n. 1, p. 115-30, 2007.

JASPERS, Karl. Balance y perspectiva. Renovación de la universidad. Revista de Occidentei, Madrid, 1953.

KANT, Immanuel. O conflito das faculdades. Lisboa: Edições 70, 1993.

KeInert, Fábio Cardoso \& SiLva, Dimitri Pinheiro. A gênese da ciência política brasileira. Tempo Social, v. 22, n. 1, p. 79-98, 2010.

KERR, Clark. The uses of university. New York: Harper and Row Publishers, 1966.

. The great transformation in higher education, 1960-1980. New York: State University of New York Press, 1991.

KHAN, Shamus Rahman. The sociology of elites. Annual Review of Sociology, v. 38, p. 361-77, 2012.

KogAn, Maurice. Academic and administrative interface. In: HenKel, Mary \& LiTTLe, Brenda. (Orgs). Changing relationships between higher education and the state. London: Jessica Kingsley, 1999. p. 263-79.

KRÜCKEN, Georg; BLÜMeL, Albrecht \& KlOKE, Katharina. The managerial turn in higher education? On the interplay of organizational and occupational change in German academia. Minerva, v. 51, p. 417-42, 2013.

KRÜCKEN, Georg \& MEIER, Frank. Turning the university into an organizational actor. In: DrorI, Gili S. et al. (Eds.). Globalization and organization. Oxford: Oxford University Press, 2006. p. 241-57.

KRÜCKEN, Georg; KOSMÜTZKY, Anna \& TORKA, Marc. Towards a multiversity? Universities between global trends and national traditions. Bielefeld: Transcript Velag, 2006.

KwaniscKA, Eunice Lacava. (Org.). Universidade de São Paulo: subsídios para uma avaliação. São Paulo: Universidade de São Paulo, 1985.

LACAZ, Carlos da Silva \& MAZZIERI, Berta Ricardo de. A Faculdade de Medicina e a USP. São Paulo: Edusp, 1995.

LAHIRE, Bernard. "Champ, hors-champ, contrechamp". In: LAHIRE, Bernard (Coord.). Le travail sociologique de Pierre Bourdieu. Paris: La Découverte, 2001. p. 23-57.

LARSEN, Ingvild \& GORNITZKA, Âse. Towards professionalisation? Restructuring of administrative work force in universities. Higher Education, v. 47, n. 4, p. 455-71, 2004.

LATOUR, Bruno. Les microbes: guerre et paix. Paris: Métailié, 1984.

. Ciência em ação. Como seguir cientistas e engenheiros sociedade afora. São Paulo: Editora da Unesp, 2011.

LE Goff, Jacques. Les intellectuels au Moyen Âge. Paris: Éditions du Seuil, 1985.

LEBARON, Fréderic. L'impérialisme de l'économie: éléments pour une recherche comparative. Actes de la Recherche en Sciences Sociales, n. 121-122, p. 104-8, 1998. 
LEGRAND, Stéphane. Le marxisme oublié de Foucault. Actuel Marx, n. 36, p. 27-43, 2004.

LEME, Ernesto Moraes. À guisa de prefácio. In: CAMPos, Ernesto de Souza. História da Universidade de São Paulo. São Paulo: Universidade de São Paulo, 1954. n.p.

LEMKE, Thomas. Marx sans Guillements. Foucault, la governamentabilité et la critique du néolibéralisme. Actuel Marx, n. 36, p. 13-26, 2004.

LENOIR, Remi. Objeto sociológico e problema social. In: CHAMPAGNe, Patrick; LENOIR, Remi; Merllie, Dominique \& PINTO, Louis. Iniciação à prática sociológica. Petrópolis: Vozes, 1998. p. 59-106.

LiMA, Márcia \& ABDAL, Alexandre. Educação e trabalho: a inserção dos ocupados de nível superior no mercado formal. Sociologias, v. 9, n. 17, p. 216-38, 2007.

LIMONGI, Fernando. Educadores e empresários culturais na construção da USP. 1988. 279f. Dissertação (Mestrado em Ciência Política). Instituto de Filosofia e Ciências Humanas. Universidade Estadual de Campinas, Campinas, 1988.

. Mentores e clientelas na Universidade de São Paulo. In: MiCELI, Sergio. (Org.). História das ciências sociais no Brasil. São Paulo: Vértice/Editora Revista dos Tribunais,/IDESP, 1989. v. 1, p. 111-86.

LiVeSEY, Herbert \& RoBBIns, Gene. Guide to American graduate schools. New York: The Viking Press, 1967.

LôBO, Pelágio. Recordações das Arcadas. São Paulo: Reitoria da Universidade de São Paulo, Divisão de Difusão Cultural, 1953.

LOPES, Ivanir Ferreira de Souza \& SANTOS, Thaís Helena dos. (Orgs.). USP 70 anos imagens e depoimentos. São Paulo: Universidade de São Paulo/Coordenadoria de Comunicação Social, 2005.

LORENZ, Chris. 'L'économie de la connaissance', le nouveau management public et les politiques de l'enseignement supérieur dans l'Union Européenne. In: CHARLE, Christophe \& Soulie, Charles. (Orgs.). Les ravages de la "modernisation" universitaire en Europe. Paris: Éditions Syllepse, 2007. p. 33-52.

LOUREIRO, Rita. L'internationalisation des milieux dirigeants au Brésil. Actes de la Recherche en Sciences Sociales, n. 121-122, p. 42-51, 1998.

Machado, José Pedro. Dicionário etimológico da língua portuguesa. Com a mais antiga documentação escrita e conhecida de muitos dos vocábulos estudados. Lisboa: Editorial Confluência: 1952.

MACHADO, Roberto et al. A danação da norma. Rio de Janeiro: Graal, 1978.

Machado Júnior, Armando Marcondes. Centro Acadêmico XI de Agosto, Faculdade de Direito de São Paulo, 1903-1993. São Paulo: Pannartz, 1988. 5v.

MackenZIE, Donald; Muniesa, Fabian \& SiU, Lucia. Do economics make markets? Princeton: Princeton University Press, 2007.

Malissard, Pierrick; Gingras, Yves \& Gemme, Brigitte. La commercialisation de la recherche. Actes de la Recherche en Sciences Sociales, n. 148, p. 57-67, 2003. 
MARANHÃo, Tatiana. Governança mundial e pobreza: do Consenso de Washington ao consenso das oportunidades. 2009. 148f. Tese (Doutorado em Sociologia). Faculdade de Filosofia, Letras e Ciências Humanas, Universidade de São Paulo, São Paulo, 2009.

MARCHI, Eduardo Cesar. História e tradições das Arcadas. Folha de S. Paulo, São Paulo, p. 2, 11 ago. 2011.

MARCovitch, Jacques. Universidade viva, diário de um reitor. São Paulo: Mandarim, 2001.

MARE, Robert. Change and stability in educational stratification. American Sociological Review, v. 46, p. 72-87, 1981.

MARINHO, Maria Gabriela. Norte-americanos no Brasil: uma história da Fundação Rockfeller na Universidade de São Paulo (1934-1952). Campinas/São Paulo: Editores Associados/Universidade São Francisco, 2001.

. Elites em negociação: breve história dos acordos entre a Fundação Rockefeller e a Faculdade de Medicina de São Paulo (1916-1931). Bragança Paulista: Edusf, 2003.

Marinho, Maria Gabriela \& MotA, André (Orgs.). Trajetória da Faculdade de Medicina da Universidade de São Paulo, aspectos históricos da "Casa de Arnaldo". São Paulo: Casa de Soluções, 2012.

Martins, Ana Luiza \& Barbuy, Heloísa. Arcadas: história da Faculdade de Direito da Universidade de São Paulo. São Paulo: Melhoramentos/Alternativa, 1998.

Martins, André Luiz de Miranda. A marcha do "capitalismo universitário" no Brasil nos anos 1990. Avaliação, n.13, n.3, p. 733-43, 2008.

MARTINS, Randy (Org.). Chalk lines: the politics of work in the managed university. London: The Duke University Press, 1998.

Mauger, Gérar. Sur la violence symbolique. In: Müller, Hans \& Sintomer, Yves. Pierre Bourdieu, théorie et pratique. Paris: La Découverte, 2006. p. 84-100.

MEC. Ministério da Educação e Cultura. Estatísticas educacionais. 1960-1971. Brasília: MEC/ Secretaria Geral/ Serviço de Estatística da Educação e Cultura, 1972.

. Estatísticas educacionais. 1971-1974. Brasília: MEC/ Secretaria Geral/ Serviço de Estatística da Educação e Cultura, 1974.

Mello, Hivy Damasio Araújo. O Banco Mundial e a educação no Brasil: convergências e torno de uma agenda. 2012. 435f. Tese (Doutorado em Ciências Sociais). Instituto de Filosofia e Ciências Humanas, Universidade Estadual de Campinas, Campinas, 2012.

Mendes, Josué Camargo. Universidade de São Paulo, súmula da sua história. São Paulo: Secretaria da Cultura, Ciência e Tecnologia; Academia de Ciências do Estado de São Paulo, 1977.

MERLE, Pierre. Les principales transformations sociodémographiques des filières de l'enseignement superieur de 1985 à 1995. Population, n. 6, p. 1181-210, 1996.

MEYER, John W. et al. Conclusion. In: DroRI, Gili S. et al. (Eds.). Globalization and organization. Oxford: Oxford University Press, 2006, p. 258-274. 
Miceli, Sergio. Condicionantes do desenvolvimento das ciências sociais. In: MiCELI, Sergio (Org.) História das ciências sociais no Brasil. São Paulo: Vértice/Editora Revista dos Tribunais/Idesp, 1989. p. $72-110$.

. A desilusão americana: relações acadêmicas entre o Brasil e os Estados Unidos. São Paulo: Editora Sumaré, 1990.

Intelectuais à brasileira. São Paulo: Companhia das Letras, 2001.

MichELS, Maria Helena. Gestão, formação docente e inclusão: eixos da reforma educacional brasileira que atribuem contornos à organização escolar. Revista Brasileira de Educação, v. 11, n. 33, p. 406-26, 2006.

MiLOT, Pierre. La reconfiguration des universités selon l'OCDE. Economie du savoir et politique de l'innovation. Actes de la Recherche en Sciences Sociales, n.148, p. 68-73, 2003.

MORISON, Robert. The contemporary university. U.S.A. Boston: Beacon Press, 1966.

MотA, André. Tropeços da medicina bandeirante: a medicina paulista entre 1892 e 1920. São Paulo: Edusp, 2005.

. USP avant USP: o caso da Faculdade de Medicina de 2011. Revista USP, n. 61, p. $210-$ $21,2004$.

Centro Acadêmico Oswaldo Cruz, 1913-1940: primeiros movimentos, primeiras histórias. In: DANILA, Arthur. Centro Acadêmico Oswaldo Cruz: a história dos estudantes da Faculdade de Medicina da Universidade de São Paulo. São Paulo: Centro Acadêmico Oswaldo Cruz, 2009. p. 71-104.

Motoyama, Shozo. Tecnologia e industrialização no Brasil. Uma perspectiva histórica. São Paulo: Edunesp, 1994.

. Educação técnica e tecnológica em questão, 25 anos do Ceeteps. História vivida. São Paulo: Edunesp, 1995.

. O almirante e o novo Prometeu. São Paulo: Edunesp, 1996.

. Fapesp, uma história de política científica e tecnológica. São Paulo: Fapesp, 1999a.

. Para uma história da Fapesp. Marcos documentais. São Paulo: Fapesp, 1999b.

. 50 anos do CNPq contados pelos seus presidentes. São Paulo: Fapesp, 2002.

. Construindo o futuro, 35 anos de pós-graduação da USP. São Paulo: Editora Parma Ltda., 2004a.

. Prelúdio para uma história: ciência e tecnologia no Brasil. São Paulo: Edusp, 2004b.

Motoyama, Shozo. (Org.). USP 70 anos, imagens de uma história vivida. São Paulo, Edusp, 2006.

MотоYAma, Shozo et al. História da Universidade de São Paulo: apontamentos historiográficos. Revista Cultura e Extensão USP, São Paulo, v. 5, p. 9-17, 2011. 
Motoyama, Shozo; Marques, Paulo \& Quemel, Maria Angélica. Uma associação para a tecnologia brasileira: ABIPTI 25 anos. Brasília: Paralelo 15, 2005.

Motoyama, Shozo \& Nagamini, Marilda. Escola Politécnica, 110 anos construindo o futuro. São Paulo: Edusp, 2004.

\& _. Fuvest: 30 anos da Fundação Universitária para o Vestibular. São Paulo: Edusp, 2007.

Motoyama, Shozo; Vargas, Renato \& Comengo, Maria Cecília. Seade, uma história exemplar. São Paulo: Seade/Imprensa Oficial, 2008.

Motoyama, Shozo \& Yamin, Rafael. Memorial da América Latina, 21 Anos. São Paulo: IMESP, 2010.

MotTA, André Patto Sá. As universidades e o regime militar. Cultura política e modernização autoritária. Rio de Janeiro: Zahar, 2014.

MoтTA, Marly Silva da. Economistas: intelectuais, burocratas e "mágicos". In: GOMES, Angela de Castro (Coord.). Engenheiros e economistas: novas elites burocráticas. Rio de Janeiro: Editora FGV, 1994. p. 82-122.

Muniesa, Fabian \& CALLON, Michel. La performativité des sciences économiques. Papiers de Recherche du Centre de Sociologie de l'Innovation, n.10, p. 1-23, 2008.

Musselin, Christine. Change or continuity in higher education governance? In: BLEIKLIE, Ivar \& HENKEL, Mary. Governing knowledge: a study of continuity and change in higher education. Dordrecht: Springer, 2005. p. 65-80.

. Are universities specific organizations? In: KRÜCKEN, Georg et al. (Orgs.). Towards a multiversity? Universities between global trends and national traditions. Bielefeld: Transcript Velag, 2006. p. 63-84.

. The transformation of academic work: facts and analysis. Research \& Occasional Paper Series, Center for Studies in Higher Education, University of California, Berkeley, p. 1-15, 2007.

NADAI, Elza. Ideologia do progresso e ensino superior (São Paulo 1891-1934). 1981. 417f. Tese (Doutorado em História). Faculdade de Filosofia, Letras e Ciências Humanas, Universidade de São Paulo, São Paulo, 1981.

Ideologia do progresso e ensino superior: São Paulo 1891-1934. São Paulo: Edições Loyola, 1987.

Nagamani, Marilda. A contribuição da Escola Politécnica da USP na tecnologia e industrialização no Brasil (1880-1990). 1994. Dissertação (Mestrado em história). 503f. Faculdade de Filosofia, Letras e Ciências Humanas, Universidade de São Paulo, São Paulo, 1994. 2v.

NaKata, Vera (Org.). Poli 110 anos, construindo o futuro. São Paulo: Escola Politécnica, 2003.

NAKATA, Vera (Org.). Escola de engenheiros e de líderes. São Paulo: Escola Politécnica, 2007.

NAKATA, Vera (Org.). Escola Politécnica da USP, 120 anos, 1893-2013. São Paulo: Riemma, 2013. 
NASSAR, Jorge. Faculdade de Filosofia, Ciências e Letras de Ribeirão Preto. Comemorações dos 40 anos desta faculdade. [Apresentação]. Paidéia, Ribeirão Preto, v. 15, n. 31, p. 180$81,2005$.

NEAVE, Guy. The evaluative state reconsidered. European Journal of Education, v. 33, n.3, p. 265-84., 1998.

Neave, Guy \& Van Vugth, Frans (Orgs.). Prometheus bound: the changing relationship between government and higher education in western Europe. London: Pergamon Press, 1991.

Newman, John Henry. Origem e progresso das universidades. São Paulo: Brusco \& Cia, 1951. . The idea of university. New York: Rinehart \& Company, 1960.

NogUeIRA, Francis Mary Guimarães. A ajuda externa para a educação brasileira: a produção do "mito do desenvolvimento": da USAID ao BIRD. 1998, 187f. Tese (Doutorado em Educação). Faculdade de Educação, Universidade Estadual de Campinas, Campinas, 1998.

OBA, Rosana. Universidade de São Paulo seus reitores e seus símbolos. Um pouco da história. São Paulo: Edusp, 2006.

OESP. Pró-reitorias: remédios para o gigantismo. O Estado de S. Paulo, São Paulo, 11 dez. 1987. p. 1.

. O novo vestibular da USP. O Estado de S. Paulo, São Paulo, 14 de abr. 2008. p. 3.

OGIEN, Albert. L'esprit gestionnaire : une analyse sur l'air du temps. Paris: Éditions de l'École de Hautes Études en Sciences Sociales, 1995.

OIT. Organization Internationale du Travail. A propos de l'OIT. Paris: OIT, n.p., 2013. Disponível em: < http://www.ilo.org/global/about-the-ilo/lang--fr/index.htm > . Acesso em: 21 abr. 2014.

OliveIRA, Hélio Lourenço de. (Org.). USP 1968-1969: Hélio Lourenço de Oliveira. São Paulo: Edusp, 1995.

OliveIRA, Marcos Barbosa de. A avaliação neoliberal na universidade e a responsabilidade social dos pesquisadores. Scientiae Studia, v. 6, n. 3, p. 379-87, 2008.

OliveIRA, Maurício Roque. A importação de metodologias administrativas no Brasil. Dissertação (Mestrado em Administração). 1999. 225f. Escola de Administração de Empresas de São Paulo, Fundação Getúlio Vargas, São Paulo, 1990

OliVEIRA, Romualdo Portela de \& ADRIÃo, Teresa (orgs.). Gestão, financiamento e direito à educação. Análise da LDB e da Constituição Federal. São Paulo: Xamã, 2002.

Padilha, Rodrigo Bastos. Antonio Francisco de Paula Souza: criador da Escola Politécnica de São Paulo (1843-1917): engenheiro, político e educador. São Paulo, Editora Leopardo, 2010.

PATAI, Daphne. História oral, feminismo e política. São Paulo: Letra e Voz, 2010.

PATI, Francisco. Espírito das Arcadas. São Paulo: Faculdade de Direito, 1950. 
PAUlA, Maria de Fátima de. O processo de modernização da universidade - casos USP e UFRJ. Tempo Social, v. 12, n. 2, p. 189-202, 2000.

. USP e UFRJ, a influência das concepções alemã e francesa em suas fundações. Tempo Social, v. 14, n. 2, p. 147-62, 2002.

PenA, Maria Valéria. A introdução de ideologias gerenciais no Brasil. Revista de Administração de Empresas, v. 25, n. 3, p. 23-30, 1985.

PICKERING, Andrew. The mangle of practice: time, agency, and science. Chicago: University of Chicago Press, 1995.

Pichon, Alain. Les cadres à l'épreuve. Confiance, méfiance, défiance. Paris: Presses Universitaires de France, 2008.

PochmanN, Marcio et al. (Coords.). Proprietários: concentração e continuidade. Atlas da nova estratificação social no Brasil. Volume 3. São Paulo: Editora Cortez, 2009.

Powell, Walter W. \& Dimaggio, Paul J. (Orgs.). The new institutionalism in organizational analysis. Chicago: The University of Chicago Press, 1991.

PRINS, Gwyn. História oral. In: BuRKE, Peter (Org.). A escrita da história - novas perspectivas. São Paulo: Editora da Unesp, 1992. p. 163-98.

PULICI, Carolina. Entre sociólogos: versões conflitivas da "condição de sociólogo" na USP dos anos 1950-1960. São Paulo: Edusp, 2008.

QueIroz FILHo, Manoel Elipídio Pereira de. Faculdade de Direito Largo de São Francisco turmas de 1949, 1950, 1951 e Agregados. Espírito Acadêmico, tipos, picardias e estudantadas. 180 Anos. São Paulo: Faculdade de Direito, 2008.

RAFTERY Adrian \& HouT Michael. Maximally maintained inequality: expansion, reform, and opportunity in Irish education, 1921-1975. Sociology of Education, v. 66 p. 41-62, 1993.

RAGO, Luiz Margareth. Do cabaré ao lar: utopia da cidade disciplinar, Brasil, 1890-1930. Rio de Janeiro: Paz e Terra, 1987.

RASHDALL, Hasting. The university of Europe in the middle ages. Oxford: The Claredon Press, 1936.

READINGS, Bill. The university in ruins. Cambridge: Harvard University Press, 1996.

REAle, Ebe. Faculdade de Direito do Largo de São Francisco: a velha e sempre nova academia. São Paulo: Saraiva, 1997.

REAle, Miguel. Recordações da Universidade de São Paulo. Revista da Universidade de São Paulo, v. 3, p. 91-101, 1986a. . Memórias: destinos cruzados. São Paulo: Saraiva, 1986b. v. 1. . Memórias: a balança e a espada. São Paulo: Saraiva, 1987. v. 2. . Minhas memórias da USP. Estudos Avançados, v. 8, n. 22, p. 25-46, 1994.

RHOADES, Gary. Reorganizing the work force for flexibility: part-time professional labor. The 
Journal of Higher Education, v. 67, n. 6, p. 626-59, 1996.

Managed professionals: unionized faculty and restructuring academic labor. Albany: State University of New York Press, 1998.

RHOADES, Gary \& LESLIE, Larry. Rising administrative costs. Seeking explanations. Journal of Higher Education, v. 66, p. 187-212, 1995.

RhoAdes, Gary \& Slaughter, Sheila. Academic capitalism in the new economy: challenges and choices. American Academic, v. 1, n. 1, p. 37-59, 2004.

RHOADES, Gary \& SPORN, Barbara. New models of management and shifting modes and costs of production: Europe and the United States. Tertiary Education and Management, v. 8, n. 1, p. 3-28, 2002.

RIBEIRO, Carlos Costa. Desigualdades de oportunidades e resultados educacionais no Brasil. Dados, v. 54, n.1, p. 41-87. 2011.

RIBEIRO, Maria das Graças. Educação superior brasileira: reforma e diversificação institucional. Bragança Paulista: Edusf, 2002.

RiCCI, Sandra. Os engenheiros e a cidade São Paulo (1904-1926). 2006. 181f. Dissertação (Mestrado em História Social). Pontifícia Universidade Católica de São Paulo, São Paulo, 2006.

RIDGEWAY, James. Closed corporation: american universities in crisis. New York: Ballantine, 1970.

RoBert, Cécile. Les transformations managériales des activités politiques. Politix, v. 79, n. 3, p. 7-23, 2007.

Roberts, Keith \& DonAhue, Karen. Professing professionalism: bureaucratization and deprofessionalization in the academy. Sociological Focus, v. 33, n. 4, p. 365-83, 2000.

RodAs, João Grandino \& Motoyama, Shozo. História da Universidade de São Paulo. Educação Brasileira: Revista do Conselho de Reitores das Universidades Brasileiras, v. 33, n. 66, p. 11-48, 2011.

RoDrigues, Lidiane Soares. A produção social do marxismo universitário em São Paulo: mestres, discípulos e "um seminário" (1958-1978). 2011. Tese (Doutorado em história) 565f. Faculdade de Filosofia Letras e Ciências Humanas, Universidade de São Paulo, São Paulo, 2011.

Rogers, Francis Millet. A educação superior nos Estados Unidos. Rio de Janeiro: MEC, 1959.

RoSE, Nikolas. Governing the soul: the shaping of the private self. London: Routledge, 1989.

Rose, Nikolas; O’Malley, Pat \& Valverde, Mariana. Governmentality. Annual Review of Law and Social Science, v. 2, p. 83-104, 2006.

Rothblatt, Sheldon \& WitTrock, Björn (Orgs.). The European and American university since 1800: historical and sociological essays. Cambridge, Cambridge University Press, 1993.

Rothen, José Carlos. Os bastidores da reforma universitária de 1968. Educação e Sociedade, 
v. 29 , n. 103, p. 453-75, 2008.

RÜEGG, Walter. Themes. In: RÜEGG, Walter (Org.). A history of the university in Europe. Universities in the nineteenth and early twentieth century. Cambridge: Cambridge University Press, 2004. p. 3-31

Russo, Eliza Maria Águeda (Org.). Preservação da memória da Faculdade de Odontologia da USP, através de registros audiovisuais. São Paulo: Look Comunicações, 2006.

SAHLIN-ANDERSSON, Kerstin \& ENGWALL, Lars. The expansion of management knowledge: carriers, flows, and sources. Stanford: Stanford University Press, 2002.

SAMARA, Eni de Mesquita \& FACCIOTTI, Maria Cândida Reginato (Orgs.). Mulheres politécnicas, histórias e perfis. São Paulo: Escola Politécnica, 2004.

SAMPAIO, Helena. O ensino superior privado: tendências da última década. São Paulo: NUPES/USP, 1998.

Santana, José Carlos Barreto de. Euclides da Cunha e a Escola Politécnica de São Paulo. Estudos Avançados, v.10, n. 26, p. 311-27, 1996.

Santos, Maria Cecília Loschiavo dos. Escola Politécnica da Universidade de São Paulo, 1894-1984. São Paulo: Reitoria da USP, 1985.

SAnTos, Eduardo Altheman Camargo. A economia do poder $e$ o poder da economia: neoliberalismo e governamentalidade em Foucault. 2013. 221f. Dissertação (Mestrado em Sociologia). Faculdade de Filosofia, Letras e Ciências Humanas, Universidade de São Paulo, São Paulo, 2013.

SÃo PAULO. Lei n ${ }^{\circ} 191$ de 24 de agosto de 1893. Approva o regulamento que organiza a Escola Polytechnica de São Paulo. Secretaria do Interior do Estado de S. Paulo, São Paulo, 24 de agosto de 1893. Disponível em:<http://www.al.sp.gov.br/ > Acesso em: 21 abr. 2014.

Decreto lei $n^{\circ} 13.855$, de 29 de fevereiro de 1944. Dispõe sôbre subordinação da Universidade de São Paulo à Interventoria Federal. Diretoria Geral do Expediente da Secretaria da Interventoria, aos 29 de fevereiro de 1944. Disponível em: < http://citrus.uspnet.usp.br/leginf/criacao/decreto13855.htm> Acesso em: 21 de abr. 2014.

SAWAYA, Paulo. Esboço histórico da Faculdade de Filosofia, Ciências e Letras da Universidade de São Paulo 1934-1969. S.1.: s.n., 1979.

SCHWARCZ, Lilia Moritz. O espetáculo das raças: cientistas, instituições e a questão racial no Brasil, 1870-1930. São Paulo: Companhia das Letras, 1993.

SCHWARZ, Roberto. Um mestre na periferia do capitalismo. São Paulo: Editora 34, 2000.

Schwartz, Laurent. Pour sauver l'université. Paris: Éditions du Seuil, 1983.

. Para salvar a universidade. São Paulo: T. A. Queiroz, 1984.

. Comité National d'Evaluation des établissements publics à caractère scientifique, culturel et professionnel: Rapport Annuel. Paris: Ministère de l'Education Nationale, 1986.

Où va l'université? Paris: Gallimard, 1987. 
SCHWARTZMAn, Simon. Formação da comunidade científica no Brasil. Rio de Janeiro: Editora Nacional/Finep, 1979.

ScOTT, Peter. The crisis of the university. London: Croom Helm, 1984.

SEIDL, Ernesto (Org.). Sociologia do poder e das elites (dossiê). Revista Tomo, n. 13, p. 1-269, 2008.

SETton, Maria da Graça Jacinto. A divisão interna do campo universitário: uma tentativa de classificação. Revista Brasileira de Estudos Pedagógicos, v. 80, n. 196, p. 451-71, 1999.

SHARIF, Naubahar. Emergence and development of the National Innovation Systems concept. Research Policy, v. 35, p. 745-66, 2006.

Shavit, Yossi \& Blossfeld, Hans Peter (Orgs.). Persistent inequality: changing educational attainment in thirteen countries. Boulder: Westview Press, 1993.

SHINN, Terry. Nouvelle production du savoir et triple hélice. Tendences du prêt-à-penser las sciences. Actes de la Recherche en Sciences Sociales, n.141, p. 21-30, 2002.

. Regimes de produção e difusão de ciência: rumo a uma organização transversal do conhecimento. Scientiae Studia, 6, 1, p. 11-42, 2008.

Shinn, Terry \& Ragouet, Paschoal. Controvérsias sobre a ciência: por uma sociologia transversalista da atividade cientifica. São Paulo: Scientiae Studia/Editora 34, 2008.

SILVA, Antônio Moraes. Grande dicionário de língua portuguesa. Lisboa: Editorial Confluência, 1952.

SILVA, Deonísio. De onde vêm as palavras: origens e curiosidades da língua portuguesa. São Paulo: Editora Girafa, 2005.

SILVA, Franklin Leopoldo e. A experiência universitária entre dois liberalismos. Tempo Social, v. 11, n. 1, p. 1-47, 1999.

. A universidade em tempos de conciliação autoritária. Revista USP, n. 60, p. 52-67, 2004.

. Universidade: a ideia e a história. Estudos Avançados, v. 20, n. 56, p. 191-202, 2006.

Slaughter, Sheila \& LeSlie, Larry. Academic capitalism. Baltimore: Johns Hopkins University Press, 1997.

SouZA, Maria Inez Salgado de. Os empresários e a educação: o IPES e a política educacional após 1964. Petrópolis: Editora Vozes, 1981.

Stal, Eva \& Souza Neto, José Adeodato. Avaliação e treinamento em administração de ciência e tecnologia: o caso do Protap. Revista de Administração, v. 22, n. 1, p. 83-94, 1987.

STRATHERN, Marylin (Org.). Audit culture: anthropological studies in accountability, ethics and the academy. London: Routledge, 2000.

TANURI, Leonor Maria. Lourenço Filho e administração escolar: prefácio. In: LOURENÇO FILHO, Manuel Bergströrm. Organização e administração escolar: curso básico. Brasília: INEP, 2007. p. 9-14. 
TAPPER, Ted \& PALFREYMAN, David. Understanding collegiality: the changing oxbridge model. Tertiary Education and Management, v. 8, p. 47-63, 2002.

TAYLOR SOCIETY. A society to promote the Science and the art of administration and of management: proceedings of the meeting of the Taylor Society. New York: Taylor Society, 1920.

TELLES JÚNIOR, Goffredo. O que as Arcadas unem a vida não separa. In: TELLES JúNIOR, Goffredo. Cinquentenário da turma de 1945 da Faculdade de Direito do Largo São Francisco. São Paulo: Saraiva, 1995.

. Carta aos brasileiros 1977 manifesto de repúdio da ditadura, e de exaltação do "Estado de Direito Já”. São Paulo: J. de Oliveira, 2007.

Thompson, Paul. A voz do passado: história oral. Rio de Janeiro: Paz e Terra, 1992.

TOMAZETTI, Elisete. A disciplina filosofia da educação entre os anos 40 e 70 em algumas universidades brasileiras. I Conferência Internacional de Filosofia da Educação Diversidade e Identidade, 1998, Porto. Diversidade e Identidade. Actas da $1{ }^{a}$ Conferência Internacional de Filosofia da Educação. Porto: Universidade do Porto, 1998. v. 1. p. 519-28.

Universidade de São Paulo. Decreto de fundação. USP, 1934a. Disponível em $<$ http://www.leginf.usp.br/?historica=decreto-n-o-6-283-de-25-de-janeiro-de-1934> Acesso em: 21 de abr. 2014.

. Estatuto da Universidade de São Paulo de 1934. São Paulo: USP, 1934b. Disponível em $\quad<$ http://www.leginf.usp.br/?historica=decreto-no-39-de-3-de-setembro-de-1934>. Acesso em: 21 abr. 2014.

Fundação da Universidade de São Paulo: inauguração oficial. São Paulo: Duprat, 1937. 166p. 1945.

Regimento interno aprovado pelo Conselho Universitário em 1944. São Paulo: Reitoria,

. Regimento da reitoria da Universidade de São Paulo. São Paulo: Reitoria, 1950.

. Memorial sobre a reestruturação da Universidade de São Paulo. São Paulo: USP, 1968.

. Estatuto da Universidade de São Paulo 1969. São Paulo: USP, 1969. Disponível em $<$ http://www.leginf.usp.br/?historica=decreto-no-52-326-de-16-de-dezembro-de-1969>.

Acesso em: 21 abr. 2014.

Regimento geral da Universidade de São Paulo de 1972. São Paulo: USP, 1972. Disponível em: <http://www.leginf.usp.br/?historica=decreto-no-52-906-de-27-de-marcode-1972>. Acesso em: 21 abr. 2014.

Cinquentenário da USP. São Paulo: USP, 1984.

Anuário Estatístico da USP. São Paulo: USP, 1987. 27v. Disponível: $<$ https://uspdigital.usp.br/anuario/AnuarioControle>. Acesso em: 21 abr. 2014.

Estatuto da Universidade de São Paulo de 1988. São Paulo: USP, 1989. Disponível em $<$ http://www.leginf.usp.br/?resolucao=consolidada-resolucao-no-3461-de-7-de-outubro-de1988 > Acesso em: 21 abr. 2014. 
. Regimento Geral da Universidade de São Paulo de 1990. São Paulo: USP, 1990. Disponível em <http://www.leginf.usp.br/?resolucao=consolidada-resolucao-no-3745-de19-de-outubro-de-1990> Acesso em: 21 abr. 2014.

. Resolução $n^{\circ} 3.920$ de 7 de abril de 1992. Dispõe sobre a criação da Comissão Permanente de Avaliação. São Paulo: USP, 1992.

. Vice-reitoria: relatório de gestão (2001-2005). São Paulo: USP, 2005.

. Relatório de gestão USP (2005- 2009). São Paulo: USP, 2009a.

. USP 2034: planejando o futuro. São Paulo: Edusp, 2009 b.

. Plano de desenvolvimento institucional da USP (2012-2017). São Paulo: USP, 2011.

. Resolução $n^{\circ} 6.061$ de 27 de fevereiro de 2012. Altera o dispositivo do Estatuto da Universidade de São Paulo. São Paulo: USP, 2012.

. Regimento de pós-graduação da Universidade de São Paulo de 2013. São Paulo: USP, 2013. Disponível em: < http://www.leginf.usp.br/?resolucao=resolucao-no-6542-de-18-deabril-de-2013> Acesso em: 21 abr. 2014.

USAID. Report on examination of Getulio Vargas Foundation Construction. Whasshigton: Usaid, 1968. Disponível em: < http://pdf.usaid.gov/pdf_docs/PDAAT086.pdf > Acesso em: 21 abr. 2014.

VAMPRÉ, Spencer. Memórias para a história da Academia de São Paulo. São Paulo: INL, Conselho Federal de Cultura, 1977.

VANSINA, Jan. Oral tradition as history. Oxford: Marston Book, 1985.

VASCONCELlOS, Eduardo et al. Administração em ciência e tecnologia: uma experiência de 15 anos. Revista de Administração, v. 24, n. 3, p. 89-100, 1989.

VASCONCELlos, Maria Drosila. L'internationalisation des écoles de gestion au Brésil. Actes de la Recherche en Sciences Sociales, n. 121-122, p. 62-5, 1998.

VenAnCio Filho, Aberto. Das arcadas ao bacharelismo: 150 anos de ensino jurídico no Brasil. São Paulo: Perspectiva, 2004.

WHITEHEAD, Alfred Norton. The aims of education and others essas. New York: The Macmillan Company, 1967.

WITTER, José Sebastião. USP 50 anos: registros de um debate. São Paulo: Reitoria da Universidade de São Paulo, 1984.

WiTTROCK, Björn. The modern university: the three transformations. In: RoTHBLATT, Sheldon \& WitTROCK, Björn (Orgs.). The European and American university since 1800: historical and sociological essays. Cambridge: Cambrige University Press, 1993. p. 303-61.

World BANK. Archives. Robert Strange McNamara. Washington: World Bank, n.p. 2013. Disponível em: < http://web.worldbank.org>. Acesso em 21 de abr. 2014.

XAVIER, Marco Antonio. Ocupação do campus Butantã da Universidade de São Paulo (19341954): representações de poder no espaço da Universidade. 1999. Dissertação (Mestrado 
em História Social). Faculdade de Filosofia, Letras e Ciências Humanas, Universidade de São Paulo, São Paulo, 1999. 2 volumes.

ZuIN, Antonio Alvaro Soares. O trote no curso de pedagogia e a prazerosa integração sadomasoquista. Educação e Sociedade, v. 1, n. 79, p. 243-57, 2002.

O trote universitário como violência espetacular. Educação e Realidade, v. 36, p. 587604, 2011. 